
10)

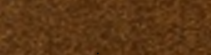

(2)

(5)

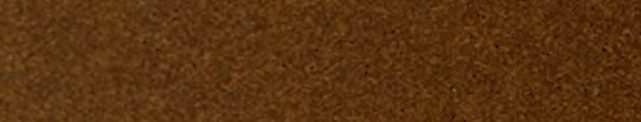

(3)

350.

35icis

(5)

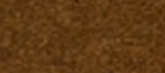

Whas 


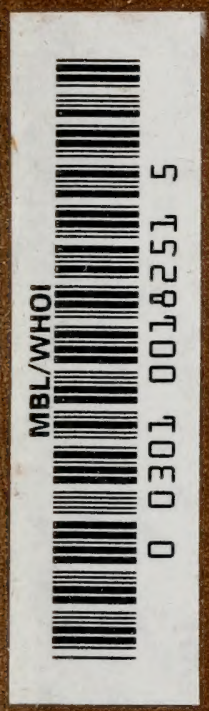




\section{.}


American Animals 




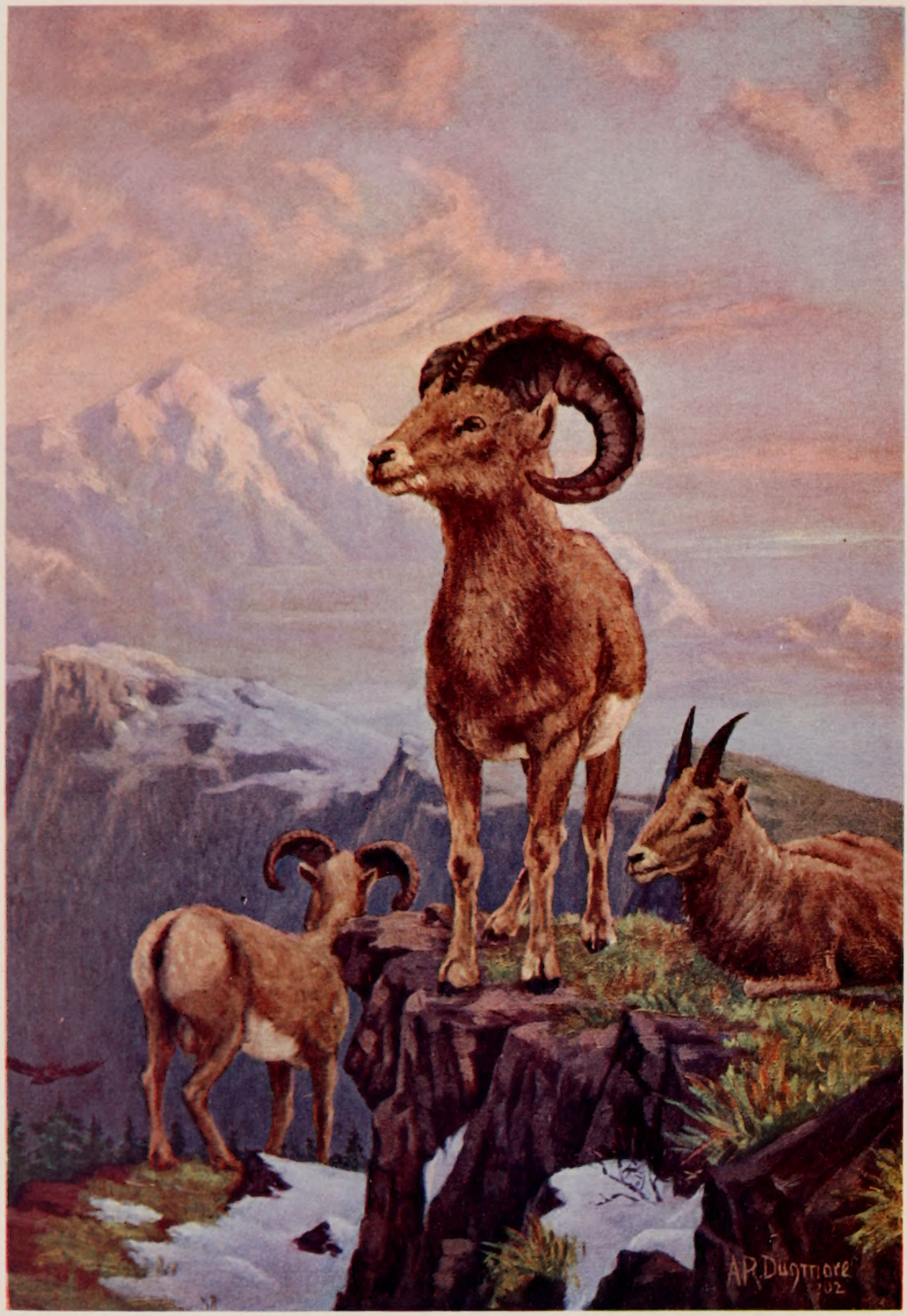




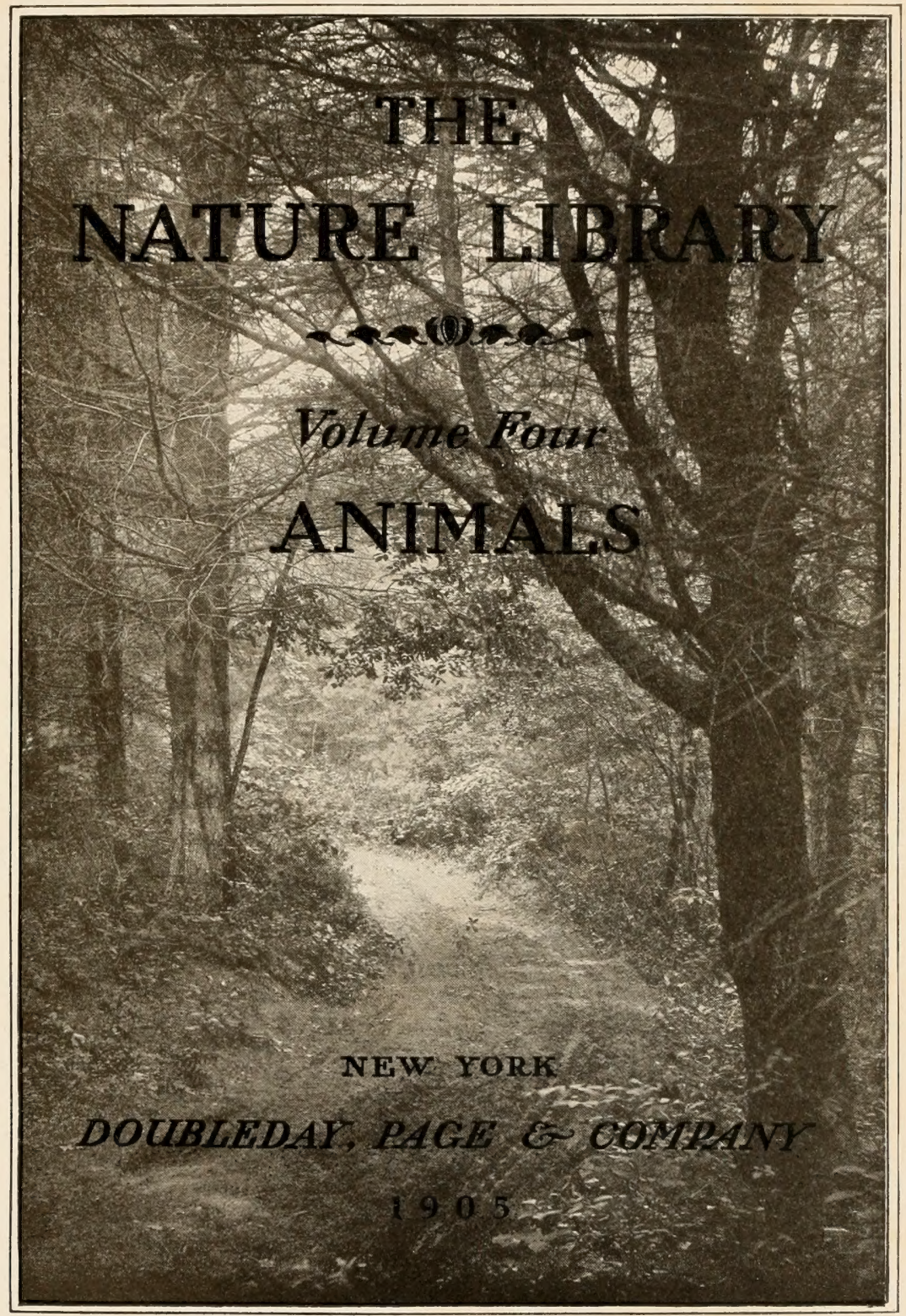


Copyright, 1902, by Doubleday, Page \& Co.

Norwoor PBress:

Berwick \& Smith Co., Norwood, Mass., U.S.A. 
AMERICAN ANIMALS A POPULAR GUIDE TO THE MAMMALS OF NORTH AMERICA NORTH OF MEXICO, WITH INTIMATE BIOGRAPHIES OF THE MORE FAMILIAR SPECIES

\author{
BY \\ WITMER STONE \\ AND \\ WILLIAM EVERETT CRAM
}

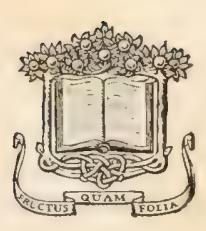

NEW YORK

DOUBLEDAY, PAGE \& COMPANY 
Copyright, 190z, by Doubleday, Page \& Co. 


\section{PREFACE}

$I^{N}$ PREPARING the present volume the aim has been to produce a work sufficiently free from technicalities to appeal to the general reader and at the same time to include such scientific information relative to our North American mammals as would be desired by one beginning their study. The key at the end of the volume will be found of service in identifying unfamiliar mammals, and includes certain characters omitted from the body of the book. As a guide to further study there has been appended a bibliography of the principal works on North American mammals.

To many of these I would express my indebtedness, especially to the writings of Allen, Merriam, Miller, Bangs and Rhoads, and also my acknowledgments to the Academy of Natural Sciences of Philadelphia and Mr. Samuel N. Rhoads for the privilege of studying the specimens contained in their collections.

The text figures are all reproduced from standard works, while the plates are largely from the brush or camera of $\mathrm{Mr}$. A. Radclyffe Dugmore, whose name is so intimately connected with illustrations of nature.

The publishers wish to acknowledge the many courtesies and the helpful cooperation of the New York Zoological Society and its Director, Wm. T. Hornaday, Esq.; many of the photographs made at the Zoological Park could not have been secured elsewhere. The same is true of the Washington Zoological Park, in which Mr. Dugmore made a number of pictures.

September 7, 1902.

Witmer Stone. 
THANKS ARE DUE TO THE NEW YORK ZOÖLOGICAI, SOCIETY AND THE DIRECTOR, MR. WILLIAM T. HORNADAY, FOR THEIR COÖPERATION IN SECURING MANY OF THE ILLUSTRATIONS : : : : : 


\section{TABLE OF CONTENTS}

Preface

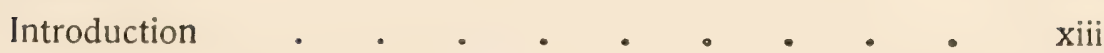

Edentates or Toothless Animals • • • • . 9

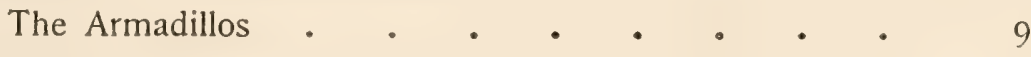

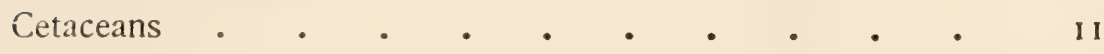

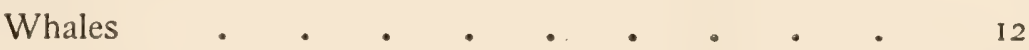

Dolphins • • • • • • • . • 20

Porpoises • . • • • • • • • • 22

Manatees and Dugongs . . . . . . 26

Ungulates or Hoofed Animals . . . . • . 28

Peccaries • • • • . • • • • 30

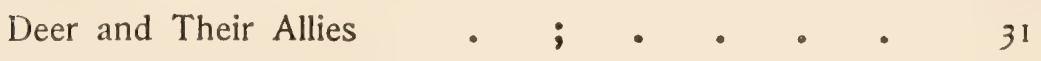

Pronghorns $\quad \cdot \quad \cdot \quad \cdot \quad \cdot \quad \cdot \quad \cdot \quad \cdot \quad \cdot 54$

The Cattle • • • • • • • • 57

Rodents or Gnawing Animals • . • . . 71

Rabbits and Hares . • • • • • • 73

Pikas • • • • • • • • • • • • 93

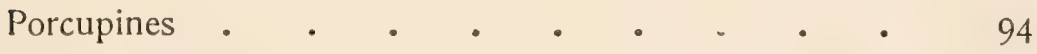

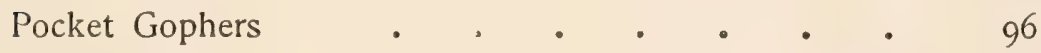

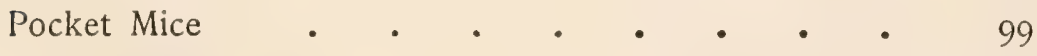

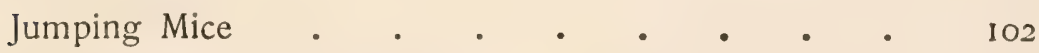

Rats, Mice and Lemmings . . . . . . 105

Meadow Mice, Lemmings and Muskrats . . . 107

American Long-tailed Mice and Rats . . . 127

Introduced Rats and Mice . . . . . 138 
Table of Contents

Rodents or Gnawing Animals - Contimued.

Beavers . . . . . . . . . 145

Sewellel . . . . . . . . . 150

Squirrels and Marmots . . . . . . 151

Moles and Shrews . . . . . . . 179

Bats . . . . . . . . . . 193

Carnivorous or Flesh-eating Animals . . . . 207

Eared Seals . . . . . . . . 209

Walruses . . . . . . 212

Seals . . . . . . . . . . . 214

Weasels, Otters, etc. . . . . . 219

Raccoons and Their Allies . . . . 247

Bears . . . . . . . . . . 255

Wolves and Foxes . . . . 264

Cats . . . . . . . . 283 


\section{LIST OF ILLUSTRATIONS}

COLORED PLATES AND HALF-TONES

Bighorn or Mountain Sheep (Ovis cervina) . . Frontispiece

'Possum Hiding in Palmetto, where he has been chased by

a $\operatorname{dog}$ (Didelphis virginiana) . . . . . . 4

A Scared 'Possum . . . . . . . . . . . 6

'Possum Climbing .

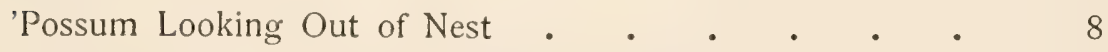

A New Jersey 'Possum (Didelphis virginiana) . . . 8

A Florida 'Possum . . . . . . . . 10

Opossum (Didelphis virginiana) Showing Young at the

Mouth of the Pouch . . . . . . . 10

Six-banded Armadillo (Dasypus sexcinctus) . . . 12

Manatees Under Water (Trichechus latirostris) . . . 26

Collared Peccary (Tayassi tayassu) . . . . . 30

Bull Elk or Stag (Cervus canadensis) . . . . 32

An Elk (Cervus canadensis) Getting His Antlers . . 34

The Rapid Growth of an Elk's Antlers . . . . 36

Elk Stag and Herd (Cervus canadensis) . . . . 38

A Startled Doe; she hears a whistle across the creek . 40

White-tail Deer (Odocoileus virginianus) . . . . 40

Virginia Deer in the Maine Woods at Night . . . $4^{2}$

Deer, in Moose Creek, Idaho . . . . . . 44

Western White-tail, or Virginia Deer (Odocoileus virginianus macrourus) in the Bitter Root Valley, Montana 44

A Young White-tail Buck (Odocoileus virginianus) . . 46

A Bunch of Mule-deer Does (Odocoileus hemionus). . 48

Young Bull Moose (Alces americamus) . . . . 50

A Pair of Bull Moose (Alces americanus) . . . . 52 
Young Woodland Caribou (Rangifer caribou) . . . 54

Typical Heads and Antlers of Cervidæ . . . . 56

Pronghorn (Antilocapra americana) • . . . . 58

Young Pronghorns (Antilocapra americana) . . 60

Pronghorns (Antilocapra americana) . . . . 62

Male Pronghorns (Antilocapra americana) . . . 64

Mountain Goat (Oreamnos montamis) . . • . 66

Young Cow Musk Ox, about 16 months old (Ovibos moschatus) . . . . . . . . 68

Bull Bison (Bison bison) . . . . . . . . 70

A Herd of American Bison (Bison bison) . . . 72

Nest of Young Cottontails . . . . . . . 76

Young Cottontail Among the Cabbages (Lepus floridanus mallurus) . . . . . . . . 76

Varying Hare (Lepus americanus virginianus) . . 86

Little Chief Hare, or Pika (Ochotona princeps) . . 92

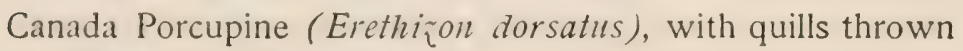
forward. In wild state . . . . . . 94

American Porcupine Swimming, with quills projecting (Erethizon dorsatus) . . . . . . . . . 96

Western Pocket Gopher (Thomomys) . . . . 98

Western Long-tail Mouse, caught in the Bitter Root Mountains . . . . . . . . . 102

Long-tailed Jumping Mouse (Zapus hudsonius) . . 102

Mice and Shrews of the Eastern States . . . . I10

Western and Southern Mice and Rats . . . . 114

Muskrat (Fiber zibethicus) . . . . • . 122

Western Wood Rat, female (Neotoma) . . . . 128

Cotton Rat (Sigmodon hispidus littoralis) . . . 130

Western Bushy-tailed Wood Rat (Neotoma) . • . 130

White-footed Mouse (Peromyscus), enlarged • . . 132

White-footed Mouse and Young (Peromyscus leucopus) • 134

House Mouse on Trap (Mus musculus) • • • • 142

Common, or Norway Rat (Mus norvegicus) . . . 142

Canadian Beaver (Castor canadensis) . . . . 146 
Beaver Lodges and a Dam

A Pair of Woodchucks by their Burrow (Arctomys monax)

Prairie Dogs (Cynomys ludovicianus)

Western Spermophile (Spermophilus), photographed in

Colorado

Say's Spermophile (Spermophilus lateralis)

White-tailed Spermophile (Spermophilus leucurus) • • 162

Young of Columbia Spermophile (Spermophilus columbianus) $\quad$ I62

Say's Spermophile in Snow (Spermophilus lateralis) • $\quad 164$

Young Prairie Dog (Cynomys ludovicianus), about one-third grown

Western Chipmunk (Tamias quadrivitatus) . . . 166

Chipmunk (Tamias striatus) . . . . . . 168

Gray Squirrel (Sciurus carolinensis) . . . . . 170

Red Squirrels (Sciurus hudsonicus gymnicus) • • 172

Young Red Squirrel (Sciurus hudsonicus gymmicus) • 174

Hoary Marmot (Arctomys Pruinosus) . • . • 174

Pine Squirrel (Sciurus hudsonicus richardsoni) • • 176

Flying Squirrel (Sciuropterus volans) . . . . 178

Common Mole (Scalops aquaticus) . . • • 188

Star-nosed Mole (Condylura cristala) . . . . 188

Marsh Shrew (Sorex palustris) . . . . . 188

Four Common Eastern Bats . . . . . . 198

Sea-lion (Zalophus californianus) . . . . . 208

Sea-lion (Zalophus californianus), barking . . . 2 ro

Walrus Bulls and Cows (Odobenus rosmarus) • • . 212

Fur Seals (Otoes alascanus) . . . . . . . 216

Harbor Seals (Phoca vitulina) . . . . . 216

Otter (Lutra canadensis) . . . . . . . . . 222

Skunk (Mephitis putida), crossing a stream . . . 226

Mink (Putorius vison) . . . . . . . 234

Weasel (Putorius noveboracensis) • . . . . 234

American Sable or Pine Marten (Mustela americana). • 244

Wolverine or Carcajou (Gulo luscus) . . • . 246 
Raccoon (Procyon lotor) . . . . . 250

Polar Bear (Thalarctos maritimus) . . . . . 254

Polar Bear (Thalarctos maritimus) . . . • . 256

Florida Black Bear (Ursus floridanus) . . • • 258

Silver Tip; variety of the Grizzly Bear (Ursus horribilis). $\quad 260$

Kadiak Bear (Ursus middendorffi) . . . . . 262

Kadiak Bear (Ursus middendorffi) . . • • • 264

Red Fox (Vulpes fulvus) . • . . . • . 268

A Young Red Fox (Vulpes fulvus) . . . . . 270

Gray Fox (Urocyon cinereoargenteus) . • . . 276

Timber or Gray Wolf (Canis occidentalis) • • • 278

Coyote (Canis latrans) . . . . . . . 282

Canada Lynx (Lynx canadensis) . . . . . 286

Cougar, or Mountain Lion (Felis oregonus hifpolestes) • 290

Jaguar (Felis onca) . . . . . . . 292 


\section{INTRODUCTION}

\section{Mammals and their Study}

THE first questions that present themselves in the study ct mammals are: What is a mammal and what is an animal ? An animal we are told is anything endowed with life, that is not a plant. Very true, but popularly we use the word in another sense, meaning a beast as opposed to a bird, a fish or a reptile-that is to say we mean one of the classes of back-boned animals.

Unfortunately we have no English name for this group. The term "quadruped," it is true, applies to a great majority of its members, but does not fit the whales or bats which belong here just as much as the four-footed beasts; nor does "quadruped" apply to man who stands at the head of the group. Therefore we have to adopt an abbreviation of the Latin name for this class of animals and call them mammals. A mammal then is characterized by having a more or less hairy body, and in suckling its young, while it has warm blood like the birds.

The relations between man and the lower mammals have always been most important. He depends upon them for meat and clothing, he uses them as beasts of burden, he hunts them and trains them to hunt each other. With the exception of the beasts of burden and those which aid him in the chase, man's attitude toward mammals has always been that of a destroyer; in whatever field he may meet them his object is always to kill.

Those which furnish good meat are slaughtered for food or are pursued from pure love of the chase; those which furnish valuable skins are killed by the trappers as a means of livelihood; fierce beasts are everywhere shot on sight, while a relentless war is being perpetually carried on against the great army of rats, mice and other despoilers of our crops.

Much of this slaughter is justified, but much is unwarranted and is speedily effecting the extermination of all the large and especially desirable mammals of the world.

Pure greed and wantonness are destroying many of the most 


\section{Introduction}

valuable and interesting mammals where moderation and proper protection would ensure their preservation for an indefinite time. In loner past ages man learned the importance of protecting the most useful mammals of the Old World-the ancestors of the sio-called domestic animals-and this he continues to do to-day, hut in the case of wild animals, which he finds in other countries, he seems blind to the importance of similar care.

In our own country the buffalo is gone, the moose and elk are rapidly decreasing, and the fur seals are threateried with extermination in spite of all laws and regulations. In Africa all the large "game" is being shot off by adventure-loving explorers and many species are even now nearing extinction; and so it is elsewhere.

While the value of mammals from a purely economic point constitutes their main importance to the world at large, their scientific characters and the study of their life and habits are most absorbing, and with the spreading interest in nature study we can well afford to give them a share of our attention.

From their high position in the animal kingdom it seems strange at first thought that we do not see more of mammals in our woods and fields. It is only the most common species that we are at all familiar with and though the country maly be teeming with bird and insect life we are not likely on an ordinary ramble to see more of the mammals than a few squirrels, a mouse or two and perhaps a rabbit, muskrat or woodchuck.

Mammals are, however, much more plentiful than we suppose. Go out after a snowfall and see what a record of foot-prints is presented. Evidently our four-footed friends are largely nocturnal in habits, and it is this fact together with their general wariness and extremely acute sense of hearing, smell and sight that render them so hard to see.

The very difficulties which beset the study of mammals in the field render it all the more attractive, and we envy the woodsman whose long practice renders conspicuous to him signs that to the beginner are passed again and again unnoticed. As we follow a trail through the forest, his quick eye notes that a bear has preceded us. Here are some herbs that he has grubbed up, there are his muddy footprints on a log and the rotten bark has peeled off with his weight as he jumped down, and here argain he has risen on his hind feet to claw and bite the bark of a tree. 
How clear the story is when once it has been pointed out! And we feel that in studying the marks of his presence we have learned something of the bear himself.

Tracks on the snow are much easier hieroglyphs to decipher; to use Burrough's words: "The snow is a great tell-tale and blabs as effectually as it obliterates. I go into the woods and know all that has happened. I cross the field, and if only a mouse has visited his neighbour, the fact is chronicled." It is, indeed, a fascinating task to read the story of the mammals in the snow, to learn to know the sharp clear-cut trail of the fox, the blurred mark of the rabbit's hairy foot, the nervous tread of the squirrels and the dainty traceries of the mice and shrews.

A knowledge of mammals doubles the interest of an ordinary ramble to the lover of nature. Even though we see but few, we learn to know their presence and see their work on every side, and the more we learn of their ways the more frequent glimpses we get of them.

The pleasure of seeing and studying a wild animal in life to me far outranks the gratification of making a good shot and "bagging my game," and I think that if the pleasure men feel in hunting were carefully analyzed it will be found that besides being close to nature it rests largely in the contest of skill and craft between hunter and game and that the mere killing is anything but a gratification.

\section{Structure and Classification}

Mammals form one of the great classes of vertebrate animals. The most important character which they have in common, but which is not possessed by any other animals, is that the young are nourished fo: some time after birth on milk secreted by the mother. Furthermore, all mammals are covered with more or less hair* in distinction to the feathers of birds, and the scales of fishes and reptiles.

Mammals are supposed to have originated from some early reptilian animal and branched off long before the birds were evolved. They first became abundantly distributed over the Tertiary period though the earliest remains occur in the Triassic.

* Entirely disappears in adult whales. 
In the arres since then one type of mammal after another has arisen, some being modified step by step into the forms that inhabit the earth to-day while others have been entirely exterminated.

In some cases the series of fossil remains are so complete that we can easily trace the ancestry of several of our modern mammals, as, for instance, the horse, which is shown to be originally descended from a five-toed beast, while successive ages show the specialization of the feet, first with four toes and then with three, until finally we have the existing horse with his one large toe or hoof on each foot.

At the present time the great bulk of mammals belong to one group known as the Eutheria-modern mammais-though we have remnants of two other more primitive groups which were much more extensively developed in the past. These are now almost entirely restricted to Australia and the neighbouring islands where they have been cut off from their mainland relattives at the time that Australia became separated from the Asiatic continent, and have there been preserved to the present day, free from the inroal of the higher forms of mammals which spread over the continents and, being better adapted to existing conditions, crowded the earlier forms out of existence.

The most primitive of the older mammals are the Prototheria -early mammals-comprising the duck bill and spiny ant-eater of Australia, animals which resemble in skeletal characters the earliest known fossil mammals, and which lay eggs somewhat like those of the reptiles.

The second group, the Marsupialia-pouched mammals-include's a large number of species in Australia and the opossums of America. One of the leading peculiarities of these animals is that their young are born at a very early stage of development in a perfectly helpless condition and are then placed in an external pouch on the belly of the female where they continue their development.

The modern mammals-Eutheria-comprise a number of distinct types the relationship of which is not always clear, though they are all derived from a common origin and are more closely related to one another than to either of the preceding groups.

The aquatic whales and manatees, while not closely related to one another, differ so much from the land mammals that it is very 
uncertain just where they branched off from the "family tree" and it is convenient to consider them first, though they are without doubt degenerate animals derived from some ancient terrestrial forms and are not themselves primitive. The remaining orders fall naturally into two series, those with compressed, hooked "claws" on the feet and those with nat nails or hoofs,

We will have then the following table of "orders" of mod. ern mammals:

Aquatic, with no hind legs and with fore legs modified into nippers for swimming, tail broad and flat; hilir little or none. Nostrils opening on top of the head in a "blow hole," teeth, if any, simple and all alike, not tuberculate.

Cetacea, whales.

Nostrils at the end of the nose as usual, tuberculate teeth in the back part of the jaws. Sirenia, manatees.

Terrestrial (except seals and bats) with all four limbs well developed, and body covered with hair.

Nails of feet compressed and hooked forming claws.

No incisor teeth; teeth without enamel.

With incisor teeth; enamel present.

Edentata, sloths, armadillos, etc. Incisors large and prominent, two in each jaw, concealed portion curved and reaching far back in the skull, canines wanting, leaving a broad gap on each side of the mouth.

Glires, rats, etc.

Incisors small, generally more than two, canines present leaving no gap at the side of the jaws.

Anterior limbs modified into wings... Chiroptera, bats. Anterior limbs normal.

Canines not prominent...... Insectivora, shrews, etc. Canines prominent........Carnivora, cats, dogs, etc.

Nails flat or developed into hoofs.

Nose modified into a trunk, toes 5 .

Proboscidea, elephants. Nose normal, feet never 5-toed, always armed with hoofs.

Nose normal, feet always 5-toed. Ungulata, horses, cows, etc. Primates, monkeys and man.

There are a few more or less obscure foreign mammals that are not accommodated in the scheme given above, and which are intermediate in their characters.

In North America we lack representatives of several orders. The Prototheria are entirely wanting and of the Marsupialia we 
have only the opossum. Of the higher orders, the Sirenia are represented by the few remaining manatees of Florida, the Edentata only by a species of armadillo which crosses into Texas from farther south. Probosiliti (elephants) are entirely lacking, and of Primatis our only native representatives are the Indian and l:skimo. Of the remaining orders we have an abundance of species.

In the scientific study of mammals we are compelled to make use of more or less obscure characters, and when separating species, we are unable to base descriptions entirely upon the external appearance, as is possible in the case of birds.

Some mammals, especially among the mice, exhibit scarcely any external differences, while an examination of their skulls and teeth shows that they belong to quite different genera.

Indeed, few mammals are very brightly marked, doubtless due to their general nocturnal habits and their need of protective colouration.

The necessity of studying some of the skeletal characters in identifying mammals makes it desirable to have an idea of the more important portions of their bony structure. While there is no reason why the structure of any particular portion of an animal's anatomy should be regarded as of more importance than another in studying its relationship, it is nevertheless a fact that in every group of animals certain organs or parts of the skeleton show a greater susceptibility to modification, and thus furnish a much easier clue to the origin and development of the species, than is offered by those parts in which there is very slight modification. Thus in the mammals it is the structure of the skull, the teeth and the lower leg and foot bones that furnish the basis for most of our classification.

The Skull.-The skull is really composed of a large number of bones, each of which has a distinctive name, but in the adult animal they have become so firmly joined together that even the lines of juncture are nearly obliterated, and we may therefore say that the adult skull consists of two parts-the skull proper and the lower jaw or mandible, the latter being separable into two symmetrical halves. The skull proper consists of the bony box or brain case, the back of which is known as the occipitil bone, and in it is the round hole or foramen through which the spinal chord joins the brain. The forward part of 
the skull comprises the upper jaw, the nasal bones, surrounding the nostrils, and the large eye sockets. The bones forming the roof of the mouth constitute the palate and those forming the

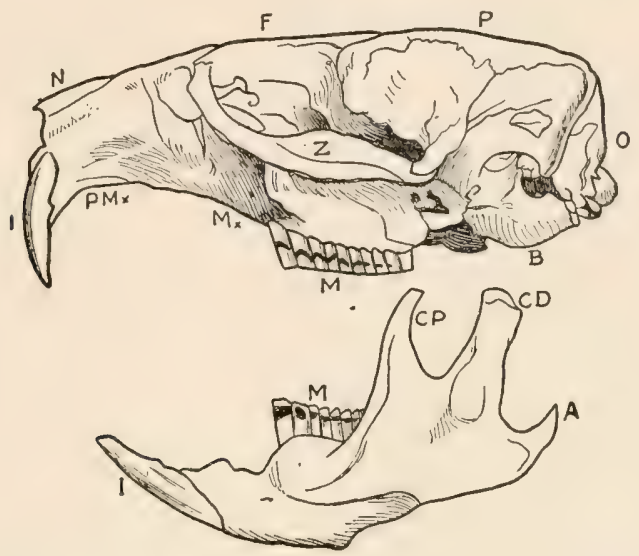

Skull and one side of mandible of Musk Rat.

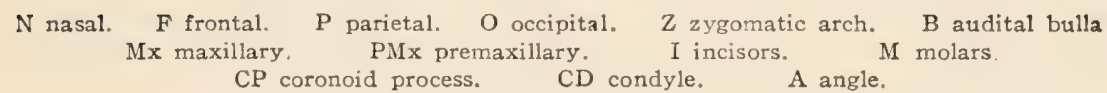

forehead are the frontals, while on the posterior portion of the lower part of the skull are two rounded "ear bones" known as the audital bulla.

The Teeth. - The teeth of mammals are divided into four groups, the incisors or cutting teeth placed across the front of the jaws, the canines, four rather elongated teeth placed at the front corners of the jaws, two above and two below, the premolars placed immediately behind the canines, and back of these the molars or grinders. Most mammals have two sets of teeth; the milk teeth and the permanent teeth. The former are weaker and are only retained during the early years of the animal's life when they are succeeded by the permanent set. The premolars are represented in the milk dentition, but the molars are not, and that is the reason for separating them. In structure, however, they are quite similar and it is often impossible to distinguish them.

The simplest form of tooth is a single-pointed cone, such as we see in the toothed whales; all canine teeth are similar to this in structure, while the incisors are generally more flattened and sometimes slightly lobed. 
Next we have tulberculate teeth, with a flat crown from which arise rounded or pointed tubercles; such are many molars and premolars. Besides these there are the flat-lopped teeth of horses, cows, elephants and many mice with tortuous ridges across their surface, these being the most complicated teeth known
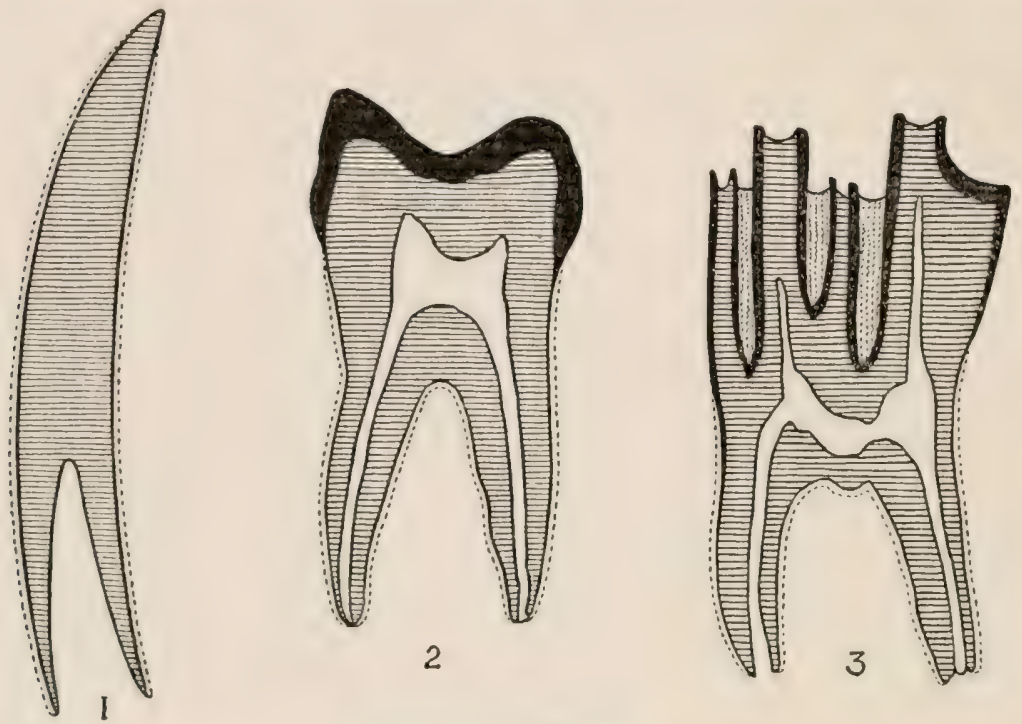

Sections of Teeth.

I An incisor or tusk of Elephant, with open puip cavity at base. 2 Human moldr with hroad crown and two roots 3 Molar of Ox, showing deeply folded enamel surface with cement filling up the depressions. (After LYDEKKER).

A tooth grows from a soft "pulp" and in its early stage is open at the base, the cavity being occupied by the pulp. Some teeth remain this way and continue to grow on indefinitely while they wear away more or less at their tips. Such are the tusks of elephants and the incisor teeth of rats and other gnawing animals. Other teeth, on the contrary, gradually close up at the base, forming one or more roots or fangs, the remnant of the pulp being contained in the inside of the tooth. Such teeth do not increase in growth after the roots are formed.

The substances that make up teeth are three: (I) dentine or ivory which forms the bulk of the tooth, (2) enamel, a very hard bluish-white substance which covers the outer surface, and (3) cement, a bone like substance which fills up the cavities 
between the ridges on the large teeth of the horse, cow and other similar animals.

The number of teeth varies greatly in different animals and furnishes us with an excellent aid to classification. Sometimes teeth are entirely wanting, as in certain whales, and again we find one or other of the groups of teeth lacking, as the canines in the gnawing mammals, or the incisors in the upper jaw of the cattle and deer.

In other families of mammals special names are used for some of the teeth; thus it will be noticed that in all carnivorous mammals one of the back teeth on each side of the jaw is much larger than the others, sometimes it is a molar, sometimes a premolar, but from its peculiar prominence it is called the carnasal tooth. Again, in the insectivorous mammals, the incisors, canines and some of the premolars are all simple in structure and so much alike that they cannot be separated by their structure; they are therefore for convenience known collectively as the unicuspid teeth.

In many mammals some of the teeth become immensely developed and are termed tusks as, for example, in the elephant, walrus, narwhal, etc.

Legs and Feet.-Next to the variations in their skulls and teeth mammals exhibit most diversity in the structure of their limbs. The limb of a mammal consists of four parts, and the bones which compose the fore limb have different names from those of the hind limb; thus we have

FORE LIMB

I. Humerus (upper arm).

II. Ulna and radius (fore-arm). Tibia and fibula (lower leg).

III. Bones of the carpus (wrist). Bones of the tarsus (ankle).

IV. Phalanges (fingers).
HIND LIMB

Femur (thigh).

Phalanges (toes).

The two bones composing the lower leg or calf which lie side by side are frequently joined together, or else the fibula is only partially developed.

It is in the bones of the hands and feet, however, that we find the greatest variation, especially in the lorg bones that form the back of our hand (metacarpals) and the instep of our foot (metatarsals) and which support the fingers and toes. These 
are sometimes immensely developed so as to form apparently another section to the leg, as we see in the horse and cow where these bones are so long that the heels on the hind feet are elevated a foot or more in the air. In these animals there is also a reduction in the number of toes and we find that such of these metacarpal and metatarsal bones as remain are fused together, while those belonging to the missing toes are mere abortive splints.

With these brief explanations we shall be better able to understand the preceding table of the mammalian orders and the further classification which follows.

\section{Limits of the Work}

So easily are mammals affected by their surroundings that we find that differences in climate, temperature, humidity, food, etc., are immediately reflected in a difference in the size, colour, or skeletal characters of the individuals of a certain region. This results in an immense number of geographic varieties of nearly all kinds of mammals which have been carefully studied and separated by systematic zoclogists.

The differences which distinguish these varieties are not always perceptible to the popular eye, but as everyone wishes to be as nearly accurate as possible, we have mentioned in the following pages every species and variety of mammal found in North America east of the Mississippi, and all the varieties of big game animals north of Mexico. Of other mammals from the West, however, only the most important species are described.

The scientific names used are those adopted in the most reliable systematic monographs of the day and no attempt has been made to solve the vexed question of what constitutes a species and what a subspecies. Those animals which would be most readily recognized as different by one beginning the study of our mammals are separately described, while geographical races and closely allied species are grouped together at the end of the account with their range and a few of their most obvious differential characters. It will therefore be understood that in so grouping them there is no intention to reduce their taxonomic rank, but simply to arrange them so that the general reader, who does not wish to study in detail the structure of every form, 
Introduction

may more easily obtain the information that he desires. Those who do desire to go deeper into the subject and study the cranial peculiarities and minute differences between the numerous subspecies are referred to the technical works quoted in the appended bibliography. 

American Animals 



\section{MARSUPIALS OR POUCHED ANIMALS}

\section{(Marsupialia)}

THE marsupials stand apart from all the other groups of American mammals having many peculiarities of structure and habit not possessed by any other family. They are in fact the survivors of an ancient population which was spread over the earth before the superior beasts of to-day made their appearance. At about the time that the marsupials had reached the height of their development Australia became separated from the mainland of Asia, and until the present time these curious primitive animals have flourished on this isolated continent, while almost everywhere else they have been superseded by more highly developed and more aggressive beasts.

Outside of Australia the only known marsupials are the opossums, which are restricted to South and Middle America, with the single exception of the well-known Virginia opossum of our Southern and Middle States.

The variety of Australian marsupials is very great; the largest and best-known are the peculiar kangaroos; others resemble in general form our smaller carnivora, still others recall the squirrels, while the flying phalangers are the counterpart of our flying squirrels and there is even a "marsupial mole!"

Among the many peculiarities of structure exhibited by these animals may be mentioned especially the mode of nourishment of the young. Birth takes place when they are extremely small, very much earlier than in the higher mammals, and they are immediately placed in a peculiar pouch situated on the belly of the female where, attached to the nipples, they continue their development until able to shift for themselves. Even then they return to the pouch for shelter, for a considerable period after they can run about.

The teeth of the marsupials are more primitive than those of most of the other mammals and are generally more numerous. As might be supposed from the variation in form and size exhibited by the marsupials their diet is likewise varied, some being 
carnivorous, others herbivorous and still others like our opossum omnivorous.

As before stated we have only one group of marsupials in America, the opossums (Family Didelphida).

\title{
THE OPOSSUMS
}

\author{
Family Didclphide
}

\section{Virginia Opossum}

\section{Didelphis virginiana Kerr}

\section{Length. 27 inches.}

Description. Hair long and rather coarse; general colour grayish white, caused by a mingling of black-tipped white under fur with long white overlying hairs; legs brownish black, feet black, toes white; head, throat and middle of lower parts white; ears naked, black with white tips; tail prehensile, nearly naked, black at the base, shading into dull flesh colour. Range. Southern and Middle States, except in the mountains, north to the Hudson and Connecticut valleys and to southern Illinois, not ranging north of what is known as the "Carolinian Fauna." In Florida and Texas slightly different varieties occur.

The opossum is our only representative of that remarkable class of beasts in which the young are born at such an early and undeveloped stage that the mother is obliged to carry them about in her pocket for several weeks; when first born a kangaroo, an opossum and a mouse are of very nearly the same size, about half an inch in length,

A mother opossum takes her half-dozen or more infants as fast as they are born and drops them into her pouch, where each seizes a teat and holds on; its mouth, which at first is open almost to the angle of the jaws, rapidly contracts and grows together when once it has taken hold of that which it is instinctively feeling for from the very first, and for the next few weeks the little family of brothers and sisters do nothing but sleep and grow, the old one forcing her milk into their mouths. 


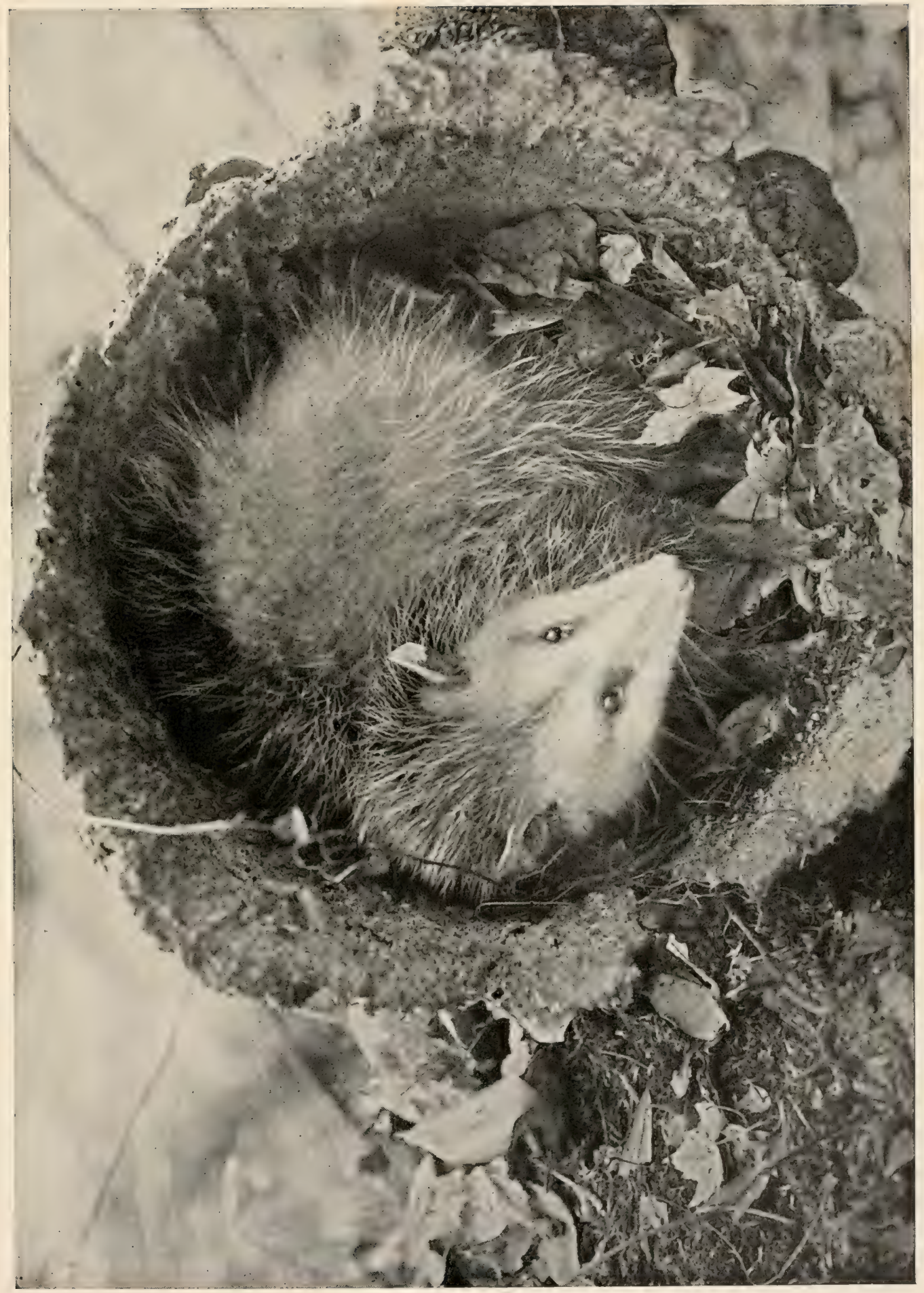



In the meantime she is obliged to forage the woods for food and protect herself and her family as best she may.

At first thought one might very naturally infer that she would be at a decided disadvantage in being so very literally burdened with a family, yet on the whole she carries them but little longer than most other creatures of her size, the chief difference being that she has them where she can do pretty much as she pleases with them, and in case of injury is much less liable to incur serious results.

Through the day she sleeps hidden in a hollow tree or stump, or dozes half in sunshine and half in shade among the branches.

But as daylight fades and the shadows creep through the undergrowth she goes forth to see what the night has to offer her, shuffling along among the dew wet leaves, pouncing on a lizard here or a blundering dorbug that has chanced to upset itself in midflight, or else she follows up the shrill throbbing of a cricket and digs him out from his hiding place. If luck happens to be with her she may discover a nest full of eggs or young birds or mice, it is all one to her.

She can also climb to the top of the tallest tree in the woods using her tail and hand-shaped feet almost like a monkey, even hanging head down by her tail and one hind foot if necessary from a branch just over a bird's nest in order to reach whatever it contains. Her prehensil? tail moreover often proves useful in supporting her while she gathers grapes and persimmons and other wild fruits of the forest, and it is said that the young ones when they first come out to see what the world is like, have a way of taking a couple of turns of their own tails about that of their parent and so anchored ride safely on her back. It would seem that these youngsters are not in the habit of occupying the pouch as long as do the young kangaroos, which it is said, remain there for a space of something like eight months, growing in that time from diminutive beings less than an inch long to fairly well-formed kangaroos of ten pounds weight which thrust out their necks when their parent is grazing and crop the grass beneath them. Even after they have learned to go alone they often climb back into the pouch again to ride whenever they are tired out.

Opossums are anything but attractive or intelligent beasts. 
About the most marked exhibition of intelligence that they ever appear to display is their well-known trick of feigning death or playing possum as a last resort in danger. Even this has become so habitual with the species as to be almost or quite instinctive and it is doubtful if they ever knowingly pretend to be deald any more than the numerous beetles and spiders which possess the same habit.

Nature most effectually assists the possum in making the ruse successful, as anyone who has ever seen it tried is bound to admit, for the long lean dull white jaws and black withered ears and skinny tail bear in themselves the very semblance of death. And when the possum plays possum he invariably draws back the gums from his glittering white teeth until he looks as if he might have been deald for a month; especially as his fur has at all times the faded, colourless look and loose wind-blown texture of hair that has been exposed to wind and weather for an entire season.

In cold weather opossums retire to their dens and only occasionally venture abroad when there is snow on the ground. They are members of an almost tropical race that hates the cold, and wherever winter is an actual fact they are rarely found.

"Opossums are very prolific, having two or three litters each year, each litter composed of from six to thirteen, in rare instances as many as fourteen or fifteen. The young remain with their mother about two months, and at times a brood of sucklings may be found in the pouch, while a second brood the size of rats may be seen on her back, clinging to her fur with their hands and steadying themselves by winding their tails around her tail and legs.

"The opossum somewhat resembles a little pig in his nexible snout, small black eyes, and erect ears; but he resembles the pig much more in his fondness for eating and the great variety of food that suits his taste.

"His principal diet consists of insects, wild fruits, nuts and herries, varied with roots, reptiles, crayfish, carrion, eggs, small rats and mice, with additions of poultry, corn, sweet potatoes, and other farmyard delicacies." "He is the natural enemy of the cotton rat, a destructive rodent living in vast numbers in the seaboard marshes of the Southern States. If all the food eaten by a possum during the year were divided into two piles according to its 


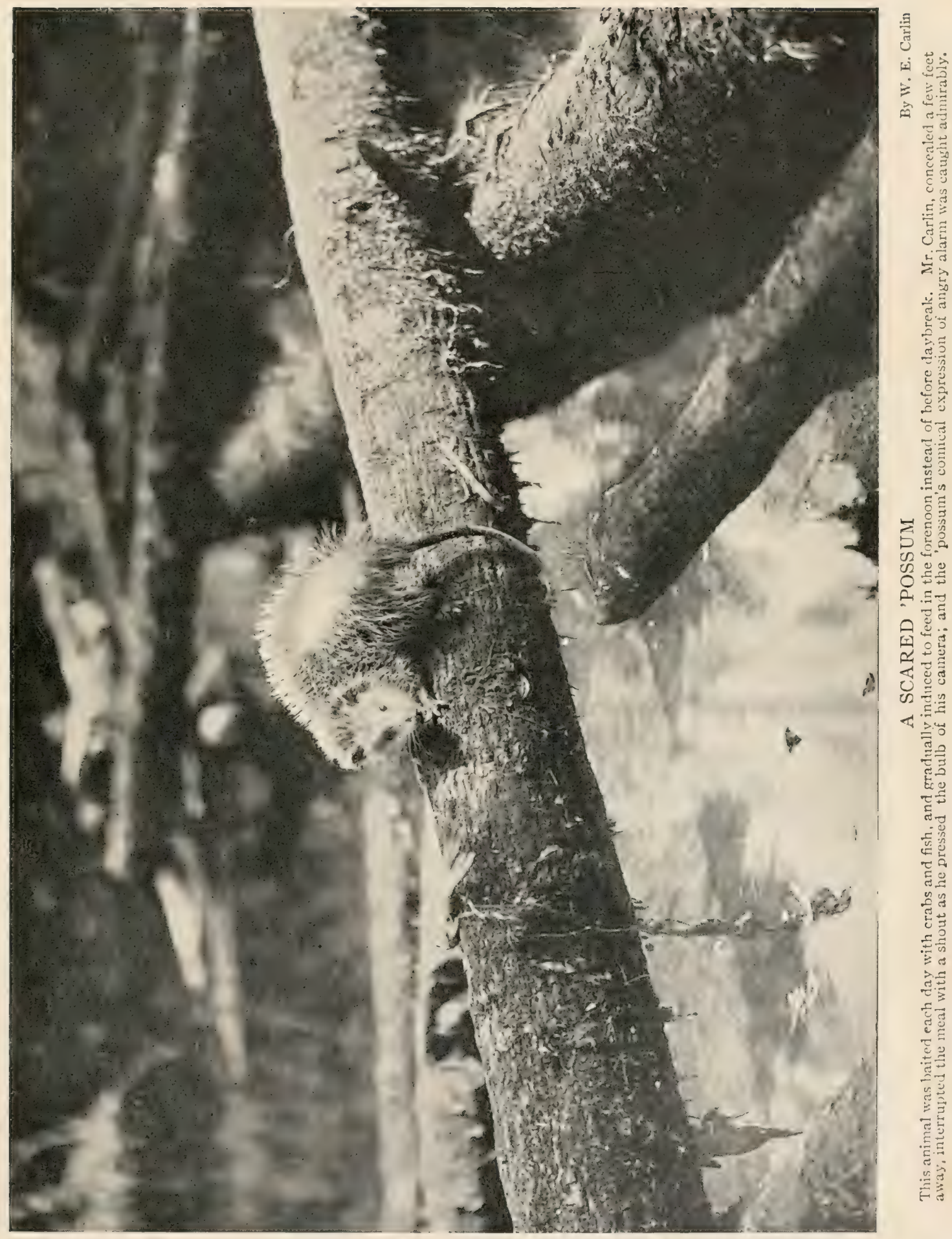



economic status in relation to the interests of mankind, there can be little doubt that the pile containing the matter, animate and inanimate, whose destruction is an advantage to us would be notably the larger."

The Negroes of the Southern States feel that the possum was especially created for their benefit and delight. They say, perhaps with truth, that no white man can ever fully appreciate the delicious joy of a moonlight possum hunt, or the delicate nlavour of roasted possum. There are plenty of white people who do enjoy hunting possums by the light of the moon, and eating their game the next day; but the varying degrees of happiness are not to be measured, and the exquisite enjoyment that the possum yields the darkey may only be guessed at. There is considerable similarity between a possum hunt and a coon hunt, so far as method is concerned. The Negroes like best to go in parties with two or three cur dogs along. Besides these there must be an axe, at least one antiquated fowling-piece and a sack for carrying the game. When the dogs start off on a hot trail, the darkies follow as best they may, stumbling along over rocks and stumps among the shadows. The possum frightened by the racket behind him soon takes to a tree for safety and flattens himself down on a branch or snuggles up in a crutch, trusting to remain unobserved.

But the Negroes flourishing their pitch-pine torches endeavour to locate their game by the glitter of its eyes in the nickering light, and if the tree is too big to cut down and difficult to climb, the rusty old firearm is brought into play. But as a general thing they much prefer capturing their possum alive if possible, either knocking him from his perch with a pole or chopping down the tree.

As soon as he strikes the ground, dogs and niggers fall upon him in one struggling, yelling heap, the dogs eager to kill the possum and their masters to get it away from them uninjured, and it is most astonishing how much rough handling an opossum can put up with without serious injury.

Sometimes he is carried home swinging by his tail from the end of a stick which has been split and snapped onto that member in such a manner as to hold him perfectly helpless.

The darkies' idea in taking him home alive, is to fatten for a few weeks in captivity, joyfully overlooking the mere question 
of economy in the matter; for the quantity of bread, yams and apples consumed by the sreedy little beast in litying up a few additional ounces of fat is a thing to be marvelled at.

\section{Varieties of the Opossum}

The opossums of North America show but little variation, but naturalists have recognized three varieties as follows, the last being allied to the opossum of Mexico.

I. Virginia Opossum. Didelphis virginiana Kerr. Range and description as above.

2. Floriat Opossum. Didelphis virginiana pigra Bangs. Similar but smaller with longer and more slender tail.

Range. Florida and lowland of Georgia along the Gulf Coast to Texas.

3. Texas Opossum. Didelphis marsupialis texensis Allen. Similar hut tail longer than in either of the above, equal to ninetenths insteid of three-fifths the length of head and body and black at base for one-third of its length. Range. Texas. 


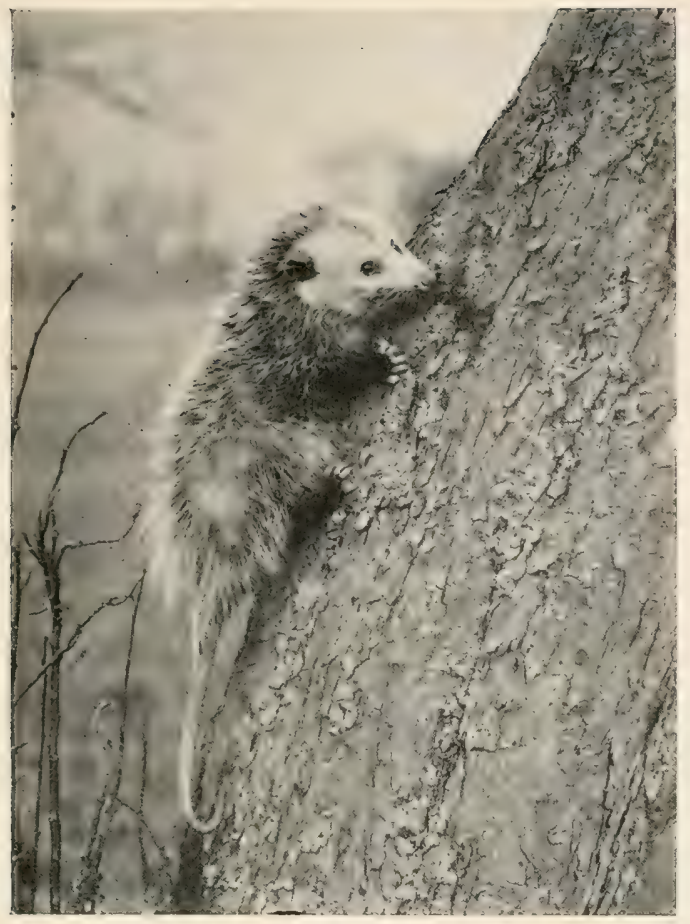

CLIMBING

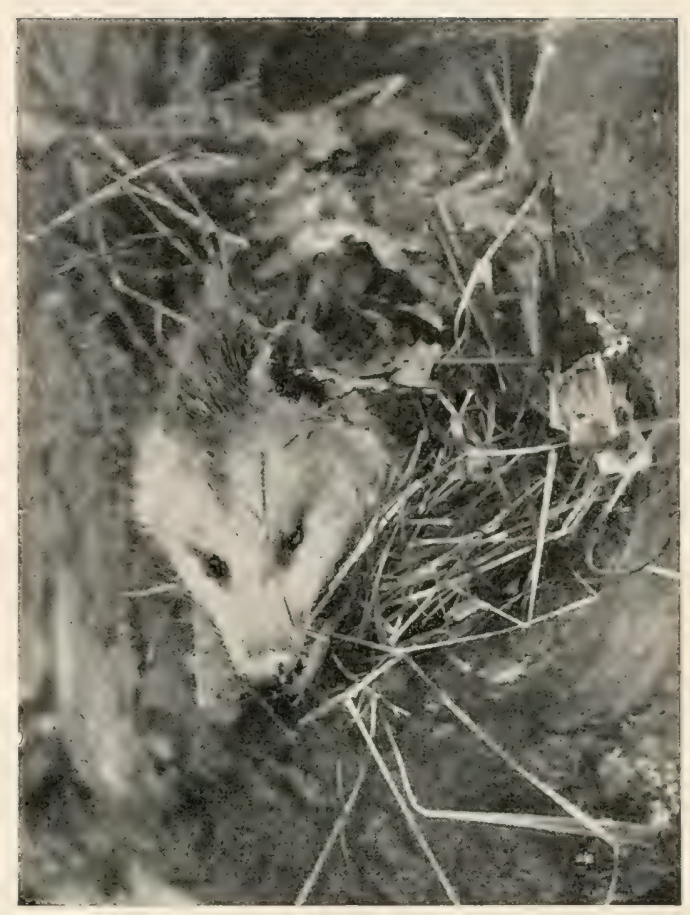

LOOKING OUT OF NEST

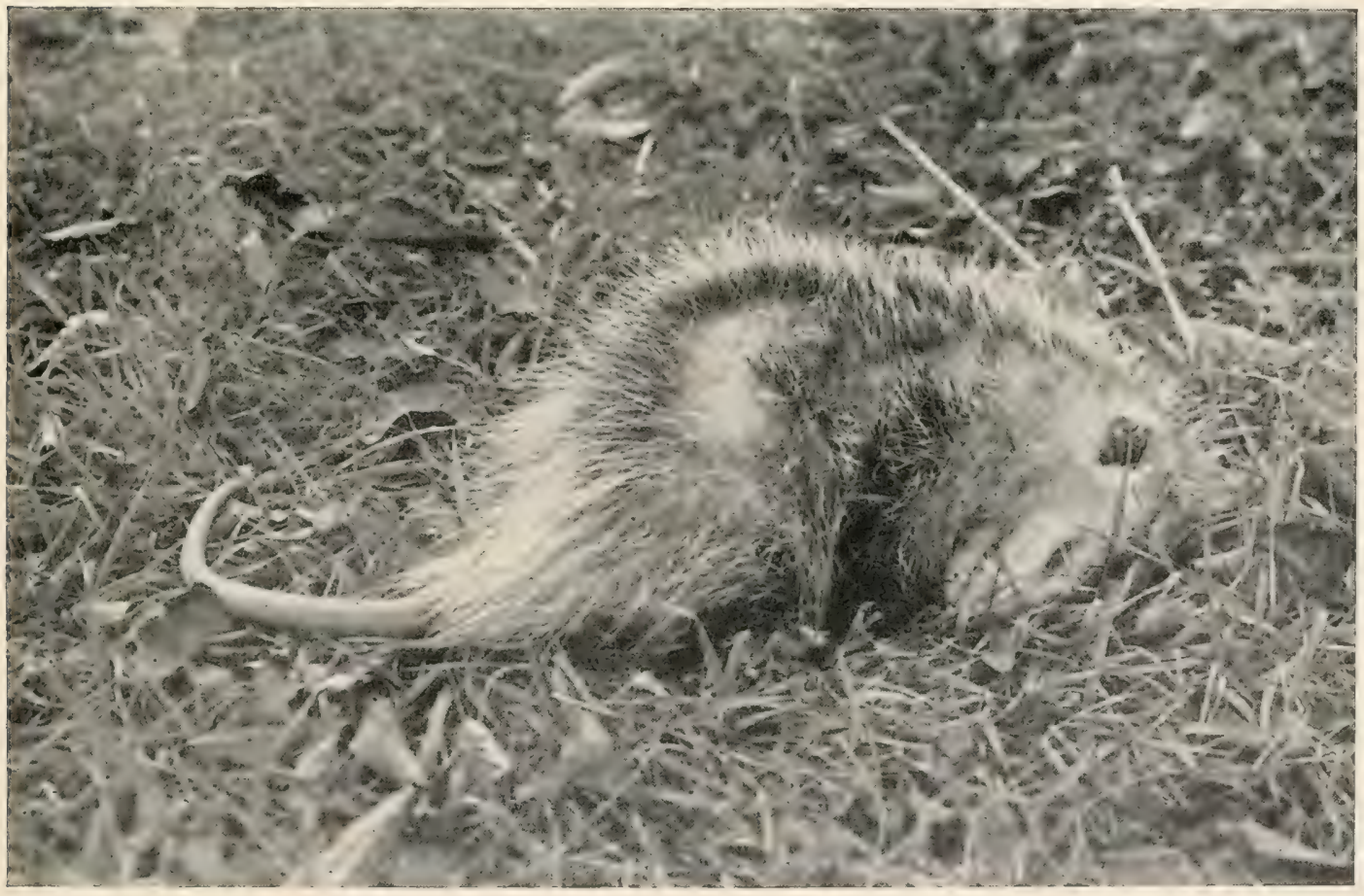

A NEW JERSEY 'POSSUM (Didelphis virginiana)

By A. R. Dugmore

"Playing 'Possum." This animal is actually alive. The picture of the animal climbing is the same individual photographed an hour or so later. 



\section{EDENTATES OR TOOTHLESS ANIMALS (Edentata)}

THE edentates stand at the bottom of the series of the nonmarsupial mammals. In distribution they are almost entirely restricted to South America, the best-known members of the group being the ant-eaters, sloths and armadillos. Of these only the ant-eaters are strictly "edentate" or without teeth; so the name is somewhat misleading, although none of them have any front teeth (incisors) and such teeth as they do possess are often rudimentary and decidedly primitive in character.

In former ages we had in North America gigantic beasts of this order, as is shown by the fossil remains of the megalonyx and mylodon, huge sloth-like animals, which existed along with the mastodon and sabre-toothed tigers and doubtless served as the chief source of food supply for the latter.

When we think of these former giants it is disappointing to find that our only representative of the edentates within the limits of the United States to-day is a single species of armadillo which crosses the Mexican boundary into the state of Texas.

This curious beast, representing the family Dasypodidce, is by no means without interest.

\section{THE ARMADILLOS}

Family Dasypodida

\section{Nine-banded Armadillo}

Tatu novemcinctum Linnæus

Also known as Peba Armadillo, Mulita.

Length. 30 inches.

Description. Body covered by a bony shell, consisting of two larger portions connected in the middle by eight bony rings 
(nine on the sides), which hinge one to the other so as to permit of the animal rolling itself into a ball. Front of the head, fore-feet and tail similarly armoured, toes of fore-feet with large claws for digging. Colour brownish-black above, somewhat varied with yellow, below yellowish white, skin on sides of face flesh colour with a few scattered yellow hairs.

Range. Southern Texas and Mexico southward to Paraguay.

Covered from end to end with his bony armament the armadillo at once recalls the box tortoise; and his sudden transformation, when harassed, into a round ball of horny plates reminds one not a little of the snapping shut of the shell of the turtle.

The armadillo is an habitual digger, making his burrows in the dry soil of the arid regions in which he lives and venturing forth mainly by night. In the matter of food he is not particular, vegetable and animal matter both appear on his bill of fare and carrion forms no small part of his diet, while the insects and maggots which it attracts are not overlooked.

The range of the armadillo within our borders is restricted and he is really more of a Mexican than an American, being one of a number of curious animals that push their way over our south-western boundary from that interesting country. 


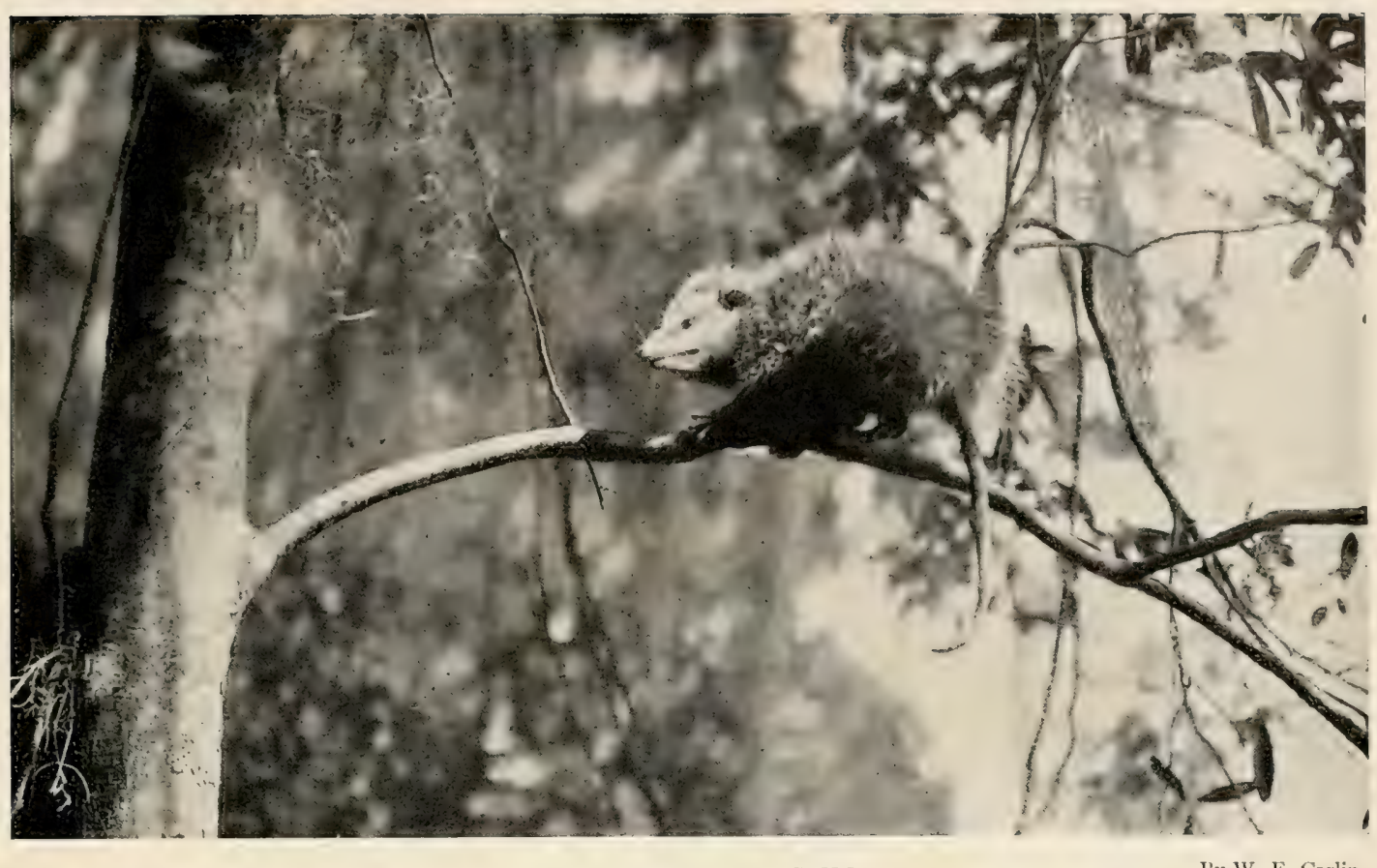

A FLORIDA 'POSSUM

By W. E. Carlin

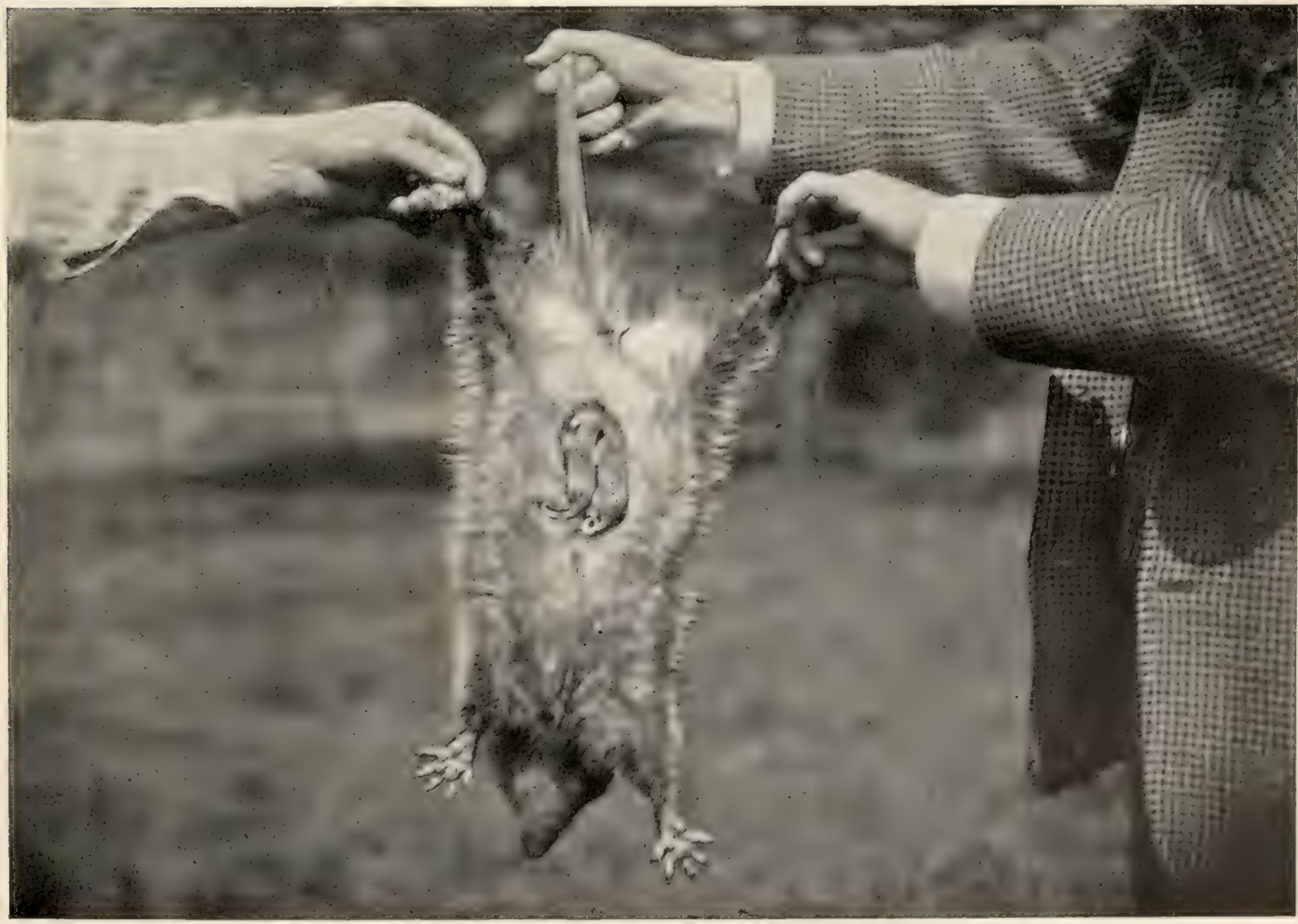





\section{CETACEANS \\ WHALES, DOLPHINS AND PORPOISES}

(Cetacea)

FEw persons associate whales with the four-footed beasts of the land. So modified are they for the peculiar life that they lead that practically no external resemblance to their true kindred remains, and it is not surprising that the popular mind classes them as fish, to which, however, they bear no relationship.

Whales are practically devoid of hair, which is characteristic of most mammals, its place in retaining the heat of the body being taken by the thick coating of fat or "blubber" lying just beneath the skin. There is no external trace of hind limbs and the fore-limbs are modified into flat flippers for swimming, while the tail is flat and forked like that of a fish, but it is flattened horizontally instead of vertically. There is practically no neck and the head, which is often very large, joins directly with the body. It is but natural, therefore, that the bones of the neck are very short and often joined solidly together. Whales have no close relationship with any other group of mammals and even the oldest fossil whales that have been discovered present much the same structure as the living species. Though they were undoubtedly descended from some form of land mammal, the change to an aquatic life must have taken place at a very remote period. As has been suggested, the immediate ancestors of the whales probably became adapted to a life on the shores of rivers and acquiring the habit of swimming were eventually carried out to sea, where peculiar environment has brought about their present structure.

The cetaceans are entirely carnivorous, and their food generally consists of small mollusks, shrimps and fishes. They frequently associate in companies or "schools" and are for the most part inoffensive and rather timid. In size they vary from the smallest porpoises, somewhat less than ten feet long, to the largest whales which reach a length of sixty to eighty-five feet 
and constitute the largest known animals. The whales and their allies are grouped in several families as follows:

1. Whalebone whales (Family Balamilat). Size very large (length 30-85 feet). mouth enormous, no teeth, but the upper jaw provided with long strips of whalebone.

11. Sperm whales (Family Phiseteriatr). Teeth all along the lower jaw, but absent entirely from the upper. Length 10-80 feet.

III. Bottle-nosed whales (Family Ziphiida). One tooth on each side of the lower jaw or with no visible teeth at all; a narrow projecting snout. Length 20-30 feet.

IV. Dolphins and porpoises (Family Delphinitar). Teeth numerous in both jaws (or with one long horizontal tusk in the narwhal). Head in some species rounded in front while others have a projecting snout. Length 5-15 feet.

\section{WHALEBONE WHALES}

\section{Family Balanida}

This family includes all of the true whales or toothless whales, as they are variously called, and the only large "whale" not included here is the sperm. Whale which is really more closely allied to the porpoises and dolphins. The whales are characterized by their immense size, enormous head, and total absence of teeth. Small teeth are, it is true, formed very early in their development, but they are entirely absorbed before birth.

Another peculiarity of the family is the presence in the mouth of "baleen" or whalebone. This consists of thin, flexible, horny plates, somewhat triangular in outline, which are attached crosswise down each side of the roof of the mouth. The inner edgres of these plates are much split up and frayed so that the slender filaments form a sieve reaching from the top to the bottom of the mouth, by which the witer is strained alwaly from the small marine animals that are scooped up by the whale and which constitute its food. By raising the tongue in the nearly closed mouth the water is expelled from the lips and the food remains.

There is a popular idea that the water taken into the mouth is discharged through the nostril or "blow hole" situated on 

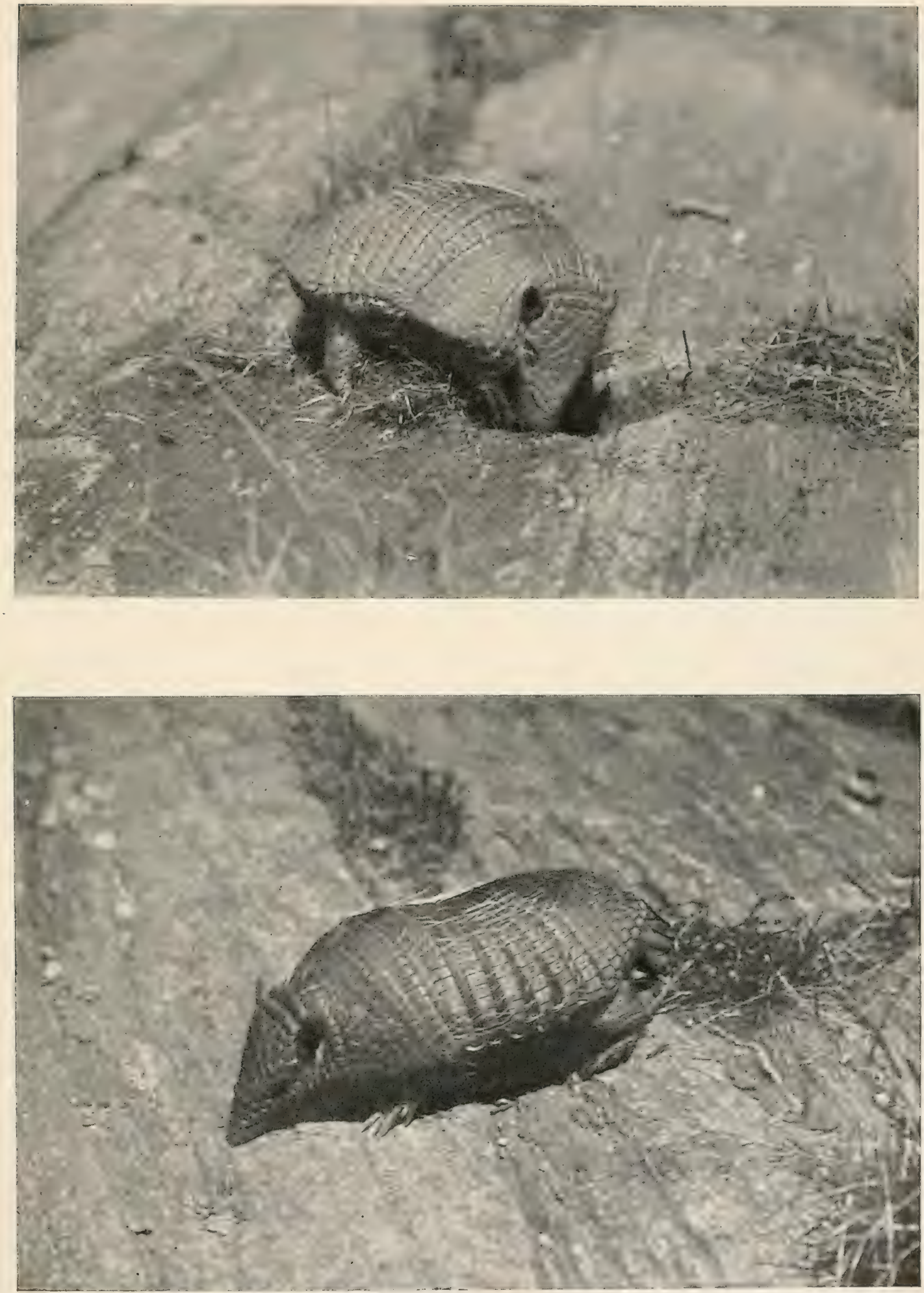

SIX-BANDED ARMADILLO (Dasypus sexcinctus)

By C. William Beebe A tropical species allied to our nine-banded Armadillo, but with shorter ears and tail and only six rings. 

top of the head, and forms the well-known "spout" of the whale. This is quite a mistake, however, as the spout is simply the discharge of air from the lungs when the animal rises to the

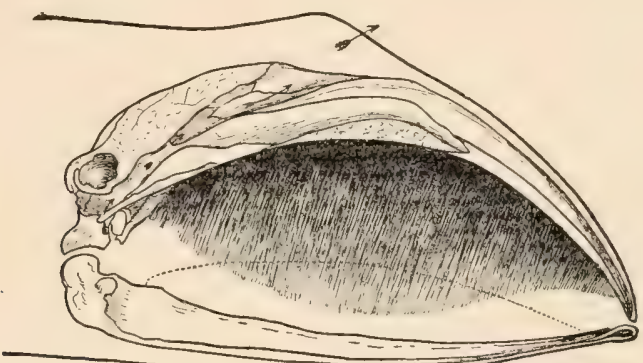

Longitudinal section through head of whale, showing position of whalebone and nasal opening. (After Lydekker.)

surface to take a new breath, and the watery appearance of the spout is due to the condensation of moisture in the discharged breath and also to the fact that some water is thrown up if

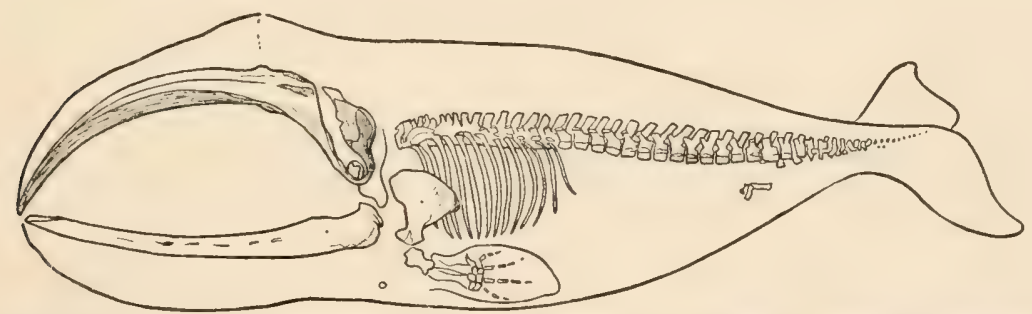

Skeleton of whale (Balcana), showing contour of body, (After Lydekker.)

the breath is expelled before the whale quite reaches the surface. We have three quite different types of whalebone whales on our coast, and from one to three species of each.

\section{Right Whale}

\section{Balaena glacialis Bonnaterre}

Length. 50 to 60 feet.

Description. Head enormous, equal to one-third of the totai length; highly arched above the level of the back; mouth cavity consequently large and whalebone very long. Bones 


\section{Right Whale}

of the neck always fused together, no fin on the back and no longitudinal groves on the throat. Colour black, sometimes slightly varied with white below. Range. North Atlantic Ocean.

Few persons have opportunities to study the habits of the large whales and those who follow the business of whaling do not, as a rule, record the facts that they may discover regarding the lives of these interesting creatures. The experience of most of us is limited to the glimpse of an occasional spout far out to sea or perhaps the sight of a stranded whale washed up on the heach, a great shapeless mass partially imbedded in the sand and often advanced in decaly. It is not always easy to identify such specimens until the skeleton is laid bare, and it is not surprising, since much of our knowledge of whales is based upon skeletons and stranded specimens cast up at widely distant points, that zoologists are still in considerable doubt as to just how many kinds of whales exist.

From the accounts of those who have studied these gigantic animals in life we learn that when not frightened they remain at the surface to breathe from one and a half to two and a half minutes during which time they spout from six to nine times and then disappear for ten to twenty minutes. When at the surfice the top of the arched head and the middle of the back are the only parts which project from the water.

This whale and the allied bowhead (Balana mystictus) of the Arctic regions are especially prized by the whalers on account of the great length of their whale-bone.

Speaking of the right whale of the Pacific, which is closely allied to the Atlantic animal, Captain Scammon says: "We find the habits of these animals when roaming over the ocean full of interest. They are often met with singly in their wanderings, at other times in pairs or triplets and scattered over the surface of the water as far as the eye can discern from the mast head. Toward the last of the season they are seen in large numbers crowded together. These herds are called 'gams' and they are regarded by experienced whalers as an indication that the whales will soon leave the grounds." It is their habit, he states, to blow seven to nine times at a "rising" and then "turning nukes," as the whalemen say, and elevating the tail from six to 
eight feet clear of the water, they go down for periods of twelve to fifteen minutes.

Whales of all sorts have been so persistently pursued and killed that they are to-day very much reduced in numbers and the survivors have become so wary that it is much more difficult to hunt them than it was in former years.

Originally whales came regularly along the New England coast and were hunted from shore, the boats putting out after them as soon as they were sighted, but as years passed they learned to keep farther out to sea and vessels had to be especially equipped for their pursuit. In his account of whale-hunting Scammon states that when the whale has been sighted the whale boats with their full equipment and manned by their regular crews are lowered from the vessel and start upon the chase. "The whale is approached in the most cautious manner to avoid exciting it. If necessary, the oars are used, but in calm weather the paddles are resorted to. When within darting distance, which is about three fathoms, the order is given to the boat steerer to stand up. He instantly springs to his feet and, seizing the harpoon (to which a long rope is attached), he darts it into the whale. If opportunity offers a second iron is also thrown before the animal gets out of reach. When the harpoons are darted the order is given to 'stern all' and the oarsmen make every effort to force the boat astern in order to be well clear of the animal in its painful convulsions from the first wounds received.

"When struck the whale may attempt to escape by running, if so, every exertion is made by the boat's crew to haul up the animal so as to shoot a bomb into it or work upon it with a hand lance or, if the creature descends to the depths below, which is called 'sounding,' every effort is made to check the movement by holding on to the line or by slowly slacking it. In this manœuvre the boat is occasionally hauled bow under water. Sometimes all the line is taken out almost instantly, when it is cut to prevent the boat from being taken down and the whale escapes.

"The whale after being struck often runs to windward, thrashing its flukes in every direction. After going a short distance it frequently stops or brings to, at the same time making a terrible noise called 'bellowing,' this sound is compared to that of a mammoth bull and adds much to the excitement of the chase and 


\section{Finback Whale}

capture. Other whales will not stop until they are hamstrung, as it were, by 'spading.' The spading process is performed by hauling the boat near enough to cut the cords that connect the body and the flukes either on top or underneath. A large vein runs along the side of the back, terminating at the juncture of the caludal fin which, if cut, will give the creature its death wound." Another method of bringing the animal to a stop is by lacerating it with numerous harpoons detached from the ropes. "When brought to, it usually remains quite stationary for a few minutes or will roll from side to side, giving the officer of the boat a good opportunity to shoot a bomb lance or use the hand lance with good effect, which soon dispatches it."

The ship is then brought alongside or, in calm weather, the whale is towed to it and the "cutting in," as it is termed, begins. A cutting stage is lowered down over the animal upon which the men may stand, the tackles are fastened to the carcass and the head is severed and hoisted on deck while the remainder is cut according to a regular system so that the blubber is removed in several great masses while the mutilated remnant of the monster floats away or sinks to the bottom. The blubber and baleen are removed from the head later.

Scammon states that the great bowhead whale will sometimes yield as much as 275 barrels of oil and the right whale 1,30 barrels, while the whalebone of the two maly amount to 3,000 and I, 550 pounds respectively.

Whaling has been engaged in since 1712 by vessels from New England ports, especially Nantucket and New Bedford, and in England and Scotland it has been carried on for over a century.

Guns for shooting the harpoons have superseded the handthrowing process and improved harpoons have been introduced carrying explosive bombs which are calculated to kill the whale as soon as they strike, but so wary have the survivors become that in this instance modern improvements will have little effect in hastening extermination already so far advanced.

\section{Finback Whale Baianoptera pliysalis (Linnæus)}

Called also Rorqual, Finner.

Length. $40-50$ feet. 
Description. Head equal to or rather less than one-quarter the total length. Not arched, but broad and flat above. A fleshy fin is present on the back, and the throat is longitudinally furrowed while the bones of the neck are separate. Colour jet black above, including the flippers, white below, marbled on the sides by a combination of the two colours. Range. North Atlantic Ocean.

The fin-back is said to be a more active and rapid swimmer than the right whale, but its general habits are much the same. Judging by stranded examples fin-back whales are the most common of the large whales on our Atlantic Coast.

Besides the common fin-back we have the blue whale (Balcenoptera musculus), a larger species of a purplish slate colour, while other closely allied varieties occur in other parts of the ocean.

\section{Humpback Whale Megaptera nodosa (Bonnaterre)}

Length. 50 feet.

Description. Similar to the finback whales, but with the back strongly convex and the flippers very long and scalloped on the edges. Sooty-black above, white beneath.

Range. North Atlantic Ocean, represented elsewhere by closely allied species.

\section{THE SPERM WHALES}

\section{Family Physeteride}

Here belong two whales, one large and one small, but both recognized by their regularly toothed lower jaw, toothless upper jaw and high vertical forehead.

\section{Sperm Whale}

\section{Physeter macrocephalus Linnæus}

Also called Cachalot.

Length. $60-80$ feet. 


\section{Pigmy Sperm Whale}

Description. Head oblong, level with the back on top and square and truncate in front, forming nearly one-third of the total length of the animal; lower jaw shallow and very narrow in front, armed with 22 to 24 large teeth on each side. Back with a hump on the neck and several humps farther back, but no dorsal fin. Colour black or blackish brown, lighter below, sometimes marbled.

Range. Tropical and subtropical oceans, now very rare in the North Atlantic.

The sperm whale or Cachalot is the largest of the toothed cetaceans, and in its great bulk recalls the whalebone whales, though the peculiar truncated head and narrow, shallow lower jaw, with its formidable array of teeth, serve easily to distinguish it. The nostrils of the sperm whale open at the extreme front of the head instead of farther back, as in the whalebone whales, and its "spout" issues diagonally forward instead of vertically upward. This peculiarity enables whalers to identify the sperm whale at very great distances.

This animal seems to feed at great depths and is able to remain under water longer than any other species-sometimes for over an hour at a time, according to Captain Scammor. When at the surface it respires thirty to sixty times at short intervals with great regularity and then, "pitching head-foremost downward, turns his flukes high in the air and when gaining nearly a perpendicular attitude descends to a great depth."

The food of the sperm whale consists of various "squids" or cuttlefish. The "ambergris" discharged from its intestines is a valued article of perfume.

\section{Pigmy Sperm Whale}

\section{Kogia breviceps (Blainville)}

Length. 10-15 feet.

Discription. In a general way much like the preceding, but differs in its small size, slender curved teeth, and in the presence of a fin on the back.

Range. North Atlantic and other oceans. Several specimens have been taken on our shores of late years, although it is a rare animal. 


\section{BOTTLE-NOSED WHALES}

\section{Family Ziphiide}

These whales are rare on our coasts and comparatively little is known of their habits. They are intermediate between the sperm whales and dolphins, both in size and structure. They all possess protruding snouts and have never more than two teeth. The front of the skull enlarges with age, the forehead becoming vertical or even projecting in very old individuals. Three species are known on our coast.

\section{Bottle-nosed Whale}

\section{Hyperoödon rostratıs (Müller)}

Length. 20 feet.

Description. Forehead more or less vertical, as described above, beak prominent, a depression on the head around the blowhole, flippers and dorsal fin moderate. No teeth visible, though two can be found at the front of the lower. jaw loosely bur ied in the gums. Colour blackish lead, somewhat lighter below.

Range. North Atlantic and deubtless other oceans.

\section{Ziphius Whale}

\section{Ziphius cavirostris Cuvier}

Length. 15-20 feet.

Description. Similar to the preceding, but with the teeth at the front of the lower jaw usually visible. Three of the neck vertebral bones are also separate, while in the bottle-nose all are united. Colour light stone-gtay, darker on the belly. Range. Pelagic.

\section{Cow-fish}

\section{Mesoplodon bidens (Sowerby)}

Length. $\quad$ I 6 feet.

Description. Similar to the preceding species, but the male with 
a tooth on each side of the lower jaw at about the middle, female toothless. Skin very smooth and polished, uniform black all over with occasional lighter blotches. Range. North Atlantic, apparently a deep-water species.

\section{DOLPHINS AND PORPOISES}

\section{Family Delpininide}

The smaller cetaceans, popularly known as dolphins and porpoises, compose this family. Properly speaking, the name dolphin belongs to those species which have a projecting snout, while porpoise refers to those with uniformly rounded head. With their usual perversity, however, our earliest settlers christened the commonest of these animals on our Atlantic Coast the "porpoise," while in reality it is a true dolphin, the same as the "bottlenose" of the coasts of Europe.

Both dolphins and porpoises have a well-developed fin on the back and with one exception (the Grampus) have a large number of sharp teeth in both jaws.

The other members of the family, the white whale and the narwhal are found only in the Arctic regions and are peculiar in many ways. Both lack the dorsal fin and the narwhal is devoid of teeth except for the single long protruding tusk.

\section{Bottle-nosed . Dolphin}

\section{Tursiops tursio (Fabricius)}

Called also Porpoise on our Atlantic Coast.

Length. 9 feet.

Description. Stout, forehead sloping, heak short and depressed,

hack fin about midway between the nose and the tip of the

tail. Colour plumbeous gray above, lighter on the sides, shading gradually into pure white on the under surface. Teeth 22 in each jaw.

Range. North Atlantic coasts from Maine to Florida and through the Gulf to Texas, also coasts of Europe.

This is the most familiar cetacean of our Atlantic seaboard, 
and few are the visitors to our seaside resorts who have not seen a school of "porpoises" passing up or down the coast just beyond the breakers, their arched backs and pointed fins rising at regular intervals above the surface of the waves and disappearing again, as the animal continues on its undulating course. Occasionally with a stronger leap than usual the powerful fluked tail is seen above the water and sometimes the entire body is exposed.

Like other members of the family, porpoises are sociable and always gather in herds or "schools" of varying size and in this way no doubt they pursue with better effect the mackerel, herring and other fishes upon which they feed.

Often at sea porpoises will associate themselves with some passing ship and for miles at a time plunge along close to her side, perhaps taking the vessel for some gigantic member of their own tribe. I have watched them travelling in this manner for long intervals and they kept close to the prow, as if piloting the ship on its way and apparently with no thought of the scraps or refuse which they might have secured had they been following in our wake.

Several species of similar habits occur in the north Atlantic which are described below, while others are found in the other seas.

\section{Common Dolphin}

\section{Delphinus delphis Linnæus}

Length. 7 feet.

Description. Beak longer and narrower than in the preceding. Colour variable; back, fin and tail black, under parts white, sides gray. The black descends on the sides to about the middle, and there is a black ring around the eye and a black line to the beak. There is usually a dusky band from the jaw to the flipper and one or two stripes on the sides. Teeth 47 to 50 above, and 46 to 51 below.

Range. Pelagic. Apparently not common on our coasts, but has Leen taken in New York Harbour, Wood's Hole, etc.

\section{Spotted Dolphin}

Prodelphinus plagiodon (Cope)

Length. 7 feet. 
Discription. Very similar in shape to the last. Purplish gray above, white below, upper parts spotted with white, lower with dark gray. Teeth 37 above, $3+$ below.

Range. Atlantic and Gulf coasts north to Cape Hatteras.

\section{Striped Dolphin}

\section{Lagcnorhynchus acutus (Gray)}

Length. 8 feet.

Discrition. Beak very short, a mere rim with a depression between it and the forehead on each side. Colour black on back, rest of body gray, sides with white and yellowish patches; a narrrow black stripe from the base of the tail halfway to the middle of the body; eye surrounded with black and black lines from it to the snout and flipper; llippers black. Teeth 35 above, 37 below.

Range. North Atlantic, southward to Cape Cod.

\section{Harbour Porpoise}

\section{Phocana phocana (Linnæus)}

Length. 5 feet.

Descrition. Head rounded in front, no beak or snout. Fin of the back more triangular than in the dolphins. Colour dark slate or blackish, shading gradually to white on the belly, sides somewhat tinged with pink or yellowish, and a dark band from the lower jaw half way to the Mipper. Teeth 26 in each jaw.

Range. North Atlantic south to New Jersey; also on coasts of Europe and in the Pacific.

As the bottle-nose (Tursiops tursio) is the commonest of the dolphins on our coast, this is the best known of the round-heatded or porpeise group. It is apparently more common on European coasts than with us and, being more northern in its range, is not so familiar as the common bottle-nose to our sea-shore visitors.

The five species which follow are all allied to the harbour porpoise, but have striking peculiarities which have earned for them distinctive popular names. 


\section{Blackfish}

\section{Globiocephala melas (Traill)}

Called also Pilot Whale, Ca'ing Whale.

Length. 15 feet.

Description. Size large, forehead vertical, high, sometimes even overhanging the lips which are slightly protruding; flippers very long (4 feet); back fin situated in front of the middle, and sloping backward. Colour uniform black with a V-shaped white mark on the breast connecting with a white stripe down the belly. Teeth 10 in each jaw.

Range. North Atlantic, south to Long Island on the American side. Further south it is replaced by the southern blackfish (G. brachupterus, Cope), entirely black, with much shorter flippers and only 8 teeth in each jaw.

This large animal resembles somewhat the bottle-nosed whale (Hyperoölon), but is recognized at once by its long flippers and numerous teeth. It is said to be more gregarious than other species, associating in herds of two or three hundred individuals which blindly follow their leader like a flock of sheep.

\section{Grampus}

\section{Grampus grisens (Cuvier)}

Length. $\quad$ Io feet.

Description. Similar to the blackfish, with the same high forehead, but recognized by the higher back-fin, and the absence of teeth in the upper jaw. Colour dark gray above, lighter below and on the head, sides with irregular lighter stripes, flippers black mottled with gray. Teeth absent above, 6 to I4 in the lower jaw.

Range. North Atlantic southward to New Jersey, also coasts of Europe and north Pacific.

\section{Killer}

Orca orca (Linnæus)

Length. 20 feet.

Description. Size large, forehead flat, back-fin enormous (6 feet 
high in the male), flippers short and rounded. Colours black above and white below in strong contrast; the white extends upward on the sides in two stripes and there is a white spot above each eye and a purplish area behind the back

fin. Teeth 10 to 13 in each jaw, large and sharp. Range. Oceans, generally distributed.

The other members of the dolphin family are easy going, rather timid animals subsisting on fish and smaller marine animals, but in the killer we find all the fierce predatory characteristics of our carnivorous land animals or the sharks among the fishes. They kill and devour the blackfish and larger whales as well as seals and large fishes. Captain Scammon says: "The attack of these wolves of the ocean upon their gigantic prey may be likened to a pack of hounds holding the stricken deer at bay. 'They cluster about the animal's head, some of their number leaping over it, white others seize it by the lips and hat the bleeding monster under the water and, when captured, should the mouth be open they eat out the tongue."

\section{White Whale}

\section{Delphinapterus leucas (Pallas)}

Length. II feet.

Discription. Head rounded, neck slightly narrowed, flippers small and rounded, no fin on the back. Colour entirely white. Teeth 9 in each jaw.

Range. Arctic seas, straying southward rarely as far as Cape Cod.

The white whale is one of the characteristic animals of the frozen north and though forced a little southward by the ice of winter it rarely reaches the boundary of the United States. In early summer when the ice breaks up and the herring and other fishes throng the bays to spawn, the white whales pursue them and large numbers of the cetaceans are frequently stranded in shallow water where the Eskimos kill them with ease.

\section{Narwhal}

\section{Monodon monoceras Linnacus}

Length. 12 feet.

Description. Head short and rounded, flippers short and broad 
no fin on the back. Colour dark gray above, white below, sides and back with darker spots. No teeth in the lower jaw and but one above--a long horizontal twisted tusk, 5 to 6 feet in length. (A short rudimentary tusk is imbedded in the skull on the opposite side.) Range. Arctic seas, accidental farther south.

This curious "sea unicorn" is another inhabitant of the far north, and its immense tusk plays an important part in the weapons and tools of the Eskimo. This tusk is really one of the front teeth, and while it appears to protrude from the middle line of the head, an examination of the skull will show that it belongs wholly to one side, which is greatly developed at the expense of the corresponding portion of the other side. A second rudimentary tusk will also be found imbedded in the bone of the skull. 


\section{MANATEES AND DUGONGS}

(Sircnia)

THFs: animals on account of their aquatic habits have been frequently associated with the whales, but there seems no real relationship between them and it is probable that each has departed from the stock of the terrestrial mammals at a different point. lust what the affinities of the manatees are we have no more definite knowledge than in the case of the whales, nor does palæontology throw any light on the question.

The resemblance between the manatees and whales is practically limited to the flipper-like fore limbs, flat tail and scarcity or absence of hair on the skin. The tail of our manatee, however, is not forked like that of the whales and the head is wholly different, relatively small and provided with a series of squaretopped molar teeth, while some species have incisors as well. Only about eight species of these curious animals are known.

\section{THE MANATEES}

\section{Family Trichechida}

This family includes only the manatees. The dugongs of the Old World and the peculiar Steller's sea cow which formerly inhabited the north Pacific, being arranged in separate groups.

\section{Florida Manatee}

\section{Trichechus latirostris (Harlan)}

\section{Called also Sea Cowv.}

Length. 9 feet.

le'seriftion. General shape cylindrical, neck short, not much contracted, forehead obligue, nose, as seen from the front, triangular, lips thick, upper one clothed with bristles and capable 


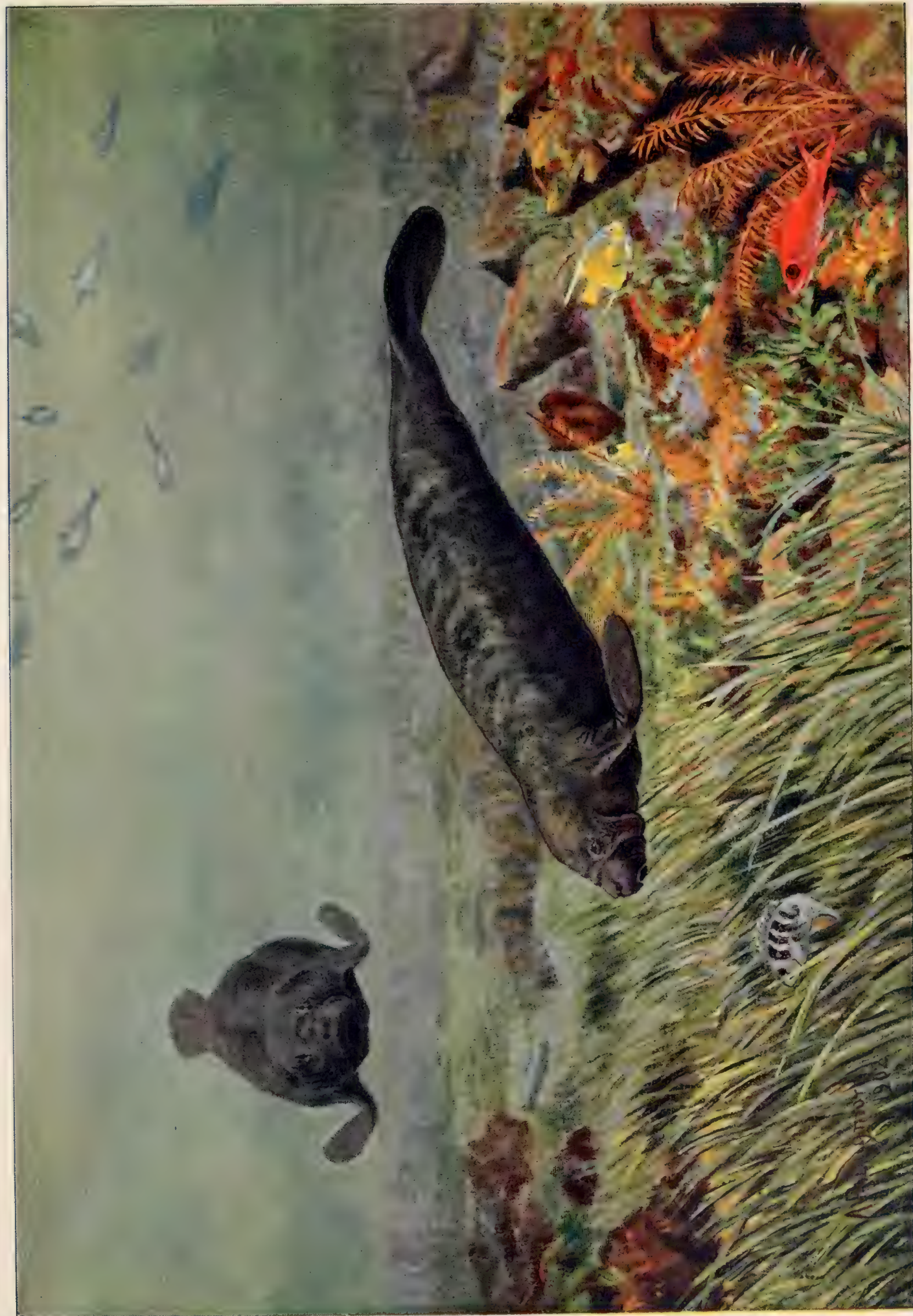



of much expansion. Tail flat and widened, then tapering to a point, flipper rather long ( $\mathrm{I}$ foot), eyes small, skin with a few scattered hairs. Colour bluish black, somewhat paler below and gray on the muzzle.

Range. Formerly the Gulf and South Atlantic coasts of the United States, now restricted to rivers and lagoons of south-eastern Florida and becoming very scarce.

The exact number of species of manatee which occur on the coasts of the New World is a matter of some doubt, but it is pretty certain that the Florida manatee is different from the Trichechus americanus of South America.

Unlike the whales, manatees are not lovers of the open ocean, but remain close along shore, feeding in the bays and lagoons on the various water plants and grasses. From the meagre accounts that we have of these animals in their native haunts they seem to spend their time lazily floating or wallowing about with the upper part of the head generally exposed. Those kept in captivity usually rest on the bottom of their tanks and rise to the surface for air at periods of from two to six minutes. They accomplish this " with the least perceptible movement of the tail and flapping motion of the paddles, raising the upper part of the body until the head reaches the surface, when the air is admitted through the nostril flap valves which are closely shut after the operation." * They seemed ill at ease when the water was drawn off and were apparently unable to progress on land. When feeding they seemed to fan the strands of grass and sea weed into the mouth by means of the copious bristles which surround it.

It is sad to contemplate the extinction of these curious beasts which present so many interesting peculiarities to the naturalist, and problems in evolution which he has yet to solve. Their harmlessness would seem to warrant their preservation, but it seems on the other hand to aid in their destruction. As fast as the settlement of the country makes their haunts more accessible their numbers lessen and, being tropical in their nature, the frosts and cold spells which have of recent years prevailed in Florida with such ruin to the orange groves have also played sad havos with the remaining small band of manatees.

* Crane. "Proc. Zool. Soc.," London, I880, p. 456. 


\section{IINGULATES OR HOOFED ANIMALS \\ (Ungulata)}

To this order belong most of the largest mammals. Representatives occur in all parts of the world except Australia and Madagascar, but they are most abundant in the tropics of the Old World.

Nearly all the "game" mammals belong to this order and through the persistent efforts of the hunters quite a number of species are rapidly approaching extinction. Here too belong the domestic animals which have served man as beasts of burden and as a source of food and clothing from time immemorial-the horse, ass, cow, sheep, goat and hog.

The ungulates are herbivorous, and many of them are gregarious, associating in large herds.

In structure they differ from all the other orders in the possession of rounded horny hoofs which terminate the toes and correspond to the claws of the rodents and carnivores. All ungulates are also digitigrade, walking on the tips of the toes with the heel much elevated. In most species the legs are decidedly long, and the feet much elongated, while there is always a reduction in the number of toes. This reaches its extreme in the horse which has but one toe on each foot, though the remnants of two others still remain in the slender bones known as "splints."

The smallest ungulates are the chevrotains and some of the antelopes of Asia and Africa which scarcely reach a height of twelve inches at the shoulder, from these they range all the waly to the gigantic rhinoceros and Indian buffalo, and the slender giraffe.

The order is divisible into two groups-the Perissodactyli or odd-toed ungulates, including the horse and zebral (one toe); the rhinoceros and tapir* (three toes), and the Artiodactili or even-toed ungulates; the hippopotamus (four toes); cimel and giraffe (two toes), and the pig, deer, sheep, ox, etc. (four toes, two of which are rudimentary).

The deer and their allies constitute the section of ruminants to which all the domestic cattle belong and which are characterized by a

* The tapir has four toes on the front feet. 
peculiar four-parted stomach and the habit of casting up the hastily cropped grass for further mastication when resting later on. This operation is called "chewing the cud," and one of the

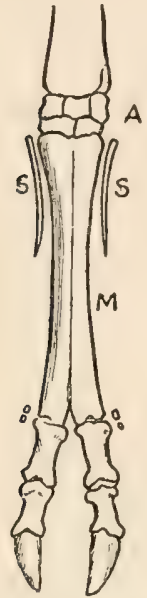

Foot of a ruminant (sheep)

A Ankle bones.

M Metatarsals fused together.

S "Splints" or remnants of other metatarsals. The corresponding toe bones are seen below. (After Lydekker). compartments of the stomach serves as a receptacle for the food, while it awaitsthis supplementary chewing. The canine teeth are often wanting in the hoofed animals and in the ruminant group the front teeth or incisors of the upper jaw are also lacking. The large grinders or molar teeth are always present and exhibit the most complicated type of tooth known. Most of the ruminants are further peculiar in the possession of horns or bony antlers growing out from the top of the skull.

Great numbers of fossil ungulates have been discovered and it has been possible to show the gradual evolution of the living species through a long series of extinct ancestors.

Remains of extinct horses and rhinoceroses have been found abundantly within the United States as well as animals for which we have no familiar names. To-day, however, our native ungulates are comparatively few in number and are grouped in four families, all of them belonging to the even-toed division.

I. Peccaries (Family Dicotylidce). Pig-like animals, not ruminant and without horns. Canine teeth large and prominent, front teeth (incisors) in both jaws.

11. Deer, elk, etc. (Family Cervidce). Ruminant animals with bony branching antlers on the head of the males (and females also in the caribou), which are shed every year. Rudimentary canines generally present but front teeth (incisors) only in the lower jaw.

III. Prong horn (Family Antilocapride). Allied to the cattle (Bovidce), but the hollow horns are forked and are shed as in the deer.

IV. Cattle and their allies (Family Bovida). Ruminant animals with hollow horns fitting over bony prominences on the skull in both males and females. These horns are 
straight or curved, but never branched, and are not shed annually. Teeth as in the deer, but the canines are entirely lacking.

\section{PECCARIES \\ Family Dicotylida \\ Texas Peccary}

Tayassu angulatum (Cope)

Length. 34 inches.

Disiription. Pig-like, with short erect ears, no tail, bristly hair and a scent gland on the back. Individual hairs banded black and white, producing a mottled appearance, the face, mane of the back, throat, legs, underparts, ears and hoofs are black, while a white collar-like band reaches from the sides of the neck over the shoulders.

Range. Texas and south-western Arkansas. The closely related collared peccary is found in Mexico.

Peccaries are the American representatives of the pig family and take the place of the wild boars of Europe. Like many other products of the western hemisphere, they are an improvement upon their like in the Old World inasmuch as they are distinctly more advanced in development. They have a complicated stomach, somewhat like that of the ruminant mammals, and have three instead of four toes on the hind feet.

In general appearance the peccary resembles a small black pirs, with a mane and slender legs, and he is said to root and Wallow in a truly pig-like fashion.

The home of the Texas peccary is low river bottoms with lense thickets and overgrown swamps. Here he may be found singly or in small droves feeding on the acorns, pecans and walnuis or grubhing up roots. Spots which are particularly frequented hy them usually smell strongly of the peculiar skunk-like odor which they emit.

Whatever there may be in the stories of the fierceness of the South American peccaries, our species seems to be a harmless 


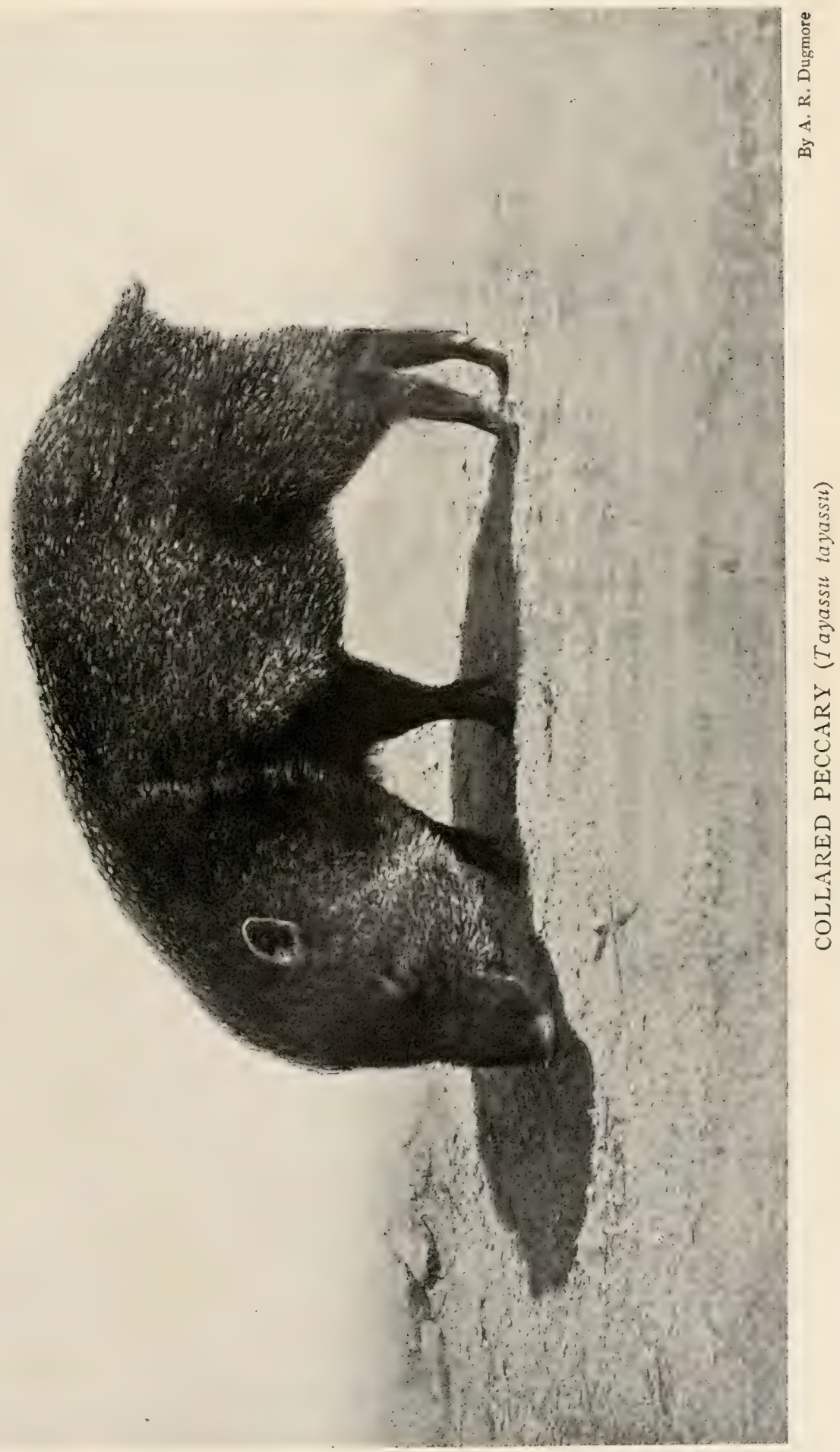



beast, preferring to escape by flight rather than turn upon its pursuers, though its sharp teeth and well-developed tusks would make it a rather formidable enemy.

\section{DEER AND THEIR ALLIES}

\section{Family Cervide}

To this family belong the majority of our American hoofed animals. As has already been explained, their most distinctive characteristic lies in their solid horns or antlers, which are shed once a year. The new horn grows rapidly and is for a time soft, full of blood vessels and provided with a downy covering known as the "velvet." When the full growth is attained the horn becomes hard and the velvet wears off. The first antlers are very simple, but each succeeding pair is, as a rule, more and more branched, so that a large number of "points" indicates to the hunter an old individual.

\section{American Elk}

\section{Cerins canadensis (Erxleben)}

Also called Wapiti.

Length. 8 feet. Height at shoulder, 5 feet 4 inches. Length of antler, 50-65 inches.

Description. Body above yellowish brown, beneath nearly black, head, chest and neck dark brown, legs clove brown, a yellowish white area on the rump about the base of the tail. Female rather lighter coloured. The antlers borne only by the male curve outward and backward with curved branches or tines projecting forward at nearly uniform distances, the lowest pair directly over the forehead.

Range. Formerly throughout the Northern states and Canada, extending southward in the mountains. Now nearly extinct in the East. In the Northwest its place is taken by the closely related Roosevelt's elk and in the Arizona Mountains by Merriam's elk.

This splendid game animal is now all but extinct east of the Mississippi river; a victim to the advance of civilization and the 
greed of the hunter. But over the miles and miles of country which he formerly roamed at will his memory will be preserved for all time in the names of towns, counties, rivers, lakes and mountains. Any locality where elk were particularly abundant or where perhaps the last one was killed has been christened in homour of the noble beast, and apparently there is not a State lying within the former range of the species that has not its Elk county or Elk township. The name, like many another bestowed by our early settlers, is unfortunate, as the elk of the Old World is practically identical with our moose, while the American elk is a true stag, having its counterpart in the red deer of Europe. Wapiti, the Indian name, is distinctive and preferable, but, of course, a change in a name so well established is out of the question, and all we can do is to remember that elk in America and Europe refers to very different animals.

In parts of Quebec the elk may possibly still exist or, at any rate did, not so many years ago and here are often found the cast-off horns buried in moss and loam or washed from the bed of a river. In northern Michigan and Wisconsin a few maly still persist.

In the Eastern States the elk seems to have lingered longest in the wilds of central Pennsylvania and men are still living who can remember the killing of the "last elk" of their several localities about fifty years ago.

The Rocky Mountains and ranges to the westward now contain all the elk that are left and at the present rate of killing their extermination would seem to be not far distant.

Like many of the Cervilax, elk are gregarious and polygamous, associating in moderate-sized herds, the strongest bull acting as master of the cows and driving the other aspirants off by themselves until such time as they can prove their superiority and acquire a herd of their own.

At the pairing season frequent savage encounters take place between the bulls, which charge one another with lowered heads in the manner of all the deer tribe. Occasionally two individuals have been found with their great branching antles locked inextricably together or perhaps merely the antlers themselves are discovered, silent witnesses of a tragedy of former years, ending in starvation or an attack by wolves, the elk in their unfortunate predicament being unable to save themselves from either one fate or the other. "After the pairing season" writes Lydekker, "wapiti collect in 


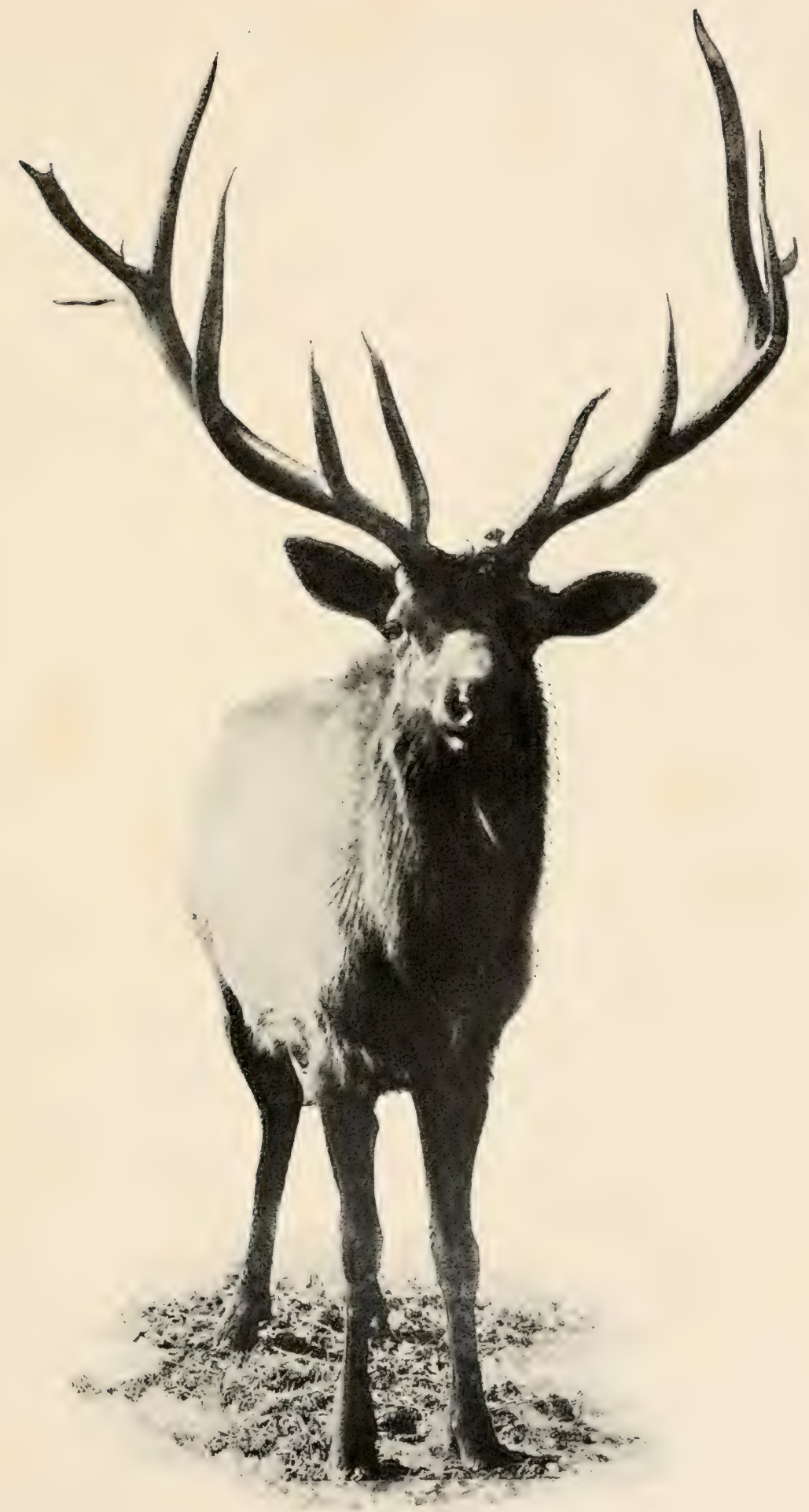

BULL ELK, OR STAG (Cervus canadensis)

By A. R. Dugmore 

large herds, which used formerly to number several hundred individuals, and wander about for a time till they finally select their winter feeding grounds. These are usually open hills where the ground is kept more or less free of snow by the wind, so that such food as there is at this season may be obtained with the least difficulty. During the hot weather, when they are much persecuted by flies and mosquitoes, wapiti resort to water, in which they will stand for hours; and, in the pairing season at least, the old stags are fond of wallowing in mud-holes from which they emerge coated with dirt and presenting anything but a prepossessing appearance. The antlers are shed in March and the new pair free from the velvet by the end of August or beginning of September. Saplings of aspen or pine appear to afford the favourite rubbing posts for freeing the antlers from the last remnants of the velvet. In a wild state the hind breeds when two or three years old ; the number of fawns at a birth being sometimes two, or rarely three, although one is the most common."

As to food the elk is not particular. Mr. Caton says: "All the grasses and most of the weeds within his reach are taken freely and the leaves and twigs of all the deciduous trees are alike enjoyed. A considerable proportion of his daily food he desires to be arboreous, yet if deprived of it he will keep in good condition on herbaceous food alone. In winter he will take the coarsest food, and will eat freely even that which the ox and the horse reject." Elk feed leisurely during the morning and afternoon, usually resting at midday, and unlike most deer they are not active during the night.

George Bird Grinnell has recently given us an excellent pen picture of a herd of elk which we cannot do better than quote. $\mathrm{He}$ writes: "From a distant ravine comes the shrill sweet whistle of a great bull elk as he utters his bold challenge to all rivals far and near. You can see him plainly as he walks out from the timber and slowly climbs the hill, followed by the group of watchful cows; and he is a splendid picture. Short-bodied, strong-limbed, round and sleekcoated, he is a marvel of strength if not of grace. His yellow body is in sharp contrast with the dark brown head and mane, and the hugely branching antlers, wide spread and reaching far back over his shoulders, seem almost too much for him to carry; so that as he marches along with ponderous tread each step seems to shake the earth. At intervals he throws back his head and utters his wild call, and before its first notes reach the ear you can see the white steam of his breath as it pours forth into the frosty air. His cows feed near to 
him as he steps along or if one straggles too far he moves slowly toward her, and shaking his mighty horns warns her to return. If you fire a snot at one of that band, speedily the old bull will show himself the herder and protector of his family. Rushing about from point to point he will gather up cows and calves into a close bunc'. and will drive them off over the hills, threating the laggards with his horns and using them too with cruel effect if the cows do not hurry. No chivalrv this on the part of the old bull. . . . He drives them forward not because he wishes to protect them from death, but because the cows are his and he does not intend to be robbed of his wives and children."

\section{Varieties of the Elk}

As with most animals of wide range the elk varies in different parts of its habitat. Three varieties have been described and it is probable that the animals formerly inhabiting the Eastern States differed somewhat from the Rocky Mountain elk. Lack of specimens will however probably leave this question forever in doubt.

1. American Elk. Cervus canadensis (Erxl.) Described above, range west to and including the Rocky Mountains.

2. Roosevelt's Elh. Cervuls occidentalis Smith. Larger and darker coloured, with heavier horns.

Ranoe. Coast range of Washington, Oregon and Northern Cillifornia.

3. Merriam's Elk. Cerwus merriami Nelson. Nose darker and head and leogs redder than $C$. canadensis, but not so dark as $C$. oicidentalis. Skull very massive, broader than either of the above. Antlers straighter at the tips.

Ranse. White Mountains of Arizona and Mogollon Mountains, New Mexico.

\section{Virginia Deer}

\section{Odocoilens virginianus (Boddaert)}

Length. 6 feet. Height at shoulder. 3 feet 1 inch. Length of Antler. 20-24 inches.

Discription. Bright rufous chestnut above in summer with a black band on the chin, throat, under parts and inside of legs white, tail brownish above, white beneath. In winter the upper parts are yellowish gray with white about the eye. Antlers curving 

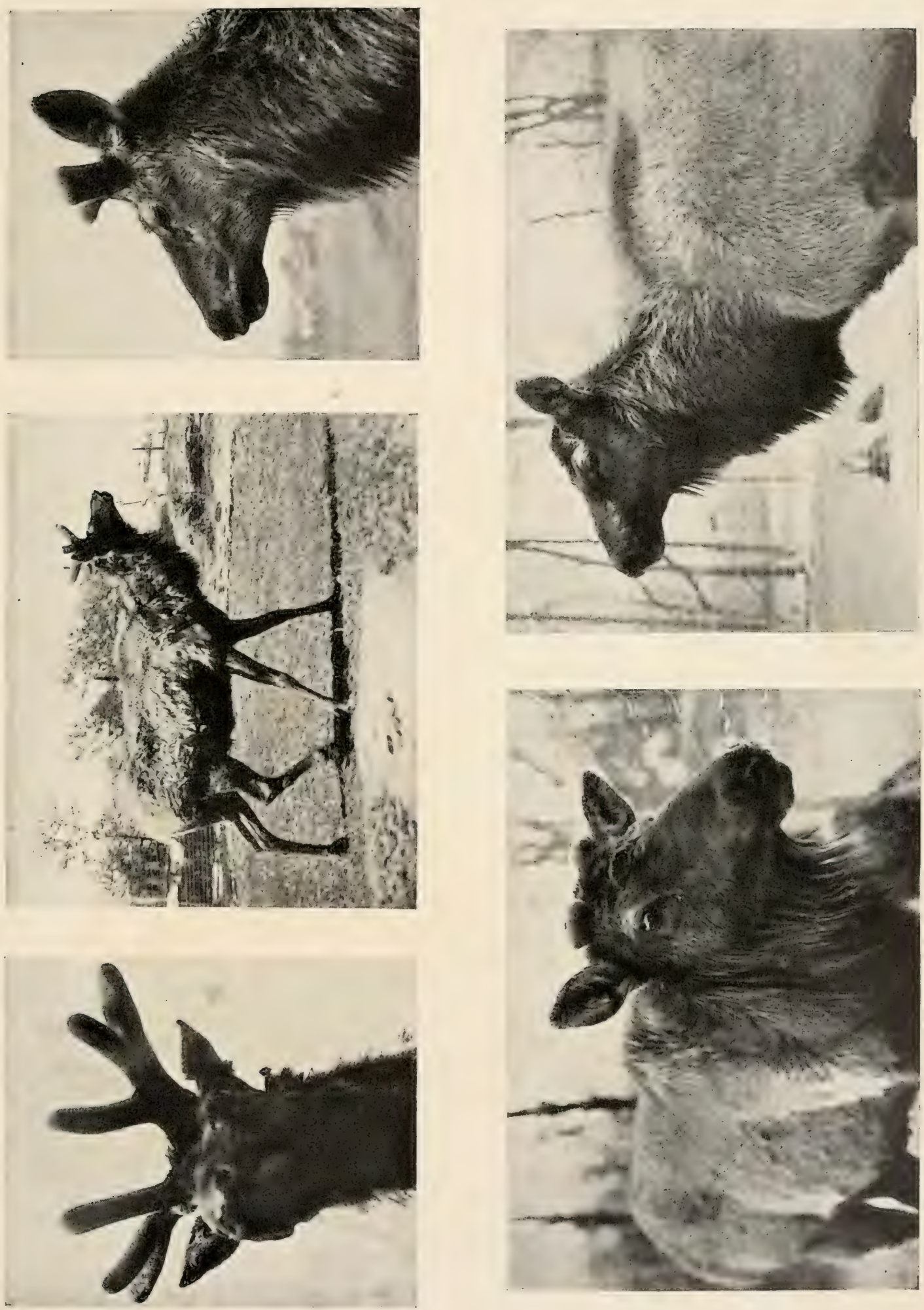

告

(2)

इี

ป

ป

ฐ

के

늘

No

国

姿

竞

氙

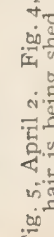



outward and then upward, the tips curving in again toward one another, there is a short upright spike near the base, beyond which the beam gives off two upright branches making three nearly equal prongs. At no point does the antler branch dichotomously.

Range. Eastern North America, separable into several geographical varieties and represented westward to the Pacific by other closely related races. (See below.)

The Virginia deer in one or other of its varieties was originally spread abundantly over our entire country, but the encroachments of agriculture upon the wilderness, the inroad of the lumberman, the fire which ever travels in his wake and the spread of towns and cities have driven the deer from a large portion of their former range and sadly decreased their numbers elsewhere. Such conditions now prevail through many parts of Pennsylvania where the devastation of the lumbermen and the ruin of the magnificent primeval forest are occurrences of yesterday. Farther north and south, in wilds as yet untouched, the deer still hold their own, and in New Jersey a few remain, thanks to the inhospitable pine barrens and impenetrable swamps, as well as to wise legislation properly enforced.

In New England within the last few years these beautiful creatures have ventured to return and dwell again in the haunts of their ancestors, wherever the destruction worked by civilization has not been too severe. Wise !aws passed for their protection have yielded good results more quickly than the most sanguine could have hoped.

In 1853 Thoreau wrote: "Minot says his mother told him she had seen a deer come down the hill behind her house and cross the road and meadow in front. Thinks it may have been eighty years ago." Evidently Thoreau supposed that that wild deer seen in Concord about 1770 was one of the last of its race ever to visit that part of the country. Yet if he had lived to be an old man he might frequently have seen them, if not at Concord, at least at other spots in New England from which they were supposed to have been driven forever. Not the pampered stock bred in game preserves, but the sturdy descendants of the native wild deer that the red men hunted through rough forests when the whole country belonged to them alone.

Now they may be seen in quiet country places in various parts of New England, browsing at the edge of leafy woodlands or resting in 
the shade of wide-topped elms in high windy pastures along with the farmer's cattle. It would certainly be difficult to find a creature leading a happier, more care free life than our wild deer of the present dily. After generations of persecution and terror, reduced to lonely individuals hiding afraid in distant forests, chased by dogs and shot at by man, fearful of greeting one of their own kind even, lest it prove an enemy in disguise, they are allowed once more to enjoy the land in safety. True to their name they have already forgiven man his savage treatment and show but slight alarm at his presence, taking retribution only in an occasional visit to his growing corn and fields of herd grass and clover.

They maly now call to each other in the twilight without fear of betraying themselves to the hunter and roam the conntry over in families or alone as suits each one the best.

If a dog so much as chases them he may be shot lawfully and his owner fined or imprisoned. What does it matter to them that in certain counties they may be hunted for a few weeks each year; who would not be willing to be shot at occasionally during so short a period with the chances in fivour each time of getting away untouched, if in return he could enjoy such splendid health throughout the year?

They now have probably fewer natural foes to contend with than almost any other creature.

Foxes, it is likely, get a few of the fawns in early summer, but the danger from them must be insignificant as compared with that the deer were compelled to face or avoid when the land was wild and Indians, panthers, wolves and lynxes hunted them winter and summer alike.

It is said that in some parts deer are already making decided nuisances of themselves by foraging on the farmer's crops; I trust it is not a far look ahead to the time when it will be true of them where l live in New Hampshire.

Only last August a full-grown buck with goodly antlers came into our field at noon, and, walking about in the tall grass, probably made as good a meal of English grass and alsike clover as his forebears were in the way of getting when they had only the wild growths of the forest and wild meadows to choose from.

When I see them enjoying all the splendid freedom of wind and sky over the brown pastures, or bounding away with tails in the air, I feel that of all the creatures driven away by the early settlers, no 

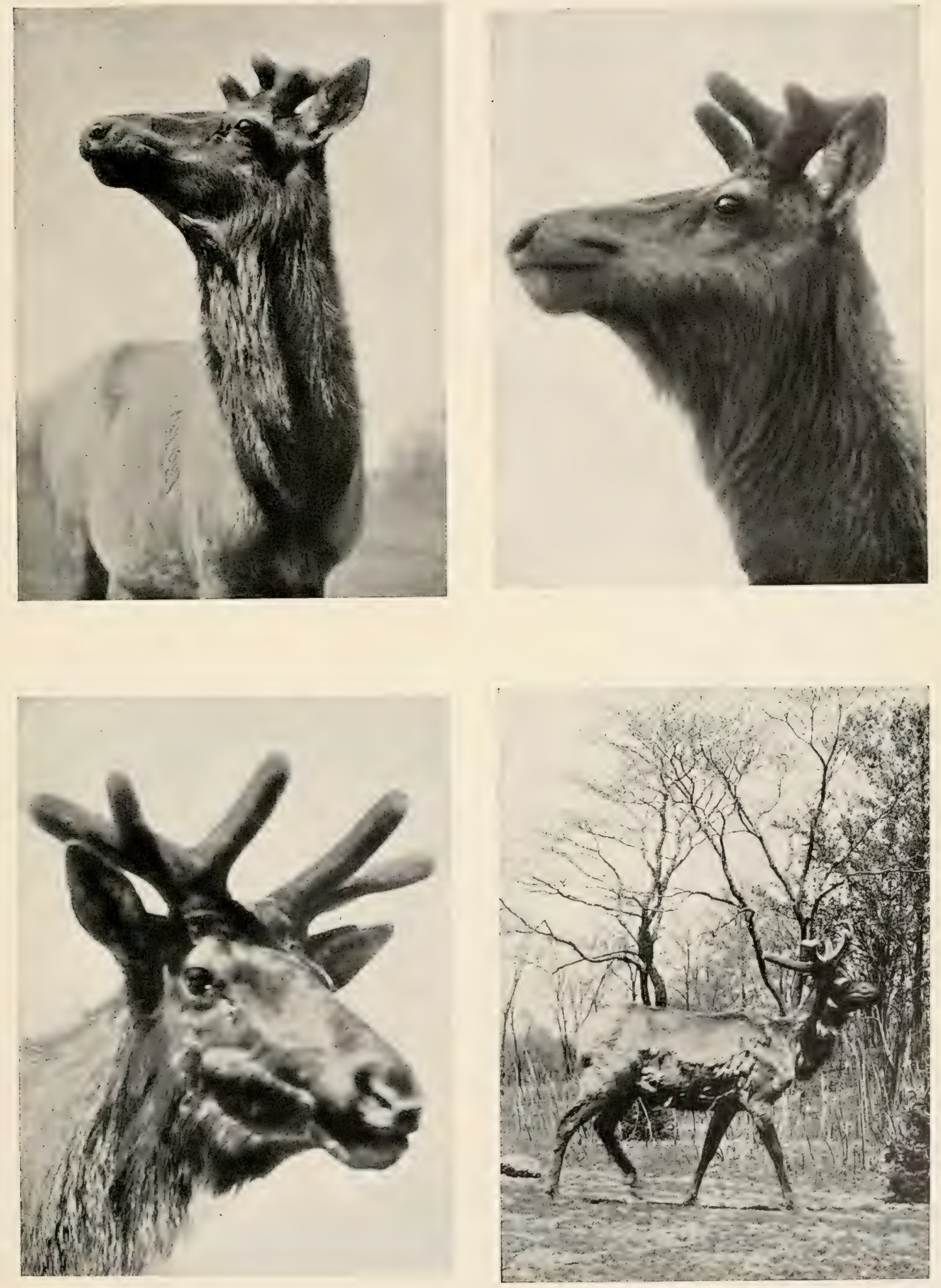

THE RAPID GROWTH OF AN ELK'S ANTLERS

Fig. 1, photographed April 2. Fig. 2, April 10. Fig. 3, April 20. Fig. 4, May 7. 

other could be so welcome a returner as the wild deer, even if he does prove in a way destructive.

The deep snows and severe weather of $1898-9$ yielded good opportunities for noting their custom of yarding.

In February when out on my snow-shoes I came upon one of these yards in the birch woods within a mile of the farm house where I write; a series of deep irregular paths marking out a loose net-work over about an acre of buried stumps and blackberry bushes. It had already been abandoned a day or two when I found it, a straight path leading off toward the northwest showing the most recent tracks. The yard had evidently been made and inhabited by a lone doe, possibly two or three with their fawns, the tracks all being alike and of small size.

In many places where the snow was only two or three feet deep they had tunnelled along beneath the heavy laden undergrowth for short distances. Again I found narrow open paths, five feet or more in depth, with almost perpendicular sides. Apparently they had fed almost altogether upon the ground growths under the snow, the twigs beside the paths showing little signs of having been browsed upon.

Four strands of barbed wire proved no obstacle to them, they passed under the bottom wire as freely as a fox or dog would do. Once or twice during the winter I found the trail of what must have been an unusually large stang in the swamps and young pine growths near there and along the borders of cultivated fields; his big hoofprints with their widespread dew claws were separated by astonishingly long intervals at times.

To go out into the forest with the fixed intention of killing anything so beautiful and harmless as a deer seems brutal and heartless enough any way you care to look at the matter. Yet the kindest hearted of men do so every fall, and though they may learn to hate themselves for every deer they have shot, they cannot give it up, and look forward just as eagerly to the next year's shooting, for there is no other sport to be compared to deer-stalking in the autumn woods just after a rain in the night, when the west wind is rising to dry the leaves and prevent the sound of a breaking twig from carrying too far. Deer-stalking is leisurely work. You move quietly along among the trees, keeping your face to the wind and watching the ground for fresh tracks. When you find tracks that lead you toward the wind you follow them as noiselessly as possible, endeavoring to 
learn from their appearance just how long since the deer that made them preceded you; when in wet places the water has not yet settled in the fuot-prints, it is time to look sharply ahead among the trees for a glimpse of your quarry. Deer usually wander about feeding all the morning, following a more or less direct course according to the lay of the land. Along the foot of a ridge by the edge of a swamp is a favourite feeding ground of theirs, and they like to trace the windings of a trout brook between low hills. In the middle of the daly they lie down to rest in the lee of a thick clump of evergreen, where they can watch their tracks for any enemy that maly be following them. Before lying down they make a practice of going back a little distance on their tracks to make sure that they are not followed. So when you have been tracking them all the morning and toward noon perceive three tracks ahead of you in place of one, you maly feel pretty certain the deer you are after is resting in some thick clump not many rods ahead. But unless there is snow on the ground to enable you to see the tracks a long way in front of you, you will hardly notice the back tracks before you have come so close as to alarm your game and send it flying off among the trees, showing you just the white flash of his tail as he disappears. If not badly frightened, however, he will probably not run very far before stopping to look back at you, choosing, if possible, a thickly wooded knoll or a hummock at the edge of the swamp and here you maly perhaps get a shot at him if you will make a slight detour and approach him from one side; to follow him directly would be useless, for he is earnestly watching his back tracks, and is certain to see you long before you can possibly see him.

\section{Varieties of the Virginia Deer}

One or other form of Virginia or white-tailed deer is found in nearly every part of the United Sates. They are all geographic variations of the same stock and they exhibit differences in direct proportion to the effect produced by the peculiar climate and surroundings in which they live. Whether they shade gradually into one another as their ranges approach, or whether differentiation has gone further and they are to be regarded as different "species" are questions that have not yet been definitely settled in many cases. Without 


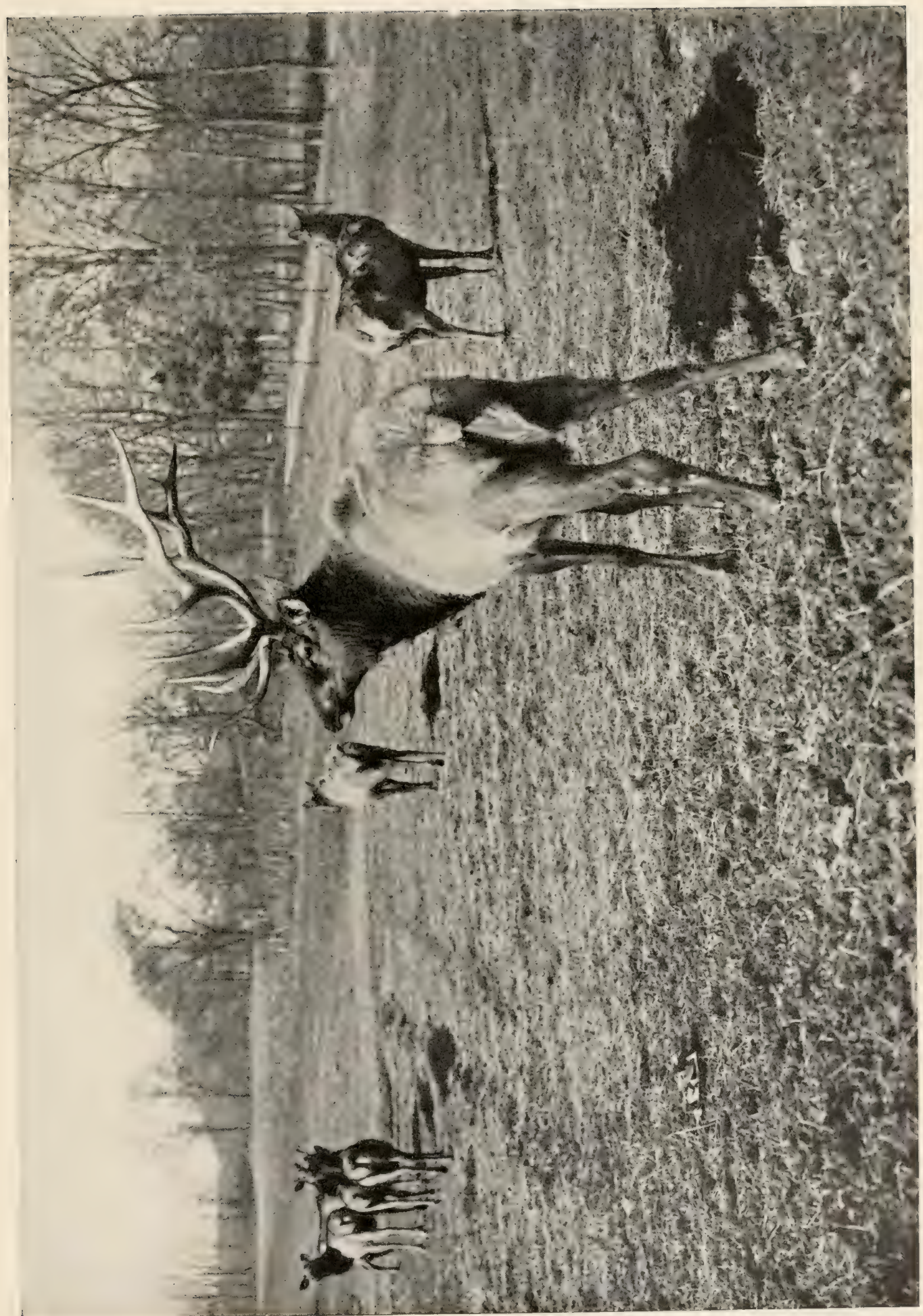



considering the fine technical points of difference, the described forms are as follows.

I. Virginia Deer. Odocoileus virginianus (Boddaert). Southern States north of Florida and Louisiana to the Middle States.

2. Northern Deer. O. virginianus borealis Miller. Rather larger and grayer.

Range. New England States and Canada to northern New York.

3. Banner-tailed Deer. O. virginianus macrourus (Rafinesque). Smaller and paier coloured.

Range. Kansas, Nebraska, and the Dakotas, etc.

4. Florida Deer. O. osceola Bangs. Very small, and exceedingly dark coloured, about one quirter smaller than the Virginia deer.

Range. Florida.

5. Louisiana Deer. O. lonisiance G. Allen. Similar but larger. Range. Louisiana.

6. Texan or Fan-tailed Deer. O. texensis (Mearns). A small very pale deer with small antiers.

Range. Texas and northern Mexico.

7. Arizona Deer. O. contesi (Rothrock). Small and pale in colour but with no black edgings to the ears.

Range. Arizona and Northern Mexico.

8. White-tailed Deer. O. leucurus (Douglass). Similar to the banner-tail.

Range. California to Washington.

\section{Mule Deer}

\section{Odocoileus hemionus (Rafinesque)}

Also called Black-tailed deer.

Length. 6 to 7 feet. Height at shoulder. 3 feet 4 inches. Length of antlers. 25-30 inches.

Description. Body heavy, ears very large, thickly haired, tail white with black tip, naked below at the base. Pale dull yellowish in summei, bluish-gray in autumn, front of the face between the eyes dusky, rest of face, throat, abdomen and inside of legs white. Antlers forking equally (dichotomous) and each prong again bifurcate.

Range. North Dakota to Texas and Colorado and west to Washington, Oregon and northern Californa. Closely allied varieties occur in California south of San Francisco.

Unless we are familiar with an animal it is often difficult to know the origin of the popular names that have been bestowed upon it. In the present case we should on first thought picture a large heavy 
animal approaching the moose in build, but such a conception is erroneous. The mule deer, like the jack-ass rabbit, owes its name not to its shape but to its enormous ears, which as we know are the most characeristic feature of the mule.

Though but little exceeding the Virginia deer in height, the present species is a heavier, more coarsly built animal with shorter legs and with very different antlers.

It inhalbits usually the rough broken country but often ascends to the higher valleys and plateaus of the mountains. Besides its peculiarities of structure the mule deer has a distinctive gait. Instead of the continuous easy springs of the Virginia deer it proceeds by a jerky series of bounds, all four legs apparently touching the ground together, or to quote from Lewis and Clarke who first discovered the species: "It does not lope but jumps."

The range of the mule deer is quite extensive through the West, and as will be seen below, the Southern representatives form distinct varieties.

The mule deer was one of those many Western novelties which Audubon and his companions met with on their memorable journey up the Missouri River in 1843. He says of his first sight of it: "On winding along the banks, bordering a long and wide prairie, intermingled with willows and other small brushwood, we suddenly came in sight of four mule deer which, after standing a moment on the bank and looking at us, trotted leisurely away, without appearing to be much alarmed. After they had retired a few hundred yards, the two largest, apparently males, elevated themselves on their hind legs and palwed each other in the manner of the horse. They occasionally stopped for a moment, then trotted off again, appearing and disappearing from time to time, when becoming suddenly alarmed they bounded off at a swift pace until out of sight. They did not trot or run as irregularly as our Virginia deer, and they appeared at a distance darker in colour."

As time went on and settlers and hunters spread over the great West the mule deer became a familiar animal, distinguished by all from the Virginia deer by its curious gait, its equally forking antlers and its black tail; the latter giving rise over a large part of its range to the name "black-tailed deer," an appellation belonging more strictly to the animal of the Columbia River region of the Pacific Coast. As a game animal it is held by many to be unsurpassed. Mr. A. G. Wallihan says of this species: "For me, at least, there is a charm 


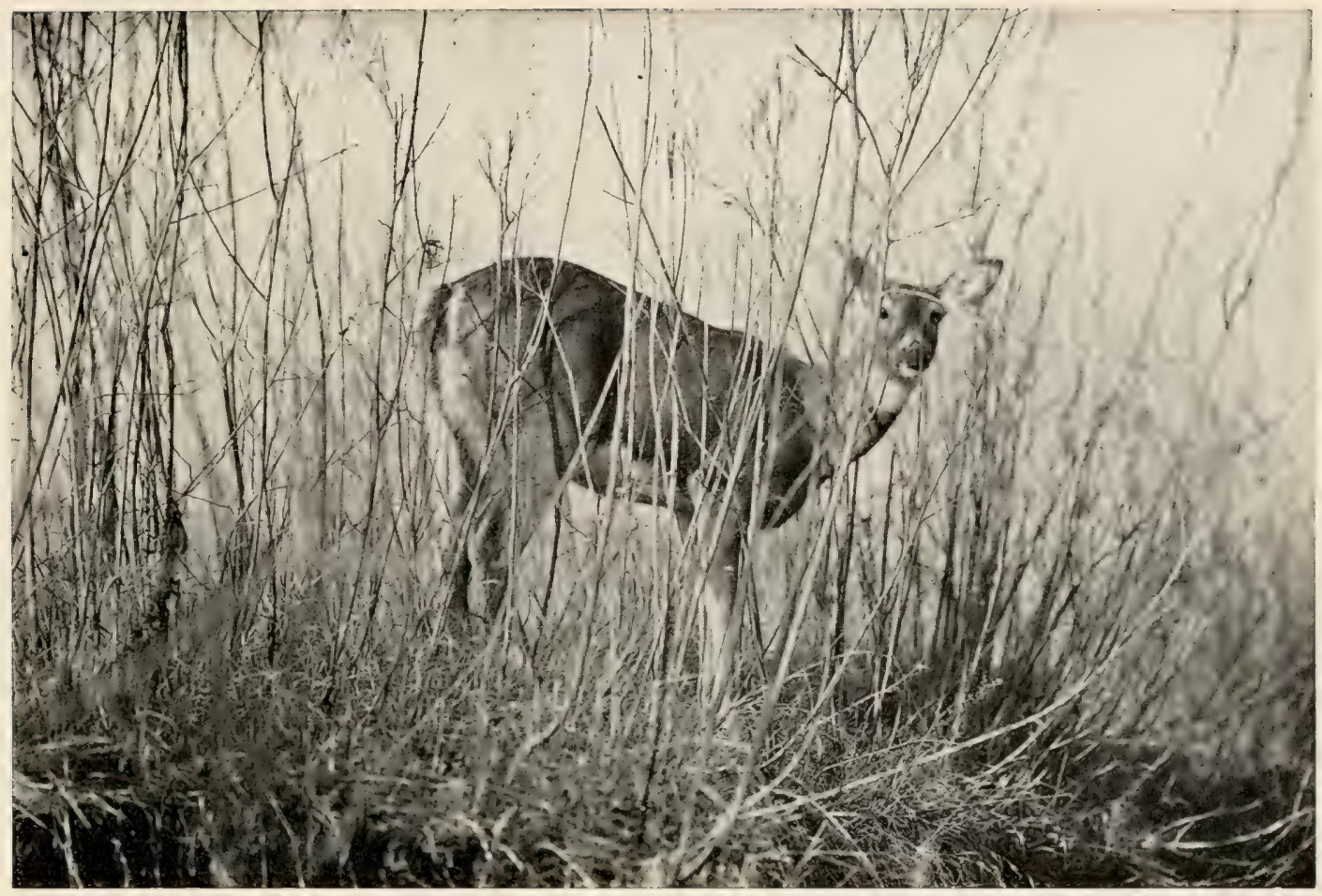

A STARTLED DOE; SHE HEARS A WHISTLE ACROSS THE CREEK

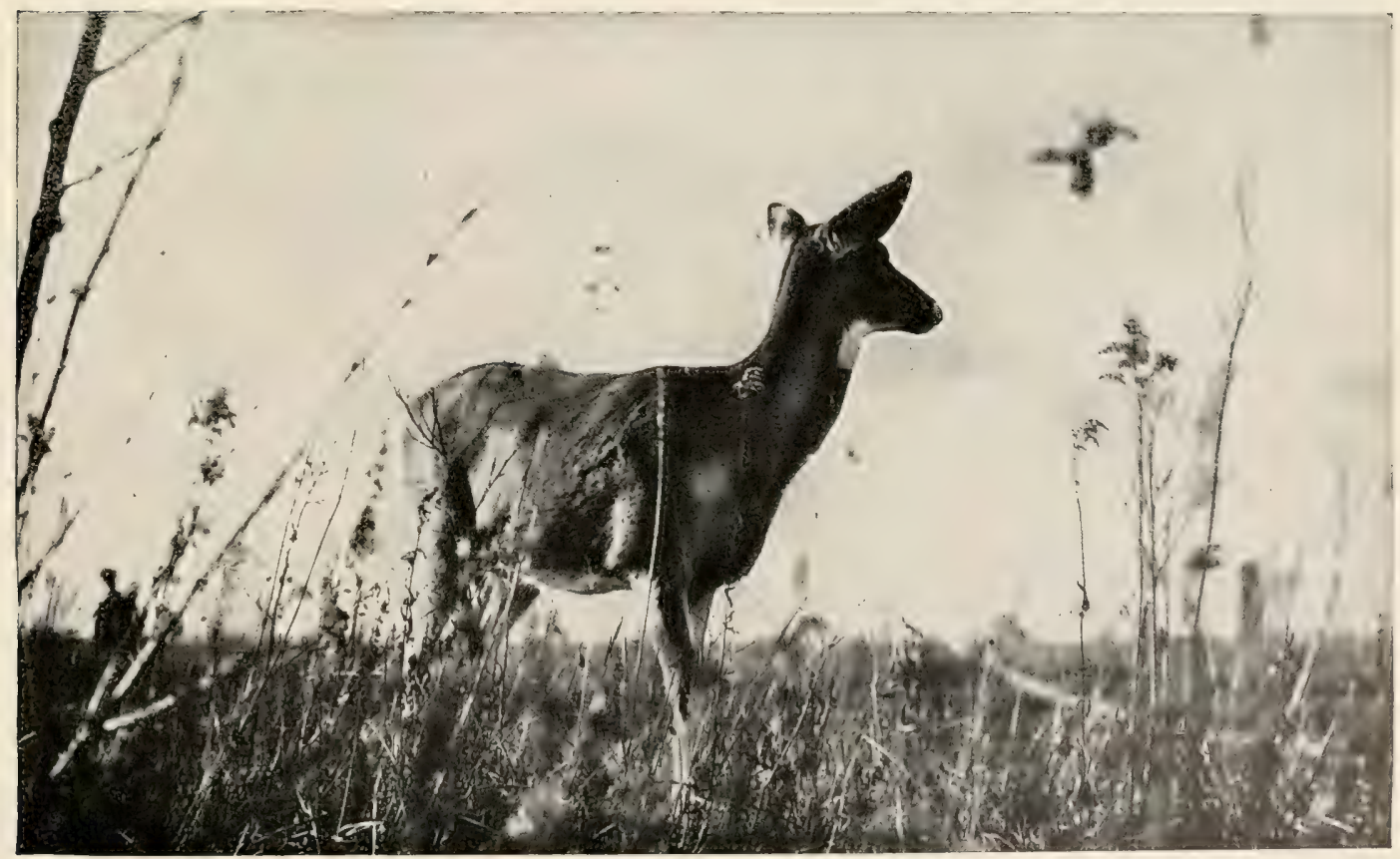

WHITE-TAIL DEER (Odocoileus virgini(unus) 

about the blacktail or mule deer, that no other game possesses. Barring the bighorn, their meat is the best, their hide tans into the best buckskin, and you turn from the large elk or the agile antelope to the graceful beauty of the blacktail buck, and find there the greatest satisfaction. The head of the bighorn is a finer trophy, no doubt, and you are led to grand scenery in the pursuit of him, but it is heartbreaking work. Where you find the blacktail you will find other pleasures, for he delights in the most charming bits of country to be found. He will jump up from the tall weeds and grass among the aspens, so close as to startle you as you ride through them, or will leap into view from the shade of a deep washout far in the desert, where he finds in the feed and surroundings something to suit his taste. He is crafty also, for if he thinks he is hidden I have known him to lie in thick bush until almost kicked out after all sorts of expedients to drive him out have failed. He, has perhaps the keenest scent and the best hearing of all the deer tribe . . . but cannot see as well as the antelope, for I have stood within ten or twenty feet of several passing bands which failed to distinguish me from a stump or rock. Antelope will approach very closely occasionally, out of pure inquisitiveness, but never a deer. If anything moves a deer sees it instantly, but he cannot tell what a still object is."

\section{Varieties of Mule Deer and Allied Species}

I. Mule Deer. Odocoileus hemionus (Rafinesque). Description and range as above.

2. Californian Mule Deer. O. hemionus californicus (Caton). Similar, with smaller ears and with a dark median stripe on the tail.

Range. Coast range of California south of San Francisco.

3. Desert Mule Deer. O. hemionus eremicus (Mearns). Paler than any of the other varieties.

Range. Desert areas of lower California and Sonora.

4. Cerros Island Deer. O. cerrosensis Merriam. Similar to the Californian variety, but much smaller.

Range. Cerros Island off the Californian coast.

5. Crook's Deer. O. crooki Mearns. Somewhat like the mule deer, but reddish-fawn in colour, tail naked at base beneath.

Range. New Mexico. 


\section{Columbian Black-tailed Deer}

\section{Odocoilcus columbianus (Richardson)}

Length. 6 feet.

Disiription. Smaller than the mule deer, with relatively shorter ears and finer hair; especially distinguished by the shorter metaltarsal gland and tuft which occupy a considerable part of the upper half of the cannon bone segment. General colour brownish gray, dirkest along the back, with a tinge of reddish brown on the head; chin, upper throat and posterior portion of underparts white, rest as above. Tail black above, basal third beneath white. Antlers similar to those of the mule deer. Summer coat redder than winter.

Range. British Columbia, through Washington and Oregon, west of the Calscade Mountains. Closely related varieties to the north and south, in Alaska and Northern California.

Our Pacific coast region is favoured with more distinct kinds of deer than any other part of the Union. Besides a representative of the widespread Virginia deer group, we find there also the larger heavier mule deer and the smaller darker species above described. The black-tailed deer, as seen above, has a very restricted distribution and was unknown to naturalists until the famous expedition of Lewis and Clarke across the Rocky Mountains and into our northwestern territory. These observant naturalists recognized in both this and the mule deer species which were unknown to them and have given in the account of their travels excellent descriptions of both. The blacktail is in many ways intermediate between the mule and the Virginia deer, but has the same peculiarity of gait and much the same style of antlers as the former.

Lydekker writes of this species: "In its general mode of life the blacktail is in some respects unlike the mule-deer, although it resembles the latter in its bounding gait when frightened. Such a fatiguing pace can, however, be maintained only for a compiratively short distance, and the deer consequently soon become blown when they start off in this manner. When starting without being frightened, they run in a more ordinary way, and are then able to hold out for a much longer time, as is also the case with the mule deer. Unlike the latter, the present species is a forest-loving animal, frequently the dense woods of conifers bordering the Pacific Coast, whose deep shade affords ample con- 


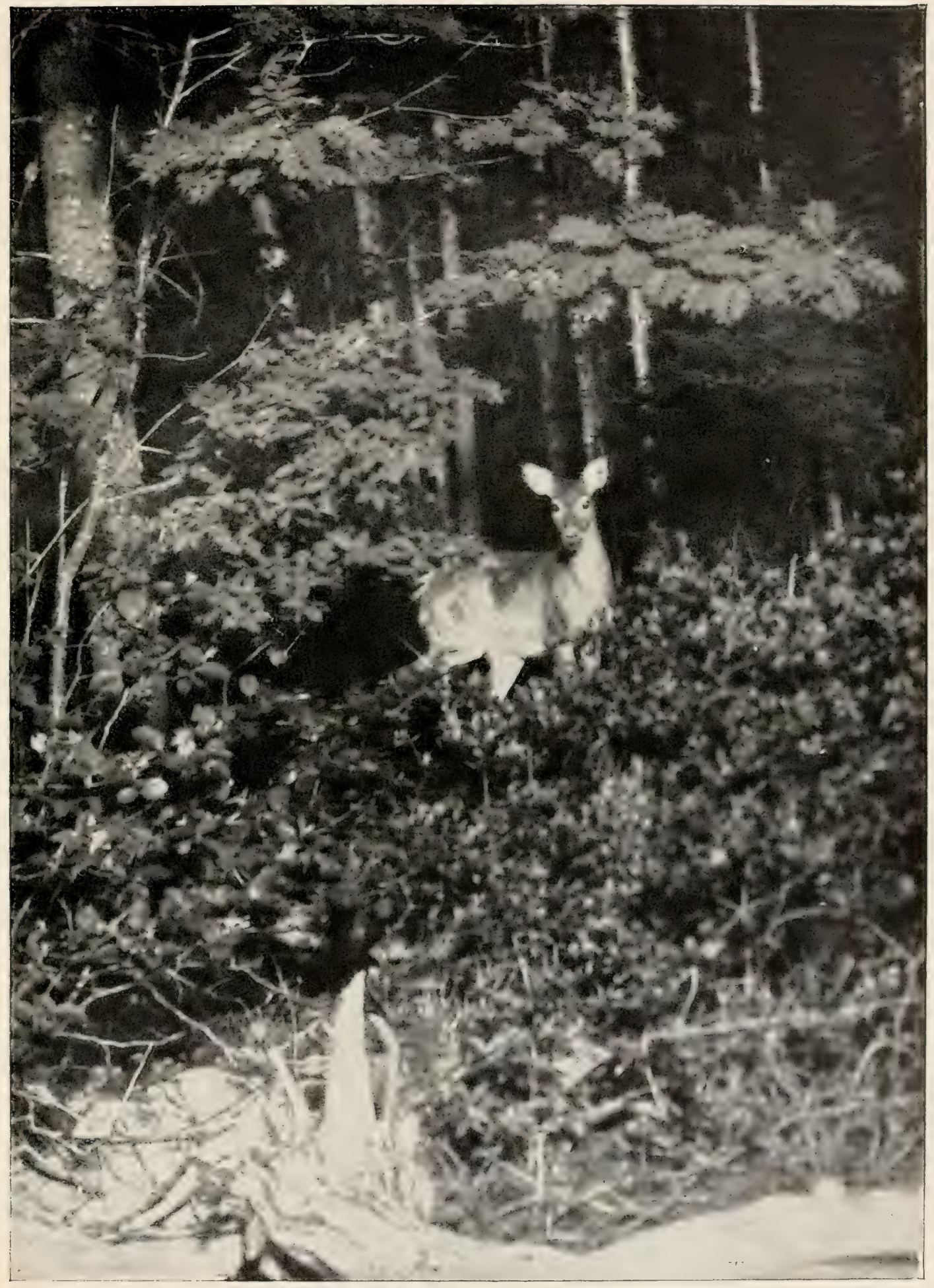



cealment. ... The fawns are usually born in May, their number being generally two, although triplets have been recorded. They are more fully spotted than those of the mule deer, the spots themselves being more sharply defined and arranged in more definite longitudinal lines. In these respects the fawns are more like those of the Virginian deer."

\section{Varieties of Black-tailed Deer}

I. Black-tailed Deer. Otlocoilens columbianus (Richardson). Description and range as above.

2. Sithan Black-tailed Deer. O. columbianus sitkensis Merriam. Similar, but ears shorter, and basal part of tail above fulvous like the back.

Range. Southern Alaska.

3. Californian Black-tailed Deer. O. columbianus scaphiotus Merriam. Colours paler and ears longer. Range. Northern California.

\section{Moose}

\section{Alces americanıs Jardine}

Length. 9 feet. Height at shoulder, 5 feet 9 inches to 6 feet 6 inches. Length of antler, 41 to 44 inches.

Description. A crest of stiff erect hairs on the neck, much elongated and forming a hump on the shoulders, nose large, the upper lip protruding well over the lower, ears large, tail very short, legs long, a pendent mass of hair on the throat called the "bell." Colour blackish-brown above, grizzled with gray on the rump, shoulders and sides of the neck, under parts black, inside of legs and their entire lower portions quite gray, feet black, ears gray. Antlers broadly palmate, solid portion nearly two feet at the widest point, several tines project forward and the outer edge of the flat portion is fringed by an irregular series of points.

Range. Eastern British America, Maine, Minnesota and Montana and formerly northern New York. Replaced in Alaska by the Alaskan moose (Alces gigas Miller), a still larger beast, and the largest known member of the deer tribe.

The moose seems like some old pre-historic creature that has lingered on into the present age, lonely and out of place, as if, 
having outlived its age and generation, it must necessarily soon become extinct from natural causes.

His massive scoop-shaped antlers and monstrous muzzle, in fact, his whole great ungainly carcass, looks as if it might well belong to some of those forgotten creatures whose bones are found in the river-drift, or dug up from beneath clay strata, buried in some long past interglacial epoch.

Yet the moose lives and breeds in our Maine woods, its flesh serves as an article of food among us and may be bought in the market.

Furthermore, he seems perfectly well fitted to look out for his own safety. His speed and endurance are astonishing, and he carries his large bulk and spreading antlers easily and swiftly through thickets where a man might well hesitate to force his way.

His long legs are very convenient when wading about after water lilies and equally so in reaching upward to peel the bark from the young trees or biting off the tender shoots. When browsing, however, he not unfrequently brings his heavy body also into play and rearing up rides the tree down by sheer force, thus bringing the upper branches within reach. Feeding off the ground is another matter, however, the neck being too short to compensate for the greal length of leg so that the beast is forced to kneel with the front feet in order to reach the ground in a level spot.

The moose is eminently an animal of the forest and is parrticularly at home in the dense thickets surrounding the shallow lakes, bogs and watercourses of the north woods, where he may be found wading through the water in search of the yellow splatterdocks, the roots of which at certain seasons form one of his choicest articles of diet. Most of the peculiarities of the moose are undoubtedly due to his habits which are in many respects different from those of other members of the deer tribe.

In running his movements are described as clumsy, never galloping or jumping, but executing a curious shuffing or ambling gait, tossing his head and shoulders as if about to break into a gallop, but only increasing his speed by lengthening his stride, spreading his hind feet in order to straddle the front ones without stepping on them, his hoofs clacking noisily as he goes.

He holds his nose up and his antlers laid back on his shoulders to avoid the branches. When he comes to a fallen 


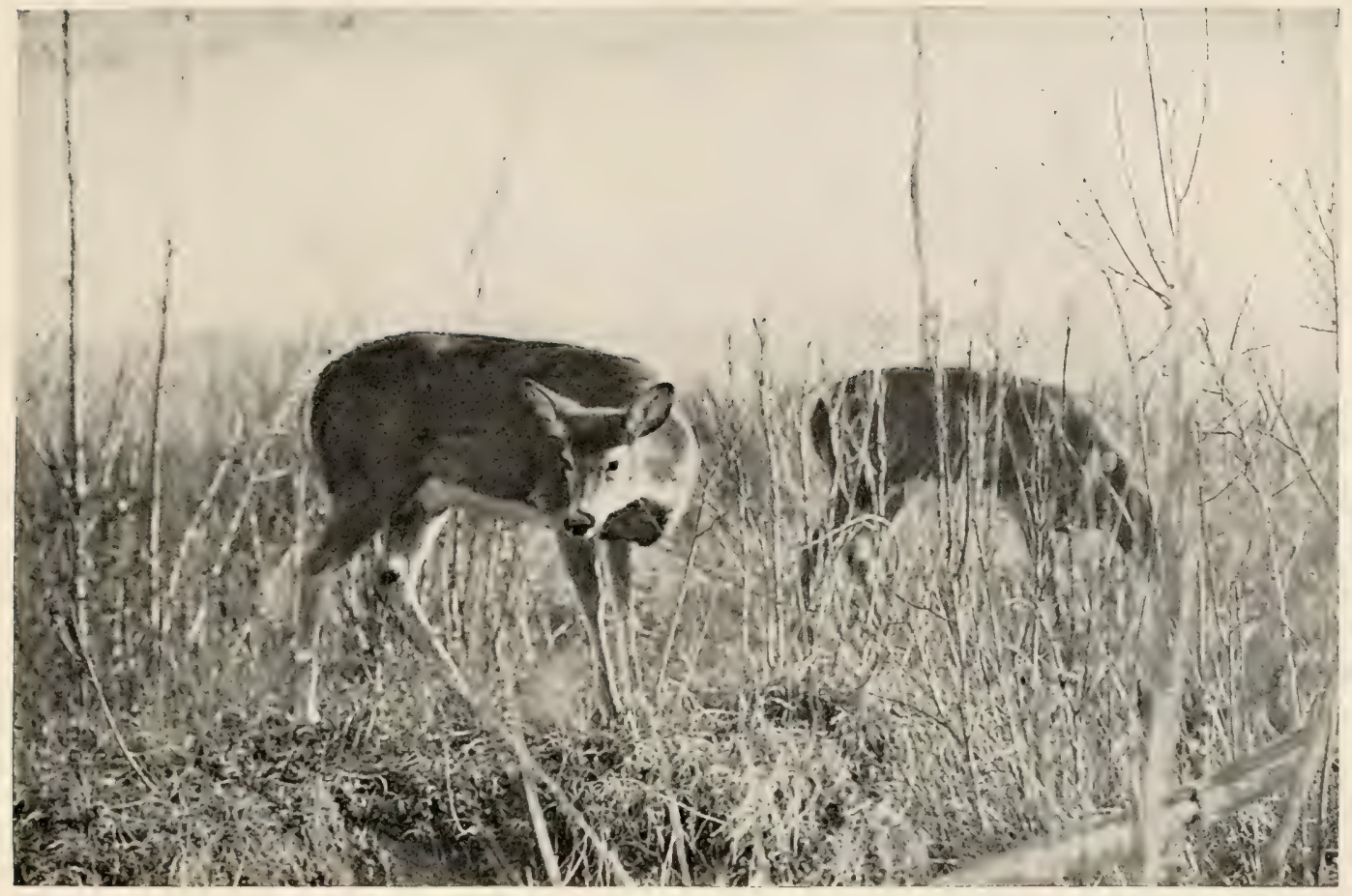

DEER, IN MOOSE CREEK, IDAHO.

By W. E. Car:in

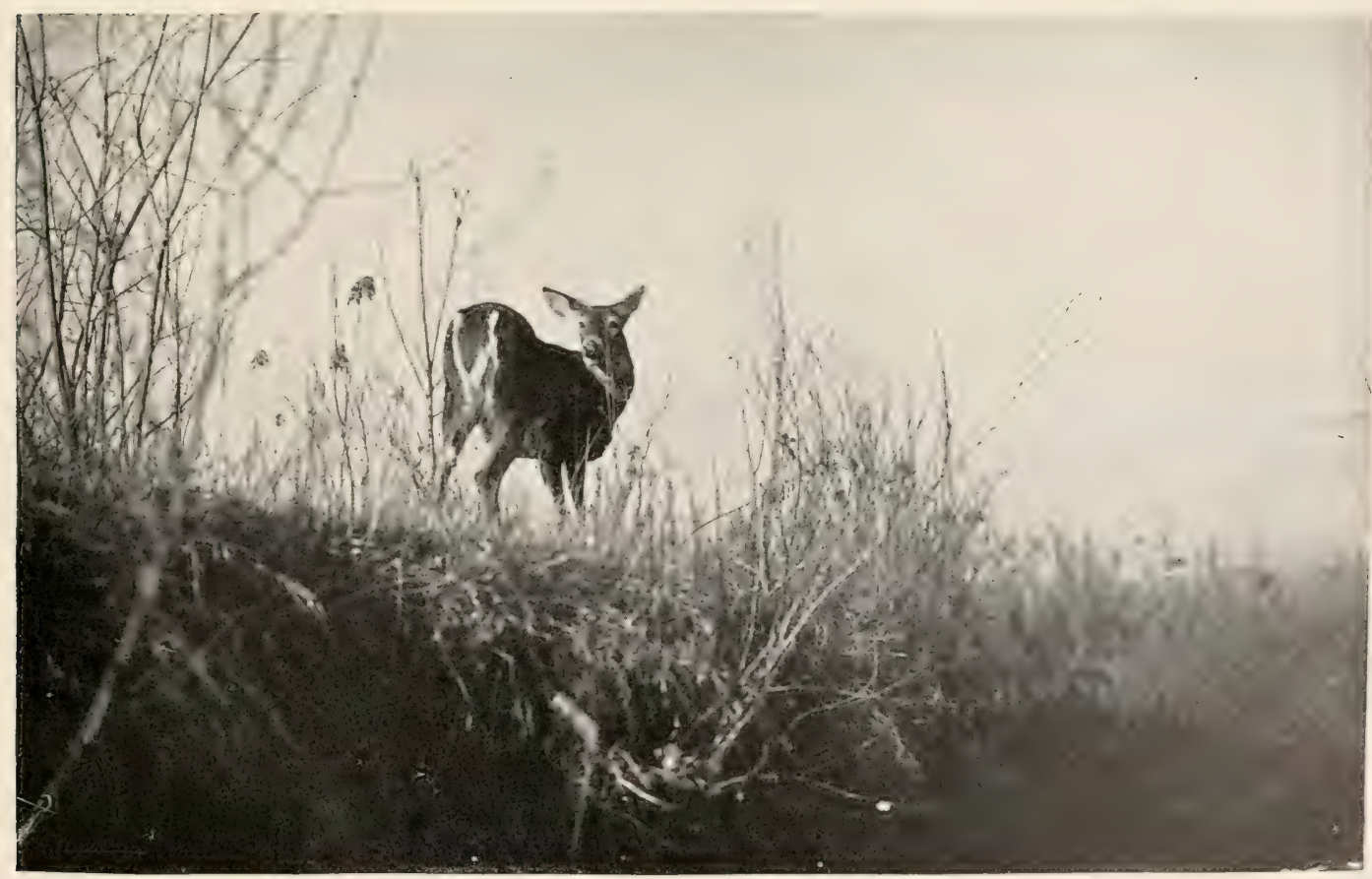

WESTERN WHITE-TAIL, OR VIRGTNIA DEER (Odocoileus virginianus macrourus) By W. E. Carliu IN THE BITTER ROOT VALLEY, MONTANA.

These photographs of wild deer were made in the spring, when the animals are more easy to approach. In each case the camera hunter lay in wait near the trail and caught the animals unawares. 

tree, as high as a man's shoulder, he does not jump it, but simply steps over without changing his gait.

In winter the moose keep to the hilly woods in the cover of the evergreens and live by browsing on green wood and moss and the resinous foliage of the evergreens. When the snow. gets so deep as to hinder their progress, they tramp irregular paths, forming a sort of labyrinth over several acres, making what is known as a "moose yard," where they pass the hardest part of the winter, sometimes several families together.

As food gets scarce and hard to reach, they extend their yards by breaking new paths through the snow, but are often reduced to short commons before the winter is over. At the approach of warm weather they move down to the swamps and lake-side, where they browse on willow, striped maple, birch, etc.; in order to get at the upper branches of a sapling they will rear up against it and bend it down with their weight. In summer they live largely on lily roots and succulent waterplants, wading and running out into the lakes and feeding with their heads partly immersed in the water. During the rutting season, which occurs in the autumn, the old bulls become savage and fearless, roaming the forest on moonlight nights, whistling and calling fiercely and clashing their antlers against trees as a challenge. The cow moose answers with a lower call, which the hunters imitate through birch-bark trumpets, in order to call the bull within gunshot.

When enticed in this manner, the bull is likely to come upon the hunter with a blind rush, and in the darkness of the wood the hunter, whose nerves are liable to fail him at a pinch, may find this sort of sport exciting, but not altogether safe.

The fawns who are born in early summer stay with their mothers for two or three years before they wander off to seek mates for themselves. It is said that they do not get their full growth until they are fourteen or fifteen years old and, if they escape a violent death, live to a great age.

Of one of the strongholds of the moose in the East, Frederic Irland writes: "The camp was on the Crooked Deadwater by the side of a beautiful stream at the head of a great river. Just across the narrow waterway one of the grandest mountains in New Brunswick rises sheer and dark, a great pyramid of eternal verdure, which in the winter is the feeding ground of hundreds of 
moose. It was into this inviting camp that we stumbled long after dark, scaring a little moose out of the very door-yard, not two hundred feet from the cabin door. The frost came down and cracked the trees that night till they popped with the cold and the sound was like a skirmish of rifles. The next morning when we awoke there was a thin glaze on the snow, and when we walked abroad it was like treading on innumerable panes of crackling window-glass. We heard three different moose get up and run when we were a quarter of a mile off. . . We climbed the mountain for an hour. Then we came to the tracks of two moose, fresh that very morning. The footprints were not extra large, but the broken twigs on two trees showed where a pair of antlers had scraped on either side and I could scarcely touch the two trees at one time with my outstretched hands. Moose with big horns do not always have large hoofs.

" "They lie down about this time in the morning' said my guide, . . . and after awhile, over the top of a fallen treetrunk I saw the mane of a great, black animal. The old fellow has not seen us yet. He swings his great horns just a little. The steam rises from his broad nostrils. Lazily he winks his eve. I can see every hair on his back. Carefully I push the camera above the prostrate tree-trunk first brushing the snow away with my hand. Tick, goes the shutter and the great beast is getting up. The antlers swing, he rises, two feet at a time, like an ox, hesitates an instant, as a moose always does, shows the little symptoms of fright so familiar to those who know the habits of the moose, and then goes down the mountains like a runaway locomotive."

In the far Northwest moose were even more abundant, though it is difficult to say how long they will withstand the sudden flood of immigration which the gold fever has recently produced in that direction. "The broad valley and mountain banks of the Klondike" writes Tappan Adney, "are an admirable feeding ground for the moose. The temperature in winter is exceedingly cold and crisp, but the snowfall is light, and by reason of the intense cold the snow does not settle or pack. There is so little wind, especially through the early part of the winter, that the snow accumulates on the trees in strange and often fantastic masses, giving the landscape, especially on the mountain tops, the appearance of having been chiselled out of pure white marble. On 


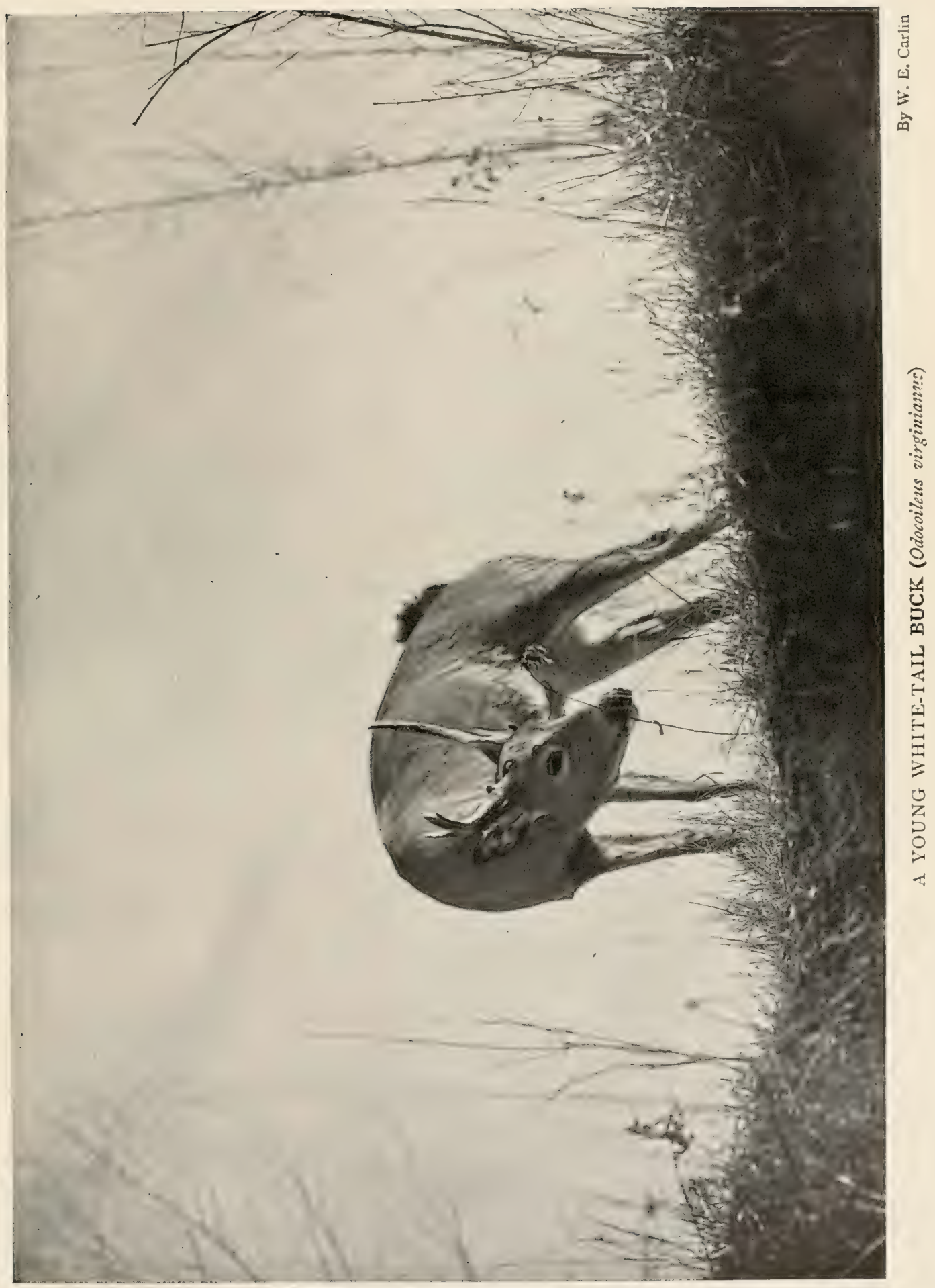



account of its lightness, the snow is no impediment to the longlegged gaunt moose, which is not obliged to 'yard,' as in more Southern deep-snow regions, but wanders at will from valley to mountain top in search of the tender twigs of willow, white birch and cotton wood. The Indians surround the moose in its feeding grounds and as it runs one or more of them is tolerably sure of a quick shot." The moose in this section has long been the main support of the Indians and in their household economy no part of the beast is wasted. To quote further, "The hides were brought indoors, the hair was shaved off, and all the sinew and meat adhering was removed by means of a sort of chisel made of a moose's shin bone. . . . The skin was now washed in a pan of hot water. The tanning, with a soup of the liver and brains, is done the next summer. The various portions of the moose were divided among the village. One family got the head, another a slab of ribs, another the fore shoulders. The shin bones were roasted and cracked for their marrow; the ears, although nothing but cartilage, were roasted and chewed up; the rubber-like 'muffle,' or nose, and every particle of flesh, fat or gristle that could be scraped from head or hoofs were disposed of. Even the stomach was emptied of its contents, boiled and eaten."

In the Old World there occurs a near relative of the moose in the forests of the Scandinavian peninsula as well as parts of Russia and Prussia. The animal is known to the English by the name of elk, which term has unfortunately been applied in this country to the wapiti.

\section{Woodland Caribou}

\section{Rangifer caribou (Gmelin)}

Length. 6 feet. Height at shoulder 4 feet. Length of antler 30 to 40 inches.

Description. Differs from all the preceding members of the deer family in the presence of antlers on the female as well as the male, the muzzle is also entirely covered with hair and the feet are more deeply cleft. Colour, dark dove-brown, lighter in the neck, posterior part of the abdomen, and inside of legs as well as a 
band just above the hoofs white, muzzle and face dark except the front of the upper lips. Grayer in winter with head and neck nearly white. Antlers with one (rarely both) of the brow tines flattened and palmate standing out vertically in front of the face, above this is another branched tine more or less palmate and the summit of the antler is again palmately expanded. The exact pattern and extent of the palmation is exceedingly variable.

Range. Wooded parts of British America, northern Maine and Montana.

The caribou's hair in summer is brown to match the dun coloured barrens and marshes. In the fall it grows longer and thicker, the new growth being very much lighter so that in midwinter and early spring the general effect is smoky white-the colour of a snowstorm in the woods, and the moss-hung, snowflecked spruce trees among which the caribou feed and seek protection during the cold weather. Their rough antlers looking like dead, weather-beaten branches also help them in their everlasting game of hide and seek.

It is evident to the most unscientific that the woodland caribou is only a branch of the great reindeer family, which has either wandered south into the woods of Canada and the northern United States, or else lingered behind when the wide extended ice sheet of the glacial period withdrew again to the Arctic regions thousands of years ago, at the time the little alpine plants, still found on Mt. Washington, got left behind by their kindred. In whichever case they certainly appear to have found the conditions favourable and have increased in size accordingly.

But the woodland caribou still feels at times the old inherited desire for wide open stretches of treeless country, particularly in summer, when they wander out over the extensive barrens and flat bog lands to pasture on the coarse sedge-grass growing there.

Although perfectly at home in the thickets where they winter, browsing on moss and lichens; their power for leaping over windfalls and bush is as yet an acquired art, not instinctive and hereditary as it is with the true deer of the wildwood. W. M. J. Long in his "Wilderness Ways" says: "Caribou are naturally poor jumpers. Beside a deer who often goes out of his way to jump a fallen tree just for the fun of it, they have no show whatever; though they can travel much further in a day and much easier. Their gait is a swinging trot from which it is impossible to jump; and if you frighten 


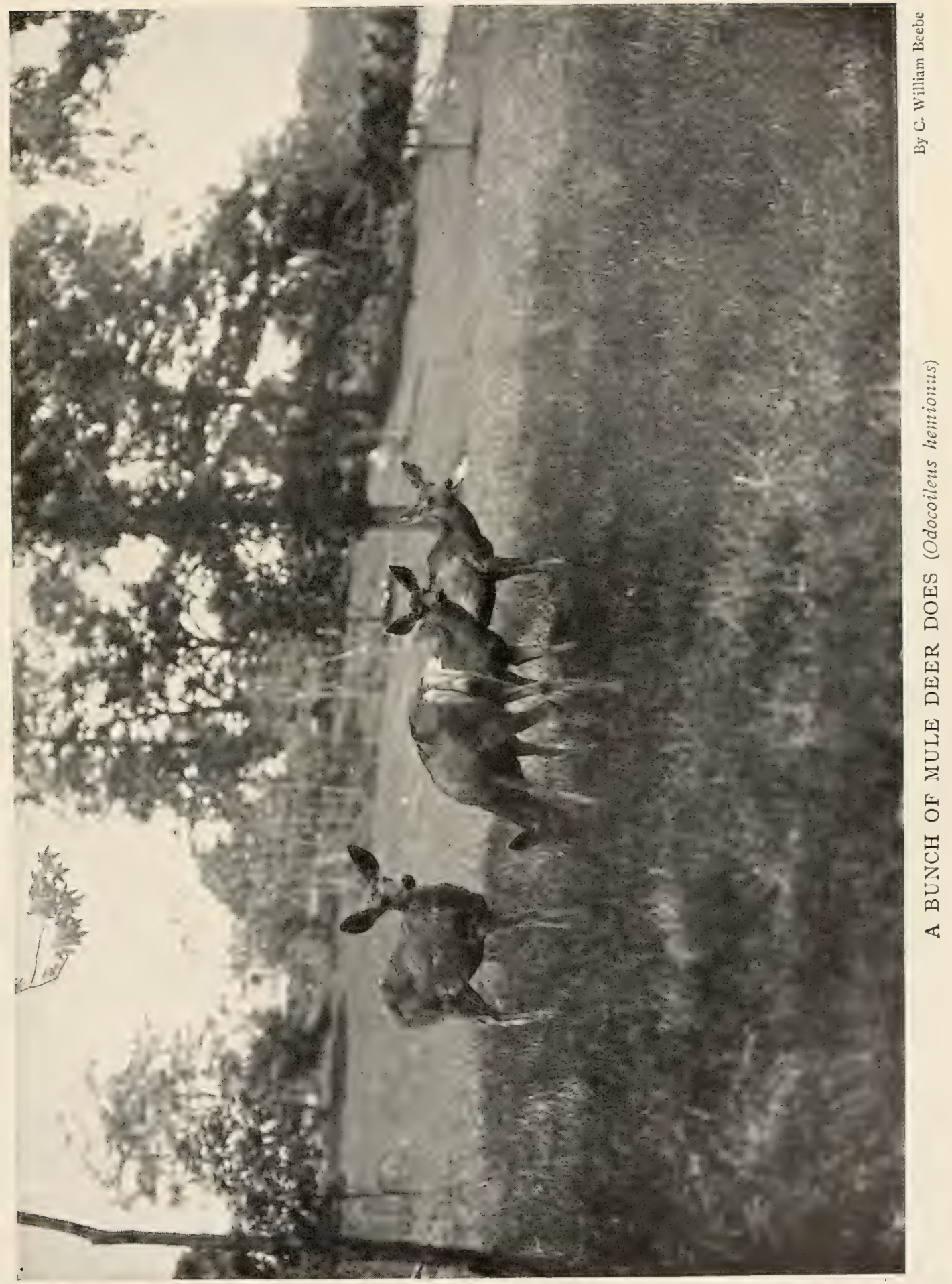



them out of their trot into a gallop and keep them at it they never grow exhausted.

"Countless generations on the northern wastes, where there is no need of jumping, have bred this habit, and modified their muscles accordingly.

"But now a race of caribou has moved further into the woods, where great trees lie fallen across the way, and where if there is anybody behind them, or they are in a hurry, jumping is a necessity. Still they do not like it and avoid jumping as much as possible. The little ones, left to themselves, would always crawl under a fallen tree, or trot round it. And this is another thing to overcome, and another lesson to be taught in the caribou school.

"One afternoon in late summer I was drifting down the Toledo River, casting for trout, when a movement in the bushes caught my attention. A great swampy tract of ground, covered with grass and low bush, spread out on either side of the stream.

"From the canoe I made out two or three waving lines of bushes where some animals were making their way through the swamp toward a strip of big timber which formed a kind of island in the mididle. Pushing my canoe into the grass I made for a point just astern of the nearest quivering line of bushes. A glance at a strip of soft ground showed me the trail of a mother caribou with her calf. I followed carefully, the wind being ahead in my favour.

"They were not hurrying and I took good pains not to alarm them.

"When I reached the timbers and crept like a snake through the underbush, there were the caribou, five or six mother animals, and nearly twice as many little ones, well grown, which had evidently just come in from all directions. They were gathered in a natural opening, fairly clear of bushes, with a fallen tree or two, which served a good purpose later. The sunlight fell across it in great golden bars, making light and shadow to play in; all around was the great marsh, giving protection from enemies; dense underbush screened them from prying eyes-and this was their school-room.

"The little ones were pushed out into the middle, away from the mothers to whom they clung instinctively, and were left to get acquainted with each other, which they did very shyly at first, like so many strange children. 
"It was all new and curious; this meeting of their kind; for till now they had lived in dense solitude, each one knowing no living creature save its own mother.

"Some were timid and backed away as far as possible into the shadow, looking with wild, wide eyes from one to another of the little carilou, and bolting to their mother's side at every unusual movement. Others were bold and took to butting at the first encounter. ...

"As I watched them the mothers all came out from the shadows and began trotting round the opening, the little ones keeping close as possible, each one to its mother's side.

"Then the old ones went faster; the calves were left in a long line stringing out behind.

"Suddenly the leader veered into the edge of the timber and went over a fallen tree with a jump; the cows followed splendidly, rising on one side and falling gracefully on the other, like gray waves racing past the end of a jetty.

"But the first little one dropped his head obstinately at the tree and stopped short. The next one did the same thing; only he ran his head into the first one's legs and knocked them out from under him. The others whirled with a bal-a-a-il-ah, and scampered round the tree and up to their mothers, who had turned now and stood watching anxiously to see the effect of their lesson.

"Then it began over again. It was true kindergarten teaching; for under guise of a frolic the calves were taught a needful lessonnot only to jump, but far more important than that, to follow their leader, and to go where he goes without question or hesitation.

"For the leaders on the barrens are wise old bulls that make no mistakes.

"Most of the little caribou took to the sport very well, and presently followed their mothers over the low hurdles. But a few were timid, and then came the most interesting bit of the whole strange school, when a little one would be led to a tree and butted from behind till he took the jump.

"There was no 'consent of the governed' in the governing. The mothers knew, and the calf didn't, just what was good for him."

The caribou is such a restless wandering fellow that it is little use to attempt hunting him by following his trail; you may succeed in getting a shot at him in this manner, but the chances alle that he will see you first, or at all events become 


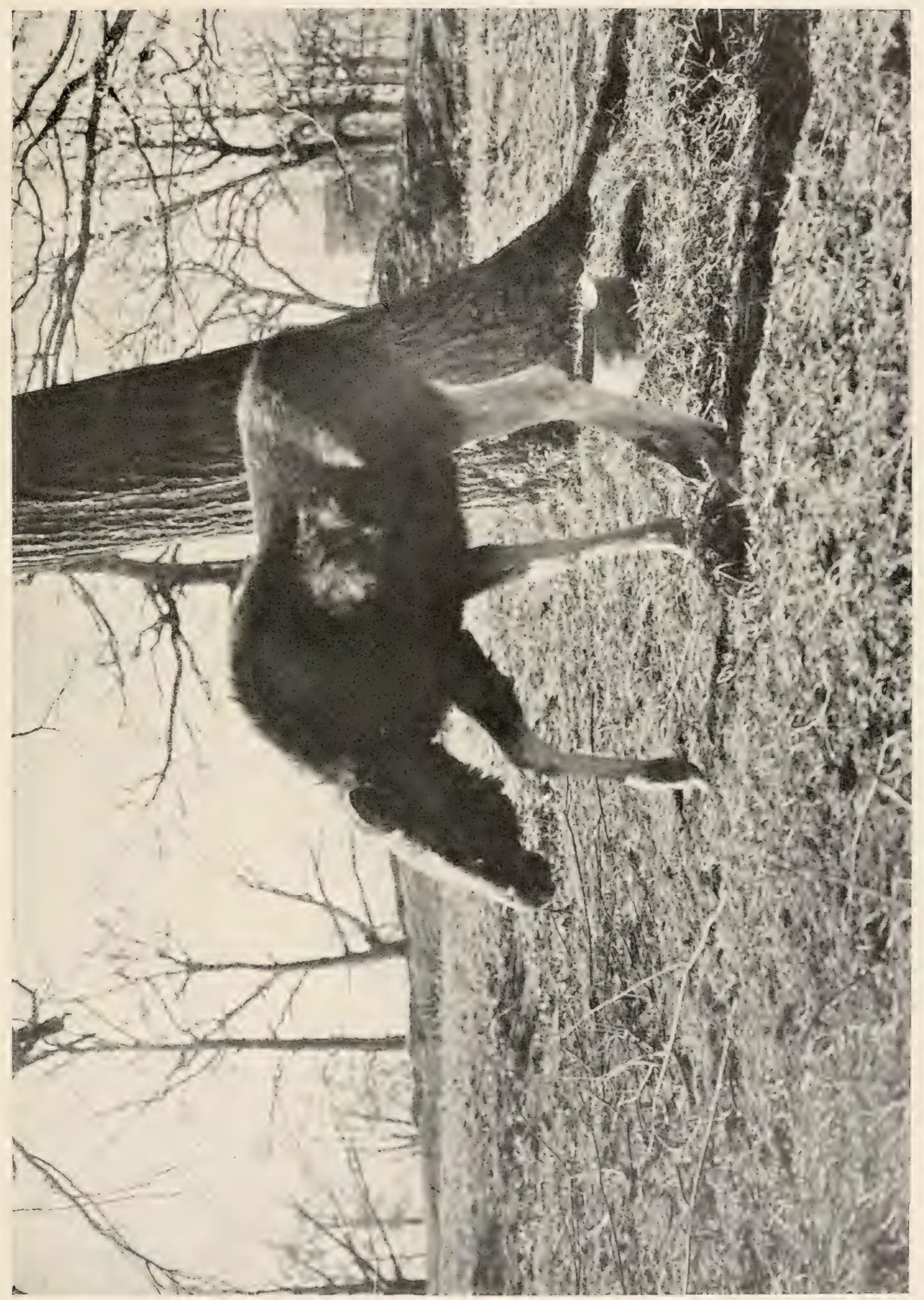



aware of your presence in some way, and after that you might as well be following the trail of a wood-nymph, as far as your chances of success are concerned.

Still hunting is the most satisfactory method of getting caribou. Keeping the wind in your face you wander silently through the forest and along by the edge of the open barren and by the lake's margin, keenly searching the skirts of the spruce thickets and birch clumps for a sight of your game. If you should chance upon a trail very recently made, it is sometimes possible, if the wind is in your favour, to follow it cautiously and get a shot; or perhaps after following it a little way the direction of the trail will tell you the caribou are in all probability heading for a certain open feeding ground or lake shore that you know of, in which case a cross cut will often enable you to intercept them.

Caribou are full of inquisitiveness and not very keen sighted, and in winter, when the woods are white with snow, some caribou hunters make a point of wearing a white flannel hunting suit and a brilliant red cap; the caribou seeing this spot of bright colour moving among the trees are tempted by curiosity to approach within gunshot.

\section{Varieties of the Woodland Caribou}

There are seven kinds of caribou in North America which appear to be quite distinct and geographically separated from one another,and all of them certainly different from the reindeer of Europe. They fall into two groups; the larger woodland caribou and the smaller Barren Ground caribou. The most striking differences between the members of the former group are given below, and of the latter beyond.

I. Woodland Caribou. Rangifer caribou (Gmelin). Description and range as above.

2. Mountain Caribou. Rangifer montanus. Seton-Thompson. Uniformly darker than the preceding with the white band above the hoof very narrow. Size rather larger.

Range. Rocky Mountains of Idaho north into Southern Alaska.

3. Stone's Caribou. Rangifer stonei Allen. Dark like the last but with a heavy white fringe of hair on the front of the neck in strong contrast.

Range. Kenai Peninsula Alaska.

4. Newfoundland Caribou. Rangifer terre-nove Bangs. Uniformly whiter than the woodland caribou, with a white ring around the eye. Antlers very massive and widespread with numerous points.

Range. Newfoundland. 


\title{
Barren Ground Caribou
}

\author{
Rangifer arcticus (Richardson)
}

Size. Smaller than the preceding. Antlers longer, 50 inches.

Discription. Smaller than the woodland caribou and allied species, colours light, almost entirely white in winter. Antlers slender with comparatively few points.

Range. Barren Grounds of Arctic America.

Recent explorations in the Northwest have discovered a much greater variety of caribou than were formerly supposed to exist, in fact, no less than seven different kinds are now known to inhabit North America. It is impossible at present to determine the exact relationship between these animals until their range has been more carefully ascertained. It is quite likely that all maly prove to be perfectly distinct species or some of them may be mere geographic races, shading imperceptibly one into the other. However this may be, the Barren Ground caribou, the smallest of the group, seems to be the most widely separated both in appearance and habits from woodland caribou of which we have just been treating. "Its range," writes Warburton Pike, "appears to be from the islands in the Arctic Sea to the southern part of Hudson's Bay, while the Mackenzie River is the limit of their western wandering. In the summer time they keep to the true Barren Grounds, but in the autumn, when their feeding-grounds are covered with snow, they seek the hanging moss in the woods. From what I could gather from the Indians, and from my own personal experience, it was late in October, immediately after the rutting season, that the great bands of caribou, commonly known as La Foule, mass up on the edge of the woods, and start for food and shelter afforded by the stronger growth of pines farther southward. A month afterward the males and females separate, the latter beginning to work their way north again as early as the end of February; they reach the edge of the woods in April, and drop their young far out toward the seat-coast in June, by which time the snow is melting rapidly and the ground showing in patches. The males stay in the woods till May and never reach the coast, but meet the females on their way inland at the end of July; 


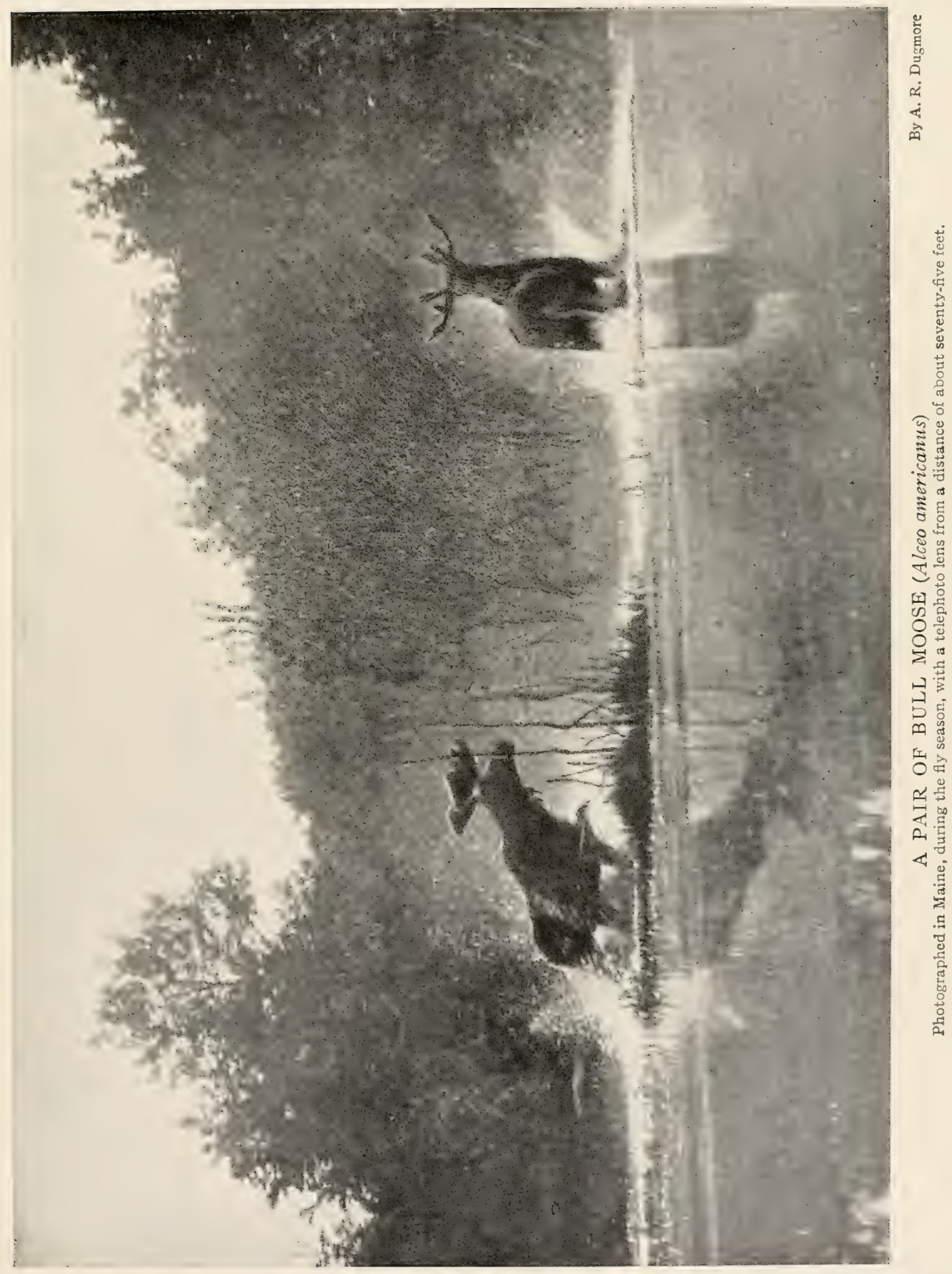



from this time they stay together till the rutting season is over and it is time to seek the woods once more."

Of their curious migration he says, "They are extremely uncertain in their movements, seldom taking the same course in two consecutive years, .. . this is in a great measure accounted for by the fact that great stretches of the country have been burnt, and so rendered incapable of growing the lichen so dearly loved by these animals." In the fall of 1889 he personally encountered one of the migrations. "With the increasing depth of the snow there was a noticeable migration of life, from the Barren Grounds. Ptarmigan came literally in thousands, while the tracks of wolves, wolverines and Arctic foxes made a continuous network in the snow. Scattered bands of caribou were almost always in sight from the top of the ridge behind the camp and increased in numbers till the morning of October 2oth, when we were awakened before daylight by the cry of "La foule," "La foule," and even in the lodge we could hear the curious clatter made by a band of travelling caribou. La Fonle had really come and during its passage of six days I was able to realize what an extraordinary number of these animals still roam in the Barren Grounds. From the ridge we had a splendid view of the migration; all the south side of Mackay Lake was alive with moving beasts, while the ice seemed to be dotted all over with black islands, and still away on the north shore, with the aid of the glasses, we could see them coming like regiments on the march. In every direction we could hear the grunting noise that the caribou always make when travelling; the snow was broken into broad roads and I found it useless to try to estimate the number that passed within a few miles of our encampment. . . This passage of the caribou is the most remarkable thing that I have ever seen in the course of many expeditions among the big game of America. The buffalo were for the most part killed out before my time, but I cannot believe that the herds on the prairie ever surpassed in size La Fonle of the caribou."

\section{Varieties of Barren Ground Caribou}
1. Barren Ground Caribou. Description and range as above.
(Richardson). 
2. Greenland Caribon. Rangifer granlandicus (Gmelin). Somewhat like the last, a white ring around the eye and very long slender antlers.

Range. Greenland.

3. Grant's Caribou. Rangifer granti Allen. Represents the Barren Ground caribou in the extreme Northwest. Skull characters quite different.

Range. Alaskan peninsula.

\section{PRONG-HORNS}

\section{Family Antilocaprida}

This family contains only the curious prong-horn of our Western plains, an animal intermediate in many ways between the deer and the cattle.

\section{American Prong-Horn}

\section{Antilocapra americana (Ord)}

Also called Antelope, Prong-buck.

Length. 4 feet, 6 inches. Height at shoulder, 2 feet, ro inches. Description. Horns hollow, like those of the cattle, but regularly deciduous, like the antlers of the deer, and forked. The two small rudimentary hoofs, usually seen in ruminant animals behind and above the large pair, are entirely absent. Muzzle covered with hair except a narrow line down the middle, eyes very large and a short mane on the back of the neck. Colour above light yellowish-brown, throat, neck and underparts white; forehead, nose and spot below the ear dark brown, sides of the head, spot behind the ear and triangular patch on the shoulder joining the throat white.

Range. Saskatchewan to Mexico; Missouri River to the Rocky Mountains, and the Cascade Mountains of Oregon and Washington.

The prong-horn or prong-buck is to be found in diminished numbers from the Missouri River to the Pacific and southward into Mexico. They are roving creatures, their movements being largely determined by the weather and the comparative abundance or scarcity of water and pasturage. In winter they seek 

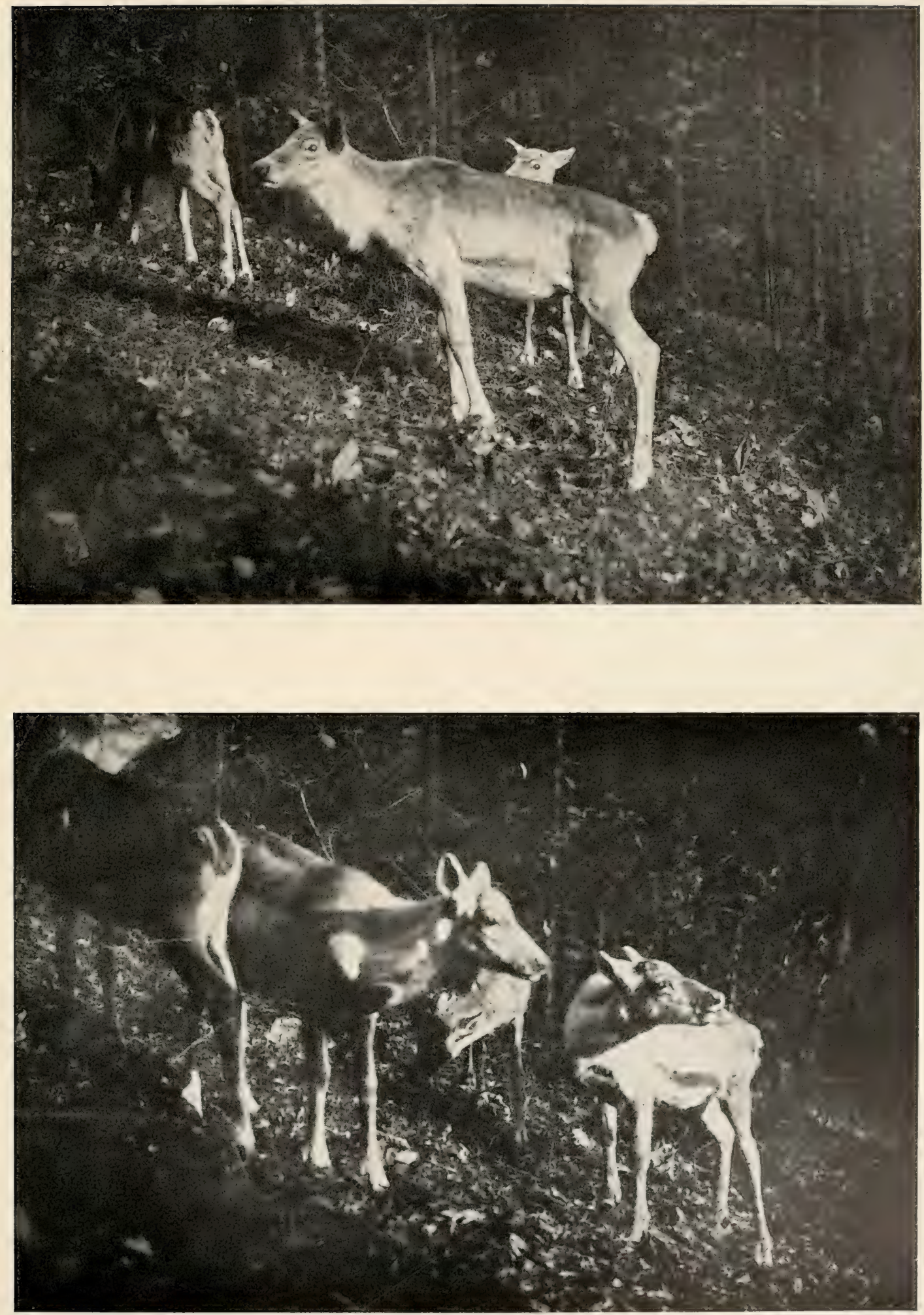

sheltered valleys among the hills and, as spring comes on, the females separate from the rest of the herd and give birth to their kids, usually two in number. These they keep in hiding and watch jealously for a fortnight. At the end of a short time they are strong and reliant on their legs and capable of following their mothers wherever they go.

The herd now wanders out over the open plains and low rolling foot-hills, where the wide free outlook makes it possible for them to detect danger at an immense distance. When alarmed, they crowd together and dash away like the wind and, being easily the swiftest runners on the continent, are in little danger of being overtaken. Their innate curiosity, however, often gets them into trouble. A handkerchief on the end of a stick, or anything, in fact, that excites their curious interest, will frequently draw them within gunshot, unless they manage to get the wind of their enemy, when, scenting danger, they are off and away.

During the summer months the old bucks live apart from the females and their families; towards autumn, however, they become more sociable and friendly, and join their mates once more, the herds constantly increasing in size until November.

In defending their kids the females use their sharp hoofs with savage effectiveness, striking a quick downward blow with their forefeet that might easily disable a wolf that came too close. It is said that they will cut a rattlesnake to pieces before he has a chance to strike.

Like other distinctively Western animals, the antelope attracted much attention from Audubon on his famous expedition up the Missouri, and all its peculiarities of habit were carefully observed. In his account of the species he says:

"Observe now a nlock of these beautiful animals; they are not afraid of man-they pause in their rapid course to gaze on the hunter, and stand with heads erect, their ears as well as eyes directed toward him, and make a loud noise by stamping with their forefeet on the hard earth; but suddenly they become aware that he is no friend of theirs, and away they bound like a flock of frightened sheep-but far more swiftly, even the kids running with extraordinary speed by the side of their parentsand now they turn around a steep hiil and disappear, then per- 
haps come in view, and once more stand and gaze at the intruder."

The wonderful watchfulness of the antelope is due naturally to its continual exposure in the open country in which it lives and the necessity of being ever prepared to get a clear start of the wolves or such other enemies as may harass it, against which flight is its only safeguard.

Like many other animals that habitually associate in flocks, the antelope has in its two white rump patches conspicuous "recognition marks," as they have been termed, by which, according to Wallace's theory, individuals can at a glance recognize their own kind, even though at a considerable distance. The rump patches of the antelope, however, are different from those of other ruminants and are of much more importance to the animal. Ernest Seton-Thompson, writing of this matter in The Century Magazine, salys: "Some years ago, while riding across the upland prairie of the Yellowstone, I noticed certain white specks in the far distance. They showed and disappeared several times and then began moving southward. Then, in another direction, I discovered other white specks which also seemed to flash and disappear. A glass showed them to be antelope, but it did not wholly explain the flashing or the moving which ultimately united the two bands. I made note of the fact, but found no explanation until the opportunity came to study the antelope in the Washington Zoo." He goes on to explain how the approach of a dog to the enclosure of the captive animals caused them to elevate the hair all over their rump patches. "The wild antelope habit is to raise the head while grazing to keep a sharp lookout for danger, and these captives kept up the practice of the race. The first that did so salw the dog. It uttered ro sound, but gazed at the wolfish-looking intruder and all the long white hairs of the rump patch were raised with a jerk that made the patch flash in the sun like a tin pan. Everyone of the grazing antelopes saw the flash, repeated it instantly and raised his head to gaze in the direction in which the first was garing. At the same time I noticed on the wind a peculiar musky smell-a smell that certainly came from the antelope." Subsequent investigation showed the presence of a musk gland in the centre of the rump patch and a mass of muscle connected with it and with the bises of the white hairs. This completed 


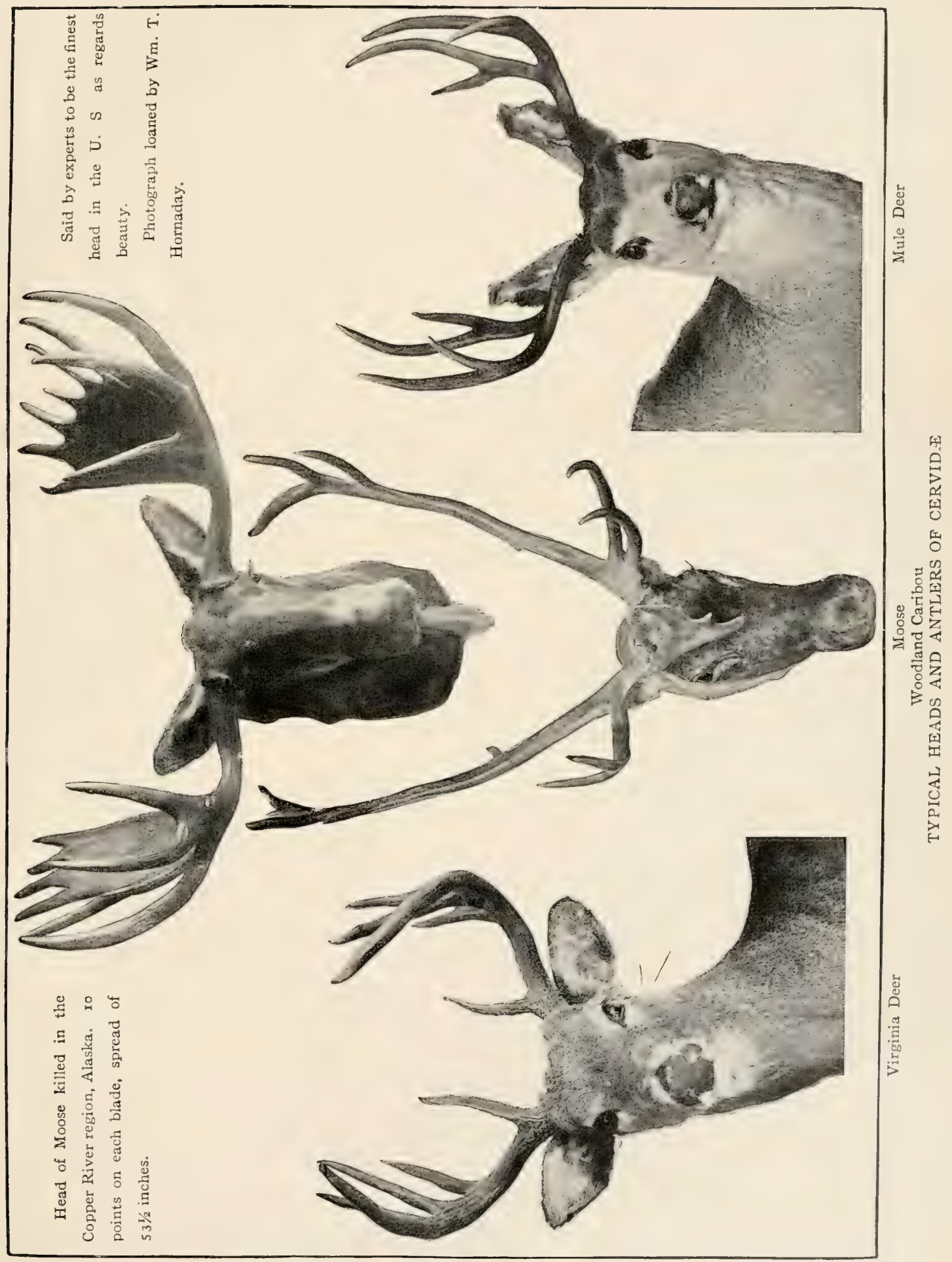



the explanation of the whole matter. "As soon as the antelope sees some strange or thrilling object this muscle acts and the rump patch is changed in a flash to a great double disk or twin chrysanthemum of white that shines afar like a patch of snow, but in the middle of each bloom a dark brown spot, the musk gland is exposed and a great quantity of the odor is set free and the message is read by all those who have noses to read. Of all animals man has the poorest nose, he has virtually lost the sense of smell, while among the next animals in the scale scent is their best faculty. Yet even man can distinguish the danger scent for many yards down the wind and there is no reason to doubt that antelope can detect it a mile away. Thus the observations on the captive animals living under normal conditions proved the key to those made on the plains and I know now that the changing nashes in the Yellowstone upland were made by the antelopes' heliograph, while the two bands signalled each other; and the smaller band on getting the musky message 'Friend' laid aside all precaution and fearlessly joined their relatives."

\section{THE CATTLE}

\section{Fanily Bovide}

To this family belong all the domestic cattle and their allies the bisons and buffaloes, wild sheep and goats as well as the great host of antelopes found in Africa and Asia. Our American representatives are few in number, comprising only the mountain goat, mountain sheep, musk ox and buffalo.

\section{Mountain Goat}

\section{Oreamnos montanus (Ord)}

Called also White Goat.

Length. 4 feet. Height at shoulder, 3 feet.

Description. Body covered with long hanging white hair and a short woolly under-fur, entirely yellowish white. Shoulders 


\section{Mountain Goat}

rather humped and head carried below their level, nose hairy, a short beard on the chin. Horns slender in both sexes and curving slightly backward, black, as are also the hoofs. Rang: Higher Rocky and Cascade Mountains to Alaska.

The higher, almost inaceessible slopes of the British Columbian Bmontums are the stronghold of the mountain goats. There usually dibove the timber-line, amid the wildest scenery, and surrounded by Glaciers and precipices they live pratically ummolested exeept by the in atiable hunters. Living in such isolation they are in little need of speed or agility and are said to be rather slow and stupid heasts. ealsily secured if the surroundings admit of an approach.

The mountain groat presents many points of interest. In the first place it is not a goat but rather an outlying member of the great antelope tribe-- to which by the way our American "antelope" does not belong. The nearest relatives of the goat are the serow of the Himalayas and the chamois of the Alps, though the long fleecy coat and goat-like beard give it a very different aspect.

In colour too it is peculiar, being the only pure white ruminant animal known; this is an excellent protection, rendering it practically. invisible during the snows of winter, though at other seasons it would seem to render it equally conspicuous.

In describing his experience in pursuit of this animal Frederis Irland writes: ". The most charming innocent creatures that I met in the Cascade Mountains were the white goats. What do you think of a wild animal which, after he knows you are on his trakk, will stop and turn back, to peer around the corner and see what you are? These statcly animals, with their long white aprons, conl hlack eyes, and sharp little horns, really seem to me too unsophisticated to shoot. At A heroft and Lillooet people hatd told me to get my hand in by shooting a goat and then perhaps I could improve by getting a sheep. As usual we were secking what we might destroy, though as a fact we let many chances go. We had aearly hurst our hearts by climbing for an hour or two un the mansard roof of North America and high above the deer pastate. The winter on the mountain tops had driven the game lown and sent the hears to their winter dens. We had found sherp traiks and were following aloner to see where they led, when suditenly we saw four white animals on the edge of an abyss of the kind which Dore has portrayed in illustrating Dante. 


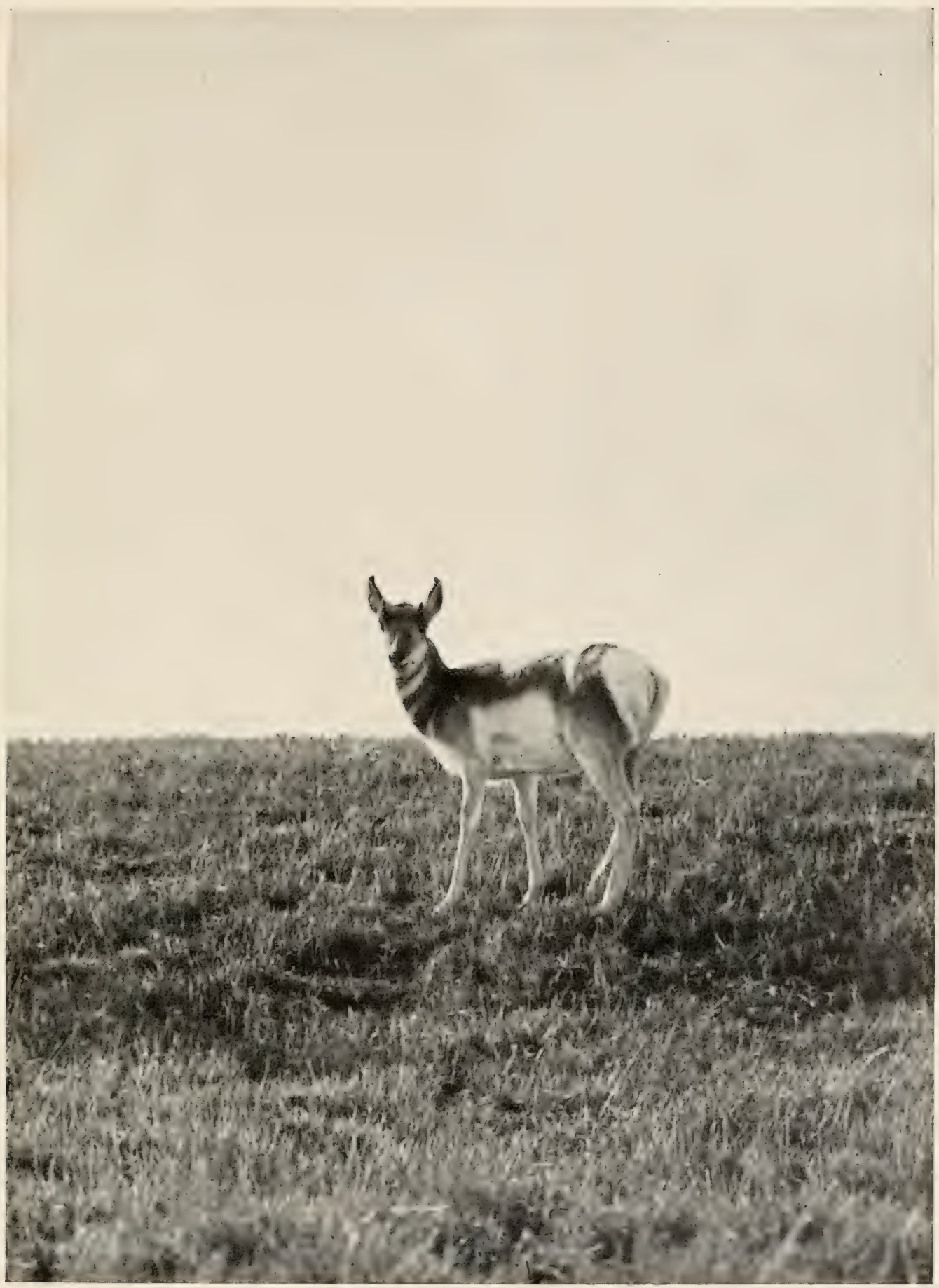

PRONGHORN (Antilocapra americana)

By W. E. Carlin

With new horns just appearing. A telephoto picture from a distance of roo yards, taken on the outskirts of the Yellowstone. 

The goats were not very far from us in a straight line, but it was a long way around. They saw us and started on a rheumatic gallop, but only went a little way, and as they reached a turn, huddled up and looked back. We picked our way over toward their last place of abode, reaching the opposite side of the canyon by means wholly unsuited to nervous people. There was just snow enough to show their tracks, which led along scandalous precipices. The fever of pursuit was on my guide, and he walked uprightly in places where I became a quadruped. This was trying to his patience, for he caught glimpses of the goats which I by reason of slower progress, was denied. In about half an hour we came to a great chimney of rock in the path, and clinging with fingers and moccasins, he went around the face of it. . . . When I came out above him I saw he had the goats in a sort of a natural trap, and they were all bunched up against a rock which I thought could not be passed. The biggest billy stood faced about, his long white beard and petticoats making him look like the high priest of some heathen temple. 'Don't shoot; he fall down' yelled my guide. At the sound of the voice the goat made a desperate attempt at the face of the rock, scrambling up at an obtuse angle, then standing on his hind legs and throwing his fore feet over, from right to left. I thought he surely would fall back but he did not. The smaller goats followed and in a moment they were gone. . . . We made a flank movement and perhaps a quarter of a mile from the first round-up we saw those four fool goats again, the big one and a small one looking back around the corner to see if we were really coming. Then we did shoot and curiosity broke up that family."

Mr.Owen Wister, in one of the Boone and Crockett Club's volumes, gives an interesting account of "The White Goat and his Country." Describing his first sight of the animal he says: "We went cautiously along the narrow top of crumbling slate, where the pines were scarce and stunted, and had twisted themselves into corkscrews so they might grip the ground against the tearing force of storms. We came on a number of fresh goat-tracks in the snow or the soft shale. These are the reverse of the mountain sheep, the $V$ which the hoofs make having its open end in the direction the animal is going. There seemed to be several, large and small; and the perverted animals invariably chose the sharpest slant they could find to walk on, often with a decent level just beside it that we were glad enough to have. If there was a precipice and a sound nat-top, they 


\section{Mountain Goat}

took the precipice, and crossed its face on juts that did not look as if your hat would hang on them. In this I think they are worse than the mountain sheep, if that is possible. Certainly they do not seem to come down into the high pastures and feed on the grass levels as the sheep will. As we continued I saw a singular looking stone lying on a little ledge some waly down the mountain ahead. I decided it must be a stone, and was groing to speak of it, when the stone moved and we crouched in the slanting gravel. . . I climbed or crawled out of sight, keeping any stone or little bush between me and the goat, and so came cautiously to where I could peer over and see the goat lying turned away from me, with his head commanding the valley. He wals on a tiny shelf of snow, beside him was one small pine, and below that the rock fell away steeply into the grorge. He looked white, and huge, and strange; and somehow I hald a sense of personality about him more vivid than any since I watched my first silver-tip lift a rotten $\log$, and, sitting on his hind legs, make a breakfast on beetles, picking them off the log with one paw." "By eight the next morning," he continues "we had sighted another large solitary billy. But he had seen us down in the path from his ridge. He had come to the edge and was evidently watching the horses. If not quick witted, the goat is certainly wary; and the next time we saw him he had taken himself away down the other side of the mountain, along a spine of rocks where approach was almost impossible. We watched his slow movements through the glass, and were reminded of a bear. He felt safe and was stepping deliberately along, often stopping, often walking up some small point and surveying the scenery. He moved in an easy rolling fashion, and turned his head importantly. Then he lay down in the sun, but salw us on our way to him, and bounced off. We came to the place where he had jumped down sheer twenty feet at least. His hooftracks were on the edge, and in the gravel below, the heavy scatter he made in landing; and then,-hasty tracks round a corner of rock and no more goat that day."

Mr. Wister says of the habits of the goat: "It has been stated that in the winter season, like mountain sheep, he descends and comes into the valleys. This does not seem to be the case. He does not depend upon grass, if indeed he eats grass at all. His food seems to be chiefly the short, almost lichen-like moss that grows on the faces and at the base of the rocks and between them in the crevices. None of the people in the Methon country spoke of seeing groats come out 

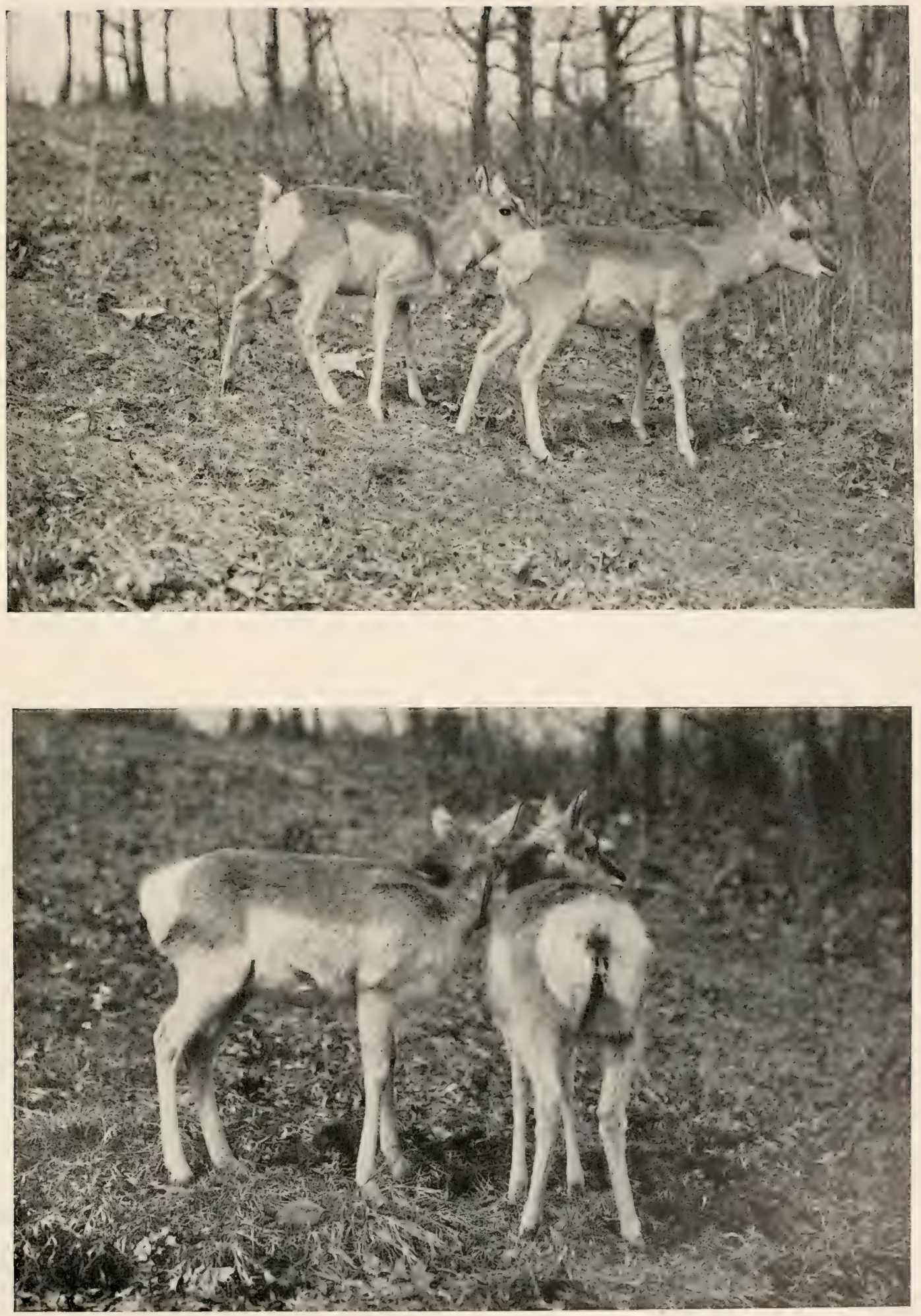

of the mountains during winter. I have not sufficient data to make the assertion, but I am inclined to believe that the goat keeps consistently to the hills, whatever the season may be, and in this differs from the mountain sheep as he differs in appearance, temperament, and in all characteristics, excepting the predilection for the inclined plane; and in this habit he is more vertical than the sheep." Of hunting them he adds; "There is no use in attempting to hunt them from below. Their eyes are watchful and keen, and the chances are that if you are working up from below and see a goat on the hill, he will have been looking at you for some time. Once he is alarmed, ten minutes will be enough for him to put a good many hours of climbing between himself and you. His favourite trick is to remain stock-still, watching you till you pass out of his sight behind something, and then, he makes off so energetically that when you see him next he will be on some totally new mountain. But his intelligence does not seem to grasp more than the danger from below. While he is steadfastly on the alert against this, it apparently does not occur to him that anything can come down upon him. Consequently from above you may get very near before you are noticed."

From the Copper River Mountains, Alaska, Mr. D. G. Elliot has described a goat with very different skull and more divergent horns which seems to represent a different species or geographic race. $\mathrm{He}$ calls it Kennedy's mountain goat, Oreamnos kennedyi.

\section{Mountain Sheep}

\section{Ovis cervina. Desmarest}

Also called Bighorn.

Length. 4 feet 6 inches. Height at shoulder, 3 feet 4 inches. Length of horn around curve, 50 inches. Circumference at base, 14 inches.

Description. Body heavy, legs rather slender, hair everywhere closely appressed, no mane or beard. Horns in female short, in male very massive, curving backward and outward and in old rams making a complete spiral circle. Colour grayish brown, darkest on the back, under parts, inner side of legs, upper throat and patch on rump and around the base of the tail whitish; lighter and grayer in winter.

Range. Higher mountains from British Columbia to Arizona. Nearly related varieties inhabit mountains to the North, South and West. (See below) 


\section{Mountain Sheep}

The bighorn might be called the chamois of our Western mountains, scaling the rugged cliffs and plunging over precipices with the same agility and confidence that mark the famous inhabitant of the Alps.

The elastic spring of the anmal when started and the easy poise of the splendid head as it settles back on the shoulders are exceedingly graceful, and the animal seems built and proportioned to the finest detail for the life that it leads.

From the edges of the Alaskan glaciers to the dry, waterless crags of the Mexican Sierras we find one variety or other of the mountain sheep.

During the breeding season an old ram presides over the flock of ewes and lambs, driving the younger rams off by themselves, as is usual among polygamous animals. The flocks are exceedingly watchful and at the slightest alarm are off instantly, selecting a course that few animals or men care to follow. In early spring the sheep venture farther down into the mountain valleys in search of food, but soon return to their rocky fastnesses among the higher slopes.

In the "Bad Lands," the easternmost pirt of their range, Audubon made the acquaintance of these noble animals in 1843 . He says: "The parts of the country usually chosen by the sheep for their pastures are the most extraordinary broken and precipitous clay hills or stony eminences that exist in the wild regions belonging to the Rocky Mountain chain. Perhaps some idea of the country they inhabit-which is called by the French Canadians and hunters 'maturaise terres'-may be formed by imagining some hundreds of loaves of sugar of different sizes, irregularly broken and truncated at top, placed somewhat apart and magnifying them into hills of considerable size. Over these hills and ravines the Rocky Mountain sheep bound up and down and you maly estimate the difficulty of approaching them and conceive the great activity and sure-footedness of this species. They form paths around these irregular clay cones that are at times six to eight hundred feet high, and in some situations are even fifteen hundred feet or more ahove the adjacent prairies; and along these they run at full speed, while to the eye of the spectator below, these tracks do not appear to be more than a few inches wide although they are generally from a foot to eighteen inches in breadth. In many places columns or piles of clay or 


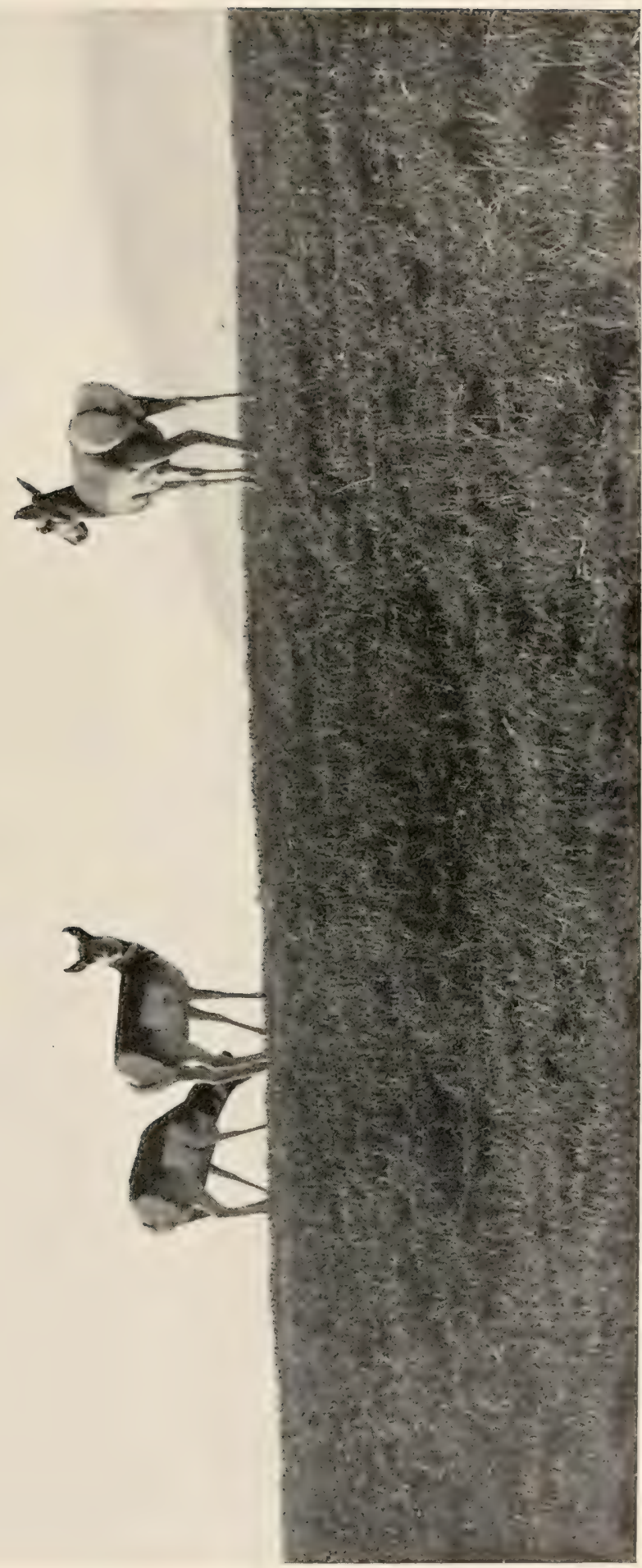



hardened earth, are to be seen eight or ten feet above the adjacent surface, covered or coped with a slaty, flat rock, thus resembling gigantic toadstools, and upon these singular places the bighorns are frequently seen, gazing at the hunter who is winding about far below, looking like so many statues on their elevated pedestals. One cannot imagine how these animals reach these curious places, especially on these inaccessible points, beyond the reach of their greatest enemies, the wolves, which prey upon them whenever they stray into the plains below.'

Like all other big game the bighorn has been relentlessly pursued by hunters and in many parts of its original range it has been exterminated. In a number of localities, however, it holds its own with remarkable persistency, thanks no doubt to its agility, wariness and the inaccessibility of its favourite ranges. The sheep furnishes not only good sport in the chase but excellent meat as well, and has the misfortune to possess a pair of horns that are prized perhaps more than those of any of our other big game. Hornaday truly says, "The head of the male bighorn is a trophy which appeals to all sorts and conditions of hunters, except indians. In the grandest head the noble redman sees no.hing more than a pair of horn spoons for his soupkettle. Thousands of Ovis cervina have been hunted down and killed for their heads alone and thousands more have met their death before the rifles of sportsmen because they are grand game."

"Their ideal haunts," writes Hornaday, "are the slopes of high mountains, above timber line, near the edge of the snow fields that are perpetual." These he states are often covered with luxuriant grass as well as gray moss. In winter they seek lower altitudes and frequent the glades of the pine woods known as "mountain parks." "It is essential, however, that one side of the mountain sheep's home ranch should fall away abruptly in ragged lines of ferpendicular rim-rock, with acres of slide-rock below, in order that the sheep may have the means of escape from their numerous enemies, particularly hunters."

"I once had an illustration of the mountain sheep's tactics on a mountain top where the rock seemed poorly provided for means of escape. Two old rams were feeding at an elevation of about 9,000 feet. The snow was fourteen inches in depth, with a slight crust upon it. When first seen they were in a fifteen-acre open meadow, near the edge of the rim-rock, bravely 


\section{Mountain Sbeep}

pawing through the snow to reach the longest of the dry, brown stems of bunchgrass that thrust their heads half way up through it. On finding themselves objects of a hunter's special notice the two rams quietly dropped over the sharp edge of the plateatu, ploughed down a narrow cleft filled with slide-rock and disappeared. Pursuit on their trail led down to the foot of a $200-f o o t$ wall of rim-rock, and close along its base for a long distance. At last the trail went farther down and dropped over the next lower wall of rim-rock in a manner that seemed deliberately calculated to make pursuit more laborious. As a change of tactics the hunt was kept up along the top of the rim-rock, but the quarry hugged the wall so closely that not even once was it sighted. It became evident that only by hours of patient work could those animals be encountered again, if at all."

Like the caribou the bighorns from different sections of the country present a very different appearance not only in colour, but in the size and shape of their horns, and instead of the one species which was known to our early explorers we have now seven species or varieties, all, however, animals of essentially similar habits.

\section{Varieties of Mountain Sheep}

I. Monntain Sheep. Ovis cervina Desmarest. Description and range as above.

2. Audubon's She'p. Ozis cervina auduboni Merriam. Slightly different skull characters from the Rocky Mountain animal to which it is very closely related.

Ringe. "Bad Lands." Western South Dakota and Eastern Wyoming.

3. Nelson's Sheep. Ovis nelsoni Merriam. Similar, but much paler. Range. Grapevine Mountains, between California and Nevada.

4. Mexican Sheep. Ovis mexicanus Merriam. Intermediate in colour between the mountain and Nelson's sheep. Ears much longer than those of the former.

Range. Northwestern Mexico and (?) southern New Mexico.

5. Stone's Sheip. Oris stonei Allen. Darker than the mountain sheep, with much more slender horns.

Ranne. Headwaters of Pease River, Rocky Mountains, and Cassiar Mountains to Stikeen Mountains, Alaska.

6. Dall's Sheep. Oris dalli Nelson. White or yellowish-white at all seasons.

Range. Alaskan Mountains, north of $60^{\circ}$ to the Arctic coast. 

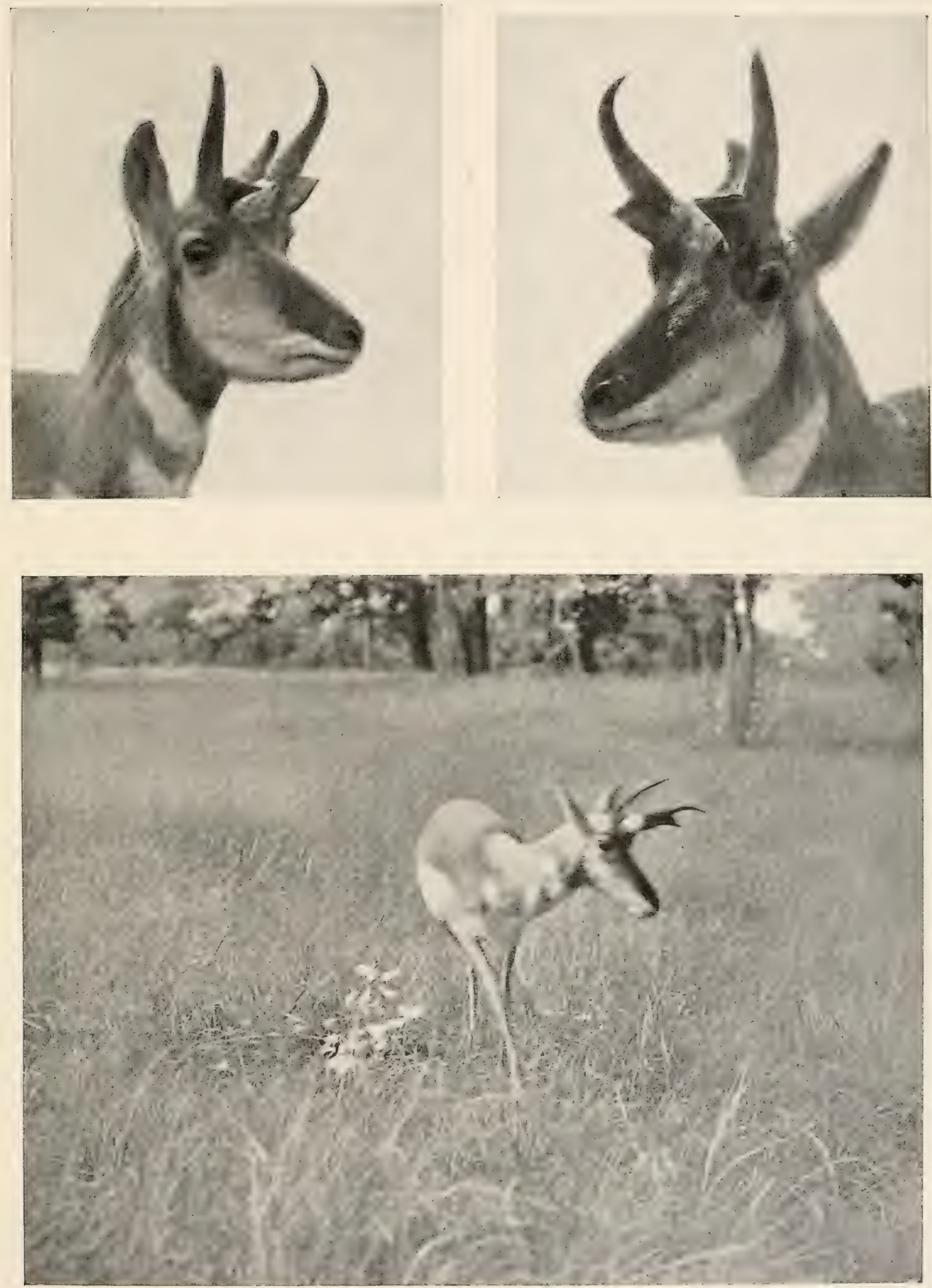

7. Fannin's Sheep. Ovis fannini Hornaday. Similar, but shoulders, back and upper parts of legs gray.

Range. Rocky Mountains, about 75 miles east of Dawson, Northwestern Territory.

\section{Musk Ox}

\section{Ovibos moschatus (Zimmerman)}

Length. 6 feet. Height at shoulder, 3 feet 6 inches.

Description. Heavily built with rather short legs and horns of the male very heavy, their bases meeting on top of the head and curving downward and up again at the tip. Entire head and body covered with a dense mane, matted and curly on the shoulders, but hanging straight on the rest of the body nearly to the ground. Colour very dark brown or blackish on the head and sides; a saddle-shaped patch on the back as well as short hair between the horns, muzzle and limbs below the knees and hocks yellowish white.

Range. Arctic barrens of North America, east of the Mackenzie River. In Greenland occurs the closely allied Peary's musk ox (O. wardi Lyddeker).

The herds of musk oxen, now confined to the Arctic regions of North America, would seem to be the last lingering representatives of a diminishing race. Related species formerly inhabited most of Siberia and parts of northern Europe, as well as Germany, England and France; their fossil remains having been found in all those countries.

Musk oxen are curious long-haired shaggy beasts, in appearance half way between bison and sheep, and combining both in structure and habits the characters of each. The old males are rank of musk, especially in the rutting season, when their flesh is practically uneatable. The females, as a general thing, are almost free from the musky odour to which the species owes its name.

It has been observed by the musk ox hunters that when the animals are fat the odour of musk is much less noticeable. The long woolly coat of the musk ox is highly valued by the Esquimaux who use it for various purposes.

Musk oxen associate in herds numbering from about twenty or thirty to as many as eighty or a hundred head. The herds appear to be largest in winter, the big bulls during the summer 
being for the most part solitary, and the herds consisting of cows and calves which gro about in small bands of from ten to twenty. The movements of the herds are described by Colonel Feiliten as very sheep-like, the old bulls, when present, taking the lead, and the whole assemblage crowding together when alarmed, much after the manner of a flock of sheep. The single calf is produced in May or June and the cows are reported by the natives to breed only once in two years, so that the rate of increase is slow. In summer, according to Mr. Pike, their food consists almost exclusively of the leaves of the small willows scittered here and there over the Barren Grounds, but grass, moss and lichens are also largely consumed, and in winter these two last, with perhaps bark, must form their sole nutriment. In spite of their comparatively short and massive limbs, musk oxen can run with considerable speed; and when thoroughly alarmed they are stated to take to hilly ground, where they display marvellous agility in climbing precipitous cliffs. In spite of stories to the opposite effect, Mr. Pike is of opinion that even old bulls are by no means dangerous animals."*

\section{American Buffalo}

\section{Bison bison (Linnæus)}

Lingth. II feet (adult bull). Height at shoulder, 5 feet, 8 inches. Description. Hind quarters light and short haired, fore quarters very heavy, with a high hump on the shoulders, and densely haired; head held well down below the level of the shoulders; horns curved outward, upward; tail with a terminal tassel. Colour, body and hind quarters pale gray brown, lower parts dark brown. shoulders, hump and upper neck covered with a dense mass of yellowish hair; head, lower part of neck and fore legs to the knees with dense shaggy hair, dark brown above and black lower down.

Range. Originally Great Slave Lake to northern Mexico, New Mexico and Nevada; eastward south of the Great Lakes to central Pennsylvania, Virginia, Georgia and Mississippi.

In 1870. Great Slave Lake to Wyoming and central Texas, eastward to central South Dakota, Kansas and Indian Territory.

In 1880 . About 550 in the extreme Northwest; 250 in Montana, Dakota and Wyoming, and 50 in Colorado and indian Territory. $†$

* Lydekker's "Wild Oxen, Sheep and Goats."

$\dagger$ From Hornaday. 


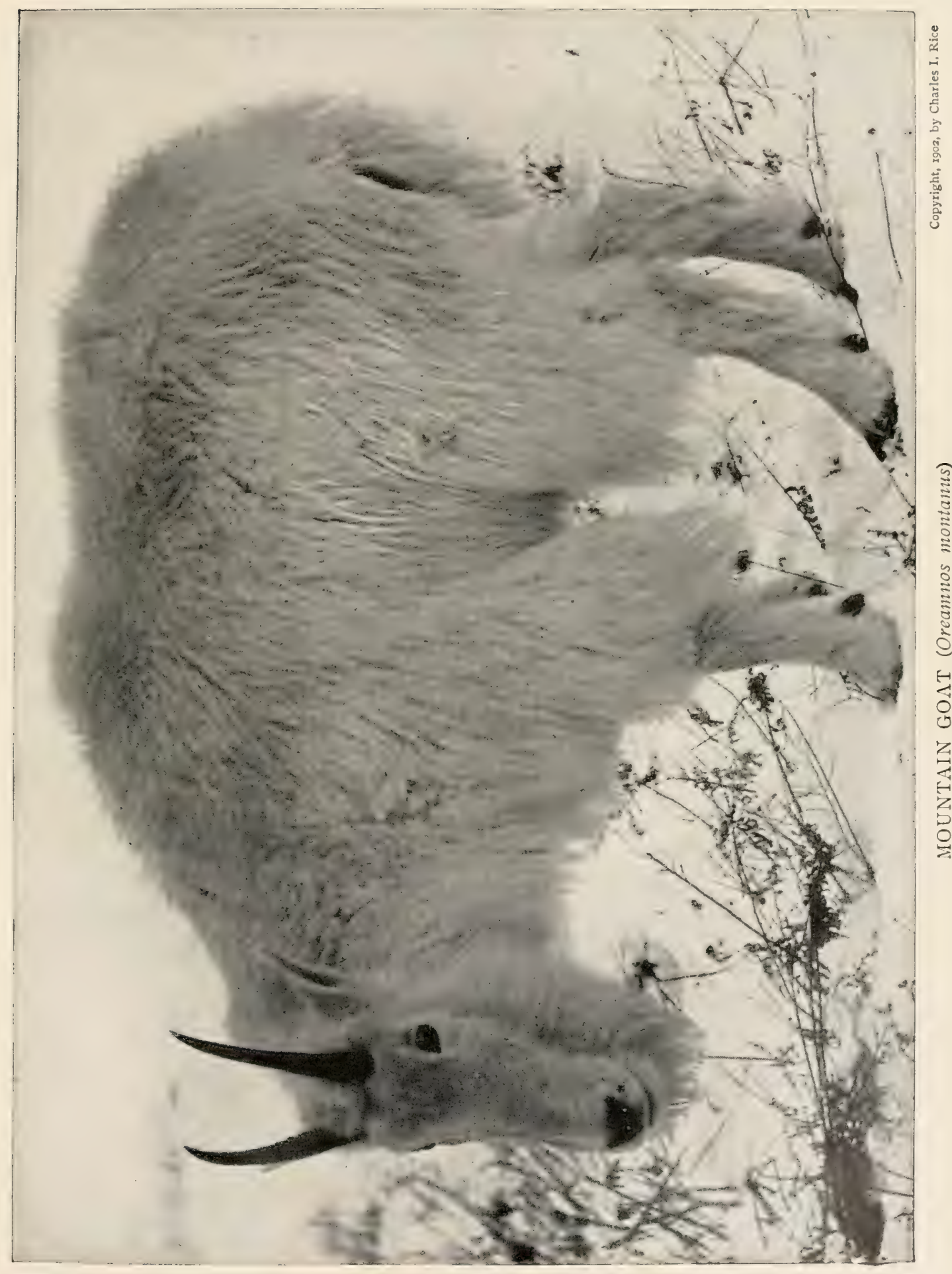



In 1890. Apparently restricted to Yellowstone Park and other preserves.

To the northwest of its range occurred a related variety known as the woodland buffalo (B. bison athabaske Rhoads).

The bison can scarcely be reckoned as a creature of our day, aiready it has taken its place with the aurochs of Europe as a thing of the past. Both species have probably reached the limit of their decline in numbers, and the remaining herds, if properly protected and cared for, may increase considerably in the years to come. But until our present civilization has worn itself out and this part of the earth's surface returns to a state of nature, and the cities have grown up through weeds and bushes to forests and woodland once more, the North American bison must continue only in memory and traditions.

For uncounted ages the bison held all the most fertile grazing land in this country as their own. When the Europeans began to form settlements in North America they occasionally found bisons in small bands near the Atlantic Coast. They were decidedly rare however, everywhere east of the Appalachian Mountains.

From Kentucky, all across the continent to Nevada, and from the Great Slave Lake to Mexico and Georgia, they wandered in mighty herds, migrating from one section to another as snowstorms and drought cut down their pasturages.

The first Western pioneers witnessed such sights as probably no other white men have ever seen or will ever see again.

Wide rolling plains blackened as far as even their hawk-like eyes could see, with huge hump-backed shaggy beasts, the old bulls bellowing and fighting and pawing up the earth which trembled everywhere as at the approach of an earthquake.

Coyotes and timber wolves skulked here and there through the herds watching for an opportunity to pull down an unprotected calf, and dodging the charge of the enraged parent as best they could.

Contrast with this the few hundred more or less degenerate representatives of this noble animal which now survive within the confines of preserves and parks or in the paddocks of zoological gardens, and all will agree that its extermination was one of the most shameful examples of man's greed and a nation's lethargy that is furnished in the history of our country.

The number of the buffalo that ranged over our Western States, even in comparatively recent years is almost inconceivable. Some 


\section{American Buffalo}

Idea, however, may be obtained from the statement of Col. R. I. Dodge, who in 1871 palssed through one of the immense herds while travelling in Arkansas. For twenty-five miles he passed through a continuous herd of buffalo. "The whole country appeared one great malss of buffalo, moving slowly to the northward; and it was only when actually among them that it could be ascertaned that the apparently solid mass was an agglomeration of innumerable small herds of from fifty to two hundred animals, separated from the surrounding herds by greater or less space, but still separated. The herds in the valley sullenly got out of my way, and turning, stared stupidly at me, sometimes at only a few yards' distance. When I had reached a point where the hills were no longer more than a mile from the road, the buffalo on the hills seeing an unusual object in their rear, turned, stared an instant, then started at full speed directly toward me, stampeding and bringing with them the numberless herds through which they passed, and pouring down on me all the herds, no longer separated, but one immense compact mass of plunging animals, mad with fright, and as irresistible as an avalanche. Reining in my horse I waited until the front of the mass was within fifty yards, when a few well-directed shots split the herd, and sent it pouring off in two streams to the right and left. When all had passed they stopped, apparently perfectly satisfied, many within less than one hundred yards. . . . From the top of Pawnee Rock I could see from six to ten miles in almost every direction. This whole vast space was covered with buffalo, looking at a distance like a compact mass."*

From careful information furnished him Mr. Hornaday estimated this herd to comprise at lest four million buffalo. He adds: "Twenty years hence, when not even a bone or buffalo-chip remains above ground throughout the West to mark the presence of the buffalo, it may be difficult for people to believe that the animals ever existed in such numbers as to constitute not only a serious annoyance, but very often a dangerous menace to waggon travel across the plains, and also to stop railway trains and even throw them off the track." $\dagger$

Buffalo were indiscriminately polygamous, very much as are domestic cattle, and at the breeding season collected in much more compact herds. The combined bellowing of the bulls at such times

* "Plains of the Great West."

f"The Extcrmination of the American Bison." Report U.S. Nat. Mus. I $8 \& 6-7$, an exhaustive treatise from which the sulsstance of this account is taken. 

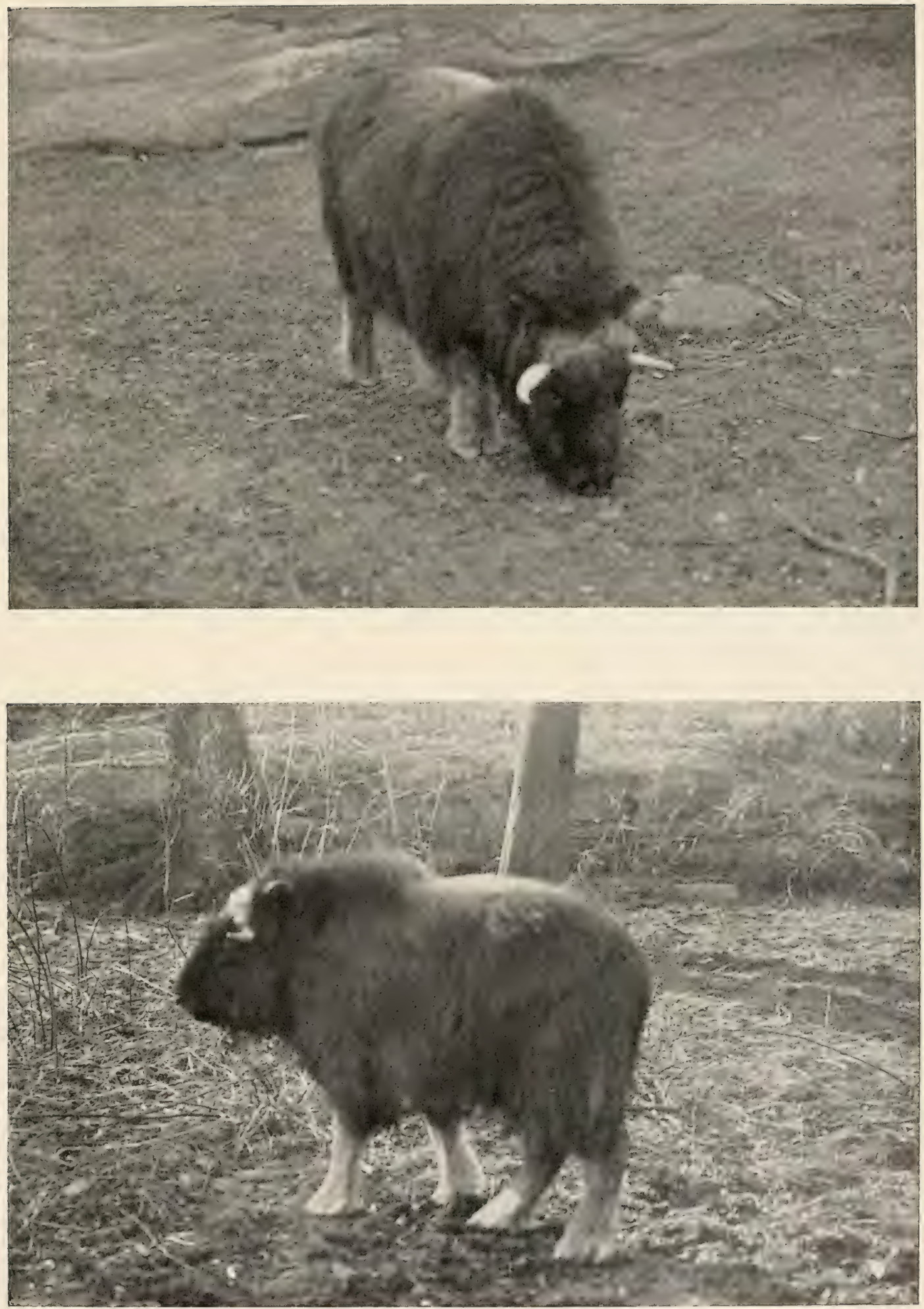

YOUNG COW MUSK OX, about I 6 months old (Ovibos moschatus)

By A. R. Dugmore

This is the second or third ever seen in captivity in a temperate climate. 

made a roar that could be heard for several miles. In winter time the herds migrated regularly to the Southern portion of their range.

After reaching their winter pastures in the South they separated more or less and returned North in the spring in scattered herds, making their migration much less conspicuous.

Their rate of travel was much faster than would naturally be inferred from their lumbering appearance, and they seldom swerved from their well-trodden "buffalo paths" for any obstacles.

Rivers a mile wide, when free from ice, were plunged into and crossed without hesitation; in winter, however, the combined weight of the herd sometimes broke the ice beneath them and large numbers were drowned at such times to feed the wolves and other prowlers along the banks when the river broke up in spring freshets.

The mating season was in the fall when the bisons occupied their Southern feeding grounds, the pairs remained in company until the spring when the cows went off by themselves to the most sheltered spots they could find and gave birth to their calves.

The latter grew rapidly and were soon able to follow the herd, though still jealously guarded and defended from all dangers by their mothers.

The old bulls in the meanwhile had associated in droves by themselves.

In order to escape the attacks of the flies and other insects they sought out muddy sloughs and shallow ponds where they could roll and wallow to their hearts' content and emerge with their coats filled and plastered over with clay which soon baked in the sun and formed a hideous but most effective armour which would last for days.

The mud-holes which the bisons made for themselves in this manner have always been known as "buffalo wallows" and are still to be found in regions where the great beasts that made them have been long extinct.

While during the last few years of their existence buffaloes became wary and realized to some extent the danger of close contact with man, they were normally stupid to a degree. As Hornaday says: "The buffalo was an animal of a rather low order of intelligence, and his dullness of intellect was one of the important factors in his phenomenally swift extermination. He was provokingly slow in comprehending the existence and nature of the dangers that threatened his life, and like the stupid brute that he was, would very often stand quietly and see two or three score or even a hundred of 


\section{American Buffalo}

his relatives and companions shot down before his eyes with no feeling than one of stupid wonder and curiosity. His stolid indifference to everything he did not understand cost him his existence."

In appearance the bull buffalo was easily tive finest of our quadrupeds. "The magnificent dark-brown frontlet and beard of the buffalo, the shaggy coat of hair upon the neck, hump and shoulders, terminating at the knees in a thick mass of luxuriant black locks, to say nothing of the dense coat of finer fur on the body and hind quarters, give to our species a grandeur and nobility of presence, which are beyond all comparison among rumirants." * .

* Hornaday op. cit. 


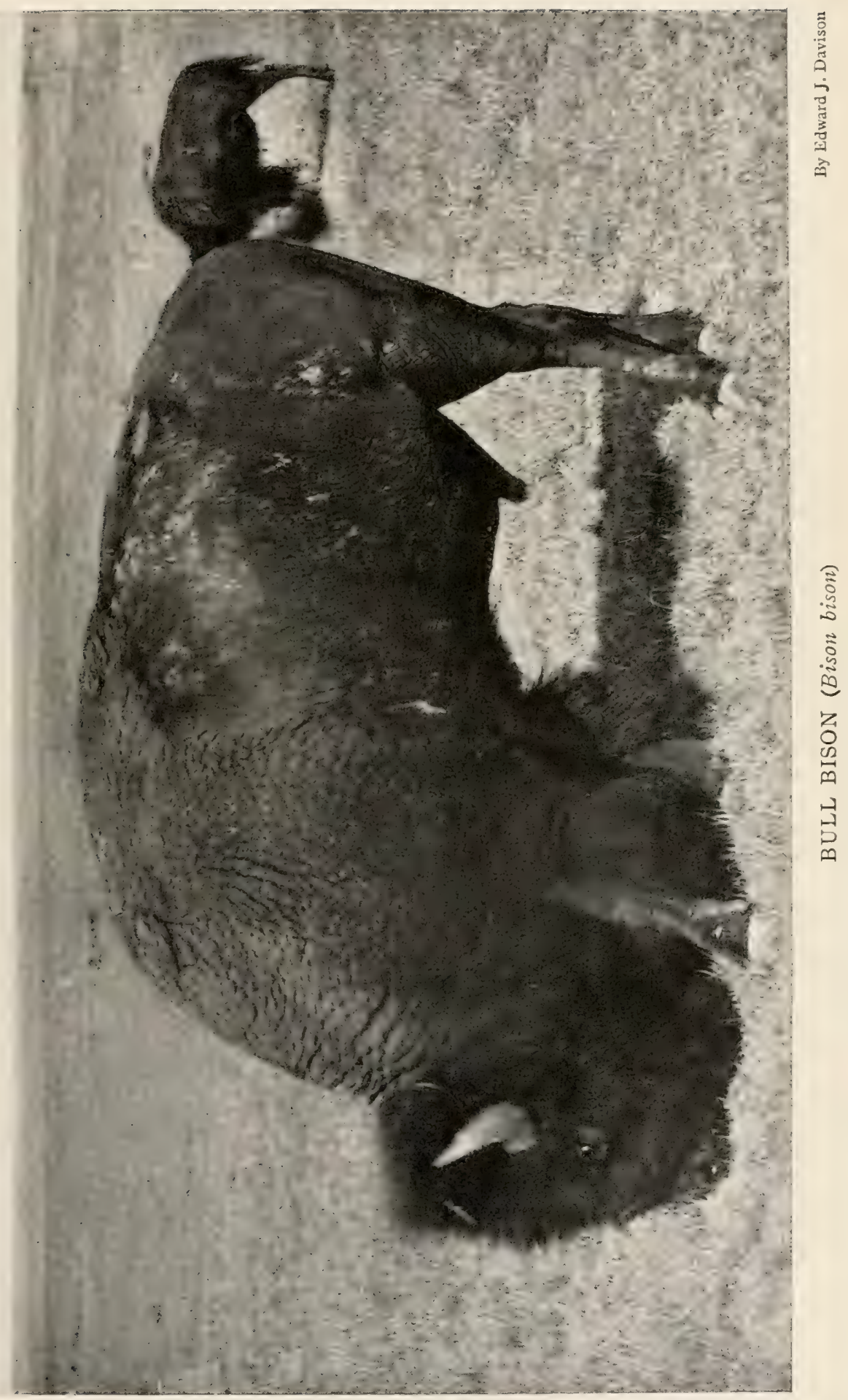





\section{RODENTS OR GNAWING ANIMALS}

\section{(Glives)}

Animals of this group may be recognized at once by the peculiar arrangement of their teeth. In the front of the mouth are two large conspicuous teeth (incisors) in each jaw, which meet vertically like two pairs of chisels, and form a very powerful apparatus for gnawing or cutting. The remaining teeth are broad flat-topped grinders (molars) placed in the back of the mouth while between the two, where the tearing teeth (canines) of the carnivorous animals are situated, the jaws are quite bare. The large gnawing teeth are further peculiar in being curved and

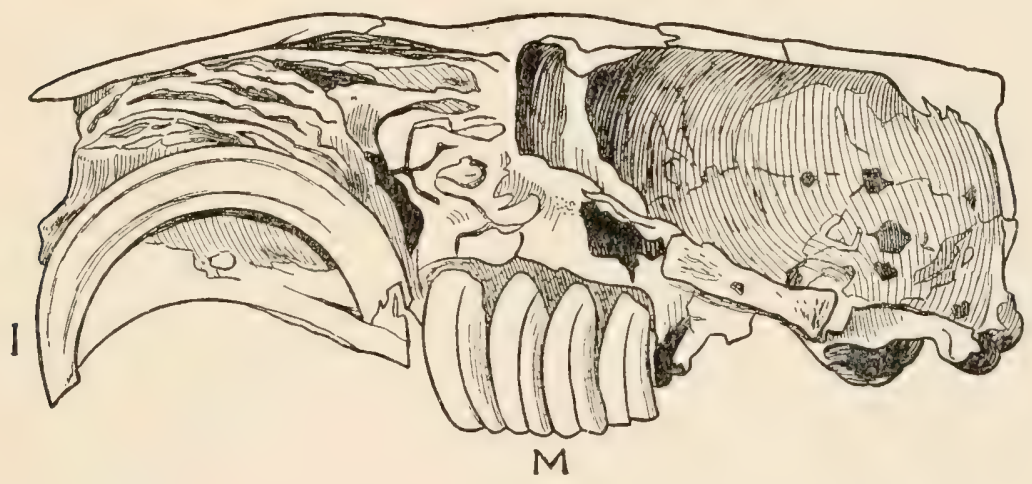

Longitudinal section through Beaver skull.

I Incisor tooth showing long curved base. M The four molars. (After Lydekker.)

deeply rooted in the jaws, while they also grow continuously from the base as they wear away at the tip, so that they never become "worn out."

Rodents range in size from the beaver to the mouse and in habits they exhibit the greatest diversity; some are burrowers, as the gophers and marmots, others are terrestrial as the rabbits, still others like the muskrat are aquatic, while the flying squirrel is even able to launch himself through the air. 


\section{Rodents or Gnawing Animals}

Such diversity of habits naturally produces great differences in structure, but no matter what individual peculiarities a rodent may possess, the characteristic "gnawing teeth" remain the same in all, and serve at once as the "ear-mark" of the group.

Our rodents are grouped in the following families.

I. Rabbits and hares (Family Leporida). Hind legs very much longer than the front pair, so that the animals progress by leaps. Ears long, tail very short and up-turned, usually white on the under or exposed side. Peculiar in having a small pair of rudimentary front teeth at the base of the upper pair of large ones.
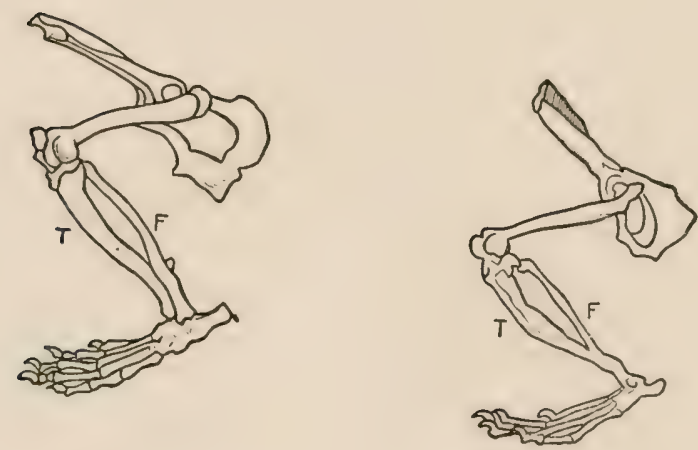

Leg of Beaver.

Showing the Tibia (T) and Fibula (F) Showing Tibia and Fibula unitod. separate for their entire length.

(After Lydekker.)

Leg of Rat.

(After Lydekker.)

II. Pikas (Family Ochotonide). Legs nearly equal, no tail, otherwise like the rabbits although the general form is more like a large rat. (Exclusively Western.)

11. Porcupines (Family Erethirontid(t). Skin with numerous sharp spines interspersed among the hairs.

IV. Gophers (Family Goomyid(t). Rat-like animals, living in subterranean burrows, eyes very small, fore legs modified for digging like those of a mole. No projecting ear, curious pouches on each side of the face, openingr outside near the mouth. 


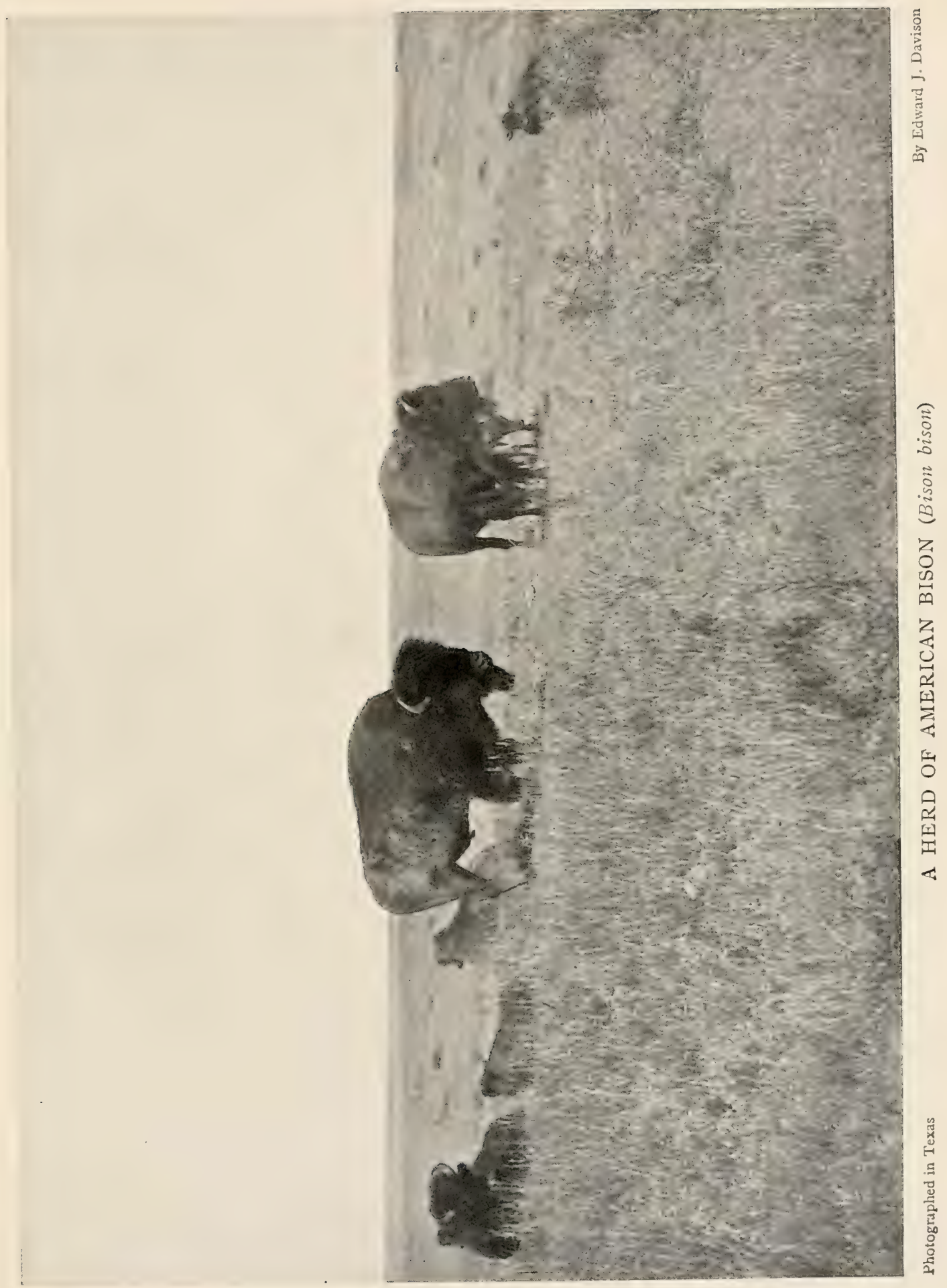



V. Pocket mice (Family Heteromyide). Slender mouse-like animals, many with hind legs much elongated, but with pouches on the sides of the face as in the gophers. (Exclusively Western.)

VI. Jumping mice (Family Zapodide). Mouse-like animals, with hind legs much elongated, progressing by long leaps; tail very long exceeding the head and body.

VII. Rats and mice (Family Muride). Hind legs little if any longer than the front pair, the latter never modified like those of moles, tail never longer than the head and body. To this family belong all the mouse and rat-like animals not included in IV, $\mathrm{V}$ and VI.

VIII. Sewellels (Family Aplodontiide). Thick-set animals with very short tail and short ears, and a peculiar fiat skull somewhat like that of the beaver. (Exclusively Western.)

IX. Beavers (Family Castorida). Tail curiously modified into a broad, nat, naked appendage.

$X$. Squirrels and marmots (Family Sciuride). Here belong all the squirrel-like animals including the spermophiles and chipmunks. They differ from the mice and their allies in their bushy tails and many peculiarities in their anatomical structure, an important one being that the two lower leg bones are separate and not fused together as in the mice, thus allowing them to use their limbs more freely in climbing, a habit which is characteristic of a majority of the species. (See cuts page 72.)

\section{RABBITS AND HARES}

\section{(Family Leporida)}

Rabbits are perhaps the most widely known of any of our wild animals. As our commonest "game" they are familiar to every gunner and equally so to those who are acquainted with them only in the markets. Their distribution, too, is almost universal and in America, from the polar regions to the tropics, they exist in one form or another. Rabbits are also frequently known as hares, and the careless usage of the two names has given rise to much confusion in the popular mind as to just what constitutes the difference between them.

As a matter of fact the European rabbit, the parent stock of all the various domestic breeds, is the only one properly en- 


\section{Rabbits and Hares}

titled to this name. It differs slightly in its proportions from the other species and is habitually a burrowing animal. The rest of the tribe, as a rule, make nests on the surface of the ground and are, properly speaking, hares. It is useless, however, to try to fix the application of names so firmly established and we must therefore take them as we find them. The big hares of our northern States are either varying hares or "snow-shoe rabbits," our little hares are "rabbits" or "cottontails" and the large hares of the plains are "jackass rabbits."

While rabbits fail to show much variation in structure among themselves, differing for the most part in size and colour, they are, however, sharply separated from all the rest of the gnawing tribe, and can be recognized at a glance. The popular eye notes at once the long hind legs and consequent jumping gait, the large ears, and the stumpy upturned tail. Look more closely and we shall find other peculiarities. The soles of the feet are not bare as in most rodents, but are covered with hair, which accounts for the lack of sharp definition in their footprints. Open the mouth and behind the two big front teeth of the upper jaw -the sign of the rodent as it were-we shall find another pair of little teeth which do not reach far enough down to aid in the gnawing. These are obviously of no use to the rabbit of to-dily, but are none the less interesting since they show us that the ancestral rabbits of the past had four large front teeth instead of two, and the species now living form in this respect a sort of connecting link between other mammals and the rest of the rodents in which all trace of these teeth hals been lost. Such characters, apparently most trivial, often throw much light upon the history and relationship of animals. Looking further into the anatomical structure of the rabbits, we find another interesting peculiarity in the arrangement of the bones of the fore legs, which are placed so that they cannot be turned inward and used as hands when the animal is feeding.

This habit is common to almost all other gnawing animals and is most familiar in the case of the squirrels which hold their food tightly in their fore paws as they sit upright upon their haunches. Ratbloits will often raise the fore part of the body clear of the ground when reaching upward, but the fore feet hang useless during such operation. In fact, beyond their use in running the fore legs seem only to be brought into play in a 
curious stamping which rabbits indulge in when angry or excited. The most conspicuous species of rabbits in the East are described beyond. In the West are many species and varieties more or less closely allied to these, and one very distinct form, the Jack rabbit.

\section{The Cottontail}

\section{Lepus floridanus mallunus (Thomas)}

Also known as Rabbit, Gray Rabbit.

Length. 17 inches.

Description. Above, a fine mixture of brown, cinnamon and russet, grayer on the rump, dusky edgings to the ears and an indistinct dusky spot between them; below, white with a brown band across the breast; lower surface of the tail pure white.

Range. Lowlands of the southern and middle States from northern Florida to the Hudson Valley in the East, and to West Virginia and Tennessee, west of the Alleghanies. Other closely related varieties replace this form to the north and south, and many allied species occur in the West.

For the last week I have been watching a rabbit that was caught in a box trap. It quickly became tame enough to allow itself to be stroked and patted without exhibiting much alarm, and when it escaped from its cage, which it did several times, offered but little resistance on being caught and replaced in bondage, at last even allowing itself to be taken up without a struggle.

It ate readily whatever was offered it-apples, raw cabbage, and even the dry hay of which its bed was composed, besides gnawing all the bark from the twigs of apple tree which I placed in its cage, but never while I was watching and, I think, only at night, apparently hardly changing its position while the daylight lasted.

Yesterday morning I found that it had not only escaped from its cage, a frequent enough occurrence, but that it had also managed to make its way to the outside world, and the snow on the lawn has since been thickly marked with its tracks leading off across the orchard finally, and I trust that by this time 
the little cotton-tailed chap is once more at home in the woods.

Like the white rabbit the cottontail has well-beaten paths, which it follows winter and summer alike, but these are usually not so extended and regular as those of its larger cousin.

In winter the goshawk has a habit of following these paths on foot in a most unhawk-like manner, especially where they are arched over by bushes that might prevent the hawks from pouncing down from above, and I believe that it is done with the intention of driving the rabbits out into the open woods where, perchance, the hawk's mate is waiting to seize them, for goshawks usually hunt in pairs throughout the winter. Even the common crow, unless I am very much mistaken, not infrequently manages to kill rabbits when the new snow is sufficiently deep and light to prevent them from making full use of their power of running.

The rabbit's custom of resorting to burrows perhaps as fiequently proves a menace to its safety as otherwise, particularly where, as is often the case, there is only one place of exit, for the mink, the skunk and the weasel can all easily enter any opening that will admit a rabbit and undoubtedly often get their dinner in that manner.

Last winter I saw what looked like a rabbit crouching among the stems of a cluster of wild rose bushes, but on approaching more closely I discovered that the animal had been dead for several days, having evidently been killed by a weasel, and in the struggle became so wedged between the briars that its captor was unable to move it and must needs satisfy itself with sucking its blood and leaving it in that position.

Later some white-footed mice and a blue jay had also been at work nibbling and pecking here and there, but by the time they had discovered it it had evidently become frozen so hard as to prevent their making much impression on it, so that at a distance of a few yards it looked as if still alive.

The gray rabbit prefers above all things briar-grown berry patches with a sprinkling of young pines and birches and numerous rotting stumps of a former generation of trees, but readily establishes itself in any kind of woods, high or low, while any isolated clump of bushes a few rods in extent, whether it be by the road-side or on the edge of a meadow is likely to harbour a family of them. 


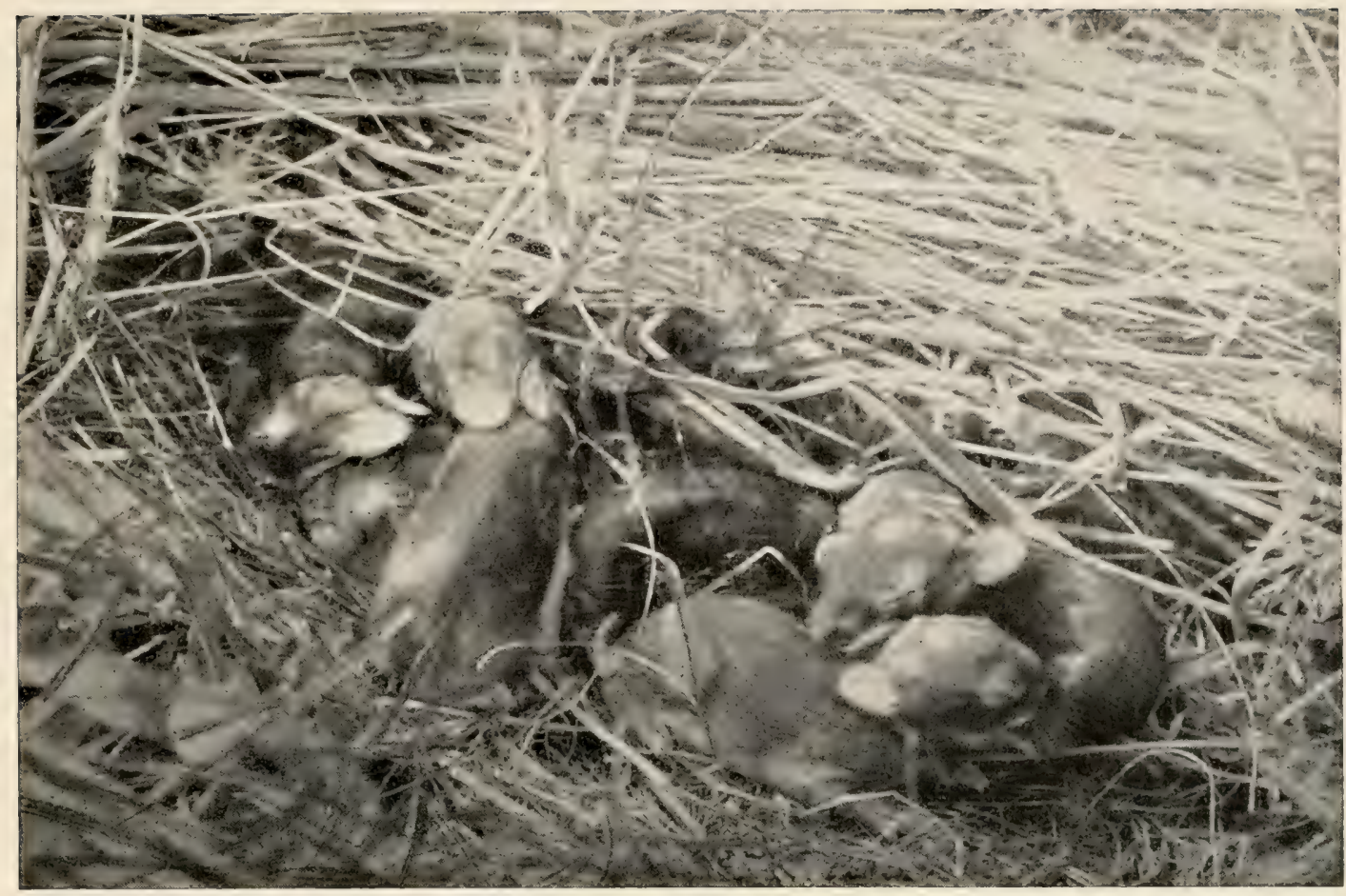

NEST OF YOUNG COTTONTAILS

This nest was in a hay-field. The young when found were covered with soft fur from the mother, so that they were hardly visible This fur was removed in order that the little blind animals might be seen.

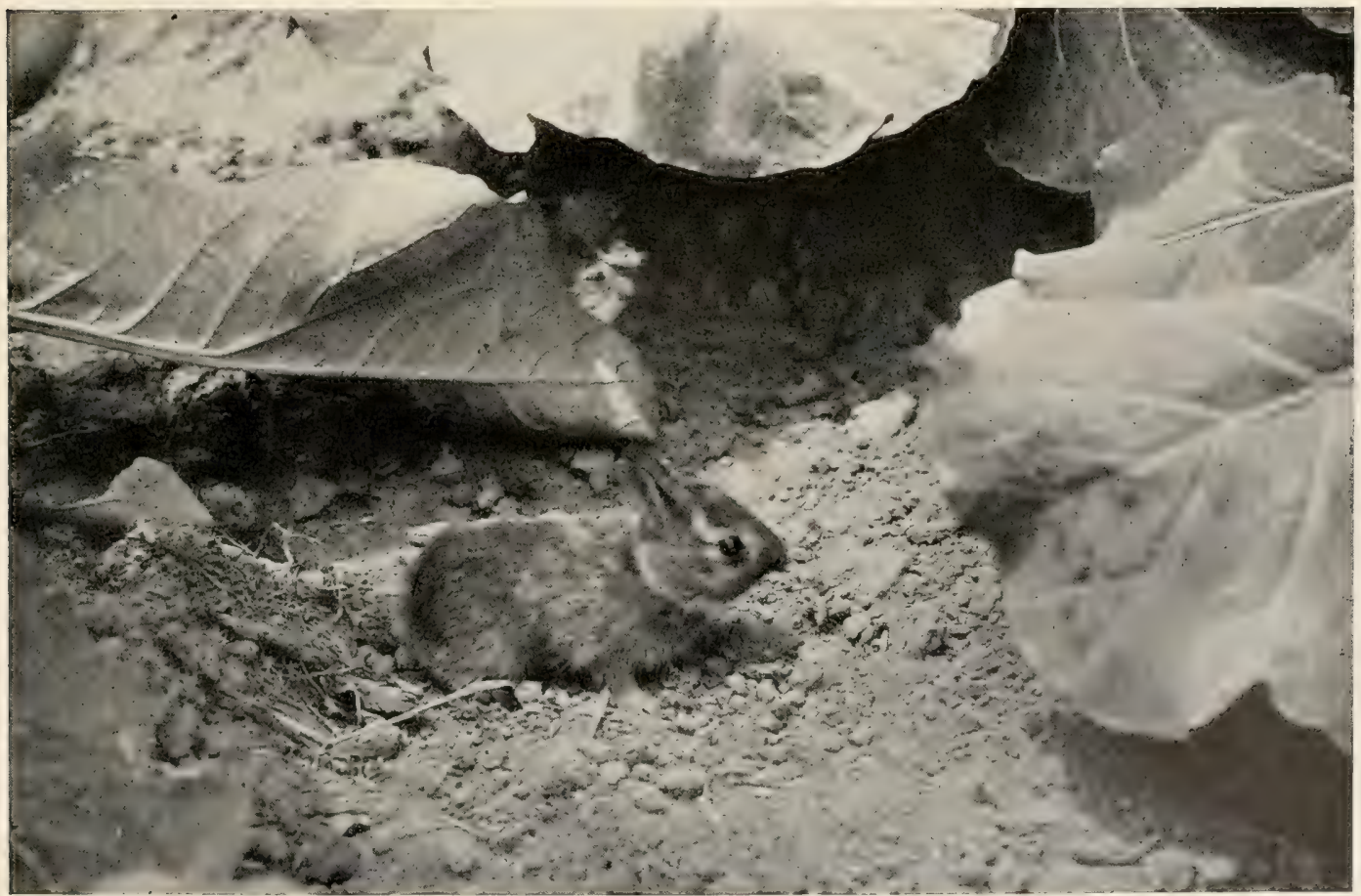

YOUNG COTTONTAIL AMONG THE CABBAGES (Lepus floridanus mailurus)

By A. R. Dugmore 

Their food seems to be of much the same general character as that of the white rabbit though perhaps a little more varied, including fruit and all kinds of garden vegetables when convenient, though the damage done in this way is hardly worth considering, in which respect it sets an example which the Old World rabbit might profit by.

Like the other members of its race it often endeavours to escape notice by crouching motionless wherever it may happen to be, often allowing itself to be all but taken before it will move, and at such times no amount of being stared at will frighten it or put it out of countenance. There it will sit perfectly motionless except for the trembling of its whiskers and the motion of its breathing until you seem to be just on the point of grasping it, when it quietly slips from beneath your hands and races away.

I have seen one sitting in plain sight on the snow among the scattered sumachs not ten yards from a path along which loads of hay were being hauled from the salt marsh to the upland. Five or six teams must have passed it, some of them followed by dogs, and still it sat there undisturbed in the sunlight, apparently absorbed in its own thoughts.

The young ones, four or five inches long, are often met with in summer all alone beneath the ferns and brambles and very serious and reserved little chaps they are, too, with their great black eyes and absurd looking triangular mouths forever in motion, as if repeating over and over to themselves some lesson which they fear they may forget.

\section{Varieties of the Cottontail}

1. Common or Southern Cottontail. Lepus floridanus mallurus (Thomas). Range and description as above,

2. Florida Cottontail. Lepus floridanus Allen. Darker all over, with no conspicuous black edgings to the ears nor black spot between them.

Range. Southern Florida north to Micco.

3. Northern Cottontail. Lepus floridanus transitionalis (Bangs). More richly coloured than the southern cottontail, with many long black hairs scattered over the back, black borders to ears and spot between them very distinct.

Range. Alleghany Mountains and northward east of the Hudson to southern Vermont and New Hampshire. To 
the southward it merges gradually into the southern cottontail and westward into the following.

4. Pravite Coftontail. Lepus floridanus mearnsi (Allen). Much lighter than any of the preceding, especially on the rump, ears light, without black edgings, and no spot between them. Size rather larger.

Range. Upper Mississippi Valley south to Indiana and east to Central Ne'w York and Ontario.

\section{Varying Hare}

Lepus americanus virginianus (Harlan)

\section{Called also Snow-shoe Rabbit, White Hare.}

Length. I9 inches

Discription. Summer. Upper parts russet to dull ferruginous, lower parts white. Winter. Entirely white, though in southern part of its range some individuals remain partially brown throughout the winter.

Range. Wooded regions of north-eastern North America southward along the Alleghanies to West Virginia, becoming scarce south of Maine.

Our northern hare or white rabbit is a perfectly typical hare with the absurdly long hind legs characteristic of the tribe, dwelling by preference in old growth evergreen forests on gently sloping hillsides with here and there dense thickets of young spruce and pine springing up between the trunks of the older trees.

Of all our wild animals they are beyond question the most helpless and incapable. It is evidently impossible for them to use their paws for grasping as most of the smaller quadrupeds habitually do, and I have never seen any evidence of their carrying things with their mouths.

Winter and summer and in all kinds of weather they have no better shelter than the drooping boughs of an evergreen, heneath which each crouches alone for protection arainst the storm and concealment from its enemies, never more than half asleep apparently and always on the alert to dash away the instant it calches the scent of fox or ermine to the windward, or the crackle of a footstep in the distance. Whenever they feel hungry they 
venture forth and hop away to the nearest regular path or roadway used in common by all the hares in the vicinity. These paths are usually pretty straight and follow the same course the year round, often extending in an interrupted sort of way for a quarter of a mile or more with numerous side paths or cross roads of less extent, leading off in the direction of their feeding grounds. After following them for a little distance the hares usually strike off at random into the undergrowth, nibbling and browsing here and there and nosing about for vagrant leaves of grass and clover such as spring up at intervals even in the darkest forests.

Throughout the warmer months they have a large and varied assortment of herbs to choose from, and it seems not wholly improbable that they should also feed occasionally on berries and mushrooms.

The young hares from the very first are provided with no more adequate shelter than that furnished by the leaves above them, and evidently must be left quite unprotected as often as their mother is obliged to find food for herself, as the old males are said not only to exhibit no feeling of responsibility in the matter of bringing up their offsprings, but even to kill them wantonly whenever the opportunity offers.

As soon as they are able to take care of themselves, or even before, judging from outward appearances, the young ones are turned adrift to support themselves as best they may. The matter of finding food at that season is easy enough, but to avoid the numerous enemies that beset them must be much more difficult and I doubt if one out of a dozen ever attains its growth.

As winter approaches and the frosts cut off their supply of food, they find themselves compelled to depend more and more upon the bark of young trees and bushes, birch and soft maple and wild apple trees.

When the buds of the gray birch begin to swell, as they do late in the winter, the hares seem to prefer them to all other food and often wander considerable distances in search of trees with low growing branches, or clusters of young trees of last season's growth whose tops are still within their reach; and a hare standing erect on its hind feet, as is their habit at such times, is able to reach much higher than might at first be supposed.

The tall stalks of the blackberry and young trees a half inch or less in diameter they cut off close to the ground or the sur. 


\section{Varying Hare}

face of the snow in order to get at the twigs and buds that grow beyond their reach. But it never seems to occur to them to carry any of it away to the cover of the evergreens where they sleep, and in consequence they are obliged to be abroad in all kinds of weather or go hungry until the storm is over.

They usually pass the day crouching motionless, half asleep in the shadow, though not averse to sunning themselves at midday, especially during the latter part of the winter.

Toward sunset they start out in search of food and are back in their forms again soon after sunrise, but whether they spend the entire night in feeding or only the hours of twilight is not easy to determine; I am inclined to think that they are abroad more or less at all hours of the night, especially when there is moonlight or in the winter when it seldom gets very dark, and as they appear to depend at all times much more upon their other senses than upon their eyesight they would hardly be incommoded by the most intense darkness, and it is hard to imagine anything much blacker than the darkness beneath the hemlocks on a summer evening, even while it is still twilight in the open fields.

In spite of its size and the great strength of its hind legs which it uses so vigorously as a final defence, kicking and striking savagely when seized, the Northern hare seems to be preyed upon by all but the very smallest flesh-eating inhabitants of the woods; in the North the sable is said to be one of its worst enemies, and it is not at all unlikely that the mink in some of his upland hunts manages now and again to seize one either by stratagem or speed; for in spite of their short legs most of the weasel tribe, of which the mink is a member, are able to beat the hares at their own game, and although the latter have a decided advantage at the start and quickly outdistance their pursuers, the tireless muscles of the long-bodied hunters are pretty sure to enable them to have their own way in the end.

Even the ermine and little weasel have been known to kill full-grown hares, and though these cases are probably not very frequent, they must find the young and half-grown ones the easiest kind of victims.

Foxes are perhaps their most dangerous and persistent enemies, and from what I have seen I am inclined to think that our American foxes work in concert when hunting them just as the English 
foxes have been seen to do, one of them lying in ambush beside the path followed by the hares in order to seize any that may pass that way in their endeavours to escape from the other foxes which are driving them from their cover. The henhawks and goshawks, the great gray owl and the horned and snow owls as well as the eagles either pounce upon them unawares from the evergreens, or pursue them at full speed through the underbrush, while in fall and winter men hunt them with dogs and catch them with various kinds of traps and snares.

Although in the summer and early fall the dense undergrowth of the forest assists the hares in their constant endeavours at concealment, in the cold weather the leaves, with very few exceptions, either fall or, shrivelled to a fraction of their former dimensions hang listless upon their stalks, allowing the eye to penetrate where before everything was hidden, and, as if this were not enough, the snow comes to flatten the ferns and grasses and lay on a background of white against which all objects are conspicuous.

The Northern hare, however, like the ermine, has this advantage over the other wood dwellers in that at the approach of winter its fur, which from March to November is cinnamon or reddish brown of a shade best suited to match its accustomed surroundings, becomes in the course of a few weeks or even less perfectly white, and although for a time the brown fur still shows in spots, the general effect is such that of those that I have seen on the snow I should say that at least one half appeared actually whiter than the snow over which they ran, and this similarity of colouring with their surround.ings makes it possible for them to crouch in safety practically invisible to human eyes, and undoubtedly often baffling the keener glances of the hawks.

Much has been written on the change of colour of the varying hare and other mammals and birds, but there are few subjects concerning which more mistakes have been made. We read of the change taking place in a single night, coincident with the first fall of snow and of the actual blanching of the the individual hairs; one statement being quite as erroneous as the other. The change is really very simple. All mammals, in northern climes at least, shed their coat twice a year, acquiring a thicker fur in winter and a thinner one in summer, and in the present species the winter coat is white while the summer one is brown and the individual hairs never alter their colour from the time they appear until they fall out. The change 
from brown to white occurs in the autumn and for a short time the animal is somewhat 'mottled.' Then in March as the weather gets warmer the snow gradually disappears from the woods, the fur of the Northern hare, probably by reason of the wearing away of the tips and the shedding of the long hairs gets more and more mottled with brown, the change in most cases that have come under my notice commencing at the back of the neck, on the feet and the under surface of the body, and in an astonishingly short time the dark summer coit is fairly resumed. Although belated snowstorms must often give them occasion to regret the loss of their winter coats, taking one year and another, the change seems to be wonderfully well timed, and at most they are really no worse off than those other inhabitants of the woods that wear their dark coats throughout the winter.

When the white people first made their homes in this part of the country they found only these big, long-legged Northern hares dwelling in the uncleared forest, never a very numerous race in all probability in spite of the advantages of tremendous swiftness and a coat which copied the colour of their surroundings at all times of the year.

Preyed upon by Indians, wolves and lynxes and the various members of the weasel tribe, which have since been exterminated, or nearly so, because of the beauty of their fur, as well as their numerous enemies which still survive in more or less reduced numbers, the coming of the white man must have proved rather an advantage than an added danger to this long suffering, thin-skinned defenceless race of animals, and it seems probable that they did increase in numbers to a certain extent for the first two hundred years or so. As recently as fifty years ago they were still common and apparently the only species in Southern New Hampshire, but somewhere about that time the little gray rabbit or cotton-tail made its appearance; no one could tell from whence, though it seems generally to have received the title of cony at first to distinguish it from the other which had always been called rabbit, and though hardly one half as large and much shorter of foot and even more timid and helpless, it now became evident that the larger species was disappearing as the smaller increased in numbers.

I am to! 1 that at one time, something like thirty years ago, there were no white rabhits to be found within miles of this place. Then they appeared and even seemed to slightly increase in numbers for a few years only to vanish as before, and it has been that way ever 
since. At intervals of perhaps seven or eight years they came back in scattered bands and endeavoured to establish themselves in their old haunts but the result was always the same.

Rather more than twenty years ago they were quite numerous for several successive seasons in a neighbour's wood lot only half a mile from here. I can just recall a cool afternoon, which I am quite sure must have been sometime in the last of autumn, when my cousin and I raced up the western slope of those woods with the sunlight streaming in beneath the pines, and the one distinct thing in my memory of that time is the image of a big, yellowish brown hare hobbling up the hill before us. That must have been about the last of their occupation of that place, and up to the present time I have only on one occasion found as much as a track there.

Several years ago our cat caught a young hare of this species, and I think it must have been the following winter that I heard of several having been killed in the neighbourhood.

From that time until the fall of 1894 I was unable to learn of the existence of any of these animals for miles around, though it seems that on the slope of a certain low pine-covered hill only three or four miles distant a colony have dwelt uninterruptedly from all accounts since the time of the red men. In the fall of 1894 a gunner told me that only a day before he had been shooting grouse along the edge of a swamp hardly a mile away, and in pushing into a thick clump of hemlocks to secure a wounded bird had started a white rabbit which he succeeded in shooting. In the course of the next few weeks I heard of several that were killed in those woods and there were doubtless many others which I failed to hear of, but all my tramps in that direction for the purpose of finding them proved unsuccessful-at least until the snow came.

Late in the winter I took a snow-shoe tramp in that direction, the first ti:ne I had been there since the first snow-fall of the season, and within two miles found the unmistakable track of a white rabbit; there was no mistaking the broad oval foot-prints, even if the distance between them had not served to distinguish them from those of the gray rabbit which crossed their line of march at frequent intervals.

The track, which apparently had been made several days, led me from the swamp into the low rolling birch land, and now other and fresher ones of the same kind joined it until a well-beaten path running east and west was formed and this presently joined another 


\section{Varying Hare}

at right angles. The latter proved to be the main highway with several branch roads similar to the first.

But I was unable to catch sight of any of the members of the community which, judging from the tracks, must have numbered several dozen at least, and as the snow was again falling rapidly and obliterating the maze of tracks I was endeavouring to unravel, I was obliged to give it up for the time being.

Several times in the course of the next month I visited those woods, sometimes finding the tracks I was in search of and sometimes not, for the colony was apparently an unsettled and roving one and I seldon found it established twice in the same place, though at times it must have stopped for several days or even weeks before starting off in search of new feeding grounds and seldom moving any great distance each time. I failed as at first, however, to see the hares themselves, though a dog would undoubtedly have driven them into sight for me had I chosen to take one along.

In March, with a companion, I was skirting the western border of the swamp and while still half a mile or more to the south of where I had seen any of their tracks, a white rabbit started out of the bushes only a few yards away and after creeping rather slowly along under cover of the ground laurel for a little distance, broke all at once into at series of tremendous bounds that soon carried it out of sight among the trees.

The snow was frozen hard, with patches of hare ground on the southern slope, so that tracking was out of the question. We tramped about there for some time and saw white rabbits running before us in four or five different instances, and though we may have seen the same rabbit twice, there were certainly more than one, and I believe three or four that we saw.

At last on the very edge of the swamp. where the dry and frozen swamp-galass and bushes stood in clumps between the ice-bound alders and maples, a big white fellow sprang out of the thick tussock and in attemping to dash away over the ice got fairly caught between the close-growing stems of a bunch of red willows and wals easily secured.

It proved to be a large male whose smooth white fur showed hut little sign of the spring shedding, only a spot here and there that hardly showed at all when the animal was in motion.

A few days later there was no sign of them to be found at that place 
or in the woods near by, and I am convinced that purely by chance we had intercepted the little band in its march southward and that those killed in this and the neighbouring towns that season where none had been seen for years, were wanderers from somewhere farther north, impelled southward by the same unreasoning impulse that is said once in every seven or eight years to drive the lemmings southward from the Arctic Ocean, and which, to a lesser degree appears to affect most of the smaller fur-clad animals of the North.

Only the winter before I had tramped through these same woods after almost every tracking snow, and $I$ am able to say positively that the gray rabbit was the only species to be found there, and three years later it was the same again; the only one that has visited these woods since then, as far as I can learn, being a solitary individual that the next winter passed within half a mile of the house where I write, going due southeast without swerving more than a few rods from a direct course at any time and crossing open fields and meadows indifferently.

I followed its tracks closely for nearly two miles and saw no evidence of its having stopped to eat or rest at any time. Finally it struck off across a wind-swept field where the drifting snow wholly obliterated its footprints, and I have often wondered what eventually became of the solitary wanderer hopping away alone towards the sea whose roar was already distinctly audible only a few miles away.

From what I can learn I should say that the border land between the countries of the white rabbit and the gray is somewhere between forty and fifty miles to the north of this southeastern corner of New Hampshire; beyond that I have been unable as yet to find the gray rabbits, though for the first thirty miles they are as abundant as they are here, and further west their range is said to extend well up into Canada.

Mr. P. C. True writing from Pittsfield, New Hampshire, under date of March ist I 899 , says: "I have consulted a number of veteran fox hunters here and gathered what information I could on the subject.

"The white rabbits, or jacks, as they are called here, have almost disappeared; what few are left are found only in the big forests. I am told that the cause of the departure is that the conies devour their young; conies are very numerous as were jacks previous 
to the last decade. The first are said to have been brought here from Massachusetts by an old fox hunter some thirty years ago."

The earlier writers of the natural history of this country pretty generally agree in giving the habitat of the northern hare as the whole of the Eastern states south to Virginia, and scarcely allude to the gray rabbit at all, some authors describing it as a Western species not found east of the Mississippi. But Thoreau's diary written in the woods of Concord, Massachusetts, half a century ago and more, makes no mention of the larger species, all the hares referred to being unmistakably cotton-tails.

Last winter, I $898-9$, I paid frequent visits to the only permanent colony of white rabbits that 1 know of in this region, situated three or four miles to the northeast, where they occupy perhaps one hundred acres of old growth timber, only occasionally wandering into the neighbouring woods and swamps where the gray rabbits abound.

But the latter in small numbers penetrate to all parts of the white rabbits' domain, some of them even taking up their quarters in the very heart of $i t$, and I have sore misgivings that sooner or later the original inhabitants will be forced to leave, for just as the white men have driven away the dark-skinned native, so among the hares matters seem to be reversed, and the dark-skinned new-comer is driving off the native whites.

\section{Varieties of the Varying Hare}

I. Varying Hare. Lepus americanus virginiamus (Harlan). Range and description as above.

2. Labralor Varying Hare. Lepus americanus Erxleben. Yellowish-brown to drab in summer, always pure white in winter.

Range. Replaces the former in the wooded regions of Labrador.

3. Nora Siotian Varying Hare. Lepus americanus struthiopus Bangs. Much darker and duller than the varying hare, with no ferruginous tints.

Range. Takes the place of the common form in Nova Scotia.

\section{American Polar Hare}

\section{Lepus arcticus Ross}

Called also Arctic Hare, White Hare.

Length. 23 inches.

Discription. Hair somewhat curly, white at all seasons except the

tips of the ears which are blackish; a few long blackish hairs 


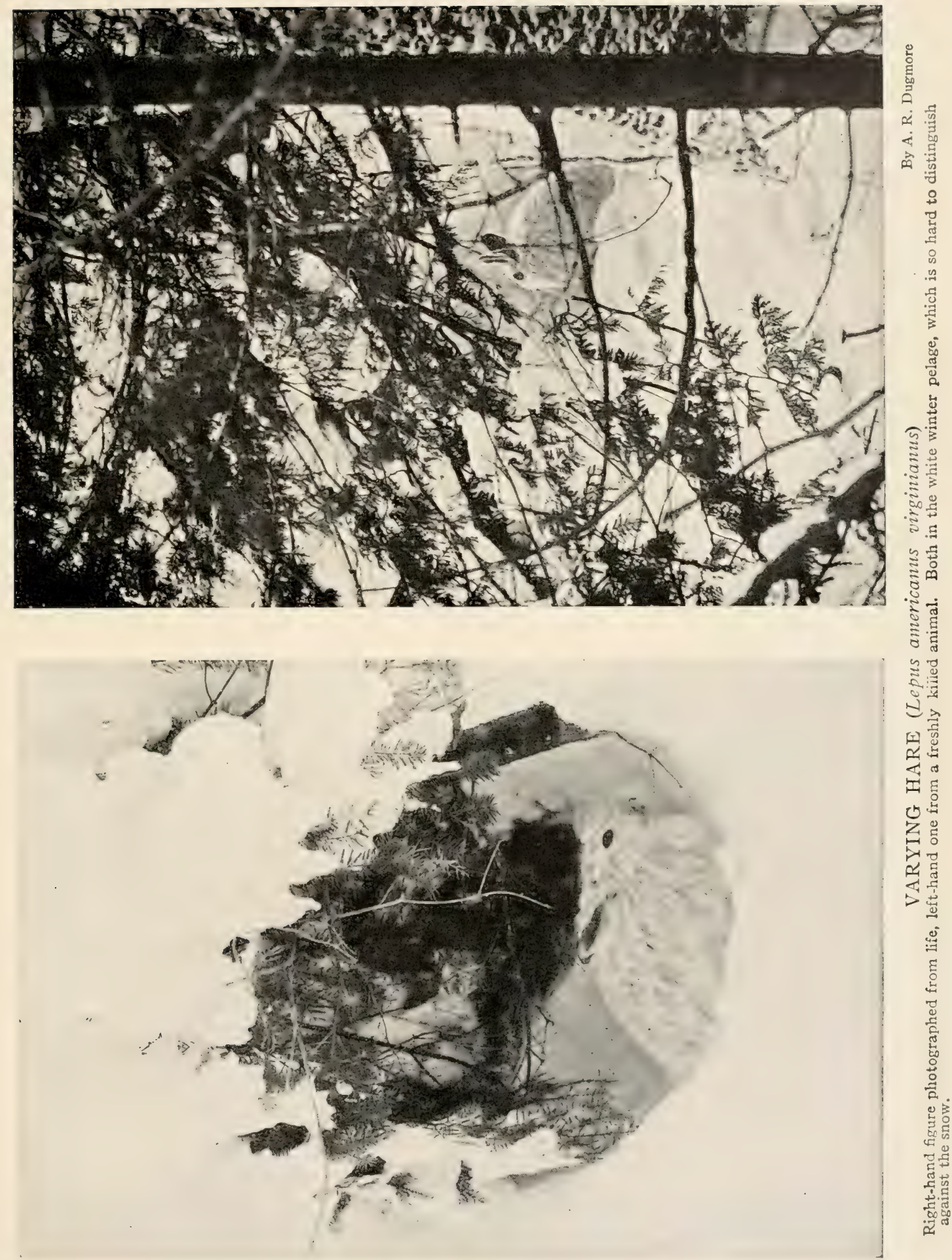



scattered over the back in summer and the ears and face slightly gray (the allied polar hares of Labrador and Newfoundland are subject to a greater change. See below). Range. Northern Baffin Land and the Arctic Islands of North America.

The polar hares are the Arctic explorers of the great race of hares and jack-rabbits, who, finding the climate and conditions up there at the top of the world well suited to their tastes, have established themselves, and continue to raise their families and live happily in that wide ice-sheeted country far away from the sun, wearing their coats of winter white from year's end to year's end.

A little farther south the hares put on their brown fur for a few months in midsummer, and in most parts of Canada are six months wnite and six months brown. The typical polar hare of the Arctic region is a creature of the snow, depending on it for protection against the weather and all other enemies. Its home is a hole dug in a snow drift, or a cranny beneath some outcropping ledge, and its food stone-worts and lichens and the twigs of dwarfed alpine plants as hardy as itself.

In the long dim-lighted winter, at the extreme north, it probably has few enemies to fear, except the little blue fox; and in the few weeks of so-called summer the gyrfalcons and the Arctic owls. But the gray-wolf and the wolverine and the Canada lynx have little fear of the cold and follow the polar hare well up within the Arctic circle.

When it is not looking for its scanty fare of herbage the polar hare sits crouching in its form, careless of the dry drifting snow which often completely buries it while it sleeps. If the gyrfalcon or the snowy owl should swing up in sight against the dark sky, it only hugs the snow the closer trusting to remain unseen; and when the Arctic fox comes prowling along the trail, the hare is ready for a run with him across miles of unbroken snow, just as eager to escape and go on living, as if there were long summers amid green fields to look forward to. It is a little curious that a member of the most thin-skinned and generally incapable race of mammals should be the one to prove itself best able to withstand the hardship of an Arctic life; yet these polar hares have been found living on ice fields over frozen seas twenty miles from the nearest land. 


\section{Varieties of the Polar Hare}

I. American Po!nr Hare. Lepus arcticus Ross. Range and description as above.

2. Bangs' Polar Hare. Lepus arctialls bangsi Rhoads. Upper parts gray in summer, ears black.

Range. Takes the place of the American polar hare in New... foundland.

3. Miller's Polar Hare. Lepus arcticus labratorius Miller. Pelage hair brown in summer.

Range. Replaces the American polar hare in Labrador.

4. Grienland Hare. Lepus granlandicils Rhoads. Differs from the American polar hare in the more protruding incisor teeth and other skull peculiarities.

Range. Replaces the above in Greenland.

\section{Marsh Hare \\ Lepus palustios Bachman}

Length. 18 inches.

Description. Above yellowish-brown, with many black hairs scattered through the pelage. Underparts grayish, underside of tail grayish, never white as in the cottontail. Ears much shorter than in that species, and feet but scantily covered with hair.

Range. Coast of North Carolina to eastern Georgia and northern Florida.

The marsh hare is an inhabitant of the low seaboard of our Southern States. It is slightly larger than the cottontail with which it is often associated, and differs in its nearly bare feet and more scanty pelage. It is distinctly an animal of the wet swamps, not hesititing to take to the water and plunge through the deepest bogs when disturbed. Bachman says that it runs low on the ground and cannot leap with the same ease, strength and arility as the cottontail. From the shortness of its legs and ears and its general clumsy appearance, as we see it splashing through the mud and mire, it somewhat reminds one of an overgrown rat.

\section{Varieties of the Marsh Hare}

1. Marsh Hare. Lepus falustris Bachman. Range and description as above. 
2. Florida Marsh Hare. Lepus palustris paludicola (Miller \& Bangs). Darker, with less buff in its colouration.

Range. Southern Florida, grading into the former to the northward.

\section{Water Hare}

\section{Lepus aquaticus Bachman}

Length. $2 \mathrm{I}$ inches.

Description. Finely mottled above with buff, rufous and black

hairs, buff predominating more than in the cottontail; belly and underside of tail pure white. Feet rather scantily haired and ears longer than in the cottontail.

Range. Lower Mississippi Valley north to Southern Illinois.

The swamps of the lower Mississippi harbour still another member of the rabbit tribe-the great water hare, an animal with habits so far as we know similar to those of the marsh hare, but in size larger than that species or the cottontail.

The difficulty of following this and the last species into their swampy retreats renders them but little known to hunters and is responsible for our lack of knowledge concerning them.

\section{Jack Rabbit}

Lepus campestris Bachman

Called aiso Prairie Hare, Jackass Hare, White-tailed Jack Rabbit.

Length. 25 inches.

Description. Larger than any of the preceding, with very long hind legs and ears. Colour above yellowish gray, sides and back of neck lighter, below white, tail entirely white. In the northern part of its range it turns pure white in winter, farther south the change is partial or possibly does not occur at all.

Range. From Western Minnesota and Iowa to the Sierra Nevada Mountains and from Central Kansas and Colorado to the Saskatchewan plains. Represented southward and westward by a group of allied species known as black-tailed jack rabbits. 
Cottontails of one form or another stretch all across our Continent and varying hares occur Westward in the horeal forests just as they do in the East, but the distinctively Western member of the hare tribe is the jack rabbit. From the Eastern border of the plains to the shores of the Pacific there is scarcely any spot where one form or another of the jack rabbit does not occur, but farther East it is unknown. The white-tailed jack rabbit is the one found on the Great Plains and upper part of the Great Basin. Southward and partly overlapping is the range of the Texan or black-tailed jack rabbit while in California is found still another species.

Living entirely in the open, jack rabbits are more than ever dependent upon the protective colouration, speed and delicacy of hearing which are so characteristic of the whole tribe. Dr. Coucs says, "The first sign one has usually of a hare which has squatted low in hopes of concealment, till its fears force it to fly, is a great bound into the air with lengthened body and erect ears. The instant it touches the ground it is up again, it does not come fairly down and gather itself for the next spring but seems to hold its legs stiffly extended, touch only its toes and rebound by the force of its impact. As it gains on its pursuers, and its fears subside, the springs grow weaker, and finally the animal squats in its tracks on its haunches with a jerk, to look and listen. One fore foot is advanced a little before the other, and the ears are held pointing in opposite directions. The attitude at such times is highly characteristic."

For its home the jack rabbit has only an open "form" beneath a bush or clump of weeds; here it sleeps in sunshine and storm always on the alert for danger, ready to dash away on the instant. When the "rabbit brush" grows thick they are comparatively safe and well sheltered, but in certain bare stretches of unbroken waste land they have to seek shelter as best they may, crouching beside some white wind-bleached stalk or in the shadow of a telegraph pole. The northern species turns white in winter and so escapes observation on the snow.

The young, from one to six in number, are brought forth in the form, which is simply a little space among the weeds and bushes where the grass, when there is any, has been trampled flat and perhaps slightly carpeted with loose fur.

The time of birth varies from late winter to early summer 
according to latitude, in the North, where only one or two litters are born each season, June is about as early as the young ones ever make their appearance.

When first born they are well furred and have their eyes open, by the time they are a week old they are active and pretty well able to look out for their own safety, and at the end of a month or two are weaned and may leave their parents and start out to get a living for themselves.

They feed on buffalo grass and weeds of various sorts and the leaves and bark of shrubs and low bushes. In the South where grease-wood and cactus are abundant they fare well; and wherever men cultivate the land, the jack rabbits make themselves at home at once and stuff on garden vegetables, alfalfa and the bark of young orchard trees and so get themselves disliked.

In a natural state their numbers are apparently held in check more by scarcity of forage than by the inroads of their enemies, and just as soon as cultivation yields them abundant fodder, they increase to an alarming extent, in spite of the farmers' efforts to destroy them.

The eagle, the Western red-tailed hawk, the prairie falcon and the marsh hawk occasionally kill jack rabbits, especially the young ones, but their most destructive foes, next to man, are the wolves and foxes. The coyote is particularly successful in hunting them, and near the border of the woods the gray fox and bob-cat kill them in considerable numbers.

In regions where the coyotes have been killed and driven off it has almost invariably followed that the jack rabbits have so multiplied as to prove a much more destructive nuisance than the coyotes had ever been.

Occasionally an epidemic reduces their numbers locally, but a very few seasons usually serve to establish them again in their former numbers.

During the fall and winter jack rabbits are hunted and killed in great numbers, the most popular method seems to be shooting them from waggons or buckboards with the assistance of dogs who start the jacks from their cover and bring in the game when it is killed. One man will sometimes kill five or six dozen jackrabbits in a day in this manner.

The greatest number, however, are killed in drives, an area several miles in extent is beaten over by men on horseback who 


\section{Jack Rabbit}

close in as they advance, driving the game before them, usually into some kind of enclosure or corral from which there is no escape. The number of rabbits taken in one day in this manner runs from a few hundred up to ten or even twenty thousand.

Driving jack rabbits, though on a much smaller scale than just described, seems always to have been a favourite pastime with most tribes of Western Indians.

By far the most exhilarating and sportsman-like method of hunting jack rabbits is coursing with greyhounds, in the same manner that coursing has always been followed in the Old World; jack rabbits are if anything swifter and more resourceful in dodging the hounds than are the European hares.

The jack rabbits are started from their forms and go off like the wind with the greyhounds in hot pursuit, while the rider follows as closely as he can. The whole thing goes with a swing and dash to the very end, the rabbit dodging, leaping and doubling frantically, until either he has succeeded in reaching the brush and safety, or the greyhound has seized him and both go rolling over and cver together along the ground.

A though the fur of the jack rabbit seems to be well enough suited for felting it is not much used at present, while the skin is too tender and the fur itself too brittle to make it of much value as fur. The Western Indians, however, have always held jack rabbit skins in high esteem for clothing. They twist the skin in narrow strips which are fastened together to make robes, the skins being twisted in such a way as to leave the fur on both sides making a warm durable robe of exceeding lightness. 

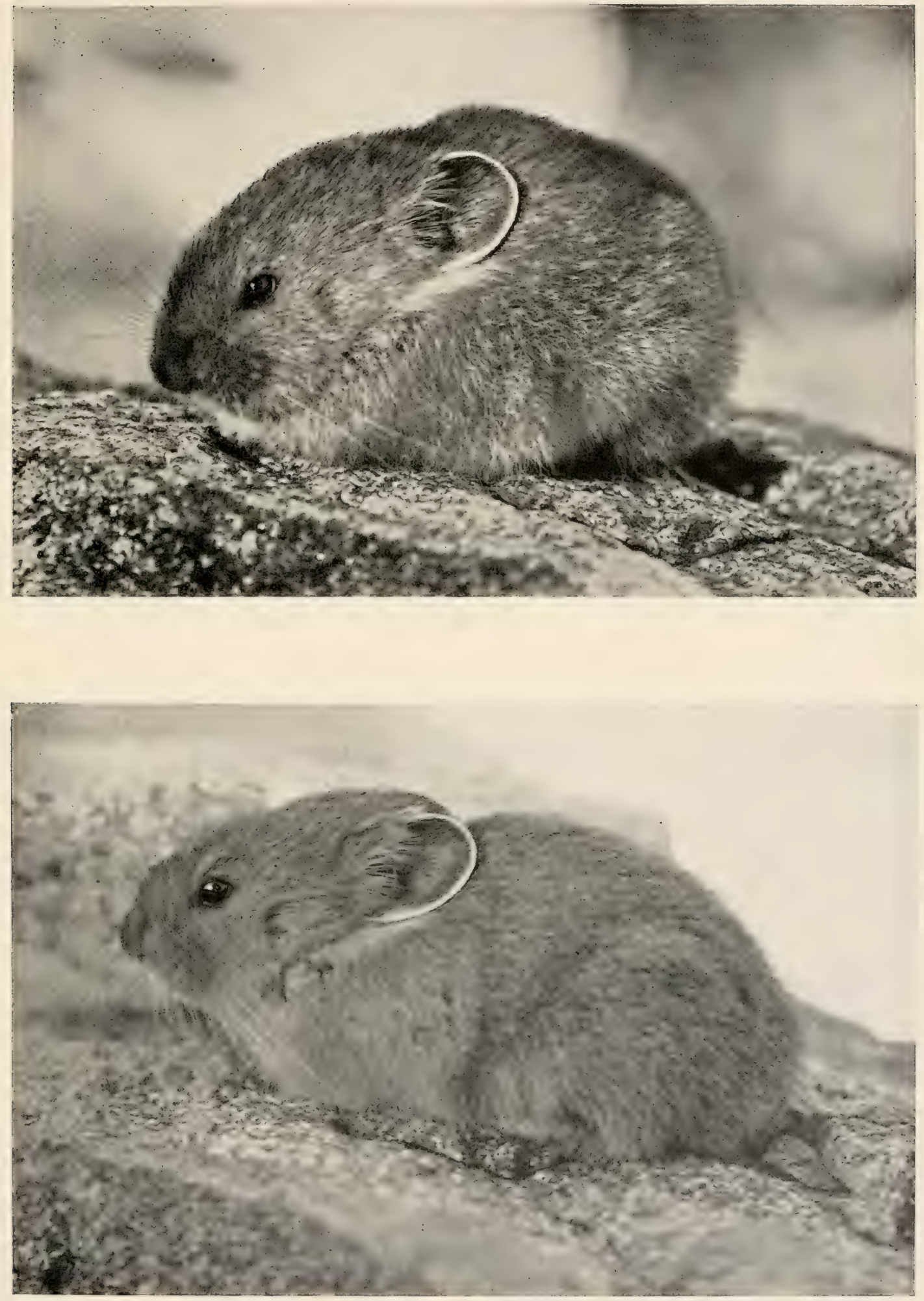

LITTLE CHIEF HARE, OR PIKA (Ochotona princeps)

By W. E. Carlin

These rare photographs, made in the Bitter Root Mountains, were secured by setting up the camera covering a rock on which the animal was in the habit of sunning himself. The instrument was carefully covered with weeds and leaves, and the photographer re tired for a protracted wait until the pika should appear. 



\section{PIKAS \\ Family Ochotonide}

\section{Pika}

\section{Ochotona princeps Richardson}

Also called Little Chief Hare, Cony.

Length. 7 inches.

Description. Allied to the rabbits in structure, but in external appearance more rat-like. Legs very short, all about the same

length, feet padded on the soles, nc external tail, ears large, fur

thick brown above, blackish on the back, yellower on the head, below grayish; ears short, edged with white, feet white.

Range. Northern Rocky Mountains, allied species in Colorado,

Northern California, Alaska, etc.

These curious little animals occur only in the northern part of Asia and Alaska and southward on the higher mountain slopes. Their haunts are rock slides where they find shelter in the numerous holes and crevices among the boulders and fallen debris. Dr. Merriam states that they run with great rapidity for an animal with such short legs, travelling considerable distances from their dens to their feeding ground. They work diligently through the day gathering various favourite alpine plants, which are piled up among the rocks forming veritable hay-stacks for their winter use. They are watchful and alert, giving vent to their shrill bleating call when a stranger approaches the vicinity of one of their colonies, dashing into their retreats only to emerge again to see if the intruder has departed. They seem never to become plump and fat and their emaciated appearance has gained for them the name of "starved rats" among the miners of certain regions.

At any rate they are harmless little beasts and will well repay the naturalist who may visit their remote habitat and make a careful study of them, and being one of those "connecting links" in nature's chain everything we learn about them seems to possess a peculiar interest. 


\section{AMERICAN PORCUPINES}

\section{Family Ercthizontide}

Wherever found porcupines may always be known by their spines. The short legs, plantigrade feet and short thick tail are also characteristic of our North American species, but foreign porcupines exhibit many differences in their structure, one kind found in South America having a long prehensile tail like our opossum. The quills or spines of the porcupine are scattered about amongst the hair and all point backward but may be elevated at will by the muscular contraction of the skin and being so loosely attached at the base are frequently impaled in the face or feet of any animal which may come in contact with them.

In the Canada porcupine the quills are usually shorter than the hair but in certain foreign species they are greatly developed.

Besides the Canada porcupine we have one other closely allied species in North Americal, the yellow-haired porcupine (Erethi ion cpixanthus) of British Columbia and western United States.

\section{Canada Porcupine}

\section{Erethizon dorsatus (Linnæus)}

Length. 28 inches.

Description. Dark-brown to nearly black, quills tipped with yellowish, two to four inches long mostly concealed by the hair, which reaches a length of six inches; toes, four on the front feet and five on the hind.

Range. Northern parts of North America south to Maine and in the higher mountains of Pennsylvania. Not found south of the Canadian faunal zone.

The porcupine is much more interesting as a species than as an individual. Looked at either as an example o. the beneficent protection which is rendered to every creature according to its needs, or as a branch of the rodent family that has succeeded in perfecting a most unique method of defence through the law of the survival of the fittest, it furnishes an interesting study. 


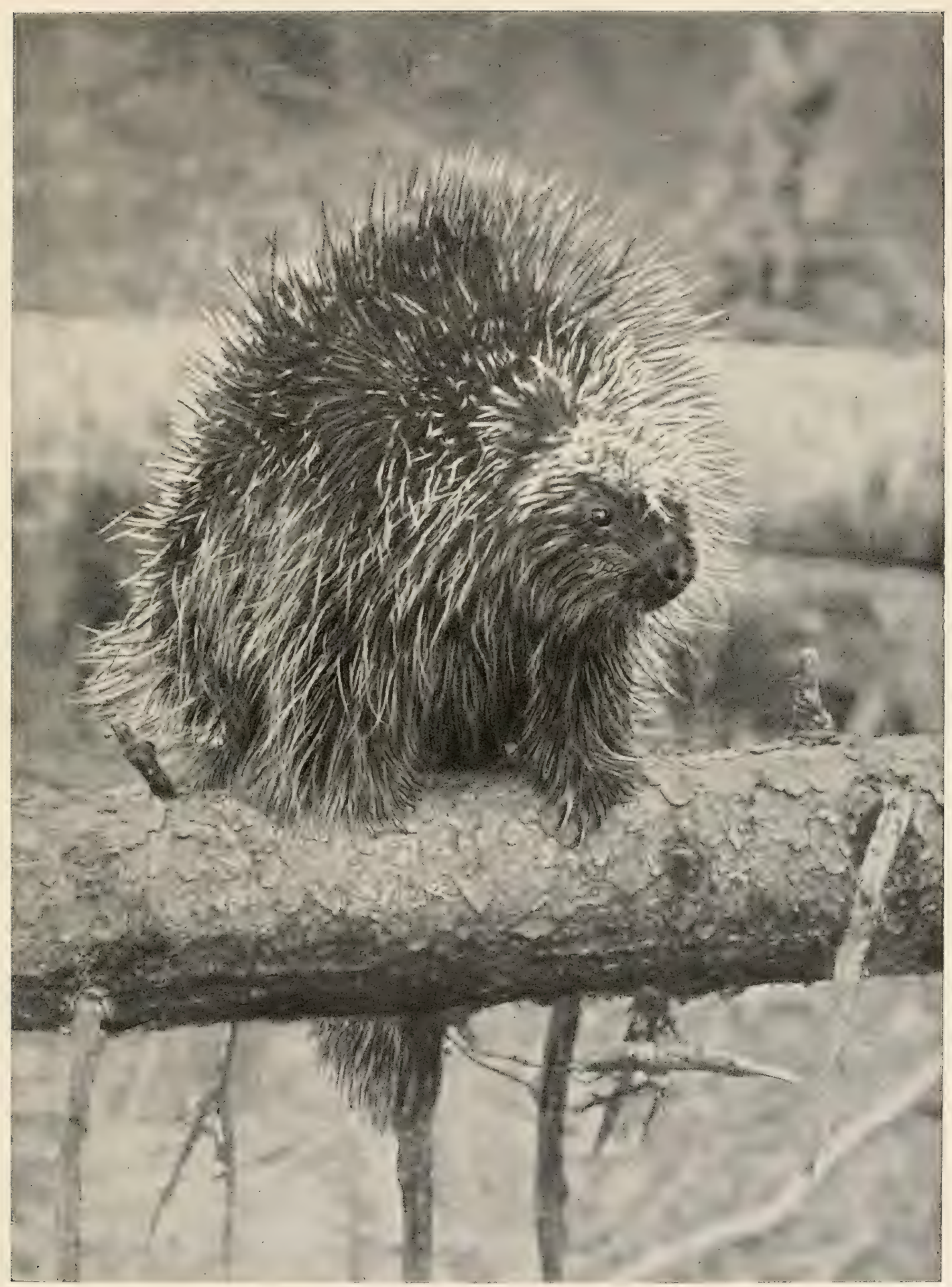

By A. R. Dugmore

CANADA PORCUPINE (Erethizon dorsatus), WITH QUILLS THROWN FORWARD. IN WILD STATE 
It is easy enough to imagine the long chain of successive steps that have led up from some far-off ancestor, who survived because of the possession of a coat of rougher and more bristling hair than his fellows, and in transmitting this to his decendants also insured them a longer period of existence. But if the one owning the most effective armour was safer from attack than his neighbours, he must also have experienced greater difficulty in finding for himself a mate, for his prickly coat and awkward stumbling carriage would make him just as unpopular with his own people as among his enemies. So instead of choosing according to his taste he must needs take what he could get, his heavy coat of mail preventing him from winning in any contest of activity with his rivals, and in all probability he would be obliged in the end to put up with some equally ill-favoured and stupid outcast of the other sex.

The Canada porcupine of the present diy is apparently a result of this sort of selection, stumping about the woods like a turtle in its shell, intent only on filling his stomach with the green bark of trees he hauls himself laboriously up among the branches and strips them bare, killing a tree for his meal.

He lacks beauty either of form, motion or colour as well as softness of fur; his eyes are little and dull with never a glimmer of thought behind them, serving little better purpose than to direct him from one tree to the next and to distinguish between daytime and night. Being independent of the protection afforded by darkness, which so many animals rely on for safety, he is free to go and come as he pleases, and at least shows the good taste to prefer the sunshine, at all events in cool weather. In fact he has probably found it safer to go about by day, for with the exception of man, the greater part of his enemies are night prowlers. The mosi persistent of these is the fisher, who manages somehow to seize him by the throat where he is least protected and so avoid serious contact with his quills.

The various big cats of the northern woods will also hunt porcupine rather than go hungry, though it is often a sorry choice for them. The porcupine's quills are hard to avoid, and each one is fitted with numberless little barbs that, once the quill penetrates the skin, keep forcing it deeper and deeper into the sufferer's flesh with every involuntary twinge of his muscles, until a vital part is stabbed and the hunter pays high for his meal, many a porcupine avenging his own death weeks after 


\section{Canada Porcupine}

he has been eaten; even the wily fisher is said to be occasionally killed in this manner.

The porcupine's home is usually a hollow log or cavern among the rocks.

Here he can sleep in comparative safety curled up with his back to the entrance, presenting a most formidable cheranx de frise against attack.

In cold rough weather he stays indoors day and night, probibly endeavouring to sleep and forget his hunger. As soon as it grows a little milder he crawls out and makes haste to stuff himself with bark and green twigs to nourish him during the next cold spell.

When the snow melts at the approach of spring and the new sap starts up under the bark to swell the buds in the March sunshine he fares somewhat better, and long before the last drift has vanished is able to gather a taste of young green leaves along sunny banks beneath the evergreens, together with the hardier sorts that winter under the snow, now laid bare again to the sunlight.

Porcupines are not prolific animals; a pair of twins to each family early in the summer appears to be the general rule, the youngsters being about as rough and ugly looking as their parents.

\section{POCKET GOPHERS}

\section{(Family Geomyida)}

These curious little animals are characterized by their large cheek pouches opening outside the mouth, and their modified fore feet with immense claws suited for digging. Their hodies are heavy and their movements somewhat clumsy. The skull is thick, and in the species of Geomys which is the only genus represented in the East, the upper incisors are grooved. In the allied genus Thomomis, which is abundantly represented in the West, this is not the case.

The gophers are nocturnal and live in communities, burrowing in the ground like the marmots. They are very abundant in our Western States and two species extend eastward into the 


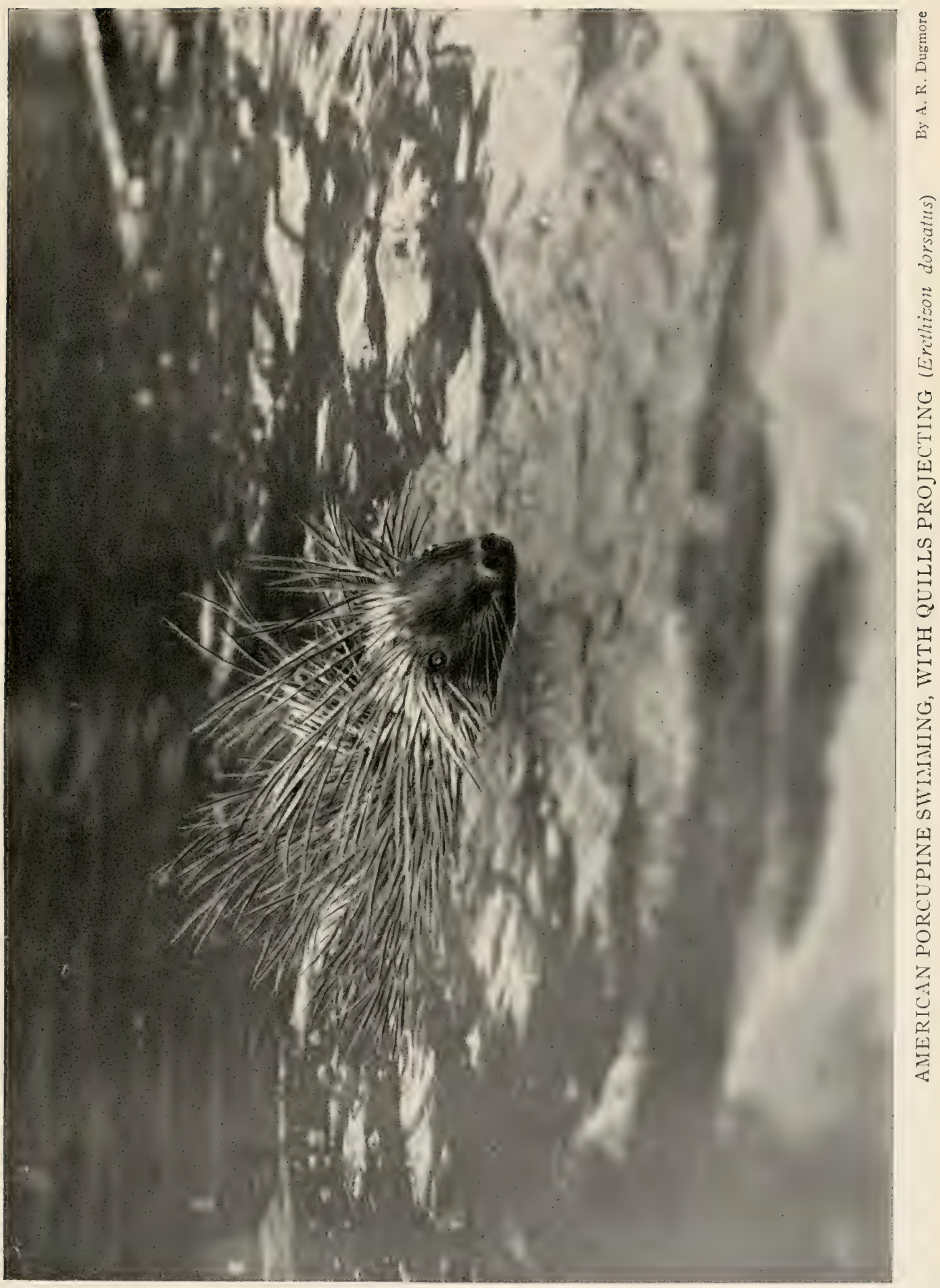



Mississippi Valley, while several closely related forms occur in the Southern States.

\title{
Georgia Gopher
}

\author{
Geomys tuza (Ord)
}

Also called Pocket Gopher, Salamander.

Length. Io inches.

Description. Cinnamon-brown with a somewhat fulvous tinge, an indistinct darker median stripe on the back; below dull ochraceous; hairs on the feet white, tail almost naked.

Range. Pine barrens of southern Georgia; represented in Florida and Alabama by closely related geographic races.

This little animal furnishes another example of the ambiguity of popular names. By all rights of priority and descent he is entitled to the name of gopher given to their Western relatives by the early French explorers, and signifying "honeycomb" in reference to their numerous burrows. Unfortunately our Southern pioneers bestowed this name upon a burrowing tortoise, while the true gopher was christened the "salamander," a name which is misleading and to which he has no just claim. Popular names, however, are too firmly established to yield to argument, and so the Georgia gopher will remain the salamander in spite of us.

Thoroughly adapted for a subterranean life, these animals spend almost all their time in their burrows, and even where they are abundant few people are acquainted with their appearance or habits, their presence being known only by their burrows and the gnawing of roots and vegetables.

"Gopher burrows seem to have neither beginning nor end," writes Vernon Bailey. "They are extended and added to yeat after year and in many cases those dug by a single animal would measure a mile or more, if straightened out. At the end of a year a gopher may often be found within twenty rods of the point from which he started, but in travelling this distance he has paid no attention to the points of the compass. He follows a tender root for a few feet, then moves to one side, encounters a stone and makes a second turn. A layer of mellow soil entices him off in another direction, and so on through a thousand devious crooks 


\section{Prairie Gopher}

and turns. At intervals openings are made through which to discharge the earth that makes the little piles called gopher-hills."

Gophers have regular storehouses where roots and other foods are stored away, being carried in the peculiar pockets on each side of the face.

1)r. Goode describes their digging habits as follows: "They dig by grubbing with the nose and a rapid shovelling with the long curved fore paws assisted by the pushing of the hind feet, which removes the earth from beneath the body and propels it back with grealt power a distance of eight or ten inches. When a small quantity of earth has accumulated in the rear of the miner, around he whirls with a vigorous flirt of the tail and, joining his fore paws before his nose, he transmutes himself into a sort of wheelbarrow pushing the dirt before him to a convenient distance."

Except during the breeding season gophers live singly. They are very pugnacious and fight viciously and, when caught away from their burrows, do not hesitate to attack their captor.

\section{Varieties of the Georgia Gopher}

1. Georgia Gopher. Geomy's tuia (Ord), Description and range as above.

2. Florida Gopher. G. tũa floridamus (Audubon \& Bachman). Rather larger and duller in colour, with a white spot under the chin.

Range. Eastern Florida, St. Mary's River to Eau Gallic.

3. West Florida Gopher. G. tuia anstrimus (Bangs). Paler, with much more white below.

Range. Western Florida.

4. Alabama Gopher. G. tuza mobilensis Merriam. Smaller and darker than the Georgia gopher.

Range. Extreme Northwestern Florida and Alabama.

5. Island Gopher. G. cumberlandius Bangs. Larger than the Georgia gopher, but like it in colour.

Range. Cumberland Island, Georgia.

\section{Prairie Gopher}

\section{Geomys bursarius (Shaw)}




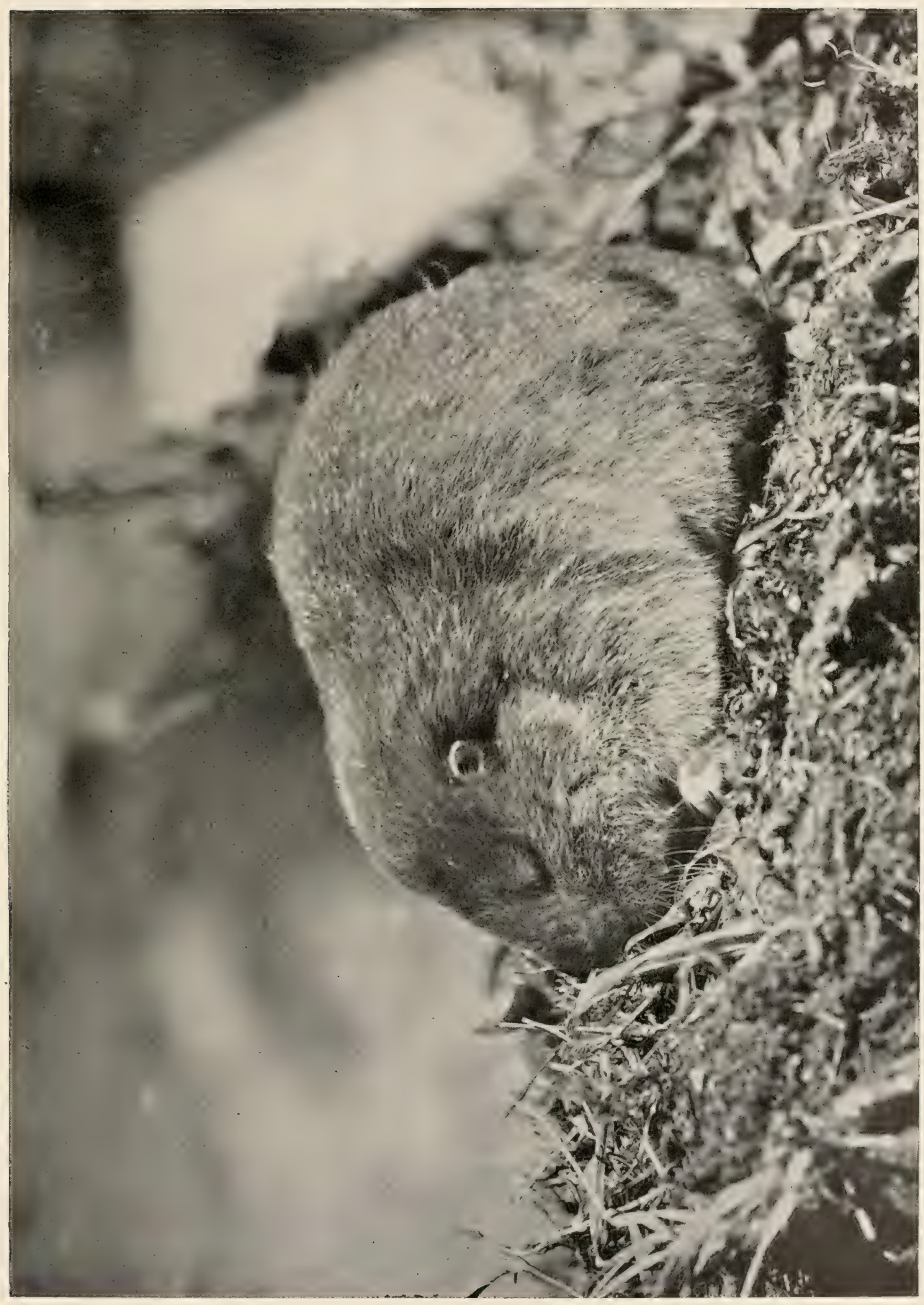



Length. 10 inches.

Description. Dark, pinkish-brown, inclining to chestnut in some specimens, but with no fulvous tints. Darker on the middle of the back; under surface slightly lighter, but not distinctly so as in the Georgia gopher; hair on the feet white; tail hairy, but scantily so toward the tip; hair of basal half brown, terminal half white.

Range. Mississippi Valley, from North Dakota to eastern Kansas and southern Missouri and including southern Wisconsin and most of Illinois.

The general appearance and habits of this animal are similar to those of the preceding species. Farther South and West are several other gophers, while from the Plains to the Pacific are found the gray gopher and its allies with ungrooved front teeth, but otherwise much like the animals above described.

\section{POCKET MICE}

\section{(Family Heteromyide)}

These mice are restricted to the western United States and Mexico and are confined largely to the arid regions, so characteristic of that portion of the country. They comprise two very different groups of animals - the true pocket mice, little mouselike creatures with rather coarse hair, and the larger kangaroo rats, with immense hind legs and long brushy-tipped tails, recalling the jerboas of the Old World.

Although so different in external appearance, these pocket mice are allied to the mole-like gophers that we have just been considering, and it will be seen at once upon examining them that they possess the same curious external check pouches. We have three modifications of the same type of animal just as we find in the true mice; the gopher corresponding to the meadow mouse, the pocket mouse to the deer mouse and the kangaroo rat to the jumping mouse. The first is adapted for a burrowing life, the second for a life on the surface of the ground and the third specially modified for leaping. 


\section{Plains Pocket Mouse}

\section{Pcrognathus flavescens (Merriam)}

Length. 5 inches.

Discrition. External cheek pouches lined with hair opening on either side of the mouth; hair harsh; grayish buff above mixed with dusky white below, sides, ring around eye and spot behind the eye clear buff, feet and legs white.

Range. Plains from South Dakota to northern Texals and west to the bise of the Rocky Mountains. Numerous other species occur throughout the sandy arid regions of the West from British Columbia to Mexico and California.

Very little is known of the life history of the pocket mice, mainly because they are strictly nocturnal in habits and pass the daytime in their burrows in the sandy ground with the openings generally stopped with earth. Like the gophers they carry their food in their curious cheek pouches and store it away in their subterranean granaries.

\section{Ord's Kangaroo Rat}

\section{Perodipus ordi (Woodhouse)}

Length. 9.60 inches.

Description. Ochraceous buff above, blackish on the rump. Sides of nose, spot behind each ear and band across the thighs white, under parts white; tail dusky down the middle, above and below, showing white bases to hairs on either side.

Range. Western Texas, New Mexico and Arizona. Many other species occur through the arid regions of the West.

This is another nocturnal inhabitant of the sandy plains of the Southwest. It makes an underground nest with numerous communicating passageways, the whole forming a low hillock which easily caves in and which horses and mules familiar with the country have learned to carefully avoid.

Ernest Seton-Thompson gives an interesting account of a nest of this little animal which he investigated. It was situated under the sheltering spines of a bunch of Spanish bayonets and thistles, which guarded effectually from would-be pursuers the nine open- 
ings through any one of which the little rat could plunge down to his subterranean dwelling. These openings led to a rather intricate series of passageways opening one into the other in such a way as to lead the intruder to another exit rather than to the nest. The latter he found was reached by a short branch leading from one of the above passageways, the mouth of which was apparently plugged up with earth by the little animal before departing, so as to further shield the nest from any intruders. The nest had a thick felting of fine grass and weed silk and a soft lining of feathers. Two other chambers were filled with over a pint of sunflower seeds and evidently served as storehouses. Of the mouse itself, which Mr. Thompson kept for a time in captivity, he writes: "He was the embodiment of restless energy. Palpitating with life from the tip of his translucent nose and ears to the end of his vibrant tail. He could cross the box at a single bound, and I now saw the purpose of his huge tail. In the extraordinary long flying leaps that Perodipus makes the tuft on the end does for him what the feathers do for an arrow. They keep him straight in the air in his trajectory.

He was the most indefatigable little miner that I ever saw. Those little pinky-white paws, not much larger than a pencil point, seemed never weary of digging, and would send the earth out between his hind legs in little jets like a steam-shovel. $\mathrm{He}$ seemed tireless at his work. He first tunnelled the whole mass through and through and I doubt not made and unmade several ideal underground residences and solved many problems of rapid underground transit. Then he embarked in some landscape gardening schemes and made it his nightly business to entirely change the geography of his whole country, laboriously making hills and canyons wheresoever seemed unto him good." Mr. Thompson had reason to suppose that the faint bird-like twitterings sometimes heard at night by cowboys and others on the plains are to be attributed to the Perodipus, being analogous to the songs which are uttered by some individuals of the common house mouse and the white-footed mouse of our woods. 


\section{JUMPING MICE}

\section{(Family Zapodida)}

These interesting mouse-like little animals are spread over all the Northern parts of North America. They differ in many respects from the true mice and can be recognized at once by their extremely long hind legs and tail and by the coarseness of their fur.

In their jumping habits and long legs they resemble the jerboas of the Old World and the kangaroo rats of our Southwestern States. Their kangaroo-like appearance has given rise to the popular belief that they are marsupials and carry their young in a pouch, which idea is of course wholly erroneous.

We have two kinds of jumping mice, the meadow species, probably the best known, and the large, more handsome, woodland jumping mouse, easily told by its white-tipped tail.

\section{Meadow Jumping Mouse}

\section{Zapus luedsonius (Zimmerman)}

Length. 8.80 inches.

Description. General colour yellowish fawn to rather dark ochraceous mixed with black-tipped hairs which predominate on the back making it much darker than the sides, belly white, somewhat suffused with buff, feet white, tail white beneath brownish above, $130 \mathrm{~mm}$. long. In autumn the fur is yellower with less dusky above.

Range. From Hudson's Bay to North Carolina, although those from the Southern States and from Labrador are slightly different. (See beyond.)

This is a mouse of uncertain and varying abundance; as a general thing decidedly rare, then there will come a summer when any one with an eye at all for seeing things, may have half a dozen or even a dozen specimens brought to his notice; the most harmless, inoffensive, kangaroo-like little things with astonishingly long tails, they go bounding off over the srass before you or cower trembling in the stubble, sometimes allowing themselves 


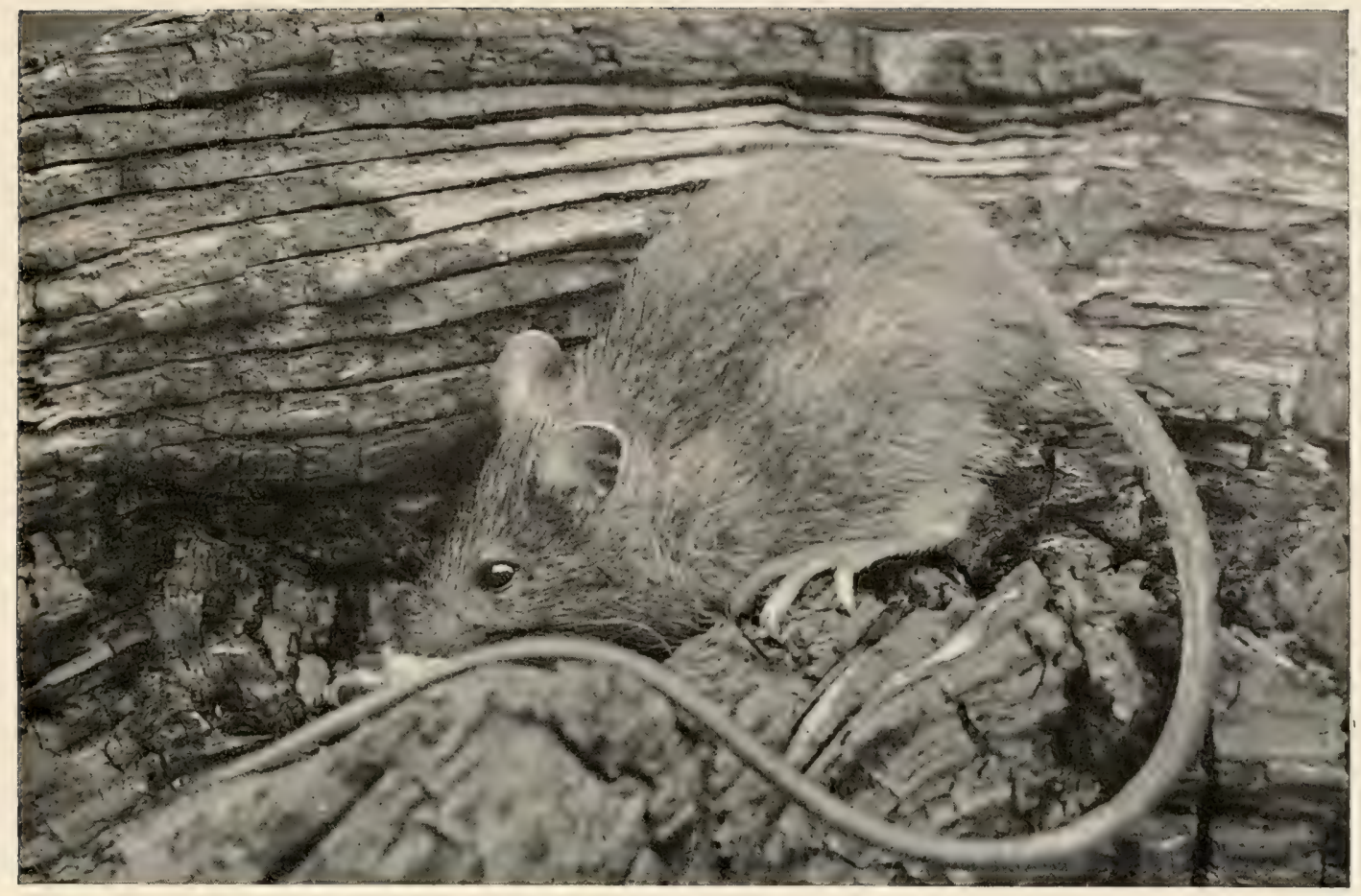

A WESTERN LONGTAIL MOUSE, CAUGHT IN THE BITTER ROOT MOUNTAINS By W. E. Carlin

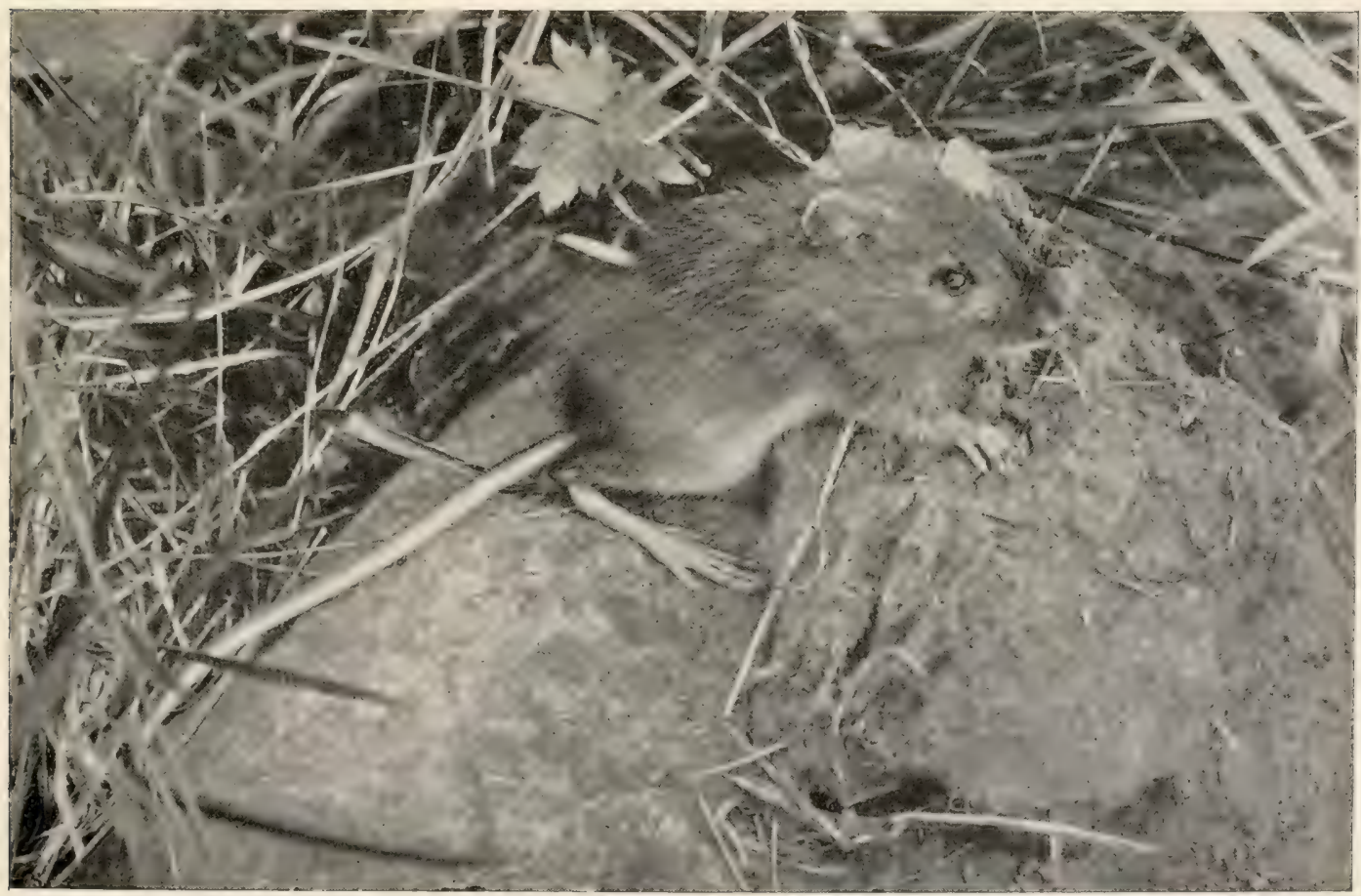

LONG-TAILED JUMPING MOUSE (Zapus hudsonicus)

By C. William Beebe 

io be stroked or even taken in the hand without offering resistance or attempting to escape. They seem to be decidedly less intelligent than other mice, trusting mainly to good luck and their gift at jumping to carry them through whatever dangers threaten. Apparently they never look before they leap, so that that which should be their safety often proves their ruin, as they are about as likely to spring directly into the clutches of a cat or other enemy as in an opposite direction; in this manner they are frequently drowned in milk-pans and tubs of water which a little ordinary caution would have avoided.

The last one I saw was on the bank of a stream in the woods where the wild grape-vines and smilax trailed along the edge of the water.

At first it attempted to escape by crouching among the grass and dead leaves, but when I stooped down to examine it it began leaping in the characteristic aimless and erratic manner of the species. Finally when I made an attempt to capture it with a landing net it leaped well out from the bank and descended in the water where the current was pretty strong; the mouse, however, proved equal to the occasion and swam swiftly enough against the stream for several yards to a floating branch along which it ran to the other end, where it again entered the water to swim ashore and hide among the driftwood and rubbish under the overhanging bank.

Jumping mice are oftenest seen just after the meadows and hay fields are cleared in August, evidently driven from their accustomed haunts and wandering lost and bewildered looking for new homes, or it may be that the summer drouth has compelled them to start out in search of water.

Their food appears to consist, like that of the other outdoor mice, largely of grass seeds, undoubtedly varied at times by the addition of berries and mushrooms and probably insects.

Ordinarily they creep about in the grass and leaves in a manner calculated to escape all notice, and it is only when threatened that they bring into use their powers of leaping, the value of which probably depends a good deal on its unexpectedness and the sudden effect of surprise it produces on the enemy.

These mice are dormant through a much longer season than are most hibernating animals, passing six months or more of every year in this condition curled up in their nests underground. 
I have seen a family of them turned up by the plough in May and they exhibited not the slightest symptom of life on being handled and breathed upon; their bodies were soft and limp and warm and had every appearance of an animal in a perfectly dormant condition.

\title{
Varieties of the Meadow Jumping Mouse
}

Though the jumping mice bear a close resemblance to one another they exhibit slight variations in different parts of their range so that the following have been distinguished.

1. Meadow Jumping Mouse. Zapus hudsonius (Zimmerman). Described above, ranges South to the mountains of New Jersey, Pennsylvania and North Carolina and in the West to Iowa.

2. Labrador Jumping Mouse. Zapus hudsonius ladas Bangs. Larger and darker, with longer legs and tail. Replaces the preceding in Labrador.

3. Carolinian Jumping Mouse. Zapus hudsonius americamus (Barton). Replaces the above in the lowlands from North Carolina to the Hudson and Connecticut Valleys.

\section{Woodland Jumping Mouse}

\author{
Zapus insignis Miller
}

Length. 9.80 inches.

Description. Larger than the meadow jump.ng mouse, with less dusky on the upper parts, sides inclining to rich orange, brightest on the cheeks; underparts pure snow white; tail with a white tip. Curiously enough this little animal has only three back (molar) teeth on each side of the upper jaw, while the meadow jumping mouse has four.

Range. Canada to New England and South through the mountains to Maryland.

Similar to the meadow jumping mouse in most respects, but far richer in colour; this beautiful little animal makes its home in the deep cool woods along some mountain stream, under the shelter of the hemlocks and laurel bushes. It seems to shun the society of man to which the other species is not averse, 
and we have in the distribution of these two a fair parallel to that of the white rabbit and the cottontail.

\section{Varieties of the Woodland Jumping Mouse}

1. Woodland Jumping Mouse. Zapus insignis Miller. Description and range as above.

2. Roan Mountain Jumping Monse. Z. insignis roanensis Preble. Smaller and darker.

Range. Mountains of the Southern Alleghanies.

3. Northern Jumping Mouse. L. insignis abietorum Preble. Larger than the woodland jumping mouse.

Range. Quebec and Ontario.

\section{RATS, MICE AND LEMMINGS}

\section{(Family Muridie)}

The late Dr. Coues described the members of this family in his usual terse style as " a feeble folk, comparatively insignificant in size and strength, holding their own in legions against a host of natural enemies, rapacious beasts and birds."

Few persons realize what a variety of them there are; spread over almost every part of the world they constitute a large proportion of the mammalian fauna and in eastern North America about one-quarter of our quadrupeds belong to this family.

They are typical members of the rodent tribe in every respect. In habits they are for the most part nocturnal, while many species live in burrows or tunnel-like runways on the surface of the ground among the grass roots and seldom, if ever, venture forth into the light. Other species like the muskrat are aquatic and have become excellent swimmers.

With few exceptions the members of this family are popularly known as rats or mice, a difference which has to do only with size. These names being originated for the two semidomestic species-the house mouse and the Norway rat-which accompany man wherever he establishes himself, were afterwards bestowed upon our wild species, according as they approached one or the other in size. Rats and mice do not therefore con- 
stitute satisfactory groups in which to classify our species. The latter, however, are divisible into two very natural assemblages which we might term the short-tailed and long-tailed groups.

The former are thick-set, short-legged and short-eared, with a very short tail, small eyes and thick fur. All of which characters stamp them as burrowing animals.

The long-tailed group, on the other hand, are sleek and graceful, standing higher on their legs, with usually large ears, big eyes and a long slender tail.

We frequently find that it is impossible to properly classify animals by external characters alone, and so in this case we find the muskrat excluded from the first group where he belongs by his long tail, but after noting this exception we may adopt the characters as satisfactory without considering the more fundamental peculiarities of teeth and skull upon which science relies. We have then three groups of the Murida:

\section{Meadow Mice, Lemmings and Muskrats}

\section{(Sub-Family Microtince)}

Thick-set, short-legged, short-eared, short-tailed, $i . c$. tail less than one-third the length of head and body (except muskrats) usually much less, mainly burrowers.

\section{American Long-tailed Mice and Rats}

\section{(Sub-Family Cricetina)}

More slender, with longer legs and generally larger ears and eyes and long tail, the latter always more than half the length of the head and body, generally much more.

\section{Introduced Mice and Rats}

\section{(Sub-Family Murina)}

Resembling in a general way the last group, but with very different skull and teeth. All natives of the Old World, whence they have been brought by man. 


\title{
MEADOW MICE, LEMMINGS AND MUSKRATS
}

\section{(Sub-Family Microtina) \\ Cooper's Lemming Mouse}

\author{
Synaptomys cooperi Baird
}

Length. 4.80 inches.

Description. Upper front teeth grooved, tail very short (.70 inch). Colour sepia brown, with many black hairs interspersed, some individuals with a slight admixture of buff or reddishbrown hairs, others somewhat grayer. Below plumbeous, generally with whitish tips to the hair, ears very short, overtopped by the hair, mammæ six.

Range. Southern New England and Michigan to Indiana and Virginia and in the mountains to North Carolina.

In external appearance the lemming mouse bears such a close resemblance to the common field or meadow mouse, with which it frequently associates, that it would readily be passed by. Without considering its minute anatomy it will be sufficient to call attention to its grooved front teeth by which it can always be recognized, its rather coarser hair and very short tail, The lemming mouse was first described by Professor Baird in 1857 and for years after its discovery it was regarded as excessively rare. Modern methods of trapping, however, have brought to light many specimens and we have learned that it is pretty generally distributed throughout our Northern States wherever conditions suitable for its requirements are to be found.

In connection with its rediscovery in our Eastern States it is interesting to know that science is indebted to that indefatigable mouse hunter, the barn owl, for the knowledge of the occurrence of the lemming mouse in several localities, the skulls having been found in the pellets of hair and bones which the owls had ejected about their nests.

Cold sphagnum bogs seem to be the favourite haunts of these little animals in the East, where they use the ample runways of the meadow mice which form an intricate network of passages beneath the damp moss and among the roots of the grass and rushes. In winter the sphagnum freezes up, forming a solid 
roof to the runways, but upon breaking into them abundant signs of life are to be seen and a trap set in such a situation is pretty sure to catch one or other of the several little animals which make these spots their home. For beside the lemming mouse and meadow mouse we find here also the red-backed mouse and the little shrew.

In Indiana Mr. A. W. Butler finds the lemming mice frequenting stony hillside pastures, while their nests are placed under stumps or logs.

Their food seems to consist of roots and tender shoots of grasses and rushes, though from the nature of their retreats it is practically impossible to gain much information als to their habits. Even when we are fortunate enough to catch a glimpse of one of the little animals it is usually merely a flash of brown fur, as he disappears with lightning speed along one of his passage ways.

\section{Varieties and Related Species of Lemming Mice}

I. Cooper's Lemming Mouse. Symaptoml's cooperi Baird. Range and description as above.

2. Dismal Swamp Lemming Mouse. Symatomvs cootiri helaletes (Merriam). Similar, but with larger head and more massive skull.

Range. Replaces the common species in Dismal Swamp, Virginia.

3. Northern Lemming Mouse. Symaptomy's fatuns Bangs. Smaller and darker, with narrower skull.

Range. Northern New England, Ontario, Quebec and New Brunswick. The northern representative of Cooper's lemming mouse.

4. Trui's lemming Mouse. Slnaftomys inmuitus True. Resembles Cooper's lemming mouse in general appearance, but has a very different skull, with much narrower, paler, coloured incisor teeth. Female with eight mammx.

Range. Labrador (Fort Chimo and Rigoulette).

5. Prelle's Limming Monse. Simatomis sphagnicola Preble. Similar to the last, but larger ( 5.25 inches long).

Range. Base of Mt. Washington, Fabyans, N. H

\section{Pied Lemming}

Dicrostonyx hudsonius (Pallas)

Length. 6 inches.

Discriftion, Summer. Gray above, more or less dappled with rusty 
ted and with a black line down the back, below dull gray tinged with rusty. Winter, nearly pure white. The most extraordinary peculiarity of this animal is the enormous dovelopment of the nails on the two middle toes of the front feet. They are square or rather club-shaped at the end and fully a quarter of an inch in length.

Range. Barren Grounds of Arctic America from Labrador to Alaska.

The name lemming is usually associated with the Arctic regions or with the barren mountains of Norway, in which latter locality the term originated. While it is true that most lemmings are found in these regions, it is also true that so far as structural peculiarities go, the lemming mice which have just been considered are quite as much lemmings as their Arctic allies, but it is hard to draw a distinction between the lemmings and meadow mice, so perfectly do they grade into one another.

The pied lemming lives in burrows in the beds of moss and lichens which cover the northern tundra and feeds solely on vegetable matter. They seem like other species of lemmings to be subject to great variation in abundance from year to year, and in localities where they abound the snow owls are also plentiful, nesting close to the haunts of the lemmings, which in such cases constitute their sole food.

So far as we know, however, the lemmings of Arctic America are not subject to such well-marked migrations as characterize those of Norway, where probably from overcrowding and consequent scarcity of food there often occurs a great exodus to some other locality. Dr. Coues says of their migration: "Nothing can stop them; they proceed straight on in their course, urged by some restless impulse, swimming broad rivers and lakes and invading towns which may lie in their way."

As to their habits Mr. E. W. Nelson states that some captive Alaskan lemmings were amusing, inoffensive little creatures and from the first allowed themselves to be handled without attempting to bite. "They would climb up into my hand and from it to my shoulder without a sign of haste or fear, but with odd curiosity, kept their noses continually sniffing and peered at everything with their bright bead-like eyes. When eating they held their food in their fore paws."

The change of colour in winter and summer is accomplished by a complete spring and fall moult of the hair, the white coat being much longer and heavier. 
In Alaska there occurs another lemming (Lemmus trimucronatus) which is of a rusty colour and never changes white in winter.

\section{False Lemming Mouse}

\section{Phenacomys latimanus Merriam}

Length. 5.30 inches.

Description. Strikingly like the meadow mouse in external appearance but with rooted molar teeth. Pale yellow cinnamon brown above with an admixture of black hairs on the back, below whitish gray; tail dark above, white below.

Range. Known only from Ungava, Labrador and the north shore of Lake Superior in Ontario. A somewhat larger species occurs in Labrador and Quebec $(P$. celatus) and others in the Northwest.

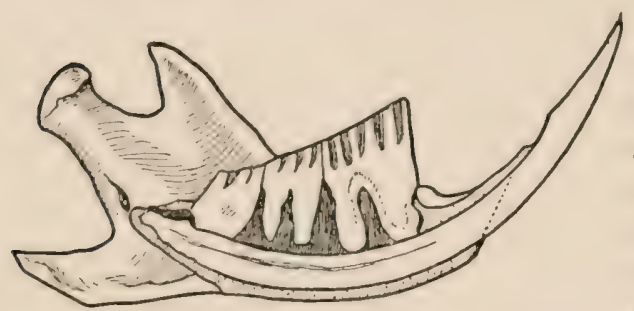

Lower jaw of Phenacomys, enlarged, to show rooted molar teeth. (After Miller.)

The most interesting point in the history of this rare mouse is its close external resemblance to the meadow mouse. For many years specimens in the National Museum passed as meadow mice until Dr. Merriam discovered that the back (molar) teeth did not grow continuously from the bottom as do those of the meadow mice, but possessed regular roots as in the red-baliked mice, a matter of small popular interest but of great scientific importance as it shows us one more link in the chain of evolution. Little is known of the habits of this mouse, though Mr. G. S. Miller, Jr., states that in Ontario he found it frequenting high upland barrens covered with stunted blueberry bushes. Its burrow was found running down by a decayed stump and terminating in a hollow,

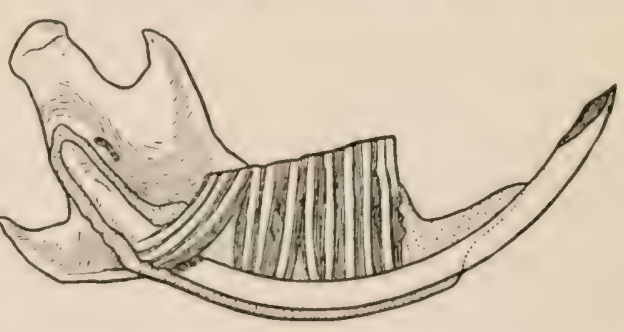

Lower jaw of Field Mouse, enlarged, to show unrooted molars. (After Miller.) evidently intended for the winter nest. Blueberries appeared to constitute its principal food at this season. 


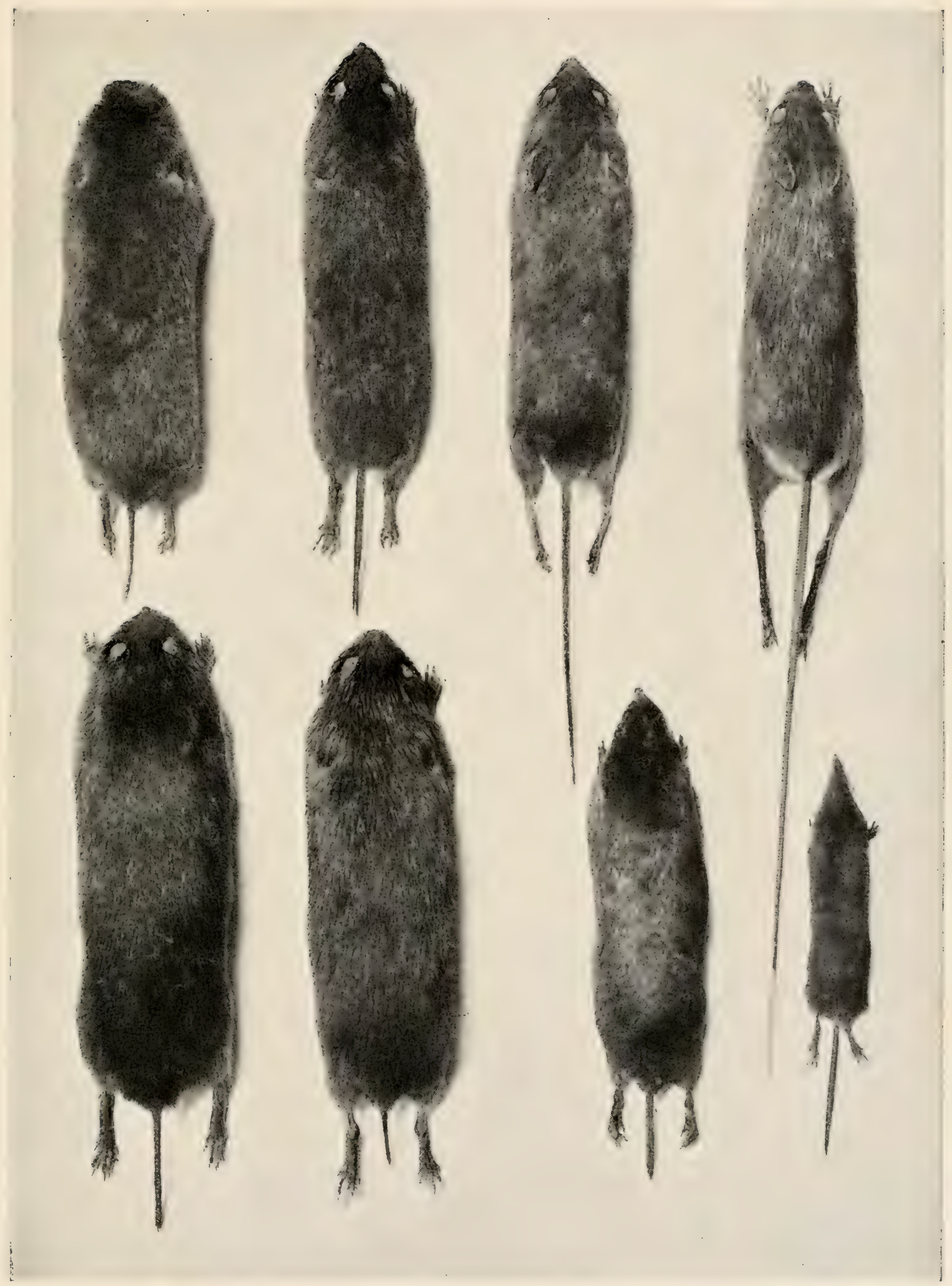

MICE AND SHREWS OF THE EASTERN STATES

Photographed from shins to show relative proportions

I. Pine Mouse (Microtus pinetorum) (uniform dull chestnut, fur very soft)

2. Red-backed Mouse (Evotomys gapperi) (rusty chestnut, brightest on back)

3. White-footed Mouse (Peromyscus leucopus) (fawn color, with white belly, ears large)

4. Long-tailed Jumping Mouse (Zapus insignis) (yellowish buff, hair rather coarse)

5. Meadow Mouse (Microtus pernsylvaricus) (blackish, grizzled with gray)

6. Lemming Mouse (Synaptomys cooperi) (similar, but tail very short and incisors grooved)

7. Short-tailed Shrew (Blarina brevicauda) (plumbeous gray, fur very soft)

8. Long-tailed Shrew (Sorex personatus) (fur similar but tinged with brown)

(About three-fifths natural size) 



\title{
Red-backed Mouse
}

\author{
Evotomys gapperi (Vigors)
}

\section{Called also Wood Mouse. Bog Mouse.}

Length. 5.60 inches.

Description. Ears short, just visible above the fur, about as in the meadow mouse. Colour bright reddish chestnut with numerous black hairs interspersed, sides buffy, below whitish, suffused with buff, feet light gray, tail brown above, gray below. Colours generally darker in summer. In New Brunswick, Ontario, and perhaps elsewhere in the northern part of its range individuals occur which are entirely gray with no trace of the red chestnut colouring. This seems to be a purely dirhromatic variety not due to age or sex.

Range. Alberta to Quebec and southward to the mountains of Pennsylvania and New Jersey.

This little mouse is a smaller cousin of the meadow mouse, similar in build but with a longer tail and always recognized by it chestnut colour. Its molar teeth, too, are rooted like those of the false lemming mouse. They are found mainly in woodland clearings, and open bogs, living in runways near the surface, or sometimes in dense patches of grass, and building their nests under a fallen log. The lumbermen of the Alleghanies see them often scurrying away as some fallen tree frightens them from their retreats, or the removal of a pile of bark lays bare their passage ways. To them and to hunters generally these animals are known as wood mice, but the term being used with equal propriety in other parts of the country for the white-footed mouse it becomes ambiguous.

A closely allied variety of red-backed mouse is the most abundant mammal on the Alpine summit of Mount Washington, where it occurs in all sorts of situations, among the rocks, in the moss and in the dwarf willows.

The red-backed mouse of southern New Jersey (E. g. rhoadsi) is an inhabitant exclusively of the cold, damp sphagnum bogs, which intersperse the sandy pine barrens. Here it lives deep down in the sphagnum, sharing the large runways wtth the meadow mouse, lemming mouse and diminutive shrews. In winter the moss is frequently frozen solid for several inches below the surface, which must force 


\section{Meadow Mouse}

these little rodents to live on such vegetable matter as they have stored away in their subterranean galleries. That either they or their associates are carnivorous at times is evidenced by the partially devoured specimens that the trapper often finds in his traps.

Young red-backed mice lack the rusty red tints and in some of the varieties a gray form of the adult occurs, an exactly parallel case to the red and graly screech owls which are simply dichromatic without relation to sex or age.

\section{Varieties of the Red-backed Mouse}

I. Red-backed Mouse. Evotomys gapperi (Vigors).

Description and range as above.

2. New Jersey Red-backed Mouse. E. gapperi rhoadsi Stone.

Darker, with more black hairs above. Teeth heavier.

Range. Cold cranberry bogs of Southern New Jersey.

3. Carolina Red-backed Mouse. E. gapperi carolinensis Merriam.

Larger and darker than E. gapperi, resembling the last.

Range. Higher Alleghanies, Roan Mit, N. C. to Pennsylvania.

4. Pallid Red-backed Mouse. E. gapperi och raceous Miller.

Duller, paler, and more ochraceous than E. gapperi.

Range. Higher slopes of the White Mountains.

5. Labrador Red-backed Mouse. E. proteus Bangs.

Larger than any of the above with longer ears. Paler than

E. gapperi and like it in exhibiting a gray phase.

Range. Wooded regions of Labrador.

6. Ungava Red-backed Mouse. E. ungava Bangs.

Resembles E. gapperi, but has very small ears and peculiar skull. Range. Ungava, Labrador.

Numerous species occur in the Northwest.

\section{Meadow Mouse}

Microtus pennsylvanicus (Ord)

Called also Field Mouse, Meadow Vole.

Length. 6.50 inches.

Discription. Body thick and compact, legs short, ears very short. I)ark brown above with a general admixture of black hairs, shading gradually into gray on the under surface. The colour of the upper parts varies considetably, some individuals being decidedly blackish, others tinged with tawny and occasional specimens quite chestnut with very few black hairs. The under surface also varies to dull buff. 
Range. Southern Canada to North Carolina westward to the edge of the Plains. Replaced to the northward by four closely related varieties, and one to the southward, while there is also an island race. (See below.)

With us the meadow mouse occupies much the same position that the field mouse does in England; in fact it is oftener called field mouse than meadow mouse by the farmers, who, it seems to me, are not so very wide of the mark in so classifying it.

It is perfectly true that it prefers meadows to dry fields, but so too does the field mouse of the old country according to
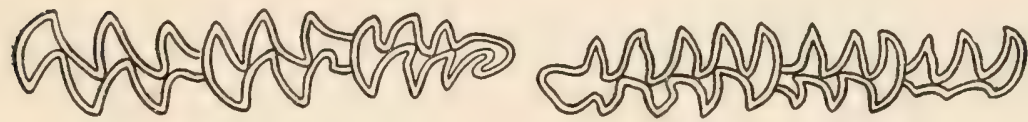

Tops of upper and lower molar teeth of Meadow Mouse, to show " triangles," enlarged. (After Miller.)

many writers, and the greater dryness of our summers might well account for any difference that exists in that direction.

Except in the severest drouths, in New England at least, even the driest and most sandy fields are populated by meadow mice at all times of the year, and in times of abundant rainfall they are, I am confident, as numerous in fields as in meadows.

In summer they regularly resort to the grain lands like genuine field mice, and beyond a doubt if grain were stacked in ricks here as it is in England these would harbour as many mice and suffer an equal amount of damage.

In the fields of Indian corn they do harm enough, making their round nests. of stripped up husks in the heart of a shock and fattening themselves at the expense of the farmer until they are routed out at harvesting.

Perhaps the most striking difference is that our species has not yet contracted the habit of spending the winter in barns; even this characteristic does not hold good farther North, as in Canada it is said to be a regular custom with it to do so.

Although many of them have their homes in dry upland fields and pastures, as a rule meadow mice show a decided fondness for water and wet places. Those living on the banks of streams become almost aquatic, and when, pursued are as likely 
as not to take to the water for safety; I have often seen them swimming about beneath the ice in shallow water, and in summer paddling along between the pickerel weed and rushes. I have also seen them dive and swim for short distances under water, and when they emerge, their fur after a few shakes proves its fitness for that sort of thing by coming out as fluffy as ever.

Yet it frequently happens that on taking to the water for safety they only find another enemy, for pickerel often seize them from beneath at such times.

Meadow mice are even abundant on the salt marshes by the sea, not only along the border where the marshes and forest meet, and by the skirts of the sand-dunes, but well out on the flat grassy stretches and by the margins of salt ponds that with each recurring moon are daily inundated by the ocean.

How they manage to escape the floods at these times I know not; it would appear that they are not much in the way of taking refuge in haystacks, even when the marsh is thickly dotted with them, as it is from August until the winter is well spent.

Perhaps they have learned to watch the subtle movement of the tide and are able to foretell each high run in time to remove themselves and their families to higher ground. This would certainly call for an astonishing amount of intelligence on their part, for the treacherous thing will ebb and flow harmlessly day after day and week after week, hardly wetting the roots of the thatch along the creeks; and then suddenly without warning and perhaps just because a coast storm is harassing the sea somewhere out at the edge of the gulf stream so far away that hardly a cloud shows above the sky-lines, it lifts itself and spreads out across the grass, flooding the paths of the mice and all their haunts in the space of a few hours.

But the meadow mice are a wise folk and I firmly believe that they do manage to foretell the floods in most instances and camp along the borders of the marsh until the danger is over. What if some of them do occasionally get overtaken by the tide? as I have said already they are practical swimmers and there is pretty certain to be an abundance of eel grass in bunches and driftwood and rubbish of all sorts floating about to serve as rafts until the waters recede to their accustomed channels. But it is my belief that the mice very rarely allow themselves to be taken unawares in any such manner.

1 have spent considerable time on the marshes when they were being overflowed for the first time in weeks and cannot recall ever 


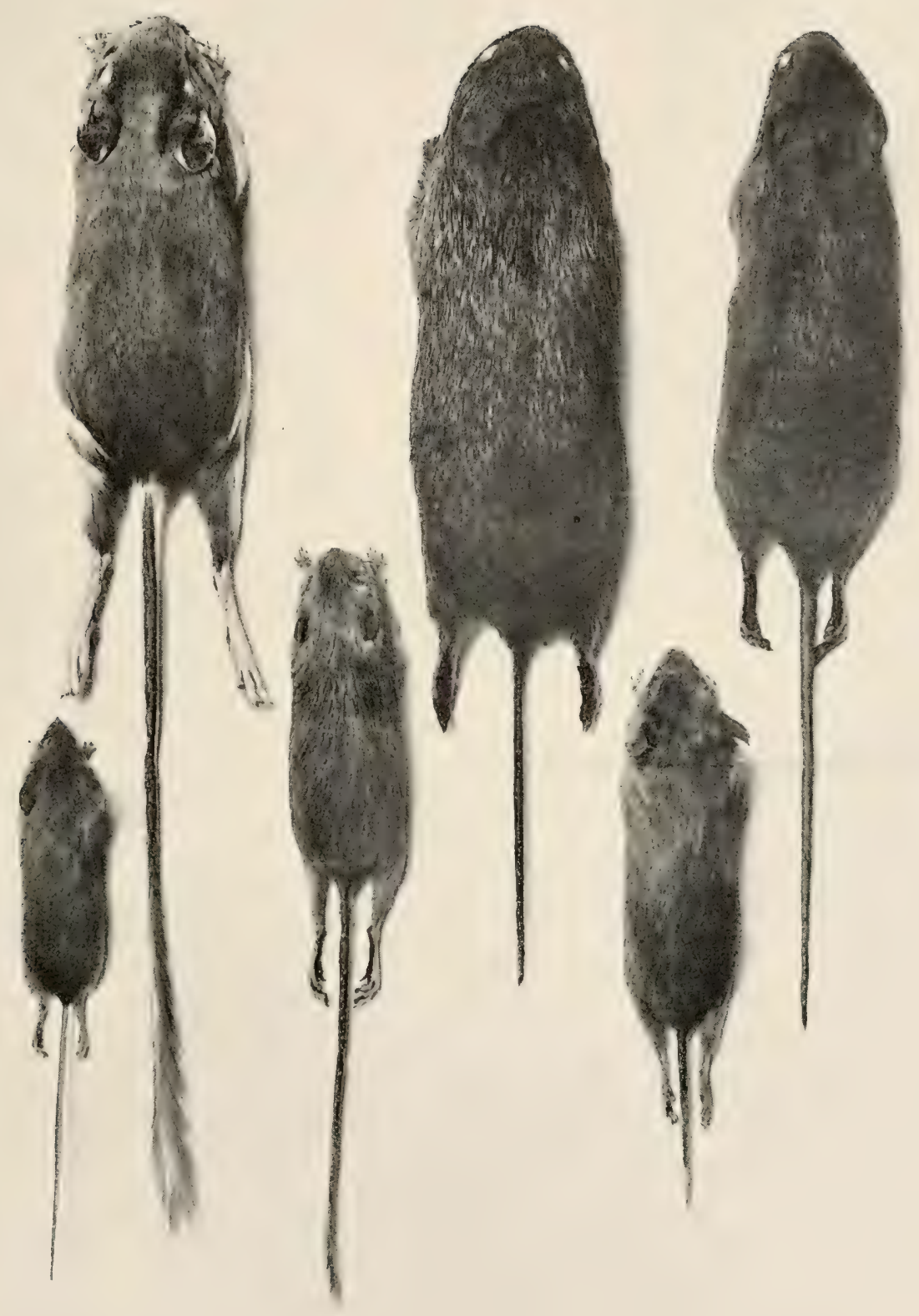

WESTERN AND SOUTHERN MICE AND RATS

Photographed from skins to show relative proportions

4. Harvest Mouse (Reithrodontomys)

1. Kangaroo Rat (Perodipus)

5. Pocket Mouse (Perognathus)

3. Rice-field Mouse (Oryzomys)

6. Scorpion Mouse (Onycomys)

(About one-half natural size) 

having seen so much as one solitary meadow mouse swimming for his life there.

Their paths are made by gnawing off the short stiff marsh grass close down to the roots leaving an even roadway something more than an inch wide. The closely ranked grass on either side bends just enough to meet overhead for a screen against the prying eyes of hawks.

The grass that is cut away to make the paths disappears completely, probably having been eaten by the mice, though when it comes to calculating the amount removed in the construction of the miles and miles of little roads that thread the meadows one cannot help wondering just how much a meadow mouse is capable of consuming in the course of a season, for they do not live upon grass alone; the isles between the stems of the fox grass and black grass swarm with brown sand-hoppers and various other salt-loving creatures which I am inclined to think furnish the principal incentive that calls the meadow mice away from the uplands; diminutive shellfish and other small fry are also eaten by them.

Meadow mice inhabit alike meadows and pastire land, orchards, gardens and cornfields and, wherever the lawns are not kept too closely trimmed and the cats are not too officious, readily take up their abode about houses, especially where there are woodpiles beneath which they can find shelter.

In wet ground every stranded piece of driftwood and fallen fence board is made to serve as roof for their crooked galleries and they frequently make their nests of withered grass in such places.

They also dig simple burrows hardly a foot in depth, having nests at the bottom where the young mice pass the first period of their lives; these young mice soon learn to ascend the almost perpendicular shafts leading up to the sunlight and may often be seen poking their stub noses out into the air to learn what the world is like.

In the winter they have their nests on the surface of the ground beneath the snow, their galleries leading off through the matted grass in all directions. I have found these nests with young ones as early as February and think it quite possible that they may be in the way of breeding throughout the winter.

Their tunnels beneath the snow are being constantly extended, allowing them to ramble about and explore the stubble for grass seeds and tender shoots in comparative safety. They have frequent doorways admitting them to the upper air, and at night are often out scampering back and forth across the snow, leaving an 
interesting tracery of footprints on its white surface, and are also not infrequently seen out in the winter sunshine among weeds and bushes that have remained uncovered In hard seasons they depend largely on the bark of different fruit trees and shrubs, and even appear to find the resinous bark of the ground juniper palatable, the vanishing snow in the spring frequently revealing stems and branches stripped bare of their covering beyond all possiblity of recovery.

Lacking the agility of other mice they have learned to stand and fight, no matter what the odds maly be, employing the same manner of defence that woodchucks do. And yet none of the regular mouse hunters appears ever to hesitate to seize one of them; inexperienced kittens, and no doubt other young animals of like appetite, often get well bitten in a first attempt, but soon discover a better method of attack. Few animals are more constantly pursued than the meadow mice; while the warm weather lasts they have to be constantly on guard against the marsh hawk and the hen hawks who diligently search the grass land in regions where they are allowed to build their nests. Crows, also, are fond of going a-mousing on foot, particularly in late summer after the grass is cut, but naturally are not nearly as successful as the hawks.

As winter approaches these foes gradually take their departure, but their places are usually more than filled by the owls of various species. With the exception of the great horned owl and the arctic owl, these lovers of the twilight may be said to iive on mice, the rabbits, squirrels and birds which they capture being only side issues or strokes of probably unexpected luck in a practically never-ending mouse hunt.

At uncertain intervals the rough-legged or winter hawks make their appearance and bend their energies in the same direction; like the owls they seem to be forever seeking for good mousing country, and having found it are apt to gather in considerable numbers and establish themselves for an indefinite period.

As quickly, however, as the meadow mice begin noticeably to decrease in numbers or the snow becomes too deep for successful hunting, these mousers from northern lands move on again to look for better hunting grounds.

The four-footed hunters, the foxes, cats and weasels of various sorts, are here at all seasons, and when meadow mice are abundant chase them persistently, and when they are not go hunting for other game. 


\section{Varieties of the Meadow Mouse}

I. Míeadow Mouse. Microtus pennsylvanicus (Ord.) Description and range as above.

2. Black Meadow Monse. M. pennsylvanicus nigrans Rhoads. Much darker, black hairs predominating.

Range. Coast of Virginia and North Carolina.

3. Acadian Meadow Mouse. M. pennsylvanicus acadicus Bangs. Brighter and more strongly russet than $M$. pennsylvanicus.

Range. Nova Scotia.

4. Labrador Meadow Mouse. M. pennsylvanicus enixus (Bangs). Similar to the meadow mouse in color but with peculiar skull, and light projecting front teeth.

Range. Labrador.

5. Ungava Meadow Mouse. M. pennsylvanicus ungava Bailey. Smaller than the meadow mouse with very broad peculiar skull.

Range. Ungava, Northern Labrador.

6. Hudsonian Meadow Mouse. M. pennsylvanicus fontigenus (Bangs). Smaller than the meadow mouse with no tawny tints, skull rarrower.

Range. Quebec and Ontario, in deep forests.

7. Gull Island Mouse. M. nesophilus Bailey. Very similar externally to the meadow mouse, but with a peculiar skull. Range. Little Gull Island N. Y.

\section{Brewer's Beach Mouse}

\section{Microtus breweri (Baird)}

Length. 7.80 inches.

Description. Larger than the meadow mouse with rather coarse fur, pale grayish yellow-brown above, ashy white below, with a tint of buff.

Range. Muskeget Island, Mass. Formerly also on Adams and South Point Island two small islets south of Muskeget.

This curious pallid mouse, originally derived from the same stock as the dark meadow mouse of the mainland, is a striking illustration of the effect of environment in moulding species. Not only has it changed materially in color, but its habits and mode of life have also undergone modification. The sandy soil of the island upon which it lives precludes the possibility of burrows, except perhaps in winter, and the mice pass the greater part of the year exposed to the full force 


\section{Rock Vole}

of the elements, their only protection being that furnished by fragments of driftwood and wreckige. Where the mice are abundant a labyrinth of well-beaten paths crosses the sand in every direction along which the mice run when pursued. The only burrows are short ones evidently intended to reach the soft parts of the beach grass which forms their food. They construct nests or forms, open at the top and large enough to hold one animal, which are scattered about everywhere. In autumn they lay up stores of the soft stems of the beach grass (Ammophila) for winter use. These are buried in the sand, as much as a peck being concealed in one place. (See Miller"The Beach Mouse of Muskeget Island.")

\section{Rock Vole}

\section{Microtus chrotorrinus Miller}

\section{Also called Yellow-cheeked Meadow Mouse}

Length. 6.60 inches.

Description. Similar to the meadow mouse but with a yellowish or

fulvous patch on each side of the face at the base of the whiskers. Range. New Brunswick and Quebec and southward to the White

Mountains, Adirondacks and Catskills. Allied varieties occur in

Labrador and Newfoundland.

Of the habits of the rock voles but little is known. Mr. Miller found them in the White Mountains living in the crevices of rock mounds overgrown with sedges and bushes, and they seemed to have no regular runways. In New Brunswick Mr. Bangs states that they live in the deep spruce forests and appear to be diurnal in habits.

\section{Varieties of the Rock Vole}

1. Rock Vole. Microtus chrotorrhinus Miller. Description and range as above.

2. Labrador Rock Vole. M. chrotorrhimus ravus Bangs, Similar, but light patches larger covering nearly the whole face. Range. Labrador.

3. Newfoundland Rock Vole. M. terra nove Bangs. Similar but larger with duller cheek patches.

Range. Newfoundland. 


\section{Prairie Meadow Mouse}

\section{Microtus austerus (Le Conte)}

Length. 6 inches.

Description. Shape much as in the meadow mouse but upper parts grizzly gray, caused by a uniform mixture of grayish white and black hairs over the whole surface. No brown or chestnut tints such as characterize the meadow mouse. Below light gray or ochraceous. The fur is harsher and more bristly than any of the other members of the meadow mouse tribe.

Kange. Upper Mississippi Valley, southern Wisconsin and Illinois to southern Missouri and west to Kansas.

The grizzly gray color and rather harsh pelage characterize these little animals which are inhabitants of the prairies of the Upper Mississippi Valley. Mr. Kennicott states that they frequent moist localities in summer and drier regions in winter. "Their winter burrows on the uncultivated prairie are often in old ant hills or if not, the earth thrown out from them forms little hillocks. They are not very deep, seldom over six inches or a foot, but are remarkable for the numerous and complicated chambers and side passages of which they are composed. In one of these chambers, considerably enlarged, is placed the nest, formed of fine dry grass." The first litter of young is apparently brought forth in this nest but later in the spring the mice construct similar nests on the surface of the ground. The prairie field mouse is not gregarious and when more than one pair are found in the same spot they are attracted by some particular food.

In cultivated fields they frequently establish themselves in corn shocks in the same manner as the common field mouse.

\section{Pine Mouse}

\section{Microtus pinetonum (Le Conte)}

Length. 6 inches.

Description. Uniform rusty brown on the upper surface, lighter on the sides, where it passes gradually into the silvery-gray of the under parts. Young individuals are quite gray above with no reddish tints. The short, dense silky fur distinguishes the species from any other mouse.

Range. Southern New York and Connecticut to Illinois and southward to Florida. 
This is the most distinct of all the meadow mouse tribe. So soft and silky is its fur that we think at once of the mole, the very small eyes and ears likewise resemble this animal, but the teeth at once show it to he a mouse and the rusty colour is not found in any of the mole tribe. The points that the pine mouse possesses in common with the mole are evidently the results of similar habits, for this little beast is the most strictly subterranean of any of the mice. He is not content with a runway on the surface among the grass roots but must go strictly underground, and many a one have I caught in raised tunnels that I took to be the work of the moles. Much damage done to vegetables and plants in the garden which is usually attributed to the meadow mouse is, I am quite sure, really the work of this silky haired cousin, the pine mouse.

\section{Varieties of the Pine Mouse}

I. Pine Mouse. Microtus pinetormm (Le Conte). Description as above, range Southern Atlantic States.

2. Northern Pine Mouse. M. pinetornm scalopsoides Audubon and Bachman. Light in colour.

Range. Southern New England and Middle States.

3. Mississippi Pine Mouse. M. pinctormm auricularis Bailey. Darker and richer in colour, with rather larger ears. Range. Lower Mississippi Valley.

\section{Round-tailed Muskrat}

Microtus alloni (True)

Also called Neofiber.

Length. 13.60 inches.

Description. This animal is essentially a very big meadow mouse

with a long tail. Colour above rich rufous brown, darker on

the head; beneath whitish, more or less tinged with rufous;

hairs plumbeous at base; tail sparsely haired, blackish in colouĩ.

Young gray above.

Range, Eastern Florida.

This curious animal is common in the fresh-water ponds and marshes of interior Florida and on the salt savannahs of the Indian River. 
According to Mr. Bangs it builds a large oval nest, sometimes, like that of the muskrat, situated in the water and rising above the surface, and at other times among the mangroves or even in a hollow stump. The former nests have two openings below which communicate, when not covered by water, with underground passage ways. While the Neofiber swims with ease it is rarely seen swimming about in the manner of the muskrat.

Mr. Chapman states that their food consists of a succulent grass which grows abundantly where they are found. "To procure the younger and more tender portions Neofiber constructs a platform of the larger stalks on which he sits and feeds at leisure on the shoots growing in his vicinity; the size of the platform depends upon the abundance of the food growing near it, the harder rejected portions constantly adding to its bulk.

\section{Muskrat}

\section{Fiber zibethicus Linnæus}

\section{Called also Musquash.}

Length. 24 inches.

Description. Body thick-set like a very large meadow mouse, legs short, tail scaly, nearly naked and flat (compressed laterally). Fur thick, with a woolly underfur, colour dark brown above, somewhat tinged with fulvous especially on the sides; beneath dull white, with scattered fulvous hairs, white on the throat, with white lips, and a brown spot on the chin. Range. Eastern North America, southward to Virginia and the middle Mississippi Valley. Replaced in Labrador, Newfoundland, lower Mississippi Valley and Dismal Swamp by closely related varieties.

The muskrat, it seems to me, is just a little cousin of the beaver. About the only striking outward difference between the lives of the two is in the attitude each assumes toward man and his works.

The beaver is wild and retiring, hating man in his destructive advance along the quiet forest streams, which the beaver family had held as their own for untold centuries, and refusing to settle contentedly within sound of his works even where most protected and undisturbed. 


\section{Muskrat}

The muskrat, on the contrary, quickly learned to profit by the settlement of the country and the consequent thinning of his natural enemies, and though hunted and trapped persistently for several months in the year, still refuses to he driven away, and may be found in colonies perfectly undisturbed by the jarring racket of a sawmill or the smoke of a factory chimney, evidently willing to put up with some of the nuisances of civilization, in order to take advantage of the ponds dammed back by man for his own personal use, and which, unlike the beaver, the muskrat has apparently never learned to make for himself.

The alobe cabins of the muskrat are, however, very similar and often practically identical except in dimensions to those of the beaver. When in the late fall the long cold nights and increasing cloudiness foretell the coming snows and ice-locked streams of winter, the muskrats erect these lodges to serve both as living rooms and as air chambers to which they may bring the freshwater clams and lily roots that they dig up from the bottom when working at a distance from their burrows in the bank. If possible, they prefer to begin the work when the water is not very high.

On flat grassy reaches half overflowed they dig up sods, the size of a man's fist, sometimes arranging them in a little circle to hold hack the water while they are at work inside, sinking a shallow well down into what will be the bed of the stream when the water gets higher. At a depth of a foot or more they hollow out a sort of chamber and from this make several radiating tunnels or subways, some of which reach well up into the high bank rods away and above high-water mark if possible, where the nest chamber is placed just under the turf or the protecting roots of a tree. Other tunnels extend in an opposite direction to the deepest parts of the channel that never freeze.

The sods and mud removed are piled up about the original opening in a more or less dome-shaped heap, which usually contains iwn rooms, one at the bottom partly or quite submerged, the - Here above it and a little to one side, ventilated at the top, and with a short passage leading down to the first.

In this way they are sure of a thoroughfare from their nest in the bank to the bottom of the stream, with a breathing-place 

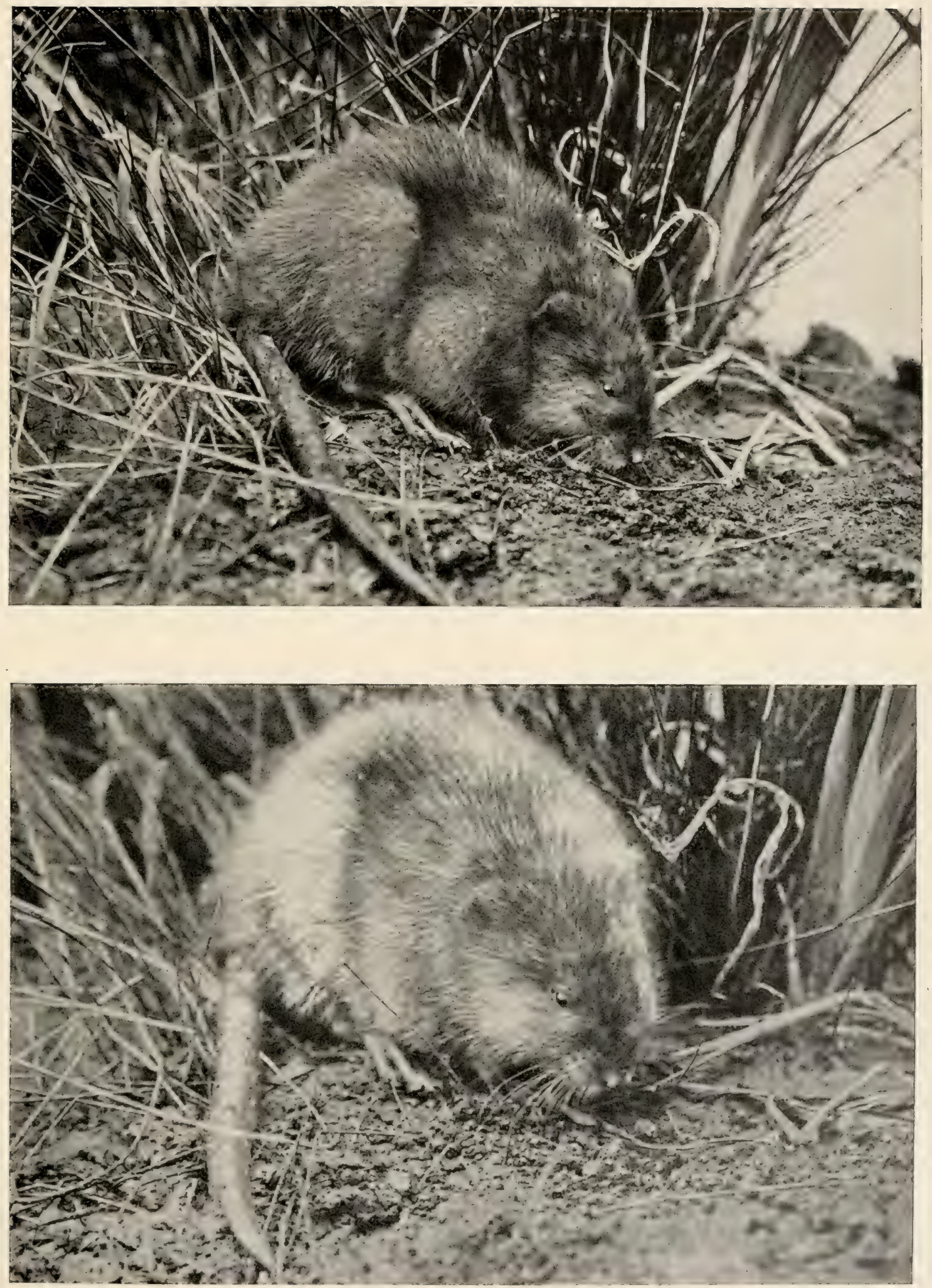

midway even in the coldest weather, when everywhere except in midchannel the water is hard frozen to the bottom.

The upper chamber in the cabin is lined with soft grass and moss and here the owners spend much of their time in winter curled up asleep, often three or four together. Some of the smaller cabins have only the upper chamber without any downward passage whatever; others are large enough to contain four or five apartments at least. Many of them are built in low willow trees or on rough frameworks of sticks which the muskrats arrange among the alders; and here they exhibit much of the constructive ability of the beavers, cutting their wood on shore in a similar manner and often towing it long distances to their building sites where they wattle it firmly between the alder stems for a foundation.

Cabins so placed are generally composed largely of cattail stalks and green twigs, while those on the ground are more often built of mud and pieces of sod. The cabins are not much used except at times of high water and in winter, though I doubt if they are ever wholly abandoned at any season. So long as the streams remain frozen, the muskrat is practically free from care and danger. The temperature about him hardly varies a degree whatever the weather may be above the ice. He knows nothing of snowstorms or sleet or high winds while the ice holds firm, though the rushing wind-driven water may be deep over the ice in times of freshet. Down where he is at work it flows with the same gentle motions as in summer, barely swinging the water weed and cresses as it slips between them. There is generally plenty of air to be had close up under the edge of the bank beneath the ice, and when this is not within reach, he has only to expel the air from his lungs against the undersurface of the ice when it is quickly purified by contact with the freezing water.

It frequently happens that the water, falling away from the ice, leaves extended caverns the width of the stream at high water and roofed over with semitransparent ice, like ground glass, that admits only a dim half-light from above.

The banks of coarse wet grass and mud show dimly along this strange underworld with the quiet unfrozen water holding its still course between them; and here the muskrats are free to come and go as they please, and swim, with their heads out of water, 
as in summer, breathing the air as they go. About the only enemies that follow them here are the minks and otters who come ostensibly to fish, yet are ever ready to seize any unwary musquash that comes their way.

This state of things seldom lasts for any length of time, however; either the ice sinks from its own weight or a thaw fills the streans agrain, and in either case the muskrats are forced on short rations of air once more, searching for stray bubbles along the edge of the ice-a strange economy in the winter life of a warm-blooded creature.

Early in the spring they begin to look for air holes under sheltered banks that gather the sun's heat and reflect it back at midday from the bottom, and here they bring their sweet flatgs and lily roots in order to enjoy them in the free air. The various openings broaden and extend their boundaries, and run together until the ice is reduced to a rapidly diminishing border along each shore.

While the streams are kept full by the melting snow and spring rains, the muskrats are somewhat restricted in their choice of landing places, and every projecting fence-rail and stump or leaning willow tree is taken advantage of.

As the water recedes they resort to the tussocks as fast as they are uncovered, and by mid-spring generally have their familiar landing places and byways through the sedge well established.

But even now, when no longer imprisoned by the ice, they swim oftener under water than on the surface, only rising from time to time to renew their breath. Their families are raised, not in their cabins but in their homes high up in the bank, two or three litters in a season, the youngest seldom more than half grown, before the still water is again skimmed over at night by the new ice of the coming winter.

In summer, during the heat of the day, muskrats are especially fond of swimming and floating about in the shadow of old willow trees, where the water is deep and cool; sometimes you will see one swimming around in short circles as if trying to catch its own tail, and uttering a curious little whimpering cry, which, although it sounds decidedly unhappy, is, I am inclined to think, a note of contentment, rather than distress.

It is very seldom heard except when the little animal is alone, and I have never been able to guess at its significance; 
it is quite different from the call-note which they use to attract one another's attention at a distance, or their more rat-like squeaking. The signal with which one warns the rest of danger is a smart slap of the muscular tail on the water.

One morning, before the light had begun to come in the east, I was sitting on the margin of a stream where there is a muskrat colony, waiting for the wild ducks that come in from the sea at daybreak.

Behind me was a dark swamp of heavy old growth hemlock where the great horned owls were calling loudly to each other. So long as they kept at that distance the muskrats apparently paid no heed to their hooting; but the instant that I replied to one of the owls, counterfeiting its hollow, low-toned voice as closely as I could, the nearest muskrat swung his tail in air and brought the flat of it down on the water with a whack, and it was most amusing to hear the succession of whacks that responded all along the edge of the water, farther and farther away, each followed by the hurried plunge of its owner beneath the surface. These great eagle owls are among the worst enemies that the muskrats have to fear, for they will watch patiently, hour after hour, from their ambush among the pine boughs and then suddenly circle out over the meadows without the whisper of a feather.

When a fox comes nosing along the stream's margin, at dusk, you may hear the warning slap, slap, of rubbery tails from hidden pools and nooks among the rushes, as the muskrats get wind of his presence. But the muskrat's tail has other and more important uses; it is both rudder and propeller as he swims, and a most convenient third leg when he stands upright to look about, or reach a higher twig when he is browsing in the undergrowth and, unless I am very much mistaken, it also gives him added impetus as he dives headlong into the water.

All through the summer and early fall the young muskrats live contented home lives with their parents, though not exactly under their protection, except as each depends on all the rest for timely warning at the first sign of danger; paddling and wading about in the shrunken streams and ponds, or curled into little brown, furry balls, fast asleep on the edge of the bank, hidden by the rank growth of flags and bullrushes, among which they have well-trodden paths, leading from place to place. 


\section{Muskrat}

But in the late Indian summer comes their Wander-Jahre, when they start out on their travels, roving and unsettled, exploring strange meadows and streams, at times all alone, and again two or three families together; starting a new cabin here or a burrow when the bank looks promising, and then moving on again, leaving their work only half finished, until at last they find the place that suits them best and settle down for the winter, ready for months of fish-like living benaith the ice. In the spring they are hunted and trapped for their fur, shot while swimming in the swollen streams or resting on the banks; and caught in steel traps set under water at their landing places; sometimes a piece of apple, parsnip or carrot on the end of at stick a foot above the trap seems to entice them into it. A still more effective bait is the musk found on the old males at this season. It is contained in two flat, oval sacs, an inch or more in length, situated between the hind legs beneath and laid bare when the skin is stripped off.

This musk, which gives the animal its name, is so powerful that professional trappers become fairly impregnated with the odour in the course of the spring trapping.

The muskrat's fur is a rich, shiny brown, with pale silky underfur like that of the beaver, only shorter and not so dense.

In its natural state the fur is often made up into caps, etc., and sold as mink and marten. Most of it, however, is plucked; the long hair being removed and the silky underfur dyed to resemble seal. The fur sold as "electric seal" is really only muskrat fur dyed.

\section{Varieties of the Muskrat}

1. Muskrat. Fiber ibethicus Linneus. Description and range as above.

2. Southirn Mushrat. F. ihethicus rivalious Bangs. Smaller and dull sooty in colour, "lacking all the beauty and lustre."

Rallę. Lower Mississippi Valley and Coasts of Alabama and Mississippi.

3. Dismal Suimp Muslirat. F. zihethicus macrodon Merriam. Much darker and richer coloured than the common muskrat with larger teeth.

Range. Dismal Swamp, Virginia.

4. Labrator Muskrat. F. filhithicus aquilonius Bangs. Smaller and darker than the common muskrat.

Range. Labrador. 
5. Newfoundland Muskrat. F. obscurus Bangs. Still smaller and darker, with different skull.

Range. Newfoundland.

\section{AMERICAN LONG-TAILED MICE AND RATS (Sub-family Cricetince)}

\section{Alleghany Wood Rat}

\section{Neotoma pennsylvanica Stone}

Length. I6.40 inches.

Description. Tail nearly as long as the body, ears prominent. Colour plumbeous above, sprinkled with black hairs and with a yellowish-brown undertone which is purer and brighter on the sides of the body becoming almost pink on the flanks. Feet and lower surface of the body pure white. Tail sharply bicoloured, dark plumbeous above and white below, closely haired so as to obscure the scales entirely. Some summer specimens are duller coloured with much less of the buff or pinkish tinge.

Range. From the Hudson highlands and northwestern New Jersey southward along the Alleghanies.

Rats and mice differ only in size and it does not follow that our American wild rats are closely related to the common house rat simply because both are big. On the contrary our wood rat finds a closer relative in the white-footed mouse of which he is in many ways simply a large edition.

House rats often wander into rather wild localities probably following the camps of engineers or lumbermen, and are not infrequently taken for wood rats. The latter, however, can always be told from his semi-domestic cousin by his hairy tail, softer fur and much larger ear, while his teeth are flat-topped somewhat like those of the meadow mice instead of having raised prominences or "tubercles."

The Alleghany wood rat inhabits wild rocky ledges along the mountains, where he can seek shelter among the loose piles of broken rocks or in the crevices and caves usually present in such localities. Here he gathers together a mass of sticks, shreds of bark leaves and 
other dehris to serve for a nest, building them sometimes into a more recrular dome-shaped structure. He seems to feed on whatever forige the forest offers, both vegetable and animal, and in large caves where fuxes or wild cats have dragged their prey, the marks of the wood rat's teeth are found abundantly on the bones which the more powerful beasts have left behind.

Although manifestly a rat he seems to lack the offensive odour and repellent characters of the house rat, and his thick, soft fur recalls the pelage of the squirrels.

The closely related Florida wood rat is said to build its nest in dense swampy thickets but probably differs little in general habits from its more northern relative.

\section{Varieties of the Wood Rat}

1. Alleghany Wood Rat. Neotoma pennsylianica Stone. Description and range as above.

2. Florita Wood R.it. N. floridana (Ord). Rather smaller and plumbeous, tail more scantily haired. Skull not nearly so heavy.

Range. Lower parts of the South Atlantic and Gulf States.

3. Mississifti Wood Rat. N. floridana rubida Bangs. Much brighter and decidedly reddish in colour.

Range. Replaces the last in the lower Mississippi Valley and western Florida.

\section{Cotton Rat}

\section{Sigmodon hispidus Say and Ord}

Length. 12 inches.

Discription. Peculiar among the long-tailed rats and mice from its superficial resemblance to the meadow mice from which, however, its long tail will at once distinguish it. It has the same short legs, and short appressed ears with the aperture nearly covered by the hair, and the fur is longer and coarser than any other member of this group. The molir teeth are round in outline and divided into triangles on top as in the meadow mice. Colour yellowish brown above thickly sprinkled with black hairs, under parts whitish. Tail only scantily haired, the scales visible.

Range. Fastern North Carolina around the Gulf Coast to Louisiana. Represented in Florida by closely allied varieties. 


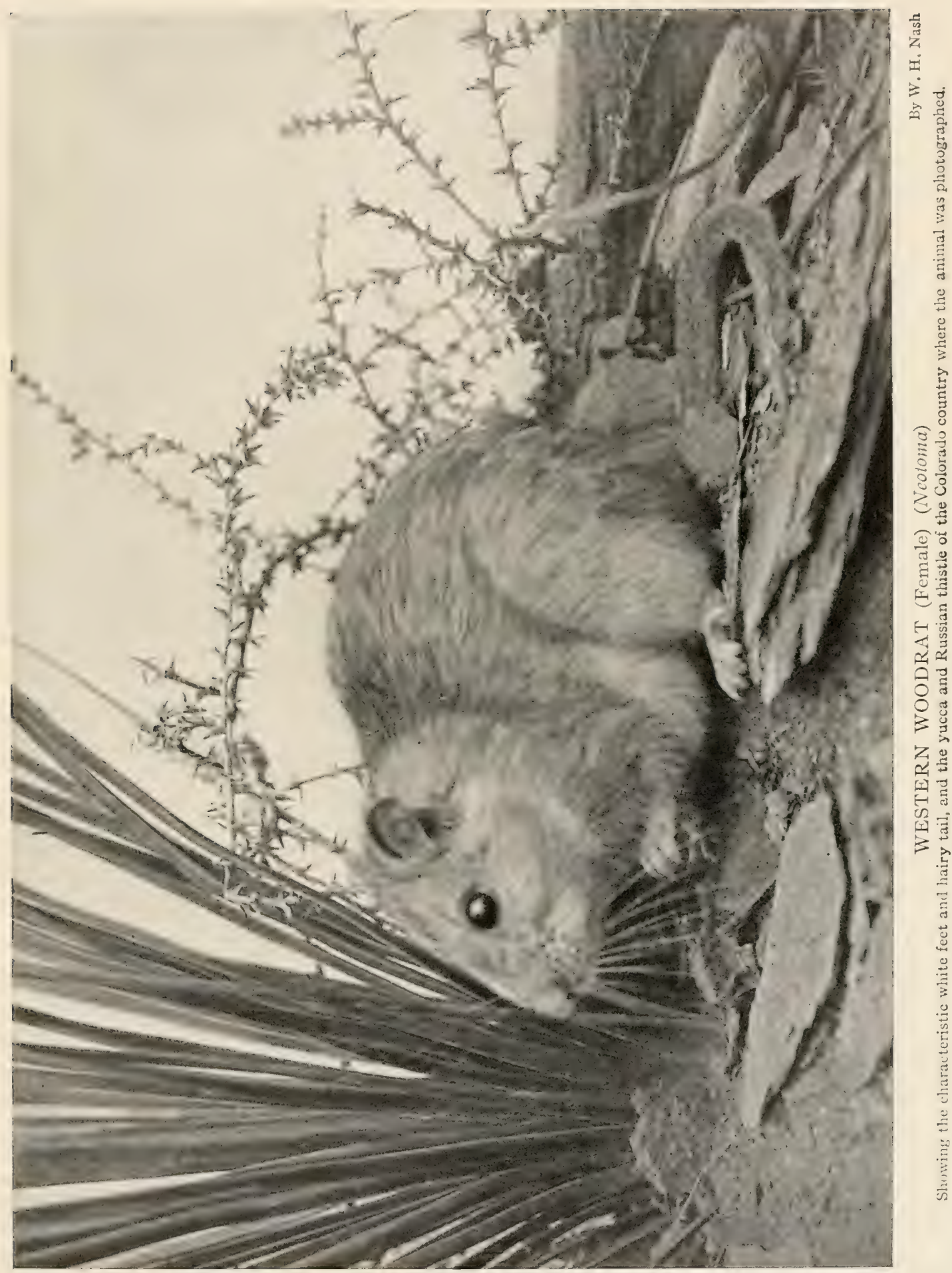



The cotton rats are Southern animals, the common cotton rat being an inhabitant of the South Atlantic and Gulf Coast from North Carolina to Louisiana.

Its favourite haunts are the hedges and ditches and deserted old fields, banks of abandoned rice plantations and similar situations. Here it burrows and constructs its underground nest. Like the field mouse of the North, the cotton rat is subject to great variation in colour and the slightest difference in environment produces an appreciable difference in the appearance of the animals.

\section{Varieties of the Cotton Rat}

I. Cotton Rat. Sigmodon hispidus Say and Ord. Range and description as above.

2. Chapman's Cotton Rat. S. hispidus littoralis Chapman. Very much darker, nearly black above finely mixed with gray, with no brown tints.

Range. East coast of Florida, Miami northward.

3. Bangs' Cotton Rat. S. hispidus spadicipygus Bangs. Smaller than either of the above, and browner than the latter.

Range. Extreme southern tropical Florida north to Miami and Tampa.

\section{Rice-field Mouse}

\section{Oryzomys palustris (Harlan)}

Also called Marsh Mouse, Rice Rat.

Length. 9.40 inches.

Description. Similar in general external appearance to a young Norway rat. Dull brownish above thickly mixed with black haiis. Tail obscurely bicoloured, scantily haired, so that the scales are visible. The best external characters distinguishing this animal from the young of the common Norway rat are the longer tail and browner colouration as well as the white fringe of hairs on the lower part of the ear and the glossy brown hairs inside. A young rat has narrow white front (incisor) teeth instead of the orange ones and the tubercles on the molars form three rows instead of two.

Range. Southern New Jersey to the Gulf States, chiefly in the coast marshes, represented in Florida by slightly different geographic varieties. 
The rice-field mouse is an abundant inhabitant of the banks of rice fields through our Southern states; though Mr. Bangs states that it is by no means confined to such places, as it occurs in dry old fields, heavy swamps, hummocks and sometimes even on sandhills.

Those which frequent the dry land burrow in the banks and construct subterranean nests after the manner of the cotton rat, but the marsh residents build their nest in the tall rank grass above the reach of high water. In the northern part of their range, in southern New Jersey, they frequent muskrat houses.

The rice-field mouse is decidedly aquatic in habits and is a good swimmer.

\section{Varieties of the Rice-field Mouse}

1. Rice-fiela Mouse. Oryzomys palustris (Harlan). Description and range as above.

2. Florida Marsh Mouse. O. palustris natator Chapman. Larger and much darker.

Range. Florida as far south as Micco and Citrus County.

3. Bangs' Marsh Mouse. O. painstris coloratus Bangs. Still larger and more richly coloured, decidedly reddish brown above.

Range. Southern tropical Florida south of Micco.

\section{Harvest Mouse}

Rcitlrodontomys lecontii (Audubon and Bachman)

Length. 5.05 inches.

Description. Front (incisor) teeth grooved. Colour russet brown, darker with more black hairs on the head and middle of the back. Grayish white beneath tail, white below, dusky above, rather scantily haired, feet white. The ears are proportionately much shorter than those of the white-footed mouse.

Range. Coast districts of North Carolina, Georgia and northern Florida, two allied forms occur in West Virginia and South Florida.

This is the smallest mouse of the Eastern States and resembles a diminutive white-footed mouse with short ears. The grooved incisor teeth, however, are peculiar and distinguish it from any other long-tailed mouse.

The harvest mouse is another resident of the Southern States and its favourite haunts according to $\mathrm{Mr}$. Bangs, are grass fields, fence 


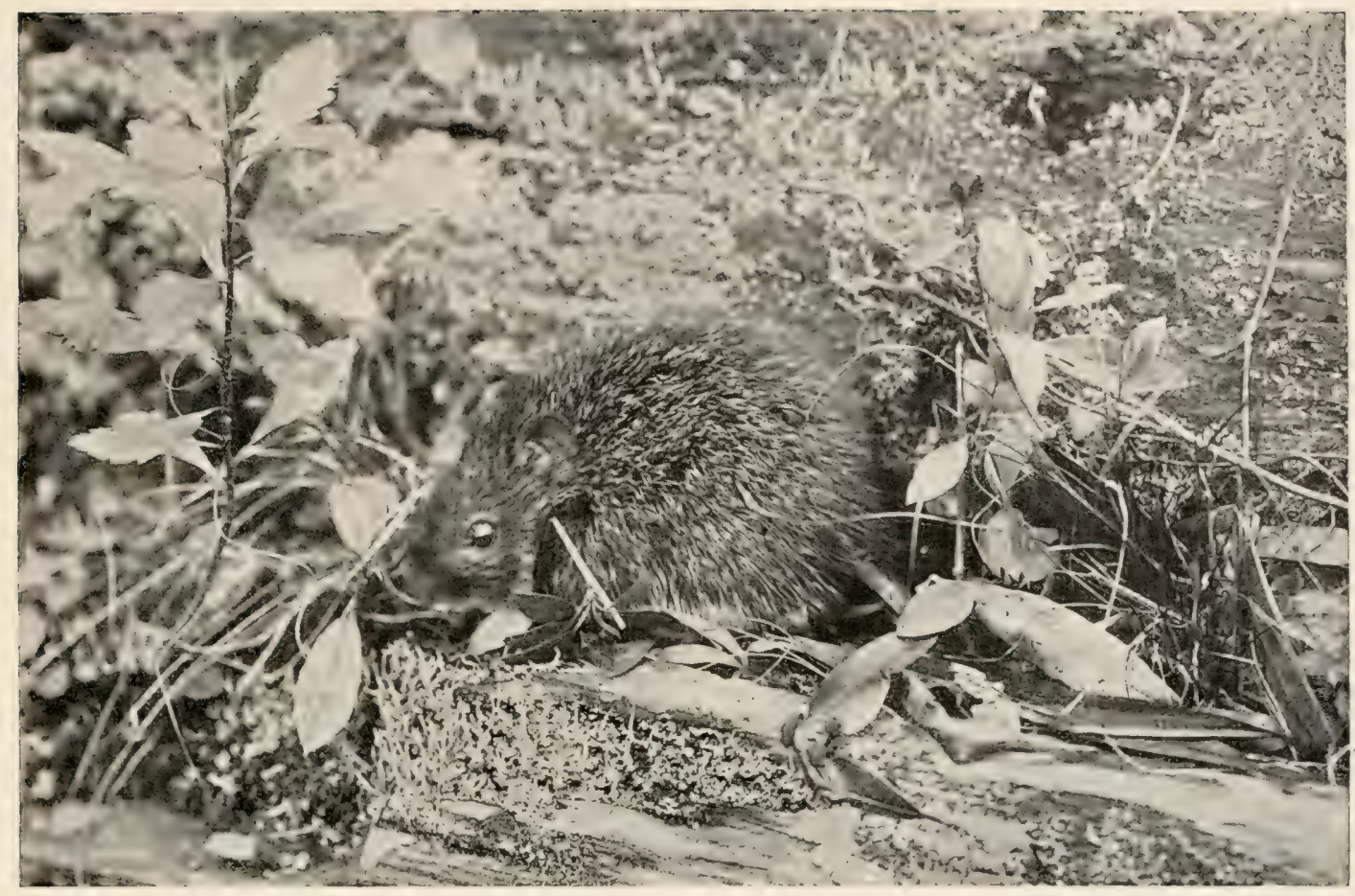

COTTON RAT (Sigmodon hispidus littoralis)

By W. E. Carliu

Photographed in Florida by cornering him, when he sat absolutely still, paralyzed with fear.

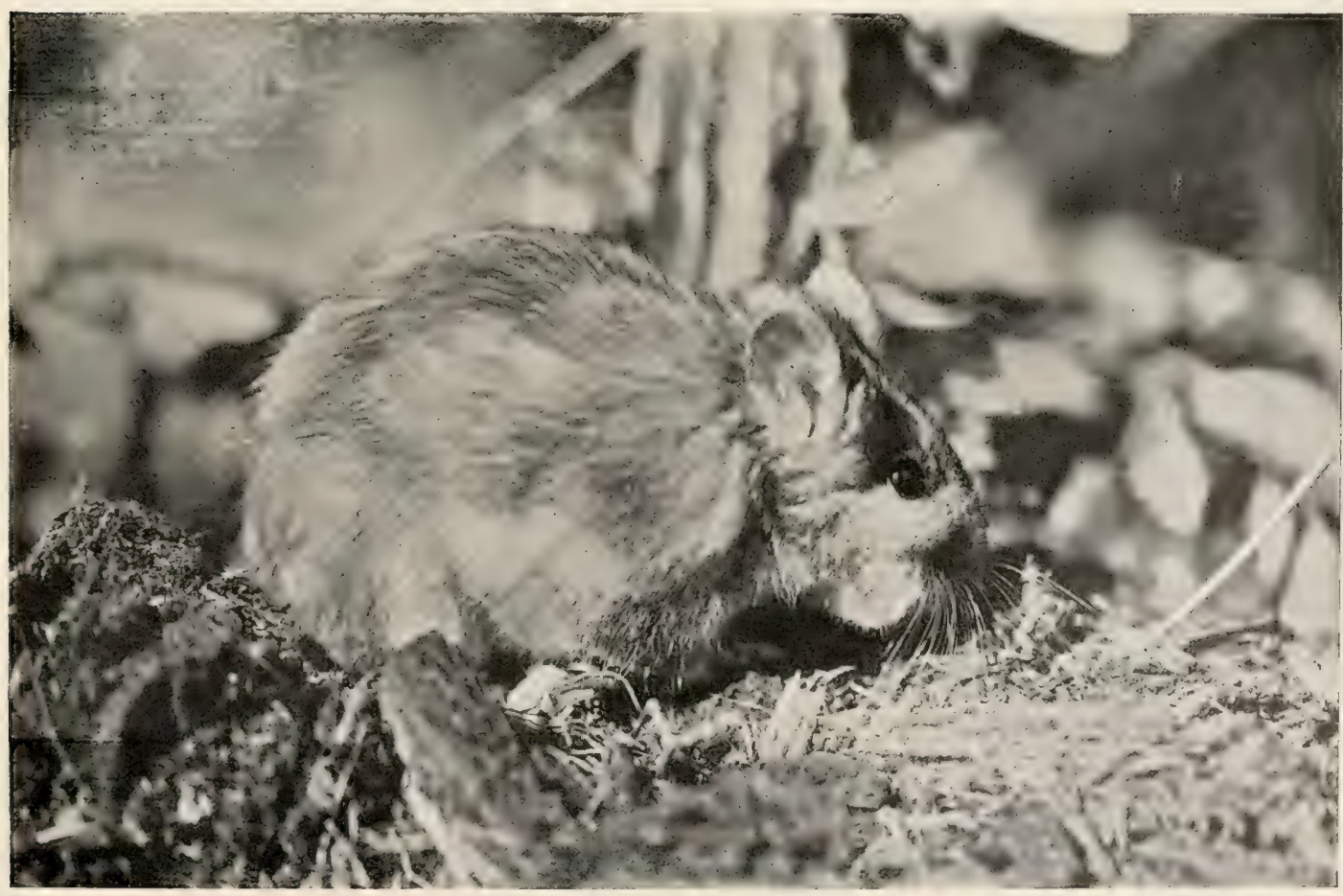



rows and old fields partly grown up with deciduous trees where the ground is covered with bunches of brown grass. Its nest is placed on the surface of the ground among the tall grass.

\section{Varieties of the Harvest Mouse}

I. Harvest Mouse. Reithrodontomys lecontii (Aud. and Bach.) Description and range as above.

2. Surber's Harvest Mouse. R. lecontii impiger Bangs. Slightly smaller and richer in colour.

Range. White Sulphur Springs, W. Va., and doubtless in Virginia.

3. Dickinson's Harvést Mouse. $R$. lecontii dickinsoni (Rhoads). Darker and more sooty in colour.

Range. Southern Florida.

\section{White-footed Mouse}

Peromyscus leucopus (Rafinesque)

Also called Deer Mouse, Wood Mouse.

Length. 6.80 inches.

Description. Brownish fawn colour above, brightest on the sides and darkest on the back where there is a considerable sprinkling of black hairs. Below white, fur plumbeous at its base, tail dusky above, light beneath, feet white. Young plumbeous gray over the whole upper surface with no brownish or fawn tints, white below.

Range. Eastern United States south of the evergreen forests and north of the Gulf States. Represented farther north, south and west by numerous related species and varieties. (See below.)

The white-footed mouse is the most beautiful of all our mice, particularly in the winter, when its fur is thick and long and bright golden-fawn-colour and white in almost equal parts; the white fur, which is literally whiter than ermine, covers the entire under surface and reaches well up on the flanks and shoulders, the line of separation being clear-cut and as straight as is possible from the tip of the nose to the tip of the tail.

The white-footed mouse has eyes like those of a flying squirrel, very large and prominent and perfectly black, in brilliant contrast to the surrounding fur. 


\section{White-footed Mouse}

Although the name wood mouse is not much used for this animal, it has always seemed to me more suitable than any other, for it makes its home in the woods at all times and seasons; only a comparatively small proportion of them, in this part of New England, live in the fields, tempted by the ripe corn and other provender which the woods fai! to supply. Wood mouse is the name I first heard it called by, and is apparently the only one ever given it in this immediate region. Deer mouse is another name frequently given to our species, either because of its speed or the colour of its fur.

The white-footed mousa does not seem to be at all particular what kind of woods it inhabits; evergreens and hardwoods, and thickets of blueberry bushes are alike suited to its taste; sometimes, indeed, a lonely old tree, standing by itself on a hillside, will harbour a family. They make their homes in the hollow roots and branches or knot holes, sometimes at a considerable height above the ground.

In summer they appropriate the nests of song birds, in bushes and low trees, fitting them up for use, just as squirrels do those of hawks and crows. It appears probable, moreover, that they are not over scrupulous in the mattter of waiting for the rightful owners to depart before taking possession, as they are great lovers of fresh meat and have often been caught in the act of devouring both eggs and young birds.

They are said sometimes to fashion nests of their own among the branches, beginning with a platform of loose twigs laid crosswise for a foundation. Their lives, in fact, are pretty closely copied after those of the squirrels. Their diet is almost identical; nuts, berries, and grain being what they chiefly depend on.

Like squirrels, they often find a way into granaries and farmhouses in search of food, particularly in the winter, when times are hard, for though they lay up generous stores of nuts and seeds and hibernate to a certain extent, large numbers of them are up and doing at all times in spite of the weather, gathering seeds here and there, and gleaning whatever scraps of meat may be left by the larger flesh eaters of the woods, and gnawing hungrily at any pieces of bone they may run across.

The great bleached and half prostrate stalks of the garget still retain scattered berries, shrivelled and frozen to be sure. but packed with seeds which the wood mice evidently find palatable, as they make a point of gathering them every winter.

They also climb for rose-hips and red alder berries and a little 

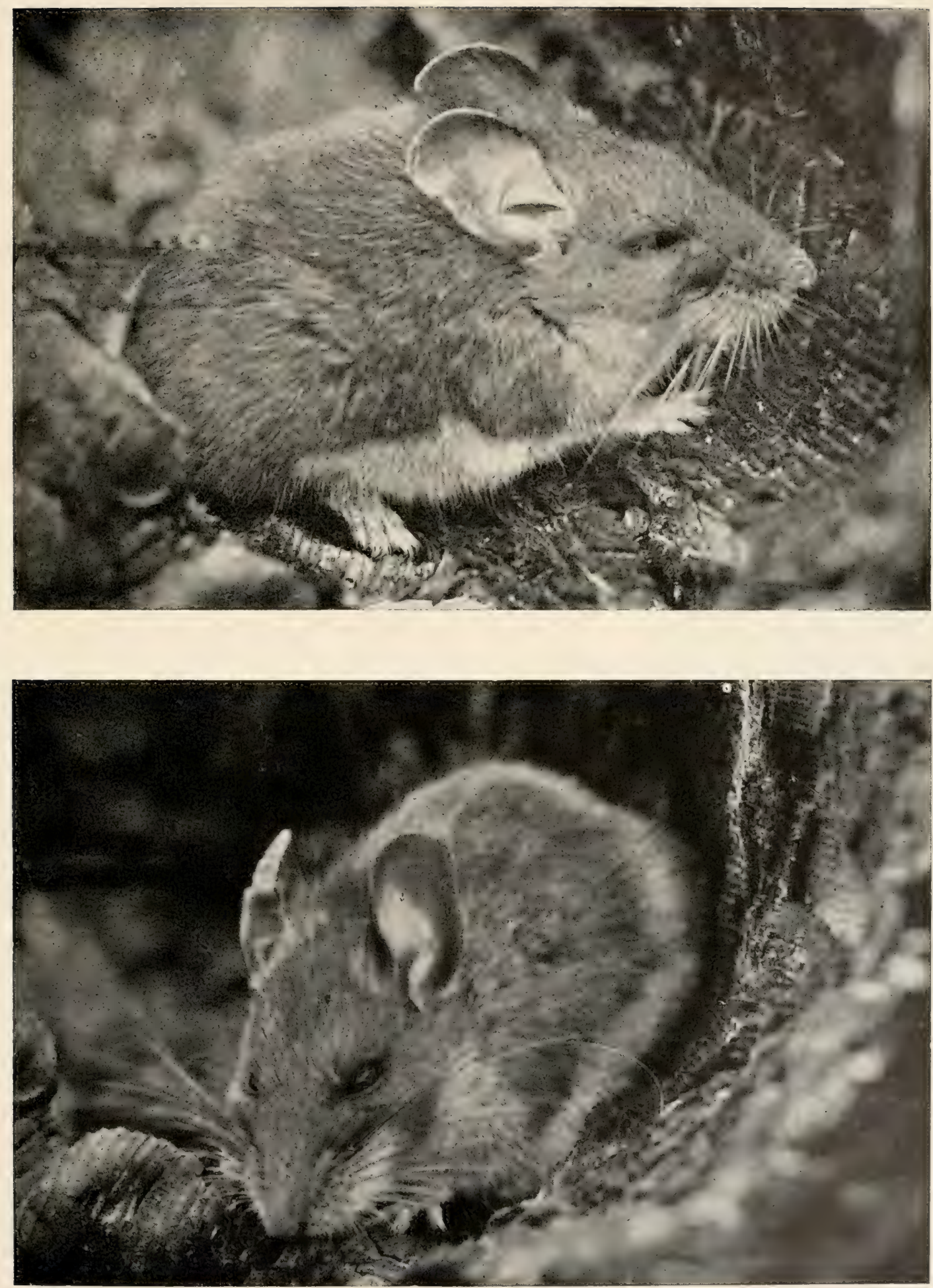

WHITE-FOOTED MOUSE (Peromyseus leucopus) (Enlarged)

By W. E. Carlin Photographed in the Bitter Root Mountains, Montana. 

coffee-like berry that grows abundantly everywhere in the swamps. I believe that those living in the evergreen woods are in the way of searching for hemlock and spruce seeds scattered by the pine finches and cross-bills and other northern birds in their feeding.

As I have already hinted at, the winter sleep of the white-footed mouse does not stretch along unbroken from winter until spring. Many of them undoubtedly sleep for periods varying from a few days to several weeks perhaps, though it is probable they oftener contend themselves with naps of less duration, wakening two or three times a day to nibble at the nuts and seeds in their granaries, like Esquimaux on the edge of their frozen sea, content with narrow quarters and each other's society so long as they are warm and have enough to eat.

Few of them, however, are so limited for room as are the Esquimaux, whether they winter underground or in hollow trees and logs buried beneath the snow; every woodchuck's burrow forsaken by its original owner and not yet appropriated by some other dweller of the woodland, makes a winter home for several families of wood mice who are all the better pleased if the entrance has become partially closed and blocked up by the trampling feet of cattle, and the slower yet more effective work of frost and rain and melting snow. The rest of the burrow remains open and unobstructed for years, one hundred feet or more of warm, dry subway, with its chamber stuffed with soft grass for the mice to curl up in as they please.

Yet these little, tender, round-bodied, white-footed mice in no way fear the cold; on the bitterest nights of winter when the thickset stars seem close down among the tree-tops, and the frozen wind hisses through the stiff branches and the dry snow is piled high around the stems of the pines, they are still out in the wind in numbers, skipping along the snow from tree to tree.

In the autumn the lindens furnish them with an abundant harvest of little round nuts which they pack away in large quantities among the roots of the trees that bear them. Living on these and their other stores which they are able to pick up from day to day, they generally manage to keep in good condition while the snow and cold weather lasts, but they are tremendous eaters and evidently find it difficult to get enough once their supplies begin to run short; at any rate they get thin and shabby during the spring months before insects and berries begin to get abundant again. 
When their nests are beneath logs and woodpiles, they are very like those of other mice, simple balls of soft grass lined with feathers and thistledown.

I have never seen the young white-footed mice before they were about half grown, at which time they are of a dull, pale slate colour.

White-footed mice are largely nocturnal in their habits and as a consequence have most to fear from the night hunters, the owls, especially the little saw whet and the screech owl which are forever taking them unaware. I am not sure that I have ever seen one of these mice come out in the sunshine, but in cloudy weather you will once in a while catch a glimpse of one; only the other day I saw one dart into a hollow $\log$ as I approached.

White-footed mice, like flying squirrels, are among the most gentle and unsuspicious of living things and though armed with long sharp teeth seldom offer any resistance when captured. I cannot recall ever hearing one squeak as other mice do, but they have a sharp little call of their own and at times a low chattering cry almost like the dim echo of a real squirrel's chatter. In captivity they soon become tame and familiar and are always ready to eat whatever is offered them without hesitation.

\section{Species and Varieties of White-footed Mice}

A vast number of species and varieties of these mice occur in the United States, especially in the West. In the East we have besides the red mouse (described further on) three groups differing mainly in size. The Florida deer mouse (length 8.50 inches) and the oldfield mice (length 5 inches) are treated under separate heads, but the remaining medium-sized species are so closely related to the common white-footed mouse that they may as well be treated together briefly and the foregoing sketch of their habits, although based on numbers $\mathrm{I}$ and 2 of the following list, applies pretty well to all. There are three distinct species of these mice with several geographic varieties of each as follows:

\section{A. The Common White-Footed Mice}

Tail shorter than the head and body, without a decided terminil pencil of hairs. Underparts of body willite, the gray of the hairs not perceptible unless the pelage is disturbed. 


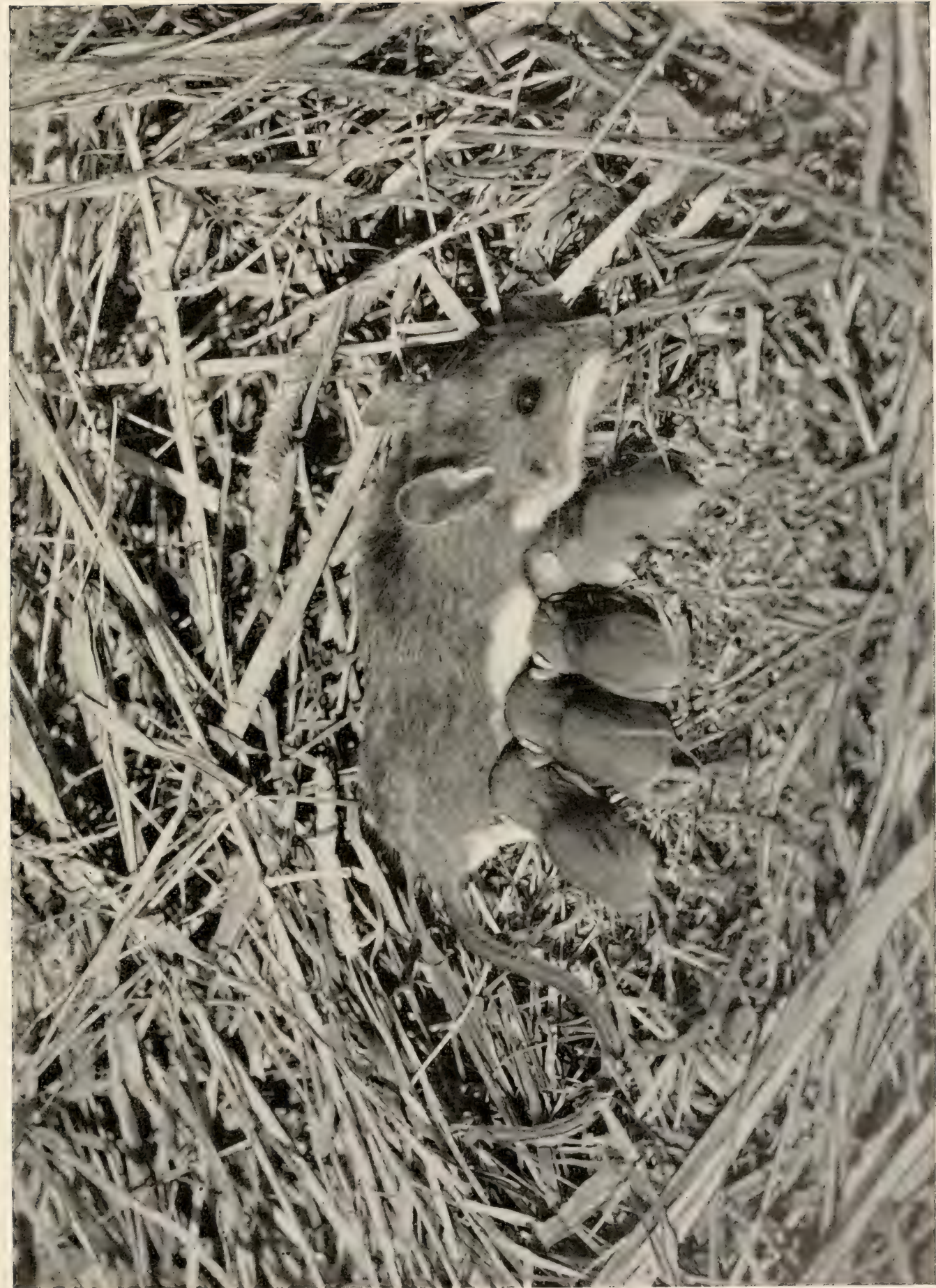



I. White-footed Mouse. Peromyscus leucopus (Rafinesque). Description and range as above.

\section{B. The Boreal White-Footed Mice}

Tail equal to or larger than the head and body, with a conspicuous pencil of hairs at the tip.

2. Canadian White-footed Mouse. P. canadensis Miller. Larger and much grayer than the above, and fawn-coloured individuals rather rare, the longer tail and conspicuous tuft of usually whitish hairs on the end serve readily to distinguish it.

Range. Cold evergreen forests of Canada and New England, southward along the mountains. In northern New York and elsewhere this and the more southerly white-footed mouse occur together, the two being easily distinguishable.

3, Hudsonian White-footed Monse. P. canadensis abietorum Bangs. Always dark gray above at all ages, never showing the russet tints.

Range. A northern form of the last replacing it in the spruce and fir forests of Quebec and Nova Scotia northward.

4. Dusky White-footed Mouse. P. canadensis umbrimus Miller. Smaller than $P$. canadensis and vellow with the dusky shading on face, ears and tail deeper.

Range. Replaces the above to the north of Lake Superior.

5. Cloudland White-footed Mouse. $P$. canadensis mubiterre (Rhoads). Smaller and darker than $P$. canadensis, with a distinct blackish dorsal band.

Range. Replaces $P$. canadensis in the spruce forests of the southernmost Alleghanies.

\section{The Cotton Mice}

Tail shorter than the head and body, without a distinct terminal pencil of hairs. Underparts with a decided gray cast owing to the greater extent of the gray bases of the hairs. These are distinctly southern as the last were northern.

6. Cotton Mouse. P. gossypinus (Le Conte). Colour similar to the white-footed mouse, but darker and less tawny, and underparts distinctly gray, as compared with the pure white of $P$. lencopus.

Range. Lowlands of the Atlantic slope from North Carolina to Georgia, replaced South and West by allied forms.

7. Rhoads' Cotton Mouse. P. gossypinus mississippiensis Rhoads. Paler, with dusky stripe on back and ring around the eye, less defined. 
Range. Mississippi Valley, northward to Tennessee. This animal overlaps the range of the common white-footed mouse in Tennessee and both occur together, just as the latter, and the Canadian species do in the North.

8. Florida Cotton Mouse. P. gossypinus palmarius Bangs. Paler, but dusky ring around the eye, well defined.

Range. Southern Florida, north to Brevard and Citrus County.

9. Lollisina Collon Mouse. P. gossipinus migriculus Bangs. Smaller than any other cotton mouse, colours darker, with a broad blackish stripe on the back.

Range. Bayou region of Louisiana.

In the West there are many other white-footed mice and another allied group known as scorpion mice, Onychomys.

\section{Florida Deer Mouse}

\section{Peromyscus floridanus (Chapman)}

Length. 8.60 inches.

Discription. Ears very large, nearly naked, hind feet very large, tail relatively short, sparsely haired. Colour bright tawny above, with black hairs sprinkled over the back and head. a black ring around the eye and black spot at the base of the whiskers. Underparts pure white, extreme base of fur gray.

Range. Florida peninsula.

This is the largest and probably most beautiful eastern Piromuscus and is entirely restricted to Florida. Its size, together with its very large ears, will serve to distinguish it at once.

Mr. Bangs salys of this species: "It lives only in the higher sandy ridges where there is plenty of black jack oak and where the bare white sand is in places covered by scattered patches of scrub palmetto. It is the characteristic small mammal of such places commonly known as 'black jack ridges' and I have never found it elsewhere."

\section{Oldfield Mouse}

\section{Peromyscus subgriseus (Chapman)}

length. 5 inches.

1)escrition. Smaller than any of the other white-footed mice. Cinnamon brown ahove, very sharply contrasting with the pure snowy white of the lower surface. 
Range. Central and Western Florida, represented in Georgia and elsewhere in Florida by related species and varieties and on the prairies of the upper Mississippi by the closely allied prairie mouse. (See below.)

These are the smallest and shortest-tailed of our white-footed mice and with the exception of the prairie mouse of the upper Mississippi Valley they are residents of our South Atlantic States. They appear to be more animals of the open ground, as contrasted with the last group, which are essentially inhabitants of woodland.

The Florida oldfield mouse is said by Mr. Bangs to "live in fields and open places and probably before so much of its range was under cultivation was restricted to sandhills and open drier prairies of interior Florida." The allied beach mouse, one of our most beautiful animals, "is confined entirely to the sandr" beaches and adjacent sandhills of the east coast of Florida. Its life depends on the sea oats (Uniola) and it is never found where that plant does not grow. It is very abundant in favourable places and its presence can always be detected by the little footprints which show distinctly in the white sand around the tufts of sea oats." (Bangs.)

The dark-coloured Northern representative of this group, the prairie mouse, is quite as much an inhabitant of the open, and bears the same relationship to the common white-footed mouse of this region as does the prairie field mouse to the common field mouse.

Mr. Kennicott states that the prairie mouse in the open prairie makes burrows in the ground at the extremities of which the nest is situated; but in cultivated districts often frequents corn shocks and nests therein.

\section{Related Species and Varieties of the Oldfield Mouse}

I. Oldfield Mouse. Peromyscus subgriseus (Chapman). Description and range as above.

2. Rhoads' Oldfield Mouse. P. subgriseus rhoadsi Bangs. Yellower than the above.

Range. Western Florida (Tampa Bay).

3. Georgia Oldfield Mouse. P. subgrisens baliolus Bangs. Much darker, with a decided dark dorsal stripe, tail nearly black. Range. Sand hills of northern Georgia. 
4. Beach Mouse'. P. niveiventris (Chapman). Beautiful pale yellowish gray, rather brighter on the rump. Below snow white, hairs pure white to the roots.

Range. Beaches of East Florida; Palm Beach to Mosquito Inlet.

5. Island Beach Mouse. P. phasma Bangs. Paler even than the last, cheeks and nose white.

Range. Anastasia Island, Fla.

6. Prarie Mouse. P. michiganensis (Aud. and Bach). Darkfawn colour, with very dark-blackish dorsal stripe, white beneath. Young, uniform, plumbeous. Ears rather small. Range. Prairies of Illinois, southern Wisconsin, etc.

\section{Red Mouse}

\section{Peromyscus muttalli (Harlan)}

Length. 7.40 inches.

Description. Differs from all the other long-tailed mice in its bright fulvous colour above and strong fulvous suffusion below and the absence of a sharp line of separation between the colours of the upper and lower surface. No dusky patch at the base of the whiskers, and young fulvous, like the adults, not gray, as in the white-footed mice. Ears rather short.

Range. Low grounds of South Atlantic States, southern Virginia to Enterprise, Florida.

Although related to the white-footed mice, the red mouse is very distinct in many respects, especially in its shorter ears and different colouration. It is not a common species.

\section{INTRODUCED RATS AND MICE \\ (Sub-Family Murina) \\ House Mouse}

Mus musculus Linnæus

Length. 6.70 inches.

Description. General colour gray, slightly tinted with yellowish- 
brown, especially on the face and shoulders, dusky on the

back; below paler gray, sometimes suffused with buff.

Range. Cosmopolitan. Introduced into America from the Old World.

I have in another place alluded to the house mouse as a foreigner; but. as a matter of fact, it is no more of a foreigner than are the descendants of the very first settlers in this country, English or Dutch. Its ancestors came across with the earliest of them, and while the white people were still but campers and squatters on the borders of a bewildering forest of unknown extent the youngest of these little hangers-on could already count grand-parents and great grand-parents of American birth, so that reckoning by generations there were even then American mice.

Still, it would hardly be safe to conclude that all or even any considerable portion of the mice that inhabit our dwellings at present are descended from these first-comers.

Immigration and emigration have proved as popular among them as with members of the human race, and every ship that crosses the Atlantic bears, among other things, its humble cargo of mice from one shore to the other, so that some of those which even now are nibbling at our pastry or the bindings of books may very possibly have spent the first part of the season in England or on the Continent, and just as possibly will be there again next year.

Mice were originally natives of Southern Asia. From there they have accompanied man in his wanderings to all parts of the world, travelling, as he has travelled, in ox-teams and on the backs of donkeys, by steamship and railway; taking up their quarters wherever he does, first in log cabins with thatched roofs, and finally, in some instances, on the nineteenth floor of a steel building where generation after generation may live and die in turn without having so much as touched foot to the earth.

Strangely enough the race seems to be proof against the changes wrought upon most animals by difference of environment. Specimens from the opposite sides of the globe, or from widely separated latitudes, are said to be practically indistinguishable, as if at last the species had hit upon a style of form and colouring, perfectly suited to all conditions of life. 


\section{House Mouse}

That peculiar tint popularly known as mouse colour seldom attracts attention to the wearer, and the almost hairless tail, while undoubtedly a most useful member, is not likely to become bedraggled or in the way in places where the sort of tail carried by the average little beast would prove a nuisance or a positive danger to its owner. A mouse's tail, although it looks naked, will be found on closer inspection to be covered with short hairs, just long enough to turn aside the moisture instead of retaining it.

Try to imagine what the tail of a squirrel or weasel would look like after having been dragged across cream and butter and the various other substances with which the average house mouse endeavours to surround itself; its owner would quickly be reduced to amputating the bothersome member in sheer desperation. Mice it is believed even use their tails for skimming the cream from pans of milk, when they are unable to reach it in any other way.

Neither is the tail of a mouse much source of danger to the little beast as might be supposed. It certainly has the appearance of a most convenient handle for cats or other enemies to seize upon, but the skin which covers it, like that of a squirrel is but loosely attached, and slips off readily enough to permit the escape of many a desperate mouse. It is not at all uncoinmon to find mice that have lost the skin from their tails in this manner. The process must necessarily be a decidedly painful one, but the wound heals in course of time and the mouse is still possessed of a tail, even if it is bereft of most of its former suppleness. One would suppose that a tail which could easily be broken clear off like those of some reptiles would be an improvement.

Of all mice the ones that dwell high up in the mows of old-style barns, interest me most. They are, perhaps, as little mischievous as any of their kind; and as comfortably situated, except as regards their water supply.

Mice I believe are compelled to drink frequently; and except when violent storms drive rain or snow through the cracks of the building, those living in the hay must evidently go to the trouble of descending to the ground as often as they are thirsty.

Their homes are in the mortises of the timber wherever the oak tenons were hadly fitted or have shrunk away, leaving cosy little pockets in the very heart of the beam, dry and warm with a passage of suitable size leading down to them, as if ex- 
pressly designed to keep a family of mice comfortable and safe.

When hungry they have only to penetrate the hay which is piled high about them, and explore the fragrant labyrinths between the stems of herd-grass and clover for seeds and dried fieldstrawberries, and the dessicated bodies of crickets and grass . hoppers pitched up with the hay when it was unloaded from the rack the summer before. I have often in mid-winter come across dried strawberries in the hay, which still possessed every bit of their June sweetness; what a feast one of those would make for a foraging mouse in mid-winter!

Then there are the scaffolds of corn fodder, containing hidden treasures in the shape of whole ears overlooked in the husking, any one of which would be enough to support a family of mice for weeks. Beyond a doubt the lives of these mice of the barn are rendered more interesting and worth while, by the simple possibility of discovering some such treasure as this at any moment.

Compare this with the life of those living in the granaries, encompassed on all sides by bins of ripe corn, and with never a change of diet except what is supplied by the capture of stray spiders and bugs.

Sometimes at night the mice of the hay mows descend to the floor and join those which have their holes in the outof-the-way corners of the barn, in their search for meat scattered about the bins where stock was fed.

Many of them, instead of living in the mortises of the timber, make round nests of grass and shredded corn leaves and husks in the recesses of the hay or in the middle of a bundle of corn fodder.

These, though safe enough at first, are sooner or later sure to be routed out by the farmer, and may well consider themselves fortunate if they are without helpless families at the time.

Being less exposed to the weather and changes of temperature than are creatures living out-of-doors, mice breed at all times and seasons; and almost any time during the winter, the fretful youngsters may be heard squeaking in their nests, resentful perhaps of the discipline brought to bear upon them by their parents. At first they are hardly larger than blue bottle flies, pink, wrinkled and transparent like shrimps; it is no exaggeration to say that any substance on which they rest may be seen through their diminutive bodies. 
Mice are notorious for their versatility in selecting their resting places, empty coffee pots and bottles being often used by them in this manner. Almost anything in fact that has an entrance smaller than the cavity inside.

Once exploring the cellar of an old farmhouse I came across something made of tin, which I was told was an old-fashioned sausige filler. It was bottle-shaped and open at both ends, and into the larger one was thrust a piece of wood which just fitted it. The remaining space was occupied by a mouse's nest of rags and scraps of paper, the funnel-shaped opening serving as an entrance, through which the mother mouse had probably come and gone hundreds of times in ministering to the needs of her family. The nest was abandoned when I found it, but if any one had chanced to pick it up when the little lodgers were at home and attempted to put it to its legitimate use he would very probably have been a good deal surprised at the result.

In most old houses there are mice living in the walls between the wainscoting and the plaster, their runways usually permitting them to go literally all over the house in comparative safety. On stormy winter nights particularly they may be heard scurrying excitedly about from place to place with no apparent cause.

Too often they penetrate to those forbidden parts of the house where food is kept and make themselves decidedly troublesome, until their fate in the guise of pussy, or the trap, overtakes them.

But it is my opinion that in cold weather at least most of them live almost wholly upon insect food, flies, spiders, wasps and the like, that have packed themselves away snugly for the winter in secret cramnies between the boards, sometimes hundreds of them closely huddled together.

\section{Norway Rat}

\section{Mus norvegicus Erxleben}

Called also Common Rat, Brown Rat.

Length. 18 inches.

Description. Heavily built with thick head and moderate ears, tail medium, always shorter than the head and body. 


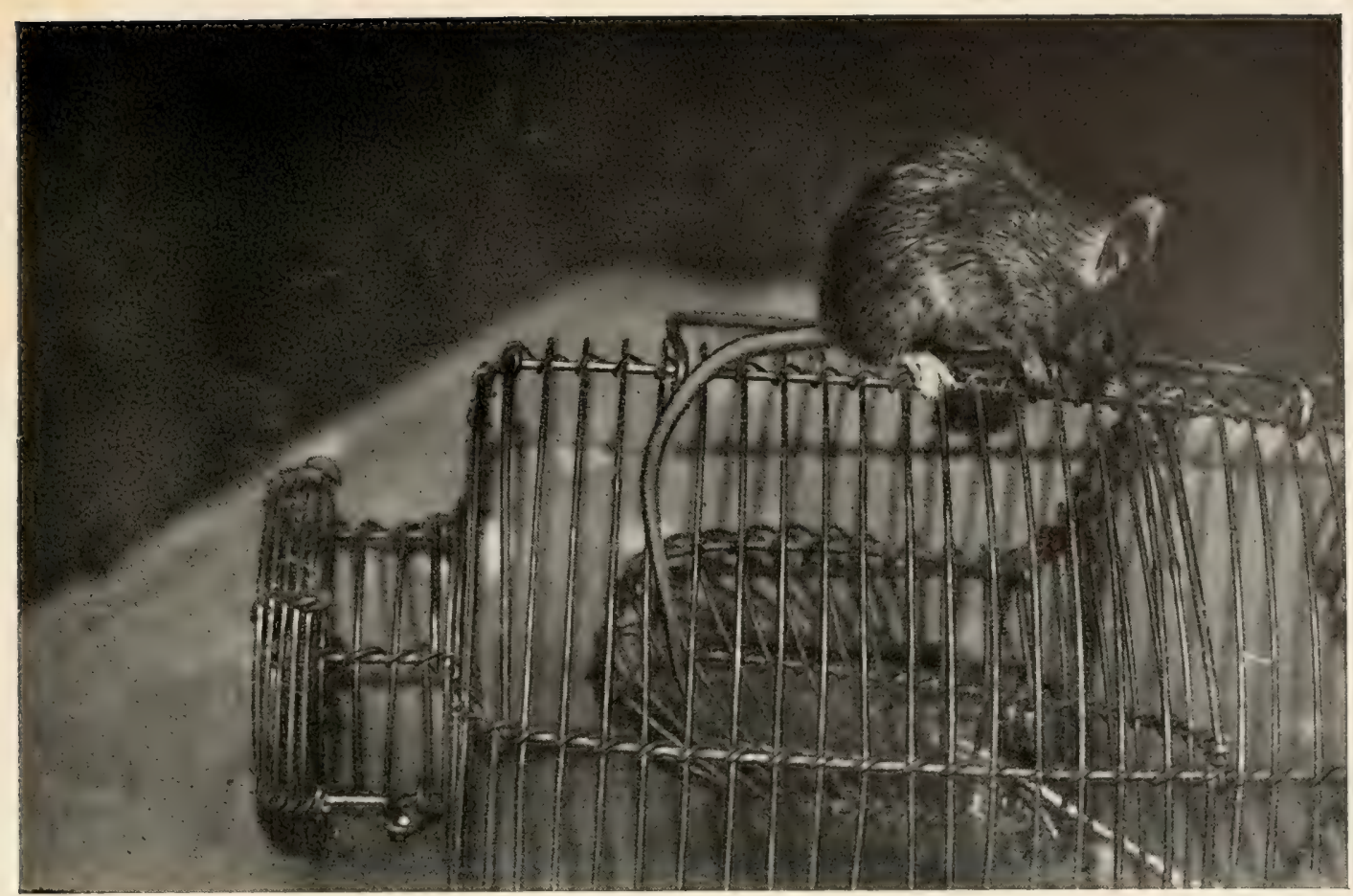

HOUSE MOUSE ON TRAP (Mus musculus)

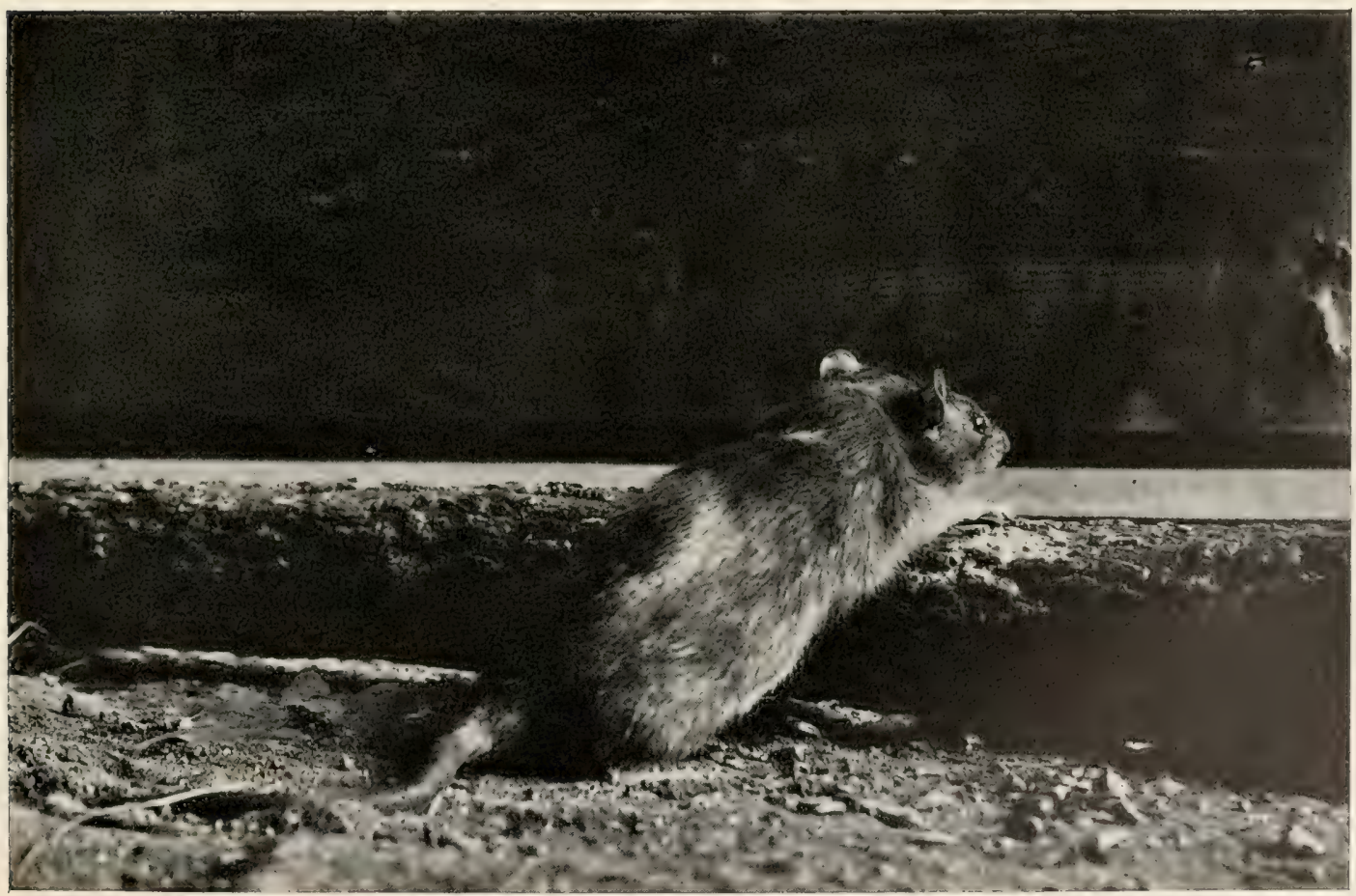



Colour yellowish-brown thickly interspersed with long black hairs, grayer on the sides and grayish-white below, feet whitish. Tail very sparsely haired with the scales very conspicuous, ears dull brown. Young dull gray with no brown tints.

Range. Cosmopolitan. Introduced into America from Europe.

In many ways mice are our benefactors in a degree not often suspected, perhaps even enough to offset much of the trouble they cause by stealing.

With rats it seems to be different. These troublesome brutes may be useful in a way as scavengers, but the good that they do in this way or in any other, is constantly overshadowed by the damage wrought by them in hundred ways, and they are probably as little beloved by man as any beast that lives.

They appear to be on an entirely different scale from mice. It is not altogether a matter of size, a brown rat reduced to a mouse's dimensions would still be coarse and rough and unattractive.

They copy in a general way the colour and proportions of a mouse, because the lives of the two are really very much alike; living as they do in the character of humble dependents on man's production, in obscure out-of-the-way corners, where a dust-coloured coat has proved most useful.

But the fur of a full-grown rat is at all seasons harsh and lifeless; the expression of its eyes is apt to be dull and hateful, in fact, there is hardly an attractive feature that rats may be said to possess.

It would be useless to deny that rats are extremely intelligent, and careful witnesses have always given them credit for looking after any helpless member of their family, old or young.

For my part I have seen but little to like or admire about them, though I am not sensible of any personal antipathy toward them, such as many feel for both rats and mice.

The black and white rats which make such amusing pets belong to a different species than the common brown rat.

I believe that they are varieties of the old black rat, a gentler and much more likable race that is said to have been partly driven out of its native land by the other, and at present only to be found in numbers in such scattered corners of the world as the brown rats have not yet found. I have never 
come across any undoubted specimens of the black rat living in a wild state; they are said to have been fairly common here before the brown rats followed them across the Atlantic.

Young hrown rats until they are nearly grown have rather soft slate-coloured fur, sometimes quite dark, and this together with their slighter build causes them to be sometimes mistaken for the black rat.

\section{Black Rat}

\section{Mus rattus Linnæus}

Length. 15 inches.

Description. More slender, with more pointed head, larger ears, and tail always as long or longer than the head and bodv. Colour glossy bluish-black above, dark-gray beneath, a few white hairs interspersed. Ears lighter coloured, nearly naked, feet pale-brownish, tail sparsely haired, scales distinct.

Range. Cosmopolitan. Introduced into America from the Old World, but everywhere disappearing before the alvance of the Norway rat, so that it is now rare, with the exception of a well-marked variety-the roof rat-which is well established in the Southern States.

The black rat, a much less aggressive and less troublesome animal, was brought to America long before the Norway rat, but upon the introduction of the latter it rapidly disappeared, being apparently quite unable to cope with it, so that we now find the black rat only at rare intervals in remote quarters where its more powerful cousin has not yet established itself. The history of this animal in America is but a repetition of its experience elsewhere and in England to-day it is as scarce as in America.

A variety of the black rat, native of Egypt and adjacent countries, has been introduced into our Southern States where it finds the climate congenial and where it is known as the roof rat. Owing probably to a difference in habits, it does not come into such direct competition with the Norway ralt and succeeds in holding its own.

\section{Varieties of the Black Rat}

1. Black Rat. Mus rattus Linnæus. Description as above. 
2. Roof Rat. Mus rattus alexandrinus (Geoffroy). Colours above brown and gray, below pure yellowish-white. Shape, ears and tail exactly as in the black rat.

Range. In America, South Atlantic States.

\section{BEAVERS \\ (Family Castoride)}

The beavers are our largest gnawing animals. They are heavily built and thoroughly adapted for an aquatic life, with their wonderful broad, flat, naked tail and webbed hind feet. Both fore and hind feet are four toed, but the second toe of the hind foot is peculiar in having two claws.

In the structure of its skeleton the beaver differs from all the preceding "mouse-like" families and agrees with the squirrels and marmots in having the two bones which form the lower leg separate and not fused solidly together.

We find in many groups of animals one or more members adapted for life in the water and the beaver is the aquatic representative of the squirrel tribe, just as the muskrat is of the mouse family and the otter of the weasel tribe.

\section{Canadian Beaver}

\section{Castor canadensis Kuhl}

Length. 44 inches.

Description. Tail and feet as described above, ears short. Body thick and heavy, closely covered with fur. Colour dark bay or blackish-brown, hairs tipped with chestnut, becoming brighter on the head, sides of the neck and rump; ears black, feet, legs and underparts seal-brown.

Range. Northeastern North America, now nearly extinct within the United States, represented to the South and West by slightly different geographic races.

Beavers are creatures with whose life history everyone is supposed to be more or less familiar; the outstanding features of their lives having been written and read over and over again by each 


\section{Canadian Beaver}

following generation. Yet they are still objects of the most intense interest to all who desire to read Nature either at first or second hand.

They are so very like some humble, primitive race of people of peaceful disposition and few wants, industrious and practical in all their affairs, and apparently depending more upon reason and less upon instinct than do the majority of the forest folk. For while it is unquestionably true that almost all of the higher wild animals must use their reasoning powers to think out the various problems of their daily lives, it is equally certain that instinct is of even greater importance to them.

Just as the lone trapper or hunter, if lacking instinct similar to theirs, and forced to rely wholly upon reason to wrest a living from Nature, would be pretty certain to starve before the winter was half gone.

Everyone knows that it is the beavers' custom to dam up small streams and build their thatched and mud-plastered log cabins on the margins of the ponds thus made. But the beavers themselves have been so trapped and persecuted as to have been fairly driven to the most remote and secluded parts of the wilderness, with men still hot on their trail, and closing in doggedly with murderous determination when with each recurring autumn the beaver fur again becomes thick and silky to tempt their greed.

At present the scattered families of this inoffensive fugitive race scarcely dare to raise a lodge of any sort, much less anything so conspicuous as a dam, and so are compelled to hide in secret burrows beneath the bank, like their cousins of the Old World, who have suffered from man's unwelcome presence for so much longer a period.

In most parts of this country beavers are supposed to have the protection of the law; but along the hidden rivers, where the few survivors lurk, law is little more than a byword, and just as long as beaver skins are allowed to be bought and sold, any attempt to protect them is bound to prove futile.

If England and America could agree to make the possession of beaver skins illegal anywhere within their boundaries, and punishable by a heavy fine or imprisonment, good results would certainly follow; for the Hudson's Bay Fur Company would then be obliged to refuse to handle beaver skins, and the trappers to leave them alone. Even then it would probably be a number of years be- 

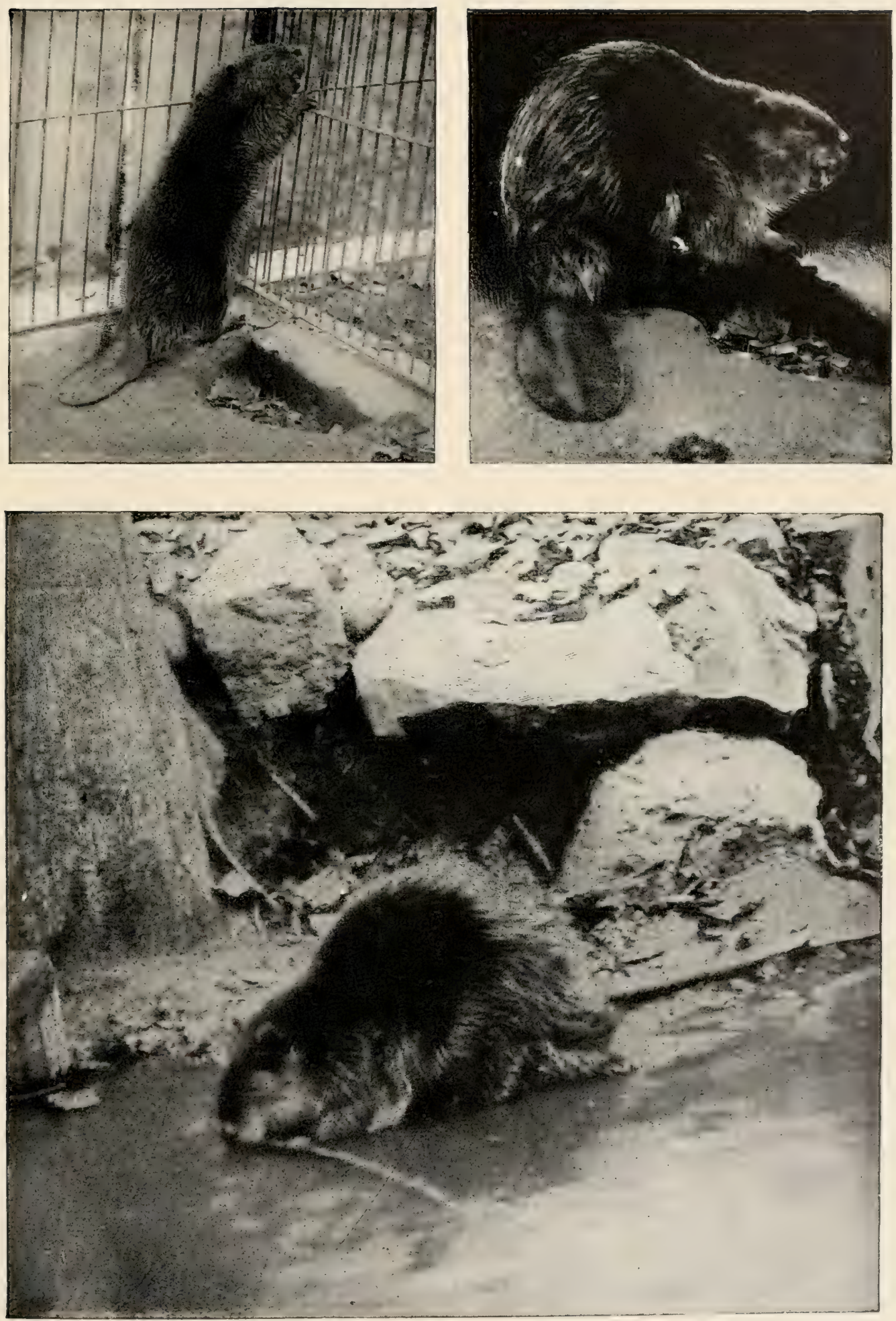

fore the beavers would venture within sound of civilization or lose even a little of their well-founded terror of man.

When a pair of beavers, after having been driven in desperation from place to place, finally come upon some hidden forest brook where they think that ferhaps at last men will permit them to settle and be happy in their own way for a few years, their first act is to decide upon a suitable location for their pond.

Then they go to work felling trees for the dam. In order to cut down a tree they gnaw deep parallel grooves around the trunk and then rip out the wood left between these grooves in large chips, their broad teeth splitting them out like a carpenter's chisel. Other grooves are then cut still deeper into the tree and the chips split out from between them as before, and so the work goes on until the tree trembles and lurches slightly in the direction of the deepest cut, hangs canting in air for an instant while the last tough fibres hold and then, slowly at first, swings over and comes smashing to the ground.

Although beavers usually gnaw all around a tree, it has frequently been stated on the very best authority, that it is their rule to cut deepest next the water in order that the trunk may fall in that direction and so lessen the distance it will have to be dragged.

But others claim that they gnaw in equally on all sides and let the tree fall where it will, or lodge hopelessly tangled among its neighbours.

All of which may only go to show that beavers, like other animals, vary in intelligence, and while some still fell their trees haphazard, others have learned something of the woodsman's craft of cutting. Judging from my own experience I should suppose that hardly one tree in ten would be likely to come to the ground if gnawed off carelessly without forethought, though I believe that trees growing near a stream do usually have a tendency to lean a little towards the water.

When the tree is down the beavers go to work trimming off the branches and cutting the trunk into suitable lengths to be dragged down to the water.

The dam is made of these short logs and trunks wattled together and filled in with stones and earth, the whole cunningly bent against the current to withstand the pressure of the water. 
It is frequently reinforced by other dams just below, that back up the water against the first and relieve it of a part of the pressure.

As the water rises the beavers watch the shores carefully and every depression in the bank likely to lead the water off to one side is promptly dammed and the pond at last brought to the desired level.

During the summer they live an easy and care free life along the banks like muskrats, feeding on lily roots and bark and green twigs generally; but with the coming on of autumn their recreation ends and they go back to work once more, repairing the dam against the coming of the fall rains and erecting their winter cabin at the edge of the water. As before stated the cabin is very similar to that of the muskrat, being roughly built of sticks and brush, and finally plastered outside with sods just before the pond freezes over.

Knowing that long before the ice melts in the spring the natural food supply in the pond is likely to be exhausted, these prudent creatures lay in an ample supply of birch, poplar and cotton wood for the winter.

The trees, which at times are only to be found at considerable distances from the water, are felled and cut into convenient lengths and dragged down to the pond along paths cleared through the undergrowth for the purpose. At times the beavers even find it worth their while to dig channels in low swampy ground, and along these they float their wood out into the pond. It is stacked in a loose pile near the cabin, the ends of the sticks buried in the mud so that they may not be floated off when the water rises to fill the pond. After the pond is full and its surface frozen over in the winter, the beavers cut strips off the bark under the ice when other food falls short; But all winter long they are still hunting for fresh supplies, following the pond's winding margin beneath the ice and exploring the various inlets and little brooks that reach back into the woods, digging up roots from the bottom and gnawing the bark from bushes and trees surrounded by water when the pond is filled. And so the winter passes quietly with them, allowing them only an occasional obscure glimpse of the sun when the wind chances to sweep a portion of the clear ice above them free from snow. 

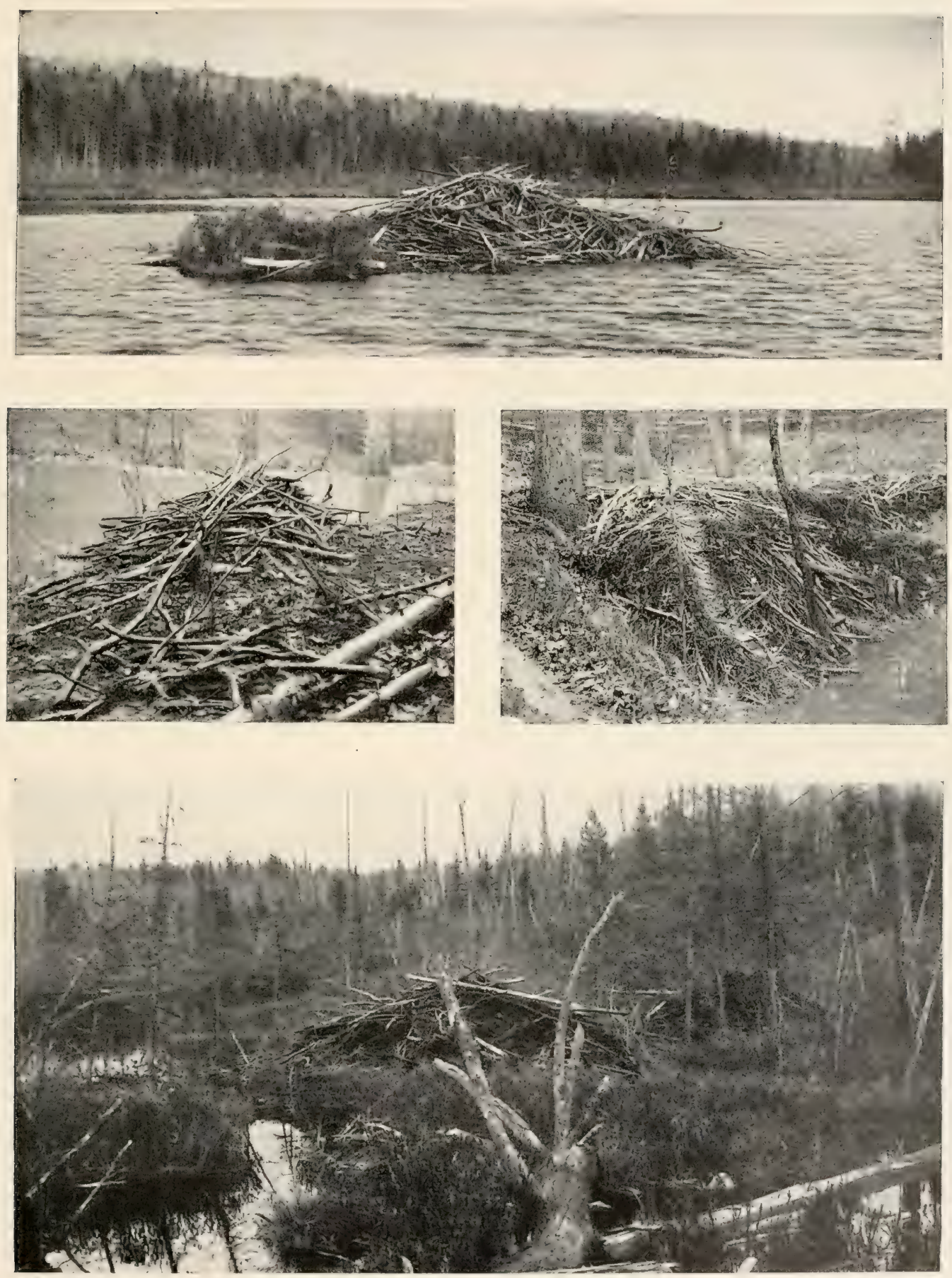

BEAVER LODGES AND A DAM.

By A. R. Dugmore 

I fancy that toward the end of winter they must get just a little impatient and watch eagerly for the first sign of open water at the edge of the ice; knowing that it is only a question of time before their whole pond shall be free once more, and they may splash and paddle in the shallow margin to their hearts' content with the spring sun warm on their backs, and their lungs filled with fresh living wind from the woods. As their family increases in size they enlarge their cabin each fall to accommodate the new members, or else construct new lodges along the shore, until, if undiscovered by the trapper, they have established a busy and contented little settlement, for they are a social folk and fond of one another's company, with the exception of certain ill-natured old bachelors who refuse to associate with the rest but live apart in burrows of their own digging.

just as among the muskrats you will find a solitary individual here and there making its lone mud-hut at the head of any little meadow brook, and apparently avoiding the rest of its kind as much as possible; the chief difference being that these recluse muskrats are generally females - at least most of those that have come under my own observations have been; while among beavers the hermits are almost always old males as already stated.

When in the course of years the beavers' colony gets so large that the matter of getting food for the whole in the immediate vicinity of the pond begins to look doubtful, the youngest generation usually starts off with the purpose of founding a new colony.

The trappers say that they always start off in pairs accompanied by the old ones; the time chosen for the pilgrimage is in the early part of the fall while the streams are still low and food abundant.

The little party explores together every promising stream and watercourse, until a suitable location is discovered for the new pond, when they all set to work, old and young together, and it is not until the dam is completed and the new cabin raised with a good supply of green wood beside it, that the old beavers go back to their own pond, to attend to the regular fall work of repairing the old dam and cabin and cutting and hauling their winter's wood down to the water, and then settle down to the dull routine and humdrum life of a beaver's winter. 


\section{Varieties of the Beaver}

1. Canadian Beaver. Casto: camadensis Kuhl. Description and range as above.

2. Carolinian Biater. C. canadensis carolinensis Rhoads. Somewhat lighter in colour; larger in size with a decidedly broader tail.

Range. Southern and lower Middle States. Now almost extinct, though still found in parts of North Carolina.

Two other races occur in the northwest coast region and in the Rocky Mountains.

\section{SEWELLELS}

\section{(Family Aplodontide)}

The sewellels are peculiarly isolated animals, having no close affinity with any other existing rodents, but constituting one of those interesting "connecting links" that have been preserved from some former geological age. They are allied to the squirrel and marmot tribe and come perhaps nearer to the beaver than anything else in their skeletal peculiarities. They have extremely broad flat skulls, thick clumsy bodies, with practically no neck, short ears and very short tail.

\section{Sewellel}

\section{Aplodontia mé (Rafinesque)}

Also called Monntain Beaver.

Length. 12 inches.

Description. Body thick-set, legs short, tail very short, projecting but slightly beyond the fur. Above reddish-brown, with scattered black hairs, grayish below, tail black.

Range. Calscalde Mountains, eastern Washington and Oregon. Several allied species or varieties are found in other parts of these States and in Northern California.

These curious animals are found only in the limited area above described. They are more or less aquatic in habits, living in 
burrows, near some stream of water, and feeding at dusk or early in the morning on vegetable material of various kinds.

\section{SQUIRRELS AND MARMOTS}

(Family Sciurida)

The squirrels and their allies include some of our handsomest and best-known rodents. They are active, intelligent animals, as a rule, with large bright eyes, bushy tails and strong muscular legs. Some species, as the marmots, are burrowers, though they spend much of their time out in the sunlight about the mouths of their holes, while others, comprising the most typical squirrels, are climbers par excellence, scaling the tree trunks or traversing the most slender branches with equal agility. This arboreal habit reaches its highest specialization in the flying squirrel which launches itself forth in its parachute-like flight from tree to tree, despising the support of slender branches upon which the other squirrels still rely. When one watches the rapid passage of the red squirrel through the trees and his sudden leaps from bough to bough, the evolution of the flying squirrel can easily be understood.

\section{Woodchuck}

\section{Arctomys monax (Linnæus)}

\section{Also called Ground Hog, Maryland Marmot.}

Length. 24 inches.

Description. Heavy and thick-set, with short legs and rather short brushy tail. Colour grizzly or yellowish-gray varied with black and rusty, underparts rusty, feet black.

Range. New York and southern New England to Georgia and

North Dakota, represented northward by an allied variety, others occur westward.

In every part of the world where the winters are sufficiently severe, there is pretty sure to be found a certain proportion of the wild animals that manage to do away with the most un- 


\section{Woodchuck}

pleasant part of the year, as far as they are concerned at least, by tucking themselves up in some out-of-the-waly corner and sleeping or dozing or hibernating the time away, each according to its own particular taste, until spring comes round again. And certainly no more satisfactory method could be devised for spending the winter, either as regards economy or personal comfort.

It is probably to this habit that the dormouse of the Old World owes its reputation of being the most ridiculously sleepy and drowsy little beast in the universe, though I fancy that a good many of the animals on this side of the Atlantic could give him points on the matter of taking protracted naps, as might naturally be expected in a climate where the temperature is liable to vary over one hundred degrees in the course of a twelvemonth. The dormouse, it would seem, does not depend entirely on its faculty for sleeping, to while away the long winter hours, but in the autumn puts by a store of hazelnuts and whenever the weather turns warmer for a few days, though it is in the very depth of the winter, he wakes up for a luncheon and a breath of fresh air, and then turns in again for another nap, so keeping a general idea of the weather as the mild English winter wears itself away.

But how much does the oldest woodchuck know of the New England winter? He can only realize that there are spring, summer and autumn, and then spring again, with only occasional flurries of snow and severe frost occurring at long intervals, perhaps a dozen times in the course of his life. If, as seems probable, the woodchuck really sleeps all winter long, then his waking hours occupy an extremely small portion of his life, for during the entire summer he spends the greater part of his time in his hole, and as he never takes his meals there, it is hard to imagine how he can occupy himself at such times except in sleeping. He is, perhaps, the least industrious animal in existence except when engaged in digging his hole, when he works away at a tremendous rate until it is finished; but once it is completed, he seldom attempts to enlarge or remodel it in any way, hut spends his days in luxurious ease, coming out to get liis breakfast soon after sumrise, while the dew is still on the grass, at which time I fancy he makes his most substantial meal, though he may occasionally be seen feeding at any time of day. At noon he is pretty sure to make his appearance ahove 


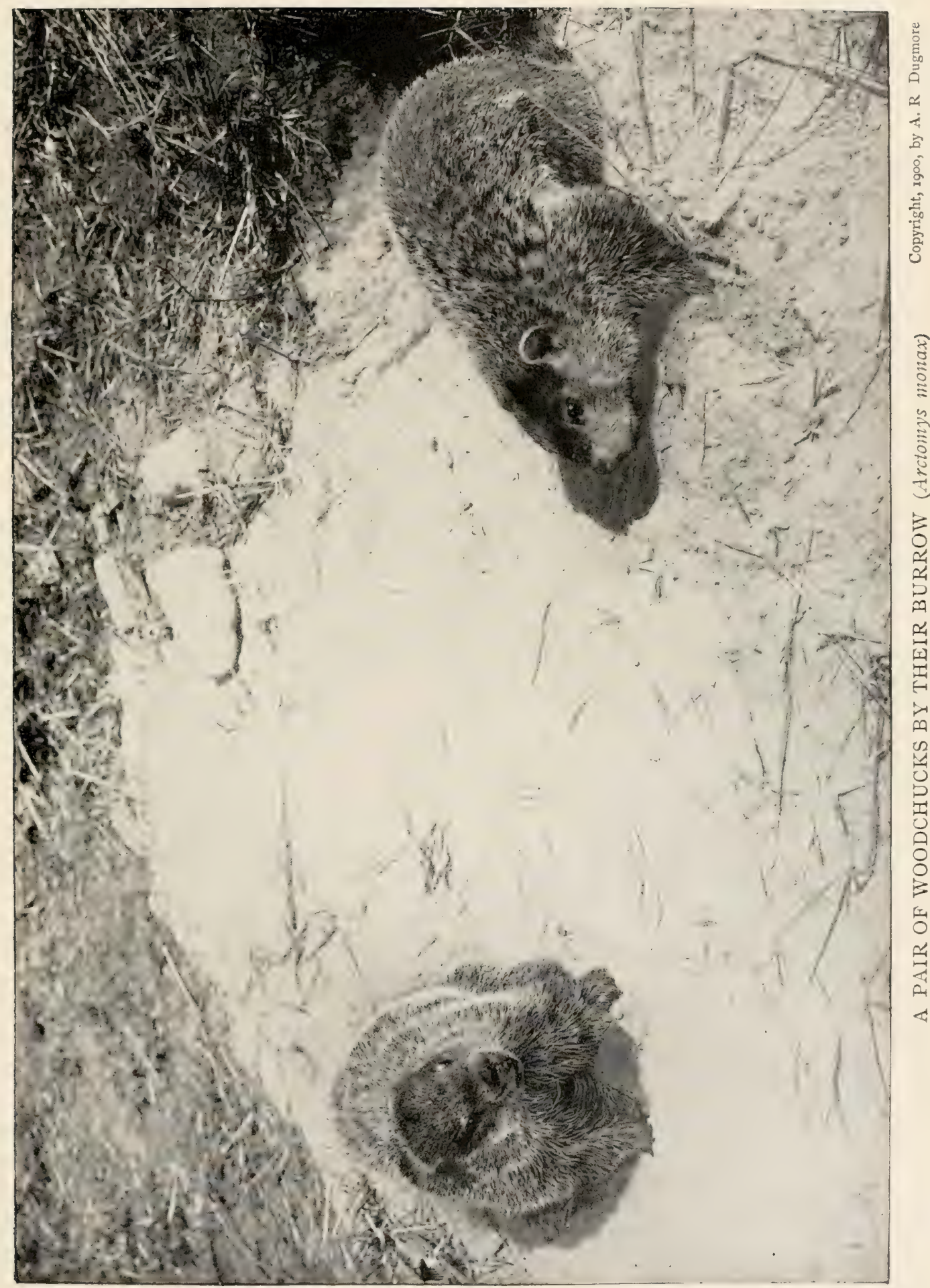



ground for luncheon, but apparently spends more time then in sunning himself than in eating. Late in the afternoon he again shows himself, and feeds until nearly sunset, when he descends into his burrow for the night. It is not often that he is obliged to go many steps from his doorway in order to fill himself, and by autumn he has usually reached a perfectly ludicrous state of obesity. There are usually several openings to the burrow, connected by well-beaten paths; similar paths radiate off into the grass in all directions, from one clump of clover to the next, and only too often to the bean patch or garden where it pleases him to eat out the tender inside of several cabbage heads in a single night. Beans he strips of leaves, pods and everything, and he is not averse to ears of corn and young pumpkin vines; in fact, there are few things raised in an ordinary vegetable garden which he does not occasionally exhibit a taste for. He is also fond of sweet apples and fruits of various kinds, frequently making his home in the orchard for the purpose of enjoying them. When the grass is tall enough he likes to move about in the various paths he has made, nibbling here and there, as suits his pleasure, and sitting bolt upright from time to time to look about him. His attitude toward his enemies is apt to be one of obstinate defiance. Other wild animals of his size, almost without exception, prefer, when in the proximity of houses, to remain in hiding during the day, only venturing out under cover of darkness. But the woodchuck often digs his hole within a few rods of a farmhouse and swaggers boldly about the garden at midday helping himself to whatever appeals most strongly to his appetite. When pursued he scrambles in frantic haste for his burrow, his black heels twinkling in the sunshine as he goes, but on reaching safety he is likely to turn about and thrust out his nose to chuckle defiance at his pursuers. If cornered, he is always ready to fight anything or anybody, and a dog lacking experience in such matters is likely to get the worst of it, for a woodchuck's incisors are weapons not to be despised. If their den is dug out, the woodchucks often manage to escape by burrowing off through the soil, after the manner of moles, filling up the holes behind them as they move along, and evidently not coming to the surface until sufficient time has elapsed to ensure their safety, though how they manage to avoid suffocation in the meantime is a question difficult to answer. They 
are often killed with shotguns, though this is no easy matter to accomplish; for though not a difficult animal to approach, the skin of an old one is pretty nearly a quarter of an inch thick, and the bones of the head are so solid that it requires the heaviest kind of shot and a gun that carries close and hard at ordinary shooting range to injure him. The majority of those that are killed are caught in steel traps at the mouth of their burrows. As soon as the woodchuck feels the grip of the trap on his foot, he settles back into his den and pulls with an amount of strength that is simply surprising, and often secures his liberty. If unable to free himself in this manner, he usually digs away the earth and blocks up the entrance of the hole with himself inside, and the owner of the trap is obliged to dislodge him as best he may. This is hard enough when the victim is a woodchuck, but if, as often happens, it proves to be a skunk, the result is truly disastrous. If left in the trap for any length of time, the woodchuck frequently releases himself by biting off his foot just below the jaws of the trap, but is less extravagant and wasteful in this matter than the muskrat, who not uncommonly leaves half an inch or more of leg sticking up above the trap, apparently gnawing it off wherever it is easiest and most convenient.

This is the woodchuck of the fields and cultivated lands. Many woodchucks, however, prefer to dwell in the pastures, where the grass is shorter and sweeter and they are less likely to arouse the ire of the owner of the land. Here they are obliged to wander farther afield in order to satisfy their appetites, but are generally in good condition for all that, and never appear to have any trouble in laying on a sufficient supply of fat during the summer to carry them over the cold season. In the pastures they are fond of sunning themselves on top of old stumps and smooth bowlders, the colour of their fur serving to make them comparatively inconspicuous when so engaged.

Then there is the woodchuck of the forest and woodlands, who really deserves the name of woodchuck, as it was in all probability first applied to the species by the early settlerschuck or chucky, I believe, being a term frequently used in Devonshire and other English farming districts to designate little pigs, who were sometimes spoken of as barnyard chuckies; so that woodchuck might very properly be translated as little pig 


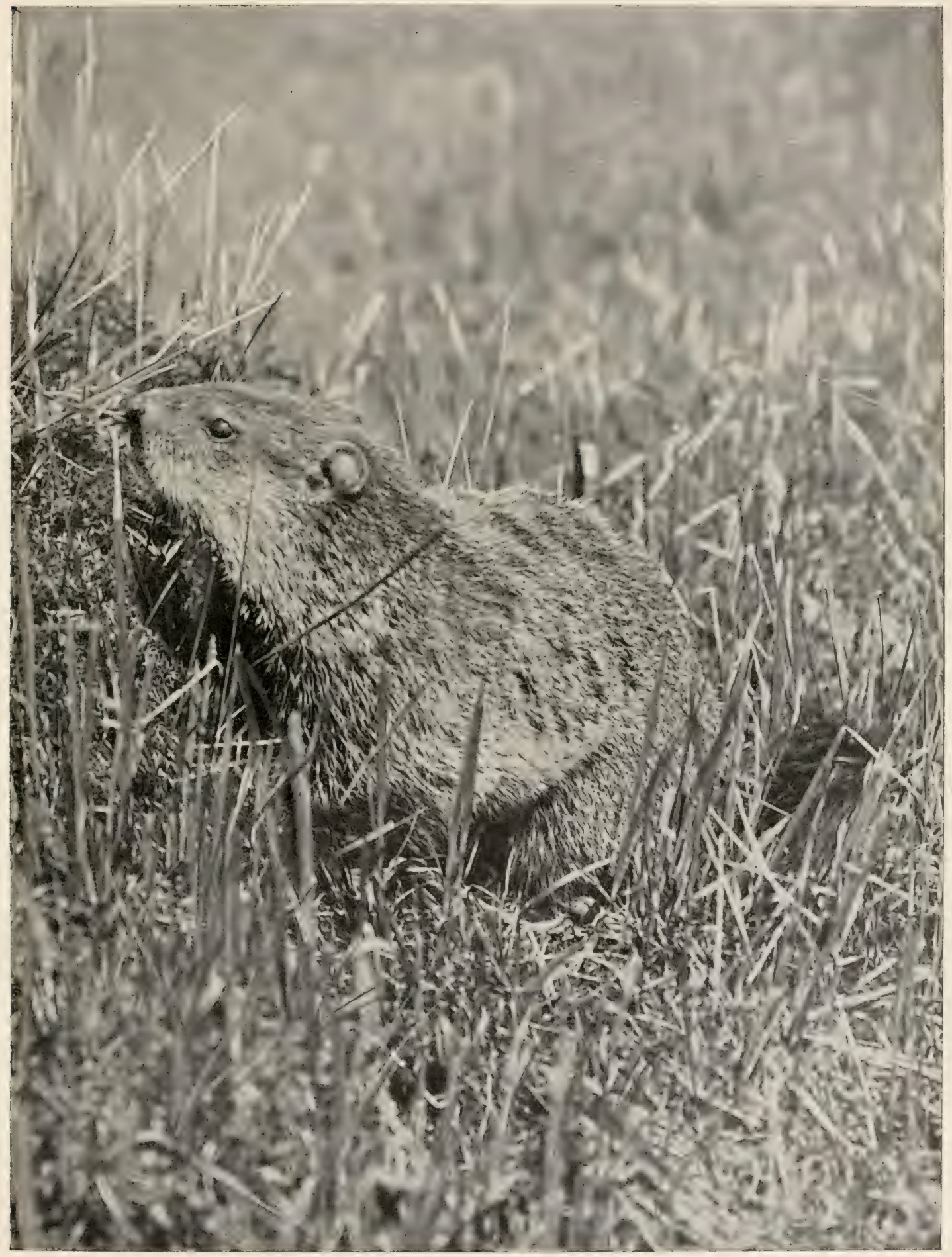



of the woods-not an altogether inappropriate title, at least as regards disposition.

The real woodchuck of the woods, instead of spending his days in the sunlit fields or open hard-wood groves and orchards, digs his hole among the rocks and ledges, beneath the roots of great hemlocks and pines, where the sun hardly penetrates and the decaying tree trunks are crossed and tumbled against each other overhead, supported and held in position by those that are still standing. Here he scrambles about among the underbrush and fallen branches, subsisting on berries and whatever green stuff is to be had in its season, probably feeding on edible mushrooms when they are to be obtained, like the partridges and squirrels who are his associates. He may frequently be seen of a summer afternoon stretched in the sun along some half prostrate log, evidently glad to take advantage of whatever of the sun's rays manage to penetrate among the shadows of his retreat. Enjoying as he does comparative immunity from the attacks of men and dogs, and having at the present day very few natural enemies to avoid, he should, and in all probability often does, live out his allotted time; and it is no uncommon thing to find the bones of these animals in hollow logs and similar places, showing no signs of having suffered a violent death. A careful observer of Nature once told me that he had once seen a woodchuck, apparently very old and feeble, laboriously digging a shallow hole in the soft earth, and that on returning, some hours later, he had discovered him curled up at the bottom of the hole quite dead, undoubtedly having died of old age after digging his own grave and crawling into it. He believed this to be a regular custom with them, and said that he had met with a number of people who asserted the same thing.

In one respect the forest woodchuck does not have so easy a time of it as his brethren who abide in the open country, seldom attaining to such an extreme condition of corpulency, and in consequence being compelled to awake and crawl out of bed much earlier in the spring, often making his appearance when the snow is still several feet deep. Such unfortunates are obliged to worry along as best they can until warm weather, seeking out the spots of bare earth beneair the evergreens and gnawing ravenously at the bark of trees or anything that can possibly be mace to answer as a substitute for food. They are soon piti- 
fully thin and so active as hardly to be recognized by one familiar only with well-fed summer specimens.

Woodchucks are seldom seen in the open pasture until the snow has about disappeared and the turf begins to feel soft under foot, with green grass and clover starting up in sheltered places, while those of the cultivated grass lands are still later about showing themselves, so that it would certainly seem that the duration of their winter nap depended largely on the food supply of the preceding summer. Still it is just possible that all the woodchucks return to the woods to "den in," in order to obtian a more even temperature than would be possible in the open ground. Instances of woodchucks having been unearthed in at state of hibernation in the winter are common enough, but whether in the woods or in the open appears uncertain.

In the summer the rambler often meets little woodchucks only a few weeks old, wandering about the fields alone and unprotected, having been driven from their homes by their hardhearted parents as soon as they were able to shift for themselves. These little waifs are not apt to show any alarm on being approached, commonly settling back on their haunches and attempting to bite anything that comes within reach, or else charging savagely at the intruder, with little husky, gurgling cries of anger. An old woodchuck will occasionally attack the person who threatens him, sometimes it would seem even when he is not cornered or confined in any way. But this is nothing to the perfectly reckless courage with which the youngster enters into the combat, as if he felt perfectly sure that he were going to have an ealsy thing of it. As soon, however, as he is quite convinced that you are not going to retreat, and that he is hardly likely to be able to dispose of you to his satisfaction, he starts off on a gallop, but as yet without any especial symptoms of fear, though if you persist in heading him off, he at last comes to realize that he is entirely at your mercy, and a wholly difterent expression comes into his eyes, he begins to tremble and shiver all over, and finally gives up all attempts to fieht or run awaly, simply crouching in the grass in abject terror.

I once obtained possession of a little woodchuck that had neen brought home uninjured by a dog. If I remember rightly, the original price of the animal was thirteen cents, with a 

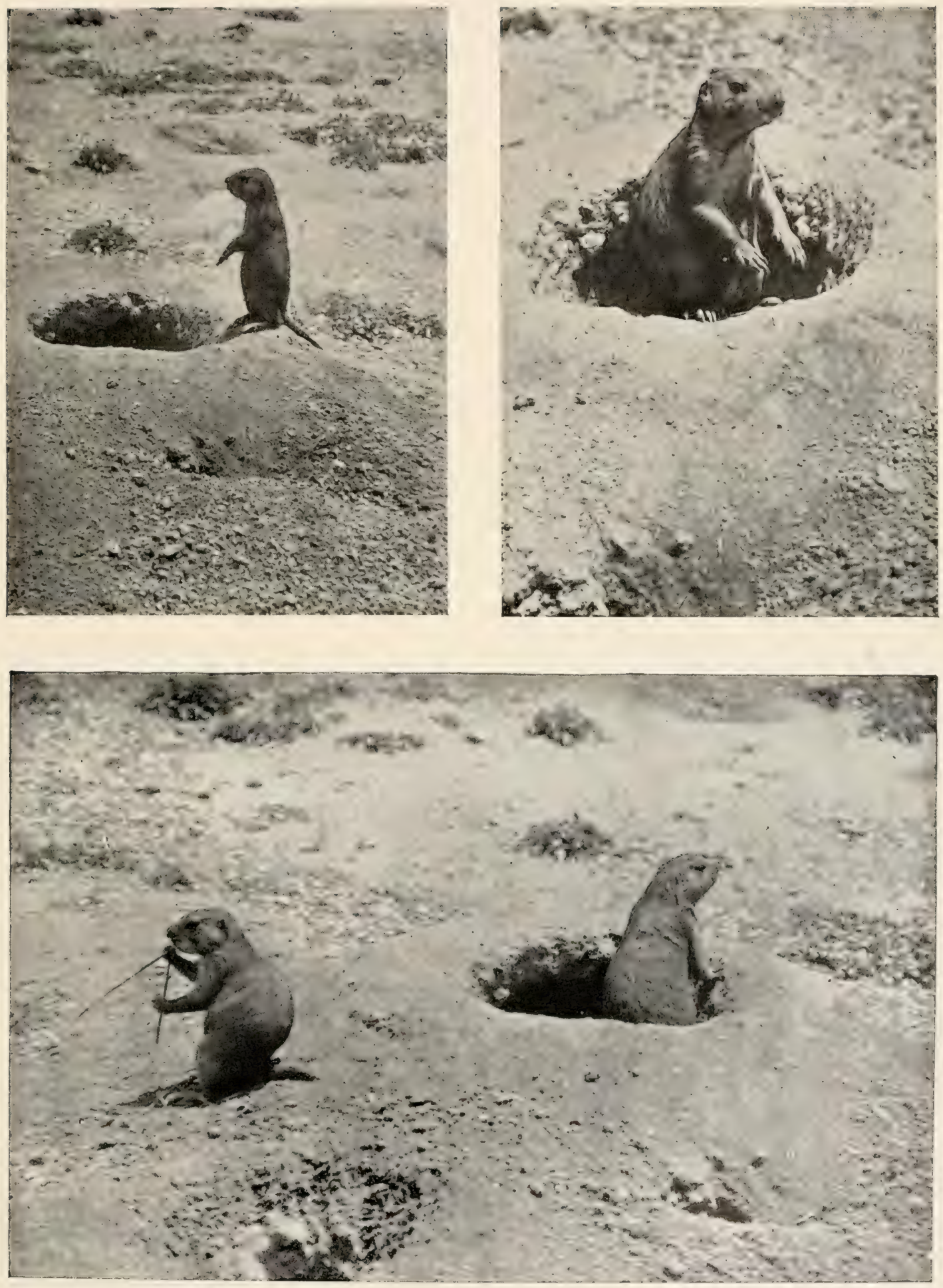

much damaged fish line and hook thrown in. He was much too young to eat solid food, so we fed him on milk with a bottle and rubber nipple. When being fed he always sat up perfectly straight, grasping the rubber firmly between his little black hands, which always looked as if clothed in close-fitting black gloves, so sharply was the line drawn between the black of his paws and the brown fur on his wrists and shoulders. When nearly satisfied he would grip it so tightly that none of the milk could escape and, taking it from his mouth, turn away his head for a few seconds of breathing space and then fall to again. He grew rapidly on this diet, and soon developed a liking for green things generally, especially caraway blossoms. As these grew far out of his reach, often three or four feet from the ground, he found it necessary in order to get at them to sit up beside the stem and, grasping it in his paws, bend it over towards him, pulling it down hand over hand until he had reached the umbel shaped cluster of flower, every particle of which he ate, allowing the stalk to spring back into place when he had finished. Strangly enough, he never troubled the vegetables in the garden in any waly, although allowed to wander about the place at his own discretion. He managed to get along fairly well with the cats, though there was not much affection on either side. Whenever he saw one of them drinking milk from a saucer, he liked to come up softly from behind and nip its heels, and then scuttle off to some place of concealment in time to escape punishment. He often persisted in this amusement until the cats retired in disgust, whereupon he would proceed to help himself to the milk they had left. If he felt sleepy, he would sit upright, letting his head hang down until his nose almost reached his hind feet, and then drop over on one side, rolled up into a perfect ball. Late in the season, he began to make extensive tunnels about the doorsteps and underneath the paths, the caving in of which was the cause of several mishaps to various members of the family. Although perfectly familiar, he was never affectionate, and towards the close of summer he left us for his native heath; and the rest of his history is hidden in obscurity, though it is safe to assume that he lived to grow up and eventually developed all the selfish and bearlike traits characteristic of his family. 
Only the other day an instance occurred which would seem to indicite that the woodchuck of the woods retires to his den much liter in the season than his cousin of the fields, who is seldom seen aloroal much after the first of September. On the first of November I came across a hollow ash tree, prostrate ahove a little brook in a swamp not far from my home, and noticed that some creature or other hald been carrymg dead grass into it quite recently. I fixed a trap in the hollow and the next day found a woodchuck held captive there, a typical woodchuck of the forest, as lean and active as a squirrel, with soft white-tipped fur almost as thick as a coon's. When I released him, he refused to run, but showed fight pluckily enough for several minutes, and then unexpectedly bolted by me into his hollow log, down which I could hear him scrambling to his nest, which appeared to be situated at the end of the cavity where the tree forked into several branches, for on breaking off a small branch here I could see that the interior wals filied with new dried grass and leaves. Undoubtedly he intended spending the winter there, and I imagine would find it quite as comfortable as the usual underground retreat, if not driven out by the rising waters in time of thaw. I reca!l once seeing what looked like a woodchuck's track in the snow about the last of November. The animal that made it had been wandering about the woods, prying into every stump and hollow log, perhaps in search of a bed; but that was years ago, and I am not even certain that it was a woodchuck's track at all.

This year I have again seen a woodchuck out in November, a tawny old fellow whose den is near the top of a little hillock beside a meadow, the same that I saw a fox trying to unearth last April.

As I crossed the meadow I could see him sitting in his doorway in the dim sunlight of Indian summer, perhaps saying goodby to his shadow and the sun and the clouds until spring returns; the turf beside his path was yet green and moist, and from deep among the grass-roots the dreamy notes of crickets sounded miles away, and seemed alvalys on the point of ceasing forever.

A few diys before I salw this same woodchuck carrying home wild apples from a tree several rods from his hole; it may be that last summer's drouth, which wals unusually severe in 


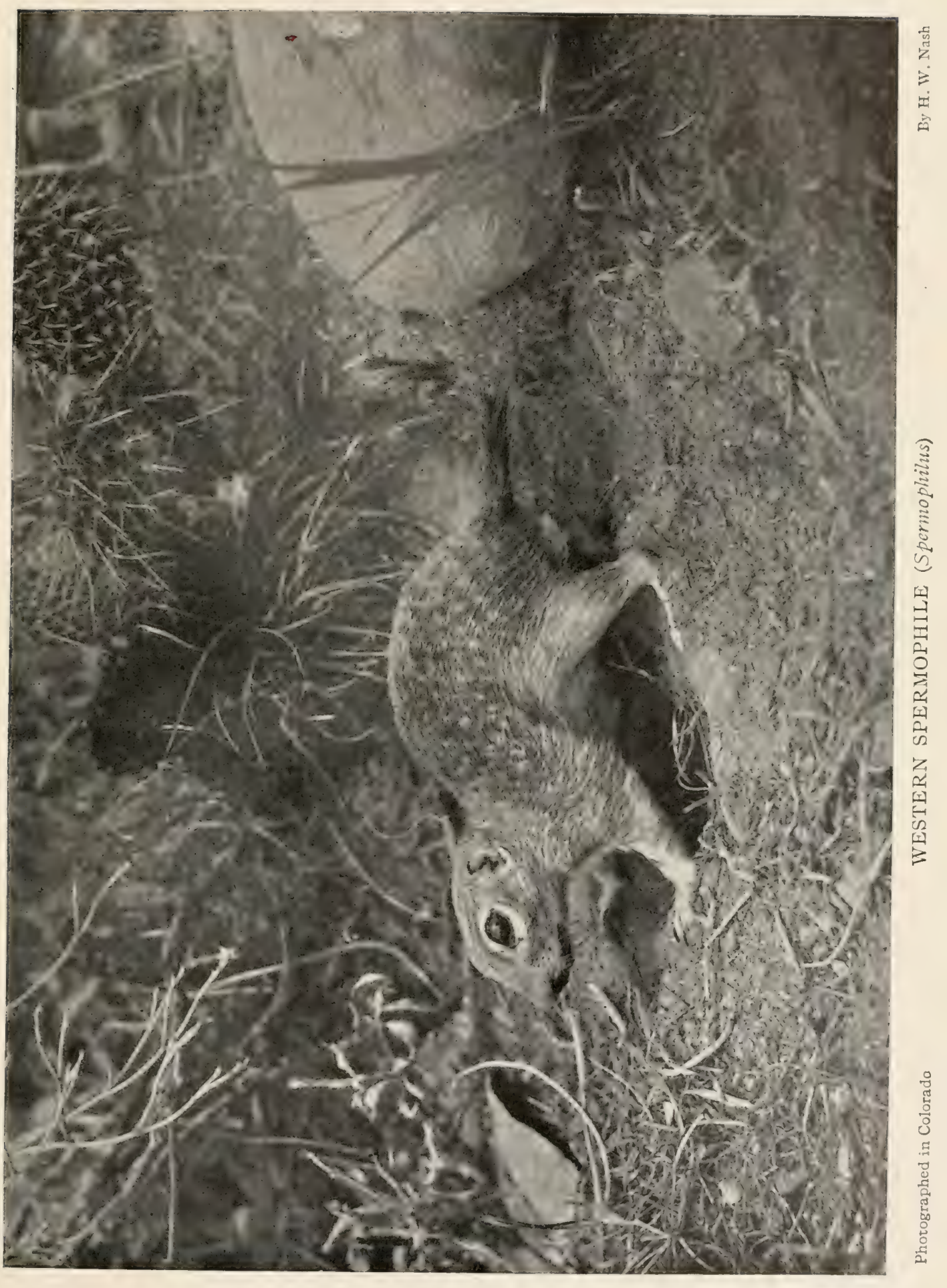



these parts, made it impossible for him to get fat enough to risk turning in at the regular time for woodchucks to retire about the first of October.

In the days of the uncleared forest before the white-men came, woodchucks, it is safe to assume, had a much longer list of enemies than now. Bears, wolves, lynxes and panthers, undoubtedly all preyed on them as occasion afforded, and it is hardly likely that the Indian hunter felt himself demeaned by stooping to the chase of such humble quarry.

At present the only native animal that the woodchucks have much to fear from is the fox. From this determined hunter they are not always safe, even in the depths of their burrows. In the winter when the ground is unfrozen, foxes will even dig them out of their winter quarters and kill them in their sleep. They dig them out in warm weather as well, though I fail to see how they ever manage to catch up with so accomplished a burrower in an underground race.

But the little woodchucks I expect are in much greater danger, for while they are still no bigger than rats, they begin to spend sunny hours exploring the grass around the burrow, or sprawled out asleep on the hot earth piled in front of it.

At such times hen-hawks or cooper's hawks might easily pick them up, but I do not remember having seen evidence that they often do. For awhile the old woodchucks make a point of look-. ing out for their safety, but in a most indifferent sort of way, quite unlike the zealous watchfulness displayed by most wild animals. The female has in fact on occasions been said to push her offspring out of the hole one at a time in order to purchase her own safety by distracting the attention of a dog that was trying to dig her out.

\section{Varieties of the Woodchuck}

ı. Woodchuck. Arctomys monax (Linnæus). Description and range as above.

2. Northern Woodchuck. A. monax canadensis (Erxleben). Darker than the above, black and brown predominating, hairs more variegated with white, cheeks gray.

Range. Boreal regions north of the preceding.

3. Labrador Woodchuck. A. monax ignavus Bangs. Similar to the last externally.

Range. Labrador. 


\section{Prairie Dog}

\section{Cynomys ludovicianus (Ord)}

\section{Called also Marmot.}

Length. 15 inches.

Description. Resembles the spermophiles but the ears are very short, and the tail very short and flat, colour brownish above varied with gray and black hairs, soiled white below, tail black toward the end.

Range. Western Texas and Kansas to the base of the Rocky Mountains north to Montana. Allied varieties occur in Arizona, New Mexico and Wyoming.

The prairie dog is perhaps the most characteristic animal of the higher drier prairies of the West. He reminds one of a miniature woodchuck, though much more gregarious and more active. Prairie Dogs associate in colonies or "dog towns," sometimes many miles in extent, where their burrows and mounds of excavated earth form a conspicuous feature of the landscape. Speaking of the occurrence of the prairie dog in Texas Dr. Kennerly says : "This interesting little animal never fails to attract the attention of every traveller on the Western prairies; and on approach to one of their settlements, after long and dreary marches, is always hailed with delight as a pleasant change from the monotony of lifeless scenes to one of cheerful activity and motion. Such occasions never fail to excite a certain degree of pleasure in every one as he watches the motions of these curious creatures as they at first assemble in numbers as if in grave consultation in regard to the intrusion of strangers upon their quiet domain, and, upon the too near approach of apparent danger, suddenly the assembly is dispersed, each one, retiring to his respective home and standing upon the edge of his den, utters his peculiar bark, as if in defiance, and then every one disappears suddenly and every voice is hushed when a single gun is discharged."

Prairie dogs feed upon grass and such other plants as furnish satisfactory fodder, and frequently strip the ground bare throughout the extent of their towns.

In all the older accounts of the prairie dog we inevitably find associated with him the rattlesnake and the burrowing owl. the three forming the theme for many a "Happy Family" story. 

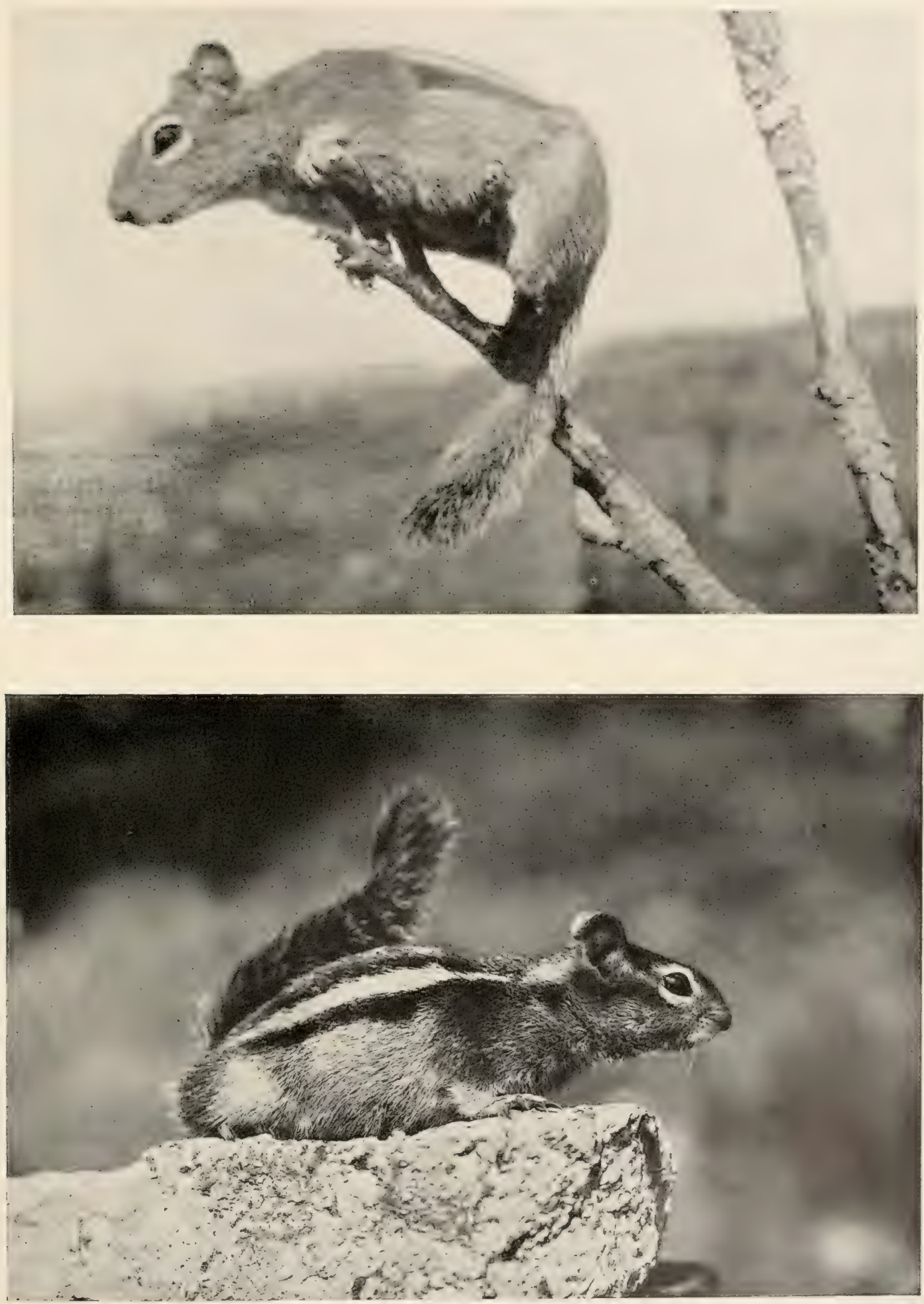

SAY'S SPERMOPHILE (Spermophilus lateralis)

Photographed in the Bitter Root Mountains after much patient baiting and watching. 

Apart from inhabiting the same region, and the fact that young prairie dogs form an acceptable article of diet for both the other members of the triumvirate, they have little to do with one another. The owls dig holes for themselves, though they may not be averse to appropriating a prairie dog's burrow, just as their relatives of the woodland will use an old flicker's hole or a crow's nest. The rattlesnake, too, will no doubt take refuge in a burrow of either of the others, though to the discomfiture of the rightful owner and the probable loss of its offspring. The stories of the peaceful cohabitation of the beast, bird and reptile are, however, the result of a lively imagination.

\section{Striped Spermophile}

\section{Spermophilus tridecemlineatus (Mitchell)}

\section{Also called Striped Gopher.}

Length. Io inches.

Description. Back striped with six buff bands and seven wider

brown bands, each of the latter containing a row of small

white spots; middle bands running from the top of the head

to the tail, others shorter; lower parts dull buff; tail rather short, flat and rather bushy.

Range. Plains of the Saskatchewan; south to Texas and east to southern Wisconsin and Michigan, nearly the whole of Illinois, northern Indiana and northwestern Ohio.

The spermophiles, closely allied to the chipmunks, form as it were the connecting link between the squirrels and the marmots. They are restricted to the prairie regions of the West, where there are a number of species, two of which cross the Mississippi. The best known and most widely distributed form is the striped spermophile or "striped gopher" as it is also called. Vernon Bailey in his report upon these animals says: "Throughout the prairies of the Mississippi Valley the little striped spermophile is a familar object as it darts through the grass to its hole or is seen standing upright on its hind feet, straight and motionless as a stick. With its short ears, smoothly rounded head, and the forefeet drooping at its sides, there is no point about its outline to catch the eye, and at a little distance it is impossible to dis- 


\section{Franklin's Spermophile}

tinguish it from old picket pin or fence stake. Standing thus the animal will often allow one to approach within a few yards, then quickly dropping on all fours it utters a shrill chatter and dives into a hole close by. Remain quiet for a few minutes and its head reappears at the entrance of the hole and the little black eyes peer at you curiously. Walk away from the place and it will soon come out and, standing up again, watch you as long as you are in within sight, uttering an occasional note of alarm or warning to its friends."

The burrows vary in length, some being short and apparently only used for shelter, while others are long with the nest at the end where the young are born, or where the animals hibernate; other adjoining cavities are used for storehouses and a large supply of grain is generally put away before winter sets in.

\section{Franklin's Spermophile}

Spermophilus franklini (Sabine)

Also called Gray Gopher.

Length. 14.80 inches.

Description. Hair coarse and harsh, gray above suffused with

yellowish brown and hairs banded with black; below paler gray

with a white throat, tail clear gray.

Range. Saskatchewan south to eastern Kansas and through northern and middle Illinois and southern Wisconsin to the western border of Indiana.

Although there are numerous spermophiles in the West, this and the preceding are the only ones to range east of the Mississippi.

Peculiar interest attaches to this animal from the fact that it was introduced into the sandy barrens of southern New Jersey where it seemed to nourish for a time, though it did not spread to any extent.

\section{Chipmunk}

Tamias striatus (Linnæus)

Called also Ground Hackee, Ground Squirrel, Striped Squirrel. Length. 9.50 inches.

Description. Head brown, back grizzly gray, rump and hind legs rufous chestnut; a narrow black stripe on the middle of the back 


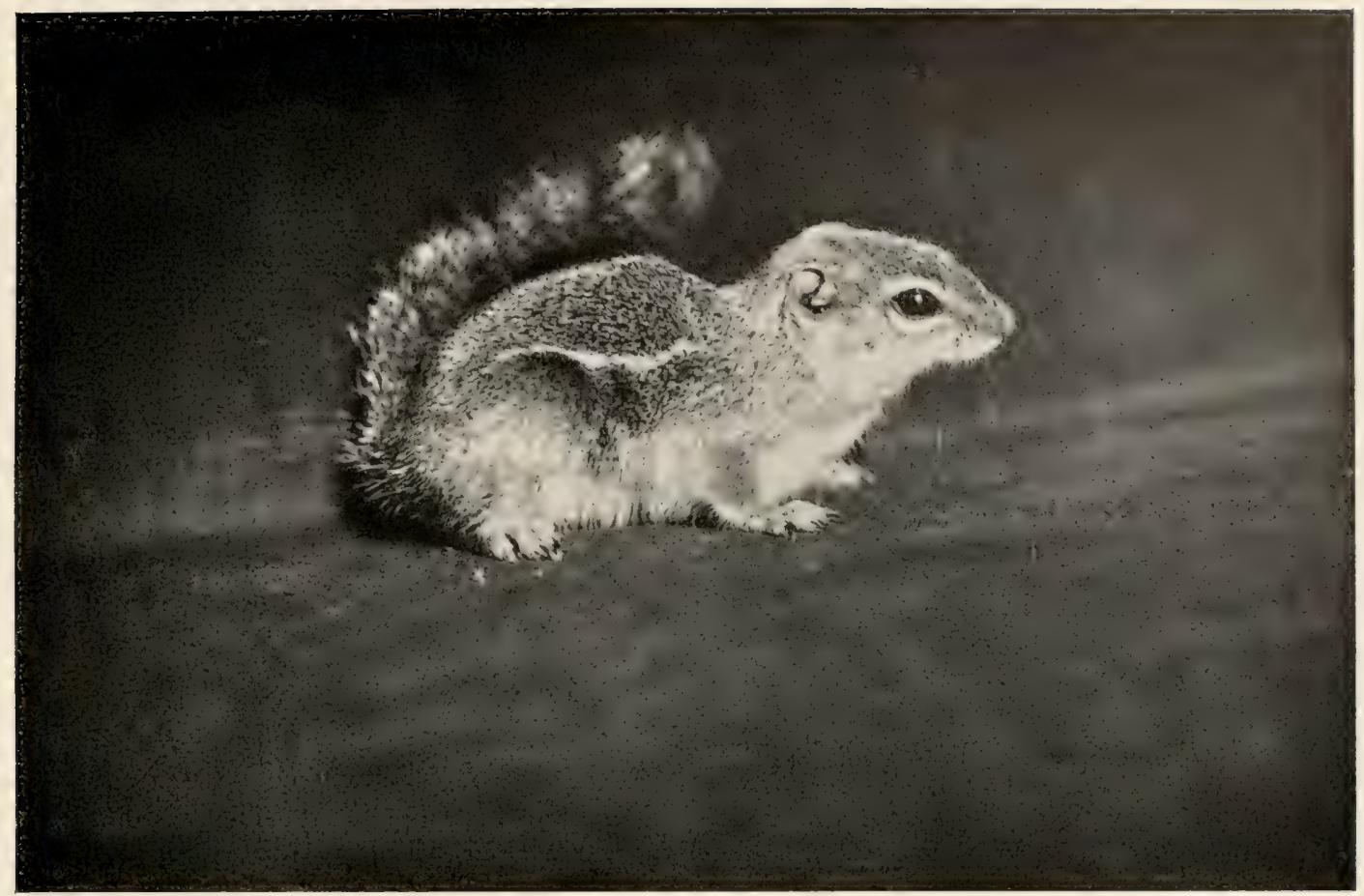

WHITE-TAILED SPERMOPHILE (Spermophilus leurcurus)

By Dane Coolidge

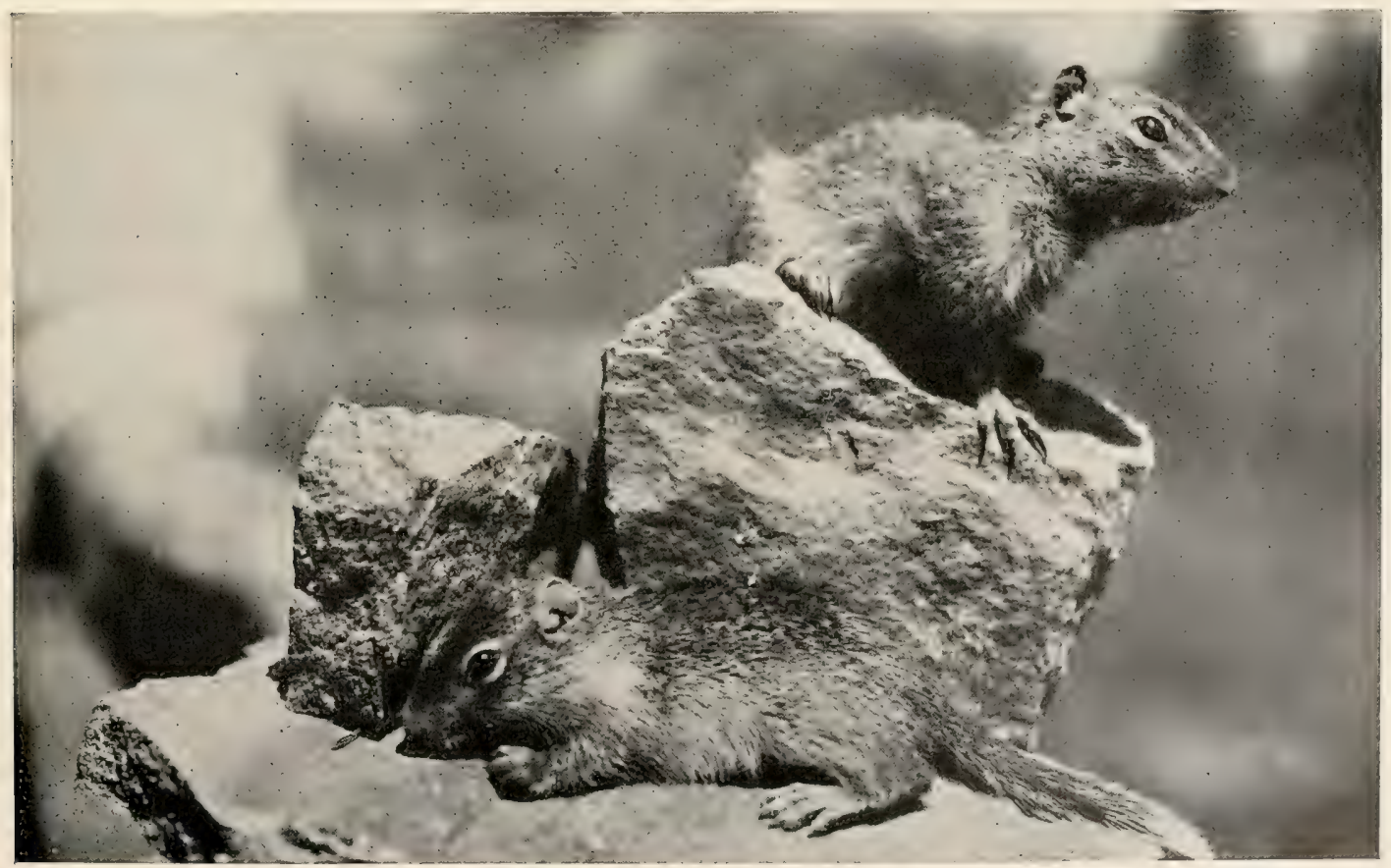

YOUNG OF COLUMBIA SPERMOPHILE (Spermophilus columbiamus) By W. E. Carlin 

from the ears to the rufous of the rump, and on each side two black stripes with a light buff stripe between them. Sides of the body buffy mixed with black-tipped hairs, below white. Tail grizzly gray above with black tips to the hairs, below rufous edged with black.

Range. Southern New York to Georgia. Northward the closely related northern hackee ( $T$. striatus lysteri) takes its place. It is much brighter and lighter in colour, bright rusty red instead of chestnut above. Numerous other species are found in the West.

Ground squirrels are unquestionably most intelligent creatures, loving the sunlight and hot weather and open yroves of hardwoods where the turf is cropped close by cattle.

Here they dig their burrows in such a manner as to avoid attracting the attention of their enemies and at the same time allowing them an unobstructed outlook on all sides from their doorways.

Choosing an open and lawn-like spot they sink a perpendicular tunnel down several feet; after which the burrow is carried along horizontally for a few yards and then ascends a trifle to the chamber, which is perhaps a foot in height and breadth and nearly twice as long and carpeted with soft grass.

A back stairway ascends to the surface by a somewhat shorter route at a considerable distance from the other opening.

Now the amount of earth removed must necessarily be considerable, yet the grass about the entrance shows no signs of it, and it requires a sharp eye to detect the position of the burrow unless its owner betrays the secret himself. I believe that in some instances, perhaps quite frequently, the hole is begun beneath a hollow stump or tree, under the shelter of a thick low growing bush, or between the rocks of a wall where the pile of fresh dirt may escape notice; and after other passages are made from the chamber to the surface the original opening is perhaps blocked with earth from the inside and abandoned. Piles of newly dug earth are always to be found in the vicinity of the chipmunk's home, but almost invariably at a distance from any burrow, often so far away in fact that it is difficult to conceive how they could have been constructed, even in the manner just described.

I am inclined to think that it is a common practice among chipmunk's to carry all the dirt removed in their cheek-pouches 


\section{Chipmunk}

to a safe distance where it may be left in a healp or scattered about over the grass; it may be that the earth hidden beneath stumps and similar places is brought there in this manner oftener than is suspected.

In going to and from his burrow the chipmunk takes careful leaps over the grass and appears strictly to avoid making any path which might serve as a guide to his enemies.

Among themselves chipmunks are most talkative little people, often a company of half a dozen or more may be heard keeping up a most animated conversation on quiet summer afternoons; each seated on his own particular rock or stump separated by intervals of a few rods they exchange chirrup for chirrup with varying inflections for hours together. At times they get up a regular chorus or chant with a kind of rhythmical movement ruming through it that is very pleasing. This chirrup or chirping note is also used as a cry of warning by simply changing the expression a trifle.

If a chipmunk is interrupted in his labours or his sunbath, or whatever he may happen to be doing, by the approach of a fox or other enemy, he not only looks out for his own safety but remembers the rest of his family as well.

If possible he gets within easy reach of his hole and from that position of safety he sends forth a steady series of alarm notes as long as the enemy is in sight.

The alarm is taken up by the others as fast as they catch sight of the fox, so that the most wily maraduder finds his approach heralded in spite of all his caution.

When one is directly attacked and compelled to dart into his hole or seek safety among the rocks, a shrill, rippling, sibilant cry informs his fellows still more exactly of the position of the enemy. One afternoon last September I heard them signalling danger from one to another at the edge of the woods, and approached calutiously, rather expecting to find a fox hunting them, for the jays by their screaming gave me reason to believe that there was one near-by.

Just as I reached the group of hardwood trees where the chipmunks were, a cooper's hawk swooped down from among the leaves overhead and gliding alnng beside the stone wall struck at first one and then another of the little striped backs, but they all dodged him successfully each sending along the alarm to the 


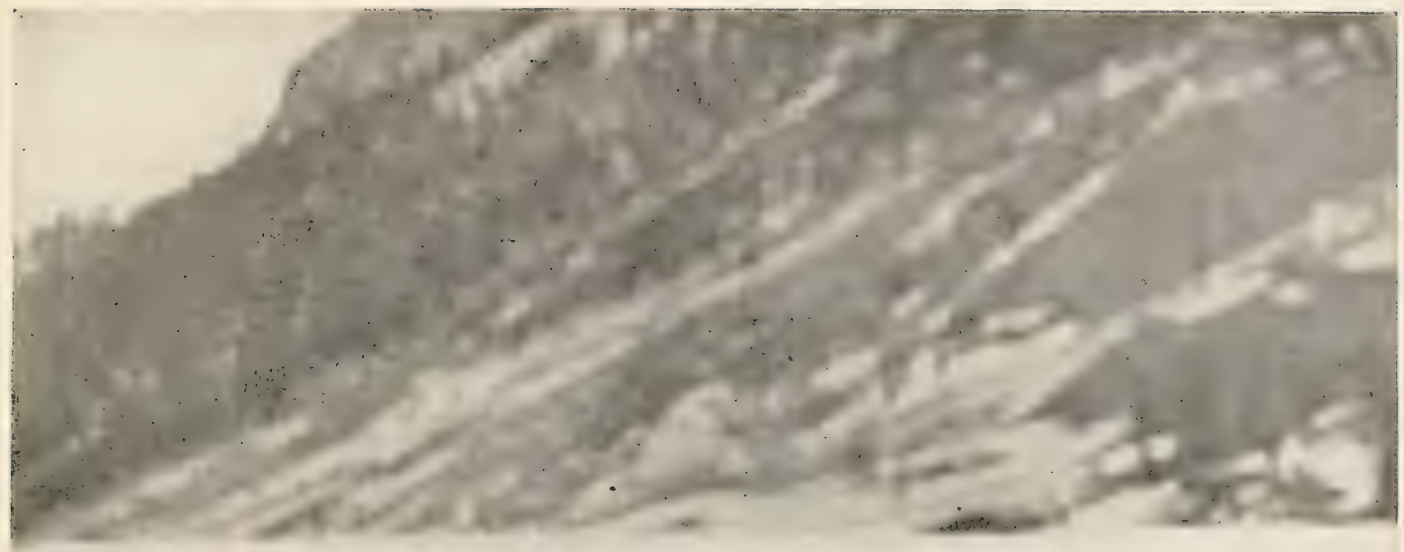

\section{SAY'S SPERMOPHILE IN SNOW (Spermophilus lateralis)}

Photographed near Crested Butte, Colorado, with the snow three feet deep, the camera being operated by a string 200 ieet long.

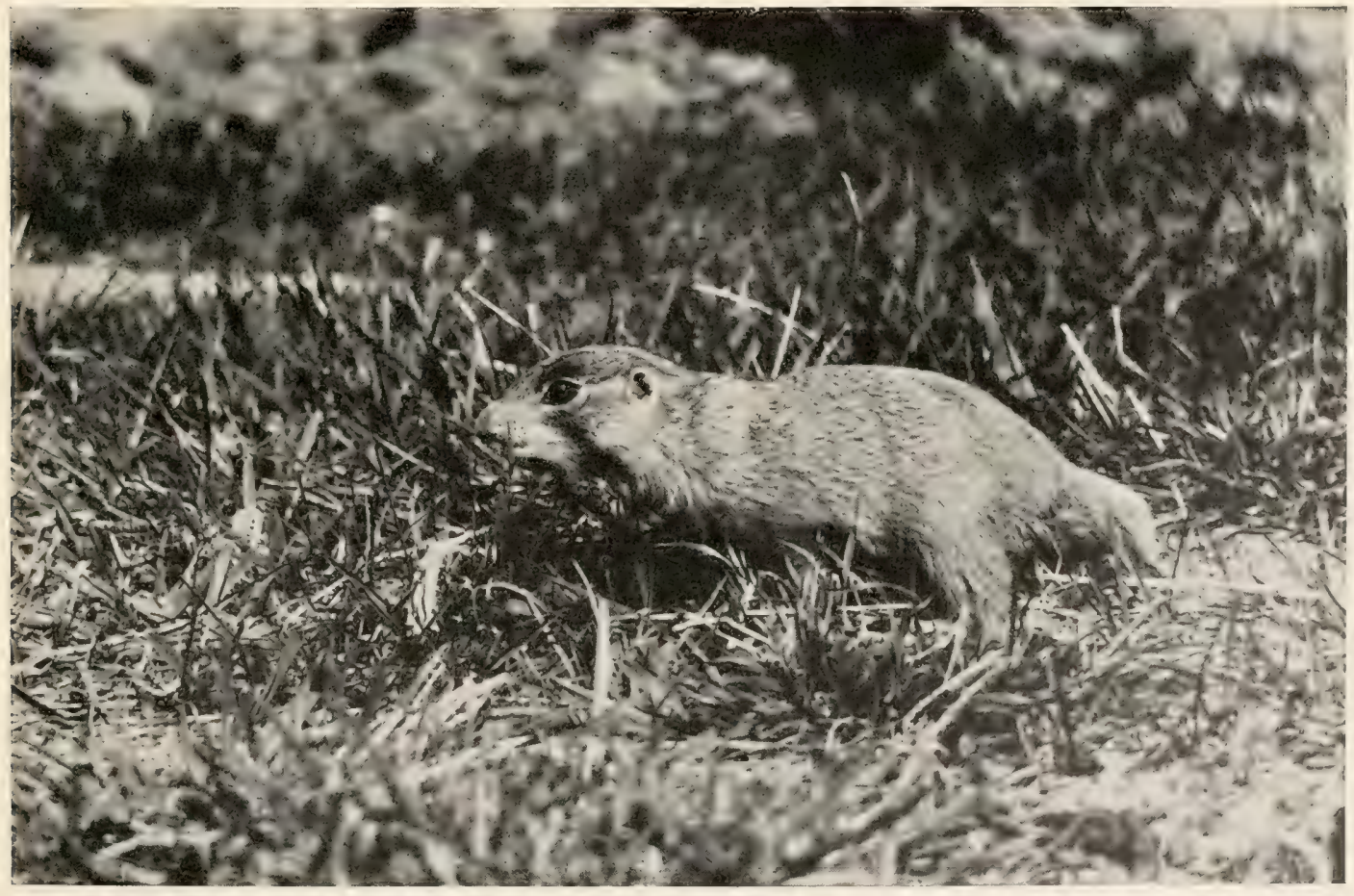

YOUNG PRAIRIE DOG (Cynomys ludovicianus) (about one-third grown)

By E. D. Warren 

next as he disappeared. The hawk vanished among the trees and evidently succeeded in deceiving the squirrels into thinking that he had betaken himself to other hunting grounds, for after perhaps ten minutes of anxious shouting between neighbouring doorways they quieted down and resumed the interrupted course of their affairs; some of them searching about in the short grass for beechnuts dropped by the jays, while others started on longer excursions through the woods and a few of the younger ones began playing together among the last year's leaves beside the wall.

But one or two took prominent positions on the highest stones of the wall as if standing sentinel, and at pretty regular intervals called a warning to the others, or perhaps it was the cry of "All's well," for by this time even the jays appeared to have forgotten the danger and were chuckling and squealing among themselves as they gathered beechnuts overhead.

None of them apparently paid any attention to the angry stuttering of a red squirrel in a great oak, and I am inclined to beiieve that red squirrels, like the shepherd boy in the fable, have so often cried wolf without cause that the other wood-dwellers have learned to distrust them.

But this one evidently knew what he was about and a sudden hysterical explosion in the midst of his clamour and then silence was followed by the reappearance of the hawk from his ambush among the oak leaves dashing this way and that after the scattering chipmunks. He failed, however, as before in each attempt, and, as if mistrusting that the red squirrel might be the cause of all his ill luck, rose in the air and rushed headlong at him as he clung to the under side of the branch. There was a short and very exciting chase before the squirrel succeeded in reaching the safety of his hole and the hawk flapped away disappointed.

The winter hibernation of the chipmunk is much like that of the dormouse of the Old World, though unlike the dormouse and most other hibernating animals, chipmunks are seldom more than comfortably fat on retiring in the autumn.

As several weeks are generally believed to elapse before the final sleep of winter overtakes them, it is quite probable that they occupy themselves in the meantime with acquiring a sufficient amount of fat to carry them on until spring.

In April and May chipmunks are pretty sure to be out in 


\section{Chipmunk}

the sunshine of every warm day we have, to retire and become dormant again, like the dormouse, at the approach of a cold wave or snow weather.

Those tirst few weeks of confinement in November must be a strange experience for such an active sun-loving creature as the chipmunk. To go down out of the bright October sunlight into a chamber utterly devoid of any light of any kind, there to remain groping about in the dark among its companions, squeezing through narrow side passages, depending on food packed away in the nest itself or in side galleries branching off from the main chamber, eating and sleeping in those cramped quarters and getting ever drowsier and drowsier, at last losing consciousness altogether, to awake and become aware in some inexplicable manner that it is time to come out into the daylight once more-this, indeed, must be a life of strange contrasts.

But while the dormouse is supposed to be chronically sleepy at all times, owing probably to its fondness for being abroad at night and sleeping all day, even in the longest days of summer, the chipmunk, when it is awake, is most unmistakably awake from sunrise to sunset, apparently without even a nap at midday when the days are at their longest and hottest.

These ground squirrels are at times rather destructive neighbours, about their worst vice being that of digging up newly planted corn. They display a great deal of cleverness in the matter of locating the seed which is usually covered with an inch or two of earth. Their cheek pouches, which reach back almost to their shoulders, enable them to carry away astonishingly large loads and, as they often persist in their nefarious work until the corn is several inches high, the damage wrought by a few families of them is sometimes considerable.

Generally speaking, it is only in the spring when their supplies are running short and before the berries have begun to ripen that they err in this direction. They seldom trouble the ripe corn to any great extent, even in seasons when nuts are scarce. In the West they appear to be much more destructive, and are popularly looked upon as a decided nuisance. They eat all kinds of berries, strawberries, raspberries and dewberries; while apples, pears and tomatoes also find favour in their eyes.

Early in the spring they go searching for the coral-red berries of the wintergreen and mitchella, where the crisp gray moss is 


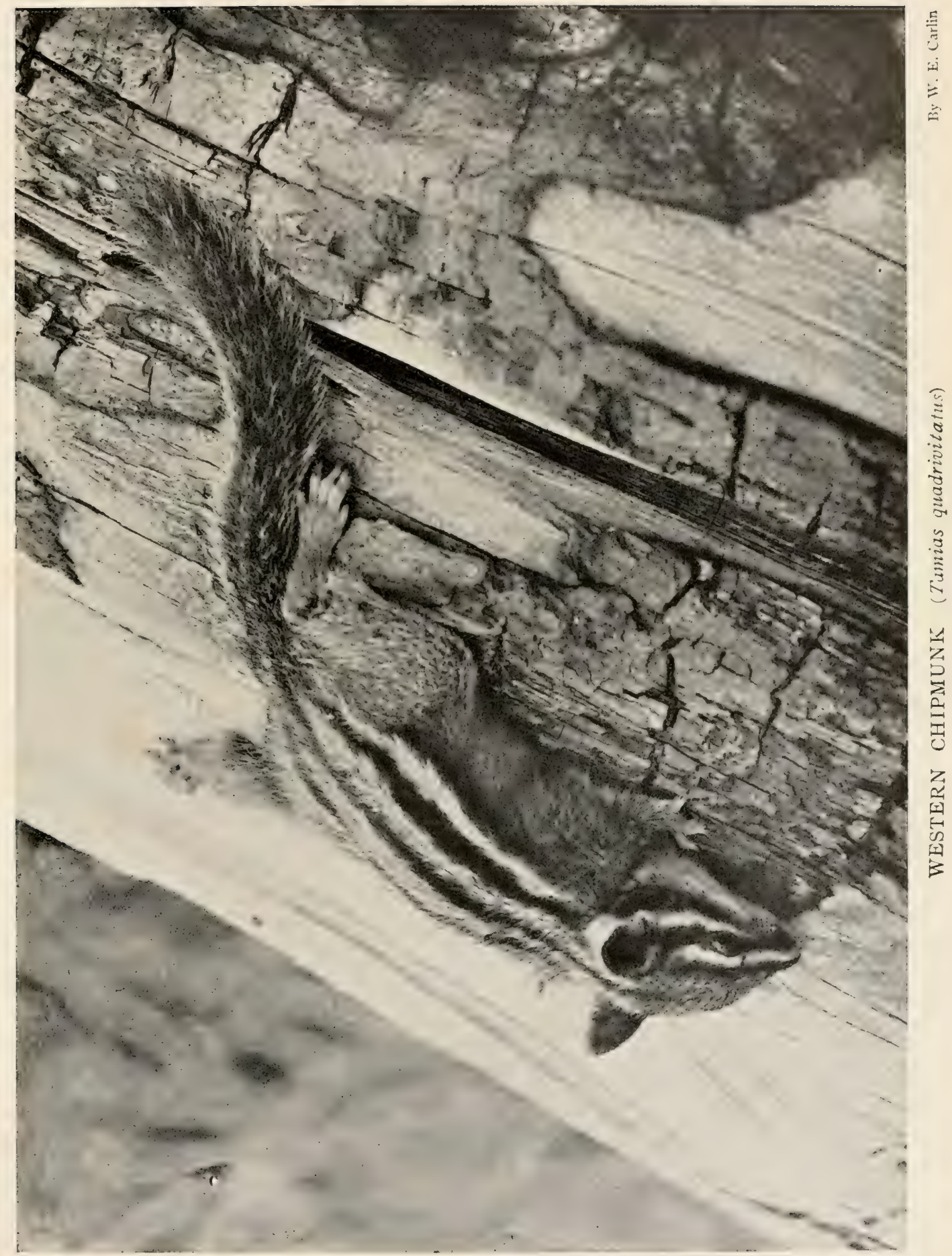



drying out around the stumps of long-forgotten pines. In a way they are hunters, too; I have seen them chasing the big, noisy, banded-winged locusts of late summer, running beneath them, as they fly along and pouncing on them when they finally come to earth. One of these big fellows must make a very satisfactory luncheon for an animal no larger than a chipmunk, everything being eaten but the wings and the extremities of the legs.

Like most rodents, they are a little too fond of robbing birds' nests; I am inclined to think, however, that they are less destructive in this direction than either squirrels or mice. I once watched a pair of them stalking some spotted sandpipers by the edge of a mill pond. They would creep up under cover of the water weed, or lie in ambush behind dried wood or a lily pad standing aslant in the mud; when they fancied themselves near enough they would rush out, sometimes both together, and the frightened sandpipers would open their long wings and lose some critical moments in getting their balance, and then take their stiff-winged flight low over the water with anxious whistlings.

The chipmunks were so active and determined about it all that, seeing them from the other bank, I at first mistook them for weasels. The sandpipers at last betook themselves away up stream to the meadows to be rid of the nuisance.

June 5th, 1900, I have just been examining the chipmunk holes on the hill in the pasture. They are, evidently enough, all constructed in about the same manner, the chief object in view being concealment. All agree in having the opening noticeably smaller than the rest of the tunnel. The short, thick grass around it is green and untrampled to the very edge, and though scarcely an inch in length, pretty well conceals the narrow doorway. There is not the least particle of loose dirt scattered anywhere about.

The turf at the mouth of the burrow is soft and elastic, but at the depth of an inch the hole becomes suddenly larger, I should say at least twice as large as at the opening, and the walls are packed surprisingly hard.

At a considerable distance, under the low-growing branches of some young pines, I found a little pile of newly-dug earth, something over a foot in diameter and two or three inches high. Yellow subsoil undoubtedly brought there as fast as it was dug 


\section{Fox Squirrel}

out in the making of one or another of the burrows, the nearest of which is several rods away.

Close by one of the recently made burrows I noticed where the chipmunk hat originally intended having his doorway and twice been obliged to abandon his work on account of unforeseen obstruction beneath the surface; roots or stones probably, for it seems imperative that the shape should be almost perpendicular for the first few feet. One of these abandoned attempts was only an inch deep and an inch in diameter at the surface, at the bottom it was flat and decidedly larger. There was no dirt scattered near, so that apparently even from the very beginning every particle that is removed is discreetly carrried away in the cheek pouches of this wily little rodent.

The other hole that was started a few feet away is six inches deep and corresponds exactly with the first six inches of the finished burrow, the walls being packed equally hard. It looks as if the little chap that made it had dug out a passage just large enough to squeeze into, and as he worked along, had enlarged it by continually turning around and packing it on all sides with his feet, in this manner insuring firm walls for his home, and at the same time lessening the quantity of earth to be removed.

\section{Fox Squirrel}

\section{Sciurus miventer neglectus (Gray)}

\section{Also called Cat Squirrel.}

Length. 23.50 inches.

Description. The largest of the true squirrels, with very long bushy tail. Colour grizzly or yellowish gray, the hairs banded with black, and with more or less rusty tints on the upper surface; underparts pale, ferruginous to nearly white; tail rusty beneath, bordered with blick. Exact colours decidedly variable in different individuals.

Range. Mountains of North Carolina and Virginia, northward through Pennsvlvania and New Jersey to central New York. Now nearly extinct through most of its range. Represented to the West and South by related varieties. (See below).

Fox squirrels are hig vigorous fellows, adapting their habits to the kind of woods they live in. Those found among hard- 

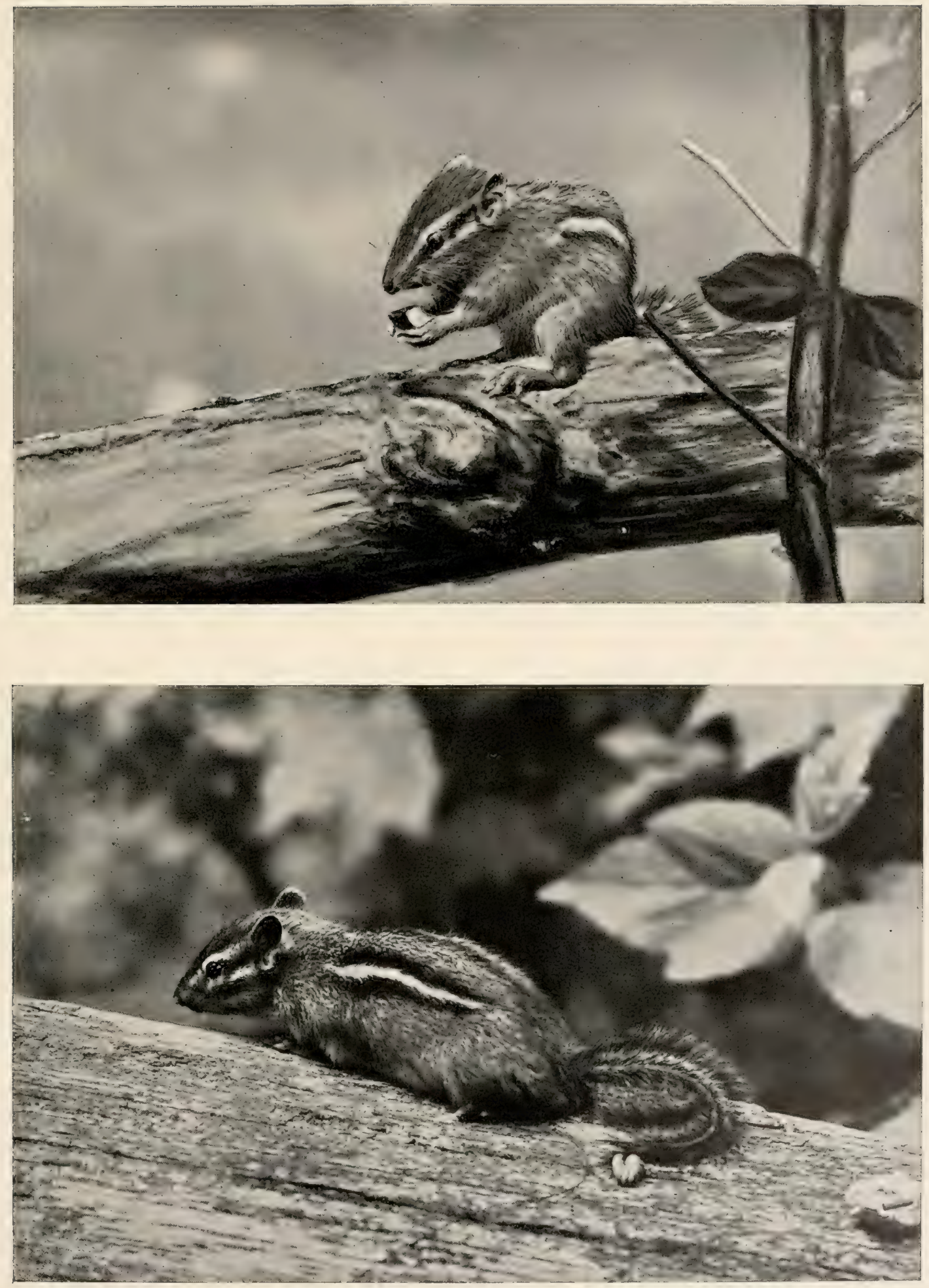

woods live very much as the gray squirrels do in summer, but are generally less provident in the matter of preparing for the cold season, preferring rather to avoid those regions where the snow lies deep for any length of time and depending for food on whatever they may find from day to day, scratching among fallen leaves for acorns and nuts, and when these fail, living on the buds of trees as best they may.

In rough weather they keep close at home in their hollow trees, choosing to go hungry rather than face the cold. In warm weather they gather wild fruit, berries and mushrooms and go into the corn fields as soon as the ears have reached the milky stage. Among the southern pines they make large nests of Spanish moss in the tree-tops, and here they bring the cones which they cut off, just as the red squirrels do the cones of the white pines in the North, biting off the scales in order to get at the seeds in a similar manner. The scales scattered about the foot of their tree often betray them to the squirrel-hunter.

A full-grown fox squirrel, owing to his size and strength. has probably little to fear from hawks, though a red-tailed hawk might not fear to attack one on occasion, or a goshawk when driven south by an unusually hard winter. The fox squirrels' worst enemies are undoubtedly the wild cat, gray fox and raccoon.

In hardwoods fox squirrels build nests of dry leaves, a large bunch frequently conspicuously bright yellow; the entrance to a warmly lined nest of broken up leaves is a small hole in the side. At other times they live in holes in trees, using dry grass and strips of soft bark for a lining.

They are much hunted as an article of food, being well flavoured and heavy, but it requires skilful watching to kill many of them.

In Florida the "crackers" look for scattered chips of the pine cones at the foot of each tree and, finding them recently dropped, hide near-by and wait patiently for hours to get a shot.

\section{Varieties of the Fox Squirrel}

I. Northern Fox Squirrel. Sciurus rufiventer neglectus (Gray). Description and range as above.

2. Western Fox Squirrel. S. rufiventer Geoffroy. Similar, but generally partially black, sometimes all black above and 
rufous below, or mottled above and black beneath. Very variable.

Range. Mississippi Valley, north to South Dakota.

3. Southern Fox Syuirrel. S. niver (Linnæus). Larger than either of the above (25.50 inches). Colours viriable, generally entirely black or black and buff above and reddish buff below. Ears and nose always white, which is never the case with other species.

Ratnge. Pine woods of Florida, west to Louisiana and north to Virginia, east of the mountains.

\section{Gray Squirrel}

\section{Sciurus carolinensis Gmelin}

Length. 18 inches.

Description. Similar in build to the fox squirrel, with large bushy tail. Colour yellowish-gray, individual hairs banded with rusty-yellow and black, decidedly rusty on the face, feet and sides. Below white. Hairs of tail rusty-yellow at base, black in the middle, with white tips.

Range. Florida to southeastern Pennsylvania, Hudson Valley, Indiana and Missouri; replaced to the North and West by slightly different geographic varieties.

The best opportunities for watching the ways of gray squirrels are to be found in the outskirts of towns and villages, where they are not allowed to be shot at or otherwise molested. For though less intelligent than the red squirrels, they are quick to perceive the advantages to be had in a civilized community while the love of stillness and the untainted air of the forest does not appear to be universal among them.

Where they are sufficiently protected they make their homes in shaded trees that have hollow branches, or any cavity in the trunk that they can enlarge for their accommodation. Here they live and raise their families and lay up stores for winter, above rattling streets and humming. wires, perfectly indifferent to the noise and heating air that reeks of human beings crowded together like cattle. They are comfort-loving animals, and away in the silent forest, a gray squirrel must be forever on the alert to guard his hidden stores against the thieving red squirrels and the wild mice of the woods, and always listening for the rustle of a fox's footstep on the leaves, or the distant screaming of a hawk. 

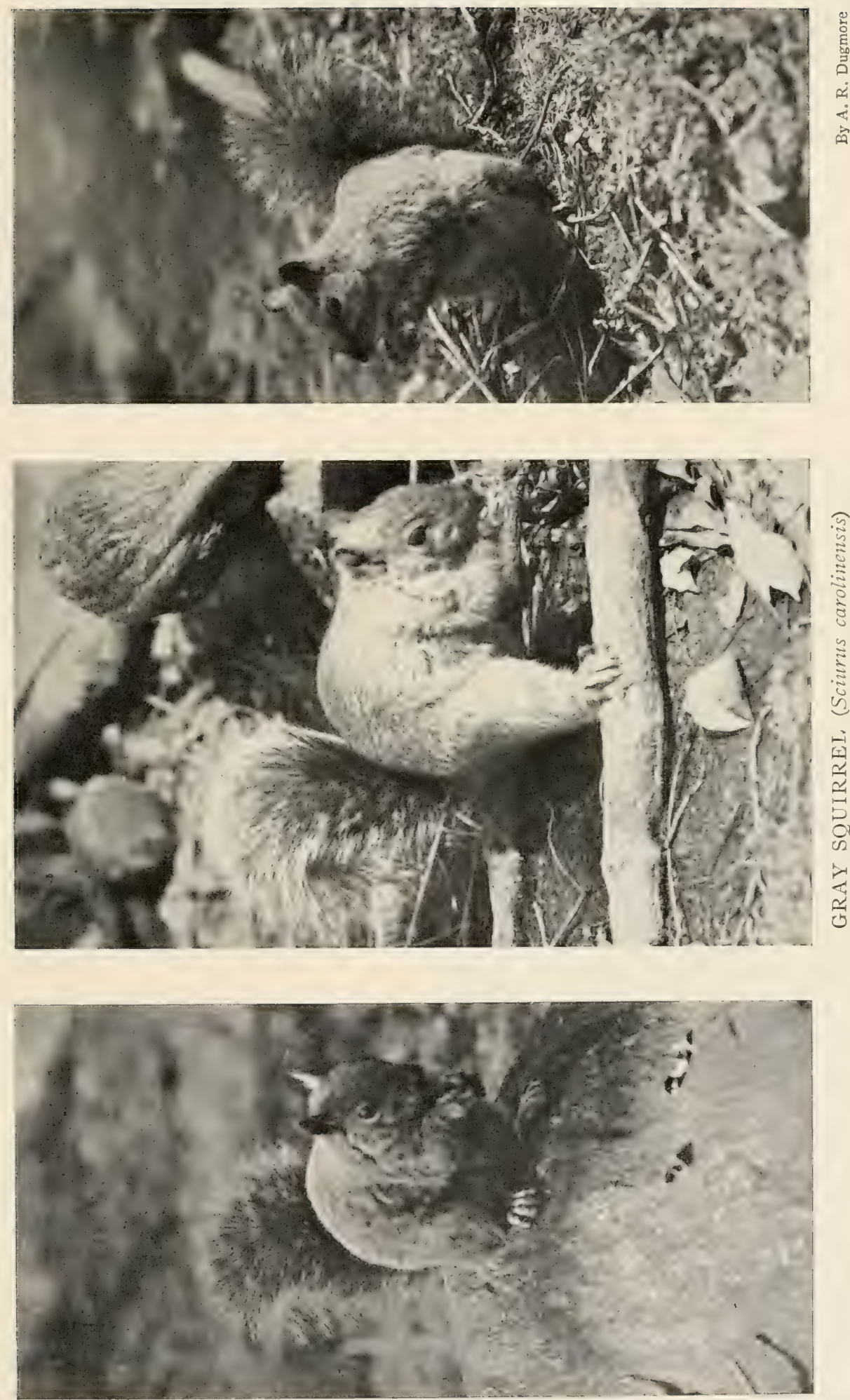

For the red-shouldered hawks are dangerous enemies, and the hours they habitually choose to spend in hunting correspond exactly with the squirrel's working hours-from sunrise to ten o'clock in the morning and from three in the afternoon until near sunset. They watch cat-like for an opportunity to take some unhappy squirrel unawares, or circling high above the treetops their keen eyes penetrate the foliage from constantly varying positions, searching branch and bole and the carpet of fallen leaves beneath till, perceiving the flicker of a bushy tail, the long wings close of a sudden fan-like, and the hunter goes down with a rush to match his quickness against the quickness of a squirrel. Or the still more treacherous goshawk and cooper's hawk, with their narrower wings and slender, yacht-like build, shoot along with baffling swiftness through the undergrowth, just in order to surprise the busy harvesters at their work.

The gray squirrels also know that, in the fall, the men that are found in the woods, unlike the town variety, carry guns and feed on squirrels to a certain extent. With very little encouragement gray squirrels will soon learn to pay you frequent visits, in your room, if you will only leave a window open for them within jumping distance of their treetop, a few nuts or a piece of cake quickly overcoming their shyness. In fact, they often prove to be something of a nuisance about the house. Even in places where they are looked upon as legitimate game they lose much of their fear of man during the close season of spring and summer.

Their habits vary but little whether they live in deep forests or within the limits of a town. Finding a suitable hole in the tree, they enlarge it to suit them, preferring to have plenty of room inside to move about in. The other day I watched one gathering dead leaves for his bed in an old apple-tree. He would run out along the branches to where the brown leaves hung shrivelled in clusters of two or three, rustling in the November wind. Biting off the twig that bore them, he would hurry back with it to his hole. Once the leaves were all brushed from the twig as he went in, and, if ever there was evident surprise and annoyance, it was depicted on his little gray face when a few seconds later he peered out of his doorway, looking for the leaves that he missed. Often half a dozen or more will occupy the same hole, and though the old males are apt to be unpleasantly ugly and tyrannical, 


\section{Red Squirrel}

they geineraliy appear to get along pretty well on the whole. They also make nests of leaves in the forks of trees, beeches in most instances; they cut off the leilves in branches, while they are still green in summer, and place them in successive layers on a rough platform of twigs in such a manner as to shed the rain perfectly, but without leaving room for more than one or two inmates within.

Gray squirrels warn each other of danger with a kind of flat, rasping bark, finally prolonged into a whining snarl, distinctly audible or an eighth of a mile or more in calm weather.

\section{Varieties of the Gray Squirrel}

1. Sonthern Gray Squirel. Sciurus carolinensis Gmelın. Description and range as above.

2. Northern Gray Squirrel. S. carolinensis lencotis (Gapper). Lighter and grayer, clear, silvery gray in winter, more yellowish in summer. Perfectly black individuals, known as black squirrels, occur in some localities, but are merely melanistic individuals and not a different species.

Renge. Alleghanies of Pennsylvania, northward to New England, New Brunswick, southern Canada and Minnesota.

3. Balvou Gray Saluirel. S. carolinensis fuliginosus (Bachman). Colours richer and darker than the southern gray squirrel, underparts often tinted with ferruginous.

Range. Bayou region of the Louisiana coast.

4. Eacrglade Gral" Squirrel. So caroline'nsis extimus Bangs. Grayer and lighter than the southern gray squirrel and much smaller.

Range. Southern Florida.

Many very handsome squirrels of this and other groups are found in the Western States.

\section{Red Squirrel}

\section{Sciumes hudsonicus gymnicus Bangs}

\section{Called also Chicliaree.}

Length. 12 inches.

Description. In winter back and upper side of tail bright chestnut, sides olive gray, the hairs banciel with black; under- 

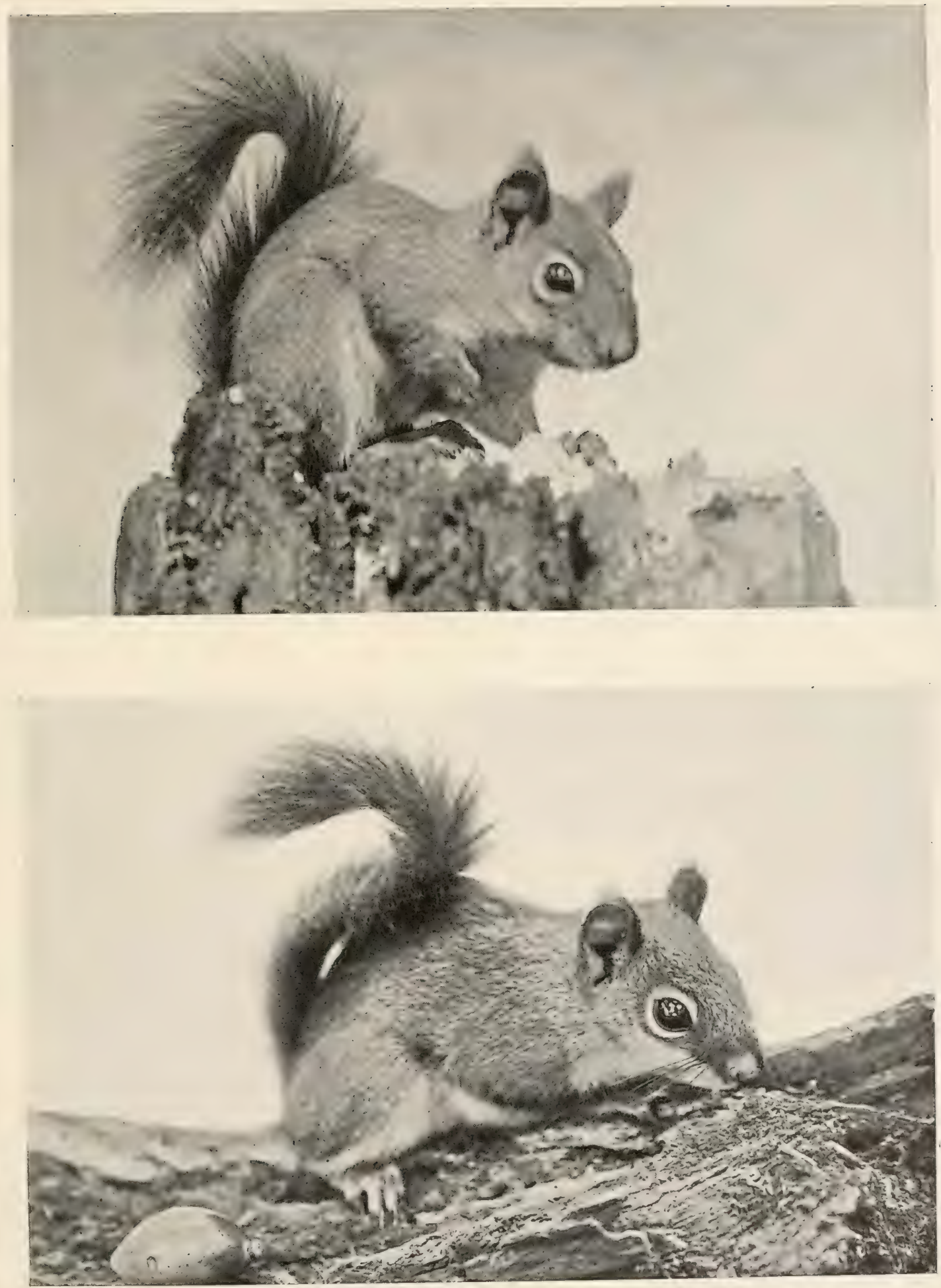

RED SQUIRRELS (Sciurus hudsonicus gymmicus)

By W. E. Carlin 

parts grayish-white. In summer no distinct rufous area on the back, and lower parts pure white with a black stripe on each side, separating the colours of the upper and lower parts.

Range. Southern Maine, Nova Scotia and Quebec, and in the mountains southward, replaced in the lower grounds and in Labrador by slightly different varieties.

The red squirrel is possessed of more petty vices and fewer virtues than any other beast that roams the woods. He is quarrelsome, noisy and mischievous and forever prying into the affairs of others. In the winter he makes a regular business of robbing his neighbours of the stores of provisions they have gathered, though he always has more than his share hidden away at home and most zealously guarded; and in summer he robs birds' nests high and low.

Yet one cannot help liking him, for a keen sense of humour and never failing good spirits tip the balance against all sorts of evil deeds. Even in northern New England the cold is never fierce enough to curb his jollity any more than the blistering heat of July.

You are sure to meet him when driving over country roads at any time of the year, for, in most of the Northern States, red squirrels are as common as robins.

Few people realize what thoroughly practical, thrifty and ingenious little animals they really are; for, unlike most thieves, they are not in anyway shiftless or lazy, but are steady hard-workers the year round. There is no idle season for them.

Other squirrels live a careless, gipsy sort of life through the warm weather, only commencing the labour of harvesting when the nuts ripen.

But as early as July, while the young squirrels have still to be watched over and looked after, the industrious red squirrels begin cutting off the green cones of the white pine and work early and late burying them, half a dozen in a place, under the pine needles, to be dug up in the winter and early spring and opened for the seeds they contain.

No amount of snow seems to bother them much when it comes to locating their buried stores.

By the time the business of gathering pine cones is over for the season, the nuts and acorns are beginning to ripen, and there are fall 


\section{Red Squirrel}

apples to be picked and stored in hollow trees, for the red squirrel is firm in exacting his tithe of the farmers and looks after the collecting of it himself. In the matter of corn, however, he prefers to wait until the farmer has gathered it into his bin, when the squirrel can generally get it without much loss of time.

The hemlock cones hold their seeds all winter, and there is never a day of snow or winter sunshine that the red squirrel may not be seen gathering them from the very tips of the swaying outer branches, in company with the chattering cross-bills and pine-finches, bent on the same errand themselves.

Although with very few exceptions red squirrels refuse to become tame in confinment, most of them are really fond of human society, their keen intelligence enabling them very quickly to decide whom they may safely trust. The lone chopper frequently enjoys the company of the merry little forester who greets him each morning with a volley of exclamations from the top of a wood pile, and endeavours to steal his luncheon before noon time, and later picks up any scattered crumbs, or runs off with the tallow the chopper keeps to grease his axe helve with. Red squirrels like nothing better than a chance to run a race with you when you are driving. One will sit, tail in the air, on the highest stone of a road-side wall, or a stake in the fence, until you are just opposite, then off he goes.

If you manage to leave him behind for a little, and then slow up to see what has become of him, you will see him come tearing after you at the top of his speed, and go by with a flourish, at last whisking up into a tree almost out of breath, where, perched on a conspicuous branch, he may watch you out of sight, hurling all sorts of epithets after you.

In the early spring red squirrels manage to keep pretty busy tapping the sugar maples, climbing for the topmost buds of trees as they begin to swell in the increasing sunlight, and watching the movements of the newly awakened chipmunks and gray squirrels, in the hope that even yet they may betray some unsuspected hoarding of nuts.

But it is no longer a matier of hoarding with red squirrels, each meal as it comes is now his rule, trusting that the abundance of summer is not far off.

In tapping the maple they gnaw saucer-shaped cavities in 


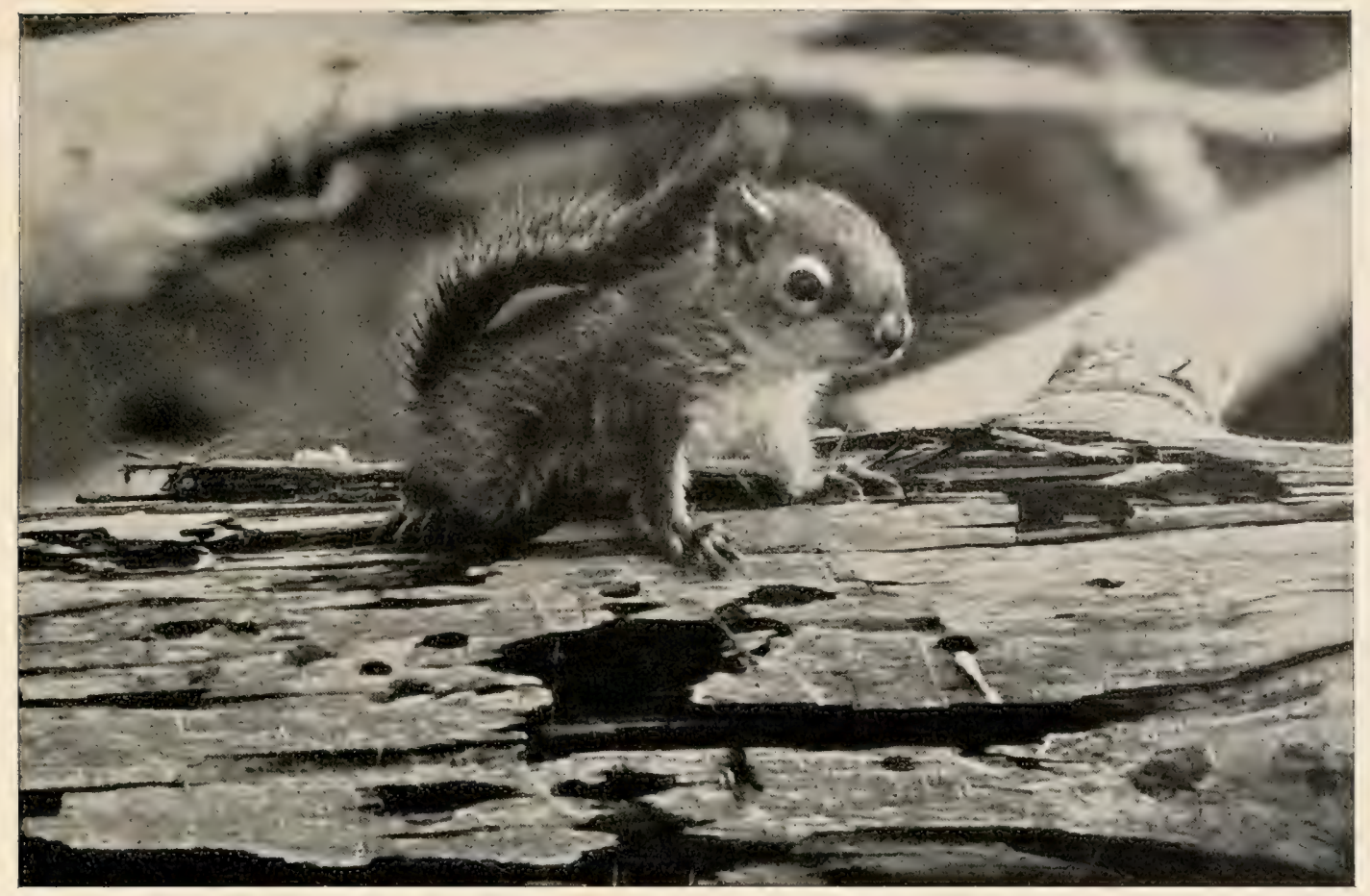

YOUNG RED SQUIRREL (Sciurus hudsonicus gymnicus)

By A. R. Dugmore

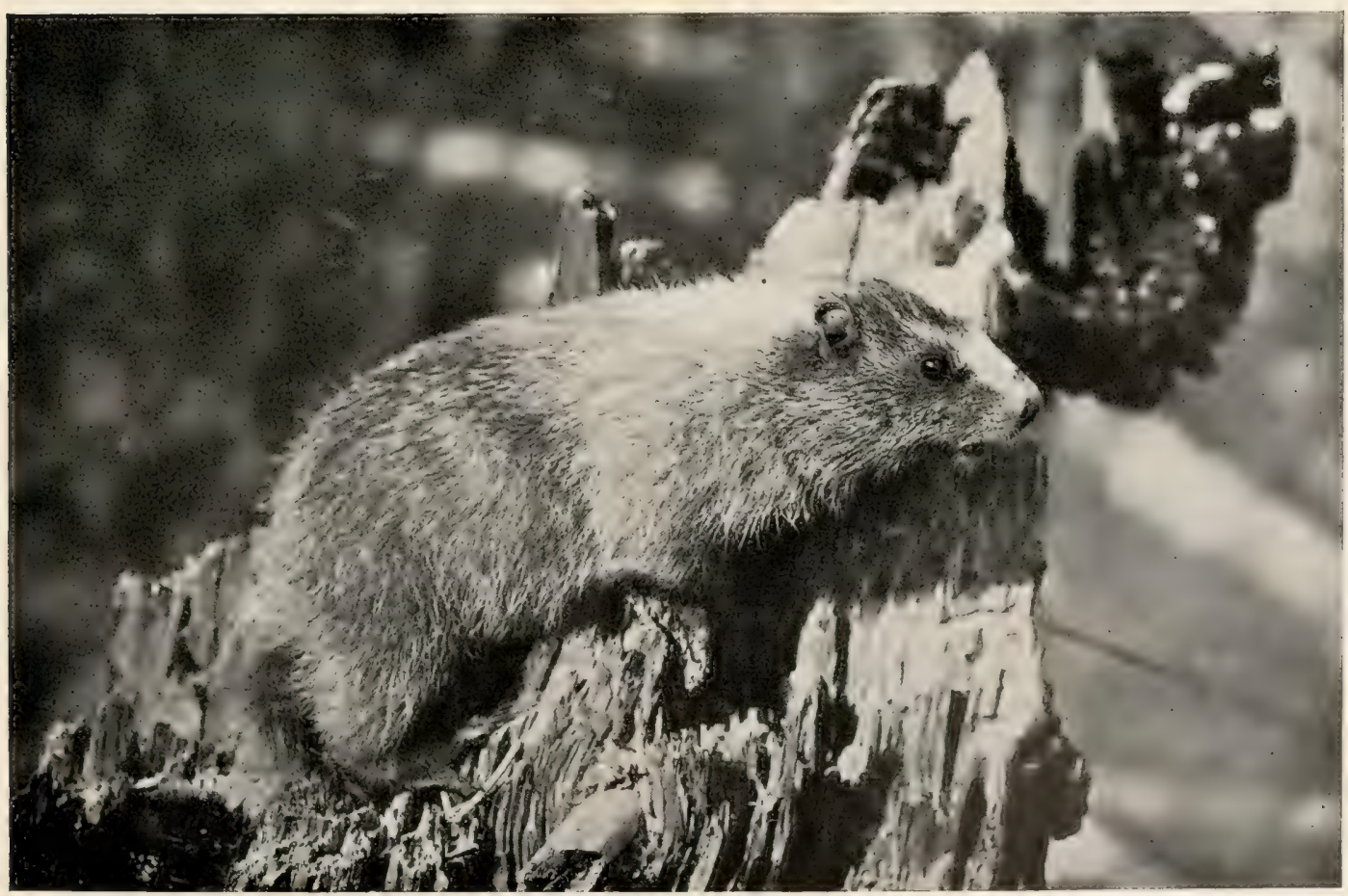

HOARY MARMOT (Arctomys pruinosus)

By W. E. Carlin Closely related to our Eastern Woodchuck 

the upper side of a branch and drink the sap that fills them, coming back a dozen times a day for the sweet refreshment.

They are hearty meat-eaters at all times, though beyond robbing birds' nests they are anything but successful hunters. But they follow the more successful hunters to take advantage of their luck, and annoy the trapper by stealing the bait from his traps. Most red squirrels are not satisfied with a single habitation. They must have an underground hole beneath the roots of a tree at all events, and in addition either a nest among the branches, or in a hollow tree, or both.

When they can get possession of the deserted nest of a hawk or crow, they roof it over with moss and strips of bark and pine needles and have a snug home for all weathers.

In most pine groves there are more such nests occupied by red squirrels than by the original owners.

At other times they arrange a platform of twigs in a crotch or against the trunk, and supported by small branches, build their nest on this, using wet moss and cedar bark and thatching it over with pine needles. They also make nests of soft grass in hollow logs and stumps or beneath a pile of wood. Red squirrels are most erratic when it comes to laying up stores for winter, sometimes they will pack away half a bushel of nuts or apples in a hollow tree, but often it is two or three in one place and a dozen in another.

Holes beneath stumps and flat stones are favourite hiding places of theirs. At other times they make little piles of nuts on the ground and cover them up with leaves, probably intending to transfer them to safer hiding when the rush of harvesting is over. They will also wedge nuts, one in a place, in the forks of small branches, and in cracks in the bark.

\section{Varieties of the Red Squirrel}

1. Northern Red Squirrel. Sciurus hudsonicus gymmicus Bangs. - Description and range as above.

2. Southern Red Squirrel. S. hudsonicus loquax Bangs. Larger and brighter red in winter with under parts always pure white.

Range. Southern Maine, Michigan and Minnesota to Virginia and Indiana, except in the Alleghanies. 


\section{Flying Squirrel}

3. Labrator Rid Squirrel. S. hulsonicus (Erxleben). Red colour in winter paler, fringe on tail yellowish or gray, lower parts decidedly gray.

Range. Labrador and Hudson Bay region to Alaska. Numerous red squirrels inhabit the Western States, those on the North West coast being quite brown in color.

\section{Flying Squirrel}

\section{Sciuropterus volans (Linnæus)}

Length. 9.40 inches.

Descriftion. Fur soft, dense and mole-like; skin of the sides produced and susceptible of being spreald out when the legs are extended, so as to form a sort of parachute. Drab above, irregularly tinged with russet, slightly brighter in summer; under parts pure white to the roots of the hair.

Range. Northern New York and Southern New England to Georgia and west to the plains. A slightly different variety replaces this in Florida, while in the Northern part of its range there occurs a much larger, quite different species. (See below.)

Flying squirrels are so persistently nocturnal that it is extremely difficult to learn much about their habits. Yet they are such beautiful, gentle, dreamy-eyed little forest folk, that one cannot help wishing to know more about them. What do they do with themselves in the quiet woods all night long, pattering about among the leaves?

If you watch with exceeding patience, you may see them in the dim light sailing from one tree to the next, but life is hardly long enough to learn much about them in this manner.

When you have found a flying-squirrel tree it is easy enough to rap on the bark with a stick and rout them out into daylight, and make them show off their power of flying to your satisfaction; but that will be about all you will get out of them at such times.

I have made them come out on dark cloudy days and watched them patiently, but their patience far exceeded mine; in fart, I am not quite sure that they did not even gro to sleep clinging there against the bark, like lichens, which they so much resembled as to suggest that their clouded cream buff colouring might 

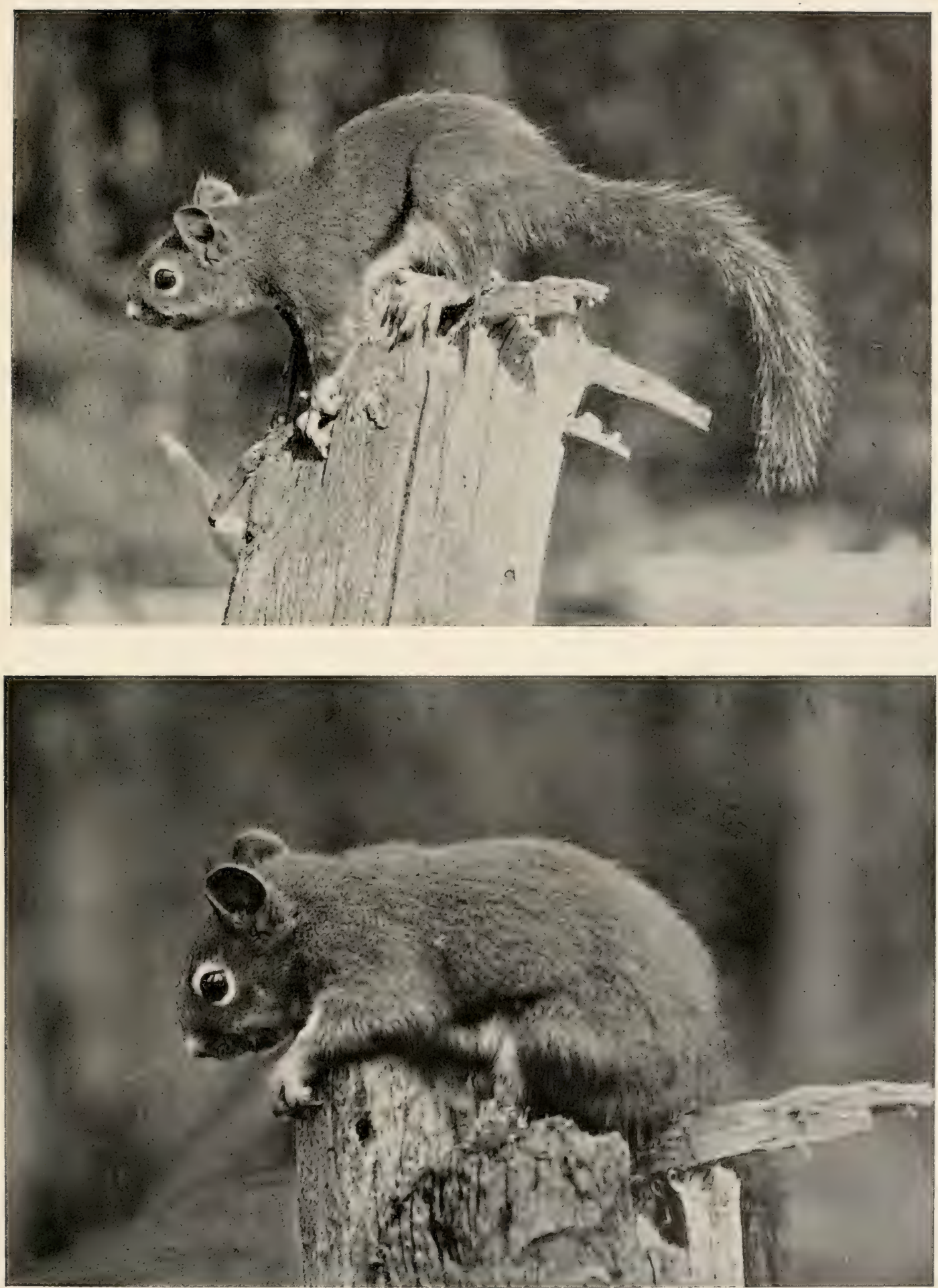

PINE SQUIRREL (Sciurus hudsonicus richardsoni)

By W. E. Carlin

A Western representative of the Eastern. Red Squirrel. Photographed in the Bitter Root Mountains, after many trials, by baiting with a species of cone. 

serve them well at imitating the fungus growth or the bark of a dead tree. Such protective copying is to be seen all through the woods. On the sime trees I noticed small, dull-white, half-moon-shaped patches of fungus, and on closer inspection found that fully two-thirds of them were moths flattened against the under sides of the branches to avoid the drip of the rain.

Unless disturbed, Flying Squirrels pass the day asleep in their warm nesis, generally in some deserted Woodpecker's hole or natural cavity in a decayed tree-trunk, though they are quite ready when opportunity offers to establish themselves in holes about the eaves or in the garret of the farm-house. The cold winter months seem also to be passed in the same way, if, indeed, the little animals are not entirely torpid at this season.

During the milder parts of the year they come forth about dusk, and, so far as we know, their activity continues throughout the night. From tree to tree they go in pursuit of food or chasing one another about in pure enjoyment of life and motion. Alighting upon a treetrunk they always go upward, scrambling and jumping until they reach the topmost branches, when they launch forth in their parachutelike descent, their legs stretched out to the utmost, so as to extend the folds of skin on either side, to which they owe their power of sailing. Flight it cannot properly be called, since they can only glide downward until just about to come to rest, when by a deflection of the body they are enabled through their momentum to shoot up diagonally a few inches and grasp the tree-trunk, ready for another climb. They sometimes cover long distances when they start from a considerable altitude, and Doctor Bachman states that he has seen them sail from the top of one tree to the base of another fifty yards away.

The young are reared in the nests and vary in number from two to four. Doctor Merriam has found them in the Adirondacks halfgrown by the end of April.

In their food Flying Squirrels are not very particular. They subsist mainly upon nuts, and, from Doctor Merriam's experience, seem to prefer acorns, hazel and beech nuts. Insects, he states, particularly beetles, do not go amiss, and they are also known to eat portions of dead birds. Some of these little animals regularly find their way into our cabin in the pine woods of New Jersey, and here they vary their diet to a considerable degree, sharing with the White-footed Mice any scraps of victuals that may be left exposed.

As pets Flying Squirrels are exceedingly gentle and affectionate 


\section{Flying Squirrel}

When raised from the nest they become perfectly accustomed to the presence of human beings, and seem to delight in clinging to one's clothing and taking refuge in any convenient pocket.

Professor F. H. King, in describing some that he kept in his house, says: "I have never known wild animals that became so perfectly familiar and confiding as these young squirrels did; and they seemed to get far more enjoyment from playing upon my person than in any other place, running in and out of pockets and between my coat and vest. After the frolic was over they always esteemed it a great favour if I would allow them to crawl into my vest in front and gro to sleep there, where they felt the warmth of my body; and it was very rare indeed during the first six months that they failed to ask the privilege; indeed, they came to consider themselves abused if turned out. When forced to go to sleep by themselves, the attitude taken was amusing: the nose was placed upon the table or other object it happened to be upon, and then it would walk forward over it, rolling itself up until the nose almost protruded from between the hind legs; the tail was then wrapped in a horizontal coil about the feet, and the result was an exquisite little ball of life in soft fur which it seemed almost sacrilegious to touch."

\section{Species and Varieties of Flying Squirrels}

We have two very different flying squirrels in the East, each divisible into two slightly different races.

1. Southern Flying Squirrel. Sciuropterus volans Linnæus. Description and range as above.

2. Florita Flying Squirrel. S. volans querceti Bangs. More russet than the preceding, somewhat rusty on the under parts.

Range. Replaces the last in southern Georgia and Florida.

3. Northern Flying Squirrel. S. sabrinus macrotis Mearns. Larger than the above (11.25 inches long), with the fur of the under parts always graly at the base. Colour, cinnamon brown in summer, sooty brown in winter, a black ring around the eye.

Range. Maine, southern Canalda, and the mountains of New York (probably also in the Alleghanies).

1. Severn Ricer Flving Squirrel. S. sabrinus (Shaw). Still larger ( 14 inches long), with shorter and broader ears. Range. Arctic America to northern Canada. 


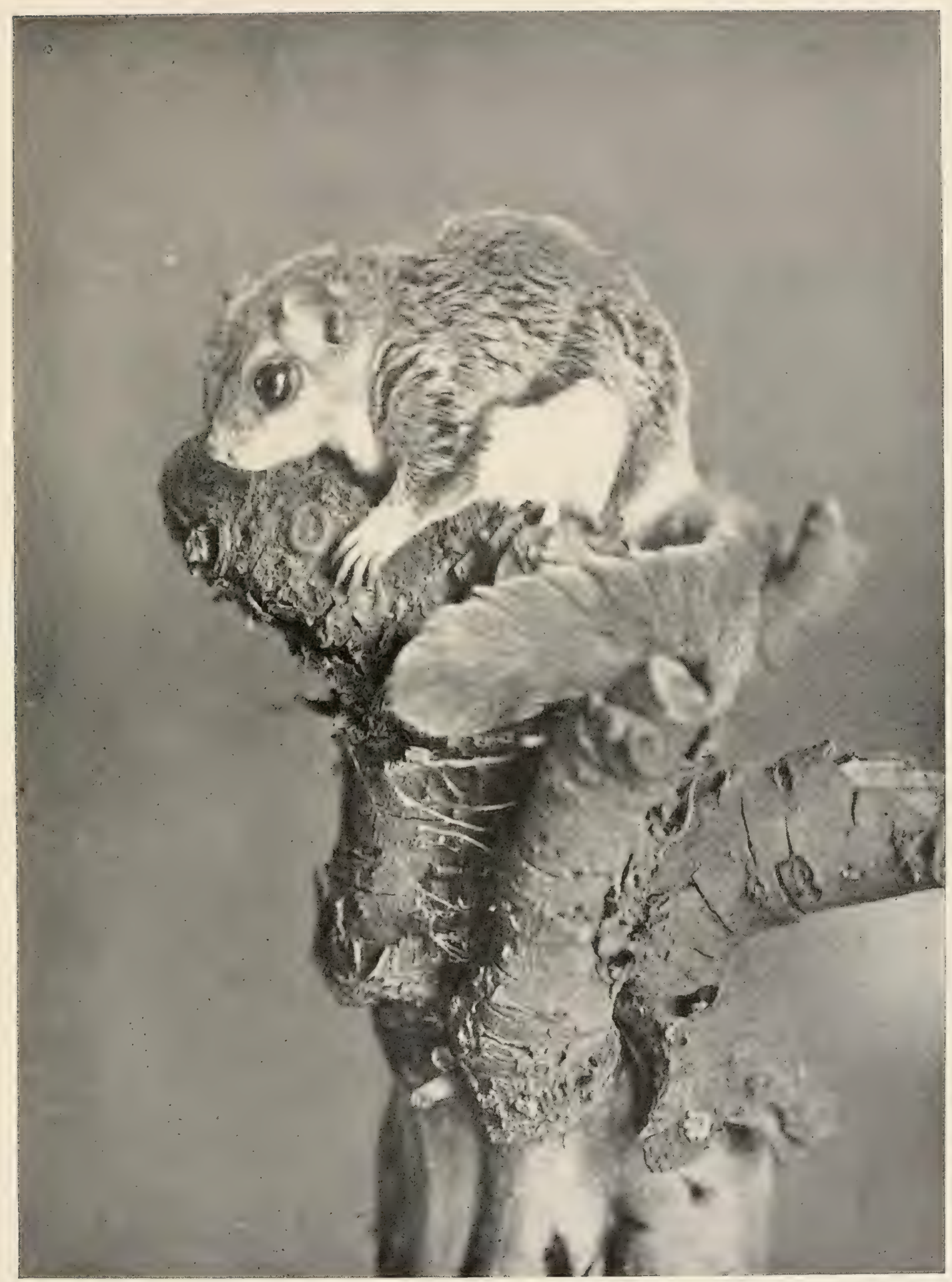





\section{MOLES AND SHREWS}

\section{(Insectivora)}

THE animals of this order are distributed in all parts of the world except Australia. The only representatives in North America are the shrews and moles, and, indeed, these two groups make up the bulk of the order throughout its range.

Nearly all the insectivores are terrestrial, the moles burrowing in the ground, the shrews living in burrows and also on the surface. They are mairily insectivorous as their name implies, though some species vary their diet.

Our American species are all of small size and are clothed with very soft, silky fur. The eyes are small and rudimentary, while the teeth bear considerable resemblance to those of the Carnivora.

Our two families may be distinguished as follows:

I. Shrews. Family Soricida. Fore feet similar to the hind ones and not modified for digging. Appearance mouselike, but with a much more slender-pointed snout. Scarcely a trace of an external ear.

II. Moles. Family Talpida. Fore feet very broad and turned on edge, specially adapted for digging. No external ear whatever.

\section{SHREWS}

\section{(Family Soricide)}

Our shrews are all of small size, some of them being the most minute mammals known. They have the same soft fur as the moles, but both eyes and external ears are better developed though still inconspicuous, as we should expect, from their living more or less in subterranean runways.

They form three well marked groups: the short-tailed shrews, long-tailed shrews and the marsh shrews. 


\title{
Short-tailed Shrew
}

\author{
Blarina brevicauda (Say)
}

\section{Called also Mole Shrew.}

Length. 5 inches.

Description. Rather stcut, tail short, about one-quarter the length of the head and body. Colour: sooty plumbeous, slightly lighter helow; varying in depth in changing light as the fur is disturbed. Front teeth chestnut coloured at the tips. Range. Atlantic States to Nebraska, south to Ohio, Maryland and the mountains of North Carolina. Replaced southward by slightly different varieties.

There is a class of little beasts common enough throughout all our Northern States, yet hardly known by name or otherwise. Resembling the mice in outward apppearance; in their manner of living and getting their food they may almost be said to copy the habits of the weasels. They have the lithe, supple bodies and short legs of the weasel tribe without the characteristic slimness of form; their flesh, like that of the weasel's, is dark, fibrous and strong smelling. This might be attributed to their similarly carnivorous habits, if it were not true that the flesh of most meat-eating animals is comparatively light-coloured and tender.

It might even be objected that shrews are not truly carnivorous but insectivorous, the fact that they are actually the smallest of heasts rendering them powerless against all but a very few of their kindred.

But ravenously fond of all kinds of flesh they certainly are, and I believe that the young of the smaller ground-nesting birds and perhaps young mice are frequently eaten by them. It would not greatly surprise me to discover that they occalsionally attack creatures larger than themselves. Of the several distinct species that should be found in most of the Eastern States, I have found but one really abundant. This one is catalogued as the mole shrew, and is found almost everywhere in great numbers. It is commonly mistaken for a genuine mole, and small wonder; about the only conspicuous difference being in the size of the fore feet, A mole's fore feet are broad and hand-shaped to the extent of 
being a deformity, and stand out from the shoulders like flippers. A shrew's feet, on the contrary, including those of the little chap under discussion, are perfectly normal in appearance and like those of mice.

The mole shrew is four or five inches long, the tail about one. It has a cylindrical, pig-like body, and dark ashy gray fur, lighter beneath. They are obstinate, savage, little brutes, but are unquestionably of immense service to the farmers, spending their lives in a most vigorous pursuit of insects of all kinds. They combine impartially the habits of the moles and shrews, sometimes burrowing along just beneath the turf which they push up in low ridges which intersect each other, apparently quite at random, without exhibiting any of the system characteristic of the works of the mo!e.

This is evidently done in search of insects, though the tunnels made in this manner are afterwards used as runways, and it may be for nurseries. This partially underground existence shows its effect on the species, not only in the mole-like shape of the body, but in the size of the fore feet, which are a little larger and broader than the hind ones, the fore feet of the other shrews being small and delicate.

But the mole shrew in adopting the habits of the moles has not given over the ways of its own people by any means. A true mole on the surface of the ground is a creature completely out of its element, its chief desire being to bury itself from sight as quickly as possible. The mole shrew, on the contrary, spends much of its time in the open air from preference, running about over the fallen leaves of the forest or along the shaded galleries of stone walls, which it is as fond of following as is the weasel.

Their keen noses enable them to scent meat at a considerable distance, and when they have succeeded in finding any that may have been left by the larger hunters, they fall upon it ravenously, tearing at it and devouring it with all the ferocity of wolves.

One that I caught in a trap had already, when I found it, disposed of the raw meat, which had served as bait, and when confined in a cage immediately seized upon whatever meat was offered it, whether raw or cooked, without discriminating between kinds. Beef, pork and cold chicken-all went the same way, while the fury of his appetite was being appeased. Both in 


\section{Short-tailed Shrew}

eating and drinking the projecting taper-like nose or trunk was turned up in order to enable him to use his mouth more freely, for a shrew's mouth opens from beneath almost like that of a shark. The sensitive trunk is doubtless of service in poking about beneath the leaves and in soft earth after worms, of which the mole shrew is particularly fond.

Many of them take up their winter quarters in cellars where they forage around in dusky corners for worms and insects, or help themselves to whatever meat is left within their reach. Their holes are dug into the surrounding soil and are probably being multiplied and extended throughout the winter in search of worms.

There is no increasing pile of dirt at the entrance to indicate the little miner's progress, however. Like a true mole, he disposes of the loose earth by pressing it aside as he goes along, making a clear passage with smooth, compact walls.

None of the shrews appear to hibernate, and whether the mole shrew ever passes the entire winter burrowing about in the ground beneath the frost, or not, is hard to determine. The genuine moles are believed to occupy themselves in this manner all winter long and, of course, it is quite possible that the mole shrew may do likewise, but I have my doubts about it.

At all events, numbers of them are out on the surface of the snow, even in the very coldest weather, when the ground beneath is like stone. Part of their food at such times is obtained by gleaning after the owls and foxes and other hunters of the woodland. If they depended on this alone most of them would starve long before spring, as even in warm weather they require food oftener than almost any other creature of their size, and though insects in small numbers are always to be found on the snow, these would hardly suffice to appease a mole-shrew's hunger. I believe that they get the greater part of their food at this season by burrowing about among the dead leaves beneath the snow in the forests, gathering the dormant insects that habitually pass the winter in such places.

The disagreeable, musky smell which they emit when frightened or angry serves to protect them from many of the maratuders of the forest, but not from all. Owls of all kinds appear to be well pleased with their flavours, and catch and devour them in large numbers. 
Neither are wease's to be cieterred by their odour from including them as a regular article of diet, but cats, and I believe a majority of the hawks, only eat them when compelled to by stress of hunger, though they frequently kill them, either mistaking them for mice, or else doing it for fun.

I have often picked up recently killed specimens that bore the unmistakable marks of the claws of a bird of prey, while cats are forever bringing them home from their hunting trips and leaving them about on the lawn or in the paths. I have never known a cat to bring one of them into the house, or show the least atom of pride over its capture. Even the most inexperienced of kittens, who invariably go off into perfect ecstasies of delight if they have succeeded in bagging a baby mouse, or a fledgling fallen from the nest, show only indifference or contempt when there is only a mole shrew to exhibit.

Foxes, I believe, usually bring them home for the cubs to play with, as they do everything else that comes within their reach in summer, but I am inclined to think that such unsavoury morsels are seldom used as food by them during the season of abundance, though undoubtedly there are often times in midwinter when many a fox is glad to get even a mole shrew for supper.

\section{Species and Varieties of Short-tailed Shrews}

Beside the common short-tailed shrew and its several geographic varieties, we have another quite distinct smaller species of a different colour. The eastern species and var1eties are as follows:

1. Northern Short-tailed Shrew. Blarina brevicauda (Say). Description and range as above.

2. Southern Short-tailed Shrew. B. brevicanda carolinensis (Bachman). Smaller throughout, otherwise similar.

Range. Southern Indiana and Virginia to Florida.

3. Everglade Short-tailed Shrew. B. brevicauda peninsule (Merriam). Grayer than the last, with larger feet.

Range. Tropical Florida, especially in the Everglades.

4. Brown Shrew. B. parva (Say). Very distinct from any of the above; colour dark-brown or iron-gray, ashy below; occurs in the same localities as the short-tailed shrew and doubtless is identical in habits.

Range. Nebraska to southern Pennsylvania and New Jersey and southward, except in the mountains. 
5. Florita Brown Shrew. B. floridana Merriam. Rather larger, with narrower skull and white teeth.

Range. Tropical Florida.

\section{Common Shrew}

\section{Sorex personatus Geoffroy}

\section{Called also Long-tailed Shrew, Shrew Mouse.}

Length. 3.75 inches.

Description. Small and slender, with a long-pointed snout supporting long "whiskers." Tail nearly as long as the head and body. Colour dark-brown above, hairs slaty at their base, brighter on the rump, and shading gradually to gray on the underside.

Range. Canada to Indiana and southern New Jersey, and in the Alleghanies to North Carolina. A somewhat similar shrew is found in the low ground in North Carolina and several others in the North. (See below).

The common shrew or shrew mouse is a smaller and much more attractive little animal than the short-tailed shrew. The smaller varieties are easily the smallest of our quadrupeds; a common mouse looks overgrown and clumsy beside one of them.

Shrew mice are active throughout the winter, skipping about over the surface of the snow from tree to tree, poking their delicate, proboscis-like noses into crevices of the bark, and investigating the dark interiors of hollow trees at the bottoms of which they have to root about in the crumbling wood and vegetable mould for their accustomed prey.

Underneath wood piles and logs are favourite haunts of these funny little beasts, and I believe that it is in such places as these that they bring up their families. Both in winter and summer they appear to prefer the neighbourhood of such little streams as neither freeze nor become stagnant at either season.

Like all of the tribe of insect eaters this little shrew finds the summer drought the most disastrous season of the year; at such times many of them perish, evidently from thirst.

I have never had an opportunity of observing their method of hunting in wirm weather. All the living specimens that I have found, except in winter, were crouching bencath old boards 
or wood piles, but knowing their choice of food and the places they inhabit and their quaint way of getting about, it is easy to imagine them stalking crickets and beetles in the shade of the humbler growth of the forest. No doubt they get lots of fun and breathless excitement and suspense before certain of the larger and more active insects are subdued. With the exception of some of the weasels they are perhaps the most hot blooded, energetic, excitable little beasts alive.

Dr. Merriam, speaking of their voracious habits, states that he once confined three of these restless little beasts under an ordinary tumbler. "Almost immediately they commenced fighting, and in a few minutes one was slaughtered and eaten by the other two. Before night one of them killed and ate its only surviving companion, and its abdomen was much distended by the meal. Hence in less than eight hours one of these tiny wild beasts had attacked, overcome, and ravenously consumed two of its own species, each as large and heavy as itself." Of the rapid progress of the shrew when at large, he says, "if one is sitting quietly in the woods it sometimes happens that a slight rustling reaches the ear. There is no wind but the eye rests upon a fallen leaf that seems to move. Presently another stirs and perhaps a third turns completely over. Then something evanescent, like the shadow of an embryonic mouse, appears and vanishes before the retina can catch its perfect image . . . Its ceaseless activity, and the rapidity with which it darts from place to place is truly astonishing, and rarely permits the observer a correct impression of its form."

I have never seen a live marsh-shrew though I have hunted and set traps for them along various little brooks and similar moist and watery places. It would appear that they occupy much the same position among the shrews that minks and otters hold in the weasel tribe, swimming about or diving beneath the surface for minnows or water beetles, or racing along the margin to stop here and there to overturn wet leaves or dig in the mud for worms.

Tadpoles and caddis worms and the multitudinous variety of wriggling larvæ that inhabit the bottoms of little brooks must furnish them with sufficient food at all seasons. In all likelihood they also make frequent excursions to higher and drier ground as the whim seizes them. 
They are considerably larger than the common shrew and darker coloured, black above and white or ashy beneath; like muskrats they have the hind feet and tail broadened and fringed with stiff hairs for swimming.

\section{Species and Varieties of Long-tailed Shrews}

There are a number of minute long-tailed shrews which are perfectly distinct from one another, but so smali are they and so much alike in superficial appearance that it is hard to distinguish them without dealing with technical terms. If we examine

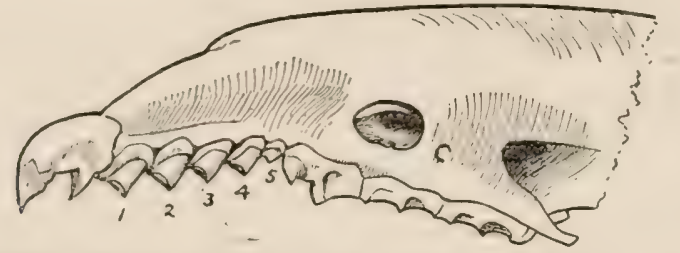

Upper jaw of Shrew enlarged, showing "unicuspid teeth." (After Miller.)

the teeth of a shrew we will find in the upper jaw three kinds: first, a pair of large protruding incisor teeth in the front, almost tusks when we consider the size of the shrew; second, three large teeth (molars) on each side in the back of the mouth, and third, four or five simple pointed teeth on each side, situated between the other two. These last are called (in the shrew) unicuspid or single pointed teeth, and furnish us the best aid in distinguishing these little animals.

Our species may be grouped as follows:

A. Length 3.80-4.60 inches. Five unicuspid teeth on each side A1. TAIL LESS THAN I.80 INCHES

1. Common Shrew. Sorex personatus Geoffrey. Description and range as above.

2 Labrafor Shrew. S. personatus miscix Bangs. Larger, paler and gralyer.

Range. Labrador and Hudson Bay region.

3. Smolil Shrix. S. fumells Miller. Larger than the common shrew, and dark slate coloured, shidding into lighter ash? below, browner in summer.

Rance. Colder and mountainous regions, New England, New

York and in the Alleghanies. 
4. Southern Shrew. S. longirostris Bachman. Externally very much like the common shrew, but with the snout and skull much larger, and the third unicuspid tooth smaller than the fourth.

Range. Bertie Co. and Raleigh, North Carolina.

5. Fisher's Shrew. S. fisheri (Merriam). Similar but larger and duller.

Range. Dismal Swamp, Virginia.

\section{A2. TAIL VERY LONG (2.20 INCHES) AND HEAVY}

6. Long-tailed Shrew. S. macrurus Batchelder. Above, dark slate, below, smoky gray. Easily known by the very thick tail with a rather long pencil of hairs at the tip.

Range. Higher parts of the Adirondacks and Catskills.

B. Very small; length 3.20-3.40 inches. Apparently only four UNICUSPID TEETH ON EACH SIDE, THE THIRD BEING EXCEEDINGLY SMALL

7. Hoy's Shrew. S. hoyi Baird. Brown above, shading to gray beneath, a touch of fulvous between the front le;s. The smallest North American mammal.

Range. Minnesota to Nova Scotia and the Adirondacks.

\section{Marsh Shrew}

Sorex albibarbis (Cope)

Also called Water Shrew.

Length. 6 inches.

Description. Shaped like the common shrew but much larger, with a body nearly the size of a Blarina. Colour, blackish slate, chin whitish beneath clouded with dusky. Tail, dark above, white below.

Range. Labrador and Canada to the Adirondacks and Alleghanies of Pennsylvania. From Minnesota west occurs a browner species (S. palustris) and still others on the Pacific coast. 


\section{MOLES}

\section{Family Talpida}

\section{Common Mole}

\section{Scalops aquaticus (Linnæus)}

\section{Called also Naked-tailed Mole.}

Length. 6.40 inches.

Discription. Hands large and naked with powerful nails, hind feet small and of usual shape, snout long and pointed, tail short and naked. Fur glossy silvery gray, varying in shade when disturbed or placed in different light; often tinged rusty.

Range. Southern Canada, southward in the lowlands to Florida, where it is represented in the southern part of the peninsula by the somewhat smaller Florida mole ( $S$. aquatius floridimus). A browner variety also occurs on Anastasia Island, Fla., the island mole (S. anastasce Bangs).

Our common mole differs but little from the well-known mole of Europe that for centuries has disfigured the rich English lawns to the rage and disgust of the gardener.

Our species is responsible for the little heaps of new earth which, with each recurring summer, are thrown up to deface our own lawns. Morning after morning new hillocks stand out defiantly, extending the line of diminutive earthworks along the turf.

These heaps are not true mole-hills, but just the loose earth throv'n up by the little miner as the easiest way of being rid of that which he displaces in digging for worms.

His work being usually carried on at a depth of five or six inches, it is evident that he must dig the earth away with his forepaws until it comes within reach of his hind feet with which he kicks it still further back.

When a certain amount has gathered behind him, judging from observations, I should say enough to fill the tunnel for a space of five or six inches, he manages, somehow, to push the whole along the narrow passage to the last opening made to 

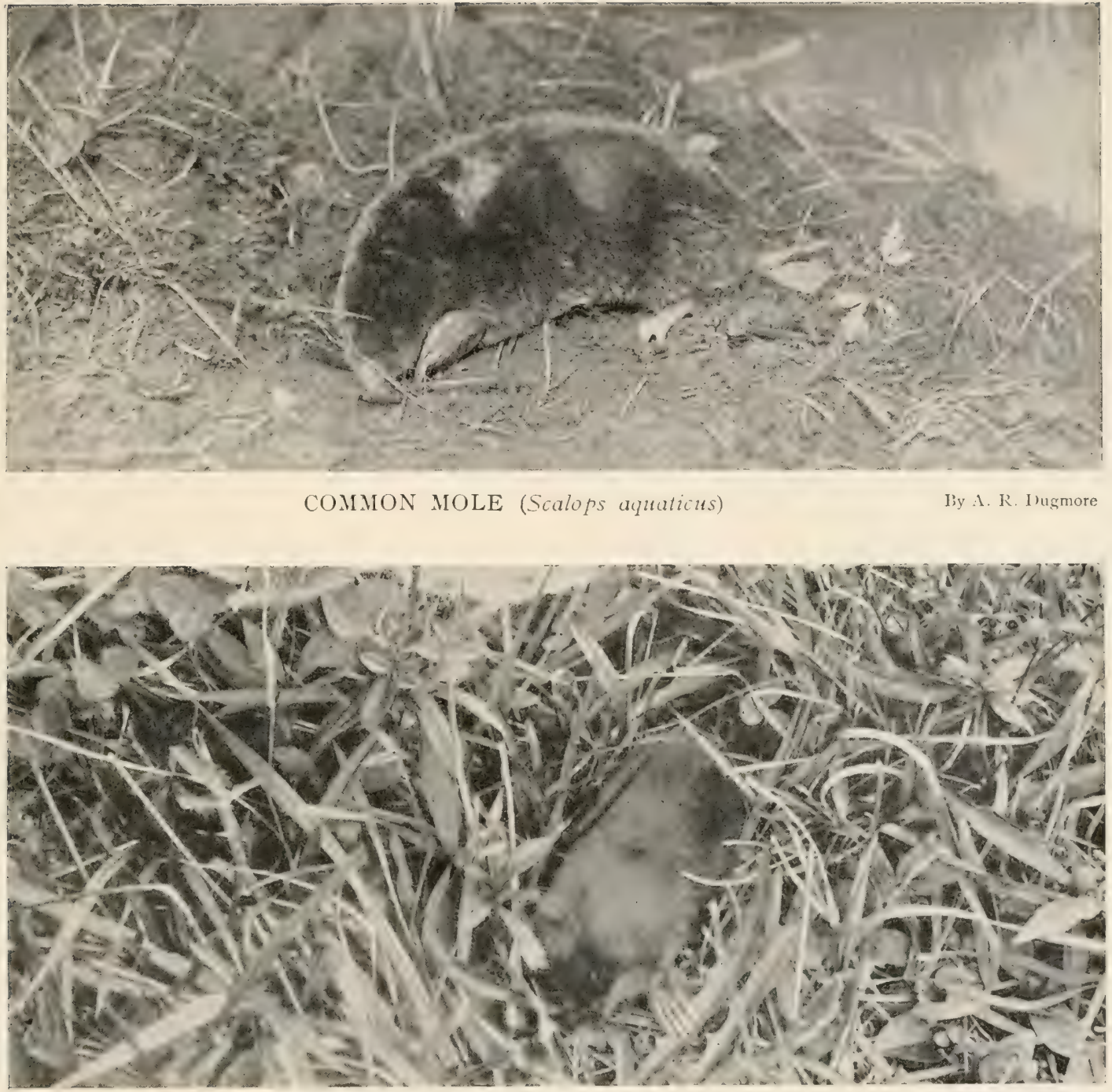

STAR-NOSED MOLE (Condylura cristata)

By C. William Beebe

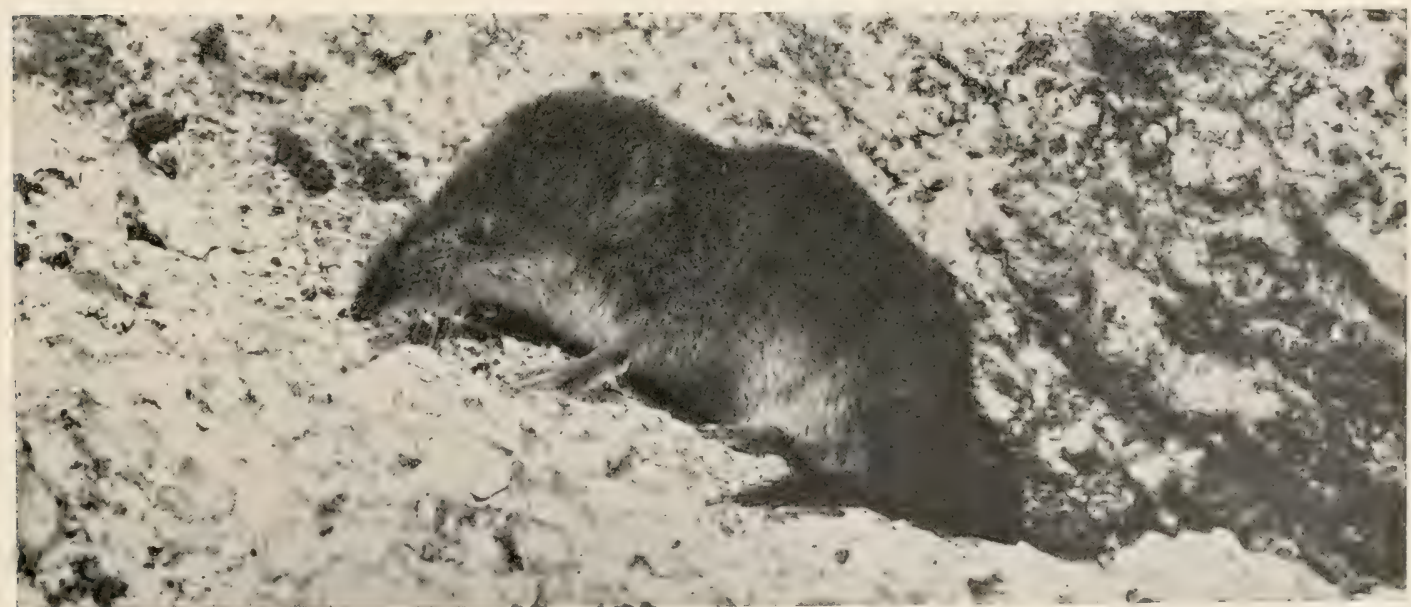



the surface. It must require a great deal of strength to accomplish this, taking into consideration the tendency lawns have for packing under such conditions. By the time he has attained a distance of a yard or more from his last dumping place, the exertion apparently becomes too great and he opens up a new outlet to the surface, and another heap is started. In this manner and in sleeping the mole spends practically all his time; forcing his unlighted way along with gimlet-like nose and scooping feet, the confining earth crowding in all about him, restricting every movement of his body.

In winter he conducts his labours at a greater depth in order to escape the frost. In spring I have found recently made tunnels in the subsoil four feet or more below the surface.

The American mole is also said to construct true mole-hills similar to those of the more famous Old World species though more deeply submerged.

A real mole-hill is an ingenious arrangement of galleries in the hard-packed earth, surrounding the nest-chamber as a safeguard and a means of escape. Two galleries encircle the chamber at distance of a few inches one above the other, and connected with it and with each other by numerous short passages, insuring a quick and certain means of retreat in any direction. From the lower gallery other passages decend to the main roadway of the colony, which is an extended passage always kept open and free from obstructing roots and earth, and used by all the individuals of a colony in going from their nest to their diggings.

1 have never seen much evidence, however, that our common mole works in colonies as the star-nosed and European species do. It seems to me rather that each starts off by himself as soon as he is able to dig alone, burrowing along at random in whatever direction food appears to be most abundant.

\section{Brewer's Mole Parascalops breweri (Bachman)}

Also called Hairy-tailed Mole.

Length. 5.80 inches.

Description. Dark gray, tail blackish and thickly haired, rather longer than that of the preceding; nose and hands similar. 
Range. Northern North America, south to the mountains of New Jersey and the Alleghanies.

This is a distinctly northern animal, occurring for the most part above the range of the common mole. Its habits seem to be essentially similar to those of the latter species, though, according to Prof. Baird, it constructs its burrows at a greater distance below the surface of the ground. Dr. Nerriam, who found it common on the edge of the Adirondack wilderness, though not in the coniferous forests, says: "Its habits, so far as I am aware, resemble those of its nearest relative (Scalops aquaticus), except that its mounds do not contain a chamber and surface-opening, and its galleries are usually malde a little deeper. Like this species, it is most common in dry meadow lands, while the star-nosed is usually found in moist and swampy places. It is not known to indulge in the little 'noonday excursions' which are characteristic of the last-named species."

On the Pennsylvania Alleghanies this mole occurs in company with various other northern animals and birds, which find there, in the higher altitude, the same congenial conditions of environment that prevail at lower levels much farther north.

\section{Star-nosed Mole}

\section{Condylura cristata (Linnæus)}

Length. 6.80 inches.

Discriftion. Dark brownish gray, paler beneath, tail long and hairy-sometimes very thick at the base. Snout with a remarkable naked appendage, somewhat resembling a star. Range. Northern North Americal, south through the middle states and farther in the mountains.

The star-nosed mole is a creature almost as well-fitted for a partially aquatic life as the otter and mink, and, as a matter of fact, does pass most of its time about the water; pushing extensive tunnels through the black peaty soil of swamps and along the borders of little brooks and ponds. The soft, black loam is thrown up in frequent heaps a foot, more or less, in diameter: the opening of the hurrow being under the bank, and as often leneath the water als above. The tunnel itself must frequently be flooded to the great discomfort of its inmates. 
I have never found their nests or young, and can not help wondering how they manage in times of freshet, when the meadows and swamps where they dwell are submerged.

But the old ones show no fear of the water; I have frequently seen them swimming both under water and on the surface, even where the current was pretty strong, and have always observed them to be perfectly confident and unfrightened at such times.

Drought seems to affect them much more severely than freshet, and in hot weather, after a few weeks without rain, many of them are to be found dead, evidently having perished from thirst. The star-nosed mole feeds principally upon worms and whatever else of insect life it comes across in its underground rambles, and judging by the carnivorous tastes of its relatives, I have little doubt that it varies this diet with small fish and reptiles and their eggs as well as the flesh of warmblooded creatures whenever it is to be obtained.

If they really hibernate in winter it must be only in an interrupted sort of way, for it is not very uncommon for them to be out along unfrozen brooks in the coldest weather, and certainly either this or the common mole is often moving about just beneath deep snow, the peculiar position of the fore paws of the creature leaving a track not easily to be confounded with that of any other animal.

The most feasible theory would seem to be that they pass the winter deep down in the swamps, below the reach of the frosts, where they may carry on their subterranean work at their leisure, occasionally entering brooks to swim about beneath the ice in pursuit of water-beetles and the like.

One, which I caught in the early part of last February, I90 I, must have been swimming near the middle of the brook not far from the bottom, where the water was six or eight inches deep; and although it had been in the trap under water for several days where I found it, its fur still kept out the water and dried as readily as otter fur, exhibiting the true quality of the coat of a swimming animal.

What is the life of these little earth folk like? They see and know little of the things most familiar to us and the other creatures that love the sun-warmed air and the sky.

Most so-called nocturnal creatures are fond of the sun and 
bask in it at mid-dily, even those that are most active at night like their sun-bath at noon.

But these little "ground-dwellers" actually appear to dislike the touch of the sun from the manner in which they avoid it. They can know little more of the grass and flowers than the moist touch of the colourless root fibres that fringe the ceilings of their tunnels and the first tender shoots of the water-plants they encounter beneath the ice months before winter shows signs of breaking above ground.

Rare water-beetles and the larvie of insects, which famous entomologists would gladly give years of patient study to learn more about, must be every-day common-place matters to the mole, but whether his "dim-eyed understanding" holds any definite image of the things he so diligently searches for or not is never to be known. Does he really distinguish between the various kinds, I wonder, more than their taste and the crunch of their crisp wing covers between his teeth? I feel certain, that while he is digging away earnestly down in the dark for his dinner, such dull thought as he has is centred on the prospects of a lucky catch, and naturally certain species of fat and well-flavoured grubs would appeal more strongly to his appetite than others.

By the law of just compensation, his immense appetite and the matter of eating, which occupies so very much of his time, ought rightly to yield him a great deal of pleasure, there seems so little else for him to enjoy. 


\section{BATS}

\section{(Chiroptera)}

BATs are at once separated from all other mammals by their peculiar modification for flight. The fore-limbs are much elongated, especially the fingers, and a thin extensible membrane stretches over this frame-work, connecting also with the sides of the body and the hind legs. Another membrane stretches between the hind legs, known as the interfemoral membrane.

Besides their flying apparatus, bats are peculiar in having their hind legs twisted around in such a way that the knee bends backwards, which render it exceedingly difficult for them to walk, a mere flapping shuffle being the result of their best efforts. On the wing, however, their movements are exceedingly graceful, and they turn and wheel in their varied evolutions with the greatest ease.

Other structures frequently mentioned in the description of bats are the peculiar leaf-like appendages to the nose and the

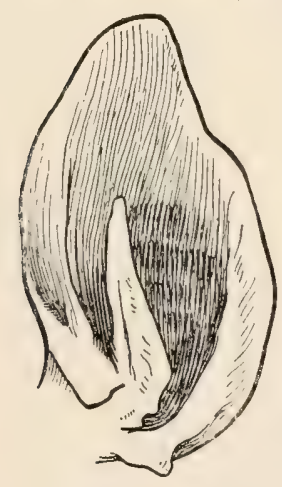

Ear of Bat, showing tragus. (After Miller) elongated lobe of the ear or tragus.

In their general anatomy and in their dentition, bats show a closer relationship to the insectivora (shrews and moles), and may, indeed, be regarded as a highly specialized off-shoot from that group.

Bats are distributed in all parts of the world, and vary in size from the small mouse-like species to the big flying foxes of the Malay region, the expanded wings of which measure as much as thirty inches from tip to tip.

These large bats and their allies are fruit all our Eastern American bats, are insectivorous, and feed while on the wing.

Bats are nocturnal in habits, and seem to be most active at dusk and early in the morning, just before dawn. The hours of day-time they spend at rest, hanging head downward by their 


\section{Leaf-Nosed Fruit Bat}

hind feet, in some dark building, cave, or hollow tree. In winter many bats hibernate in similar quarters, but there is also a southward migration of certain species, like that of the birds.

The voice of bats is exceedingly high-pitched and squeaking, and is most often heard when they have been captured or disturbed during retirement in the day-time.

In such of our eastern bats as have been studied during the breeding season, two young seem to be the regular number in each litter, and they are usually born in July.

Our American bats represent three families, as follows:

I. Leaf-nosed Bats. Family Phyllostomaride. Size large, tail usually wanting, a curious leaf-like appendage on the end of the nose.

II. Fre'tailed Bats. Family Noctilionide. Size rather small, tail present but the terminal half free from the interfemoral membrane, projecting beyond it. No appendage on the nose.

III. Common Bats. Family Vespertilionida. Similar to the last but with the interfemoral membrane reaching to the tip of the tail.

\section{LEAF-NOSED BATS \\ (Family Phyllostomatide)}

\section{Leaf-Nosed Fruit Bat}

\section{Artibeus perspicillatus (Linnæus)}

Length. 2.75 inches.

Description. Head broad and thick, nose-leaf, consisting of a high-pointed central lobe and two smaller lateral ones separated from the middle one by the nostrils. No tail. Interfemoral membrane reaching to the ankles, but much hollowed out in the middle. Colour, deep brown or gray, with more or less ashy tips to the fur. Range. Tropical America, north of Key West, Florida.

This is only a rare straggler to our southernmost coast, and is the only representative of the leaf-nosed or vampire bats that we have in the eastern United States, though one occurs in California and another in Texas. 
In tropical America they are numerous, and feed mainly upon fruit, as does the present species; two species, however, suck blood from living animals, and concerning them many fanciful stories have been written.

\section{FREE-TAILED BATS \\ (Family Noctilionida)}

\section{Florida Free-Tailed Bat}

\section{Nyctinomus cynocephalus (Le Conte)}

Length. 2.50.

Description. Ears nearly united on top of the head, sides of the snout with deep wrinkles, short spines on the muzzle and on the outside of the ear. Colour, plumbeous or dusky brown, fur whitish at the base.

Range. South Atlantic and Gulf states.

Habits apparently similar to the bats of the next family.

\section{Common Bats}

\section{(Family Vespertilionida)}

The bats of this family, found in the eastern United States, may be distinguished as follows :

A. EARs Very large, JOINEd TOGether by their Bases in Front.

B. EARS MOderate, NOT JOINED TOGETHER IN FRONT.

Big-eared Bat.

I. Interfemoral membrane covered completely with fur on the upper side, uniform with the back. Red Bat and Hoary Bat.

1). Interfemoral membrane naked or only sparsely haired, near the base.

1. Fur black, with silvery white tips. Silver-haired Bat.

2. Fur light, yellowish brown, banded or mottled with dusky.

Pipistrelle and Leather-winged Bat.

3. Fur dark, glossy brown, not mottled. Big Brown Bat, Little Brown Bat and Twilight Bat. 


\section{Big.-eared Bat}

\section{Corynorhinus macrotis (Le Conte)}

Length. 4.20 inches.

Descriftion. Ears very large, joined together in front; a round hump or swelling on each side of the head, between the eye and the nostril. Hair above, yellowish brown; below, grayish white, throat darker and tinged with yellow; all hairs dark brown at the base.

Range. Gulf coast north to Kentucky and South Carolina.

\section{Little Brown Bat}

\section{Myotis lucifugus (Le Conte)}

Length. 3.40 inches.

Description. Fur above, glossy brown; paler and more yellowish below; wing membranes naked except a narrow strip near the body.

Range. Whole of North America east of the Rocky Mountains. Covering the same range there is a very similar species, Say's Bat ( $M$. subulatus), with thinner membranes, longer ears and narrower skull. These and the Pipistrelle are the smallest of our bats.

Bats are easily the queerest things to be found in this part of the world.

In spite of their general abundance, and their way of congregating more thickly about dwellings than anywhere else, their ways are little known. We know, at least, that they are warmblooded, furry, milk-giving little inhabitants of dark, stuffy corners of old buildings and hollow trees. Awake, at the most. some four out of every twenty-four hours of their drowsy little lives, they never make any nests or even attempt to fix ove! the crannies where they hide and where the little bats are born. These helpless things are not left at home at the mercy of foritging rits and mice. When the old bat flits off into the twilighi the youngsters often go with her clinging about her neck, swinging away over the tree-tops and along the foggy water-side, while she chases the numberless little flying things of the dark. 
At times, however, she deposits them on the branch of a tree, where they hang sheltered by the leaves, while she goes off foraging by herself.

The wings of a bat might be pretty accurately described as abnormally-webbed fore feet. The bones of the fore arm and the fingers are lengthened and drawn out to such an extent, that a man in like condition would have fingers at least four feet long.

These slender finger bones are connected with each other, and with the hind feet and tail, by a thin, dark-coloured, parchment-like, almost naked skin. The wing, as a whole, corresponds exactly with the accepted idea of a devil's or goblin's wing; and the short, puggy head, with its big shapeless ears and wide mouth and little blinking eyes, is of just as impish and devilish an aspect.

Yet bats are the most gentle and friendly of living things. Not only do they seek out the shelter of our buildings and pass much the larger portion of their time there, but on hot summer nights, when they are all flying abroad, they actually seem fond of our society and flutter unafraid around us, just as swallows do in the sunshine.

The chief attraction may be the mosquitoes and other pests that come to torment us, but even if it is, the bats are still performing a friendly office, though from a selfish motive; and I believe that outside of that, they are still sensitive to the attraction which nearly every small animal feels towards any larger one who has never given it cause to be afraid.

According to the books there are four or five different species to be found in this part of the country, but the only sort that I have found in New Hampshire in any abundance is the little brown bat, smaller than the others, with a soft, silky coat of olive brown.

Most northern bats become thoroughly dormant in cold weather, and it has been stated, on good authority, that their daily sleep is, in reality, hibernation, differing from the sleep of other warm-blooded animals in the same manner that their winter hibernation does. But this probably only refers to certain species. The little brown bats that spend the days behind my blinds apparently only sleep in the ordinary way, as they frequently get to crowding and nudge and poke each other with their sharp bony elbows, becoming half awake and squeaking 
peevishly as they endeavour to arrange themselves more comfortably for the remainder of their nap. But this activity may be due to the increased irritability of the muscular fibre, which is said to be an invariable accompaniment of hibernation. When I threw open the blind last October, exposing them to the full glare of the afternoon sunlight, they maintained the same position and showed little sign of awakening, but half an hour later had disafpeared, though the sun was still several hours high. This year the blinds were left open for the first part of the summer, and the bats were obliged to look up new sleeping quarters. In July I closed the blinds, hoping to entice the bats back to their former apartments; and, sure enough, about the first of the month 1 was delighted to see a solitary individual hanging by his toes in one corner of the window fast asleep. Wishing to have him pose as model for an illustration, I unceremoniously routed him out and deposited him on my desk, where he spent a most unhappy morning, losing all patience with me before the portrait was half completed,- which was hardly to be wondered at, considering the circumstances. As often as I tried to get him to change his position, he would break forth into shrill stuttering protests and snap viciously at everything within reach; but he soon quieted down on being left alone, and slept complacently close to my hand while I sketched him. Several times he escaped and flew deliberately downstairs, which I think few birds would have the intelligence or coolness to do. All those that I have seen in similar circumstances fluttered helplessly against the glass or ceiling and absolutely refused to fly downward under any provocation; but my bat flew up or down with equal willingness, and from room to room, earnestly searching for a passage to the open air. Whenever he felt tired he would hang himself up in the fold of a curtain to rest, apparently being fast asleep as soon as he was fairly settled. Glass he soon learned to avoid as slippery and treacherous; but the mosquito screens furnished better foothold, and the way he would scuttle about over these was something marvellous. Finally I carried him outdoors and gave him his freedom, and, in spite of the sun, he seemed to find no difficulty in seeing, but started directly for the barn window, which was partly open, and entered it as the swallows did. No one seeing him at the time could reasonably have accused him of blindness; nor did the term "blind as 

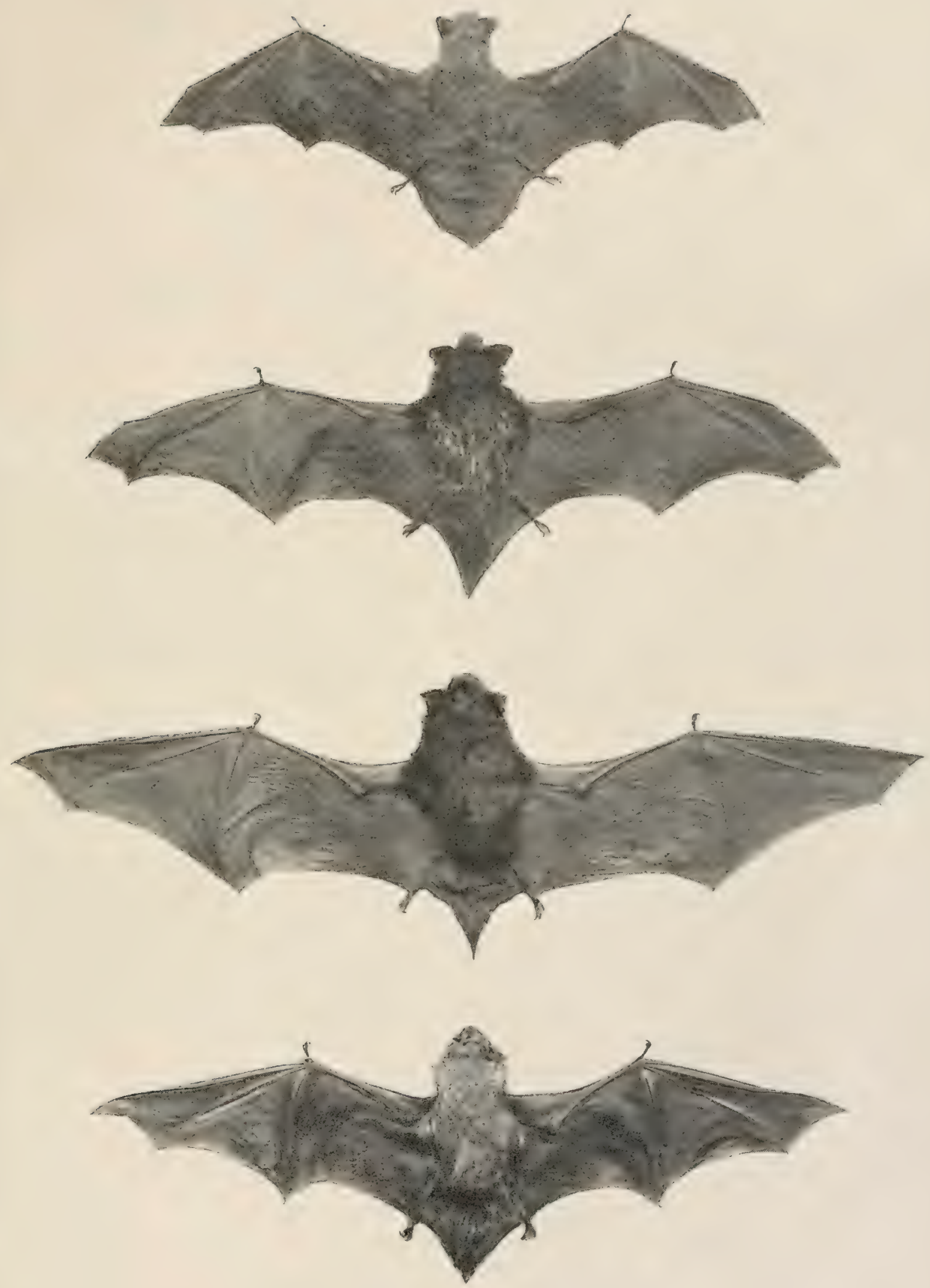

FOUR COMMON EASTERN BATS

From Stuffed Specimens

I. Pipistrelle (Pipistrellus subflavus) (fur yellowish brown)

2 Silver-haired Bat (Lasionycteris noctivagans) (fur black with silvery tips)

3. Brown Bat (Vespertilio fuscus) (fur dark brown)

4. Red Bat (Lasiurus borealis) (fur rusty red)

(About two-fifths natural size) 

a bat" seem applicable when you caught the gleam and sparkle of his wicked little eyes, peering out from beneath his woolly eyebrows. He evidently decided that he had chosen an unsafe sleeping place, and for a little while the window was deserted; but in a few days I noticed a smaller specimen of his race in the opposite corner, and the day following there were nine of varying size ranged along the upper sash in their usual characteristic attitudes. One near the middle of the row was wide awake; washing himself after the manner of a cat, he would lick his foot or a portion of his wing and rub his head with it the wrong way of the fur, and scratch himself rapidly behind the ear with one of his little thumb nails at the bend of his wing, the long bone of his fore-arm beating a tattoo on the glass beside him as he did so. The elasticity of the wing membrane is truly astonishing; he would seize an edge of it in his mouth and stretch it into all kinds of grotesque shapes in his endeavour to get it clean enough to suit his fancy, and sometimes, when at work on the inside, he would wrap his head up in it entirely, the thin rubbery stuff conforming to the general outline of his skull in the most startling manner.

Judging from those in the window, it would appear that bats are not given to occupying the same roosting places with any great degree of regularity, but spend the night chasing insects wherever these are to be found in great abundance, and hang themselves up to sleep where daylight happens to catch them. I kept an exact account of the number sleeping in the window during the month of August of the year 1898, beginning with the first Saturday, and soon noticed that for some inexplicable reason they were given to congregating there on Sunday nights, and that their numbers usually fell off until the middle of the week, and then increased again until Sunday. Here are their numbers as I set them down each day on my calendar: Saturday, 4; Sunday, 16; Monday, 9; Tuesday, 4; Wednesday, 2; Thursday, 5; Friday, 10; Saturday, I0; Sunday, ı 8 ; Monday, I0; Tuesday, 2; Wednesday, o; Thursday, o; Friday, I; Saturday, I. The third Sunday I was away, and so failed to take account of them, but on Monday there were 3, and 2 on Tuesday. For the next three days the window was unoccupied, Saturday I found I, Sunday 2 and Monday 3, after which they abandoned the window almost entirely, though $I$ occasionally found a solitary specimen snuggled in one 


\section{Little Brown Bat}

corner of the sash. I find that they habitually sleep in the barn in the narrow space between the ridge pole and the roof boards, though whether their numbers vary there from day to day as they do in the window, I am unable to ascertain. I have an idea that they also spend the winter there, for they are said usually to choose some such place to hibernate in.

As twilight comes on, the bats in the window begin to grow somewhat more restless, scrambling down from time to time to peer out between the slats as if to pass judgment on the weather. Then suddenly one of them launches out and downward at an angle toward the earth for a few yards, then sweeps up and away among the tree tops. Another foliows, and then two or three torether, till in very short time the blinds are empty; but outside in the darkness the bats are zigzagging about in pursuit of their supper.

\section{Large Brown Bat}

\section{Vespertilio fuscus Beauvois}

\section{Called also Carolina Bat.}

Length. 4.60 inches. Expanse of wings. 12 inches.

Description. Flight membranes naked except the base of the interfemoral membrane. Fur silky, dark brown, rather lighter below.

Ranire. Gulf Coast north to Maine and Ontario. One of the commonest bats in the lowlands of the Middle States.

This is one of the commonest bats through the southern United States as far north as the upper limits of the Carolinian fiunal belt, through southeastern Pennsylvania, southern New York and the Connecticut Valley.

In the Hudson Valley, Dr. A. K. Fisher says: "They are the last to make their appearance in the evening. In fact, when it gets so dark that objects are blended in one uncertain mass, and the bat hunter finds that he is unable to shoot with any precision, the Carolina hats make their appearance as mere dark shadows, tlitting here and there while busily engaged in catching insects. We have to make a snap-shot as they dodge in and out from 
the dark tree tops, and are left in doubt as to the result until, in the gloom, we may perchance see our little black and tan, seemingly as interested in the result as we are, pointing the dead animal."

About Philadelphia this is our commonest species, and any evening throughout the summer and autumn numbers of them may be seen circling about in localities where their favourite insect-food abounds. One old garden that I recall, skirted by an ancient grape-wall and surrounded by shade-trees, was always a favourite resort for bats, and many an exciting evening has been spent both in securing specimens and studying the habits of these interesting animals.

The large brown bat was always distinguishable on account of his size which, in the uncertain twilight, was frequently exaggerated, and more than once one of this common species was mistaken for a possible hoary bat, an animal which, in spite of our efforts, was never detected in this spot.

The large brown bat is seen late in autumn and on mild evenings in mid-winter, and they not infrequently fly into houses during the latter season and seek temporary shelter only to sally forth again the next night to the terror of certain of the occupants of the bedrooms, causing an excitement that could scarcely be surpassed were they the famous vampires of the tropics.

In summer-time they still more frequently enter houses in the evening in pursuit of nies and other insects which are attracted by the lights, and pass back and forth wheeling and twisting with the utmost dexterity, and always avoiding objects which may stand in their path.

Since the introduction of electric lights along the streets of the city, the bats are frequently to be seen flying about in their radiance, reaping a rich harvest of their favourite food.

\section{Georgia Pipistrelle}

\section{Pipistrellus subflavus (Cuvier)}

Length. 3.40 inches. Expanse of wings. 8.50 inches.

Description. Wing membranes thin, only furred near the base of the interfemoral membrane. Fur, light yellowish brown, 
blotched or mottled with dusky, below uniform yellowish brown.

Range. Eastern United States, southern Pennsylvania and lower Hudson Valley, west to lowa and Texas. About Lake George, N. Y., and probably elsewhere northward occurs a closely related variety, the northern pipistrelle ( $P$. subflavus obscurus Miller), which is darker and less yellow.

The Georgia bat or pipistrelle is quite common in south-eastern Pennsylvania, apparently much more so than the little brown bat which it so closely resembles when on the wing that identification is practically impossible.

\section{Silver-haired Bat}

\section{Lasionycteris noctivagans (Le Conte)}

Length. 4 inches. Expanse of wings. 9 to 10 inches.

Discription. Interfemoral membrane sparsely haired. Fur, dark brown or black, with silvery-white tips. Ear short and rounded.

Range. North America, south throughout Pennsylvania and the southern Alleghanies.

Generally speaking the silver haired bat is the commonest species in the northern parts of the United States, though as all bats are somewhat local in distribution, one kind will perhaps be more abundant in one locality and another in another. It is frequently seen about Philadelphia, although not nearly so abundant there as the large brown and red bats.

It seems to be an early flier, and my experience coincides with Dr. Merriam's, that it is far more plentiful in the early evening than later on in the night.

In flight it always seems to be slower and less erratic than the larger species.

Dr. Murriam says: "Like many other bats it has a decided liking for water-ways, coursing up and down streams and rivers, and circling around lakes and ponds. . . Next to water courses, the horders of hard-wood groves are the favourite haunts of the silver-haired bat. By standing close under the edge of the 
trees one sees many that at a little distance would pass unobserved. While searching for their insect prey, they may be seen to dart in and out among the branches and to penetrate in various directions the dense mass of foliage overhead.

According to information furnished to Dr. Merriam, this species passes the day in hollow trees, while the young have been found clinging to the twigs of an old crow's nest.

\section{Red Bat}

\section{Lasiumus borealis (Müller)}

Length. 4.40 inches. Expanse of wings, II inches.

Description. Base of wing membranes, whole interfemoral membrane and base of the ears densely furred. Fur varying in colour from bright rusty red to grayish tinged with rufous; always lighter on the lower surface, hairs generally somewhat tipped with white, and a whitish patch in front of each shoulder. Range. Canada to Texas and Northern Florida. One of the commonest species. In Florida there is found a darker variety, the Florida red bat ( $L$. borealis osceola, Rhoads), though in winter the Northern red bat migrates southward and both forms occur together.

This species is nearly as common about Philadelphia as the large brown bat, and seems to range rather farther north, being by far the commonest bat in those parts of Pennsylvania lying between the Carolinian belt and the mountains.

The red bat comes out earlier in the evenings than the other kinds, sometimes when it is still quite light, so that the bright. rufous colour of the fur is easily seen. At such times I have frequently been amused by the way in which they will pursue a stone tossed into the air anywhere in their vicinity. Without a thought of the possibility of its being thrown at them, they wheel suddenly and dart after the falling missile, following it closely almost to the ground. Where dark caves are to be found, these bats congregate there in immense numbers during the daytime, but in most localities they frequent lofts and garrets which offer them suitable shelter. One such resort, which I examined some years since, was in a garret usually kept dark by closed shutters. The bats entered by little cracks between the bricks and woodwork of the gable. When the window was 


\section{Hoary Bat}

opened and a flood of light admitted, several hundred of the little animals were discovered clinging in a compact mass to the rough bricks and mortar of the chimney. They twisted up their ugly little faces and uttered their shrill squeaking objections, the whole mass looking like a great tawny "hydra-headed" monster. Upon stirring them with a stick the air immediately became filled with bats, and there was a grand scurry for the openings under the roof, whence they scattered in the unwelcome sunlight in a mild rush for another shelter. One summer two little bats were discovered hanging close together on the branch of a low tree on the lawn; during the daytime the parent remained with them, folding her wings about them, but at dusk she generally left them while she foraged for food. After a couple of days, however, they disappeared, doubtless transferred to some other spot safe from prying eyes.

\section{Hoary Bat}

\section{Lasiurus cinereus (Beauvois)}

Length. 5.40 inches. Expanse of wings, 12 to 15 inches.

Description. Much larger than the red bat, but with the same distribution of fur over the interfemoral membrane. Fur mingled dark-brown and light yellowish-brown, more or less tipped with silvery white. White predominating below.

Range. Maine, Ontario and mountains of New England, New York and the Alleghanies, migrating southward in winter throughout the United States.

The hoary bat is the largest bat of the Northern and Middle States, and is the rarest of all our Eastern species. Even in the North, where they make their home among the forests and mountain wildernesses, they are only seen occasionally, and still less frequently are specimens secured. Dr. C. Hart Merriam has graphically described his efforts to obtain specimens of this rare animal in the Adirondacks. "The twilight is fist fading into night," he writes, "and your eyes fairly ache from the constant effort of searching its obscurity, when suddenly a large bat is seen approaching, perhaps high above the tree tops, and has scarcely entered the limited field of vision, when, in swooping for a passing insect, he cuts the line of a 
distant horizon and disappears in the darkness below. In breathless suspense you wait for him to rise, crouching low that his form may be sooner outlined against the dim light that still lingers in the northwest, when he suddenly shoots by, seemingly as big as an owl, within a few feet of your very eyes. Turning quickly you fire, but too late! He has vanished in the darkness. For more than a week each evening is thus spent, and you almost despair of seeing another hoary bat, when, perhaps on a clear cold night, just as the darkness is becoming too intense to permit you to shoot with accuracy and you are on the point of turning away, something appears above the horizon that sends a thrill of excitement through your whole frame. There is no mistaking the species--the sizt, the sharp, narrow wings and the swift flight serve instantly to distinguish it from its nocturnal comrades. On he comes, but just before arriving within gunshot he makes one of his characteristic zigzag side shoots and you tremble as he momentarily vanishes from view. Suddenly he reappears, his flight becomes more steady, and now he sweeps swiftly toward you. No time is to be lost, and it is too dark to aim, so you bring the gun quickly to your shoulder and fire. With a piercing, stridulous cry he falls to the earth. In an instant you are stooping to pick him up, but the sharp grating screams, uttered with a tone of intense anger, admonish you to observe discretion. With delight you cautiously take him in your hand and hurry to the light to feast your eyes upon his rich and handsome markings. He who can gaze upon a freshly killed example without feelings of admiration is not worthy to be called a naturalist."

To the southward of the Canadian fauna the hoary bat occurs only as a migrant during the winter months, early spring and late autumn, and it is here, if anything, a rarer sight than in its true home to the northward. I have known of specimens being secured about Philadelphia, but in spite of many evenings spent in looking for it at times, when its occurrence seemed most likely, I have never been successful in obtaining a glimpse of this interesting bat. 


\section{Leather-winged Bat}

\section{Dasyptcrus intemedius (H. Allen)}

Length. 5.60 inches. Expanse of wings, 16 inches.

Discriftion. Membranes thick and leathery. Fur light yellowishhrown, with plumbeous bases; slightly tipped with dusky. Range. Gulf States and Northern Mexico.

\section{Twilight Bat}

\section{Nycticeius humeralis (Rafinesque)}

Length. 3.70 inches. Expanse of wings, 9 inches.

Description. Ears and membranes thick and leathery, fur sparse and short, dull umber-brown above, lighter beneath.

Range. South Atlantic and Gulf States, rarely northward to Southern Pennsylvania.

A common bat in the South, with habits essentially like those of other species. 


\title{
CARNIVORES OR FLESH-EATING ANIMALS
}

\author{
(Camivora)
}

NEXT to the rodents the carnivorous animals are probably the most numerous order of mammals, and occur in all parts of the world except Australia.*

These animals, as their name implies, are typically nesheaters, and most of them live on animals which they kill themselves. We therefore find them usually ferocious, strong and agile, though many species become quite tame and gentle when domesticated, and exhibit great intelligence.

The carnivora are divisible into two suborders-the peculiar seals (Pinnipedia) $\dagger$, which are adapted to an aquatic life, and the terrestrial carnivora (Fissipedia). The latter, which are the typical representatives of the order, may be more minutely considered. Their most distinguishing characters are, as usual, to be found in the skull and teeth. Of the latter the canines are very large and

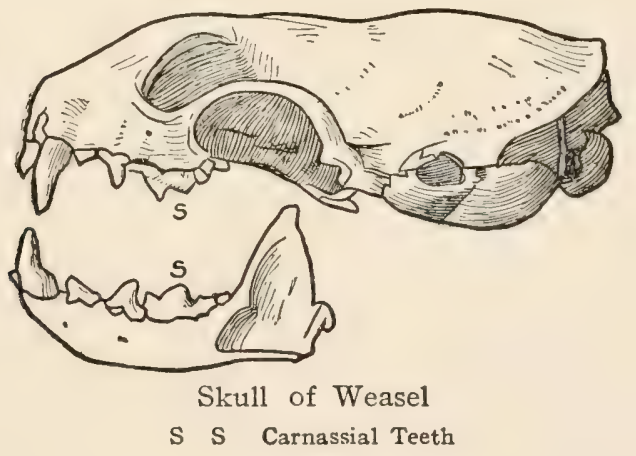

easily distinguished, while the back teeth, or molars, are always tuberculate and generally more or less sharp and pointed, and suited for cutting and tearing nesh.

* The Dingo or Australian dog was probably introduced.

$\dagger$ See under Phocida, p. 2 I4. 
One tooth in each jaw is peculiarly large and modified for this purpose and has been named the "carnassial-tooth" or "flesh-tooth."

The fect of the carnivores are moderate and never elongated, as in the hoofed animals, and are provided with sharp claws; these are frequently "retractile," that is capable of being withdrawn into folds of the skin and thus protected from wear and tear while the animal is walking. The carnivores are said to be plantigrade or digitigrade, according to whether the whole foot touches the ground when walking, as in the bears, or only the tips of the toes, as in the cats.

The families found in eastern North America are as follows:

\section{Feet modified into flippers, suborder Pinnipedia}

1. Eared Sials. Family Otariida. Hind flippers capable of being turned forward for walking when on land, head seal-like, ears small, but well developed.

11. Walmuses. Family Odobanida. Hind flippers used in walking as in the last. Body enormous and unwieldy, no external ears, upper canine teeth immensely elongated into long down-pointing tusks.

III. Seals. Family Phociale. Hind flippers directed backward and only capable of use for swimming, no external ear and no tusks.

1I. FeEt not MOdified into flippers, SUboRder Fissipedia

A. Toes, five on all feEt

IV. Weasels, Otters, etc. Family Mustelida. Size generally small and shape slender, with long tail (except the wolverine and badger). Tail sometimes tipped with black, but never annulated.

V. Raccoons, etc. Family Procyoniar. Size medium; tail long, generally bushy and annulated, black and white for its whole length.

V1. Bears. Family Ursida. Size large, tail very short, uniform in colour with the back.

B. TOES, FIVE ON THE FORE FEET, BUT FOUR ON THE HIND FEET

VII. Wolves and Foxes. Family Canider. Toes not retractile. VIII. Cats. Family Felide. Toes retractile. 


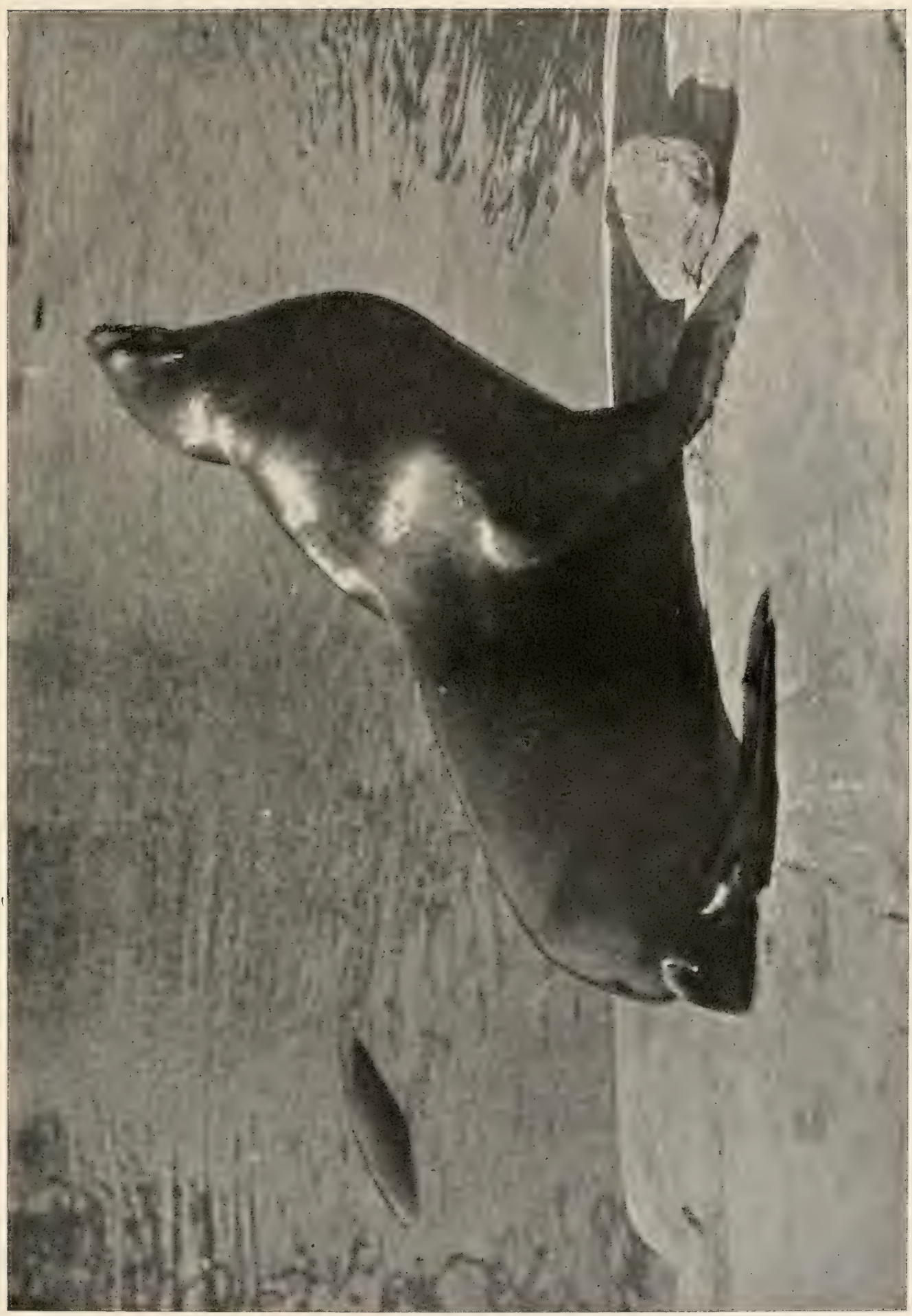

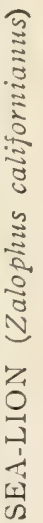





\section{EARED SEALS}

\section{(Family Otariida)}

These Iarge seals are found in North America only on the Pacific Coast, the best known being the fur seal of Bering Sea, the hair seal and sea lion.

\section{Fur Seal}

\section{Otoes alascamus (Jordan \& Clark)}

\section{Called also Sea Bear.}

Length. 6 feet. (Female 3 feet so inches.)

Description. Body covered with a very fine soft underfur and a coarser, longer growth of hair overlying it; colour chestnutbrown to black, in old individuals strongly mixed with gray, especially above. Females very much smaller and generally lighter than the males.

Range. Pribilof Islands, Bering Sea in the breeding season, at other times all along the coast of California.

Of all our native American animals none have been brought so prominently to the attention of the general public as the fur seal of Alaska. Ever since the discovery of their breeding grounds in the North Pacific and the realization of the value of their skins in the markets of the world, they have been the cause of legislation and disputes in which Russia, the United States and Great Britain have been involved.

The many government investigations, with their voluminous reports, have given us a more exhaustive account of the life and habits of the fur seal than we possess of any of our other animals; and, indeed, a beast possessing so many peculiarities is well worthy of the attention, entirely apart from the commercial side of the question.

Originally all the fur seals of the North Pacific were regarded as representing but one species, but it now appears that there are three distinct herds which keep quite separate from one another and which form three recognizable races or species, differing both in colour and structure. The most numerous and at the 


\section{Fur Seal}

same time only strictly American species is the Alaskan fut seal of the Pribilof Islands, the other species inhabiting respectively Bering and Medni Islands, and Robben Island in the Sea of Okhotsk.

The fur seal is a migratory animal, spending the summer and autumn in its breeding ground on the Pribilofs and passing the winter at sea, ranging down the coast as far as southern California. The females reach maturity at the end of their second year, while the males do not gain their full size and strength until seven years old. As in most gregarious and polygamous animals this results in several distinct stages of growth which are designated by the sealers by special names. There are the adult "bulls" and "cows," as well as the new-born "pups," while the young males of three years are the "bachelors" and the older ones the "half bulls."

The summer life of the breeding ground or "rookeries" as described by visitors is exceedingly interesting. About the first of May the old bulls begin to arrive and take up their positions on the bleak rocky beaches. By June the cows appear and as fast as they land are taken in hand by the bulls, each one eventually surrounding himself by a "harem" which he guards and rounds up, forcing back any cow that attempts to escape. The single pup is born shortly after the arrival of the cow and as soon as it has become sufficiently strong to be left she repairs to the sea to feed, returning to it at intervals.

Meanwhile the "bachelors" and "half bulls" arrive at the rookery, but herd by themselves and make no attempt to intrude upon the harems. The late arriving bulls which fail to secure harems locate immediately behind their more fortunate rivals and by their efforts to encroach upon adjoining harems or steal cows they continually precipitate desperate fights which frequently result in their own destruction and caluse great uproars throughout the rookery.

The old bulls, which often for a space of two months have been forced to fast in order to maintain their positions in the rookery, begin to seek their feeding ground at sea about the middle of July. They are usually much emaciated as compared with their fat, sleek appearance at the beginning of the season, the great thick coilt of hlubber having been absorbed to supply their bodies in lieu of food. The killing for the market is re- 


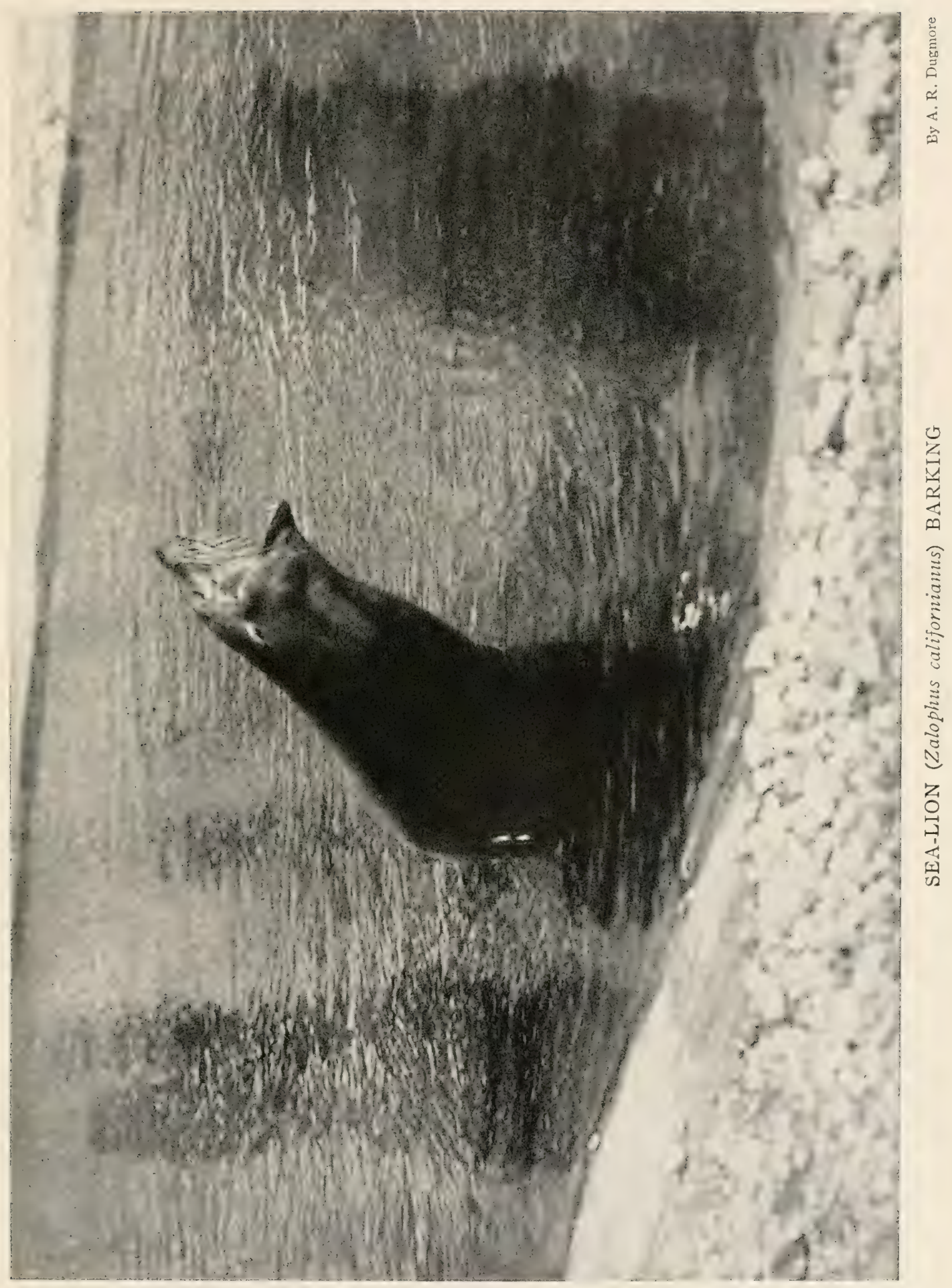



stricted to the bachelor seals, which from their habit of herding apart from the others can readily be driven aside, and those desirable for killing selected. The skins of four-year-old animals are less valuable and those of the old bulls worthless.

By the exercise of care and the enforcement of a definite limit to the number to be killed in a year, the stock of seals could easily be maintained, but the pelagic sealing when the animals are away from their rookeries is most destructive.

\section{Steller's Sea Lion}

\section{Eumetopias stelleri (Lesson)}

Length. Io feet. (Female 8 feet 6 inches.)

Description. Lacks the dense fur of the preceding. Hair, reddish brown inclined to golden in summer, duller and browner in winter.

Range. Bering Straits to California.

This animal is a hair seal like the following and lacks the soft velvety underfur of the fur seal. It is the largest of the group, considerably exceeding the fur seal, which in habits it much resembles. Throughout the Bering Sea region it is the only sea lion, but farther south its range overlaps that of Gillespie's hair seal, and in the neighbourhood of San Francisco both occur together and are often confused under the same general name. The present species is, however, much the rarer at this point.

\section{Gillespie's Hair Seal \\ Zalophus californianus (Lesson)}

Called also Sea Lion, Gillespie's Seal.

Length. 7 feet.

Description. Dark reddish brown in summer. Much lighter in

winter, when the upper parts are pale grayish, though still brown beneath and on the limbs. Form much more slender than either of the preceding, with a much longer and more slender snout than the fur seal.

Range. Pacific Coast of the United States north to California (San Francisco.) 


\section{Atlantic Walrus}

This is the common sea lion of the California coast and the one generally seen in menageries and zoological gardens. It is the smallest of our eared seals, as well as the most slender and most agile. Its habits resemble those of the other species, and on the islands of the California coast the same battles are waged for the mastery of the harems as are conducted on the Pribilofs by the fur seal. The short, barking cry of the hair seal is famil- iar to all who have seen these animals in captivity, and is quite different to the prolonged roar of the Steller's sea lion.

\section{WALRUSES}

\section{(Family Odóbenida)}

The walruses are closely allied to the seals, being, like them, carnivorous mammals modified for an aquatic life. From the true seals they differ in their immense size and fat, clumsy form, also in the structure of their hind feet, which can be turned forward so as to assist in supporting the animal when on shore; and in the enormous tusks in the upper jaw which represent the canine teeth. Another peculiarity of the walruses is found in the horny flaps which terminate the toes and project out beyond the claws.

In the structure of both feet and toes, as well as in other respects, the walruses are closely allied to the eared seals of the Pacific.

\section{Atlantic Walrus}

\section{Odobenus rosmanus (Linnæus)}

Length. 10 feet 6 inches.

Discription. Body very thick and heavy, neck short, no external ealls or tail. Muzzle covered with stiff bristles, tusks 12 to 15 inches long. Hair scanty, general colour of body yellowish brown; old males much wrinkled over the back and shoulders and often nearly devoid of hair, showing numerous bare patches. 


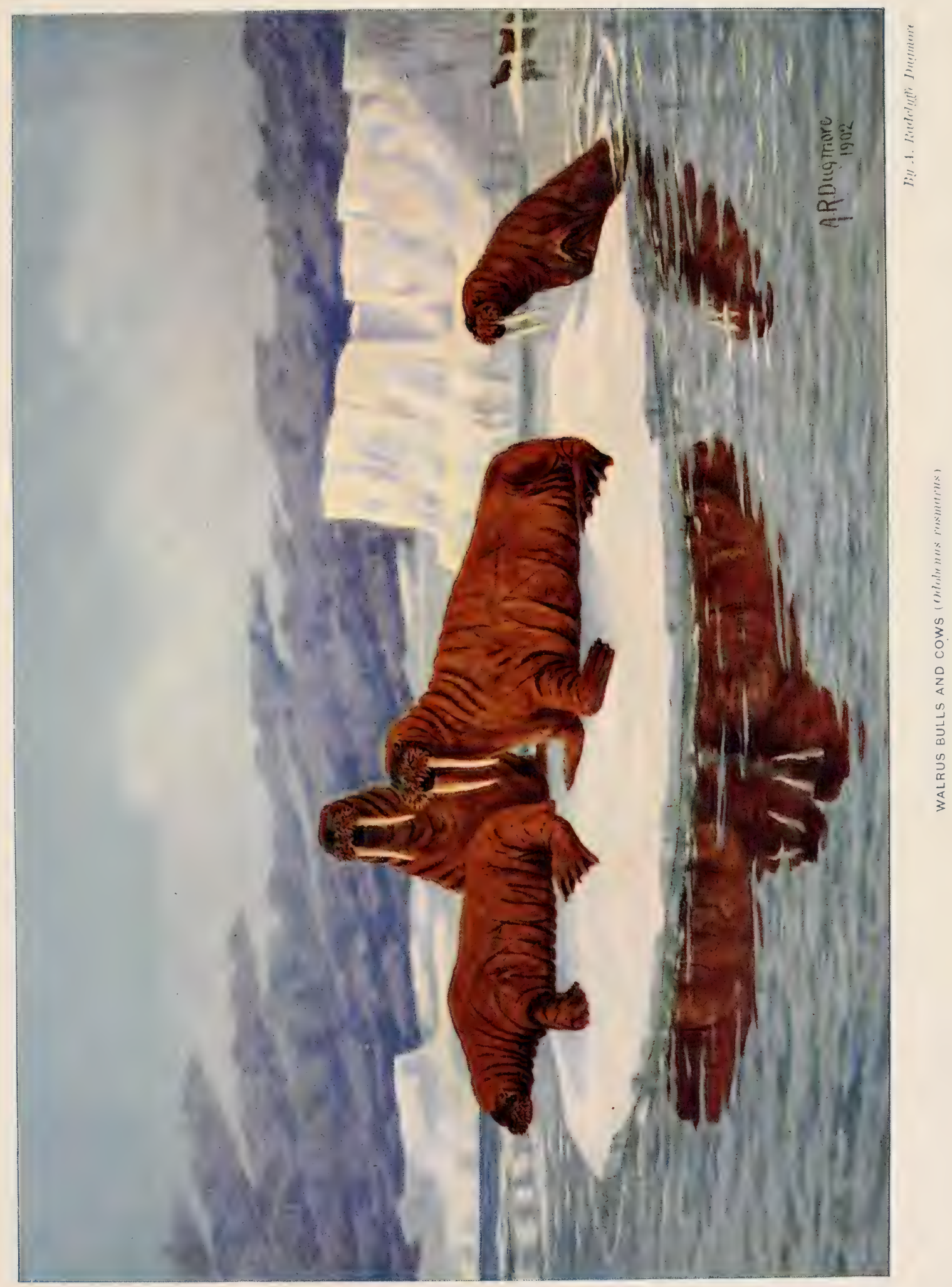



Range. Arctic regions of the Atlantic, south to the shores of Hudson's Bay, Labrador and to latitude $65^{\circ}$ on the Greenland coast; also islands north of Europe. On the northwest coast of North America south to Bering Sea and Norton Sound occurs the allied Pacific. walrus (O. obesus Illig.), with longer tusks.

The walrus is such a heavy, clumsy, ungainly beast that it has small chance of success at fishing, but its great size and strength are safeguards against the attacks of most of those flesh-eaters who find the seal easy prey; even the polar bear hesitates to come within reach of an old walrus.

The walrus gets the greater part of its food by digging with its tusks in the mud beneath the comparatively shallow water, grubbing up mollusks, and such mud-loving fish as lack sufficient activity to get out of its way. Seaweed and other marine growths are also eaten in considerable quantities, and it is probable that these, together with star-fish, sea-urchins sea-anemones and cockles, are gathered in and ground up together between the molars that crush the heaviest oyster shell without much effort.

The great tusks of the walrus are useful in other ways besides raking over the sea's bottom for food. They answer the purpose of boat-hooks when the walrus desires to drag its lumbering bulk out on the ice or a shelving reef among the breakers, and are stout, if unwieldy, weapons of defence in case of attack.

The walrus is often seen in large herds lounging about on the shore, one across the other like swine, all roaring and grunting together.

The young are born on shore in spring or early summer, at which time the old ones often go for weeks without either eating or entering the water.

When attacked they show considerable courage and aggressiveness in defending their charge, endeavouring at the same time to head off the enemy and roll their offspring into the sea, when they are said to seize them in their mouths, and diving, swim beneath the surface.

Though walrus at any age are far from attractive, the old males are particularly repulsive. They become nearly devoid of hair and present a most disgusting appearance. Elliott says of 
them, speaking of the Pacific species: "They resemble distorted, mortified, shapeless masses of flesh; the cluster of big, swollen, watery pimples, which were of a yellow, parboiled flesh-colour, and principally located over the shoulders and around the neck, painfully suggested unwholesomeness."

\section{SEALS}

\section{(Family Phocida)}

Seals are carnivorous animals modified for life in the water. To this end their bodies are cylindrical, tapering away from the middle; the limbs are short with the feet flattened and webbed for swimming, the forward pair acting as paddles and the hinder ones, which are placed close together and permanently directed backward, forming a rudder or propeller. Seals have no external ears and the first or "milk-teeth" are never fully developed, being generally absorbed before birth.

Seals while most at home in the water, come out regularly on the shore, especially at the breeding season. They make their way very clumsily on land, however, on account of the structure of their hind feet, and are much poorer walkers than the eared seals of the Pacific which can turn their hind feet forward.

Seals are often popularly confused with whales, with which they have no near relationship whatever, as can be seen at a glance. Their dog-like head and hairy body bear evidence of their much closer affinity to the land mammals, while the presence of hind feet and the absence of the broad, fish-like tail further distinguish them from the whales.

Seals occur in all oceans but are more plentiful toward the poles.

Our east coast species may be distinguished as follows :

a. Front teeth (incisors) six above and four below. No blidder-like sack on the head.

b. Muzzle narrow, sloping gradually from the top of the heild; first and second toes of fore feet longest.

c. Teeth large, rather crowded and set obliquely in the jaws. 
cc. Teeth small, distinctly separated and placed straight in the jaws.

d. First toe always longer than the second. Ringed Seal dd. First toe not longer than the second. Harp Seal b6. Muzzle broad, forehead convex, middle toe longest. Bearded Seal. b66. Muzzle broad, facial part of head very long, first, and second toes longest, whiskers crenulated.

Gray Seal.

aa. Front teeth 4 above, 2 below, a bladder-like sack on the head of the male.

Hooded Seal.

\section{Harbour Seal}

\section{Phoca vitulina (Linnæus)}

\section{Also called Common Seal.}

Length. 4 feet.

Description. Colouration variable; generally yellowish-gray above irregularly spotted with black, beneath yellowish-white with small black spots. Often dark-brown everywhere varied with light spots. First toe never longer than the second.

Range. North Atlantic south occasionally to New Jersey and in Europe to Mediterranean, replaced on the Pacific by the closely allied Palla's seal. (Phoca largha Pallas.)

Three distinct species of the genus Phoca occur on the eastern coast of North America: the harbour seal, ringed seal and harp seal. The last two are of Arctic distribution, while the first and best-known species is found as far south as the coast of New England and the Middle States.

All the seals are gregarious, especially during the breeding season, and are migratory to a greater or less extent, the harbour seal being apparently less of a wanderer than the others. The harbour seal is also distinctly a coast species, seldom venturing far to sea, and living and breeding on the exposed rocky ledges along the shore. The others, on the contrary, are found out in the open ocean and frequent the ice floes of the northern seas. Young seals at birth are covered with a thick white woolly coat, which is later supplanted by the ordinary hair, and until the change occurs they do not take to the water. As a rule, but one young is produced each year; sometimes it is born upon the bare rocks, while in case of the ringed seal an excavation is made under the snow communicating with a hole through the ice, and here the young remains for several weeks, tended by the mother. 


\section{Harbour Seal}

The two northern species, more especially the harp seal, which is easily killed in numbers on its breeding ground, furnish most of the skins and oil of commerce. Their skins, however, while of considerable value for leather, are not to be confused with the beautiful hides of the Alaskan fur seal or "sea bear" which furnish the valuable sealskin of the furrier.

On the New England coast the harbour seals may be looked for at any time of the year, but farther south they are seldom seen except in winter, haunting inlets and the mouths of rivers.

The first one that I ever had an opportunity of observing I met in its native element in August. We were both swimming just inside the river's mouth at Hampton, N. H.; its round head broke the surface between myself and the boat, showed wet and shining for a few seconds and was gone, to appear again bobbing around at the edge of the breakers on the bar.

Seals appear to be the most abundant along the New England coast late in summer and autumn when they may be seen from time to time swimming by the headlands or sprawling on the wave-splashed rocks and beaches; the young are silid to be born at this season in caves just out of reach of the tide.

Although the seals are just as warm-blooded, air-breathing mammals as any, their race has lived in the sea for so long that they have become almost as aquatic as fish; in fact, fish chased by seals have been known to look for safety in the shallow ripples at the edge of the strand and on sand-flats, as if aware that their pursuers were even more incapable and helpless than themselves when partly ashore. The seals always seek protection from their own enemies in deep water and fish there by preference.

The common seal of our harbours appears to be as little adventurous and seafaring as any of its kind, keeping near the land at all times and hunting inlets and the mouths of rivers which it enters with the incoming tide, sometimes swimming inland for one hundred miles or more between wooded banks and farm-lands, where it may fish in still pools out of reach of the ocean's growling.

By nature it is gentle and affectionate, quickly becoming tame if well treated and fond of being caressed and made much of ; a genial, well-meaning creature without much instinctive fear of man and cager to make friends with any animal that will 

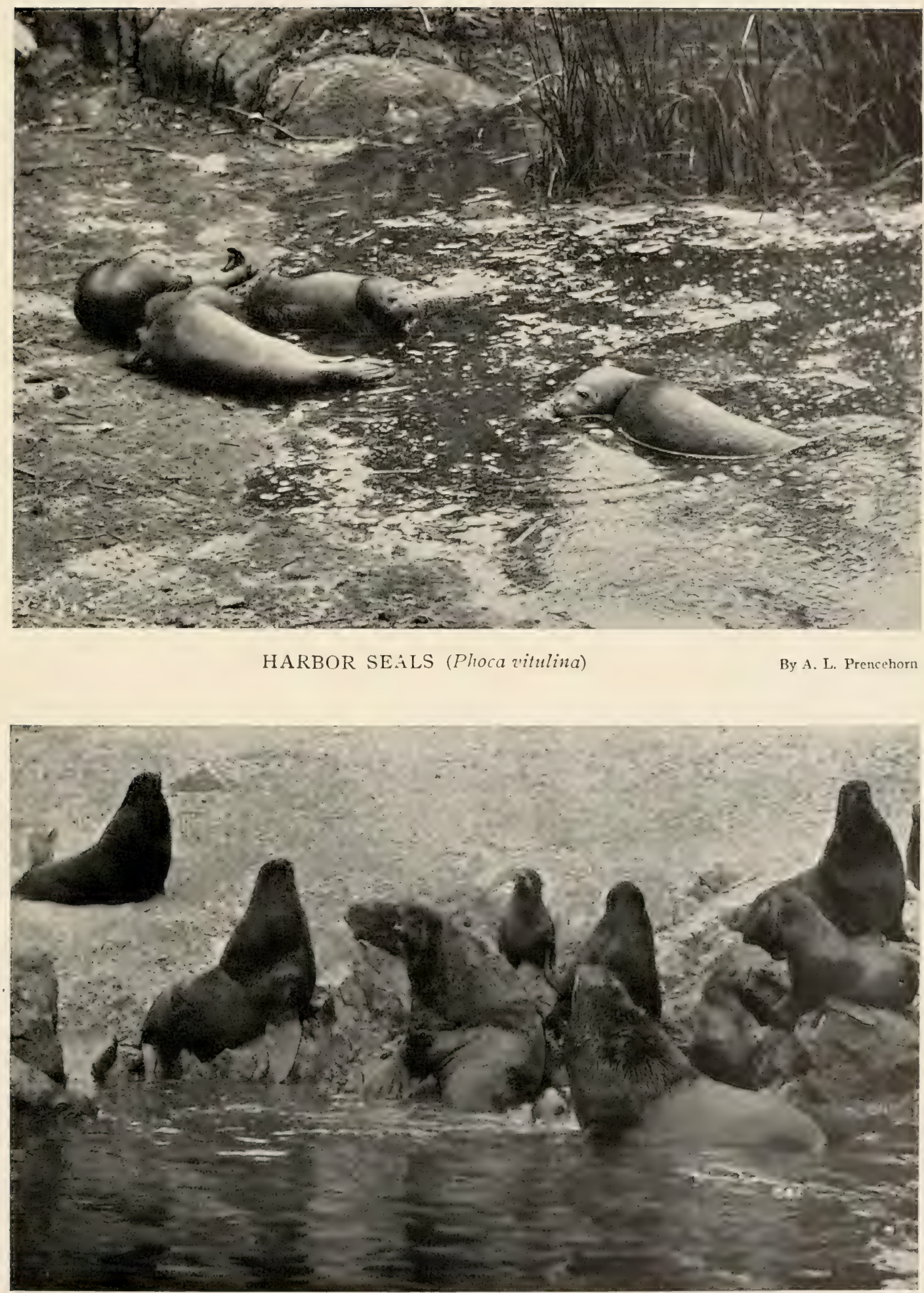

meet it fairly. Yet men persist in shooting at them on every occasion, though a dead seal of this species is of little value, either to commerce or science, and the fishermen and duck hunters tell me that not one in every fifty that are killed is ever secured. The harm seals do to sea fishermen must be of little account, except on a few occasions, when they get into the habit of robbing nets; and as they have few enemies in this latitude, they might well be allowed to become familiar and common features of our beaches and summer resorts. Sharks and swordfish are about their worst enemies, and it is said that the seals are not safe from their attacks even when resting on floating ice far out of the water, for these great ravenous brutes of the sea have been seen to throw themselves half out of water on the edge of the ice and overbalance it sufficiently as to force the unfortunate seal to slide down its slippery surface within their reach. Along the rough Labrador coast and still farther north, the polar bears catch them in a somewhat similar manner; swimming well around to the leeward of the unsuspecting seal asleep on the ice-floe, they dive and make their hidden approach beneath the surface, only rising once or twice for breath before reaching the edge of the ice where they have effectually cut off the seal's retreat to the water.

\section{Ringed Seal}

\section{Phoca hispida Schreber}

Length. 4 feet.

Description. Similar to the harbour seal, but more slender, with narrower head and longer limbs. Colour variable; often blackish above, darkest on the back, lighter on the sides, with large oval whitish spots, below yellowish-white, sometimes lighter, irregularly mottled with black, sometimes marbled with light dark-centred spots. First toe always longer than the second.

Range. Arctic seas south to the northern Atlantic and Pacific.

\section{Harp Seal}

Phoca gronlandica (Fabricius)

Length. 5 feet.

Description. Build more slender, as in the last. Colour of adult 
male white or yellowish-white, with face black and a curved black band on each side, meeting over the shoulders and again above the tail. Female and young variously mottled.

First toe of forefoot (flipper) not longer than the second. Range. Arctic seas to northern Atlantic and Pacific.

\section{Bearded Seal}

\section{Erignathus barbatus (Fabricius)}

Length. 7 feet.

Description. Gray above, darker along the middle of the back, often more or less mottled. Young in the woolly stage gray. The fact that the middle toes are the longest materially alters the shape of the "flipper," and this fact, together with the large size, will serve to readily identify this species.

Range. Arctic seas to north Atlantic and Pacific, south to Newfoundland.

\section{Gray Seal}

\section{Halichaenus grypus (Fabricius)}

Length. 8 to 9 feet.

Description. Flippers shaped as in the harbour seal, face twothirds instead of one-half the length o the head, bristles of the cheeks curiously crenulated. Colour of adults silverygray to nearly black, generally with black spots.

Range. North Atlantic, south to Newfoundland and Great Britain.

\section{Hooded Seal}

\section{Cystophora cristata (Erxleben)}

Length. 7 feet.

Description. Front teeth four above and two below instead of six and four, as in all other true seals. Colour bluish-black above, lighter beneath, varied with whitish spots. Sometimes light-grayish with dark spots. Young in woolly stage pure white. Head of the male with a movable muscular bag, extending from the nose to behind the ears.

Range. Arctic seas, southward casually to the United States.

This and the harp seal are Arctic species frequenting the 
ice floes. The latter is largely killed by the sealers, but the present species is decidedly rare on the coast of North America.

\section{WEASELS, OTTERS, ETC. (Family Mustelide)}

Under this head are grouped a somewhat varied assemblage of animals, which are closely related so far as their skulls and skeletons are concerned, though they present considerable diversity in their external appearance.

The typical members of the family are the slender-bodied weasels. Then there is the heavy-bodied wolverine, which reminds one of a bear; the semi-aquatic otters, which indicate the way in which the seals have been evolved, and the flat-bodied badger, the burrowing member of the family.

\section{Otter}

\section{Lutra canadensis Schreber}

Length. 3 feet 6 inches to 4 feet.

Description. Body long and somewhat flattened, feet short, toes webbed, tail very bruad and flat at the base, not abruptly constricted where it joins the body. Colour uniform sealbrown, brighter beneath, size variable, males generally larger. Range. Northern North America, south to Central New York and Pennsylvania, replaced southward and in Newfoundland by closely allied varieties.

The otter has followed a fisherman's life so persistently that he has grown to look very much like a seal. I never see one swimming under water, or with just its head above the surface, without being struck by the resemblance.

The head and neck in particular, whether seen in profile or as the animal faces you, are remarkably seal-like. Even when the otter is splashing about in the shallow ripples, or climbs out on the bank or some half-sunken log, his shape is still seen to be more like that of a seal than a land animal. His short 
legs are hardly to be distinguished at a little distance, while his heavy short-haired tail is almost as thick at its base as the rest of his body and tapers away fish-like to a point. The sea otter of the North Pacific being nearly as much of a marine animal as is the seal itself, shows the transformation to a perfectly fish-like shape still further advanced. Even the common otter of our fresh waters swims out from the river's mouth into the sea at times, and has more than once been caught in nets sunk deep in the ocean; undoubtedly the transition is still going on and the otters born a few thousand years hence will look even more like seals than do those of the present day.

Yet though their legs are short and their bodies so long and heavy as almost to drag along the ground and leave a deep furrow in the snow whenever the otters go about on land in the winter time, they yet make regular journeys overland from one stream or pond to the next. They even essay to go hunting in the woods and thickets occasionally when fishing proves unproductive.

1 have never found much evidence, however, that they are often very successful at such times, though their great strength and suppleness would easily enable them to kill deer or sheep.

When travelling overland otters follow the smoothest course they can find, going round stumps and hummocks and beneath logs in preference to climbing over them.

Following the same course week after week, often in families of four or five together, they soon establish a distinct path clear of obstacles; crooked and tortuous yet keeping to the same general direction, and in most cases leading to some rapid or springhole beneath the bank where the water seldom freezes.

Otters are beautiful swimmers; they glide and shoot along through the water, twisting and turning like the fish they so delight in chasing. I have seen one pursuing a muskrat, as a pickerel pursues a shiner, splashing through the shallow water where the stream had overflowed its banks. At times both would be invisible beneath the surface for several minutes, to appear again perhaps out in the current at a distance, the muskrat always diving and dodging for its life.

Otters will also catch wild ducks on the water, raising and seizing them from beneath. They catch their fish by fairly swimming them down in spite of all their twisting and darting. 
Where fish are reasonably abundant an otter can in this manner easily catch ten times as many as he can eat, and at such times is apt to satisfy himself with just tasting a mouthful from each, preferring the flaky meat just back of the head. Otters are also excellent judges of the different kinds of fish, agreeing with us in choosing trout, salmon and eels from among those that live in the rivers. Like seals, they are affectionate and genial, fond of each other, and, when trained, exhibiting a dog-like devotion to their masters. The old ones take the most solicitous care of the offspring and defend them against all comers; a dog that discovers an otter's den and imprudently attempts to dig it out is more than likely never to return to his master.

When the young otters are large enough, their mothers take them into the water for their first swimming lesson. It is said that at first they are mortally afraid of the water and have to be carried into it by force.

I have never had any opportunities of observing them at that age, but as late as September, when the young ones were as big as cats, I have seen one climb on its mother's shoulders, as if tired, and ride there as she swam against the current. They were hardly a dozen yards away, and when she saw me the old one dived, taking the youngster down with her. A few moments later they came up again side by side, with their heads close together, and a very attractive picture they made, bobbing up and down among the pickerel weed, watching me intently; from time to time the old one would lift her head nearly a foot out of the water, as if to see me more distinctly.

Presently the young one climbed on her shoulders again, whereupon she dived, and the next that I saw of them they were playing about in the shadow of an old bridge twenty rods further up stream.

The otter's home is a den beneath the bank, usually with the entrance under water for safety. This is evidently not regarded as absolutely essential, however, for otters have been known to have their nests in caves, high up in the banks and at the bottom of hollow trees.

Last summer 1 found the home of a family of otters beside ? little muddy brook that is nowhere more than a few inches deep. Their main entrance appeared to be through a hollow $\log$, the other end of which was buried in the swamp beneath 


\section{Otter}

a tangle of old tree trunks fallen and leaning at all angles and interlaced with a thick growth of smilax and nightshade.

It is quite possible that they had an underground passage leading to a somewhat larger brook a few rods away, though I saw no evidence of anything of the kind.

It was late in the season when I found the place and the young otters were well grown, and apparently spent most of their time away on long tramps and fishing excursions with their parents. From what I have seen of them I should say that otters pair for life and that the male does his part in taking care of his offspring.

The whole family keep together for the first year at least, probably until the young otters find their mates and set up housekeeping for themselves. They are generally gone two or three weeks on their fishing excursions, following the streams and sleeping in certain hiding-places that they know of beneath the steep banks. They will follow in Indian file up the course of littie brooks until there is scarcely water enough to wet their feet, and then strike across lots through the dark woods by well-remembered paths that lead to the head-waters of some other stream. Down this they trace their way among twisted roots and alder stems, watching for trout as they go, until they reach the river and swim out into the deep water, looking beneath lily pads for pickerel that may be hiding there, then down along the muddy bottom edges for horned-pout and eels.

Horned-pout are favourite fish of theirs and are caught in large numbers in defiance of their ugly spines; in eating them the otters make an exception to their rule, and begin at the tail, leaving the head and armed neck on the bank.

Having reached the river the otters may go either up or down stream, as suits them best. Inland they know there are quiet ponds where they may catch perch and chub, and in the other direction are thatch-fringed "eel creeks" winding through salt meadows at certain seasons alive with herring and ale-wives.

They do not occupy the entire trip in fishing, however; here and there they land on grassy banks, or among the pines, and romp about like puppies, rolling over and over in the grass, and clawing up the turf and throwing it about. A favourite pastime of theirs appears to be the pulling at the opposite ends of a stick as if to see which is the stronger. But they 

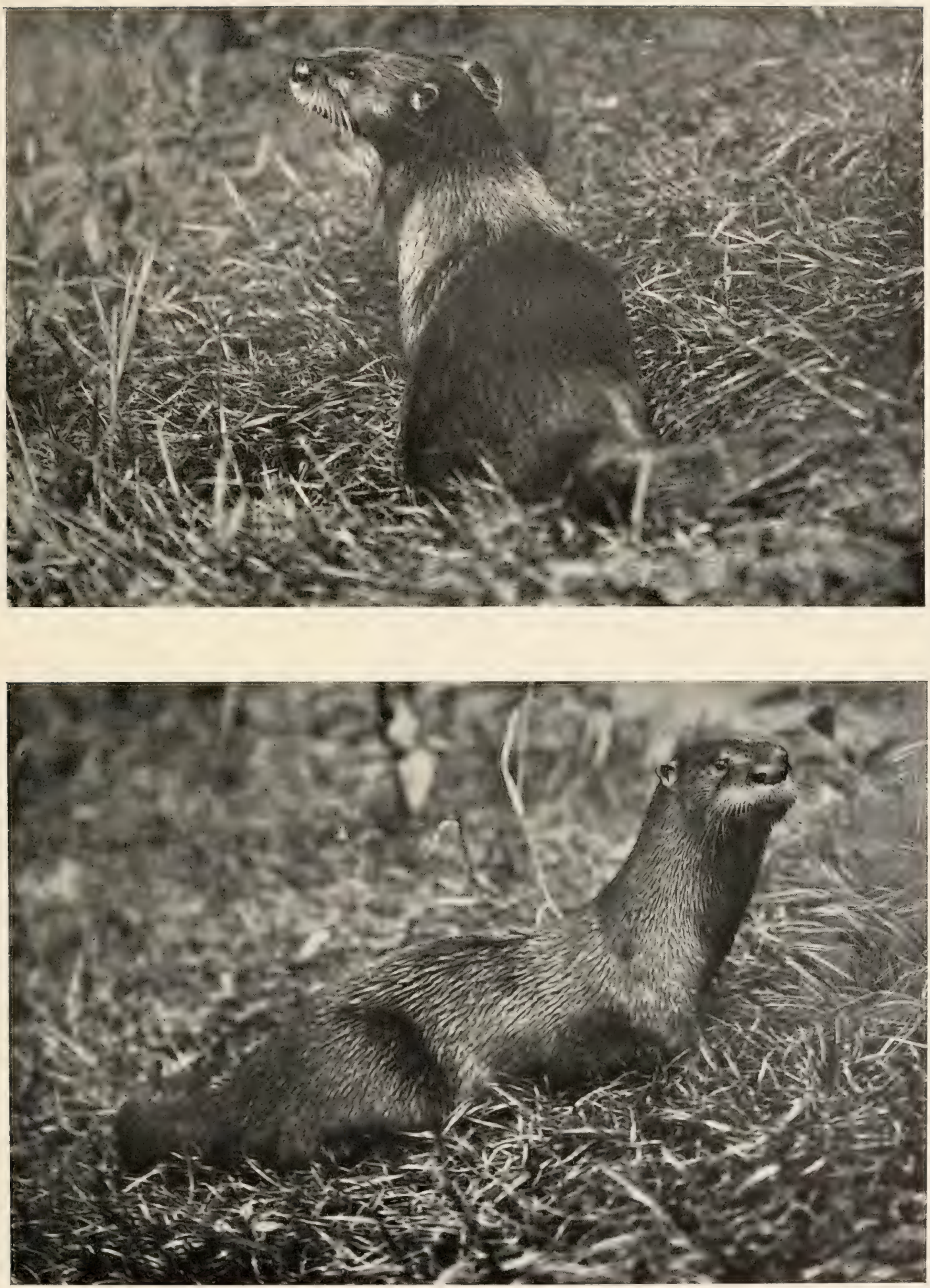

OTTER (Lutra canadensis)

By C William Beebe

A very difficult animal to photograph. These pictures represent a great amount of work and over a dozen attempts. 

get the greatest fun from sliding; where the bank is sufficiently steep and slanting they make a roundabout path leading up to the top of the bank and from there they slide down the slippery surface into the water one after another like boys sliding down hill on the snow.

There is usually a playing ground at the head of each of their slides, where the turf is dug up and trampled and broken sticks scattered about.

In places where the water remains open in the winter the otters take advantage of the snow crust formed by the water dripping from their fur and freezing on the snow, and when travelling overland in snowy weather they always slide down any declivity they come to.

In the Northern States and Canada they pass most of the winter under the ice.

\section{Sea Otter}

\section{Latax lutris (Linnæus)}

Length. 4 feet.

Description. Thick set, muzzle well beset with bristles presenting much the same appearance as that of the fur seal; tail onequarter the length of the body. Fore feet rather small, hind feet very large, fully webbed between the toes, teeth curiously blunt and rounded. Body covered with a dense under fur and a longer coarser outer coat as in the fur seal. Colour, black with whitish tips, head and neck grayish or yellowish white. Range. Shores of north Pacific, formerly south to northwestern United States, becoming very scarce everywhere.

This curious and interesting animal of our northwest coast has been reduced to danger of extinction by the fur hunters, who find in its skin the most valuable pelt furnished by any North American quadruped.

H. W. Elliott says of it: "There is no sexual dissimilarity in colour or size, and both parents manifest the same intense shyness and aversion to man, coupled with the greatest solicitude for their young, which they bring into existence at all seasons of the year. As the natives have never caught the mothers bringing forth their offspring on the rocks, they are disposed to believe that their birth takes place on kelp beds in pleasant or not over-rough weatiner. The female has a single pup, born about fifteen inches in length, and provided during the first month or 
two with a coat of coarse brownish grizzled fur, head and nape grizzled, grayish, rufous white. The fur is prime at two years, though the animal is not full-grown until its fourth or fifth year.

"The sea otter mother sleeps in the water on her back, with her young clasped between her fore-paws. The pup cannot live without its mother. Their food is almost entirely composed of clams, mussels and sea urchins, of which they are very fond and which they break up by striking the shells together, held in each fore-paw, sucking out the contents as they are fractured by these efforts. They also undoubtedly eit crabs and fish, and the juicy, tender fronds of kelp. They are not polygamous, and more than one individual is seldom seen at a time when out at sea. They are playful, it would seem, for I am assured by several old hunters that they have watched the seaotter for half an hour as it lay upon its back in the water, and tossed a piece of sea-weed in the air from paw to paw, apparently taking great delight in catching it before it could fall into the water."

\section{Varieties of the Otter}

I. Northern Otter. Lutra canadensis Schreber. Description and range as above.

2. Carolina Otter. L. canadensis lataxina (Cuvier). Much lighter brown, becoming pale grayish brown on the throat Range. Lower Middle and South Atlantic States.

3. Florida Otter. L. canadensis vaga Bangs. Darker and redder than the last but not so black as the Northern otter, almost as dark below as above.

Range. Florida, southern Georgia and along the Gulf Coast to Louisiana.

4. Newfoumlland Otter. L. degener. Bangs. Very dark, practically black with brown reflections. Size smaller than any of the preceding.

\section{Skunk}

\section{Meplitis putida (Cuvier)}

\section{Called also Polecat.}

Length. 2 feet.

Description. Body covered with long hair, tail very large and bushy; colour black with a white palch on the back of the neck, from which two stripes extend down the back and 
along the sides of the tail, and a white stripe down the forehead. Sometimes the white is almost restricted to the patch on the neck, and in the other specimens the stripes are united, making the whole back white.

Range. New England to Virginia and Indiana, replaced to the North and South by closely allied varieties.

The skunk belongs in the same group with the minks and weasels, all the members of which are capable of emitting a powerful, almost suffocating odour when angry, and this undoubtedly gives them a decided advantage in a hand-to-hand combat. But the present species has made itself notorious by perfecting this gift to a degree that furnishes it with a complete defense against all but the most desperate enemies. The general effect on the race is very noticeable.

No longer being compelled to be forever on the alert to escape or repulse the sudden attacks of an enemy, the little beast of the black and white fur has grown fat and lazy. It still retains much of the slender and graceful form of the weasels, but has allowed its muscles to become soft and tender, and so burdened with fat as to render rapid and prolonged exertion almost an impossibility; its flesh in the meantime having become palatable to every meat-eating creature, not even excepting man. All those who through want or curiosity have ever tasted it, agree in pronouncing it equal in flavour and tenderness to that of any four-footed creature: while no one, not even an Indian or a wolf, will eat the flesh of a mink or weasel unless rendered desperate by hunger. Is it not possible that the peculiar quality of the flesh of these weasels has been developed partly as a safeguard?

For large, warm-blooded game of whose flesh it still retains the fondness characteristic of its family, the skunk must depend on luck or strategy to supply the want of the agility which its race has thrown away. During the summer and autumn this loss is hardly felt; grasshoppers, crickets and the like are to be picked up everywhere in abundance, and compose the regular fare of the species; snakes are also caught by them in considerable numbers, and birds' nests containing eggs or helpless young are to be had for the seeking. The short burrows of the field-mice seldom reach many inches below the turf, and the nests containing the young mice are easily uncovered. 


\section{Skunk}

Catching grasshoppers in the hot sunshine of mid-summer is not by any means an easy task, but by moonlight or the early gray of the morning while the grass is heavy with dew it is more like picking strawberries than hunting.

As the season wears on the nights grow longer and the dew heavier, while the grasshoppers and crickets get bigger and more sluggish. By the last of October the skunks go rolling and tottering about on feet that are apparently much too small and much ton close together to support them comfortably, the creature's anatomical structure being still like that of the other weasels and scarcely fitted for carrying such a load of fat with ease and dignity.

By the time the supply of insect food comes to an end the skunk finds himself quite unfitted to engage in more active hunting, so he proceeds to look up a suitable underground retreat in which to pass the winter. If his summer home has been in the woods, then the same burrow which he has been occupying is all that is required; and if, as is usually the case, he is still living with his family, numbering perhaps six or eight members, they all turn in together and sleep for weeks or even months.

Those that have passed the warm season in the open, where the ground freezes too deeply to be comfortable in winter, are under the necessity of looking up lodgings in the woods before the snow comes.

It often happens that such a family will hit upon a hole already occupied, and the two families, aggregating a dozen or more individuals, will pass the cold season together in perfect harmony.

The original occupants, if they are sufficiently awake to realize anything, are probably glad of the additional warmth contributed by the new comers.

Skunks are easily the most abundant of all our carnivora, yet I have never seen more than five or six, all told, out. of their own accord in the daytime. In the evening, particularly in warm weather, it is common enough to see them moving about in the uncertain light with the leisurely, unhurried manner which they usually affect.

Generally there are very few skunks awake in December and January. In some seasons I have tramped the woods daily 

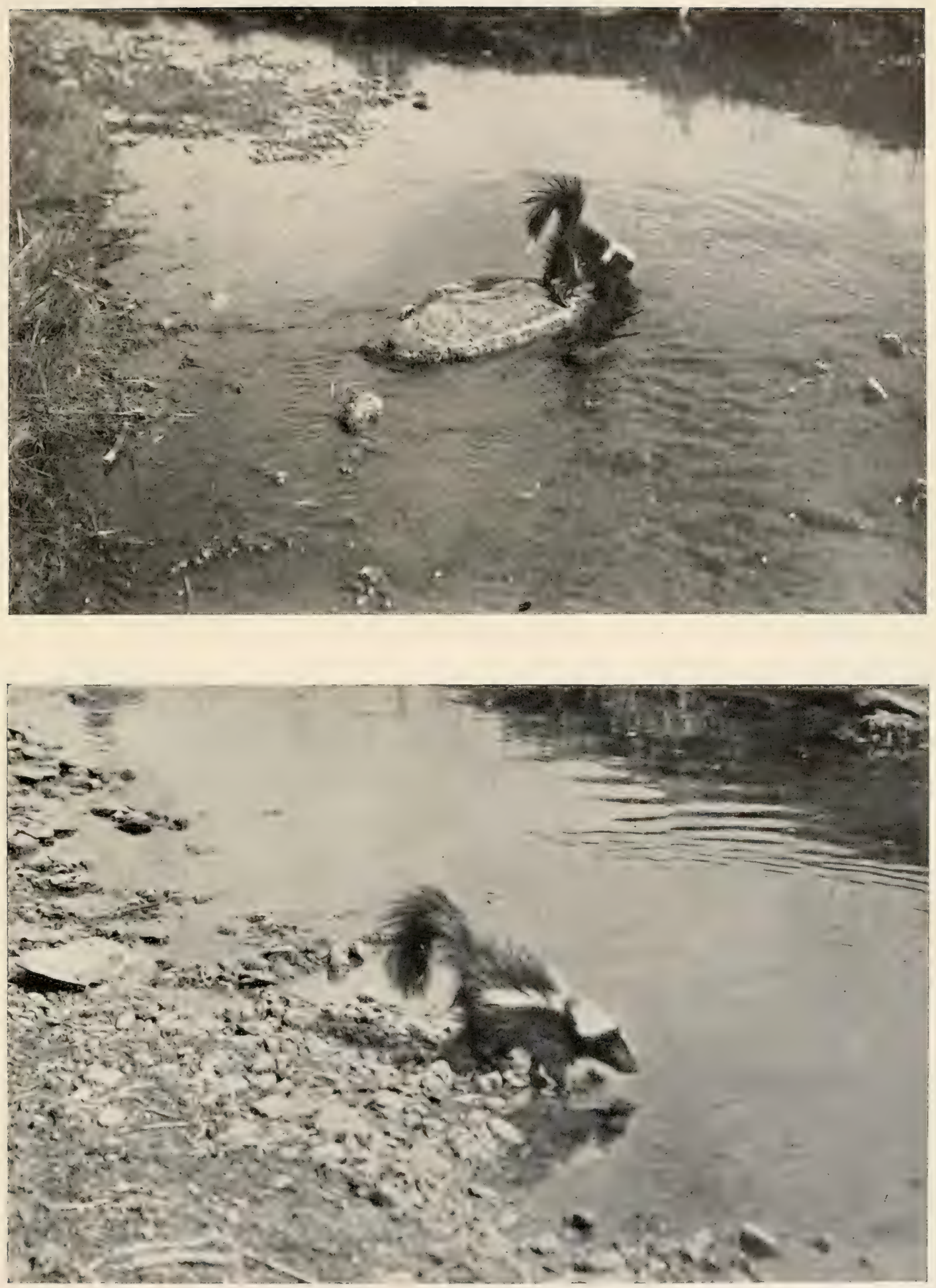

SKUNK CROSSING A STREAM (Mephitis putida)

By W. E. Carlin 

without seeing so much as one of their footprints during either of these months. And again, their tracks will be fairly numerous throughout the winter; and this does not depend entirely on the mildness or severity of the season either.

Early in February they are pretty certain to put in an appearance, sparingly while the cold weather lasts, but after the first really penetrating thaw the snow in all woods is thickly punched with their footprints, and for yards about their holes it takes on the colour of the dirt brought up from the depths on their feet.

Now that they are fairly awake and hungry, cold weather is powerless to keep them indoors. During the still cold nights of February they shuffle about over the snow-crust from sunset to sunrise, judging from the amount of ground they manage to cover each night.

They are now very different creatures from the heavy-bodied sluggards of the autumn. Those that can still boast a goodly layer of fat on their ribs must soon part with it. Insects in February are so scarce as hardly to be worth considering at all, an occasional grub or beetle dug out of a moulding stump being about all that can be safely counted on at this season. For their daily sustenance the skunks are now obliged to kill creatures far more active than themselves, and I have always wondered how, even in their reduced state of flesh, they can possibly compete successfully with the foxes and weasels in the chase.

It is hard to imagine one, even though half famished, making so much as a short dash of sufficient speed to enable it to seize so swift an animal as a rabbit, yet in one way or another they manage to do so quite frequently. It is probable that they often succeed in surprising them in their holes, for while the wood-chuck burrows, which the rabbits occupy, are nearly always constructed with several openings, the simple-minded creatures almost invariably make no effort to keep more than one of them open, allowing all the rest to become closed with snow and ice early in the winter.

As the snow grows less there is a marked tendency among the skunks to abandon the woods and thickets for the more open land, where they may hunt for meadow-mice about the newly exposed patches of moist turf, and snap up such snakes as have been driven from their winter retreats by the melting snow. 
Whenever the frost has left the soil sufficiently, they dig out narrow pits as deep as they are able to reach with their forepaws, the long claws of which enable them to rake out the soil with great rapidity. These little excavations, each with its accompanying pile of dirt, are to be seen anywhere during the warm months in regions where skunks abound.

They are undoubtedly made in search of insects, but just what particular kind are oftenest obtained in this way I have never been able to discover.

With the increasing warmth of the season, bugs of all kinds begin to crawl out of their hiding places on all sides to breed and multiply, and these, with mice and reptiles, serve to keep the skunks in food until the nesting season of birds comes on. But it is probably short rations at best, and with characteristic boldness and indifference they visit barns and farm buildings, where they generally do more good than harm, living largely on mice and rats and whatever meat is to be picked up about the ground. Still, when temptation offers in the shape of fowls roosting within reach, the old weasel instinct is likely to be aroused, and the skunk proves his ability as a hunter of big game.

In May food begins to be fairly abundant and easily procured, such as birds' nests and new families of mice, and the steadily increasing supply of bugs and reptiles.

It is at this time that the little skunks are led forth by their parent to receive instructions in the necessary art of getting a living. They present a most attractive and not by any means uncommon spectacle on warm, still evenings in early summer; the old one moving leisurely along, with half a dozen youngsters in her train like Indians on the war-path.

The black and white of the young ones is even more sharply contrasted than that of their parents, as if new and unworn by use, the short fur lying smooth and even without mixing where the opposing colours come together.

With each recurring evening the devoted little band starts out on its nightly hunt, chasing dor-bugs and other night flying beetles, blundering along in the darkness. In the utter blackness which exists beneath the undergrowth in the forest they go searching for the nests of thrushes and ground-building warblers and partridges. 
The discovering of the partridge nest means a banquet for the entire family-two big eggs apiece at least, and perhaps the unfortunate hen partridge herself to be divided among them; for it is quite possible that a partridge, driven from her nest in the night in trying to avoid the one that first started her, might fall into the clutches of one of the others, especially if she tried to draw off the enemy by pretending a broken wing.

If birds' nests are not always to be had, there are families of young rabbits in every thicket, helpless and practically unprotected, for if the old rabbit were to attempt to act on the defensive, which is hardly likely, she would simply be accepted by the skunks as a welcome addition to the meal. There are also the nests of the wood mice and shrews to be dug out from beneath the old stumps and logs, and among the sodden leaves and decaying wood in the damp hollows are abundant snails and other crawling things to fill in any vacancy when better things are not forthcoming.

The skunk is one of the most likable little beasts in the woods, being most intelligent and good natured, and without the wildness of most of our native animals. Except on rare occasions it is perfectly free from any unpleasant odour whatever, and is at all times exceedingly neat and particular in its personal habits. It is easily tamed and makes a safe and amusing pet.

\section{Varieties of Skunks}

Eastern Skunk. Mephitis putida (Cuv.). Description and range as above.

Canada Skunk. Mephitis mephitica (Shaw). Larger, with shorter and more slender tail (equal to half the length of body), pattern more constant, the white stripes varying little in length or width.

Range. Nova Scotia, Quebec and Ontario.

Florida Skunk. Mephitis elongata (Bangs). Medium in size, tail very long (longer than the body), white stripes very broad.

Range. Florida to North Carolina and Southern Mississippi. Louisiana Skunk. Mephitis mesomelas (Licht). Size very small (14 inches long), tail very short, usually wholly black.

Range. Louisiana to Texas and Missouri.

Illinois Skunk. Mephitis mesomelas avia (Bangs). Similar to the last, but larger.

Range. Prairie region of Illinois, Indiana and Eastern Iowa. 


\section{Little Striped Skunk}

\section{Spilogale ambarvalis (Bangs)}

Length. I foot 3 inches.

Description. A diminutive of the common skunk, with a different colour pattern. Black, with a broad white patch on the forehead, a crescent before each ear and four parallel stripes on the back, interrupted and broken behind. Tail black with a terminal tuft of white hairs.

Range. Florida; local and most common on the eastern peninsula. In Mississippi, Alabama and Western Georgia north to West Virginia occurs a somewhat larger variety, with the white markings much reduced-the Eastern striped skunk, S. ringens (Merriam). Others occur in the West.

These little skunks have much the same habits as their larger brothers, possessing the same attractive appearance and the same ability to make their presence extremely disagreeable.

\section{American Badger}

\section{Taxidea taxus (Schreber)}

Length. 27 inches.

Description. Body rather thick set and flat, feet rather short, claws on fore feet very large, tail short. Colour, grayish, mottled with black on the back in irregular transverse bands; tail gray; lower parts dirty white; centre of face black, including the eyes and region just above them; a white median stripe from the nape nearly to the snout; sides of face and throat white; a large black patch in front of each ear. Legs and feet black.

Range. Western North America, east to Wisconsin and Texasformerly to Ohio.

This flat, thick-hided, long-haired creature differs from its long-suffering European cousin chiefly in its more carnivorous diet, and in preferring wide-stretching flatlands to dark forests, such as the Old World badger loves to hide in.

But if badgering and badger-baiting had ever been popular in this country, our species would unquestionably have put up as invincible a defence against the dogs urged on to torture it as ever baldger did, its skin being equally tough and its jaws 
possessed of the same relentless bull-dog grip, locking themselves mechanically as they close. If left alone, however, the badger is a very timid, gentle and, in a way, useful animal.

It lives in burrows of its own digging and is exceedingly cautious about exposing itself by day; comparatively few people have been so fortunate as to see one except when caught in a trap in its doorway, or drowned out.

When by any chance a badger happens to be at any distance from its hole when approached, he usually prefers lying quiet in the grass to making any run for it, being decidedly heavy and slow of foot. At such time he will flatten himself down almost like a door mat or a turtle. His long silky gray hair, parted in the middle down along his spine, spreads out into the grass on each side, so that he seems to be only a slight hummock in the prairie, undoubtedly often deceiving the keenest sighted into passing without so much as suspecting his presence.

Even in a cage he will practice the same ruse to escape notice. I have seen one spread himself out on the dirt which covered the bottom of his cage, so successfully that out of every twenty people passing close by him to stare at the miserable captives in the neighbouring cages, I am positive not more than one or two at most realized that his cage had an occupant; his black and white striped head, looking so conspicuous in a mounted skin, was somehow no more in evidence than his fog-tinted fur.

The badger feeds principally on gophers, field mice, ground squirrels, prairie dogs and such, like humble earth folk, laying open their burrows with his strong claws faster than they can dig away through the earth in their efforts to escape him. He also eats grasshoppers, beetles, small snakes, etc.

In cold weather he keeps to his den, probably wholly dormant, for on appearing again in the spring, after months of confinment underground, he is still almost as fat as in the preceding autumn.

\section{Mink}

Putorius vison (Schreber)

Length. 21 inches.

Description. Larger than the weasel, with a thicker tail. Colour always very dark-brown, nearly black, with a spot of white on the chin and often on the chest or belly also. 
Range. Northern parts of North America, south in the Alleghanies to Pennsylvania and probably to North Carolina. In the lowlands to Florida the minks belong to slightly different varieties.

The mink is endowed with boundless resources in the face of danger as well as in the matter of getting a living. Wander where he will day or night, it is of small consequence whether the enemy that attacks him is fox, dog, wildcat, otter or owl, he is always within a couple of jumps of some place of refuge. If the water is near, he dives without a splash, and darts away like a fish, almost as much at home as the fish themselves in the swirling depths of the eddies and dim passages beneath sunken logs and drift-wood, only coming to the surface here and there for a breath until the enemy is left hopelessly behind.

When the water is not within reach, he can go up the nearest tree like a squirrel, or dart into any hole or crevice that would hide a rat; and lacking this, can out-run and out-dodge any ordinary pursuer: for, though short of leg, his body is long, and so supple that he uses the entire length of his spine in running, doubling himself into the form of a hoop and straightening out again at every jump with incredible swiftness.

I have seen him show such speed on numerous occasions that I have little doubt that the swiftest hawk or fox would have to do his very best and be lucky in the bargain in order to catch him. As a last resort he can fight, as many an incautious creature several times his size has learned to its cost.

Referring to the mink's faculty for hiding anywhere they may chance to be, I have seen them disappear instantly among the dry oak leaves that carpet the open where hardwood grows, and they will do the same thing in short thin grass or shallow snow with a suddenness that leaves the beholder wondering. At such times, if they deign to show themselves again, it will in all probability be several rods at least from where they disappeared, and then perhaps only for the briefest glimpse.

Only yesterday I was sitting beneath a sheltered bank, warmed by the thin sunlight of late November and well out of the reach of the roaring north wind, when I heard a rustling among the leaves eight or ten rods away. Looking toward the sound, I saw, just for an instant, a beautiful little female mink with the sun full on her back, then saw only the russet coloured 
leaves sloping up between the tree trunks; but even while I looked there was the mink again several rods farther away and just in the act of vanishing as before.

I squeaked like a mouse to call her, but the wind was so loud in the trees that I failed to make myself heard; so I imitated the chatter of a red-squirrel as closely as I could, and instantly the mink came skipping toward me over the ice of a little pond that day between us.

1 do not think that I have ever seen any other four-footed creature, not even a deer or a fox, run with such baffling swiftness. I could just catch the one image of her coming head up across the sunlit ice before she disappeared in the sere frozen water grass almost at my feet.

Last Christmas day I saw a very large mink hunting a little party of ruffed grouse among the pines and birches on a hillside. The grouse kept taking short nervous flights here and there, while the mink beat the underbrush like a pointer and seemed to be everywhere at once, and nowhere for more than a second at a time, until finally he turned up where I least expected to see him, almost behind me, digging excitedly beneath an old log, after mice apparently, scattering the wet willow leaves to right and left in his eagerness. On another occasion, when I was duck shooting, I saw a mink in the pines across a river, and called him over to my side in order to have a look at him. Running down the steep bank, he dived, and, swimming under water, only rose when within a few yards of where I stood, and at once popped into a burrow at the water's edge. A few seconds later he emerged from another opening half-way up the bank, and running a little way toward me, sat perfectly erect, eyeing me curiously, then dropped to all fours and ran round to the other side to look me over from that point of view.

It was raining heavily all the time and there was no wind, so he failed to catch my scent, and for some time continued to examine at a distance of two or three paces without taking alarm. When sitting upright he showed a narrow white line down his throat, broken into a chain of spots between his fore legs. At last, having satisfied his curiosity, he started off along the bank with his head turned to one side, watching the raindotted face of the water keeniy, perhaps hoping to see the bulging eyes of a frog or a fish rising to break the surface. 
Minks combine the habits of the land and water hunters more successfully, perhaps, than any other animal. In warm weather they are fond of exploring wet swamps and low lands, where they find an abundance of frogs and lizards, and dig all sorts of grubs, beetles and earthworms from the black peaty soil and leaf-mould around old weather-beaten stumps and rotten logs.

They are most inveterate nest robbers and mousers, chasing the little blunt-headed furry meadow mice along their runways in the thick grass being their favourite sport.

In April the female fixes herself a cozy nest in some hole among the rocks, or inside a hollow log or stump generally hidden away among flagrs and bullrushes beside a stream.

The young minks stay with their mother until cold weather, learning to fish and hunt; the frogs, mice and young birds furnish plenty of sport for them while the warm weather lasts, and they seldom wander far, until the sons of the family are as big or bigger than their mother. But the frosty autumn weather makes them restless, and they soon get into the way of going off separately on longer hunting excursions, to be gone several days or a week, perhaps, at a time, no longer returning when tired to sleep together in the same nest where they were born, but camping each alone wherever the fortunes of chase happen to lead them, for a mink is always able to find good sleeping quarters anywhere at a moment's notice.

The mink is not properly either nocturnal or diurnal; when well fed and tired, after a hard chase, he turns in and sleeps until rested, and then yawns and stretches himself and starts out agrain for another jolly hunt, perfectly indifferent to the time of the day. It may be black rainy midnight or a brilliant October morning: when he wakes, off he goes, hungry and eager for fresh adventures, exploring unknown territory and chasing birds such as he has never seen before, as the Northern cold drives them down in flight before it. His first snowstorm is likely to find him dozens of miles from home. Now and again he runs across other members of his species and the two hunt and fish together for a few days, but they soon part company again in most instances; one, it may be, preferring to follow down along the tidewater creeks after eels, while the other anticipates better fun chasing partridges and squirrels in the upland woods. 


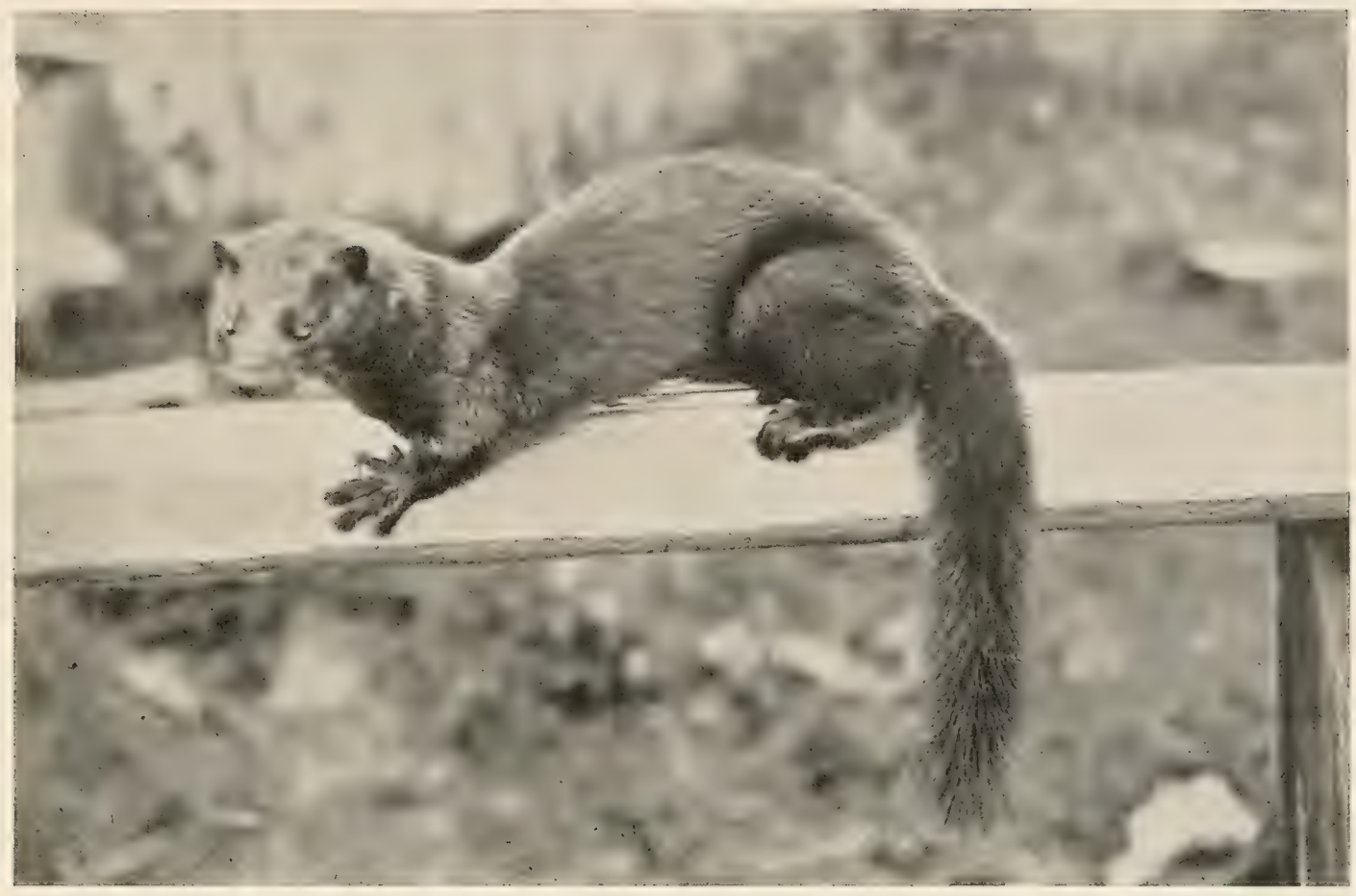

MINK (Putorius rison)

By C. C. Speight

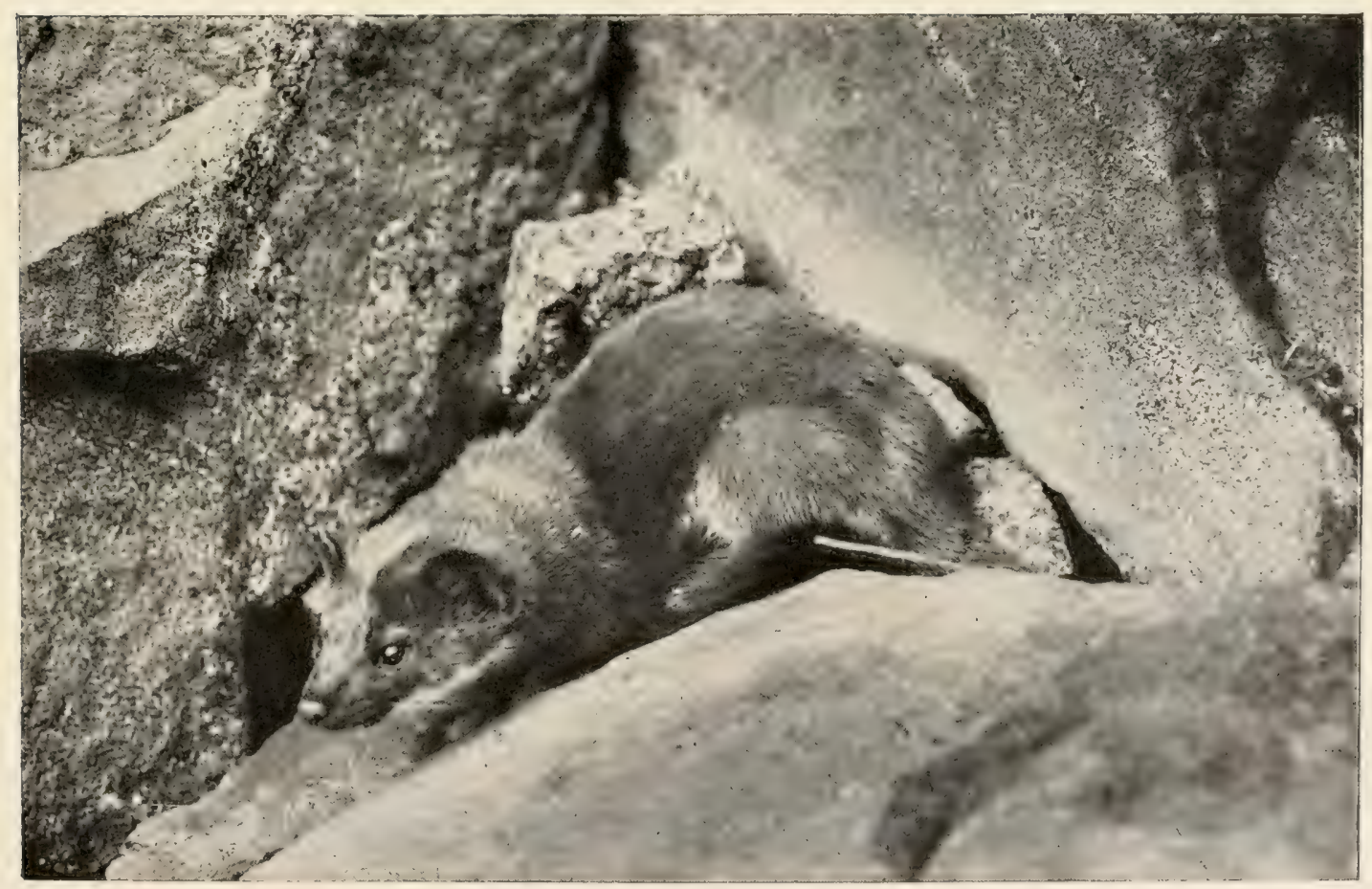

WEASEL (Putorius noveboracensis)

By W. E. Carlin

Caught by the camera as he reappeared after being chased into his hole in the rocks. 
While minks are not social animals, they are, I am certain, much less in the way of putting up pitched battles when they meet than are the majority of the woodland folk. Sometimes half a dozen or more old males will gather about some particularly good fishing hole and to all appearances get along perfectly together for weeks.

In winter, when the still waters are frozen, they haunt open rapids and warm springs in the woods, or finding entrance beneath the ice of a closed brook, make extended excursions along the dim buried channel, alternately running beneath the ice and along the brook's border where the falling away of the water has left a narrow strip of unfrozen turf beneath ice and snow. Here they catch small fish and meadow mice, or, tracing the brook's course down to the wider reaches of the river, find larger fish and muskrats to try their strength upon. Water, however, is not essential to the minks' happiness at any season, for they can hunt rabbits all winter long in the snow as successfully as the sable or fisher.

\section{Varieties of the Mink}

Northern Mink. Putorius vison (Schreber). Description and range as above.

Southern Mink. P. vison lutreocephalus (Harlan). Length, 28 inches. Larger and lighter, dark chestnut-brown, with white spots below as in the last.

Range. Coast of Southern New England through the lowlands to North Carolina.

Louisiana Mink. P. vison vulgivagus (Bangs). Smaller and light yellowish-brown, chin and spots on under parts purer white. Range. Coasts of Louisiana and Texas.

Florida Mink. P. lutensis (Bangs). Similar to the last, but still smaller, with longer head.

Range. Salt marshes of Southern States, South Carolina to Florida.

\section{New York Weasel}

\section{Putorius noveboracensis (Emmons)}

Length. 16 inches. Female 13 inches.

Description. Tail always more than one-third the total length. 
Dark chocolate-brown above, white on under parts, terminal third of the tail black. In winter pure white except the black of the tail. This change in colour is complete only in the northern part of its range. The difference in size of the male and female is remarkable, and the latter is sometimes confused with Bonaparte's weasel, which has a much shorter tail.

Range. Eastern United States, New Hampshire to Virginia, and westward to lllinois. To the north and west and in higher parts of North Carolina it is replaced by very closely allied varieties.

The various kinds of weasels in this country are much alike in their habits, and there is probably as much difference to be observed between the ways of individuals of each species as between the different species. There are certain family characteristics, however, which apply to all of them. First of all, they are hunters; if they ever follow the example of the majcrity of the flesh-eaters and partake of beechnuts, berries, mushrooms, or herbs on occasions, they have evidently never been caught at it and reported by the student of nature.

They hunt tirelessly, following their prey by scent, and kill for the mere joy of killing, often leaving their victims uneaten and hurrying on for more; when game is abundant they content themselves with sucking the warm blood. In cold weather they frequently hide the game they are unable to eat as a provision against period of hunger.

They like best to follow old tumble-down stone walls overgrown with weeds, squeezing into every crevice that may harbour a mouse or chipmunk; white-footed mice in particular furnish them no end of sport, for they are scarcely inferior to the weasels themselves in leaping powers, and are very abundant everywhere in the woods. In eating a mouse, the weasel first sucks the blood through the large veins of the neck, then bites through the skull and eats the brains, and after that, if still hungry, he eats the flesh, turning back the skin as he does so, leaving it turned inside out with the feet and tail attached.

Meadow-mice, moles, shrews, and the common mice and rats of barns and corn ricks, are also hunted by the weasel, but where white-footed mice are abundant they are pretty certain to receive his first attention.

In winter the larger weasels kill large numbers of gray rabbits, 
and are often to be found in thick growths of young pine and birch that have sprung up, together with blackberry vines and briers, on land cleared of old-growths of pine forests.

I have known the rabbits when chased by weasels to leave the woods and rush frantically out into the open, as if aware that their enemy was even better suited for rapid progress through briers and brambles than themselves, though they usually seek safety from their foes in just such places. And it certainly seems as if they knew what they were about at such times, for the weasels seldom leave the woods to follow them.

In summer they catch grasshoppers, crickets, and beetles of various sorts, and rob every bird's nest they find. Ground-feeding birds are especially liable to be caught by them, and they have even been seen to spring into the air and catch birds on the wing.

Owing to their slimness and elastic muscles they have a decided advantige over most of the other wood-dwellers, and have little difficulty in killing birds and animals several times as large as themselves.

I cannot learn of any other creature that is more thoroughly possessed of the lust for blood than are these slim-bodied little hunters.

The larger kinds, including the ermine or long-tailed weasel and Bonaparte's weasel, appear to be the most savage and bloodthirsty; the New York and the least weasel, from what I can learn, are somewhat more civilized in their ways. A New York weasel which I kept in captivity for a few days was gentle and docile from the very first, and perfectly fearless.

Within less than an hour from the time she was first removed from the trap to her cage, she would take meat from my hand without the slightest hesitation, and never offered to bite my fingers even when touching them with her nose. This tameness could not have been brought about by hunger, for when 1 found her in the box-trap she had not wholly eaten the rabbit's head which i had used for bait.

The weasels of the Northern States and Canada turn white at the approach of winter. The end of the tail, however, does not change colour, but remains perfectly black as in the summer.

I am inclined to think that this black point serves its owner in a variety of ways, though at first thought one might think it 
would prove conspicuous on the white surface of the snow and in contrast with the intense white of the remaining fur. But if you place a weasel in its winter white on new-fallen snow in such a position that it casts no shadow, you will find that the black tip of the tail catches your eye and holds it in spite of yourself, so that at a little distance it is very difficult to follow the outline of the rest of the animal. Cover the tip of the tail with snow and you can see the rest of the weasel itself much more clearly; but as long as the black point is in sight, you see that, and that only.

If a hawk or owl, or any other of the larger hunters of the woodland, were to give chase to a weasel and endeavour to pounce upon it, it would in all probability be the black tip of the tail it would see and strike at, while the weasel, darting ahead, would escape. It may, moreover, serve as a guide, enabling the young weasels to follow their parents more readily through grass and brambles.

One would suppose that this beautiful white fur of winter, literally as white as the snow, might prove a disadvantage at times by making its owner conspicuous when the ground is bare in winter, as it frequently is even in the North; yet though weasels are about more or less by day, you will seldom catch so much as a glimpse of one at such times, though you may hear their sharp chirrup close at hand. Though bold and fearless, they have the power of vanishing instantly, and the slightest alarm sends them to cover. I have seen one standing within reach of my hand in the sunshine on the exposed root of a tree, and while I was staring at it, it vanished like the flame of a candle blown out, without leaving me the slightest clue as to the direction it had taken. All the weasels I have ever seen, either in the woods or open meadows, disappeared in a similar manner.

How hawks, owls or foxes ever succeed in catching them is a mystery, yet they do from time to time, though certainly not often enough to reduce the number of weasels at any season. Still, though weasels breed rapidly, they never become very numerous, for which there is reason to be thankful.

In summer the weasel's fur is a peculiar shade of soft reddish-brown, and in spring and fall the blending of white with brown gives a curiously pied and mottled appearance; the tail at 
such times being divided in sections of brown, white and black.

Weasels make their homes under stumps and in the hollow roots of old trees, or else they take possession of the burrows of ground-squirrels, often having killed the original occupants.

They also make use of woodchucks' burrows, particularly such as have been abandoned by woodchucks for a season, and later appropriated by cotton-tail rabbits, who the weasels are undoubtedly glad to find at home.

Weasels travel by silent gliding leaps, often covering several yards at a bound, their hind feet falling exactly in the tracks of the front ones. Their footprints in the snow are close together in pairs, one foot slightly in advance, and the pairs separated by intervals of from one to ten feet or more. In soft snow their slender bodies leave their impress from one pair of footprints to the next.

They are great wanderers, traveling miles in a single night, and frequently being gone on long hunts for weeks together.

\section{Varieties of the New York Weasel and Related Species}

New York Weasel. Putorius noveboracensis Emmons. Description and range as above.

North Carolina Weasel. P. noveboracensis notins Bangs. Similar, but darker, with belly yellow instead of white. Does not turn white in winter.

Range. North Carolina.

Maine Weasel. P. noveborcicensis occisor Bangs. Larger, with longer tail and heavier, broader skull.

Range. Maine, probably to Ontario.

Long-tailed Weasel. P. longicanda spadix Bangs. Larger than any of the above ( 18 inches long), with the under parts strong buffy yellow.

Range. Eastern Minnesota.

\section{Bonaparte's Weasel}

\section{Putorius cicognani (Bonaparte)}

Length. II inches (female 9 inches).

Description. Smaller, difference in sizes of sexes not so striking,

tail decidedly shorter-not much more than one-quarter the 
total length. Dark brown above, tail tipped with black, belly and under parts white tinged with yellow. Pure white in winter with a yellow tinge on the rump, and tail black tipped.

Range. Boreal forests south to New England and the mountains of Pennsylvania. A larger variety, Richardson's weasel $P$. iliogllani richardsoni (Bonaparte), occurs in Northern British America.

This smaller, short-tailed weasel is an animal of the boreal forests, overlapping in parts of its range one or other of the preceding long-tailed species, from which it probably differs little in habits.

\section{Least Weasel}

\section{Putorius rixosus Bangs}

Length. 6 inches.

Description. Smallest of the weasels, with no black tip to the tail, which is very short. Colour, dark reddish brown above, white below. In winter pure white throughout.

Range. Arctic America, south to Northern Minnesota, replaced on the Artic coast of Alaska by the Eskimo weasel P. rixosus estimo Stone. In Western Pennsylvania occurs another little weasel, allied to the least weasel, the Alleghany weasel $P$. alleghaniensis Rhoads.

\section{Florida Weasel}

\section{Putorius peninsule Rhoads}

Length. 15 inches.

Disiription. Never turns white in winter. Chocolate brown, darker on the head, chin whitish, rest of under parts yellowish, irregular spots of white sometimes present on the face, between and behind the eyes.

Range. Peninsula of Florida. The allied bridled weasel $P$. frenatus (Lichtenstine), with distinct white marks on the face, occurs in Texas.

This is a distinctly Southern weasel, our other Eastern weasels 
being all animals of the more northern States, or of the mountainous regions.

\title{
Fisher
}

\author{
Mustela pennanti Erxleben
}

Called also Fisher Marten, Pekan.

Length. 3 feet.

Description. Larger and heavier than the weasels and minks, with

longer and bushier tail. Grizzly grayish brown, lighter on the

fore part of the body and darker brown posteriorly; tip of the

tail black; darker also on the throat and legs; tail full and bushy.

Range. Boreal regions of eastern North America southward through the Alleghanies; an allied variety replaces it to the westward.

The fisher is by far the largest of the martens as well as one of the handsomest, a long-bodied, vigorous hunter, with the agility of a sable and the strength of a wolverine.

Possessing many of the habits of the pine marten, he has a shrewder intelligence and greater boldness in hunting; for he manages somehow to kill the Canadian porcupine in defiance of his spiny armour, and will circumvent a savage old she bear and kill her cubs while she is away. It is said that the fishers of the Rocky Mountain region even kill young grizzlies in this manner. The fisher's private hunting grounds are gloomy hemlock and spruce covered hills and ridges, where they cover immense distances in a single night, traveling by bounds, nose in the air, to catch every scent that is in the wind.

They are as much at home in the tree-tops as are the pine martens, and climb to where the partridges roost, and catch them in their sleep.

Hares' flesh is their regular diet, but they vary this according to the season and as their appetites and the fortunes of the chase shall determine, their bill of fare ranging from insects and dead fish to bear meat and young venison.

They are also fond of beechnuts like the pine marten, and will go long distances for a sprig of catnip, just as the mink or wildcat will, or an ordinary domestic tabbie. 
Fishers sleep all day in hollow trees or logs, preferring a goodsized cavity high up among the branches. In mild weather they like to take their naps on the horizontal branches of fir-trees, stretched at length, like a cat on a window-sill.

Although hating settled regions and cultivated lands, they exhibit no special fear of man in the wilderness, often turning the tables on the trapper and following his trail, just as the trapper follows theirs. Many a trapper has been driven almost to desperation by some sly old fisher who insists on looking after his traps for him, pulling marten traps to pieces from behind in order to get at the bait without risking his own precious skin, eating or tearing to pieces any pine-marten or mink that may have been caught, and dragging steel traps out of the snow to spring them. If he should chance to get pinched in a marten trap, his great strength usually sets him free again, teaching him only to be a little more careful the next time.

When at last the trapper has succeeded in outwitting this wily fellow-hunter, and brings his beautiful pelt back to camp, he feels the thrill of triumph of a hard-won victory.

The fisher is one of the very wildest of all wild animals, and I believe that hardly another suffers so much from being caged. Of course, all of the hunters are rendered infinitely miserable and unhappy by being deprived of the freedom which is their life ; but of all those that I have seen imprisoned, not even the pine martens or lynxes looked at, me with such hopeless despair as the fisher, and I earnestly hope that I may never have to see another in a calge. There is cruelty enough in the woods, heaven knows; but the trapper who sets his steel trap with a spring pole that jerks the game into the air and keeps it hanging by a leg through long days and nights, in all weathers, is merciful by contrast with him who can be hired to catch a fullgrown fisher uninjured in order that it may drag out a wasted life in prison for no fault of its own.

\section{Marten \\ Mustcla americana Turton}

Called also American Sable, Pine Marten. Length. 24 inches.

Description. Smaller than the fisher, with less bushy tail. Colour, 
rich brown, somewhat lighter below, throat with a light tawny spot, ears high and pointed.

Range. Boreal forests south through the mountains to Pennsylvania.

Martens love best thick old-growth forests of evergreen, where dead trees lean together and stretch along the ground half buried and crumbling.

Here they live among the trees almost like squirrels, racing along old windfalls and up among the branches, to leap over into the next tree-top and so away through the woods; chasing the red squirrels in the pine boughs, and catching them too in spite of all their quickness. Then down to earth again, bounding off on the trail of a hace, eager and excited with the scent of fresh game in their nostrils.

In warm weather they keep more to the swamps and low, moist woods, where the dead leaves lie wet in the hollows.

Although martens kill all sorts of birds and animals indiscriminately, they appear to prefer partridges, rabbits and squirrels, hunting them most persistently. They will follow the trail of a hare, nose to the earth, quartering along its crooked course until their terrified prey starts up before them from its hiding place; then for a little while it is a close hot chase by sight. If the marten fails to seize him in the first few jumps, the hare may outdistance him and go flying away over stumps and logs out of sight among the trees. The marten, however, merely drops his nose to the trail once more and follows it up without a break, perfectly certain of success in the end. Even in deep soft snow the marten is able to chase the hare with success, his feet being broad and well furred, supporting him on the surface, where a mink's or even a weasel's would sink deep.

Like the mink and weasel, martens have little to fear from native enemies; the much larger fisher is said to kill them occasionally, and it is not improbable that the great horned owl now and then manages to pounce on one unawares.

But though they are almost free from the strong musky odour characteristic of the other weasels, very few of the carnivores care to taste their flesh unless driven to it by extreme hunger.

Before the coming of the Europeans they must have multiplied exceedingly in all the northern forests, to the terror and 


\section{Pine Marten}

destruction of all kinds of small game. It has been observed, however, that about once in every eight or ten years they almost disappear in a most unaccountable manner from all parts of the region they inhabit.

There is no evidence of disease among them at such times, or that they have migrated in a body, as gray squirrels, hares and lemmings do when they find themselves overcrowded.

The sible hunters all agree, however, that they invariably refuse to be enticed into a trap by bait of any sort just before the periods of scarcity, though commonly unsuspicious and easily taken. Martens prefer to make their nests in holes high up in some old tree, and find the nests of the larger woodpeckers perfectly suited to their needs. Having established themselves in a woodpecker's or squirrel's hole, they like to watch whatever is going on in the woods beneath them, with just their noses poked out into the air, ready to slip back out of sight if danger threatens. Their nests are made of moss and leaves in the bottom of the cavity.

In the mountainous rocky country they often live in crevices among the ledges or a seam in the face of the cliff. They multiply rapidly, the females having half a dozen or more kittens early in the spring.

Although they exhibit much less apprehensiveness in man's presence in the wilderness than the otter, for example, they absolutely refuse to inhabit woods in the vicinity of any regular settlement, disappearing completely at the approach of civilization. While the otter, though quick to abandon his favourite slides and playgrounds if he finds the merest suspicion of a man's tracks near by, only moves to some other point along the stream, and establishes a new landing place, though it may just be on the outskirts of a village. Although martens are carnivorous animals, they are said to be very fond of beechnuts, and I should not be in the least surprised to learn that in the summer they eat berries of various kinds as well, for most of the flesh-eaters make an exception in favour of some sort of vegetable diet, just as almost all rodents like meat for a change.

\section{Varieties of the Pine Marten}

Marten. Mustela americana Turton. Description and range as above. 


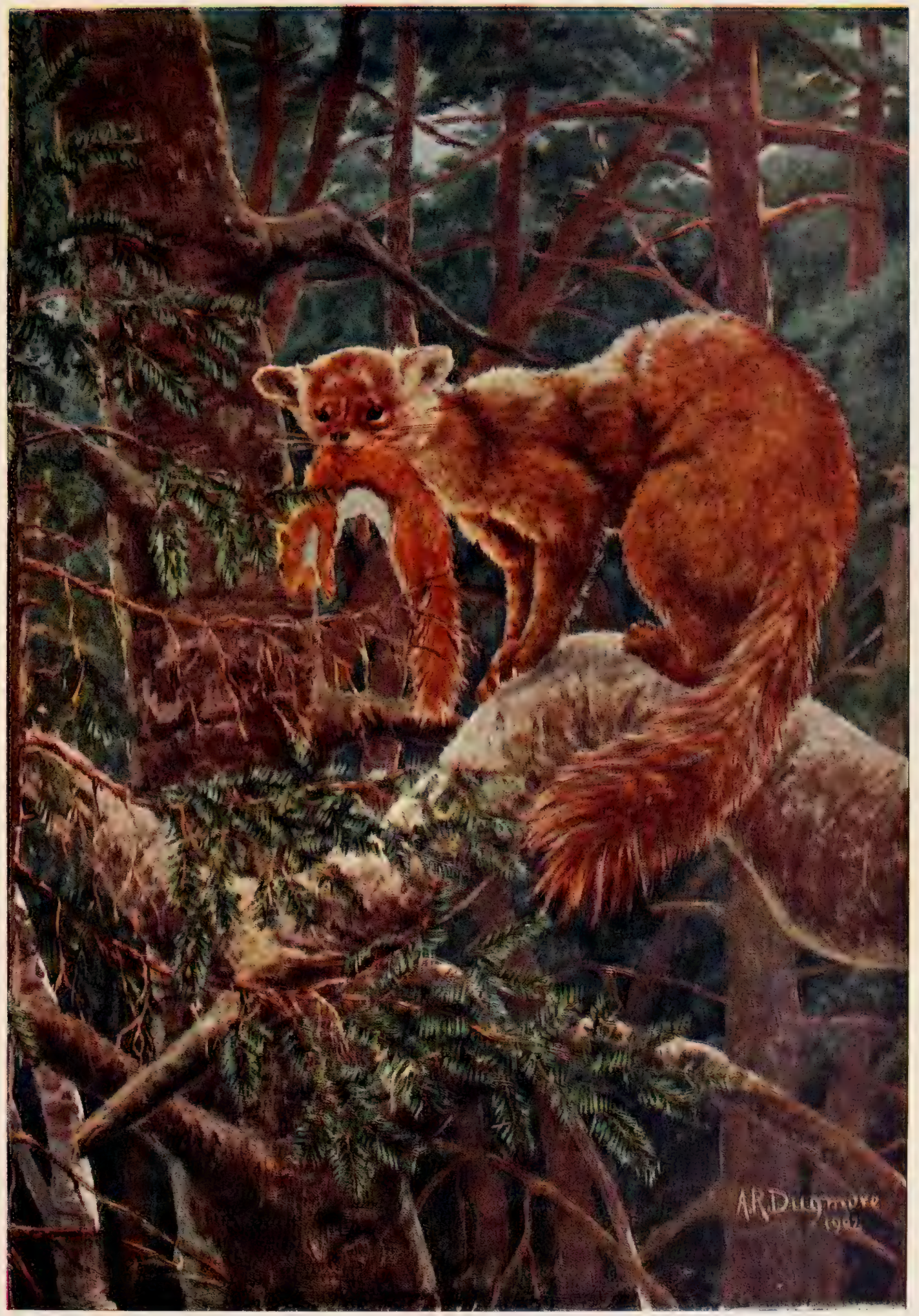



Newfonndand Marten. M. atrata Bangs. Darker brown, almost black; throat patch orange.

Range. Newfoundland.

Labrador Marten. M. brumalis Bangs. Larger and heavier, colour darker.

Range. Northern Labrador.

\section{Wolverine}

\section{Gulo luscus Linne}

Also called Glutton and Carcajou.

Length. 30 inches.

Description. Heavy and bear-like, walking on the sole of the foot. Hair long and shaggy; general colour blackishbrown, lighter on top and sides of the head; feet black, a pale yellowish-white band from the middle of the body on each side, widening out on the flanks and joining over the basal portion of the tail.

Range. Boreal North America, Northern New York (formerly) northward.

The wolverine is a most unlovable brute, sullen and greedy; his home is in the north woods from the St. Lawrence and the Great Lakes north to the very limit of the trees and beyond. $\mathrm{He}$ is also occasionally found in the northern United States.

Like the skunk, he is a member of the active and sinuous weasel and marten family; and just as the skunk has developed a method of defense so effective as to allow its owner to dispense with the agility of his race and become soft and fat through laziness and lack of exercise, the wolverine has developed his native shrewdness and heavy strength at the expense of his agility.

No longer capable of running down a hare or climbing for birds and squirrels, he tramps it doggedly along through the forest, covering immense distances, and never missing an opportunity of getting a meal without risking his own safety. He now systematically robs the white and half-breed trappers of their game, the meat with which they bait their traps, and their stores of provisions, just as in past ages he undoubtedly robbed the native red man of his frozen fish and venison; and he steals from his fur-coated four-footed fellow-hunters as well.

Where winters are long and severe, lynxes, martens, weasels 
and foxes have been taught by hunger to practise the very closest economy. When luck goes with them and they manage to kill more than they can eat at one time, they usually bury what is left in the snow, or drag it away to some more secrete hiding place, knowing from bitter experience that all the other flesh-eaters are forever on the prowl, and not a bit overscrupulous about appropriating what they find.

But no amount of clever hiding is likely to avail them if there happens to be a wolverine in the neighbourhood. He seems to be gifted with a perfectly fiendish ingenuity in the matter of searching out buried treasures of meat, and at the same time meanly insuring himself against being robbed in return. For his capacious stomach makes it possible for him to eat more than most creatures of his size, and if anything is left after he has gorged himself he buries it and so defiles the snow about it and scents it with his disgusting odours that it is said that no other animal, no matter how hungry, will touch it.

In warm weather he probably finds it easier to satisfy his appetite in a more legitimate manner, following the summer methods of hunting adopted by most of his family, skulking through swamps and thickets after birds' nests and young creatures of various sorts that have not yet learned to take proper care of themselves.

He also feeds on insects and reptiles, and digs out the underground homes of mice and lemmings whenever his keen nose tells him that he is likely to find the little owners at home. He is even said to dig out foxes in early summer, killing and eating the fox cubs when he is so lucky as to succeed in cornering them at the extremity of their den.

The wolverine's own home is a burrow, and here in midsummer the five or six little wolverines are born; they are somewhat lighter coloured and more attractive than their parent, who shows her one admirable trait in her affection for them and her fearless attacks on any man or beast that threatens their safety.

When I think of the wolverine I always seem to see him through distant openings in low, dark northern forests, where the pointed spruce trees thin out at the edge of the barren, and the dull snow-threatening winter sky hangs close over the endless snow beneath; not even the little blue fox or musk-ox seems more suggestive of the northern cold. 


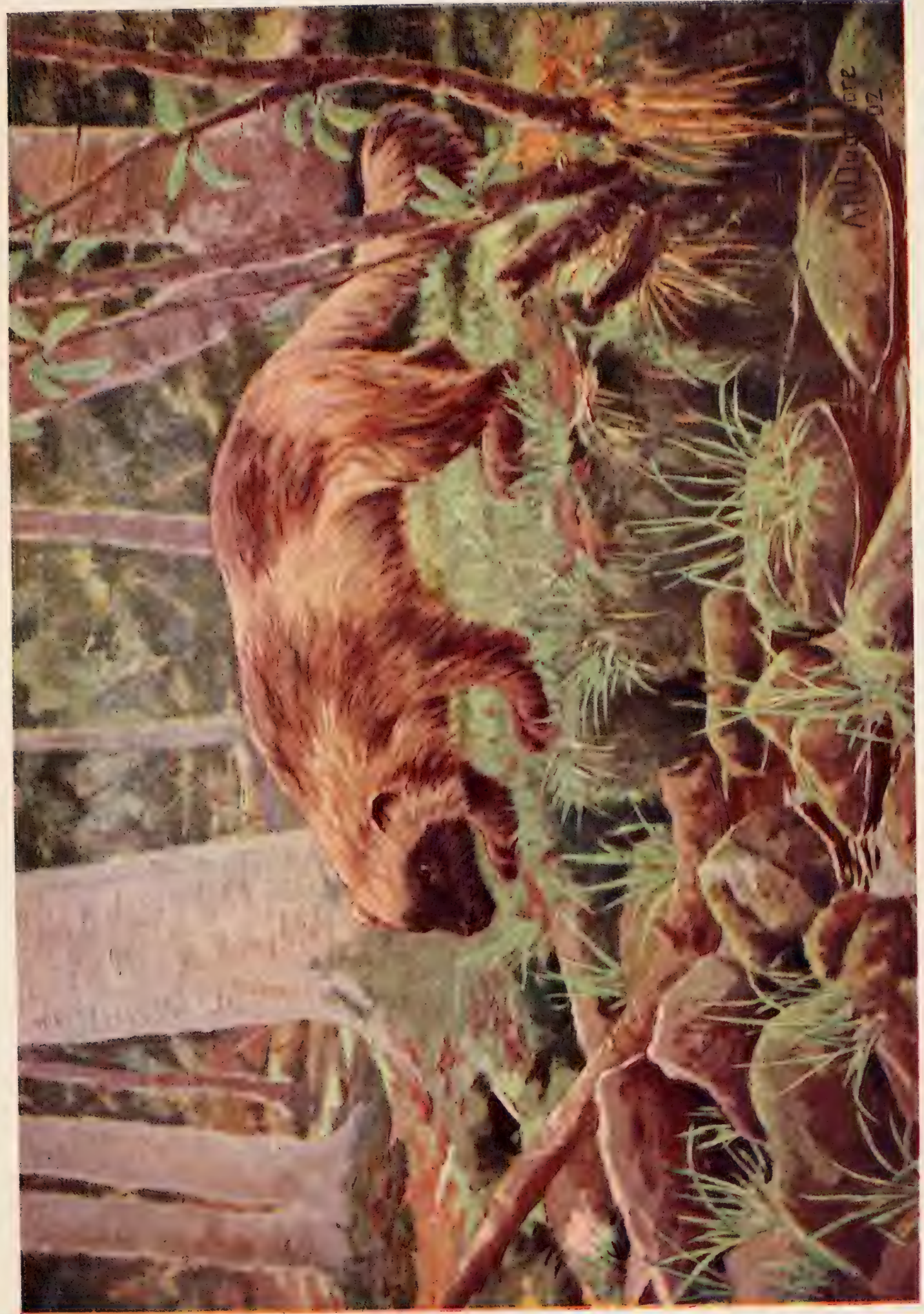



The wolverine is thoroughly hated by Indian and white trapper alike; he is often known as Indian devil, or north shore devil, and his capture gives greater satisfaction than the value of his fur alone would seem to warrant.

But his catching is no such easy matter, for he is slyer than a fox when it comes to springing a trap without harm to himself. The most successful method of trapping him seems to be to bury both trap and bait deep in the snow, as if with the intention of keeping it away from him.

\section{RACCOONS AND THEIR ALLIES}

\section{Family Procyonide}

Small or medium sized bear-like animals, mainly tropical, but represented in North America by the Raccoon and in the west also by the Bassaris and Coati. All of these may be recognized by their black and white-ringed tails.

\section{RACCOON}

\section{Procyon lotor (Linnæus)}

Called also "Coon."

Length. 32 inches.

Description. Form stout, tail thick, snout pointed, long hair, rather coarse. General colour gray or yellowish at base of hair, dusky or black at tips; dark on the back; face whitish, with a black area on each cheek surrounding the eye; feet black; tail very bushy, grayish-white, strongly ringed with black.

Range. Eastern United States to the Rocky Mountains, replaced in Florida by the Florida Raccoon $P$. lotor elucus Bangs, a gaunter animal, more yellow in colour. Other varieties occur westward.

It is interesting to note the pronounced difference which exists between the various species of our native wild animals as regards the readiness with which they manage to adapt 


\section{Raccoon}

themselves to the changed conditions forced upon them by the settling of the country and the consequent thinning of the forests and swamps.

In a previous chapter I have mentioned the pine marten, or American sahle, as a creature to all outward appearances, at least, well enough fitted for dwelling in a partially cultivated region without departing so very widely from the ways of its ancestors, but which has, nevertheless, been invariably one of the very lirst to disappear before advancing civilization, the value of its fur alone certainly not being sufficient to account for its extermination.

The raccoon, on the other hand, furnishes us with just the opposite example. A creature of somewhat clumsy and deliberate movements as compared with the majority of the wooddwellers; requiring a pretty large space for a hiding-place or hedroom, and generally insisting on a hollow tree of good size or cavern among the rocks for its accommodation; persecuted everywhere and at all seasons both by men and dogs, and in spite of it all, not only holding its own in most places where it has ever heen found in any numbers, but apparently even increasing and establishing itself in districts where, until quite recently, it has been practically unknown.

I cannot discover that they have ever been abundant in this vicinity (Southern New Hampshire) from the time when the country was first settled to the present. In fact, all those that I can obtain any account of as having been killed here, until quite recently, appear to have been regarded almost as curiosities hardly to be recognized even by the oldest hunters, yet one would suppose that formerly the country must have been much better suited to their tastes than now.

From all accounts the original growth of forests that stood here was composed much more largely of hard woods, white oak, beech and maple than the woods now left us, composed principally of white pine, hemlock and birch, furnishing neither food nor lodging to the raccoon's taste.

Within the last two or three years, however, raccoons have unquestionably hecome not uncommon in this and most of the neighlouring townships. so that coon hunts are becoming quite pojular and usually prove fairly successful, the barking of coon 
dogs on moonlight nights in the autumn being now a common sound.

Every now and then one also hears of some local sportsman or other bringing home a raccoon which he had killed quite unexpectedly when out after other game; only a week or two ago a raccoon was caught in a mink trap near here.

They are also said to be increasing in the same way in other parts of New England, even in the vicinity of large towns-Boston, for example.

Of course it is impossible to say as yet whether this increase is likely to continue indefinitely or to prove merely transitory. I see no reason why coons should not thrive here to a certain extent as they do in other parts of the country, for they are among the most widely distributed of our wild beasts, and although hollow trees are not perhaps of such frequent occurrence here as in hard-wood regions or in old-growth forests, I believe that they are as much so as in many places where coons are and always have been abundant.

In some parts of the country they are said to dwell in burrows which they dig in the high banks of streams by preference; in rough, ledgy land they appear to prefer cavities beneath the rocks to hollow trees, even, probably finding greater safety there.

Corn is more generally raised here than almost any other crop, and furnishes the coon with his favourite diet, complaints of the damage done by them in this direction having of late become quite frequent.

When the corn is in the milk the raccoons strip down the ears that are within their reach, and in sheer wastefulness and wanton extravagance usually manage to destroy several times as much as they actually eat.

Though so much smaller, they are said to be quite nearly related to the bears, and it would certainly appear that they possess about all of the characteristic traits of the ursine family, shuffling about the woods in a wholly bear-like manner, prepared to dine on anything that offers, either animal or vegetable; nuts, cherries, wild grapes and blackberries, bugs and reptiles are all on the list, which does not end there, however, for raccoons are skiiled both at fishing and hunting, though it is probable that in both these pursuits they are compelled to de- 
pend largely upon strategy to accomplish their ends. Fish is probibly not a very steady article of diet with them at any scason, for, though good swimmers and not at all averse to entering the water, they lack both the skill and the suppleness of the mink and otter which would enalle them to plunge in boldly and seize their prey with their teeth.

From the accounts of numerous eye-witnesses it would appen to be a pretty regular practice with them to lie in wait It the edge of the water and hook out any fish that comes within reach by a smart stroke of the fore paw with claws extended.

Being night wanderers, they undoubtedly often manage to surprise slecping birds, both on the ground and among the branches, as it is a common custom with them in thick woods to travel for long distances among the tree-tops without once deseending to earth, robbing the nests of birds and squirrels on the way.

Try to imagine the terror of a family of squirrels, sleeping snuggled up together within their thick walls, at having this great shaggy monster come scrambling along the branches at midnight and proceed to tear their roof to pieces above their heals, compelling them to scatter as best they may, blind as humans in the darkness, and wholly at a disadvantage against this night-seeing enemy.

On the ground the raccoon prowls about wet places from choice, along the borders of swamps and brooksides, following the paths made by sheep and cattle where they go down to drink. Every fallen tree on his path tempts him to mount and run along it to the other end, this habit being so universal with the raccoon family that coon-trapping is often successfully followed by simply setting steel traps on prostrate logs without any bait or other inducement whatever, though occasionally a piece of tin or other shining metal is hung just over the trap to attrat his attention in the moonlight, the coon's curiosity being proverbial. It is said that on discovering anything of the kind one will amuse himself for hours sitting upright and striking it with his paws to make it whirl and spin in the air.

His thick fur enables him, like the bears, to rifle bee trees in comparative safety, and to dig bumblebees' and hornets' nests out of the turf. 


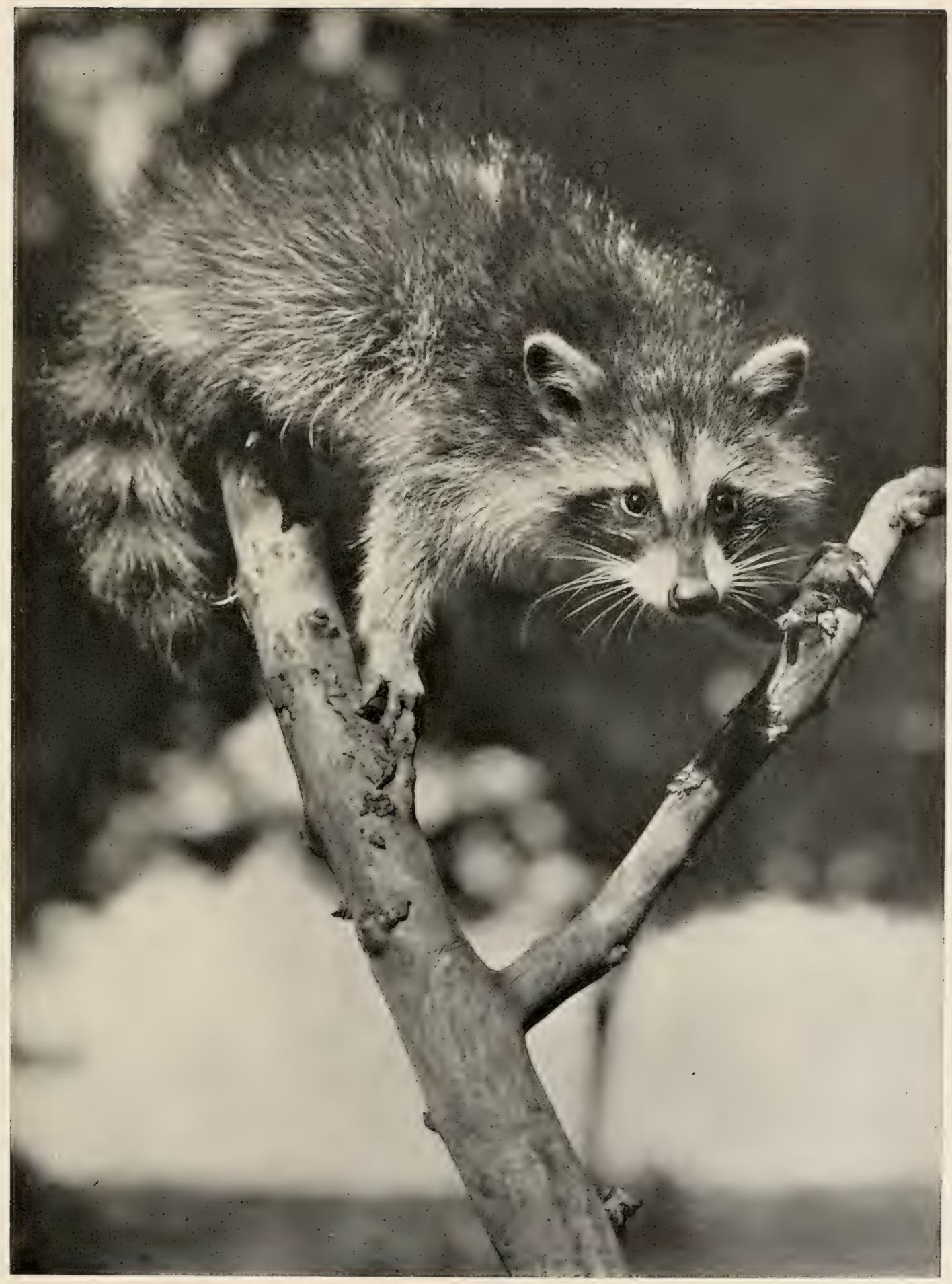




\section{.}


Raccoons, like most other climbing animals, make frequent use of the nests of hawks and crows to sleep in. At other times they flatten themselves along the thick branch of a tree, their gray fur harmonizing admirably with the colour of the bark, or else they ascend to the tops of dense foliaged hemlocks and, circling their fat bodies completely around the main stem, doze away the time in comfort, supported by the numerous elastic branches about them, quite invisible from the ground. If a company of blue jays discover one in this position there is sure to be a tremendous racket right away, their shrill voices jarring the quiet of the tree-tops like an alarm clock set to awaken the coon from his slumbers.

Compared with most of our flesh-eating beasts, raccoons are regular stay-at-homes. Of course there are exceptions, and undoubtedly many of them are possessed of the wandering habit, but I believe that the majority of them return regularly at daybreak, however they may have passed the night, whether peacefully gathering wild grapes or berries in the thickets, or robbing the farmer's hen-roost. This last is perhaps about the worst form of vice in which they ever indulge. A coon at large in a henhouse appears to lose all discretion or fear of final retribution, killing right and left while his enthusiasm lasts, and then gorging himself on the results of his carnage. Unlike foxes, most of whom carefully avoid a second visit to any farmyard that they have once ravaged in this manner, a coon is likely to return the following night to go on with his horrid work, and in most instances is made to suffer the penalty of his misdeeds-a characteristic which would appear to indicate a certain dullness of intellect, at least as compared with that of the fox; for as long as the latter is able to quietly capture two or three chickens each week under cover of the corn, he seems to realize that there is but little danger of calling down the vengeance of the farmer upon his head, and may keep up the game for months; but wholesale robbery he knows to be a more serious matter, and hardly to be repeated with safety.

The track of the raccoon is easily recognized either in soft earth or snow, the footprints being long with a narrow and quite distinct heel, almost like that of the human foot. They are commonly in pairs a few inches apart, one a little in advance, the pairs separated by a distance of something less than a yard. 


\section{Raccoon}

though of course, as the coon varies his speed the order of his footprints changes also.

The track of a skunk might be supposed to answer to this description, having as it does the similar heel mark; its small size, however, as well as the fact that its toes are not separated, as in the raccoon's tracks, serves as a distinction between the two.

The woodchuck's track is really almost the only one that could well be mistaken for that of a raccoon. To distinguish the two one has only to remember that the woodchuck's footprints are shorter, and show the mark of a pretty well defined thumb like that of a squirrel.

The young raccoons vary from three to six in number, and are born in April or May. At first they are as blind and helpless as young kittens, and remain under the care and protection of their parents for the first season at least. Their crying when they are separated from the old ones is said to resemble that of a human infant under similar circumstances.

The adults also have a kind of whimpering cry or call which is often heard on moonlight nights. It seems to be of a somewhat variable nature, at times resembling the quavering note of a screech owl or laughing hoot of a barred owl, and again sounding like a colt's whinnying.

This similarity to other sounds of the country renders it hard to identify, and from various circumstances I am inclined to think that it is never to be heard at any great distance.

On the arrival of cold weather young and old curl themselves up together; occasionally several families will occupy the same hollow tree. In this manner they pass the first and severest part of the winter in a more or less lethargic condition, hardly relapsing into such a state of unconsciousness that a few days of warm weather will not tempt some of them out on the snow.

Back they go again, however, into winter quarters at the advent of the next cold wave, and for the remainder of the season confine themselves to naps of a few days or at most a week's duration.

By the time spring has fairly taken possession of the woods they are all out again, searching among the sodden leaves and dehris left by the last rain of the winter for newly awakened snakes and beetles. It is at this season that they are oftenest 
compelled to go hungry, and, like the other hibernating beasts, they lose flesh rapidly during the spring months, though the omnivarous nature of their appetites gives them a decided advantage over the woodchucks and the rest of the vegetable eaters in the general scramble for food.

It is curious that the quaint custom of washing meat of all kinds before eating it should be clung to so religiously by the raccoons of all parts of the country. Raccoons are so easily domesticated and prove such amusing pets that accounts of tame coons are to be picked up almost anywhere, and although exhibiting plenty of originality in most ways, they all seem to agree in this one particular: that when meat is oftered them it must be thoroughly washed or else eaten only under protest appar ently, many a coon preferring to go hungry rather than eat flesh which it has not first been allowed to wash. Moreover, they are not willing to let any one else do the work for them, insisting rather on being allowed to do it all themselves, holding their food in both fore paws and sousing it about in the water until it is reduced to a pallid, flabby, unappetizing mess which only a coon could look upon without misgiving.

The latin title lotor, as well as the names applied to this species by both German and French naturalists, and I think by some of the Indian tribes of this country, have reference to this washing habit.

The coon never has, and probably never will achieve, that fame and popularity in the North which it holds in the South. It undoubtedly owes the position which it holds there to the peculiar mixture of insight and imagination with which the negro observes the wild things about him, looking upon them as little wild people dwelling in the woods and fields as best they may, and hardly differing from his own race except as he himself differs from the whites; the raccoon to them is "brother coon" and the rabbit "brother rabbit."

Before the war, the white children on the Southern plantations obtained most of their knowledge of natural history from the slaves, and although they received real facts and quaint negro ideas and superstitions wonderfully blended, I am convinced that with it all they got an appreciation of the true innerselves of the little beasts not to be obtained from books or any amount of the scientific research of the trained naturalists. 


\section{Texas Bassaris}

The Northern farmer, lacking this early training, in too many instances wholly ignores the wild creatures that inhabit his woodlot, except when compelled to defend himself against their inroads on his property. It is the exception, even among farmer boys in the North, to ever take the trouble to study their ways closely in order more successfully to shoot or trap them for profit. Most of those who endeavour to add to their pin money by trapping and shooting during the comparatively idle season of late fall and winter and early spring, simply follow the direction given them by those who followed the profession before them and who, undoubtedly, in their time received the same from their elders.

\section{Texas Bassaris}

\section{Bassariscus astutus flavus Rhoads}

\section{Called also Ring-tailed Cat, Civet Cat, Cacomistle.}

Length. 28 inches.

Descrition. Much more slender than the Raccoon, with a long

tail. Colour, yellowish-brown, inclining to gray above, below

white; tail ringed with black and white.

Range. Texas, with an allied variety in California and Oregon, and others in Mexico.

The Bassaris is a beautiful little animal, with its slender, almost weasel-like body and handsome ringed tail. It seems to be more characteristic of Mexico than of our own country, and, although it ranges well northward in suitable regions, but little has been learned of its life history. Its nocturnal habits and life among the rocks and trees probably has much to do with this. In captivity it is said to be gentle and docile.

\section{Mexican Coati}

\section{Nasua narica (Linnæus)}

\section{Called also Coati mondi.}

Length. 3 feet.

Descriftion. Coon-like; tail tapering to a point; nose much 


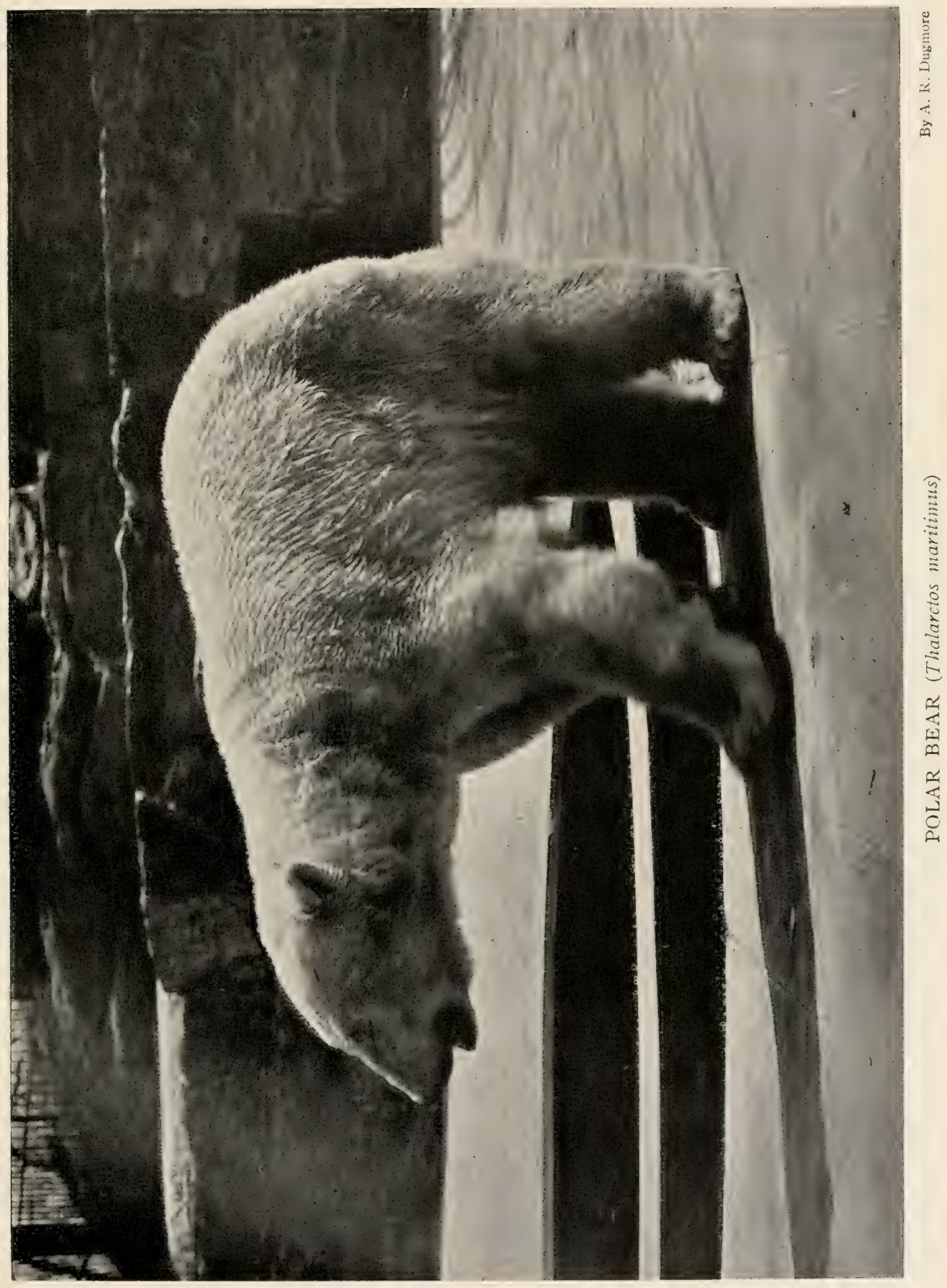



lengthened and tapering, forming the most characteristic feature of the animal. Fur thick and long. Colour, darkbrown, sometimes with rufous tints, generally tipped with white or gray, nose and region around the eyes white. Tail usually faintly ringed with grayish-white, sometimes only perceptible on the basal portion below, or occasionally with rings entirely lacking.

Range. Mexico, crossing the Rio Grande into Southern Texas.

This curious beast, reminding one of a coon with nose and tail pulled out to a point, is a characteristically tropical animal, which ranges just over our southwestern border.

\section{$B E A R S$ \\ Family Ursida \\ Polar Bear}

\section{Thalarctos maritimus (Phipps)}

Length. 7 feet.

Description. Entirely white at all seasons, or slightly tinged with yellowish; fleshy parts of nose and lips black. Range. Circumpolar regions South to Northern Labrador.

The Polar Bear is the beach ranger of the northern seas. Other bears the world over keep to the shady thickets and forest tangles, where, when the hunting is poor, they can gather wild berries and nuts, and grub roots out of the black earth. But the polar bear rarely tastes vegetable food except in the few short weeks of an Arctic summer. In the desolate, treeless north, he shuffles along over ice-crusted ridges, powdered with snow. His favourite hunting grounds are along the margin of the ice-fields, where the drifting floes grind against the fixed ice of the shore line, and rend and split with the heaving of the ocean. Here he watches for seals at their breathing holes, as patiently as a cat watches for mice, or stalks them under cover of the ice cakes at the edge of the breakers.

If he sees one resting on the ice where there is small chance of creeping on it undetected, he plunges into the sea 


\section{Polar Bear}

and swims far out among the whitecaps to the leaward and makes his approach under water. $H e$ is a powerful swimmer even in a heavy sea, and catches salmon swimming like an otter.

Anything eatable that floats or is cast ashore is his food, a deald while or a herring being alike acceptable. With comparatively few exceptions, it is only the old males of the species that face the dull length of an Arctic winter out-of-doors. In the autumn, when the snowstorms become heavy and frequent, and the driving scud from the sea shuts out the low sun, most of the she bears look round for some protected hollow in which to pass the winter.

Under the projecting shelf of a ledge and between neighbouring rocks are filvourite winter dens of theirs. Sometimes one will dig a cave for herself in the snowdrift, or, curling up in the bed of a rock, she lets the snow bury her as it will, the one object in any case being to have plenty of snow piled above her for protection against the coming winter. In those northern latitudes the summers are far too short for a young bear born in the spring to gain sufficient strength for withstanding the hardships of the rough winter that closes in so rapidly.

The young polar bears are born soon after the old one has buried herself for the winter, and for months she hibernates there under the snow with only a slender breathing shaft kept open by the warmth that rises from her fat body.

For the entire winter the cubs draw all their nourishment from her and grow strong and lusty, while she, being without food of any sort, becomes lean and gaunt during her long rest before the late spring releases them from their prison.

In the latter part of the winter the cave is gradually enlarged by their breathing and the warmth of their bodies, which melts away the snow around them, until finally they succeed in hreaking awaly a passage and come out into the flat rays of the sun. There are now great companies of wild fowl and sea-birds gathering to nest among the cliffs, and seals with their young on the ice; so the old bear has a good chance to recuperate her strength and teach her cubs to hunt and fish for themselves.

When more nourishing food is hard to get, she crops the 

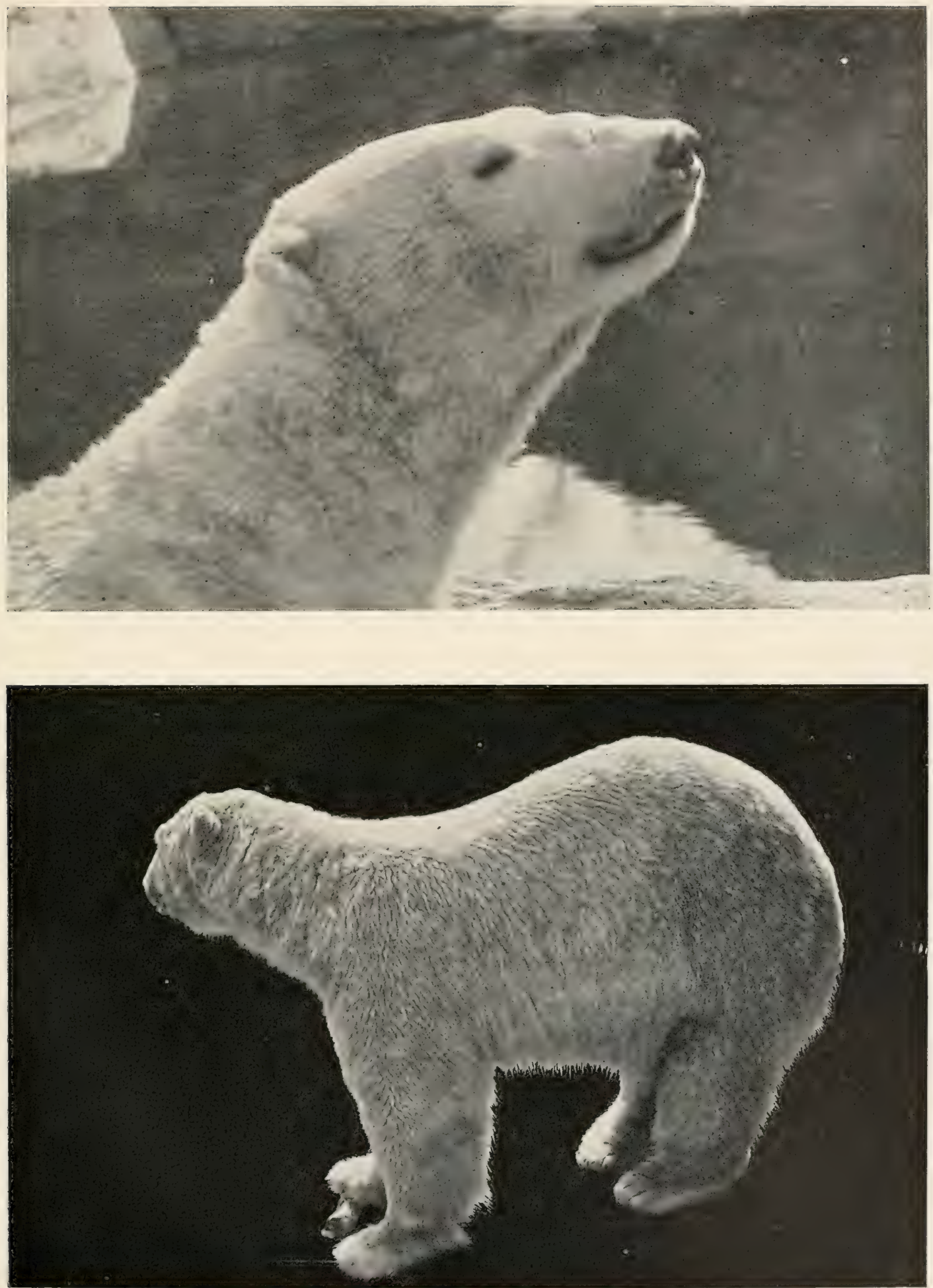

salt grass back of the beaches, and later gathers berries and roots from the bogs thawed for a little while at the surface by the long hours of sunlight. The polar bear's courage in defense of her young is well known. Almost every Arctic explorer has brought back vigorous accounts of her valour and self-sacrifice. If only the humans could have shown up half as well as the bears in these encounters; they would make much more cheer ful reading.

\section{Black Bear}

\section{Ursus americanus Pallas}

\section{Called also Cinnamon Bear.}

Length. 5 feet.

Description. Colour entirely black, with a brownish tinge on the face. Some individuals are uniform dark chestnut or cinnamon, with purplish reflections in certain lights, and are called "Cinnamon Bears." For many years this colour phase was thought to represent a distinct species.

Range. Forest regions of North America, except the Gulf States, and Labrador, where allied varieties occur.

The black bear originally inhabited nearly all the woods of North America. It is still fairly common in lonely regions where there is much thick timber and rough land.

The black bear differs from the typical bear of literature in a great many ways; the bear of folk-lore and story-books, that roars and attacks people on sight, is the brown bear of Europe, a rough, shaggy beast, clumsy and awkward, like our grizzly bear. The black bear is a smooth-coated, well-shaped fellow, savage enough when attacked and compelled to fight for its life, or to protect its cubs, but at other times timid and inoffensive. When you walk through the woods the shy rabbit allows you to approach to within a few steps before it takes fright and goes bounding away, but the black bear is much more easily frightened. Long before you have got within sight of him he is running for his life with almost the speed of a fox, yet in his encounters with dogs he has proved himself a dangerous antagonist, plucky and ready to fight. The fact is, his terror of man is the only thing that could possibly save him. If he had as- 


\section{Black Bear}

sumed the same attitude toward man in this country that the brown bear has in Europe, the last of his race would have been shot in the days of our grandfathers.

Except in early spring, black bears live principally upon vegretalle food; blueberries are their favourite diet, though fruit of any kind seems to suit them well enough.

They also dig for roots and bugs, and catch grasshoppers and crickets in the grass.

When there is plenty of such food to be had, they will, it is said, pass the newly killed carcass of a deer or a sheep without noticing it.

This, however, probably depends a good deal on the individual, some of them being always fond of meat. Like all bears, they are pissionately fond of honey and very clever at finding bee-trees. When a bear has discovered a bee-tree he courageously attacks it with teeth and claws, endeavouring to enlarge the opening sufficiently to enable him to reach the honey. But the stings of the enraged insects about his nose and mouth cause him to stop frequently. If the bear is at work at the foot of the tree, he can roll on the ground in order to get rid of his tormentors when the pain becomes too severe, but if he is high up on the trunk he can only rub them off against the bark and hold his ground, knowing it will not be long after the honeycomb is broken into before the bees will leave him in peace, each hastening to fill its honey-bays before it is too late. Black bears hibernate throughout the winter, stowing themselves away in hollow trees and caves among the rocks. In the extreme north of this range they follow the example of the polar bear, curling up in a cave or hollow where the drifting snow will bury them and keep them warm until spring. When they come out at the end of the winter the skin on the feet cracks and peels off, leaving them soft and tender.

They now have rather a hard time of it for a few weeks; for food is scarce and difficult to get even for an animal in the best condition; and to be handicapped with sore feet and weakened by a four-months' fast at the same time is hard luck.

They now roam the woods in the hope of finding some animal or hird uncovered by the melting of the snow, and sniff for newly awakenced snakes and hugs around mosis old stumps 


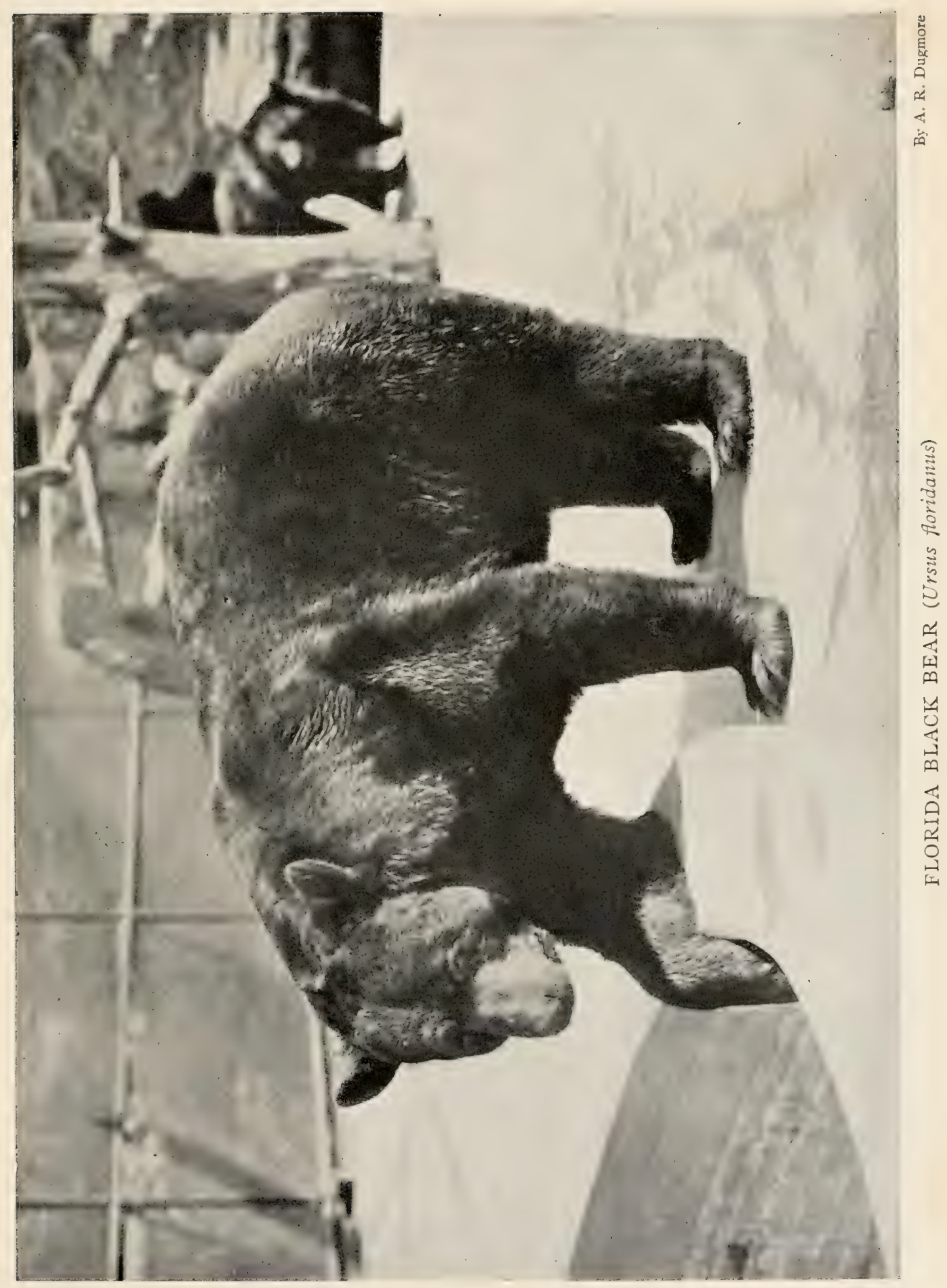



and decaying timber. Later, when the ice has melted, they can get succulent plants along the margin of lakes and ponds, and catch suckers and other fish that run up the "rattling shallows." Then they go looking for checkerberries on sunny banks in the woods, or, if the opportunity offers, kill cows and sheep that have been turned out to pasture. In summer they keep to gloomy swamps and mountain-sides, where they feed on roots, nettles, etc., to a certain extent. In hot weather they get lots of fun wallowing in the mud like so many pigs.

In August and later they visit the farmers' corn-fields and munch the juicy ears and stalks; pork is a favourite meat of theirs, and they often show an astonishing degree of boldness, for an animal usually so shy, in breaking into pig-pens in the night. As autumn advances they gather nuts, acorns, wild grapes, berries and mushrooms. It is at this season that they get the most honey, and also dig up the nests of savage yellow-jackets, in spite of all the stinging that inevitably follows.

The cubs are sportive creatures, full of pranks, running, leaping, wrestling, boxing, and playing hide-and-seek, and attempting all sorts of tricks and jokes to tease the old one. But though they do everything they can think of to worry her, she thinks everything of them, and guards them jealously; and when she is with them is about the only time that she is ever really dangerous. She leads them all over the woods, teaching them everything she knows: how to catch mice and dig ants out of a rotten $\log$, or slap a bull-frog out of the water.

Most bears retain a sense of the humorous, even after they are full-grown and surly; in captivity they are less to be pitied than most wild animals, for this keen sense of fun enables them to get a great deal of amusement out of an old hat or an empty barrel, especially if any one is watching and ready to take a hand in the game.

The black bear, moreover, is almost always interested in observing the curious ways of the humans in front of his cage. Even in the woods he often exhibits a desire to study the habits of men, creeping up under cover from behind to watch them as they endeavour to catch fish for food, or gather blueberries just as he himself does. There are more people who have been watched and studied in their summer outings by bears than are aware of it, for the bear is ever careful to keep well hidden, and 


\section{Glacier Bear}

hurries off the instant he thinks his presence is mistrusted. It is not at all unlikely that the bears in Northern New England are quite as well informed concerning the summer habits of men in those parts as we are concerning them.

\section{Varieties of the Black Bear}

The black bears differ from the grizzlies in generally smalles size, and in having the claws of the front and hind feet nearly 'qual in size, and the hair nearly uniform in length all over the hody. The varietics have been separated almost entirely on characters of the skull, as follows:

Blacti Bear. Ursus americanus Pallas. Skull rather short and broad, Io by 7 inches. Range as above.

L.zprafor Bear. U. amiricanus sornborgeri Bangs. Smaller, with broader skull, 8 by 5 inches.

Florita Bear. U. amerianus floridanus (Merriam). Skull long and narrow; forehead mich elevated, II by 7 inches.

Louisinni Bear. U. Inteolus Griffith. Skull large and long, much flattened on the forehead, 11.5 by 7.5 inches.

\section{Glacier Bear}

\section{Ursus cmmonsi (Dall)}

Length. 4 feet:

Descrition. General colour resembles that of the silver fox. Fur remarkahly soft, with a rich under-fur of a bluish-black shade, many of the long hairs white. Dorsal line black; sides mingled black and silvery white. beneath grayish-white; outer side of limbs black; sides of muzzle and lower anterior parts of check bright tan colour; no shade of brown elsewhere on the fur. Claws short, strongly curved, and sharp; ears very short.

Ranne?. Glacier region Mount St. Elias, etc., to Juneau, Alaska.

This curious and little-known animal is an inhabitant of the St. Elias Alps, frequenting the edges of the glaciers It is known to fur-dealers by the name of blue bear, and is said to be shy and less fierce than other species. 


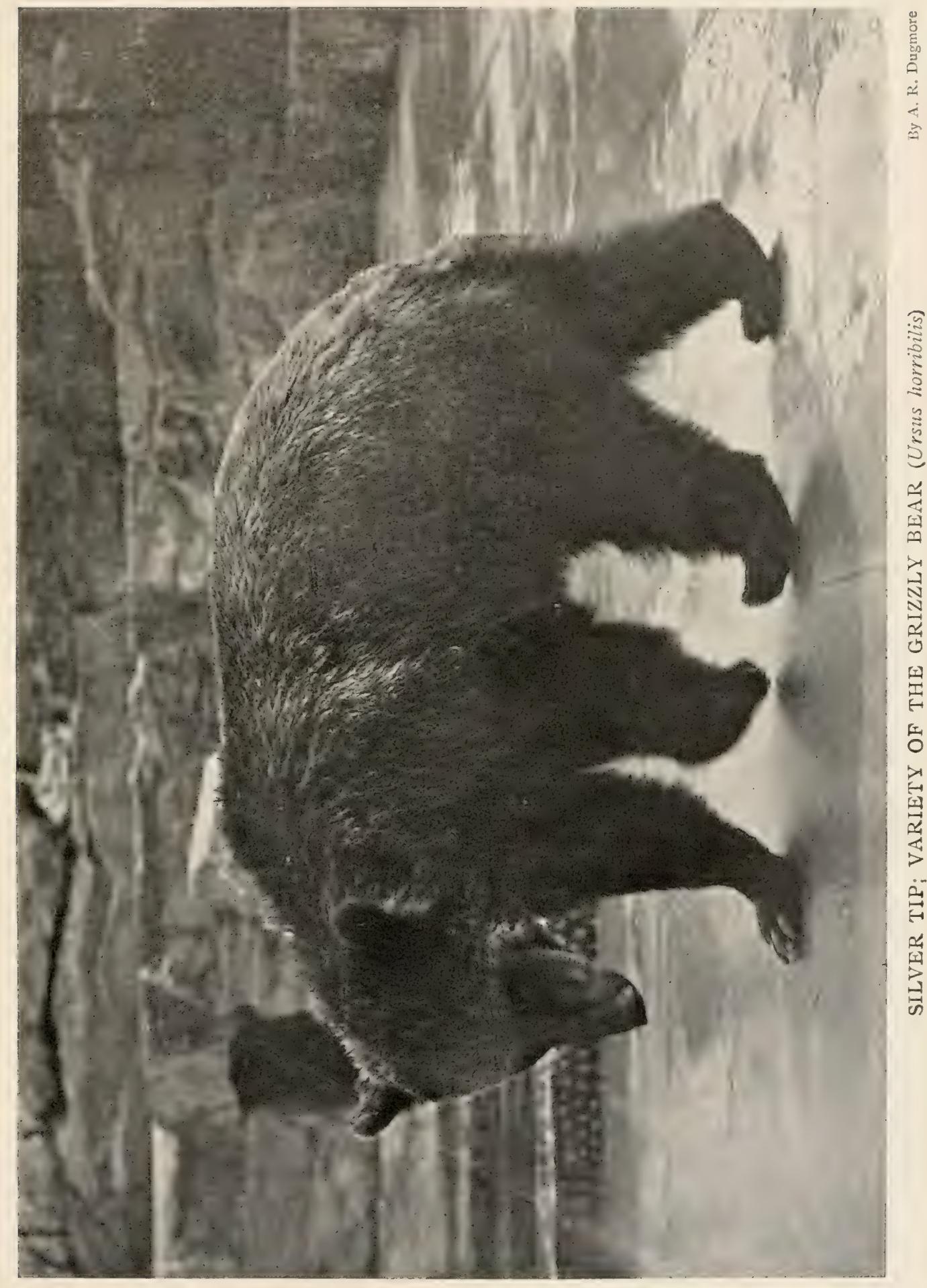





\section{Grizzly Bear}

\section{Ursus horribilis Ord}

Length. 6 feet 6 inches.

Description. Fur shaggy, especially long on the shoulders and flanks; front claws much longer than the hind ones, and strongly curved; hind foot relatively longer than in the black bear. Brownish-yellow; darker on the back and legs; long hair, often reddish-brown.

Range. Rocky Mountains of Utah to Alaska. Closely related varieties occur in the Southern Rockies and at Norton Sound, Alaska, while a smaller ally, the Barren-ground bear, U. richardsoni Reid, ranges from Hudson's Bay to the Mackenzie and northward.

The grizzly bear is a great rough brute, heavy and lumbering, and easily the largest and most ferocious bear to be found in any part of the world. At the present day, however, he seldom ventures to attack man except in self-defense. In the land where grizzlies are found, only those beasts have survived that excelled in keeping out of sight. Wildness has therefore of late years served the grizzly better than strength and courage in the struggle for existence. He still finds his great muscles useful in the matter of getting a living; there is nothing lives in his country that the grizzly cannot kill and carry away, with the possible exception of the cougar. Indians and certain old-time hunters claim that the cougar will attack and kill a full-grown grizzly; but beyond their stories there seems to be no evidence whatever that a cougar ever killed a grizzly that was too old to be called a cub.

In the earlier days the grizzly bear regularly hunted the bison among the foot-hills of the Rockies.

It is said that one was able to kill and drag off an old bull bison weighing one thousand pounds or more.

At the present time, when the grizzly wishes to go after big game he generally hunts the horses and cattle owned by the herders, and so gets himself disliked. He also hunts deer and wapiti, and in the most northern part of his range an occasional moose.

But he lives to a large extent on much humbler fare; rambling among the crags, with low-hung swinging head, he listens 


\section{Grizzly Bear}

for mice in the grass, and digs them out with claws fashioned to kill an $o x$ at a blow. He also eats insects, berries and wild plums, and munches green fodder in the meadows. The cubs are said to be as funny and amusing as young bears of any sort, and being less unwieldly than the old ones, frequently climb trees.

When an old grizzly has established a hunting range for himself, he writes his challenge with his massive claws and tusks on the trunk of a pine as high as he can reach. His tremendous strength is generally known and respected by other four-footed hunters, who might otherwise be tempted to poach on his preserves. If another bear, wandering in search of better hunting grounds, happens along this path, he is certain to see these warning claw marks, and rising on his hind feet he also strikes the bark in a similar manner. If he fails to scar the trunk as high as the other bear has done, he continues on his travels, leaving the first in undisputed possession. But if the new-comer finds that he can reach as high or higher than the one who first left his challenge there, he is more than likely to remain in the immediate vicinity, scarring other trees here and there, and hunting when and where he pleases.

Unless the first bear has observed the challenge of the newcomer, and, losing courage, retires from the neighbourhood, the two are bound to meet sooner or later and a tremendous fight ensues.

When the supremacy has been finally decided, the vanquished bear, if indeed he has not been killed outright, betakes himself to some distant part of the forest to nurse his wounds in solitude.

The method of challenging all comers is common to a great many wild beasts, large and small; not only bears of all kinds and many of the smaller hunters, but deer and moose as well. And I am inclined to think that when the house-cat stretches up to sharpen its claws on the trunk of a tree, it is a similar challenge for other cats to read.

And who knows but the same instinct, brought up from past aures and more than half forgotten, urges domestic cattle to rub their horns as high as they can reach against any smooth-boled free in the pasture just as moose and wild deer do in the forest? 


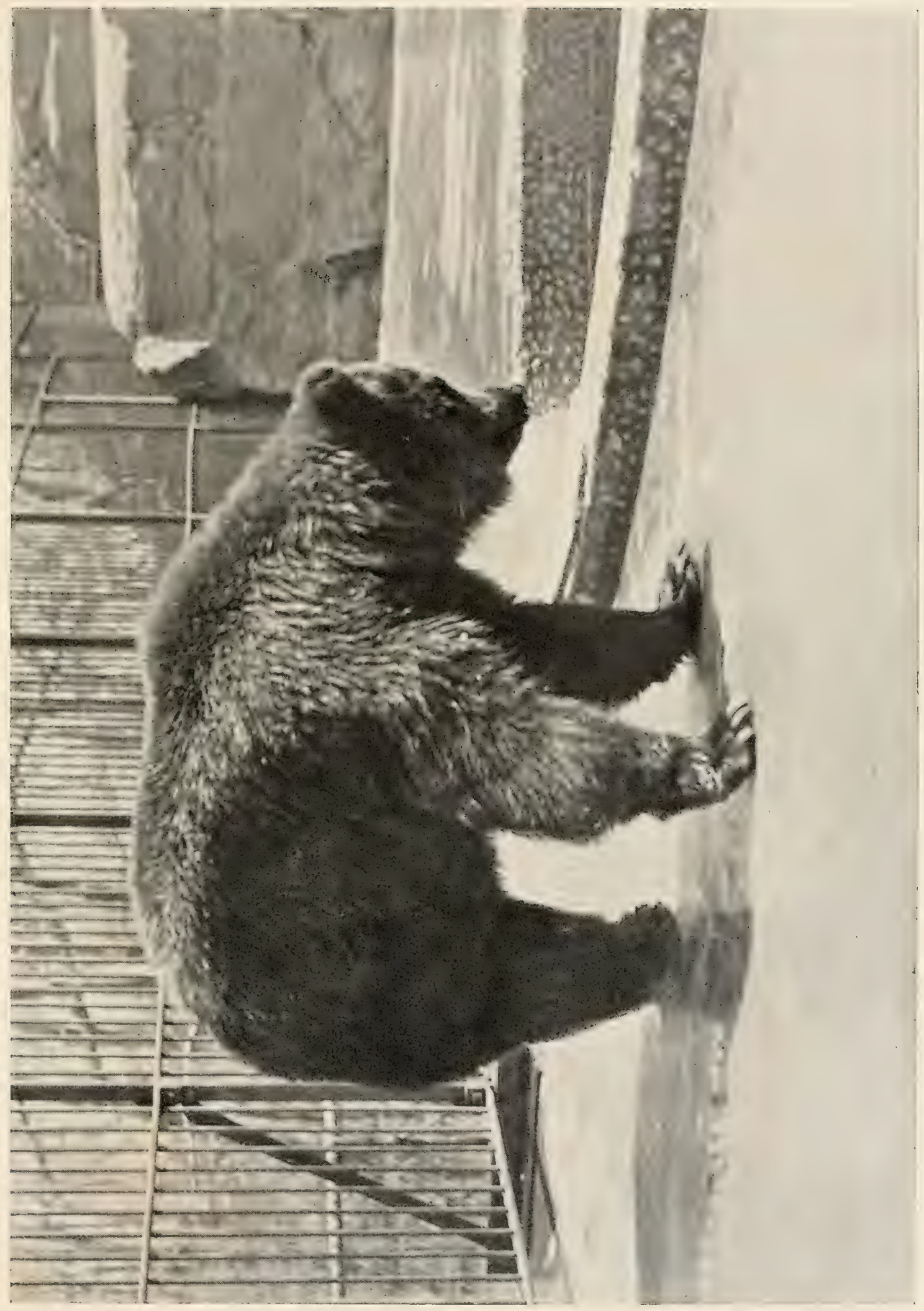





\section{Varieties of the Grizzly Bear}

1. Grizzly Bear. Ursus horribilis Ord. Description as above.

Range. Northern Rocky Mountains from Utah to the interior of British Columbia.

2. Alaskan Grizzly. Ursıs horribilis alascensis Merriam. Skull larger, and other cranial and dental peculiarities.

Range. Norton Sound District Alaska.

3. Sonoran Grizzly. Ursus horribilis horriaus Baird. Frontal region of skull not elevated at or behind the eye sockets, as in $U$.horribilis, but hollowed between them.

Range. Southern Rocky Mountains and outlying peaks and ranges, Colorado to Arizona.

4. California Grizzly. Ursus horribilis californicus Merriam. Rather larger than the last. Ears longer.

Range. Southern California. (Rapidly approaching extinction.)

No satisfactory comparison of skins of these animals, nor the large brown bears, has been made as yet, and they have been studied mainly from skulls.

\section{Kadiak Bear}

\section{Ursus middendorff Merriam}

Length. Skin, Io feet. Skull, 15 inches.

Description. Largest of the American bears. Colour similar to the grizzly but skull presenting many points of difference. Range. Kadiak Island.

This enormous bear and the allied Yakutat and Sitkan bears are restricted to Alaska and adjacent islands. They present differences of structure from both the grizzlies and black bears and are larger than either.

\section{Species and Varieties of Brown Bears}

1. Kadiak Bear. Ursus middendorff Merriam. Range and description as above.

2. Yaliutat Bear. Ursus dalli Merriam. Frontal region of skull flattened instead of arched.

Range. Yakutat Bay, Alaska.

3. Pavlof Bear. Ursus dalli gyas Merriam. Much larger than the last.

Range. Pavlof Bay, Alaskan Peninsula. 
4. Sitka Bear. Ursus sithensis Merriam. Rather smaller than the Yakutat bear but structure of teeth different from any of the above and approaching the black bears.

Range. Sitkan coast region, Alaska.

5. Kiditer's Biar. Ursus libideri Merriam. Allied to the Yakutat bear, but smaller, with smaller teeth.

Range. Alaskan Peninsula.

\section{WOLVES AND FOXES}

\section{Family Canida}

The dogs and their allies, the wolves and foxes, resemble the cats in being digitigrade, or walking on the toes, and in having only four toes on the hind feet, but differ in having their claws duller, shorter, and not retractile.

\section{Red Fox}

\section{Vulpes fulvus (Desmarest)}

Called also Cross Fox, Silver Fox, Black Fox.

Length. 40 inches.

Desiription. Fulvous or rusty red, grayish on the rump and flanks;

hairs of the tail black toward the end, tip of tail whitish; leus black, partly white on the inside; throat white; ears largely tipped with black. Considerable variation occurs in the colouration of the red fox, especially in the northern part of his range. One phase similar to the above, but with a black band across the shoulders and another along the back, is known as the "cross fox," while the "silver fox" is a gray phase and the "black fox" a black phase of the same animal.

Range. Northern North America south to Georsia. Replaced in Nova Scotia and Newfoundland by slightly different varieties.

The reputation for shrewdness and cunning which the fox has always borne is well-earned and indisputable. One of the moit characteristic traits of the whole fox tribe is the quickness with which they gather experience and learn to avoid new dangers. The early settlers found little difficulty in trapping and 

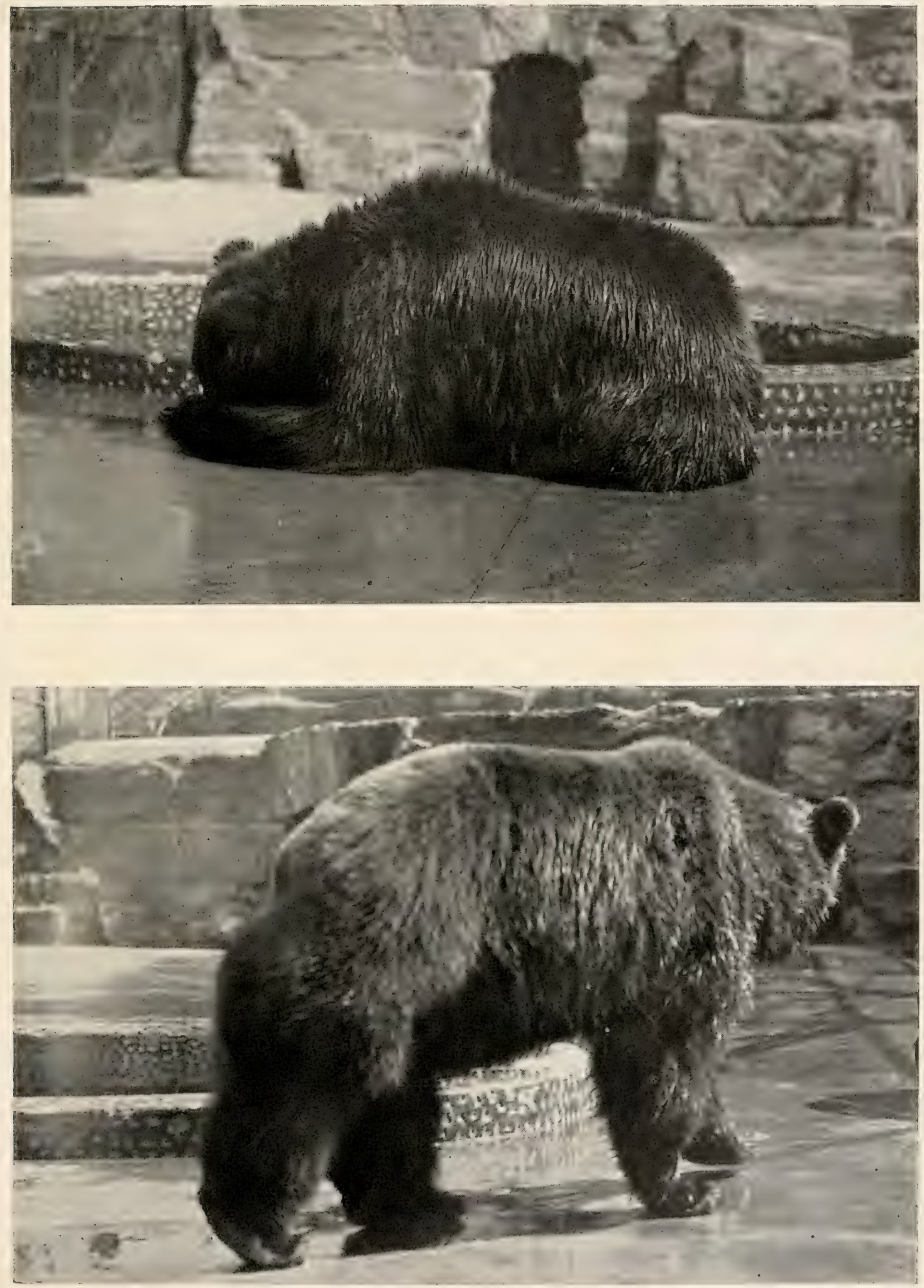

shooting the foxes which skulked about their clearings, and even now those found in wild, unsettled country are comparatively easy to outwit. But the red fox of cultivated districts has learned a great deal from watching the ways of men, and has already very nearly caught up with Reynard of the Old World in the matter of a highly developed intellect.

He now holds his own against man, as much by boldness and audacity as by caution; few of our wild animals look on man with so little awe.

Only last winter I saw two sturdy fox-hunters hurrying through the snow, eager to head off a fox, which, judging from their remarks which I overheard, they imagined would cross the stream at a point a mile ahead.

And all the time there was the fox they were after coolly following in their footsteps at a safe distance, while the hounds, baffled and outwitted, bayed dolefully in the woods somewhere on the other side of the stream.

This trick of following the hunter is not in the least uncommon. I have frequently, when returning in my own tracks from a tramp on snow-shoes, found the fresh trail of a fox who had been following me.

But you will seldom catch him at it; the instant you stop he slips behind a tree, and if you turn back, vanishes in the shadow of the forests.

I once saw my father driving home the cows on a summer evening with an old fox, of whose presence he was totally unaware, trotting along the sunlit sheep-path scarcely one hundred steps behind him.

The fox's boldness in robbing hen-roosts is well known; and as most foxes know too much to visit the same place twice, it is only rarely that they get caught at it.

I know of one instance when an enthusiastic fox hunter, arriving at daybreak in order to have an early start with the hounds, heard a disturbance in his hen-pen, and looking in to see what was the trouble, met a fox just coming out.

The fox slipped by him and dashed away for the woods; and the hunter, thinking that this certainly was a good beginning for a day's sport, put his dogs on the trail, confident of getting at least one new pelt that day. But all day the fox eluded them, and when at nightfall they came home unsuc- 


\section{Red Fox}

cessiul, beneath ditrening skys, they were undoubtedly every hit as weary als the fox they had been chasing. One bright windy Sunday in February, a few years ago, a farmer of my acpuaintance happening to look out of the window saw a fox stretching himself to his full height on two legs in order to louk through a arak into the hen-house. The farmer seized his gun, and rumning to the door let fly both barrels, but befire the shot could reach him, the fox had dodged behind a comer of the huilding. and keeping it between himself and the aiming. was quickly out of range.

But the fox likes best to catch chickens in summer, when the corn-fields, orchards and hedgerows furnish him safe ambush and effectually cover his retreat. One hot morning last summer a fox chased some hens up across the new-mown griss land to within one hundred feet of the open door where we were standing, and calthing the hindermost one, threw her across his shoulders and started for the woods. I caught up a rifle with one hand and shot-gun with the other, and thus thoroughly equipped hurried to the rescue.

I was too late to save the unfortunate hen, however; the fix stopled when he reached the lower end of the field, and stretching himself in the warm grass, held her down with his paws, biting her tentatively to make sure she was dead. I make a slight detour and crawled cautiously to the top of the nearest knoll, but even then the fox was much too far away for the shot-gun to reach him; so, resting on my elbow, I allimpted to get his range with the rifle, but only succeeded in throwing some dust in his eves, and away he went like an arrow.

I have known a fox to kill three or four full-grown fowls in an orchard close to a farm-house where the family were at ho:akfist, and get away without being seen, carrying one of his victims with him.

On another occasion, quite recently, one of my neighbours laal thirty pullets taken in a single night. Fighteen of them were found next morning in a heap at the foot of an oak tree. Another farmer tells me that he has lost one hundred and fifty in one season, all presumably going to the foxes.

Yet, although the farmer and the fox are such inveterate cnemies, they manase to benefit each other in a great many ways quite unintentionally. 
The fox destroys numberless field mice and woodchucks for the farmer, and in return the farmer supplys him with poultry, and builds convenient bridges over streams and wet places, which the fox crosses oftener than the farmer, for he is as sensitive as a cat about getting his feet wet.

On the whole, I am inclined to believe that the fox gets the best part of the exchange, for, while the farmer shoots at him on every occasion, and hunts him with dogs in the winter, he has cleared the land of wolves and panthers, so that foxes are probably safer than before any land was ploughed.

When the snow is deep the farmer's sled makes the best of paths for the fox, who appropriates them for his own use just as unconcernedly as he does the regular highway. But to see a fox get round the farmer's dogs, in order to make friends with them, is one of the most astonishing revelations of character. Usually the dogs seem hardly to know at first what to make of his advances, but the fox is pretty certain to succeed in bringing them to his side in the end, and after that they may be seen playing together day after day.

If, as I am sometimes tempted to believe, the fox really works this scheme with the deliberate purpose of making it safer for him to get at the farmer's chickens, he is gifted with a degree of shrewdness beyond anything he has been credited with.

It is only recently that I have come to realize what persistent woodchuck hunters foxes really are. I find that the shrill alarm cry of the woodchuck, heard echoing back and forth across the pasture-land, is a pretty reliable foretelling of the approach of a fox.

The appearance of a man or dog causes no such general alarm among them.

Last April, on a windy afternoon of bright sunlight, I saw a big dog-fox hard at work digging out a woodchuck's hole on the slope of a sandy hillock at the edge of a meadow.

Every few minutes he would back out of the hole, and, shaking the loose earth from his yellow fur, look intently across to the other opening of the burrow, as if expecting at any moment to see the woodchuck try to make his escape by way of the back door. A little distance away a woodchuck was signalling the dangers to any others of his kind that might 


\section{Red Fox}

he within hearing: hi was safe enough at all events; the hole hesile which he was sitting was ringed in by corded beech roots with an entrance much too narrow to admit a fox.

In summer time foxes like best to hunt the woodchucks that are just learning to go about alone.

I have never seen an actual encounter between a fox and a full-grown woodchuck: the fight must frequently prove a sharp one, for the woodchuck, though clumsy as compared with a fox, is a stubborn lighter, and knows how to use his chisellike teeth to good purpose.

In the autumn, when the hounds are out and the uplands sing with their baying, it is only natural to think of the fox with pity, and for the time being, at least, to forgive him a portion of his sins.

If he is being hunted in the English manner, with horses and hounds, your pity is certainly not misplaced. To be run down and overtaken and torn to pieces by overpowering numbers, when at list his strength fails him and all his wiles have proved in vain, is a cruel end for any animal to meet. Fox hunting as it is practiced in most of our northern states, however, though it may not be quite so good form, is yet perfectly sportsmanlike, and a great deal pleasanter for the fox.

To say that the foxes frequently get their share of the fun while being hunted sounds absurd enough, but is nevertheless true. Only two or three hounds are used, and the hunter, instead of following, endeavours to head off the fox and shoot him. About the only cruelty in this sort of hunting is when an occasional fox is wounded and escapes, and must heal his shot wounds and gret along as best he may for the next few weeks.

When the fox first hears the hounds baying in the distance he listens anxiously, and can soon tell by the course they are following whether they are on his trail or that of another fox; in the latter case he simply goes to sleep again, or watches the course of the hunt at a safe distance. But if he finds that the hounds are on his track, he stretches himself and starts off lasurely, planning all sorts of stratagems to throw off the scent.

It does not worry him in the least to have the dogs close on his heels; he knows that they are afraid to touch him, and that he can easily leave them miles behind whenever he cares to 

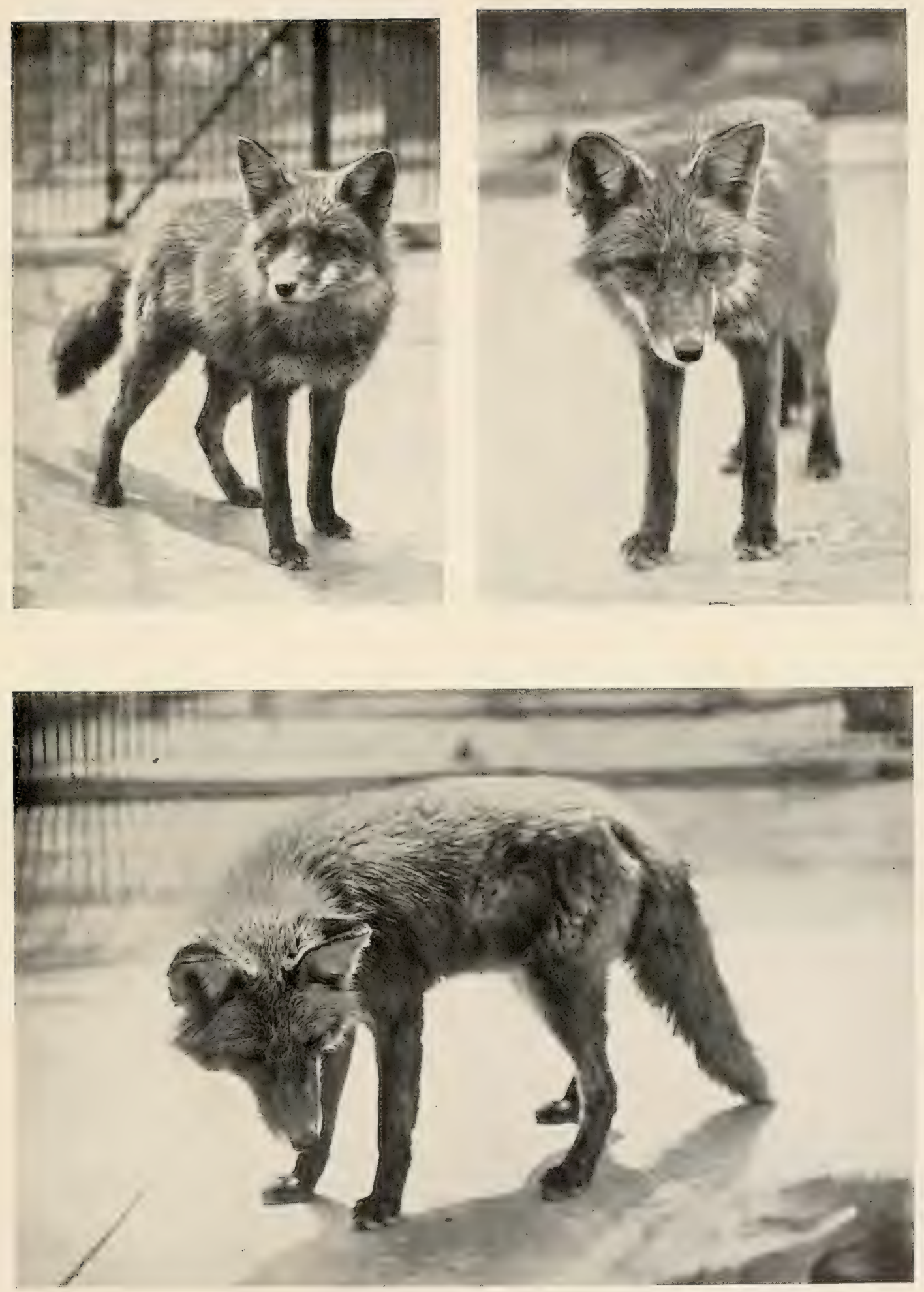

RED FOX (Vulpes fulvus)

By A. R. Dugmore 

I have more than once seen a fox turn and drive the hounds back when they got too close; so he trots along at his leisure, husbanding his strength and scheming to keep out of the way of the hunter. From time to time he will go back in his own footsteps for a distance, and then leap away to one side and go off in a new direction. Again he runs along on top of a rail fence or stone wall, or over the wet stones of a shallow brook.

One of his favourite tricks is to cross over deep water on thin ice just strong enough to bear him, knowing that in all probability the hounds will break though, and perhaps be swept under the ice if the current is strong enough; more than one valuable dog has been drowned in this manner, but I have never known a fox to miscalculate the strength of the ice and break through himself. If the stream is not wholly frozen over, he runs along at the very edge of the deep water, where the ice is thin and treacherous, until he comes to a place where he can jump across to the thin ice that reaches out from the opposite bank.

Then away he goes across the meadows, headed for some sheltered nook he knows of, where he may curl up in the sun on the warm pine needles and sleep until the noisy hounds, footsore and apparently all but exhausted, come panting up to awake him. When the snow is very light and dry, and just deep enough to make it harder for the fox than for the hounds, he has a much worse time of it; but it much oftener happens that while the hounds plunge in up to their breasts at every step, he skips off over the white surface without breaking through. Although he knows of three or four dens within easy reach, it is only when wounded or tired out by a long run in light snow that an old fox ever takes to earth, though last season's cubs sometimes become frightened when the hounds get too close, and allow themselves to be driven in.

Except in very rough weather, foxes prefer to sleep in the open air, in cool weather choosing the south side of a hill away from the wind.

While they do most of their hunting in the morning and evening twilight, they are up and about more or less at all hours of the day and night, and are frequently to be seen out after game at high noon in the hottest part of the summer, or sitting on 


\section{Red Fox}

their haunches dog-fashion in the middle of a meadow, listening for mice. Two years ago, in September, I was going through a piece of low, swampy woodland where every leaf dripped and shimmered from the late shower. The blue jays and thrushes were scolding at a hawk somewhere among the trees, and in onder to find out what it was that disturbed them I imitated the cry of a young bird in distress as well as I could. In a few minutes a Cooper's hawk appeared and alighted in a low tree not far away; but he was not the only hunter that I had deceived, for while I was watching the hawk I caught sight of a young fox coming from another direction and already within three or four rods of me. The woods were fairly free from underbrush just there, and he was walking leisurely along over the wet leaves, looking about eagerly on all sides and then up at the blue jays that were screeching overhead. He looked as if just waked up from his nap, and kept shutting his eyes and yawning until his jaws stood at right angles with each other. Although but little more than half-grown, he had lost all trace of the fat, woolly appearance of a fox-cub; his new autumn coat of red fur was as bright and smooth and his legs as black as anything could be. He was absolutely unconscious of my presence, and for a few moments I saw the woods as they should be seen, and forgot that I myself was there; but only the fox and the yellow-eyed hawk and the blue jays and the wet leaves after the rain; all grouped to be seen once so clearly as to never grow indistinct in memory.

When the fox was within a few yards of me he stopped short in his tracks and stared for a few seconds, but without taking fright; on the contrary, he came still nearer, until, when only a few steps away, he caught my scent, and turning went bounding off among the trees. Almost always when you meet a fox in the woods he pretends not to see you, but changes his course casually, as if, perhaps, he had just heard a mouse over there among the stumps. He does not increase his speed in the slightest degree until he is behind some tree or rock; then away he goes at a tremendous rate, always keeping the tree between you and himself until well out of gunshot.

The thin, querulous, husky barking of the fox is not by any means an attractive sombl, particularly when heard in the distance on still winter nights; but at times they utter a long. wild screech that lluuls 'o credit 11 a panther. This cry is heard oftenest 

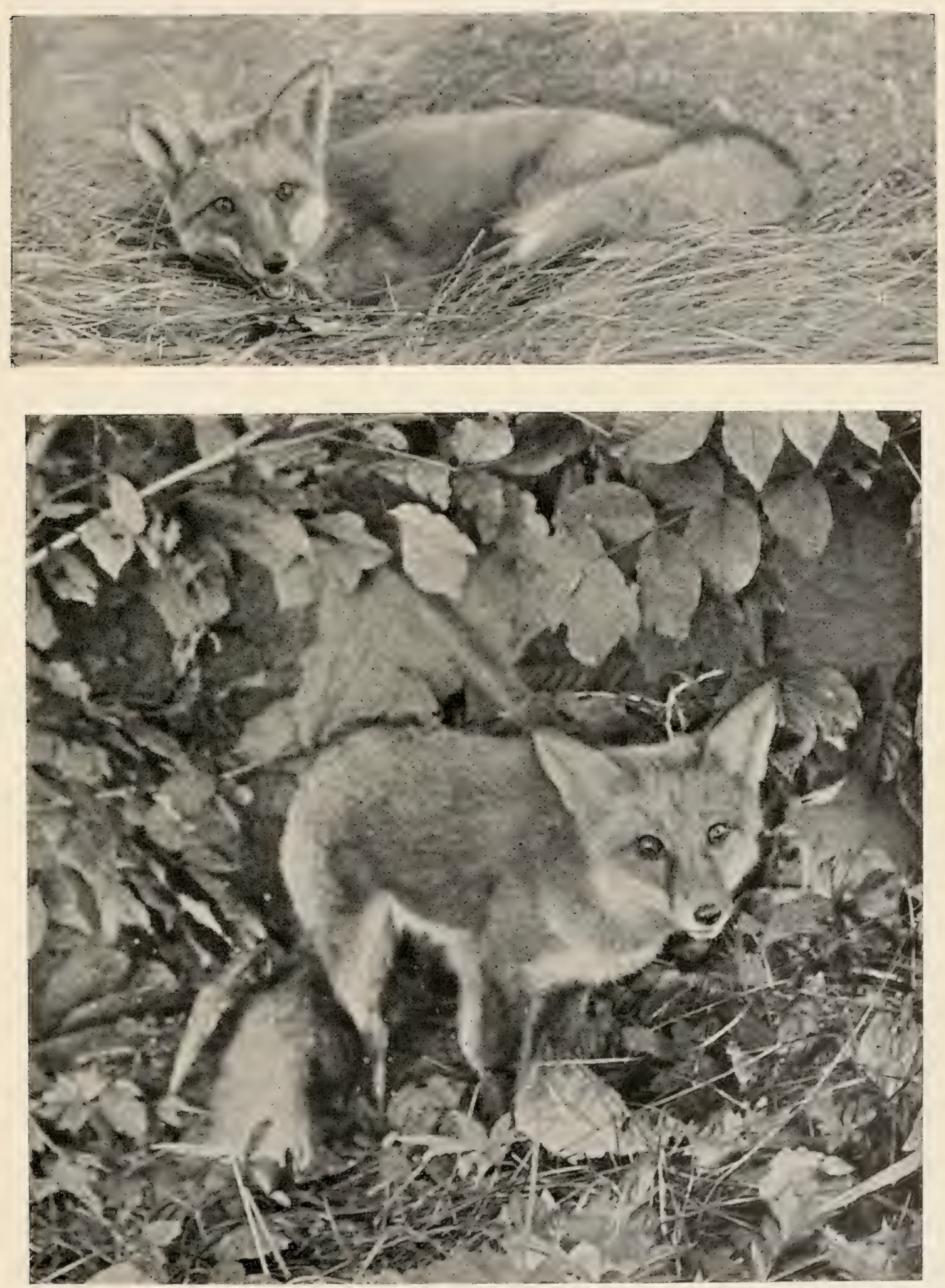

A YOUNG RED FOX (Vulpes fulvus)

By W. E. Carlin 

in the spring, when there are young foxes to be protected, and in its tones there is a menace to all intruders.

A fox's ears are wonderfully keen, and he depends upon them much more than upon his eyesight, both in hunting and in avoiding his enemies.

This morning, January 31, 1902, a little before noon I was crossing an open clayey pasture when 1 heard a crow in the distance give the call which means a fox in sight. Presently I saw Reynard himself trotting along at the edge of a pine grove; when he passed behind a thick clump I ran forward a little way and stopped, watching an opening among the trees where I felt pretty certain he would show himself again. Sure enough, in a very few minutes he appeared and trotted out across the meadows.

He was at least one hundred and fifty yards away and going from me, but the air was still and I squeeked like a meadowmouse, hoping that perhaps his big ears might catch the sound even at that distance, though the sharpest human ears could scarcely have heard so faint a noise at a tenth part of the distance.

Yet the fox heard it and stopped instantly, and turning, came leaping lightly over the hassocks in my direction. Every few rods he stopped, cocking his ears above the sere meadowgrass to listen; then I would squeek, a little lower each time, and instantly catching the direction of the sound, he would come trotting towards me, using greater caution than at first, and keeping under cover of the hassocks as if to avoid frightening his game. When he got within fifty yards there were no more hassocks or bunches of grass for concealment, only the smooth, sheep-trimmed sod where I crouched in plain sight, with my back to what little sun shone through the flecked and mottled clouds that covered the sky. He looked at me sharply as if mistrusting something, and if I had moved either my head or hand the fraction of an inch he would have been off like an arrow to the woods. But I held myself perfectly motionless, and when the expression of his shrewd, gray face and the set of his ears showed that his suspicions were subsiding, I squeeked once more, very faintly, calling him at last almost up to me. But now he saw that there was certainly something wrong, and that I was neither a rock or stump or even an old scare-crow; so, to make sure, he 


\section{Red Fox}

circled around to get the wind of me, trusting more to his nostrils than to his eyesight.

He was a larege male, glay about the lace and cheeks, and perfectly black on his legs and the backs of his ears. His tail wals a supurb white-tipped brush, well grizzled with black. When I spoke to him he spromg into the air and went bounding alwaly to the woods, then stopped and looked back at me for a few seconds before disappearing among the trees.

\section{Varieties of the Red Fox}

While the "cross fox," "silver fox," etc., are merely individual colour varieties, there are several well-marked geographic forms of the red fox.

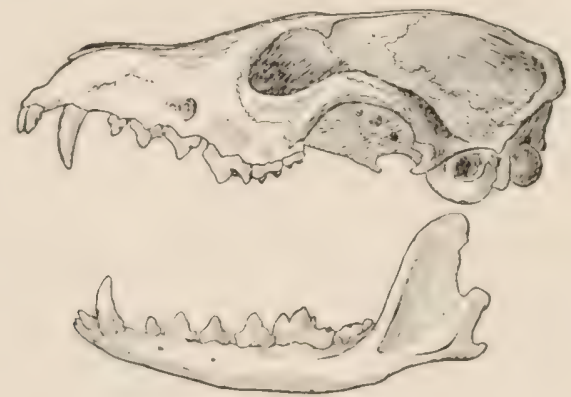

Skull of Red Fox

Red Fox. Vulpes fultus (Desmarest). Description and range as above.

Nora Siotia Rid For. $\quad V$. fulvus rubriosid Bangs. Larger and brighter rusty red.

Range. Nova Scotia.

Vewifombllum Red fox. $V$. deletrix Bangs. Smaller than the red fox, with larger hind feet and claws. Color paler and less rusty.

Range. Newfoundland.

\section{Kit Fox}

Vulpes velox (Say)

Length. 25 inches.

Disimption. Yellowish-gray above, darkest on the back, hairs 
tipped with whitish, legs lighter; under parts white; tail buffy below, tip white, very full and bushy; a black patch on each side of the muzzle.

Range. Nebraska to Colorado and northward over the plains.

This is a much smaller animal than our red and gray foxes, and is restricted entirely to the Western plains.

\section{Arctic Fox}

\section{Vulpes lagopus (Linnæus)}

Also called Blue Fox, White Fox.

Length. 40 inches.

Description. Upper parts brown, belly whitish, fur everywhere bluish-gray at the base, and sometimes this colour predominates. In winter the whole animal is pure white.

Range. Arctic regions. There appear to be several geographic forms.

The little blue foxes of the far north live in communities or fox-villages, digging twenty or thirty burrows together in places where the soil is light and sandy. In summer they hunt for lemmings in the moss-grown tundras and barren grounds, digging them out of their holes or pouncing on them as they traverse their runways in the thick, wet sphagnous beds that cover the swamps and boggy places.

At this season the Arctic fox lives in luxury, for besides the lemmings there are numberless wild fowl nesting by the margin of every stream; and on the ridges, willow grouse and snow ountings hide their eggs in the reindeer moss and low bushes, or in warm hollows where the short-lived blossoms of the northland crowd together in dense borders of bright colours.

The lemmings are so numerous and easily caught that a very few hours each day spent in hunting them would easily keep the fox supplied with meat.

But the little stub-nosed blue-fox, though he lacks something of the wily shrewdness of the long-headed red fox of the woodland, is nevertheless a very intelligent beast.

Knowing that summer will soon be over, and the lemmings safe in their hidden roadways beneath ice and snow, and the 


\section{Arctic Fox}

birds all driven north before the cold, he hunts diligently while game is yet abundant, and brings home load after load of fatbodied lemmings to be packed awaly in cold-storage for the winter.

Where the blue fox lives the frost never wholly leaves the ground; so he digs down in the moist turf until he reaches a temperature only just above freezing, and packs down several dozen lemmings in a place, covering them with moss and sods.

These caches of frozen lemmings are his principal food supply for the greater part of the year.

Of course there are always polar hares to be found, but the catching of them is not so easy, for of the two the hare's legs are longer, and there is small chance of creeping upon him unawares in that snow-sheeted country. Yet though the hunting is poor and he has plenty of meat laid by for the future, and a warm, cozy chamber underground, the arctic fox is not the sort of fellow that sits at home and nods in the corner waiting for spring to come back again.

In the fall his fur becomes perfectly white, like that of the Northern hare and the ermine, and the plumage of the ptarmigan, in order that he may creep unseen among the snow-drifts, avoiding the eyes of the game he is seeking, and of the gray wolf, who is his worst enemy. He may run cheerfully all day long, or all night long, without success, enjoying the chase for itself, and the cold free winds across the barrens, knowing all the time that he will not have to go hungry, unless, worse luck, the wolf or the wolverine has found his stores and robbed him. In that event he would probably turn thief himself and steal from his more fortunate neighbours, if his prowess at hunting failed to keep him supplied with food. It is pretty generally affirmed by the hunters that the young foxes of the year, who have as yet not established homes of their own, travel southward as the winter advances, killing their meat from day to day in new hunting grounds, or going hungry if the fortunes of the chase refuse to smile on them. But as the daylight lengthens and the sun swings in sight again across the south, they turn back to join the old foxes once more.

And now they pair and dig new burrows for themselves, where the little woolly fox cubs are born and brought up. Their Wandir-Jahe is now over, and they go seriously to 
work bringing home all the lemmings they are able to kill and packing them down against the coming of another winter.

But these stores are all for themselves and not to be shared with their cubs, who, after their first summer of fun and carelessness is ended, must start south in their turn, each hunting for himself and avoiding the wolf and the half-breed trappers as best he may, until the season comes for him to return and settle down as a member of the same remote colony of little blue foxes on the shores of the frozen sea.

The Arctic fox is in many ways the most attractive of its race, being wholly free from the rank odour characteristic of the other foxes.

It is, moreover, remarkably neat and cleanly, both regarding its fur and in the care of its burrow. Although, as before stated, it is not so sly as the red fox, especially in the matter of traps, it is intelligent and quick to learn, and, living on the edge of a settlement, would undoubtedly soon be as difficult to outwit as its long-legged cousin of temperate latitudes.

In its family life it is certainly the equal, if not indeed the superior, of many of the native Eskimo tribes inhabiting the same regions, at least in matter of forethought, cleverness and morality.

\section{Gray Fox}

Urocyon cinereoargenteus (Schreber)

Length. 39 inches.

Description. General colour gray, hair banded black and white; darker on the back. Sides of the neck, ears and band across the breast rusty red; tips of ears black, feet and parts of leg rusty, as well as the under surface of the body. Inner side of legs, throat and middle of breast white. Tail much coarser than that of the red fox without the soft under fur.

Range. Southeastern New York and New Jersey to Georgia and north in the Mississippi Valley to Tennessee. Replaced in Florida and in the West by slightly different varieties.

The gray fox is a creature of the forest, incapable of holding his own for long in a cultivated country; not so much 


\section{Gray Fox}

because of any inborn hatred of civilization, like that which drives the beaver and marten forever off into the wilderness. He would apparently be perfectly willing to dwell, like the red fox, as a free-booter on the borders of a plantation, living on mice and rame birds, or stealing the farmer's chickens as occasion offered; but the farmer usually proves too much for him.

The gray fox is sly and cunning by nature, but he lacks that astonishing shrewdness and faculty for working out deeplaid schemes which enables the red fox to turn the tables on the hunter repeitedly in the most unpromising situations.

Physically the graly fox has the advantage in a number of ways; being smaller and less conspicuously coloured, he has a much better chance of tricking.

He can also climb trees better than the red fox, and is equally swift at running and more tireless, while his rough gray-brown fur is much less eagerly sought after than is the beautiful pelt of the red fox.

Gray foxes seldom live in burrows; most of them have their camps in hollow logs and old tree-trunks, where they can take refuge in rough weather or when chased by aogs. At other times they like to sleep in the open air, hidden among the bushes and undergrowth. They are clever hunters, and living as they do farther to the south, and avoiding those regions where the snow lies deep in winter, seldom lack for food at any season.

They catch and eat almost every small creature that lives in the forest-insects, fish, reptiles, birds, and small mammals; they also at times eat wild grapes and berries, and very likely acorns, chestnuts and mushrooms, like most of the carnivorous animals.

The female hides her young in a nest of leaves at the bottom of a hollow tree, and later brings them out to give them lessons in hunting and woodcraft. When they have learned to take care of themselves a little they separate, to wander where they will, unprotected, picking up a living here and there als best they may. The barking of the gray fox is thin and husky, fainter than that of the red fox, and serves chiefly to call the sexes together in the spring. 

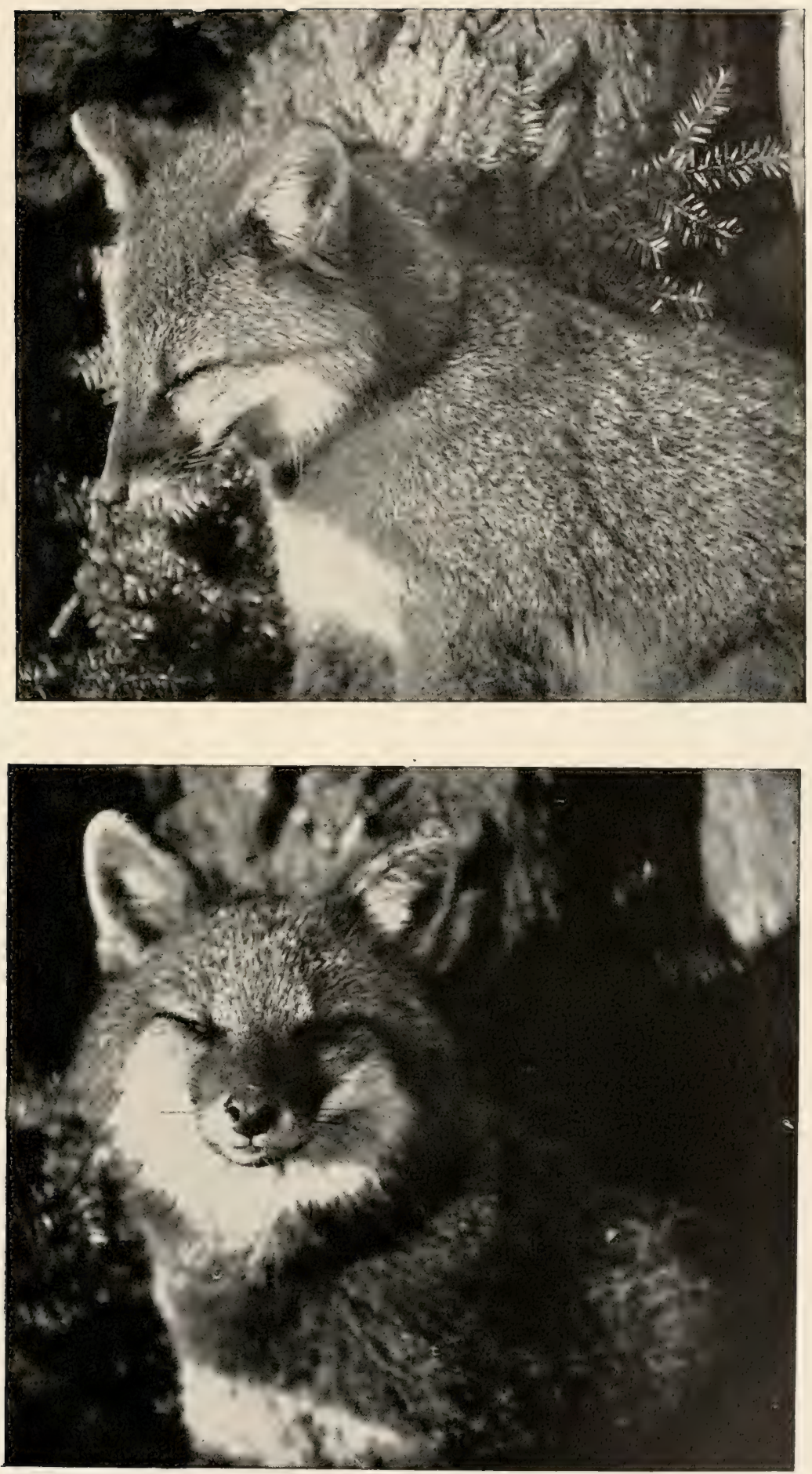

GRAY FOX (Urocyon cinereoargenteus)

By H. K. Job 



\section{Varieties of the Gray Fox}

Gray Fox. Urocyon cinereoargenteus (Schreber). Range and description as above.

Florida Gray Fox. U. cinereoargenteus floridamus Rhoads. Smaller, fur coarser, and fulvous of breast paler, with no white on the under parts.

Range. Southern Georgia and Florida.

Wisconsin Gray Fox. U. cinereoargenteus ocythous Bangs. Larger with more yellow and rusty tints and less pure gray than the eastern gray fox.

Range. Upper Mississippi Valley.

\section{Gray Wolf}

\section{Canis occidentalis (Richardson)}

Called also Timber Wolf.

Length. 4 feet 9 inches.

Description. Prevailing colour gray; dark, almost black along the back, with a dusky patch on the shoulder and hips. Sometimes more rufous.

Range. Formerly over most of North America, now very rare east of the Mississippi River. The exact number of varieties of American wolves has not been determined; probably the Black Wolf Canis ater Richardson, which still exists in the Florida everglades, is a distinct species, and also the Arctic Wolf C. albus (Sabine), which is pure white with a black tip to the tail.

The gray wolf that formerly ranged in great packs over every part of this country is practically the same as the dreaded wolf of Europe. Local varieties in both countries differ more widely from each other than typical specimens from the same latitude in Europe and America. Yet, while in Russia, Germany, and even France, the wolves still menace the peasantry whenever an exceptionally hard winter drives them to desperation, in this country they were quickly driven off and exterminated in most sections, even where heavy forest-growth and broken country afforded them the best protection.

Gray wolves were always wandering, unsettled beasts at times, especially in the winter, hunting up and down the country in great 


\section{Gray Wolf}

packs, and more rarely wandering alone or by twos and threes. Any sort of a country appears to suit them well enough, provided there is game to be had. If anything, they were more numerous in low, black swamps of hemlock and tamarack in the North and the everglades of Florida than in the dense forests of mountainous countries and uplands. But above all else they preferred the wind-blown prairies of the West, where they followed the bison herds in their wandering after new and green pastures. The wolves seldom molested the buffaloes unless they were disabled by wounds or sickness. The young calves were what they were after when they skulked through the herd, dodging the old bulls and angry cow-buffaloes in the tall bunch-grass of the plains. At present the alkali deserts and badlands and the barrens of the Hudson Bay country harbour the greater number of those that still run in the open. In the heavy timber of the Rockies those wolves that like to hunt in the shadow of the forest find abundance of deer and smaller game and good hiding that not only enables them to hold their own in numbers, but even to increase in many sections.

Whether going in packs or singly, they almost never resort to still-hunting or ambush, but run down their prey by combined speed and endurance.

While they have been said to adopt as a member of their own pack a dog that had deserted his master and taken to a wild life, evidently sensible of the kinship that exists between them, they look upon one thit submits to the authority of man and acts as his servant as the henchman of their worst enemy, and their legitimate prey.

They will also run down and kill their cousins, the foxes, who, though swifter than the wolves for a short distance, lack their endurance and wind.

In summer the wolf packs separate to a certain extent into pairs that seek out secluded retreats, and dwell for a time in dens or burrows of their own digging, the she wolf nursing her whelps at home while her mate keeps her supplied with food. After the young wolves have learned to kill for themselves, the family joins the pack again, knowing that their peculiar method of hunting depends upon numbers for success. 

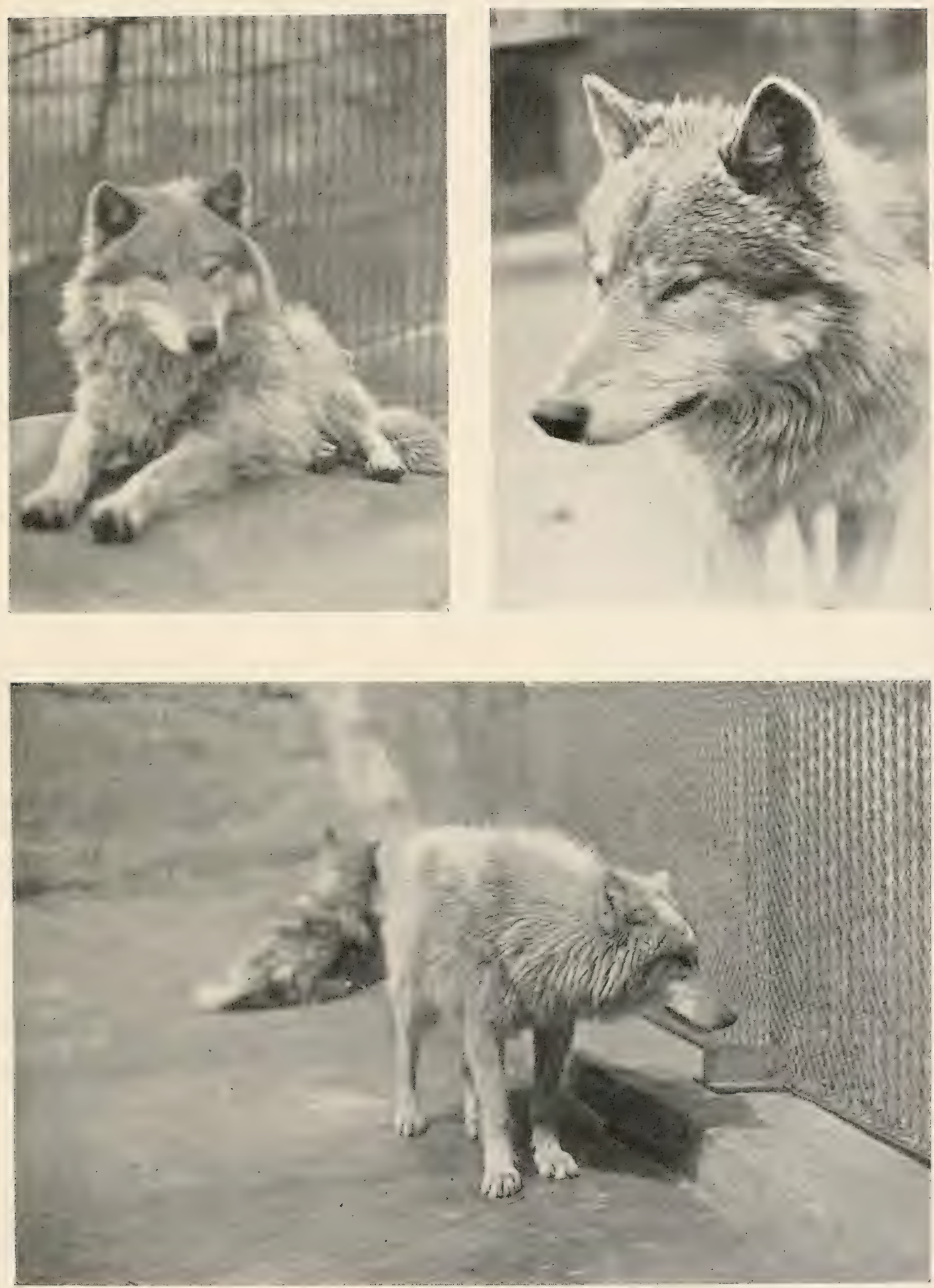



\section{Coyote}

\section{Canis latrans Say}

\section{Called also Prairie Wolf.}

Length. 4 feet.

Description. General colour fulvous, grizzled with black and white hairs; under parts whitish; tail tipped with black.

Range. Northern Mississippi Valley to the Rocky Mountains, with allied species south to Texas and Mexico, and westward to California and British Columbia. Dr. C. Hart Merriam has shown that many of these coyotes are very different from one another, and as in many of our other larger animals, we find that instead of one wide ranging form of the older authors there are really several perfectly distinct species. The distribution of the various coyotes has not yet been satisfactorily worked out.

Coyotes are small, slinking wolves that live in burrows on the plains, where they feed principally on jack rabbits, ground squirrels and mice.

They are often called prairie wolves to distinguish them from the timber wolves or gray wolves. They combine the swiftness, shy cunning and greed of the wolf and fox tribes, but lack the ferociousness of their larger cousin, the timber wolf.

Being active, healthy brutes, they undoubtedly enjoy their wild, unrestricted life of action and adventure, and are happy in their own way, except when suffering from unusually hard luck at hunting. Yet somehow they always look distressed and miserable, and their whining howl at night seems to express all the hopeless despair of some wretched spirit of the blind "viewless wind" that whirls away before a storm "seeking for something lost, it cannot find."

Like the gray wolf, coyotes hunt in packs at night, yapping and howling as they run.

They often follow the hunter at a safe distance in the hope of picking up the offal of the game he has killed. The coyote is now rare east of the bunch-grass plains. In Arkansas, Missouri and Illinois, where they were once common, they are seldom seen. But in the Butie regions of the upper Missouri and 
the Colorado valleys they range in great numbers, making their dens among the broken sandstone ridges of that lonely country. In the flat lands they dig burrows for themselves or else take possession of those already made by badgers and prairiedogs. Here in the spring the half-dozen or more coyote pups are brought forth, and it is said that at this season the old ones systematically drive any large game they may be chasing as near to their burrow, where the young coyotes are waiting to be fed, as possible, before killing it, in order to save the labour of drigging it any great distance. When out after jackrabbits two coyotes usually work together. When a jack-rabbit starts up before them one of the coyotes bounds away in pursuit while the other squats on his haunches and waits his turn, knowing full well that the hare prefers to run in a circle, and will soon come round again, when the second wolf takes up the chase and the other rests in his turn. In this manner the jack is finally tired out and overtaken. When some particularly shy old jack-rabbit starts off for a straightaway run instead of circling, the coyote in pursuit tears away to one side and generally succeeds in turning him back towards the spot where the other wolf is waiting.

When hunting antelope and deer the coyotes spread out their pack into a wide circle, endeavouring to surround their game and keep it running inside their ring until exhausted.

Sage-hens, grouse and small birds the coyote hunts successfully alone, quartering over the ground like a trained pointer until he succeeds in locating his bird, when he drops flat in the grass and creeps forward like a cat until close enough for the final spring.

It is a well-known fact that a coyote will follow a trapper or a party of roving Indians, picking up the scraps left about their camp-fire, or wherever they mal have been skinning game. If unmolested at such times, he soon loses much of his native wildness and exhibits considerable boldness.

During hard seasons, when there is little food to be had and even grophers and field-mice are hard to find, the coyote, it is said, adopts a partially vegetable diet, eating the fruit of the prickly pear, and in winter wild-rose hips and Juniper berries. 
Mr. Ernest Ingersoll, in the Popular Science Monthly, gives a most vigorous account of a coyote attacking a doe-antelope and her fawn. He says: "I remember at a place where I was encamped for two or three nights in Southwestern Wyorising, the rough ledge of a butte-face just across the creek was the home of a family of these wolves, and I often saw the mother lying at the mouth of their den, and the four whelps gleefully romping in the sunshine.

"The father of the family kept out of view at first; but later 1 caught sight of him in pursuit of a doe-antelope and her fawn. The doe was backing away over the plain, keeping the little one, which seemed to understand its part perfectly, close to her hind legs.

"Following her closely ran the wolf, often making a dash to the right or left to get at the fawn; but each time the brave little mother, whisking alertly, would present to him her lowered head and make a dash at his skull with her sharp fore-hoofs. Thus she retired, but I fancy that the pursuer's longer breath and varied tactics won the day at last." Mr. Ingersoll goes on to say: "The nocturnal prowlings, secretive disposition, and remarkable craftiness of this animal, together with the annoyance it has the power to inflict, cause it to figure prominently in the myths and religious history of the Indians of the far West. Some of these stories I propose to recall, and I am sure that they will suggest to every reader at least the Reynard of European folk-lore, if not other interesting parallels.

"The Deity and creator of the Karok religion was Kareya, who made the fishes, the animals, and, finally, man. Him he commanded to assemble all the animals, in order to assign to each its rank, by distributing bows and arrows. The longest to the most powerful, and so on down the scale.

"The beasts and birds came together the night before the distribution, and all went to sleep except the coyote, who determined to stay awake all night and go forth earliest in the morning to get the longest bow. He took extraordinary pains to keep awake, but over-reached himself in an excess of ingenuity and fell asleep just before dawn. When he opened his eyes only the very shortest bow was left for him. But Kareya, pitying his weakness and disappointment, gave him cunning ten times 
greater than before, so that he is sharp-witted above all animals in the woods. In return the grateful coyote befriended the man and his children ever afterwards, doing many helpful things for them.

"When Kareya made the fishes he did not let the salmon come up the Klamath, in consequence of which the Karoks, who lived on its upper reaches, were sore pressed for food. But Kareya had made a great fish dam at the mouth of the river, and given the key to two old hags to keep, who never ceased their watching, even to sleep. Seeing that the Indians were nearly starved, the coyote befriended them. He made a visit to the hags on an ingenious pretext, but only succeeded in discovering that the key was kept too high for him to reach it. He stayed all night in the cabin with the hags, pretending to sleep, but watching their movements all the time out of the corner of his eye.

"In the morning one of the hags took down the key and started to get some salmon for breakfast. Then the coyote happened to think of a way to get the key. Jumping up, he darted under the hag, throwing her down and causing her to fling the key a long way off; before she could scramble up the coyote had seized the key and opened the dam.

"Thus the salmon could ascend the Klamath and the Karoks had plenty of food. But they had no fire to cook it with, because Kareya had hidden it in a basket which he gave to two sleepless hags far towards the rising sun. So coyote promised to try to get this second boon for them.

"He stationed a line of animals all along the way from the home of the Karok to the far distant land where the fire was kept, the strongest near the fire, and last of all concealed an Indian under a hill. This done, the coyote insinuated himself politely into the good graces of the old guardians, and lay all night by their hearth, feeling very comfortable and pretending sleep. But he was soon convinced that without help there was no way to elude their vigilance; so in the morning he stole out and had a talk with the Indian under the hill, after which he went back and lay down by the hearth as hefore. Presently, as had been preconcerted, the Indian was heard hammering at the door, as if to break it in, and the old beldams rushed out to drive him away. 


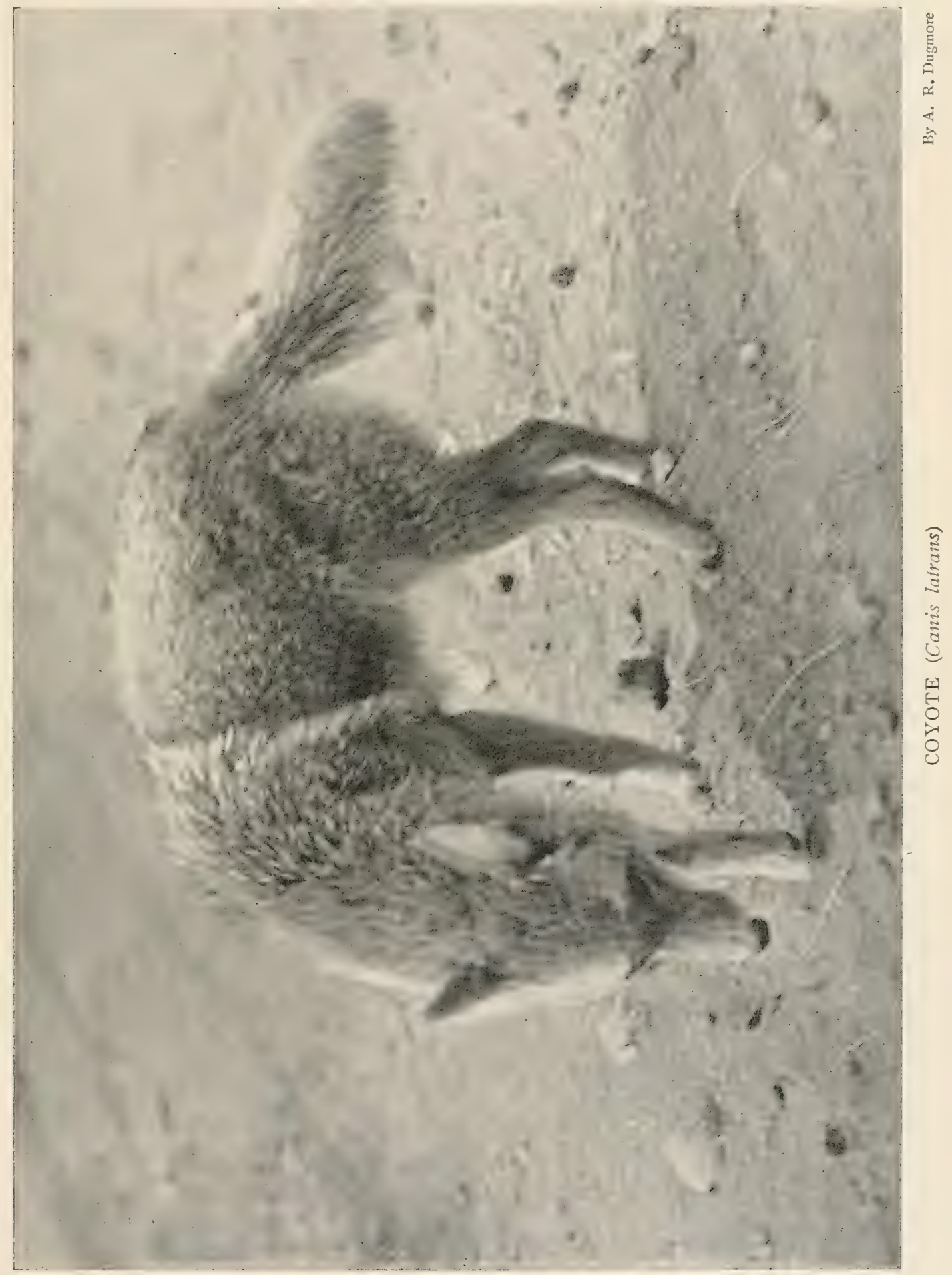



"This was the coyote's opportunity. As the hags dashed out at one door, he seized a flaming brand in his teeth and leaped through the other. He almost flew over the ground, but the hags saw him and the sparks and gave chase, gaining on him fast. By the time he was out of breath he reached the puma, who took the brand and ran with it to the next animal, and so on. Last of all was the frog, who caught the last spark of fire in his mouth, swallowed it and dived, the hags catching his tail, twitching it off in the act. The frog swam under water a long distance, then came up and spat the fire into a $\log$ of driftwood, and there it has stayed ever since, so that when an Indian rubs two pieces of wood together the fire comes forth."

Most tribes of Western and Northwestern Indians are friendly to the coyote, and their dogs seem to be partly at least of coyote descent.

The coyote is much too cunning to allow himself to be trapped. The trappers say that there is only one animal that is harder to catch, and that is the wolverine. The coyote's ravenous appetite, however, frequently gets him into trouble, for in winter he picks up and bolts every scrap of meat that he can find, first making sure that there is no hidden trap beside it. But he cannot always tell when meat has been poisoned, and large numbers are destroyed every season by scattering scraps of poisoned meat where they will be sure to find it.

The soft yellowish-gray fur of the coyote is rather pretty, but is not of the right quality to make it a valuable fur. The best skins seldom sell for more than 50c. or $75 \mathrm{c}$; even at this price large numbers are collected each winter. They are usually made up into lap-robes or great coats, and sometimes into driving gloves.

\section{CATS}

\section{Family Felide}

In addition to our American Wild Cats there belong to this family also the Domestic Cat and the Lion, Tiger, Leopard and other most powerful carnivora. Fossil remains found in both the Eastern and Western States show that there were much more powerful members of this family existing here in past geological 
ages, among which were several sabre-toothed tigers with enormous teeth or tusks five or six inches in length.

\section{Wild Cat}

\section{Lyıx ruffus (Guldenstædt)}

Also called Bay Lynx, Bob Cat, Catamount.

Length. 38 inches.

Discription. Legs rather long, ears tufted, tail very short (6 inches). General colour yellowish-brown, tinged with rufous (much redder in summer), spotted with dark brown or black, narrow lines on the head and blackish stripe down the back, chin and throat white, below white spotted with black.

Range. Eastern North America, replaced in Florida, Nova Scotia and the West by allied varieties.

Wild cats or bob cats were once common in all the thick woods of this country, but are now only to be found in the most thinly settled backwoods districts.

These big stub-tailed cats do not appear to insist on deep, dark forests for their homes, though they seldom remain long in a region where much of the land has been cleared and cultivated. Hillsides and clearings overgrown with brambles and young growth are quite as much to their taste as dense forests of heavy timber.

For the greater part of the year they hunt alone or in pairs, prowling on soft furry paws through bushes and tangled berry patches where rabbits have their paths.

Lacking skill at following a trail, and the speed and tircless perseverance which make foxes and weisels such successful hunters, they catch most of their game by lying hidden in ambush and springing out suddenly on whatever small game comes within reach.

They also go still-hunting after the manner of cats generally, trusting to luck that they may come unexpectedly upon some little beast or bird busy about its own affairs.

When the wild cat hears the faintest movement in the underbrush he instantly crouches with all four feet beneath him, 
and remains perfectly motionless, watching and listening, intent to learn whether it is an enemy to be avoided or possibly game for his dinner. In the latter case he creeps forward with the utmost caution, planning, if possible, to head off his victim in order to seize it at the first alarm. When out hunting, the bob cat utters a wild scream from time to time; its object evidently is to startle any creature that may be in hiding near by into betraying its presence by a startled jump.

And certainly any animal would require strong nerves to remain unmoved when this jarring yell bursts through the stillness close at hand. It has been described as a low sort of growling, followed by a sudden quick repeated caterwaul, or yang-yang-yang. I have frequently heard just such a cry in the woods at night, but have to confess that I have never been able to trace it to the creature that made it.

Following up these various voices of the night is baffling work at all times, and there is still much confusion of ideas regarding them and much yet to be learned.

I have more than once heard a red fox utter a scream that would do credit to a cougar, and the farmers here in New Hampshire tell me that the skunk has a most blood-curdling yell of its own. How much truth there is in this I am unable to say, but the belief is too widely held in these parts to be wholly overlooked.

Wild cats roam about in the twilight of early morning and evening more than at midday. They sleep in hollow trees and caverns among the rocks and ledges, and in some such place in a warm nest of leaves they hide their kittens. In warm weather they like to doze in the sun, either stretched along a horizontal bough or curled up in a little patch of sunlight in the midst of a berry-patch. They wander about all winter in the snow and cold, living as best they may, stalking hares and grouse among the evergreen, or watching patiently beside a squirrel-hole in a tree-top, just as a domestic cat will stand guard at a mouse-hole in the barn.

They resemble the domestic cat in a number of ways, being great mousers and destroyers of small birds and their nests, and equally fond of catnip, rolling over and over in the strongscented herbs and rubbing it into their fur and eating the blossoms and leaves. 
Wild cats are at all times shy and exceedingly cautious about showing themselves, but are savage fighters when cornered or defending their kittens; a dog that offers to molest them is pretty certain to be severely used hefore he is allowed to escape. In thinly settled towns wild cats will occasionally raid the farmyaris and carry off turkeys and chickens, but as a general thing they confine themselves to wild game. It is said that when the country was new they had a habit of following the flocks of wild turkeys from place to place, lying in ambush to waylay them as they fed among the beech woods and thickets.

In distant sheep pastures among the hills wild cats might easily kill lambs and carry them off, or even pull down old sheep, but I cannot learn that any such ravages have ever been charged to them.

This may possibly be due to the fact that when a farmer finds that any of his lambs have been killed, he prefers to lay the blame on stray dogs, knowing thai the town is obliged to pay him for all such damages, and does not assume responsibility for the misconduct of the wild beasts in the woods.

\section{Eastern Varieties of the Wild Cat}

Wild Cat. Lynx ruffus (Guldenstredt). Range and description as above.

Florida Wild Cat. L. ruffus floridamus (Rafinesque). Similar to the preceding but darker with stronger markings.

Range. Florida.

Noza Siotic Wild Cat. L. gigas Bangs. Much stouter and larger than L. ruffus, colour darker and blacker above.

Range. Nova Scotia.

\section{Canada Lynx}

\section{Lynx canadensis Kerr}

\section{Called also "Loup Cervier."}

Length. 40 inches.

Descriftion. Feet much larger than in the wild cat, tail shorter, fur much longer and looser. Colour light gray mottled with brownish, caused partly by the dark bases to the hairs. 


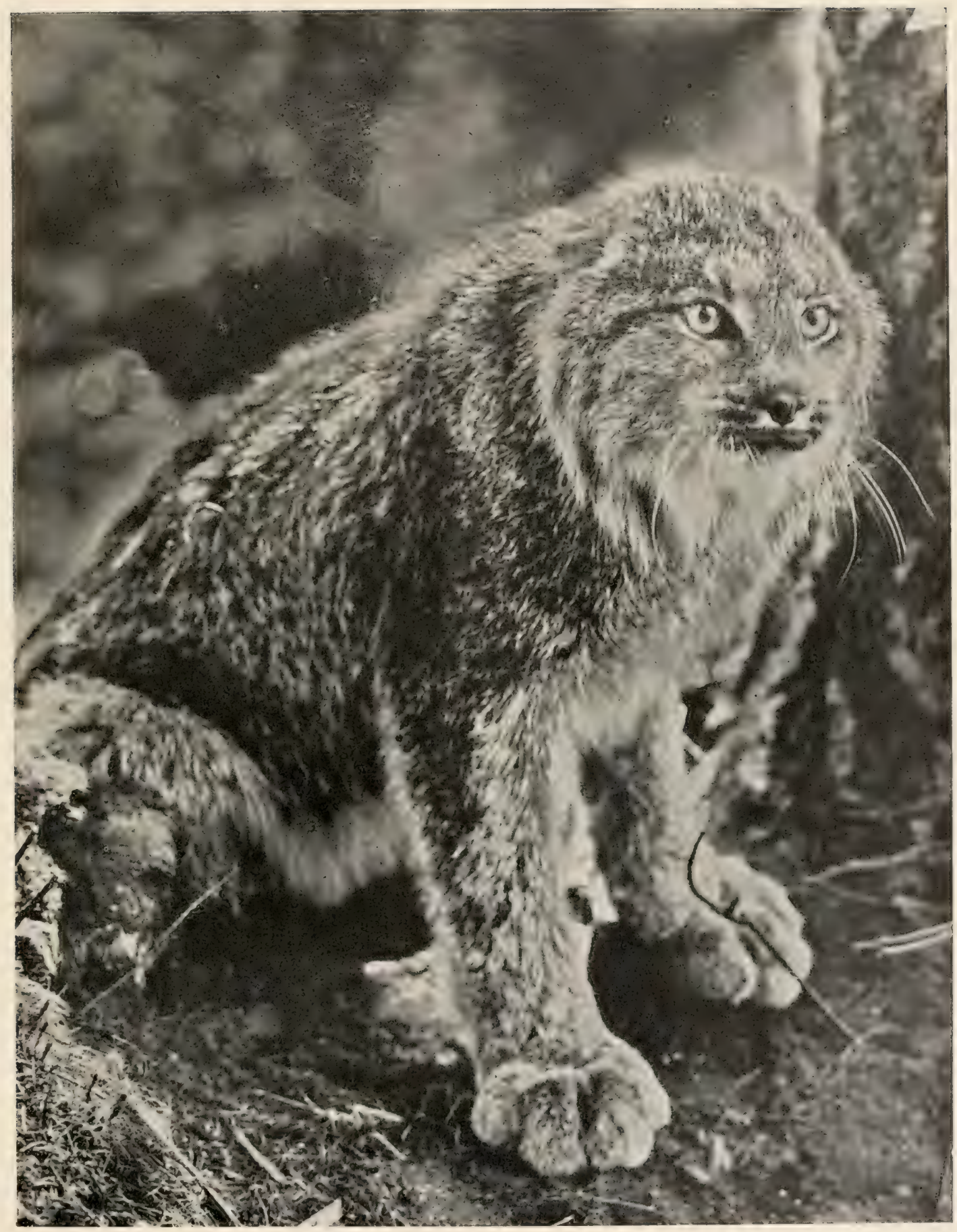

CANADA LYNX (Lynx canadensis)

By W. E. Carlin

Caught in a trap and then turned loose with a light clog on hind legs, the photograph being taken while the animal is brought to bay by fox terriers. 

tips of ears with tufts of long black hairs. Under parts white, tail tipped with black, face-ruff long, white bordered with black. Range. Boreal North America, south formerly to the mountains of Pennsylvania. Replaced in Newfoundland by the allied Newfoundland Lynx L. subsolanus Bangs, darker and more richly coloured; and in Alaska by a paler form. L. canadensis mollipilosus Stone.

The Canada lynx is the real lynx of all the north, that mysterious creature whicis the ancients believed possessed the power of seeing through all substances, whether opaque or not to other eyes.

The distinction between this species and the lynx of Northern Asia and Europe appears to be no more than may with safety be ascribed to local environment. Those branches of the family which have strayed southward into the forests of a more temperate climate have invariably decreased in size, showing that the true home of their race is in the north.

The Canada lynx is a savage, flat-faced beast, with enormous muscular legs and paws out of all proportion to the size of its lean body and absurd retrousse tail. Its soft fur of clouded gray is so blended with various shades of pale buff and tawny as to be extremely difficult to distinguish in any light or against almost any background; even in the cruel publicity of a barred cage it is still indistinct, and one might well fancy the cage empty at a little distance.

In the northern woods the lynx travels with silent leaps, his broad paws supporting him on the snow, or alighting without a sound among brittle twigs or dry leaves of a past summer, enabling him to pounce on grouse or hare before they have time to take alarm. He can also climb trees with ease, to rob the nests of birds and squirrels, or stretch himself along a lower branch from which he can launch himself on whatever may pass beneath. Yet since every creature that he hunts is equally well fitted for the contest, and even more earnest and watchful in its endeavours to avoid him and so enjoy its own wild life in the woods a little longer, the lynx must necessarily go without food often for days together in the winter, glid enough perhaps to pull some frozen scrap of flesh or skin out of the snow, dropped there by more fortunate hunters weeks before. The lack of insect scavengers is not felt in the woods in win- 


\section{Cougar}

ter; every scrap of flesh that is scattered is wanted by one warm-blooded creature or another before warm weather comes again. The lynx appears to have its summer home in tangled thickets and snirls of young growth, where the interlocking branches of fillen trees afford protection. Here the ill-natured kittens are raised and taught to hunt, so that when the bitter struggle of winter is forced upon them they may, if possible, hold their own and prolong their lives at the expense of others, in order that their race may live. They hold on to life grimly through long, cold nights in the dark Northern forests, believing somehow that at last spring will be in the woods again, bringing flight birds from the South, and awakening the small creatures that sleep all winter down deep in the frozen earth where the most desperate lynx can never reach them. Until then the lynxes must hunt as best they can, tireless and in splendid health, and quite unconscious of the cold, but oh, so hungry!

One of the most astonishing facts in nature is the length of time that most flesh-eating animals can go without food, on long hunts through deep snow, night after night, breathing frozen air that drives a man hungry soon after the heartiest meal, they maintain their strength ready for a desperate struggle when at last the long pursuit draws to successful end.

\section{Cougar}

\section{Felis couguar Kerr}

\section{Called also Puma, Mountain Lion, Panther, Painter.}

Length. 8 feet, 6 inches; tail, 3 feet.

Description. Body relatively longer than in the lynx, tail very much longer, no tufts on the ears. General colour pale rufous or yellowish-brown, darker along the back and tail, tip of tail blackish; face grayer, under parts dirty white. Ranlic. Formerly Eastern North Americal, now probably extinct, though a closely allied variety, $F$. coryi Bangs, the Florida Cougar, still exists in Florida, and others from the Rocky Mountains westward and south throughout South America.

Apart from the blood-curdling tailes of most doubtul authenicity with which every one is familiar, accounts pretty gen- 
erally agree in stigmatizing the cougar as an arrant coward. The truth seems to be that, like all the other wild beasts of this country, his race has learned through bitter experience that the only possible chance of life is to keep out of man's way. Whenever an American wolf, bear or cougar has disobeyed this rule, he has almost invariably been killed or badly wounded at once. No wonder that the survivors have learned caution.

If India, for example, had been inhabited by tribes of wild men, born hunters like almost every tribe of our American Indian, and finally settled by frontiersmen and backwoodsmen, who never entered the woods without an ax or a gun, it is highly probable that reliable accounts of human beings having been attacked by either leopards or tigers would be almost unknown.

I am unable to learn that in any part of the world there is a race of man-eating wild beasts that has survived generations of experience with native tribes of wild men capable of driving an arrow through a panther body at half the range of a gunshot, and of hitting any spot they wished.

Man-eating tigers have for so long been regarded by the natives of most parts of India as invincible, or else protected by the native religions, that they have had things pretty much their own way. One determined hunter for every fifty frightened unarmed men would scarcely serve to intimidate any animal. Many tribes of North American Indians looked upon the bear with veneration; but for all that, any bear so courageous as to let himself be seen by them got an arrow between his ribs right away, and in time the whole tribe of American bears learned that the chances were against them, just as the wolves and cougars arrived at a similar conclusion. Those that turned maneaters might for a few seasons hunt their human prey successfully, and if gifted with unusual cunning get away unscratched for a while, but the vengeance of the tribe would be certain to overtake them before very long, and only the more cowardly ones of their species would survive to perpetuate the race.

When the white man came the wild beasts of the wilderness found that they had a yet more dangerous enemy to face. The guns of the early settlers were not very handy or reliable weapons, but when they did go off they were capable of scattering half a handful of slugs in the most painful manner; and 


\section{Cougar}

from that time to this there has hardly been an opportunity for the slyest cougar to attack man, woman or child without bringing down sudden and awful retribution on his head.

Even now almost every farmhouse in the country has a rifle or shot-gun behind the door.

I believe that if lions and tigers had been indigenous to North Americal, they would long ago have learned to leave man unmolested.

In Northern Europe bears, wolves and lynxes still occasionally attack human beings, and very likely get away without being shot at in many instances. There are plenty of dauntless hunters and dead shots in all parts of the Old World, but they are in the minority. The peasants who make up by far the grcater part of the inhabitants of the wilder districts are generally unarmed, and in no way fitted to take personal rengeance on any creature that should attack one of their number.

When it comes to a question of fighting on anything like equal terms, the cougar is by no means a coward. In a fair fight, a full grown male cougar could kill the largest dog without much trouble. Even now they kill cattle and horses from time to time, though every such indiscretion on their part is a challenge to the enraged owner, with his Winchester, bear-trap or strychnine.

Although originally found in every wooded part of the United States, they were so quickly driven off by the settlers that not much is known of their habits here in the East. A few have lingered along in the wilder districts of the Northeastern States even down to the present day; but their every footprint has been eagerly searched for and heavy steel traps set where they were likely to step; while the slightest rumour of a panther in the region would call out scores of zealous hunters armed with shot-guns loaded with buckshot and rilles of every description, and accompanied by dogs of all breeds for tracking.

The last cougar killed here in Northeastern New Hampshire, where I write, wals shot in a neighbouring town something like forty years aro. But there are still rumours from time to time of them having been seen in the northern part of the State, especially since deer have become more common. In the Eastern States they appear to have made their homes in hollow 


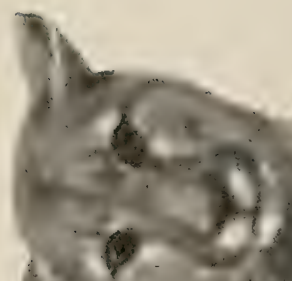

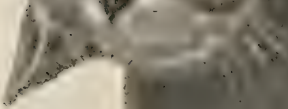

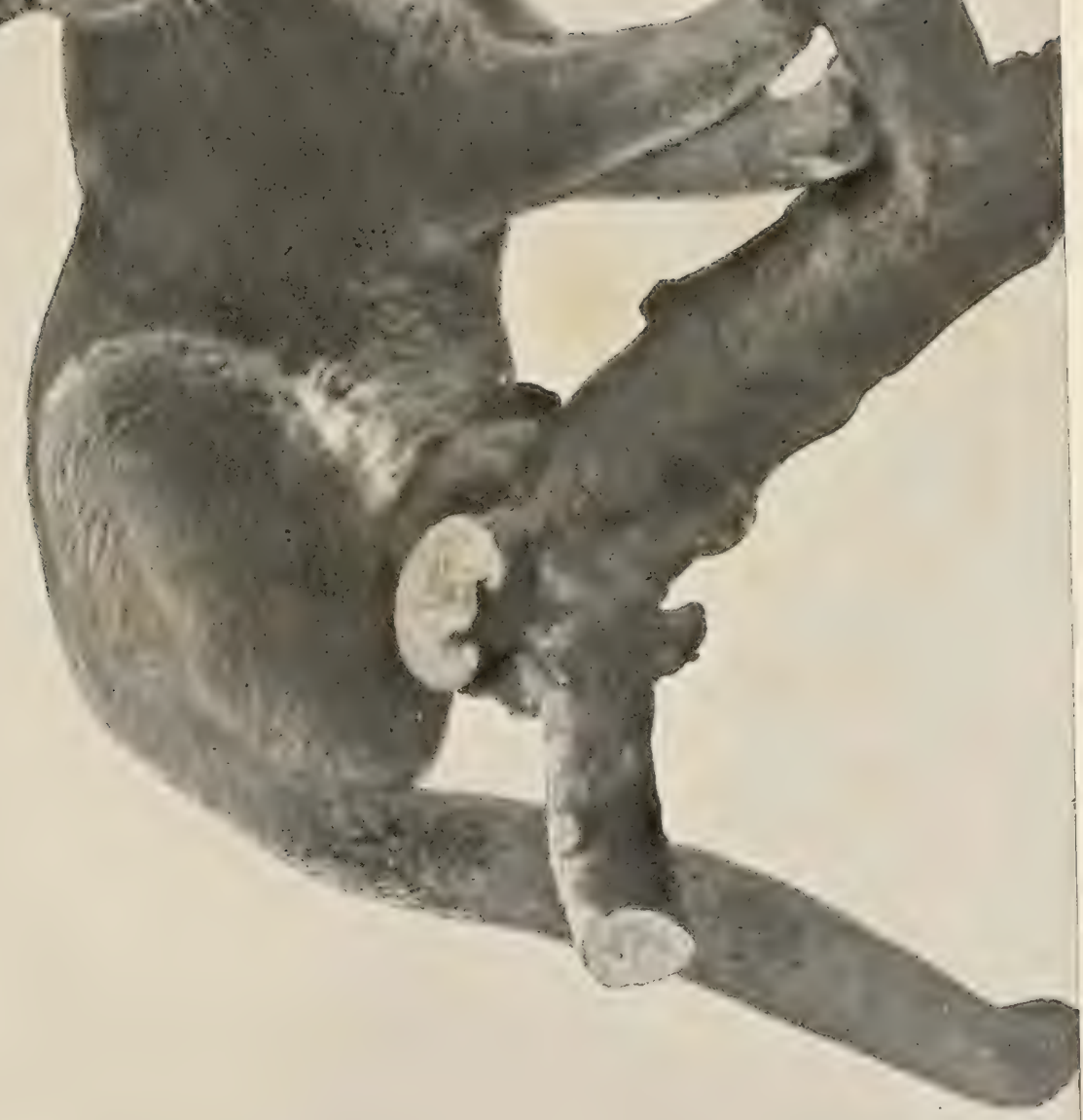



trees oftener than among the ledges, while in fair weather they were given to sleeping out-of-doors, stretched along a branch in the shade. On their hunting excursions they steal noiselessly and cat-like through the thickets, scarcely displacing a twig, still-hunting being their favouise method of obtaining food. Though usually silent, they at times utter a loud penetrating scream.

Among hunters there is a pretty wide-spread theory that the cougar's change in colour follows the seasonal change of the wild deer's coat, becoming more or less spotted in summer to imitate the young fawns. This is, however, quite erroneous, for although the kittens, like those of all the cat tribe, are spotted, the adults are never mottled. The shade varies in winter and summer, and there seems to be a good deal of individual variation, some being browner and others more of a blue gray.

In Mr. Theodore Roosevelt's admirable article on the cougar in Scribner's Magazine he writes: "Fables aside, the cougar is a very interesting creature. It is found from the cold, desolate plains of Patagonia to north of the Canadian line, and lives alike among the snow-clad peaks of the Andes and in the steaming forests of the Amazon. Doubtless careful investigation will disclose several varying forms in an animal found over such immense tracts of country and living under such utterly diverse conditions. But in its essential habits and traits the big, slinking, nearly uni-coloured cat seems to be much the same everywhere, whether living in mountain, open plain or forest, under Arctic cold or tropic heat. When the settlements become thick it retires to dense forest, dark swamp, or inaccessible mountain gorge, and moves about only at night. In wilder regions it not infrequently roams during the day and ventures freely into the open. Deer are its customary prey where they are plentiful, bucks, does and fawns being killed indifferently. Usually the deer is killed almost instantly, but occasionally there is quite a scuffle, in which the cougar may get bruised, though as far as I know, never seriously. It is also a dreaded enemy of sheep, pigs, calves, and especially colts, and when pressed by hunger a big male cougar will kill a full-grown horse or cow, moose or wapiti. It is the special enemy of the mountain sheep. In 1886, while hunting white goats north of Clarke's fork of the 


\section{Jaguar}

Columbia, in a region where cougar were common, I found them preying as freely on the goats as on the deer. It rarely catches antelope, but is quick to seize rabbits, other small beasts, and even porcupines.

"No animal, not even the wolf, is so rarely seen or so difficult to ret without dogs. On the other hand, no other wild beast of its size and power is so easy to kill by the aid of dogs. There are many contradictions in its character. Like the American wolf, it is certainly very much afraid of man; yet it habitually follows the trail of the hunter or solitary traveller, dogging his footsteps, itself always unseen. When hungry it will seize and carry ofl any dog, yet it will sometimes go up a tree when pursued even by a single small dog wholly unable to do it the least harm. It is small wonder that the average frontier settler should grow to regard almost with superstition the great furtive cal which he never sees but of whose presence he is ever aware. The cougar is als large, as powerful and as formidably armed as the Indian panther, and quite as well able to attack man; yet the instances of its having done so are exceedingly rare. But it is foolish to deny that such attacks on human beings never occur. . . It cannot be too often repeated that we must never lose sight of the individual variation in character and conduct among wild beasts."

\section{Mexican Jaguar}

\section{Felis hernandezii}

Length. 7 feet; tail, 2 feet.

Discrition. A large keopard-like animal, tawny yellow above, white below, spotted with black along the back, and with blick, light-centered rosettes on the sides, each with a central black dot. Tail ringed black and yellow.

Raznge. Lower Louisiana, Texals, New Mexico and Mexico, and represented by allied varteties in Central and South America.

This large cat, though common in Mexico, is of rare occurrence within the borders of our country, and like other species of Southern Texas, is only a stritgreler from farther south. Where plentiful, it preys on all sorts of animals, even overoming the tapir with ealse. Stories are told of its attacking 


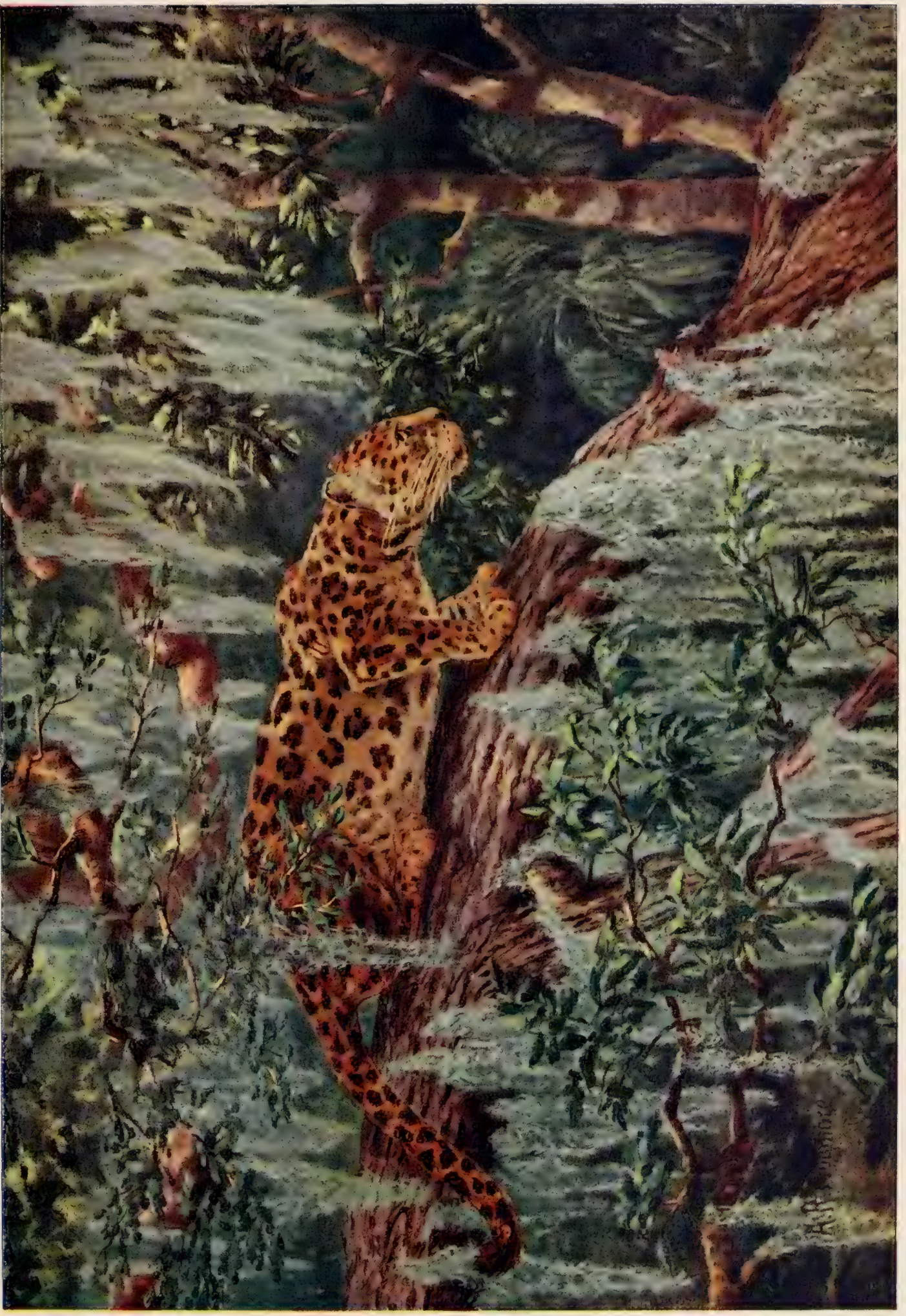



Indians, but, as has been said, "truth and fiction" are so hopelessly mingled in such tales that it is best to withhold credence in most cases.

\section{Ocelot}

\section{Felis pardalis Linnæus}

Length. 45 inches, tail 15 inches.

Description. Colour rufous tawny or brownish with blackish spots, rosettes and stripes, very variable in pattern. Below white with black spots.

Range. Lower Louisiana and Texas, throughout South America.

This is a small spotted cat, ranging from the tropics to just within our borders. It is very variable in colour and doubtless when carefully studied will prove to present several well marked varieties. Its habits within the United States are very little known.

\section{Cacomitl Cat}

\section{Felis cacomitli Berlandier}

Length. 40 inches, tail 20 inches.

Description. Nearly uniform smoky gray, somewhat lighter beneath, darker in winter.

Range. Rio Grande Valley: exact range not ascertained. A similar animal, the Yaguarundi, ranges farther south through South America.

This is another Mexican visitor, belonging to the plaincoloured group of cats. A somewhat similar species, the Eyra (Felis eyra Fischer), may also occur within our limits. It is plain, reddish-brown, 32 inches in length. 



\section{A KEY TO THE GENERA OF NORTH AMERICAN MAMMALS}

Animals are classified scientifically into groups of different rank, known as orders, families and genera, and the technical name of any species consists of the name of the genus to which it belongs, coupled with its own individual specific name. If it shows definite variations in size, colour, etc., in different parts of its range, these geographic races are indicated by a third or sub-specific name.

In the preceding pages the mammals have been arranged by orders and families in their natural sequence, and the characters of these larger groups explained. Inasmuch as a large number of the genera of American mammals are represented in our limits by but a single species, it was not deemed advisable in a work of this kind to treat the several genera and the more minute characters upon which they are based under separate headings, especially as many of the generic characters are given in the descriptions of the species.

In order, however, to facilitate the identification of any mammal which the reader may have in hand, the following key has been prepared by which it may be traced to its genus, while the page numbers following refer directly to the body of the book where the descriptions of the several species may be found. In this key the most obvious generic characters are contrasted and the dentition of each genus is given. In stating the dental formula it will be understood that the figures indicate the number of teeth on one side of the jaws only, the number above the line referring to the upper jaw, that below to the lower; the letters indicate: $i$, incisors, $c$, canines, $p$, premolars, $m$, molars.

Only genera treated in the foregoing pages are included. 


\section{AQUATIC MAMMALS WITH THE LIMBS MODIFIED INTO FLIP. PERS FOR SWIMMING.}

A. No external trace of hind limbs; fore pair of flippers fin-like without claws; tail broad and flattened horizontally; little or no hair on the body.

B. Tail rhomboidal in outline, bluntly pointed at the tip; teeth, $\mathrm{i} 2 \frac{2}{2}, \mathrm{c} 8$, $\mathrm{p} \frac{0}{6}, \mathrm{~m}{ }_{6}^{6}-11$ (Manatee) ................. Trichechus, 26

BB. Tail broadly forked at the end into two flukes (Thales and Dolphins).

C. Mouth enormous, without teeth, but provided with whalebone.

D. No fin on the back; throat not furrowed.......... BALENA, I3

DD. Dorsal fin present; throat furrowed longitudinally.

E. Flippers moderate, edges not scalloped.... BALANOPTERA, IG

EE. Flippers very long, edges scalloped......MEGAPTERA, I7

C. No visible teeth and no whalebone.......... HYPEROODON, I 9

CCC. Jaws provided with teeth; no whalebone.

D. A single long tusk, projecting forward, no other teeth.

DD. No protruding tusk.

E. No teeth in the upper jaw.

F. Teeth in the lower jaw 20-25 on each side. Physeter, I7

FF. Teeth in lower jaw 4-I4 on each side.

G. Head protruding beyond the mouth, dorsal fin short, tail nearly square behind ................ Iogra, r 8

GG. Head not protruding, dorsal fin high, tail deeply cleft. GrampUs, 23

FFF. Teeth in lower jaw one on each side.

G. Teeth at the front of the jaw.............

GG. Teeth at the middle of the jaw..... MLSOPLODON, I9

EE. Teeth in both jaws.

F. Teeth few; 8-I 3 on each side above and below.

G. Teeth confined to the front portion of the jaws.

GG. Teeth distributed all along the jaws.

GLOBIOCEPhalus, 23

H. An enormous dorsal fin, teeth $\frac{10}{10}-1 \frac{3}{1} \ldots . .$. ORCA, 23

HH. Dorsal fin wanting, teeth $\frac{9}{y}$. DELPHINAPTERUS, 24

FF. Teeth numerous, 22-50 on each side above and below.

G. A projecting snout or beak.

H. Teeth, $22 \ldots \ldots \ldots \ldots \ldots \ldots$ TuRsiops, 20

HH. Teeth, $\frac{3}{3}$. . . . . . . . . PRODELPHINUS, 2 I

HHH. Teeth, $4750 \ldots \ldots$ DELPHINUS, 21

GG. No projecting beak.

H. Beak a distinct rim; teeth, $\frac{35}{3}$, LAGENORHYNCHUS, 22

$\mathrm{HH}$, Beakentirely wanting; teeth, $26 . .$. PHOC $\mathrm{xNA}, 22$

A. Both fore and hind flippers well developed, claws or nails present. Tail rudimentary; body covered with hair (Seals, etc.).

B. Body large and shapeless; long down-pointing tusks in the upper jaw; teeth, $\mathrm{i} \frac{1}{6}, \mathrm{c} \frac{1}{1}, \mathrm{p} \frac{3}{3}, \mathrm{~m} \frac{0}{0} \ldots \ldots \ldots \ldots$ ODOBENUS, $2 \mathrm{I} 2$

BB. Shape more graceful; no tusks.

C. Ilind flippers capable of being turned forward for walking when on shore.

D. A dense soft under fur in addition to the long hairs which cover the body; teeth, $\mathrm{i}_{2}^{3}, \mathrm{c}_{1}^{\frac{1}{1}}, \mathrm{p}+\mathrm{m}_{1}^{2} \ldots \ldots \ldots$ OTOEs, 209

DD. No perceptible soft under fur; molars $\frac{1}{1}$.

E. Back tecth separated from last premolar by a considerable

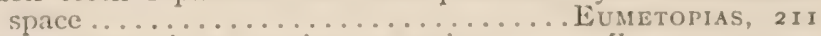

EE. Back tecth in a continuous series......... Zalopius, 2 II

CC. Hind flippers permanently directed backward.

D. A hood-like appendage on the head of the male; teeth, i ${ }_{1}, \mathrm{c}$,

DD. No hood on the head of the male; teeth $\mathrm{i} 3, \mathrm{c} \frac{1}{\mathrm{I}}, \mathrm{p}+\mathrm{x}, \mathrm{m}$. 


\section{A Key to the Genera of North American Mammals}

E. Facial part of head very long; whiskers crenulated.

Halicherus, 2 I 8

EE. Facial portion of head short, about equal to the brain-case; whiskers not crenulated.

F. Muzzle broad, forehead convex ........ ERIgnathus, 2 I8

FF. Muzzle narrow, forehead sloping gradually. PHocA, 2 I 5-2 I 7

II. AERIAL MAMMALS WITH THE FORE LIMBS MODIFIED FOR FLIGHT AND COVERED BY AN ELASTIC MEMBRANE WHICH EXTENDS DOWN THE SIDES OF THE BODY AND BETWEEN THE HIND LEGS (BATS).

A. Tail wanting; a curious leaf-like appendage on the nose; teeth, $\mathrm{i} \frac{2}{2}, \mathrm{c} \frac{1}{1}$, $\mathrm{p} \frac{2}{2}, \mathrm{~m} \frac{2}{3} \ldots \ldots \ldots \ldots \ldots \ldots \ldots \ldots \ldots \ldots \ldots \ldots \ldots \ldots \ldots \ldots \ldots \ldots \ldots$ ARTIBEUS, 194 AA. Tail present; no appendage on the nose.

B. Tip of tail projecting beyond the interfemoral membrane; teeth, $\mathrm{i} \frac{1}{3}$,

BB. Interfemoral membrane reaching to the tip of the tail.

C. Interfemoral membrane completely covered with fur; teeth, $i \frac{1}{3}, c \frac{1}{1}$,

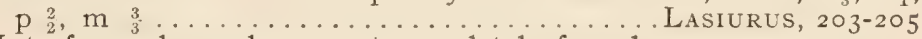

CC. Interfemoral membrane not completely furred.

D. Ears very large united by their bases; teeth, $i \frac{2}{3}, c \frac{1}{1}, p \frac{2}{3}, m \frac{3}{3}$.

DD. Ears not united by their bases.

CORYNORHINUS, I96

E. Upper incisor teeth one on each side close to the canine.

F. Size large (length 5.60 ins.); teeth, $\mathrm{i} \frac{1}{3}, \mathrm{c} \frac{1}{1}, \mathrm{p} \frac{1}{2}, \mathrm{~m} \frac{2}{3}$.

FF. Size small (length 3.70 ins.); teeth the same.

DASYPTERUS, 206

EE. Upper incisors two on each side.

Nycticeius, 206

F. Color of fur black with white tips; teeth, $\mathrm{i} \frac{2}{3}, \mathrm{c} \frac{1}{1}, \mathrm{p} \frac{2}{3}, \mathrm{~m} \frac{3}{3}$.

FF. Color of fur brown or yellowish brown.

LASIONYCTERIS, 202

G. Size large (length 4.60 ins.); teeth, $\mathrm{i} \frac{2}{3}, \mathrm{c} \frac{1}{1}, \mathrm{p} \frac{1}{2}, \mathrm{~m} \frac{3}{3}$.

GG. Size small (length 3.40 ins.).

VESPERTILIO, 200 H. Teeth, $\mathrm{i} \frac{2}{3}, \mathrm{c} \frac{1}{1}, \mathrm{p} \frac{2}{2}, \mathrm{~m} \frac{3}{3} \ldots \ldots$ Pipistrellus, $20 \mathrm{I}$ HН. Teeth, $\mathrm{i} \frac{2}{3}, \mathrm{c} \frac{1}{1}, \mathrm{p} \frac{3}{3}, \mathrm{~m} \frac{3}{3} \ldots \ldots$ Мrotis, I96

\section{MAINLY TERRESTRIAL MAMMALS WITH FOUR WELL- DEVELOPED LEGS, ADAPTED FOR WALKING.*}

A. Body covered by a bony carapace or shell; teeth, $\frac{7}{7}-\frac{8}{8} \ldots \ldots$. TATU, 9 AA. Body covered with hair or fur.

B. Tail naked and prehensile; ears naked; female with teats opening in a pouch on the belly in which the young are carried; teeth, $\mathrm{i} \frac{5}{4}, \mathrm{c} \frac{1}{1}, \mathrm{p} \frac{3}{3}, \mathrm{~m} \frac{4}{4} \ldots \ldots \ldots \ldots \ldots \ldots \ldots \ldots \ldots \ldots \ldots \ldots \ldots$ Didelphis, $4-8$ BB. Tail not prehensile; ears not naked; no marsupial pouch.

C. Toes terminating in hoofs.

D. Form pig-like; teeth, i $\frac{2}{3}, \mathrm{c} \frac{1}{1}, \mathrm{p} \frac{3}{3}, \mathrm{~m} \frac{3}{3} \ldots . .$. TAYASSU, 30 DD. Form not pig-like; males (and females of same species) with horns.

E. Horns hollow, not branched, fitting over a solid bony core; teeth, i $\frac{0}{4}, \mathrm{c} \frac{0}{0}, \mathrm{p} \frac{3}{3}, \mathrm{~m} \frac{3}{3}$.

F. Shaggy mane over the head and shoulders ..... Bison, 66

FF. Long hair over the whole body; horns massive, OviBos, 65

FFF. Form sheep-like; hair short; horns spiral .. Ovis, 6 I-6 5

*The hind feet are webbed and somewhat flipper-like in the Sea Otter, and in the Flying Squirrels there is an expansion of skin on the sides of the hody for flying. 


\section{A Key to the Genera of North American Mammals}

FFFF. Form guat-like, hair long, pure white . Oresmos, 57 EE. IIorns hollow, forlied, and shed periodically; tecth, i ", c".,

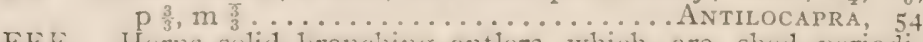
EEE. II rns solid hranching antlers, which are shed periodically; tecth, i $\frac{0}{4}, \mathrm{c} \frac{0}{0}-\frac{1}{4}, \mathrm{p} \frac{3}{3}, \mathrm{~m} \frac{3}{3}$.

F. Nose completely covered with hair.... RANGIFER, 47-54

FF. Nose not completely haired.

G. Antlers broadly palmate or flattened....ALcEs, 43 GG. Antlers not flattened.

H. Animals medium or small; antlers not more than twenty-five inches long...... Odocorleus, 34-43

HH. Animals large; antlers four to five fect.

Cervus, $3 \mathrm{I}-34$

CC. Toes terminating in claws.

1). $\Lambda$ gap on each side of the jaws caused by the absence of canine teeth. Incisors two in each jaw, large and protruding, working against each other like a pair of chisels.

E. A pair of small rudimentary incisors behind the upper pair of large ones.

F. Tail short; hind legs much longer than the front ones; teeth, $\mathrm{i} \frac{2}{1}, \mathrm{c} \frac{0}{0}, \mathrm{p} \frac{3}{2}, \mathrm{~m} \frac{3}{3} \ldots \ldots \ldots$..........

FF. No external tail; legs about equal; $\mathrm{p} 2 . .$. Ocrotona, 93

EE. No extra incisors.

F. Hair interspersed with sharp spine-like quills; tecth, $\mathrm{i} \frac{1}{1}, \mathrm{c}{ }_{0}^{0}$, $\mathrm{p} \frac{0}{0}, \mathrm{~m} \ldots \ldots \ldots \ldots \ldots \ldots \ldots \ldots \ldots \ldots \ldots$ ERETHIzON, 94

FF. Without spines.

G. Form mole-like; fore fect modified for digging; no external car; teeth, $\mathrm{i} \frac{1}{1}, \mathrm{c} \frac{0}{0}, \mathrm{p} \frac{0}{0}, \mathrm{~m} \frac{4}{4}$.

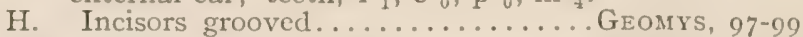

HH. Incisors not grooved ............ Thomomrs, 96

GG. Form not mole-like; fore feet normal.

H. Body heavy and thick-set, I2-20 inches long exclusive of tail; legs short.

I. Tail very broad, flat, covered with scales; teeth, $\mathrm{i} \frac{1}{1}, \mathrm{c} \frac{0}{4}, \mathrm{p} \frac{1}{3}, \mathrm{~m} \frac{3}{3} \ldots \ldots \ldots \ldots$ CASTOR, $45^{-1} 5^{\circ}$

II. Tail long and narrow, flattencel vertically, and nearly naked teetll, $\mathrm{i} \frac{1}{1}, \mathrm{c} \frac{0}{0}, \mathrm{p} \frac{0}{0}, \mathrm{~m} \frac{3}{3}$.

III. Tail hairy; teeth, $\mathrm{i} \frac{1}{1}, \mathrm{c} \frac{0}{5}, \mathrm{p}_{1}^{2}-\frac{1}{1} \mathrm{~m} \frac{3}{3}$.

FIBER, 12 I-I 27

J. Tail very short, less than the head.

JJ. Tail moderate, longer than the head,

Aplodontia, I 50

ARCTOMYS, $15 \mathrm{I}-159$

HH. Form mouse-like or rat-like; size not larger than a common rat (body less than 10 ins. without tail); teeth usually, $\mathrm{i} \frac{1}{1}, \mathrm{c} \frac{0}{0}, \mathrm{p} \frac{0}{5}, \mathrm{~m}_{3}^{3}$.

I. Pouches on the sides of the face opening near the mouth.

J. Tail very long; teeth as above. PERODIPUS, xoo

Jj. Tail moderate; teeth, i $\frac{2}{1}, \mathrm{c} \frac{0}{0,} \mathrm{p} \frac{1}{1}, \mathrm{~m} \frac{3}{3}$. II. No external check pouches. PEROGNATIUS, Ioo
J. Hind legs much longer than the front ones;
tail excecding head and body; tecth in one tail excecding head and body; tecth in one
species, i $\frac{1}{1}, \mathrm{c} \frac{0}{6}, \mathrm{p} \frac{1}{1}, \mathrm{~m} \frac{3}{3} \ldots \mathrm{Z}_{\mathrm{APUS}}, \mathrm{IO}_{2}-105$

JJ. Hind legs not markedly longer than front ones. I. Thick-set, short-legged, short-cared mice of the meadow mouse type.

L. Tail less than one-third the length of head and body, generally much less. 
M. Upper incisors grooved.

SYNAPTOMYS, IO7-IO8

MM. Upper incisors not grooved.

N. Tail so short as to be barely visible beyond the hair.

O. Color mottled (white in winter).

OO. Color tawny orange.

DicRosTONYX, IOS LEMMUS, I Io
usually about one inch long.

O. Molar teeth rooted (See p. rio). P. Color dark-brown; teeth heavy .. Phenacomys, ilo PP. Color rusty; teeth lighter.

OO. Molars not rooted.

$$
\text { Evotomys, III-II }
$$

Microtus, II 2-I 20

LL. Tailequal to two-thirds the head and body.

M. Fur coarse; many buff hairs among the brown ones: molars rooted.

SigMODON, I 28 -I 29

MM. Fur fine uniform. like that of the Muskrat; molars not rooted.

Microtus ALLENi, I 20

KK. Slender with longer legs and prominent ears and eyes; tail always more than half the head and body (except Onychomys), generally much more.

L. Tubercles on molar teeth in three rows (introduced species).....Mus, I 38 -I 45

LL. Tubercles on the molars, if present, in two rows (native species).

M. Size large, rat-like; molars flat on top, divided into triangles.

NEOTOMA, I 27 -I 28

MM. Size medium, rat-like; molars tuberculate ; strongly resembling a young Common Rat.

ORYZOMYS, I29-I 30

MMM. Size small ; mouse-like.

N. Tail always more than half the head and body; often about equal.

O. Upper incisors grooved.

REITHRODONTOMYS, I3O-I3I

OO. Upper incisors not grooved.

Peromyscus, I 36

NN. Tail short, less than half the head and body... ONychomys, I 36

IHH. Form squirrel-like; teeth, $\mathrm{i} \frac{1}{1}, \mathrm{c} \frac{0}{0}, \mathrm{p} \frac{2}{1}, \mathrm{~m} \frac{3}{3}$.

I. An extensible fold of skin on the sides of the

body for flying.... ScIUROPTERUS, I 76-I 78

II. No extensible skin for flying.

J. Burrowing animals; tail not bushy.

K. Tail very short, I-3 to I-4 head and body.

KK. Tail $\mathrm{I}-3$ to $\mathrm{I}-2$ head and body.

Cynomys, I60

SPERMOPHILUS, I6I-I 62

KKK. Tail I-2 head and body; body prominently striped ....... TAMIAS, I62 


\section{A Key to the Genera of North American Mammals}

JJ. Arboreal species, tail long and businy.

SCIURUS, I6S-I 76

DD. Tooth row nearly continuous, leaving no large gap at the side of the jaw. Incisors small and always more than two.

E. Size small (less than seven inches long), fur always drab or iron gray, soft and silky; eyes rudimentary.

F. Fore fect flattened for digging (Moles).

G. A fleshy star on the nose; teeth, $\mathrm{i} \frac{3}{3}, \mathrm{c} \frac{1}{1}, \mathrm{p} \frac{4}{4}, \mathrm{~m} \frac{3}{3}$.

GG. No fleshy star on the nose.

H. Tail naked; teeth, $\mathrm{i} \frac{3}{2}, \mathrm{c} \frac{1}{6}, \mathrm{p} \frac{3}{3}, \mathrm{~m} \frac{3}{3} \ldots$ ScALOPS, ISS

HH. Tail hairy; teeth, $\mathrm{i} \frac{3}{3}, \mathrm{c} \frac{1}{1}, \mathrm{P} \frac{4}{4}, \mathrm{~m} \frac{3}{3}$. PARASCALOPS, 189

FF. Fore fect normal.

G. Tail short $1-4$ the head and body; teeth, $\mathrm{i}-\frac{3}{2}, \mathrm{c} \frac{1}{1}, \mathrm{p} \frac{2}{1}$,

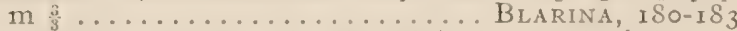

GG. Tail at least $\mathrm{I}-2$ the head and body; teeth, $\mathrm{i} \frac{4}{2}, \mathrm{c} \frac{1}{10}$, p $\frac{2}{1}, m \frac{3}{3} \ldots \ldots \ldots \ldots \ldots \ldots \ldots$ SOREX, $I 8_{4-1} \delta_{7}$

EE. Size medium or large; eyes well developed.

F. Toes webbed.

G. Hind feet large and very different from the front ones, resembling flippers; teeth, $\mathrm{i} \frac{3}{2}, \mathrm{c} \frac{1}{1}, \mathrm{p} \frac{3}{3}, \mathrm{~m} \frac{\mathrm{T}}{2}, \mathrm{LATAX}, 223$

GG. Feet all alike; teeth, i $\frac{3}{3}, \mathrm{c} \frac{1}{1}, \mathrm{p} \frac{4}{3}, \mathrm{~m} \frac{1}{2}$.. LUTRA, 2 I9-223

FF. Toes not webbed:

G. Toes, five on all feet.

H. Teeth, $\mathrm{i} \frac{3}{3}, \mathrm{c} \frac{1}{1}, \mathrm{p} \frac{4}{4}, \mathrm{~m}^{\frac{2}{2}}$.

I. Nose produced into a slender snout; tail obscurely ringed................................. 254

II. Nose not lengthened; tail strongly ringed with black and white.

J. Body thick-set; feet plantigrade. PROCYON, 247

Jj. Body slender, weasel-like; feet only partially

HH. Teeth, $1 \frac{3}{3}, \mathrm{c} \frac{1}{1}, \mathrm{p} \frac{4}{4}, \mathrm{~m} \frac{1}{2}$.

I. Body heavy, bear-like; fect slightly plantigrade.

II. Body more slender; feet digitigrade.

Gulo, 245

HHH. Teeth, $\mathrm{i} \frac{3}{3}, \mathrm{c} \frac{1}{1}, \mathrm{p}_{2} \frac{3}{2}-\frac{3}{3}, \mathrm{~m}, \frac{3}{2}$.

I. Claws long and conspicuous; colors black and white. J. White in two long stripes. MEPHITIS, 224-229

JJ. Markings more complicated. . SPILOGALE, 230

II. Claws very long and conspicuous; color gray.

III. Claws short; color brown (often white in winter). PuTORIUS, 23 I-240

HHHH. Teeth, i $\frac{3}{3}, \mathrm{c} \frac{1}{1}, \mathrm{p} \frac{4}{4}, \mathrm{~m}_{\frac{2}{3}}$; size very large (Bears).

I. Color white............... Tralarctos, 255

II. Color, black, brown or tawny.... URsus, 257-264

GG. Toes, five in front and four behind.

H. Toes not retractile; teeth, $\mathrm{i} \frac{3}{3}, \mathrm{c} \frac{1}{1}, \mathrm{p} 4, \mathrm{~m} \frac{2}{3}$.

I. Upper incisors lobed............. CANIS, $277-283$

11. Upper incisors not lobed.

J. Tail with soft under fur. .... Vulpes, $264-275$

Jj. Tail coarse ......... UROCYON, $275^{-277}$

HH. Toes retractile.

I. Tail very short $\left(4-6\right.$ ins.); teeth, $\mathrm{i}_{3}^{3}, \mathrm{c} \frac{1}{1}, \mathrm{p} \frac{2}{2}, \mathrm{~m} \frac{1}{1}$.

II. Tail long, equal to more than half the head and body; tecth, $\mathrm{i} \frac{3}{3}, \mathrm{c} \frac{1}{1}, \mathrm{p} \frac{3}{2}, \mathrm{~m} \frac{1}{1}$. . FELIS, 288-293 


\section{BIBLIOGRAPHY}

The following list is not intended to be complete, but will refer the student to the most recent reviews of the various groups of North American mammals, as well as to the principal general works on the subject and some of the more important local lists.

\section{MAMMALS IN GENERAL.}

I891. Flower, W. H., and LyDEKKER, R.An Introduction to the Study of Mammais, Living and Extinct, pp. $1-763$.

Cf., also, volumes on Mammals in the Standard and Royal Natural Histories.

\section{ANATOMY OF MAMMALS.}

I88 r. Mivart, St. G.-The Cat. An introduction to the study of backboned animals, especially Mammals, pp. I -557.

\section{GENERAL WORKS ON NORTH AMERICAN MAMMALS.}

I825. HARLAN, R.-Fauna Americana; being a description of the Mammiferous animals inhabiting North America, pp. r-3 I 8 .

1826-8. GODMAN, J. D.-American Natural History; 3 Vols., pp. (I) I-350: (II) I-33I; (III) $\mathrm{I}-264$.

I 846-54. AUduBon, J. J., and BachmaN, J.The Viviparous Quadrupeds of North America: 3 Vols., Roy. 8vo. There is a large edition of folio plates and an edition of the text with small plates intercalated.

1859. BAIRD, S. F.-Mammals of North America. I Vol., $4^{\circ}$, with 87 plates. Originally published in I 857 as Vol. VIII of the Pacific R. R. Survey Series. (Does not include Whales, Seals or Bats.)

1900. Miller, G. S., JR.-Key to the Land Mammals of Northeastern North America. Bull. N. Y. State Museum. No. 38, Vol. VIII, pp. 6 r - r 60 .

rgor. Elliot, D. G.-A Synopsis of the Mam. mals of North America and the Adjacent Seas. Field Columbian Museum; publication 45 , pp. $1-47 t$. Contains descriptions, ranges, and figures of skulls.

rgor. Miller, G.S., JR., and RehN, J. A. G.Systematic results of the study of North American Land Mammals to the close of the year rgoo. Proc. Bost. Soc. Nat. Hist., Vol. XXX, No. I, pp. $\mathrm{I}-352$, The most accurate list ever published, with reference to original place of publication of every species.

\section{HABITS OF OUR WILD ANIMALS.}

Cf. Publications of the Borne and Crockett Club. American Sportsman's Library. Lydekker's Great and Small Game of Europe, Asia and America. Emest Seton
Thompson's "Wild Animals I "Have Known," "Lives of the Hunted," etc., and many articles in the magazines, as well as a number of the special papers given below.

\section{GEOGRAPHICAL DISTRIBUTION.}

I871. AlLEN, J.A.-Mammals and Winter Birds of East Florida. Bull. Mus. Comp. Zool. II.; pp. 375-425 treat of Geographical Distribution.

1892. AlleN, J. A.-The Geographical Distribution of North American Mammals, Bull. Amer. Mus. Nat. Hist., IV, pp. 199-

1892. MERriam, C. H. - The Geographic Distribution of Life in North America with special reference to the Mammalia. Proc. Biol. Soc. Wash., VII, pp. I-64.

I 894. MERRIAM, C. H.-Laws of Temperature Control of the Geographic Distribution of Terrestrial Animals and Plants. Nat. Geogr. Mag., VI, pp. 220-238.

\section{FAUNAL PAPERS.}

(PARTIAL LIST.)

1900. OsGood, W. H.-Mammals of the Yukon River region. N. A. Fauna No. I9, pp. $2 \mathrm{I}-45$

1900. STCNE, W.-Mammals of Pt. Barrow, Alaska. Proc. Acad. Nat. Sci., Phila., I 900. pp. 33-49.

Igor, OsGooD, W. H.-Mammals of Cook Inlet, Alaska. N. A. Fauna No. 2 I .

1898. BANGS, O.-A List of the Mammals of Labrador. American Naturalist, XXXII, pp. $489-507$

I897. MILIER, G. S., JR.-Notes on the Mammals of Ontario. Proc. Bost. Soc. Nat. Hist., Vol. XXVIII, pp. r-44.

1892. Herrick, C. L.-Mammals of Minnesota. Bull. No. 7, Geol. and Nat. Hist. Survey Minn., pp. $1-209$.

r894. Mrller, G S., Jr.-On a Collection of Small Mammals from the New Hampshire Mountains, Proc. Bost. Soc. Nat. Hist., Vol. XXVI, pp. I 7 7-197.

1869. AlLEN, J. A.-Catalogue of the Mammals of Massachusetts. Bull. Museum Comp. Zool., I, pp. 143-252.

I 898. MEARNS, E. A-A Study of the Fauna of the Hudson Highlands. Bull. Amer. Mus. Nat. Hist., XVI, pp. 303-352.

I 898 . Mearns, E. A.-Notes on the Mammals of the Catskill Mountains, N. Y. Proc. U. S. Nat. Mus., XXI, pp. 34I-360. 
809. MrLler, G. S-Preliminary List of New York Mammals. Bull. N. Y. State IIus., Vol. VI, No. 29, pp. 273-300.

I807. RHOADS, S. N.-A Contribution to the Mammalogy of Northern New Jersey. Proc. Acad. Nat. Sci. Phila., I897, pp. 2333.

1897 RHoAds, S. N.-A Contribution to the II ammalogy of Central Pennsylvania. Proc. Acad. Nat. Sci. Phila., I 897, pp. 20.4226.

S96. BaILeY, VernoN.-List of Mammals of the District of Columbia. Proc. Biological Soc. Wash. 1 896 , pp. 93-101.

\$96. RHOADS, S. N.-Contributions to the Zoology of Tennessee. No. 3. Mammals. Proc. Acad. Nat. Sci. Phila., I897, pp. 175205.

\$894. RHOADS, S. N.-Contributions to the Mammalogy of Florida. Proc. Acad. Nat. Sci. Phila, $x 894$, pp. $152-16 x$

I 898. BANGS, O. The Land Mlammals of Peninsular Florida and the Coast Region of Georgia, Vol. XXVIII, pp. I57-235. Cf, also "North American Fauna," and various reports of explorations and contributions to proceedings mentioned at end of bibliography.

\section{MARSUPIALS.}

I gor. ALLEN, J. A.-A Preliminary Study of the North American Opossums of the Genus Didelphis. Bull. Amer. Mlus. Nat. Hist., XIV, pp. 149-188.

\section{WHALES AND DOLPHINS.}

1874. Scammon, C. M.-The Marine Mammals of the Northwestern Coast of North America, $p$ p. I-310.

I884. GOODE, G. BRown.-Natural History of Useful Aquatic Animals, U. S. Fish Com. Fisheries and Fishery Industries of the U. S. Section I (text and atlas of plates), pp. $x-36$, treats of Mammals, Whales, etc., by Goodc; Seals, by Allen; Manatee, by True; Fur Seal, by Elliot.

1889. TRUE, F. W. - A Review of the family Delphinidx. Bull. U. S. Nat. Mus., No. $3^{6}$, pp. $1-10 \mathrm{I}$.

\section{MANATEES.}

1895. BAngs, O.-The Present Standing of the Florida Manatee in the Indian River Waters, Amer. Nat., XXIX, pp. 7.8.3-787.

1884. STEJNEGER, L.-Investigations Relating to the Date of the Extermination of Steller's Sea Cow. Proc. U. S. Nat. Mus., I884, pp. I 8 I.

\section{HOOFED ANIMALS.}

881, CAton, J. D.-The Antelope and Deer of America, pp. $1-426$

1877. AlLEN, J.A.-Ilistory of the American Bison. Ann. Rep. U. S. Geol. Surv. Terr., 1875. PD. 443-587. An earlier edition published in Mem. Mus. Comp. Zool., IV, No. Io (IS76).

1880. HORNADAY, IV. T.-The Extermination of the American Bison. Rep. U. S. Nat. Mus., I 886-7, pp. $360-548$.

808 , LYDEKKER, R. Wild Oxen, Sheep and Goats of All Lands, Pp. $x-318$
ISoS. LYDEKKER, R.-The Deer of All Lands. A History of the Family Cervidx, Living and Extinct, pp. $x-320$.

1900. Allen, J. A.-Note on the Wood Bison. Bull. Amer. Mus. Nat. Hist., XIII, pp. 6367.

1000 ALLEN, J. A-The Mountain Caribou of Northern British Columbia. Bull. Amer. Mus Nat. Hist., XII, pp. I-xS. Ct. also XIV, 21 . I $+3-143$.

I ) OI-Allen, J. A.- The Musk Oxen of Arctic America and Greenland. Bull. Amer. Mus. Nat. Hist., XIV, pp. $60-86$.

Igor. HORNADAY. W. T. - Notes on the Mountain Sheep of North America, with a Description of a New Species. Fifth Annual Report N. Y. Zool. Soc., pp. 77-122.

\section{RODENTS.}

1877. Covis, Elliots, and AlLeN, J. A.Monographs of North American Rodentia. Vol. XI of U.S. Geol. Survey of the Territories under F. V. Hayden. Contains in appendix a bibliography of papers relating to North American Mammals, up to 1877 .

\section{(a) RABBITS}

I 894. BAngs, O.-Geographical Distribution of the Eastern Races of the Cottontail. Proc. Bost. Soc. Nat. Hist., XXVI, pp. 404-

IS94. AlleeN, J. A.-On the Seasonal Change of Colour in the Varying Hare (Lepus americanus Erxl). Bill. Amer. Mus. Nat. Hist., VI, pp. I07-1 28.

1806. RHoAds, S. N.-Synopsis of the Polar Hares of North America. Proc. Acad. Nat. Sci. Phila., $x 806$, pp. $35 \mathrm{I}-376$.

I 806. PALMER, T. S.- The Jack Rabbits of the United States. Bull. No. 8. U. S. Dept. Agric., Div. Ornith. and Mam., pp. $\mathrm{I}-\mathrm{S}_{4}$.

I898. BANGS, O.- The Eastern Races of the American Varying Hare. Proc. Biol. Soc. Wash., XII, pp. 77-82.

\section{(b) RATS AND MICE.}

304 RHoADS, S. N.-A Contribution to the Life History of the Alleghany Cave Rat. Proc. Acad. Nat, Sci. Phila., I894, pp. $213^{-}$ 221

S05. AlleN, I. A.-On the Species of the Genus Reithrodontomys. Bull. Amer. Mus. Nat. Hist., VII, pp. ro7-1 43.

I 806. Miller, G. S., JR.-Genera and Subgenera of Voles and Lemmings. N. $\Lambda$. Fauna (U. S. Dept. Agriculture) No. 12, pp. $x-78$.

I \$96. Merrias, C. H.-Revision of the Lemmings of the Genus Synaptomys, with descriptions of New Species. Proc. Biol. Soc. Wash., X, pp. 55-64.

1806. BANGS, O-The Cotton Mouse, Peromyscus gossypinus. Proc. Biol, Soc. Wash., X, PP. 31 19-1 25 .

I806. MILLER, G. S. JR.-The Beach Mouse of Muskeget Island. Proc. Bost. Soc. Nat. Hist., Vol, XXVII, pp. 75-87.

I So7. MILDER, G. S. JR-Synopsis of the Voles of the Genus Phenacomys. Proc. Biol. Soc. Wash., XI, pp. 77-87.

I 800 . PREBLE, E. A.-Revision of the Jumping Mice of the Genus Zapus. N. A. Fauna (U. S. Dept. Amriculture) No. I 5, pp. I $=30$.

r 000 . OsGoon, WV . H.-Revision of the Pocket ifice of the Genus Perognathus. N. A. Fauna (U. S. Dept. Agriculturc) No. I 8 , pp. $x-63$. 
rgoo, BaIley, V.-Revision of American Voles of the Genus Microtus. N. A. Fauna (U. S. Dept. Agriculture) No. I7, pp. $x-88$.

IOOI MERRIAM, C. H.-Synopsis of the Rice Rats (Genus Oryzomys) of the United States and Mexico. Proc. Wash. Acad. Sci., III, pp. 273-295.

\section{(c) GOPHERS.}

I895. Merriam, C. H.-Monographic Revivision of the Pocket Gophers, Family Geomyidx (exclusive of Thomonys). N A. Fauna (U. S. Dept. Agriculture) No. 8, pp. $1-220$.

I 805. BAILEY, V.-The Pocket Gophers of the United States. Bull. No. 5, U. S. Dept. Agric., Div. Ornith. and Mam., pp, I-46.

\section{(d) BEAVERS.}

r868. Morgan, L. H.-The American Beaver and His Works, pp. I-330.

I 808. RHOADS, S. N-Contributions to a Revision of the North American Beavers, Otters and Fishers. Trans. Amer. Philos. Soc., XIX, pp. 4I 7-439.

\section{(e) SQUIRRELS.}

I89o. Allen, J. A.-A Review of Some of the North American Ground Squirrels of the Genus Tamias. Bull. Amer. Mus. Nat. Hist., III, pp. 45-1 I 6.

I Soo. ALLEN, J. A.-On Seasonal Variations in Colour in Sciurus hudsonius. Bull. Amer. Mus. Nat. Hist, III, pp. I-44.

I806. BANGS, $\mathrm{O}-\mathrm{A}$ Review of the Squirrels of Eastern North America, X, pp.145-I67. x 807 . RHOADS, S. N.-A Revision of the West American Flying Squirrels. Proc. Acad. Nat. Sci. Phila., 1897, pp. 314-327. I 898. Allen, J. A.-Revision of the Chickarees; or North American Red Squirrels (Subgenus Tamiasciurus). Bull. Amer. Mus. Nat. Hist., X, pp. 249-298.

\section{SHREWS AND MOLES.}

I895. MERRIAM, C H.-Revision of the Shrews of the American Genera Blarina and Notiosorex. Synopsis of the American Shrews of the Genus Sorex. N. A. Fauna No, Io, pp. $x-34$ and $57-98$.

I 895. MILLER, G. S., JR.-The Long-tailed Shrews of the Eastern United States. N. A. Fauna (U. S. Dept. Agriculture) No. Io, pp. $35-56$.

1 806 . TRUE, F. W.-A Revision of the American Moles. Proc. U. S. Nat. Mus., XIX, pp. I-I I 2

\section{BATS.}

I893. AlleN, HARRISON-A Monograph of the Bats of North America. Bull. 43. U. S. Nat. Mus., pp. I-I 08 .

1897 MrLleR, G. S., JR.-Revision of the North American Bats of the Family Vespertilionidæ. N. A. Fauna (U. S Dept. Agriculture), pp. 1-1 35 .

\section{SEALS.}

I880. AlLEN, J. A.-History of North American Pinnipeds. A Monograph of the Walruses, Sea Lions, Sea Bears and Seals of North America. U.S. Geol. Survey of the Territories, F. V. Hayden in charge. Miscellaneous Publication No. I 2, pp. I785.

x 896 . Report on the Condition of Seal Life on the Rookeries of the Pribilof Islands I $803^{-}$ 95. Senate Doc. I37, 54th Congress, Ist session. 2 Vols. and atlas of plates.

I808. JORDAN, D. S. et al. The Fur Seals and Fur Seal Islands of the North Pacific Ocean. U. S. Treas. Dept. Doc, 2017 Division of Special Agents; 4 Vols.

\section{OTHER CARNIVORES.}

I896. Merriam, C. H-Preliminaty Synopsis of the American Bears. Proc. Biol. Soc. Wash., X, pp. 65-83.

1896. MERRIAM, C. H.-Synopsis of the Weasels of North America. N. A. Fauna (U. S. Dept. Agriculture) No. I I, pp. I33.

I 896. BANGS, O.-A Review of the Weasels of Eastern North America. Proc. Biol. Soc. Wash., X, pp. $\mathrm{I}-24$.

I896. Bangs, O.-Notes on the Synonymy of the North American Mink. Proc. Bost. Soc. Nat. Hist. Vol. XXVII, pp. $x-6$.

1877. Coves, E.-Fur Bearing Animals. A Monograph of North American Mustelidx. U. S. Geol. Survey of the Territories Misc. Publ. No. 8, pp. $\mathrm{I}-348$.

rgor. Howell, A. H.-Revision of the Skunks of the Genus Chincha [-Mephitis]. N. A. Fauna (U. S. Dept. Agriculture) No. 20, pp. $\mathrm{x}-45$.

x 893. RhosDs, S. N.-Geographic Variation in Bassariscus astutus. Proc. Acad. Nat. Sci. Phila., I 894, pp. 413-418

I897. MERRIAM, C. H.-Revision of the Coyotes or Prairie Wolves, with Descriptions of New Species. Proc. Biol. Soc. Wash., XI, pp. I9-33.

I900. Merriam, C. H.-Preliminary Revision of the North American Red Foxes. Proc. Wash. Acad. Sci., II, pp. 661-676.

I897. BANGS, O.-Notes on the Lynxes of Eastern. North America. Proc. Biol. Soc. Wash., XI, pp. 47-5I.

I901. MERRIAM, C. H.-Preliminary Revision of the Pumas (Felis concolor group). Proc. Wash. Acad. Sci., III, pp. 577-600.

Cf. also many papers in Proceedings Ac. ademy Natural Sciences Philadelphia Bulletin American Museum Natucal His tory New York, Proceedings Biological Scciety of Washington and of the Wash. ington Academy of Sciences, Proceedings Boston Society Natural Sciences, etc. for descriptions of species and reports on collections from various parts of the coun. try. 



\section{INDEX}

Abietorum, Peromyscus, I 35 Zapus, 105

Acadian Meadow Mouse, I I 7

acadicus, Microtus, I I 7

acutus, Lagenorhynchus, 22

Alabaina Gopher, 98

alascanus, Otoes, 209

alascensis, Ursus, 263

Alaskan Grizzly, $26_{3}$

Moose, 43

albibarbis, Sorex, 187

albus, Canis, 277

Alces americanus, 43

gigas, 43

alexandrinus, Mus, I 45

alleghaniensis, Pretorius, 240

Aıleghany Weasel, 240

Wood Rat, I 27

alleni, Microtus, I 20

ambarvalis, Spilogale, 230

American Badger, 230

Elk, 3 I

Marten, 242

Sable, 242

americana, Antilocapra, 54

Mustela, 242

americanus, Alces, 43

Lepus, 86

Trichechus, 27

Ursus, 257

Zapus, IO4

angulatum, Tayassu, 30

Antelope, 54

Antilocapra americana, 54

Aplodontia rufa, I 50

Aplodontidae, I 50

aquaticus, Lepus, 89

Scalops, 188

aquilonius, Fiber, I 26

Arctic Fox, 273

Hare, 86

Wolf, 277

articus, Lepus, 86

Rangifer, 52
Arctomys monax, I 5 I

canadensis, I 59

ignavus, 159

Arizona Deer, 39

Armadillo, Nine-banded, 9

Peba, 9

Artibeus perspicillatus, I 94

Artiodactyli, 28

astutus, Bassariscus, 254

athabascae, Bison, 67

Atlantic Walrus, 2 I 2

ater, Canis, 277

atrata, Mustela, 245

auduboni, Ovis, 64

Audubon's Sheep, 64 auricularis, Microtus, I 20

austerus, Microtus, I I 9

australis, Scalops, I 88

austrinus, Geomys, 98

avia, Mephitis, 229

Badger, American, 230

Balænidae, I 2

Balæna glacialis, I3 mysticetus, I 6

Balænoptera Musculus, $\mathbf{7}$ physalis, 16

Baleen, I 2

baliolus, Peromyscus, I 37

Bangs' Cotton Rat, I 29

Marsh Mouse, I 30

Polar Hare, 88

bangsi, Lepus, 88

Banner-tailed Deer, 39

barbatus, Erignathus, 2 I 8

Barren-ground Bear, 26 I Caribou, 52

Bassaris, Texas, 254

Bassariscus astutus flavus, 254

Bat, Big-eared, rg6

Carolina, 200

Fruit, I 94

Hoary, $204^{\circ}$

Large Brown, 200

Leaf-nosed, I 94 
Bat, Leather-winged, 206 Little Brown, I96

Red, 203

Say's, I 96

Silver-haired, 202

Twilight, 206

Bats, 193

Common, 195

Free-tailed, $x 95$

Bay Lynx, $2 S_{4}$

Bayou Gray Squirrel, I 72

Beach Mouse, I3 8

Brewer's, Ix 7

Island, I 38

Bear, Barren-ground, 26 I

Black, 257

Cinnamon, 257

Florida, 260

Glacier, 260

Grizzly, 26I

Kadiak, 263

Kidder's, 264

Labrador, 260

Louisiana, 260

Pavlof, 263

Polar, 255

Sitka, 264

Yakutat, $26_{3}$

Bears, 255

Bcarded Seal, 2 I 8

Beaver, Canadian, I45

Carolinian, 150

Mountain, I 50

bidens, Mesoplodon, I 9

Big-eared Bat, I96

Bighorn, 6I

Bison, American, 66

Woodland, 67

Bison athabascal, 67

bison, 66

Black Bear, 257

Fox, 264

Meadow Mouse, I I 7

Rat, I 44

'Wolf, 277

Blackfish, 23

Black-tailed Deer, 39

Black-tailed Jack Rabbit, 89

Blarina brevicanda, 180

carolinensis, $\mathrm{I}_{3}$

peninsulae, 183

parva, 183

floridana, 184

Blubber, I I

Blue Fox, 273

IVhale, 17

Bob Cat, 284

Bog Mouse, I I I
Bonaparte's Weasel, 239

borealis, Lasiurus, 203

Odocoileus, 39

Bottle-nosed Dolphin, 20

Whales, I9

Bovidae, 57

Bowhead, 16

brevicanda, Blarina, I80

breviceps, Kogia, I8

breweri, Microtus, I I 7

Parascalops, i 89

Brewer's Beach Mouse, I I 7

Mole, I89

Bridled Weasel, 240

Brown Rat, I 42

Brown Shrew, i 83

Florida, I 84

brumalis, Mustela, 245

Buffalo, American, 66

Woodland, 67

bursarius, Geomys, 98

Cachalot, I 7

Cacomistle, 254

Cacomitl Cat, 293

cacomitli, Felis, 293

C'aing Whale, 23

Californian Black-tailed Deer, 43

Grizzly, 263

Miule Deer, 4 I

californianus, Zalophus, 2 I I

californicus, Odococleus, 4 I Ursus, 263

Camel, 28

campestris, Lepus, 89

Canada Lynx, 286

Porcupine, 94

Skunk, 229

canadensis, Arctomys, I 59

Castor, 145

Cervus, 3 I

Lutra, 2 I 9

Lynx, 286

Peromyscus, I 35

Canadian Beaver, 145

White-footed Mouse, I 35

Canidx, 264

Canis albus, 277

ater, 277

latrans, 279

occidentalis, 277

Caribou, Barren-ground, 52

Grant's, 54

Greenland, 54

Mountain, 5I

Newfoundland, 5 I

Stone's, 5 I

Caribou, Woodland, 47

caribou, Rangifer, 47 
Carnivora, 207

Carnivorous Animals, 207

Carolina Bat, 200

Otter, 223

Red-backed Mousc, i I 2

carolinensis, Blarina, 183

Castor, I 50

Evotomys, I I 2

Sciurus, I 70

Carolinian Beaver, I 50 Jumping Mouse, I $\mathrm{O}_{4}$

Castor canadensis, I 45 canadensis carolinensis, I 50

Castoridæ, I 45

Cat, Bob, 28 :

Cacomit1, 293

Civet, 254

Ringtailed, 254

Wild, 284

Cat Squirrel, I 68

Catamount, 284

Cats, 283

Cattle, 57

celatus, Phenacomys, i Io

cavirostris, Ziphius, In

Cerros Island Deer, 4 I

ccrroseusis, Odocolleus, 4 I

Cervidae, $3 \mathbf{I}$

cervina, Ovis, 61

Cervus canadensis, 3 I

merriami, 34

occidentalis, 34

Cetacea, I I

Cetaceans, I I

Chapman's Cotton Rat, $\mathbf{2} 29$

Chickaree, I 72

Chipmunk, I 62

Chiroptera, I 93

chrotorrhinus, Microtus, i I

cicognani, Putorius, 239

cinereoargenteus, Urocyon, 275

cinereus, Lasiurus, 204

Cinnamon Bear, 257

Civet Cat, 254

Cloudland White-footed Mouse, I 35

Coati, Mexican, 254 Mondi, 254

Collared Peccary, 30

coloratus, Oryzomys, I 30

Columbian Black-tailed Deer, 42

columbianus, Odocoileus, 42

Common Bats, 195

Dolphin, 2 I

Mole, I88

Rat, I 42

Seal, 2 I 5

Common, Shrew, I 84

Condylura cristala, I 90
Cony, 93

Coon, 247

cooperi, Synaptomys, ro7

Cooper's Lemming Mouse, Io7

coryi, Felis, 288

Corynorhinus macrotis, I 96

Cotton Mouse, I 35

Florida, 136

Louisiana, I 36

Rhoad's, I35

Cotton Rat, I 28

Bangs's, I 29

Chapman's, I 29

Cottontail, 75

Florida, 77

Northern, 77

Prairie, 78

Southern, 75

couesi, Odocoileus, 39

Cougar, 288

Florida, 288

couguar, Felis, 288

Cowfish, I9

Cricetinx, I 27

cristata, Condylura, I yo

cristata, Cystophora, 2 I 8

crooki, Odocoileus, 4 I

Crook's, Deer, 4 I

Cross Fox, 264

cumberlandius, Geomys, 98

cyanocephalus, Nyctinomus, I 95

Cystophora cristata, 2 I 8

dalli, Ovis, 64

Ursus, 263

Dall's Sheep, 64

Dasypodidæ, 9

Dasypterus intermedius, 206

Deer, 3 I

Arizona, 39

Banner-tailed, 39

Black-tailed, 39, 42

Cerros Island, 4 I

Crook's, 4 I

Fantailed, 39

Florida, 39

Louisiana, 39

Mule, 39

Northern, 39

Texan, 39

Virginia, 34

White-tailed, 39

Deer Mouse, I 3 I

Florida, I 36

degener, Lutra, 223

deletrix, Vulpes, 272

Delphinapterus leucas, 24

Delphinidæ, 20

Delphinus delphis, 2 I 
Ielphis, Delphinus, 2 I

Desert Mule Deer, 4 I

dickinsoni, Reithrodontomys, I 3 I

Dickinson's Harvest Mouse, I 3 I

Dicrostonyx hudsonius, Ios

Didelphidae, 4

Didelphis Marsupialis texensis, 8 virginiana, 4 pigra, 8

Dismal Swamp Lemming Mouse, ios Muskrat, I 26

Dolphin, Bottle-nosed, 20

Common, 2 I

Spotted, 2 I

Striped, 22

Dolphins, 20

dorsatus, Erethizon, 94

Dugongs, 26

Dusky White-footed Mouse, I 35

Eared Seals, 200

Eastern Skunk, 229

Striped Slsunk, 230

Edentata, 9

Edentates, 9

Elk, American, 3 I

Merriam's, 34

Roosevelt's, 34

clongata, Mephitis, 229

clucus, Procyon, 247

emmonsi, Ursus, 260

enixus, Microtus, I I 7

cremicus, Odocoileus, 4I

Erethizon, dorsatus, 94

Erignathus barbatus, 2 I 8

Ermine, 237

eskimo, Putorius, 240

Eskimo Weasel, 240

Eumetopias stelleri, 2 I I

Eutheria, xiv

Everglade Gray Squirrel, I- 2

Evotomys gapperi, I I I carolinensis, I I 2

ochraceus, I I 2

rhoadsi, I 12

proteus, II 2

ungava, I 12

extimus, Sciurus, I 72

Eyra, 293

False Lemming Mouse, r ro

fannini, Ovis, 65

Fannin's Sheep, 65

Fan-tailed Deer, 39

fatuus, Synaptomys, ro8

Fect, xix

Felidac, $28_{3}$

Felis cacomitli, 293

$$
\text { coryi, } 288
$$

Felis cougar, 288 eyra, 293

onca, 292

pardalis, 293

Fiber obscurus, 127

zibethicus, I 2 I

aquilonius, 126

macrodon, 126

rivalicus, I 26

Field Mlouse, I I 2

Finback Whale, r6

Finner, I 6

Fisher, 24I

Fisher Marten, 24I

fisheri, Sorex, IS 7

Fisher's Shrew, I87

Fissipedia, 207

flaviscens, Perognathus, roo

flavus, Bassariscus, 254

Florida Bear, 260

Cougar, 288

Cotton Mouse, I 36

Cottontail, 77

Deer, 39

Decr Mlouse, I 36

Free-tailed Bat, 195

Flying Squirrel, I 78

Gopher, 98

Gray Fox, 276

Manatee, 26

Marsh Hare, 89

Marsh Mouse, I 30

Mink, 235

Mole, I 88

Opossum, 8

Otter, 223

Raccoon, 247

Skunk, 229

Weasel, 240

Wild Cat, 286

Wood Rat, I 28

floridana, Blarina, 184

Geomys, 98

Lepus, 77

Lynx, 286

Peromyscus, I 36

Urocyon, 277

Ursus, 260

Flying Squirrel, $>76$

Florida, I 78

Northern, i 78

Severn River, 178

Southern, 177

fontigenus, Microtus II

Fossil Ungulates, 28

Fox, Arctic, 273

Black, 264

Blue, 273

Fox, Cross, 264 
Fox, Gray, 275

Kit, 272

Red, 264

Silver, 264

White, 273

Foxes, 264

Fox Squirrels, 168

Northern, I 69

Southern, I 70

Western, I69

franklini, Spermophilus, I 62

Franklin's Spermophile, I62

Free-tailed Bats, I95

frenatus, Putorius, 240

Fruit Bat, 194

fuliginosus, Sciurus, I 72

fulvus, Vulpes, 264

fumeus, Sorex, I 86

Fur Seal, 209

fuscus, Vespertilio, 200

gapperi, Evotomys, I I I

Geomyidae, 96

Geomys bursarius, 98

cumberlandius, 98

tuza, 97

tuza floridanus, 98

mobileusis, 98

Austrinus, 98

Georgia Oldfield Mouse, I 37

Pipistrelle, $20 \mathrm{I}$

gigas, Alces, 43

$$
\text { Lynx, } 286
$$

Gillespie's Seal, 2 I I

Giraffe, 28

glacialis, Balæna, I3

Glacier Bear, 260

Glires, 7 I

Globiocephalus melas, 23

Glutton, 245

Gnawing Animals, 7 I

Goat, Kennedy's, 6 I

Mountain, 57

White, 57

Golden Mouse, I 38

Gopher, Alabama, 98

Florida, 98

Georgia, 97

Gray, I62

Island, 98

Pocket, 96, 98

Prairie, 98

Striped, I6 I

West Florida, 98

gossypinus, Peromyscus, 135

Grampus, 23

Grampus griseus, 23

granti, Rangifer, 54

Grant's Caribou, 54
Gray Squirrel, I 7o

Bayou, I 72

Everglade, I 72

Northern, I 72

Southern, I 72

Gray Fox, 275

Florida, 276

Wisconsin, 277

Gray Gopher, I6 2

Rabbit, 75

Seal, 2 I 8

Wolf, 277

Greenland Caribou, 54

Hare, 88

griseus, Grampus, 23

Grizzly Bear, 26 I

Alaskan, $26_{3}$

California, 263

Sonoran, 263

groenlandica, Phoca, 2 I 7

groenlandicus, Lepus, 88

Rangifer, 54

Ground Hackee, I6 2

Hog, I 5 I

Squirrel, r 62

grypus, Halichorus, 2 I 8

Gull Island Mouse, I I 7

Gulo luscus, 245

gyas, Ursus, 263

gymnicus, Sciurus, 172

Hackee, Ground, $\mathrm{I}_{2}$

Northern, ${ }^{6} 6_{3}$

Hair Seal, 2 I I

Hairy-tailed Mole, i 89

Halichøerus grypus, 2 I 8

Harbor Porpoise, 22

Seal, 2 I 5

Harp Seal, 2 I 7

Harvest Mouse, I 30

Dickinson's, 13 I

Surber's, I3 I

Hare, Arctic, 86

Jackass, 89

Little Chief, 93

Marsh, 88

Prairie, 89

Varying, 78

Water, 89

White, 78,86

Hares, 73

helaletes, Synaptomys, ro8

hemionus, Odocoileus, 39

Heteromyidae, 99

Hippopotamus, 28

hispida, Phoca, 2 I 7

hispidus, Sigmodon, I 28

Hoary Bat, 204

Hooded Seal, 2 I 8 
Hoofed Animals, 28

horrixus, Ursus, 263

horribilis, Ursus, 26 I

Horse, 28

House Mouse, 138

hoyi, Sorex, 187

Hoy's Shrew, I 87

Hudsonian Meadow Mouse, I I 7

White-footed Mlouse, I 35

hudsonicus, Sciurus, 176

hudsonius, Dicrostonyx, 108 Zapus, 102

humeralis, Nycticeius, 206

Humpback Whale, i7

Hyperoodon rostratus, I9

ignavus, Arctomys, 159

Illinois Skunk, 220

impiger, Reithrodontomys, I 3 I

innuitus, Synaptomys, Ios

Insectivora, I79

insignis, Zapus, 104

intermedius, Dasypterus, 206

Island Beach Mouse, I 38

Gopher, 98

Jack Rabbit, 89

Jackass Hare, 89

Jaguar, 292

Jumping Mice, 102

Jumping Mouse, Carolinian, IO4

Labrador, 104

Meadow, ${ }^{02}$

Northern, 105

Roan\}Mountain, 105

Woodland, 104

Kadiak Bear, 263

Kangaroo Rat, Ord's, 100

Kennedyi, Orcamnos, 61

Kennedy's Mountain Goat, 6 r

Killer, 23

Kidderi, Ursus, 264

Kidder's Bear, 264

Kit Fox, 272

Kogia breviceps, 18

Labrador Bear, 260 Jumping Mlouse, 104

Marten, 245

Meadow Mlouse, I 7

Muskrat, 126

Red Squirre!, 176

Red-backed Mouse, I 12

Rock Vole, i 18

Shrew, 186

Varying Hare, 86

Woodchuck, 159

labradoreus, Lepus, 88

ladas, Zapus, 104

Lagenorhynchus acutus, 22

lagopus, Vulpes, 273
Large Brown Bat, 200

largha, Phoca, 215

Lasionycteris noctivagans, 202

Lasiurus borcalis, 203

cincreus, 20.4

Latax lutris, 223

lataxina, Lutra, 223

latinianus, Phenacomys, iro

latirostris, 'Trichechus, 26

latrans, Canis, 279

Leaf-nosed Bats, 194

Least Weasel, 240

Leather-winged Bat, 206

lecontii, Reithrodontomys, I 30

Legs, xix

Lemming Mouse, Cooper's, 107 Dismal Swamp, Io8

False, I ro

Northern, ros

Preble's, io8

'True's, Io8

Lemming, Pied, Io8

Lemmings, 105,107

Lemmus trimucronatus, I Io

Leporidae, 73

Lepus americanus, 86 americanus struthiopus, 86 virgianianus, 78

articus, 86

bangsi, 88

labradorius, 88

aquaticus, 89

campestris, 89

floridanus, 77

mallurus, 75

mearnsi, 78

transitionalis, 77

groenlandicus, 88

palustris, 88

palustris paludicola, $S_{9}$

leucas, Delphinapterus, 24

leucopus, Peromyscus, I 3 I

leucotis, Sciurus, I 72

leucurus, Odocoileus, 39

Lion, Mountain, 288

Little Chief Hare, 93

Striped Skunk, 230

Brown Bat, 106

littoralis, Sigmodon, I 29

Long-tailed Shrew, I 84,187

Weasel, 239

longirostris, Sorex, IS 7

loquax, Scuirus, x 75

lotor, Procyon, 247

Louisiana Bear, 260

Cotton Mouse, 136

Deer, 39

Mlink, 235 
Louisiana Skunk, 29

louisianæ, Odocoileus, 39

Loup Cervier, 286

lucifugus, Myotis, 196

ludovicianus, Cynomys, I 60

luscus, Gulo, 245

lutensis, Putorius, 235

Iuteolus, Ursus, 260

Lutra canadensis, 2 I 9

lataxina, 223

vaga, 223

degener, 223

lutreocephalus, Putorius, 235

lutris, Latax, 223

Lynx, Bay, 284

Canada, 286

Newfoundland, 287

canadensis, 286

gigas, 286

ruffus, 284

ruffus floridanus, 286

subsolanus, 287

1ysteri, Tamias, I6 3

Maine Weasel, 239

mallurus, Lepus, 75

Manatee, Florida, 26

Manatees, 26

maritimus, Thalarctos, 255

Marmot, Maryland, I 5 I

Marmots, I $5 \mathrm{I}, \mathrm{I} 60$

Marsh Hare, 88 Florida, 89

Marsh Mouse, I 29

Bang's, I 30

Florida, I 30

Marsh Shrew, I 87

Marsupialia, xiv, 3

Marsupials, 3

Marten, American, 242

Fisher, 24I

Labrador, 245

Newfoundland, 245

Pine, 242

Maryland Marmot, I 5 I

Meadow Jumping Mouse, Io2

Meadow Mice, ro7

Meadow Mouse, I I 2

Acadian, I I 7

Black, I I 7

Gull Island, I I 7

Hudsonian, I 7

Labrador, i 77

Prairie, I I 9

Ungava, I 77

Yellow-cheeked, ir 8

Meadow Vole, I 2

mearnsi, Lepus, 78

Megaptera nodosa, I 7 melas, Globioccphalus, 23

mephitica, Mephitis, 229

Mephitis avia, 229

elongata, 229

mephitica, 229

mesomelas, 229

putida, 224

Merriam's E1k, 34

mesomelas, Mephitis, 229

Mesoplodon bidens, 19

Mexican Coati, 254

Sheep, 64

Mexicanus, Ovis, 64

Mice, 105

Introduced, $I_{3} 8$

Jumping, I 02

Long-tailed, I 27

Meadow, Io7

Pocket, 99

michiganensis, Peromyscus, 138

Microtinae, I07

Microtus alleni, I 20

austerus, I I 9

breweri, II 7

chrotorrhinus, I I 8 ravus, I 8

Microtus, nesophilus, I I 7

pennsylvanicus, I I 2

acadicus, I I 7

enixus, I I 7

fontigenus, I I 7

nigrans, I I 7

ungava, I I 7

Microtus, pinetorum, I I 9 pinetorum auricularis, I 20 scalopsoides, I 20

terrænovae, i is

Middendorffi, Ursus, 263

Miller's Polar Hare, 88

Mink, 23 I

Florida, 235

Louisiana, 235

Northern, 235

Southern, 235

miscix, Sorex, I86

Mississippi Pine House, I 20

Wood Rat, I 28

mississippiensis, Peromyscus, I 35

mobilensis, Geomys, 98

Mole, Brewer's, I89

Common, I 88

Florida, I 88

Hairy-tailed, I 89

Naked-tailed, I 88

Star-nosed, igo

Mole Shrew, iso

Moles, I 79, 188

monax, Arctomys, I 5 I 
monoceras, Monodon, 24

Monodon monoceras, 24

montanus, Oreamnos, 57

Rangifer, 5 I

Moose, 43

Alaskan, 43

moschatus, Ovibos, 65

Mountain Beaver, I 50

Caribou, 5 I

Goat, 57

Lion, 288

Sheep, 6 I

Mouse, Beach, I I 7, I 38

Bog, III

Cotton, I 35

Deer, I3I

Field, II 2

Golden, 138

Gull Island, I I 7

Harvest, I 30

House, 138

Lemming, IO7

Marsh, I 29

Meadow, I 12

Oldfield, 136

Pine, I I 9

Mouse, Prairie, I 38

Red, I38

Red-backed, I I I

Rice-field, I 29

Scorpion, 136

Shrew, I 84

White-footed, I 3 I

Wood, I I I, I3I.

Mule Deer, 39

California, 4 I

Desert, 4 I

Mulita, 9

Muridæ, 105

Murinae, $x_{3} 8$

Mus musculus, $x_{3} 8$

norvegicus, 142

rattus, I 44

alexandrinus, 145

musculus, Balænoptera, I 7 MIus, 138

Musk Ox, 65

Peary's, 65

Muskrat, I 2 I

Dismal Swamp, 126

Labrador, I 26

Newfoundland, 127

Round-tailed, I 20

Southern, I 26

Musquash, I 2 I

Mustela, americana, 2.42 atrata, 245

brumalis, 2.45 pennanti, 241

Mustelidx, 2 I 9

Myotis lucifugus, I,6

subulatus, I06

mysticetus Balæna, I 3

macrocephalus, Physeter, 17

macrodon, Fiber, 126

macrotis, Corynorhinus, I 96

Sciuropterus, I 78

macrourus, Odocoileus, 39

macrurus, Sorex, 187

narica, Nasua, 254

Narwhal, 24

Nasua narica, 254

natator, Oryzomys, I 30

neglectus, Sciurus, 168

nelsoni, Ovis, 64

Nelson's Sheep, 64

Neofiber, I $20^{2}$

Neotoma pennsylvanica, I 27

floridana, I 28

floridana rubida, I 28

nesophilus, Microtus, i 7

Newfoundland Caribou, 5 I

Lynx, 287

Marten, 245

Muskrat, 127

Otter, 223

Red Fox, 272

Rock Vole, i 8

New Jersey Red-backed Mouse, I I 2

New York Weasel, 235

niger, Sciurus, 170

nigriculus, Peromyscus, I.36

nigrans, Microtus, I I 7

Nine-banded Armadillo, 9

niveiventris, Peromyscus, 138

Noctilionidae, I95

noctivagans, Lasionycteris, 202

nodosa, Megaptera, I 7

North Carolina Wcasel, 239

Northern Cottontail, 77

Decr, 39

Flying Squirrel, $\mp ; S$

Fox Squirre1, I 69

Gray Squirrel, I 72

Jumping Mouse, I 5

I.cmming Mouse, 108

Mink, 235

Otter, 223

Pine Mlouse, r 20

Pipistrelle, 202

Red Squirrel, I 75

Woodchuck, 159

norvegicus, Mus, 142

Norway Rat, 142

notius, Putorius, 239

Nova Scotia Red Fox, 272 
Nova Scotia Varying Hare, 86

$$
\text { Wild Cat, } 286
$$

noveboracensis, Putorius, 235

novemcinctum, Tatu, 9

nubiterrae, Peromyscus, I 35

nuttalli, Peromyscus, 138

Nycticeius humeralis, 206

Nyctinomus cyanocephalus, I 95

obesus. Odobenus, 2 I 3

obscurus, Fiber, I 27

Pipistrellus, 202

occidentalis, Canis, 277

occisor, Putorius, 239

Ocelot, 293

Ochotona princeps, 93

Ocythous, Urocyon, 277

ochraceus, Evotomys, I 12

Odobenidae, 2 I 2

Odobenus obesus, 2 I 3 rosmarus, 2 I 2

Odocoileus cerrosensis, 4 I

columbianus, 42

sitkensis, 43

scaphiotus, 43

couesi, 39

crooki, 4 I

hemionus, 39

hemionus californicus, 4 I eremicus, $4 \mathrm{I}$

leucurus, 39

louisianae, 39

osceola, 39

texensis, 39

virginianus, 34

borealis, 39

macrourus, 39

Oldfield Mouse, I 36

Rhoad's, I 37

Georgia, I 37

onca, Felis, 292

Onychomys, I 36

Opossum, Florida, 8

Texas, 8

Virginian, 4

Opossums, 4

ordi, Perodipus, roo

Ord's Kangaroo Rat, roo

Oreamnos kennedyi, 6 I montanus, 57

Orca orca, 23

Oryzomys palustris, 129 palustris natator, 130 coloratus, I 30

osceola, Odocoileus, 39

Otariidae, 209

Otoes alascanti 209

Otter, 2 I 9

Carolina, 223
Otter, Florida, 223

Newfoundland, 223

Northern, 223

Sea, 223

Ovibos moschatus, 65

wardi, 65

Ovis cervina, 6 I cervina auduboni, 64

dalli, 64

fannini, 65

mexicanus, 64

nelsoni, 64

stonei, 64

Ox, 28

Ox, Musk, 65

Pacific Walrus, 2 I 3

Painter, 288

Pallas's Seal, 2 I 5

Pallid Red-backed Mouse, I I 2

palmarius, Peromyscus, 136

paludicola, Lepus, 89

palustris, Lepus, 88

Oryzomys, I 29

Sorex, I 87

Panther, 288

Parascalops breweri, $\mathrm{r} S \mathrm{~g}$

pardalis, Felis, 293

parva, Blarina, I 83

Pavlof Bear, $26_{3}$

Peary's Musk Ox, 65

Peba Armadillo, 9

Peccaries, 30

Peccary, Collared, 30

Texas, 30

Pekan, 24 I

peninsulae, Blarina, 183

Putorius, 240

pennanti, Mustela, $24 \mathrm{I}$

pennsylvanica, Neotoma, I 27

pennsylvanicus, Microtus, I I 2

Perissodactyli, 28

Perodipus ordi, roo

Perognathus flavescens, Ioo

Peromyscus canadensis, I 35

abietorum, I 35

umbrinus, 135

nubiterrae, I 35

floridanus, I 36

gossypinus, I 35

mississippiensis, I 3 .

palmarius, I 36

nigriculus, I 36

leucopus, I 3 I

michiganensis, ${ }_{3} 8$

niveiventris, 138

nuttalli, I 38

Peromyscus, phasma, i 38

subgriseus, I 36 
Peromyscus baliolus, I 37 rhoadsi, I 37

personatus, Sorex, $x \& 4$

perspicillatus, Artibeus, I 94

1) hasma, Peromyscus, $\mathrm{I}_{3} \mathrm{~S}$

P'henacomys celatus, I IO latimanus, I Io

Phoca groenlandica, 2 I 7 hispida, 2 I 7

largha, 215 vitulina, 2 I 5

Phocrna phocrna, 22

Phocida, 2 I 4

Phyllostomatidae, I 94

1) hysalis, Balienoptera, I 6

Physeter macrocephalus, 17

Physeteridae, 17

Pied Lemming, ros

Pig, 28

Pigmy Sperm Whale, I 8

pigra, Didelhpis, 8

Pika, 93

Pilot Whale, 23

Iine Marten, 242

Pine Mouse, I I

Mississippi, I 20

Northern, I 20

pinctorum, Microtus, I I9

Pinnipedia, 207

Pipistrelle, Georgia, 201

Northern, 202

Pipistrcllus subflavus, 20 I obscurus, 202

plagiodon, Prodelphinus, $2 i$

Plains Pocket Mlouse, 100

Pocket Gophers, 96, 98

Pocket Mice, 90

Pocket Mouse, Plains, ìoo

Polar Bear, 255

Polar Hare, 86

Bangs', 88

Grecland, 88

Miller's, 88

Polecat, 224

Porcupine, Canada, 94

Yellow-haired, 94

Porcupines, 94

Porpoise, 20 llarbor, 22

Porpoises, 20

Pouched Animals, 3

Prairic Cottontail, $7 \delta$

Dog, 160

Gopher, 98

Hare, 89

Meadow Mouse, I I 9

Prairic Mouse, 1.38

Wolf, 279
Preble's Lemming Mouse, ros

Primates, xv, xvi

Irinceps, Ochotona, 93

P'roboscidea, $\mathrm{xv}, \mathrm{xvi}$

Procyon lotor, 247 elucus, $2+7$

Procyonidae, 247

Prodelphinus plagrodon, 2 I

Prong Buck, 54

Prong Horn, American, 54

proteus, Erotomys, I I 2

Prototheria, xiv

Puma, 288

Florida, 288

putida, Mcphitis, 224

Putorius alleghaniensis, 240

cicognani, 239 richardsoni, 239

frenatus, 240

longicanda spadix, 239

lutensis, 2.35

noveboracensis, 235

notius, 239

occisor, 239

peninsulac, 240

rixosus, 240

eskimo, 240

vison, $2,3 \mathrm{I}$ lutreocephalus, 2.35

vulgivagus, 235

qucrceti, Sciuropterus, $17 \mathrm{~S}$

Rabbit, Snow-shoe, $7 \mathrm{~S}$

Rabbit, Gray, 75

Jack, 89

Rabbits, 73

Raccoon, Florida, 247

Raccoons, 247

Rangifer, artcicus, 52

caribou, 47

granti, 54

groenlandicus, 54

montanus, 5 I

stonci, $5 \mathrm{I}$

terrac-novac, $5 \mathbf{I}$

Rat, Black, I 44

Brown, I 42

Common, $\mathrm{I}_{4} 2$

Cotton, $\mathrm{I}_{2} \mathrm{~S}$

Kangaroo, , оo

Norway, 142

Rice, I 29

Roof, $1 \neq 5$

Wood, 127

Rats, 105

Introduced, $1_{3} 8$

Long-tailed i 27

rattus, Mus, I 44

ravus, Microtus, I 8 
Red Bat, 203

Red Fox, 264 Nova Scotia, 272

Newfoundland, 272

Red Mouse, ${ }_{3} 8$

Red Squirrel, I 72

Northern, I 75

Southern, I 75

Labrador, i 76

Red-backed, Mouse, i I I

Carolina, I I 2

Labrador, I I 2

New Jersey, I I 2

Pallid, I I 2

Ungava, I I 2

Reindeer, 52

Reithrodontomys lecontii, I30 impiger, I3 I dickinsoni, I 3 I

Rice Rat, I 29

Rice-field Mouse, I 29

richardsoni, Putorius, 239 Ursus, 26 I

Richardson's Weasel, 239

Right Whale, I 3

Ring-tailed Cat, 254

Ringed Seal, 2 I 7

ringens, Spilogale, 230

rivalicus, Fiber, I 26

rixosus, Putorius, 240

Roan Mountain Jumping Mouse, I05

roanensis, Zapus, I05

Rock Vole, i 8

Labrador i 8

Newfoundland, I I 8

Rodents, 7 I

Roof Rat, I 45

Roosevelt's Elk, 34

Rorqual, r6

rosmarus, Odobenus, 2 I 2

rostratus, Hyperoodon, I9

Round-tailed Muskrat, I 20

rubida, Neotoma, I 28

rubricosa, Vulpes, 272

rufa, Aplodontia, I $5 \circ$

ruffus, Lynx, 284

rufiventer, Sciurus, I69

Ruminants, 28

Rhinoceras, 28

rhoadsi, Evotomys, I I I, I I 2 Peromyscus, I 37

Rhoad's Cotton Mouse, I 35 Oldfield Mouse, 137

Sable, American, 242

sabrinus, Sciuropterus, 178

Salamander, 97

Say's Bat, I 96

Scalops, aquaticus, I 88
Scalop , aquaticus, australis, 188 scalopsoides, Microtus, I 20

scaphiotus, Odocorleus, 43

Sciuridæ, I 5 I

Sciuropterus sabrinus, 178 macrotis, 178

volans, 176 querceti, 178

Sciurus caroilnensis, I 70 leucotis, I 72

fuliginosus, $7^{2}$ extimus, $I_{72}$

hudsonicus, 176 gymnicus, 172 loquax, I75

niger, $\mathrm{I} 7 \mathrm{O}$

rufiventer, 169 neglectus, I 68

Scorpion Mouse, 136

Sea Bear, 209

Cow, 26 Steller's, 26

Lion, 2 I I Steller's, 2 I I

Otter, 223

Seal, Bearded, 2 8

Common, 2 I 5

Fur, 209

Gillespie's, 2 I I

Gray, 2 I 8

Hair, 2 II

Harbor, 2 I 5

Harp, 217

Hooded, 2 I 8

Pallas', 2 I 5

Ringed, 2 I7

Seals, 2 I 4

Eared, 209

Severn River Flying Squirrel, 178

Sewellel, I $5 \circ$

Sheep, Audubon's, 64

Dall's, 64

Fannin's, 65

Mexican, 64

Mountain, 6 I

Nelson's, 64

Stone's, 64

Short-tailed Shrew, I80

Northern, 183

Southern, I 83

Everglade, 183

Shrew, Brown, I 83

Common, I 84

Fisher's, I 87

Hoy's, I87

Labrador, I 86

Screw, Long-tailed, I84, I87

Marsh, 187 
Screw, Mole, iso Short-tailed, I so

Smoky, I 86

Southern, I87

Water, I 87

Shrew Mouse, I $\$$

Shrews, 179

Sigmodon hispidus, 128 hispidus littoralis, 129 spidecipygus, 129

Silver Fox, 264

Silver-haired Bat, 202

Sirenia, 26

Sitka Bear, 264

Sitkan Black-tailed Deer, 43

sitkensis, Odocoilcus, 43

Ursus, 264

Skull, 'The, xvi

Skunk, 224

Canada, 229

Eastern, 229

Florida, 229

Illinois, 229

Little Striped, 230

Louisiana, 229

Smoky Shrew, I 86

Snowshoe Rabbit, 78

Sonoran Grizzly, 263

Sorecidac, I 79

Sorex albibarbis, I 87

fumeus, i 86

hoyi, 187

longirostris, I 87

fisheri, 187

macrurus, 187

palustris, I 87

personatus, I 84

personatus miscix, I 86

sornborgeri, Ursus, 260

Southern Cotton-tail, 77

Flying Squirrel, I 77

Fox Squirrel, I 70

Gray Squirrel, 172

Mink, 235

Muskrat, 126

Red Squirrel, 175

Shrew, I 87

spadicipygus, Sigmodon, I 29

spadix, Putorius, 239

Sperm Whales, 17

Spermophile, Franklin's, 162 Striped, i $6 x$

Spermophilus franklini, $\mathrm{I}_{2}$ tridecemlincatus, I6 I

sphagnicola, Synaptomys, ro 8

Spilogale ambarvalis, 230

Spilogale ringens, 230

Spotted Dolphin, 2 I
Squirrel, Cat, 168

Fox, 168

Flying, I 76

Gray, 170

Ground, 162

Red, I 72

Striped, I 62

Squirrels, I 5 I

Star-nosed Mole, I 90

stelleri, Eumetopias, 2 I I

Steller's Sea Cow, 26

Sea Lion, 2 I I

stonei, Ovis, 64

Rangifer, 5 I

Stone's Caribou, 5 I

Sheep, 64

striatus, Tamias, I 62

Striped Dolphin, 22

Gopher, I6 I

Spermophile, I6 I

Squirrel, I 62

struthiopus, Lcpus, 86

Striped Skunk, Eastern, 230

Little, 229

subflavus, Pipistrellus, 201

subgriscus, Peromyscus, 136

subsolanus, Lynx, 287

subulatus, Myotis, 196

Surber's Harvest Mouse, I 3 I

Synaptomys cooperi, I07 helaletes, ro8

fatuus, 108

inninitus, 108

sphagnicola, 108

Talpidae, I 88

Tamias striatus, 162 lysteri, I 63

Tapir, 28

Tatu novemcinctum, 9

Taxidea taxus, 230

taxus, Taxidea, 230

Tayassu angulatum, 30

Tayassuidx, 30

teeth, The, xvii

terrae-novac, Microtus, I IS

Rangifer, 5 I

Texas Bassaris, 254

Deer, 39

Opossum, 8

Peccary, 30

texensis, Didelphis, 8

Odocoileus, 39

Thalarctos maritimus, 255

1'homomys, 96

Timber Wolf, 277

'Tonthless Animals, o

transitionalis, Lepus, 77

'richechidae, 26 
Trichechus americanus, 27

latirostris, 26

tridecemlineatus, Spermophilus, I6 I

trimucronatus, Lemmus, I Io

True's Lemming Mouse, , 88

tursio, Tursiops, 20

Tursiops tursio, 20

tuza, Geomys, 97

Twilight Bat, 206

umbrinus, Peromyscus, I 35

Ungava Meadow Mouse, I 7

Red-backed Mouse, I I 2

ungava, Erotomys, I 12

Microtus, I I 7

Ungulata, 28

Ungulates, 28

Urocyon cinereoargenteus, 275

floridanus, 276

ocythous, 277

Ursidæ, 255

Ursus americanus, 257 floridanus, 260 scruborgeri, 260

dalli, 263 gyas, $26_{3}$

emmonsi, 260

horribilis, $26 \mathrm{r}$

alascensis, 263

californicus, $26_{3}$

horriæus, $26_{3}$

kidderi, 264

luteolus, 260

middendorffi, 263

richardsoni, $26 \mathrm{r}$

sitkensis, 264

vaga, Lutra, 223

Varying Hare, 78

Labrador, 86

Nova Scotia, 86

Vespertilio fuscus, 200

Vespertilionidae, I 95

velox, Vulpes, 272

Virginia Deer, 34

Virginian Opossum, 4

virginiana, Didelphis, 4

Lepus, 78

Odocoileus, 34

vison, Putorius, 23 I

vitulina, Phoca, 2 I 5

volans, Sciuropterus, I 76

Vole, Meadow, I I 2

Rock, i i 8

vulgivagus, Putorius, 235

Vulpes deletrix, 272

fulvus, 264

fulvus rubricosa, 272

Vulpes lagopus, 273

velox, 272
Walrus, Atlantic, 2 I 2

Pacific, 2 I 3

Walrusses, 2 I 2

Wapiti, 3 I

wardi, Ovibos, 65

Water Hare, 89

Shrew, I 87

Weasel, Alleghany, 240

Bonaparte's, 239

Bridled, 240

Eskimo, 240

Florida, 240

Least, 240

Long-tailed, 239

Maine, 239

New York, 235

North Carolina, 239

Richardson's, 239

West Florida Gopher, 98

Western Fox Squirrel, I 69

Whale, Blue, I 7

Bottle-nosed, I 9

Ca'ing, 23

Fin-back, I 6

Humpback, I 7

Pigmy Sperm, i 8

Pilot, 23

Right, I 3

Sperm, I 7

White, 24

Ziphius, I9

Whales; I I

Whales, Whalebone, I 2

Whalebone, I 2

Whatebone Whales, I 2

Whaling, I4

White Fox, 273

Goat, 57

Hare, 78

Whale, 24

White-footed Mouse, I3 I

Canadian, I 35

Cloudland, I 35

Dusky, I 35

Hudsonian, I 35

White-tailed Deer, 39

Jack Rabbit, 89

Wild Cat, 284

Florida, 286

Nova Scotia, 286

Wisconsin Gray Fox, $27 \%$

Wolf, Arctic, 277

Black, 277

Gray, 277

Prairie, 279

Timber, 277

Wolverine, 245

Wolves, 264 
Wood Mouse, II I, I 3 I

Wood Rat, Alleghany, I 27 Florida, $12 \mathrm{~S}$

Mississippi, I $2 S$

Woodchuck, 151

$\mathrm{La}^{2}$ rador, 159

Northern, I 59

Woodland Caribou, 47

Jumping Mouse, I 04

Yaguarundi, 293

Yakutat Bear, 263

Yellow-cheeked Meadow Mouse, ins

Yellow-haired Porcupine, 94
Zalophus californianus, 2 II

Zapodidac, 102

Zapus hudsonius, Io2 americanus, 104 ladas, 10.4 insignis, 104 roanensis, 105 abictorum, 105

Zebra, 28

zibethicus, Fiber, I 2 I

Ziphiidae, 19

Ziphius cavirostris, 9

Ziphius Whale, 19 



